UNIVERSIDADE DE SÃO PAULO

FACULDADE DE FILOSOFIA LETRAS E CIÊNCIAS HUMANAS

PROGRAMA DE PÓS-GRADUAÇÃO EM GEOGRAFIA FÍSICA

\title{
MAPEAMENTO E ANÁLISE GEOMORFOLÓGICOS COMO SUBSÍDIO PARA IDENTIFICAÇAO E CARACTERIZAÇÃO DE TERRAS INUNDÁVEIS. ESTUDO DE CASO DA BACIA HIDROGRÁFICA DO RIO DOS SINOS - RS.
}

Tese apresentada ao Programa de Pós-Graduação em Geografia Física, do Departamento de Geografia da Faculdade de Filosofia, Letras e Ciências Humanas da Universidade de São Paulo, como parte dos requisitos para a obtenção do título de Doutora em Geografia. Orientador: Prof. Dr. Jurandyr Luciano Sanches Ross.

ADRIANA DE FÁTIMA PENTEADO

SÃO PAULO

2011 
ADRIANA DE FÁTIMA PENTEADO

\section{MAPEAMENTO E ANÁLISE GEOMORFOLÓGICOS COMO SUBSÍDIO PARA IDENTIFICAÇAO E CARACTERIZAÇÃO DE TERRAS INUNDÁVEIS. ESTUDO DE CASO DA BACIA HIDROGRÁFICA DO RIO DOS SINOS - RS.}

Tese apresentada ao Programa de Pós-Graduação em Geografia Física, do Departamento de Geografia da Faculdade de Filosofia, Letras e Ciências Humanas da Universidade de São Paulo, como parte dos requisitos para a obtenção do título de Doutora em Geografia.

Banca Examinadora

Prof. Dr. Jurandyr Luciano Sanches Ross

Prof. Dr. Adilson Avansi Abreu

Prof. Dr ${ }^{\mathrm{a}}$. Cleide Rodrigues

Prof. Dr ${ }^{\mathrm{a}}$. Chisato Oka - Fiori

Prof. Dr ${ }^{0}$. Bernardo Sayão

São Paulo, ------- de -----------------------------de 2011. 


\section{AGRADECIMENTOS}

A Universidade de São Paulo - USP pela oportunidade de estudar nesta instituição de qualidade impar que desenvolve seus alunos não só no nível intelectual, mas nas artes, nos esportes e na cultura em geral, em um período em que cada vez mais a educação tem se tornado uma mercadoria, onde os que não podem pagam, e os conseguem a adquire como direito social.

Ao meu orientador Jurandyr, aos íntimos Jura, que me deu um voto de confiança e orientou esse trabalho e por mais uma amizade que aqui se concretiza.

Ao Conselho Nacional de Pesquisa - CNPq que me possibilitou dedicação exclusiva na difícil empreitada de elaboração de uma tese.

Aos professores Roberto Verdum, Nina Fujimoto da UFRGS, Albano e Leonardo Maltchik da UNISINOS por terem se disponibilizado a ajudar na idéia ainda embrionária do projeto de tese.

A Agência Nacional das Águas - ANA e ao Instituto Nacional de Pesquisas Espaciais - INPE pela disponibilização de dados.

A Sandro Henrique Petry pelo acompanhamento nos campos, pelas discussões filosóficas sobre o que aqui chamados de "banhados", revisão técnica do trabalho e tradução do resumo para o inglês.

Ao amigo querido Moisés por ter compartilhado dos bons e maus momentos dessa caminhada.

Ao amigo Roberto por ter disponibilizado de coração aberto ajuda incondicional na elaboração deste trabalho.

Ao amigo pantaneiro Beto Pelegrin pela ajuda técnica na elaboração dos mapas de uso do solo.

A amiga Eliane Nunes pelos litros de chimarrão compartilhados que muito ajudaram na higienização mental, essencial em um trabalho de cunho intelectual. 
Ao amigo Tadeu Gaspareto pela ajuda técnica e disponibilização de abrigo contra o frio e chuva em eventuais idas a São Paulo.

Aos companheiros de apartamento e de estudos Ema e Ivan.

Ao meu Pépinot que pacientemente me fez companhia deitado aos meus pés na espera hipotética de um passeio.

Aos amigos curitibanos Germano, Leocádia e Patrícia Laine pelo companheirismo que já atravessou década.

A Marisa Fierz companheira e amiga no laboratório de Geomorfologia da USP.

Ao Doutor Fernando Rebello que aceitou ser co-orientador deste trabalho em intercâmbio na Universidade de Coimbra, fato não consumado devido a questões de ordem material.

Ao pesquisador e professor Reinaldo Corrêa Costa por ter se disponibilizado a ler e contribuir com este trabalho.

Ao professor Fausto Borjes pela correção ortográfica.

Ao amigo Leandro Dalfin e ao pesquisador Olivier Chauveau pela tradução do resumo para o francês.

A minha mãe Cleusa e ao meu irmão Rodrigo Penteado.

A todos aqueles que acreditaram neste trabalho. 
0 edifício científico encontra- se em desequilíbrio e constantemente em progresso. 0 erro não desempenha aí apenas o papel de um acidente psicológico, mas faz, por assim dizer, parte integrante do movimento do espírito que cria a ciência; a tal ponto que se poderia pensar em definir o conhecimento científico como 0 conhecimento errôneo. Entendamos por isto apenas que este conhecimento implica a possibilidade de conferir um sentido preciso ao erro, de reconhecê- lo, e de dele partir para um novo progresso.

Gaston B achelard 


\section{RESUMO}

A área de estudo da presente pesquisa compreende a bacia hidrográfica do rio dos Sinos localizada entre as coordenadas de $50^{\circ} 10^{\prime}$ e $51^{\circ} 20^{\prime}$ de longitude oeste e entre $29^{\circ} 15^{\prime}$ e $30^{\circ} 00^{\prime}$ de latitude sul, atingindo municípios da Região Metropolitana de Porto Alegre - RMPA e da chamada Serra Gaúcha. O objetivo do trabalho foi o de estudar as terras inundáveis da área especificada a partir de parâmetros geomorfológicos contextualizando-as dentro de uma concepção sistêmica da paisagem, adotando como recorte espacial a bacia hidrográfica. Buscou-se contribuir nas questões relativas às variadas nomenclaturas, definições e no método de estudo dessas áreas. $\mathrm{Na}$ escala da bacia analisaram-se a litologia e a pedologia a partir de mapas já presentes na literatura. Elaborou-se mapeamento geomorfológico na escala 1:100000, perfis transversais e longitudinais e análise de dados pluviométricos que serviram como base para a definição das imagens mais apropriadas para a delimitação do limite superior aproximado das terras inundáveis. Em escala de detalhe, 1: 10000 mapearam-se os lagos naturais, bem como aqueles com origem antropogênica, foi também possível refinar o limite das terras inundáveis estudadas. Por meio da elaboração dos mapas de uso nos limites e entorno das terras inundáveis foi possível uma visão do estado atual de conservação destas áreas. A metodologia operacional compreendeu o uso de técnicas do Sistema de Informações Geográficas e do Sensoriamento Remoto. A metodologia teórica metodológica foi embasada em Ab' Saber (1969) que propôs três níveis básicos de pesquisa em geomorfologia, Ross (1992) com a proposta de taxonomia do relevo e Bertalanffy (1975) a partir da Teoria Geral dos Sistemas - TGS. No que se referem aos resultados na escala da bacia temos como principais formações litológicas: derrames basálticos e depósitos sedimentares, ambos pertencentes à Morfoestrutura da Bacia Sedimentar do Paraná e depósitos cenozóicos do Terciário e do Quaternário. As morfoesculturas resultantes compreendem áreas de planaltos, planícies e depressões relativas. Os basaltos de formação mais ácida formaram planaltos tabulares, os basaltos de constituição intermediária e básica formaram morros que variam entre 150 e 750 metros de altitude aproximadamente. Nos depósitos da formação Botucatu e Rosário do Sul predominam as colinas e morros de baixa altitude. As planícies flúvio - coluvionares e fluviais estão restritas aos depósitos do Quaternário e do Terciário respectivamente. Os solos localizados nas terras inundáveis foram o chernossolo háplico órtico no trecho médio e superior da bacia e o planossolo háplico eutrófico no trecho inferior. A partir da análise dos dados pluviométricos, que compreendeu o intervalo entre 1999 e 2008, constatou-se que as imagens mais apropriadas para a delimitação do limite superior aproximado das terras inundáveis seria a de outubro de 2005, porém utilizou-se a imagem de setembro de 2005, pelo fato desta, e não da outra, estar disponível. O mês de setembro foi antecedido pelo segundo mês com maior índice pluviométrico para 2005, assim, não houve grande prejuízo na utilização desta imagem. Dos seis mapas elaborados referentes ao aspecto natural das terras inundáveis constatou-se a incidência de lagos em todas as áreas, excluindo apenas o caso do mapa do trecho um - jusante onde não há sinal de divagação de canal e alta taxa de alteração dos aspectos naturais. A maioria dos lagos se formaram naturalmente a partir do estrangulamento e abandono de meandro, há também lagos de 
origem antropogênica. A existência ou não de lagos definiu nomenclatura mais específica das terras inundáveis como fluvias ou flúviolacustres. A partir dos mapas das principais alterações antrópicas contatou-se que no trecho médio e de montante predomina a utilização agrícola. Nas áreas do trecho dois e três de jusante há maior incidência de vegetação natural, porém, de forma insuficiente, a ocupação urbana neste trecho se apresenta na maioria das vezes de forma concentrada. Constatou-se que nas áreas mais a jusante as terras inundáveis são maiores do que nas áreas mais a montante, o que pode ser explicado, entre outros fatores, pela influência do relevo na configuração espacial destas áreas. Acredita-se que a partir dos esforços aqui realizados que tiveram por base pressupostos conceituais e aplicados da Geomorfologia, foi possível melhor compreender as terras inundáveis, para a área de estudo e de forma geral independentemente de fatores de localização ou espaciais.

Palavras chave: Geomorfologia, Terras Inundáveis, Mapeamento. 


\begin{abstract}
The study area of this research comprises the Bells river basin located between the coordinates $50^{\circ} 10$ 'and $50^{\circ} 20^{\prime}$ west longitude and between $29^{\circ} 15^{\prime}$ and $30^{\circ} 00^{\prime}$ south latitude, reaching municipalities in the metropolitan area of Porto Alegre - RMPA and in the area of the called Serra Gaúcha. The aim of this work was to study the floodable lands in the specified area through geomorphological parameters, contextualizing these areas in a systemic approach of the landscape - the river basin. The methodology comprised, in a basin scale, geological and pedological analysis based on existing maps in the literature, 1:100000 scale geomorphological mapping, analysis of rainfall data that was the basis for defining the most appropriate images for the delineation of the approximate superior boundary of floodable lands. Scale of detail 1: 10000, water bodies placed in the defined areas, as well as major changes from land use, were mapped. High-resolution images were used in order to refine the floodable land boundaries, and these images served as well for paleochannels, land use and anthropogenic lakes mapping. The operational methodology included the use of techniques of Geographic Information System and Remote Sensing. The theoretical methodology was based on Ab'Saber (1969) who proposed three basic levels of research in geomorphology, Ross (1992) with the proposed taxonomy of relief and Bertalanffy (1975) from the General Systems Theory - TGS. With regard to the results on the basin scale, we have as main lithological formations: basalt flows and sedimentary deposits, both belonging to morphostructural of Paraná Sedimentary Basin, and Tertiary and Quaternary Cenozoic deposits. The forms of relief are related to these structures, the more acidic basalts form tabular plateaus, the basalts of intermediate and basic constitution formed hills ranging between 150 and 750 altitude meters approximately, in the Botucatu and Rosário do Sul deposits predominate the hills and low altitude mountains, the fluvial-colluvial and fluvial plains are restricted to Quaternary and Tertiary deposits respectively. The soils from floodable lands form Mollisol in the middle and superior section of the basin and Haplic Eutrophic Planosol in the lower part. The driest months are January, February and March, and the wettest
\end{abstract}


are October, May and June in the period between 1999 and 2008. We can find, from the six generated maps, that the incidence of lakes is higher in the lower section in the cases that have not lost their natural characteristics due to human action. Most of the lakes are formed naturally from the meander stranglehold, and there are lakes of anthropogenic origin. Differences in relation to water bodies have defined more specific classification of land as fluvial or fluvial-lacustrial. We can find, from the six generated maps concerning the natural aspects of wetlands, that there is incidence of lakes in all areas, excluding only the case of the section 1 -downstream, where there isn't any case of meandering and there's high rate of anthropogenic action. Most of the lakes are formed naturally from the meander stranglehold, and there are lakes of anthropogenic origin. Differences in relation to water bodies have defined more specific classification of land as fluvial or fluvial-lacustrial. From the maps of the major anthropogenic changes it was found that in the middle and higher river sections the land is used for agriculture predominantly. In the areas corresponding to sections two and three, downstream, there is a higher incidence of natural vegetation, however it's still insufficiently. The urban settlement is most often concentrated. It was found that in further downstream areas the wetlands are bigger than in the upstream areas: this phenomenom can be explained by the shape of relief in the adjacent areas and even by the study of areas beyond the boundary of floodable land. Finally, we conclude that a kind of approach, as addopted in this research (which was based on geomorphological analysis), opens up possibilities for classification and better understanding of floodable lands - the phenomenon studied.

Keywords: Geomorphology, Wetlands, Mapping. 


\section{RÉSUMÉ}

Cette étude couvre le bassin hydrographique du fleuve rio dos Sinos, qui s'étendentre les longitudes $50^{\circ} 10^{\prime} \mathrm{W}$ et $51^{\circ} 20^{\prime} \mathrm{W}$ et les latitudes $29^{\circ} 15^{\prime} \mathrm{S}$ et $30^{\circ} 00^{\prime} \mathrm{S}$, incluant les communes de la région métropolitaine de Porto Alegre- RMPA et de la région appelée Serra Gaucha. L'objectif de ce travail était d'étudier, à partir des paramètres géomorphologiques, les zones inondables de la région spécifiée, dans le contexte d'une approche systémique du paysage, en adoptant le bassin hydrographique comme échelle spatiale. Nous avons cherché à apporter notre contribution concernant les questions relatives à l'usage de nomenclatures variées, à la définition des termes employés et à la méthode d'étude de ce type de domaine géographique. À l'échelle du bassin, la lithologie et la pédologie ont été analysées à partir des cartes existantes dans la littérature. Une cartographie géomorphologique des profils transversaux et longitudinaux à l'échelle 1:100000 a été développée, et l'analyse des données pluviométriques a servi de base pour choisir les images satellites représentantde la meilleure manière l'extension maximale approximative des zones inondables. Les lacs d'origine naturelle, ainsi que ceux d'origine anthropique, ont été cartographiés à une échelle de détail de $1: 10000$, ce qui a contribué à affiner la délimitation des zones inondables étudiées. Grâce à la préparation decartes del'utilisation des espaces dans les limites, et les environnantes de terres inondées, était possible d'avoir une vision plus actuelle de l'état de conservation de ces zones. La méthodologie opérationnelle a consisté à utiliserles techniques de Système d'Information Géographique et de Télédétection. La méthodologie théorique a été élaborée en utilisant les trois niveaux basiques de recherche en géomorphologie proposés par Ab'Saber (1969), la taxonomie de relief définie par Ross (1992) et la théorie générale des systèmes - TGS, d'après Bertalanffy (1975). Les résultats à l'échelle du bassin indiquent queles principales formations lithologiques sont les coulées basaltiques et les dépôts sédimentaires, tous deux relevant dela morphostructure du bassin sédimentaire du Paraná, et plus particulièrement des dépôts cénozoïques du tertiaire et quaternaire. Les morphosculptures résultantes comprennent des zones de plateaux, de plaines et de dépressions relatives. Les basaltes de formation plus acide ont formédes plateaux tabulaires, et les basaltes de constitution intermédiaire et alcaline ont formé des monts dont l'altitude varie entre 150 et 750 mètres environ. Dans les dépôts des formations Botucatu et Rosario do Sul, dominent les collines et les monts de basse altitude. Les plaines fluvio-colluvionnaires et fluviales sont limitées respectivement aux dépôts du quaternaire et dutertiaire. Les sols situés dans les zones inondables, sont de type chernosols hapliques orthiques dans la section médiane et supérieure du bassin, et de type planosols hapliques eutrophiques dans la section inférieure. L'analyse des données pluviométriques, relevées entre 1999 et 2008, a permis de definir la période d'octobre 2005 comme référence pour choisir l'image satellite représentantde manière appropriée l'extension maximale approximative des zones inondables, mais celle-ci n'étant pas disponible, nous avons dû utilisé l'image de septembre 2005. Le mois de septembre ayant été précédé par le second mois présentant l'indice pluviométrique le plus élevé pour 2005, l'utilisation de cette image n'a pas semblé grandement préjudiciable. Sur les six cartes produites par rapport à l'aspect naturel de les terres inondées, on a constaté l'incidence des lacs dans tous les domaines, à l'exclusion seulement le cas d'une partie aval de la carte, où il n'y a aucun signe de canaux sinueux et il y a un taux élevé d'origine anthropique. La plupart des lacs se sont formés naturellement par la strangulation et l'abandon du méandre, il y a aussi des lacs d'origine 
anthropique. La présence ou l'absence de lacs a conduit à la classification plus spécifique de lesterres inondées comme fluvial ou flúviolacustres. A partir des cartes des principaux changements anthropiques, on a constaté que dans la section intermédiaire et amont, l'utilisation prédominante est agricole. Dans les zones de l'aval de la section deux et trois, il y a une incidence plus élevée de la végétation naturelle, cependant, encore insuffisamment. L'implantation urbaine est présentée, dans la plupart des cas, sous forme concentrée. On a constaté que dans les zones plus en aval, l'inondation des terres sont plus élevés que dans les zones plus en amont, ce qui peut s'expliquer par la configuration de relief dans les zones voisines, et par l'étude du relief de zones au-delà de la frontière des terres inondées. On croit que des études utilisées dans cette recherche, qui était basée sur la géomorphologie, il a été possible de mieux comprendre les terres inondées, non seulement dans la zone d'étude, mais d'une manière plus globale.

Mots-clés: Géomorphologie, Terres Inondées, , Cartographie. 


\section{ÍNDICE DE SIGLAS}

A: horizonte superficial do solo

A: área

AB: Transição entre horizonte pedológico A e B.

a--------------b: perfil

ABICALÇADOS: Associação Brasileira das Indústrias de Calçados

AM - Amazonas

ANA - Agência Nacional das Águas

B: Perfil pedológico com concentração de argila ou húmus, bem estruturado.

Btm: B textural cimentado

Btg: B textural gley

Btmg: B textural cimentando gley

Bt: horizonte B com incremento de argila em relação ao horizonte A ou E.

C: solos

C: comprimento da bacia

CBERS: Satélite Sino-Brasileiro de Recursos Terrestres

CCD: High Resolution CCD Câmera

COMITESINOS: Comitê de Gerenciamento da Bacia Hidrográfica do rio dos Sinos

CONAMA: Conselho Nacional de Meio Ambiente

CORSAM: Secretaria de Habitação e Saneamento

CPT - Centro de Pesquisas do Pantanal

CPRM: Serviço Geológico do Brasil

Cr: cromo

DBO: Demanda Bioquímica de Oxigênio

DOD: Departamento de Defesa

DNOS: Departamento Nacional de Obras Públicas

DQO: Demanda Química de Oxigênio

DNA: Ácido desoxirribonucléico

E: eluvial 
E: leste

EMBRAPA: Empresa Brasileira de Pesquisas Agropecuárias

EUA: Estados Unidos da América

FEPAM: Fundação Estadual de Proteção Ambiental

FAO: Food and Agriculture Organization of the United Nations

Ff: Fator de forma

GPS: Global Posicion System

H: Amplitude altimétrica

IBGE: Instituto Brasileiro de Geografia e Estatística

Ic: Índice de circularidade

IQA: Índice de Qualidade da Água.

INAU - Instituto Nacional de Áreas Úmidas

INPE: Instituto Nacional de Pesquisas Espaciais

INPA - Instituto Nacional de Pesquisas da Amazônia

IPH: Instituto de Pesquisas Hidráulicas

IPPC: Integrated Pollution Prevention and Control

Kc: Coeficiente de compacidade

JKB: Formação Botucatu

$\mathrm{Km}$ : quilômetros

Ksgb1: Vulcanismo Serra Geral, rochas intermediárias e básicas.

Ksga1: Vulcanismo Serra Geral, rochas ácidas.

LANDSAT: Land Remote Sensing Satellite

M: metros

MA: Maranhão

MDE: Modelo Digital de Elevação

METSUL: Metereologia

METROPLAN: Secretaria de Obras Públicas, Irrigação e Desenvolvimento Urbano.

Fundação Estadual de Planejamento Metropolitano e Regional

MPA: Massa Polar Atlântica

MT: Mato Grosso

MTA: Massa Tropical Atlântica 
MTC: Massa Tropical Continental

$\mathrm{N}$ : norte

NE: nordeste

NIMA: National Imagery and Mapping Agency

NUPAUB - Núcleo de Pesquisas Sobre Populações Humanas em Áreas Úmidas Brasileiras

NO: Noroeste

O: oeste

P: Perímetro da bacia

PCRS - Planície Costeira do Rio Grande do Sul

PNSB: Pesquisa Nacional de Saneamento Básico

Pró - Sinos: Programa de Educação Ambiental da bacia hidrográfica do rio dos Sinos

Pró - Várzea: Projeto Manejo dos Recursos Naturais da Várzea

PUC - Pontifícia Universidade Católica

Qf4: Depósitos do Quaternário

RMPA: Região Metropolitana de Porto Alegre

Rr: Razão de relevo

Rrl: Razão de relevo relativo

Rrs: Formação Rosário do Sul

RS - Rio Grande do Sul

S: sul

SE: sudeste

SCEVRS: Sistema de Proteção Contra Enchentes no Vale do rio dos Sinos

SEMAE: Serviço Municipal de Água e Esgoto. São Leopoldo - RS

SEMMAM: Secretaria Municipal de Meio Ambiente. São Leopoldo - RS

SEMC: Secretaria de Energia, Minas e Comunicações

SRTM: Shuttle Radar Topographic Mission

SIG: Sistema de Informações Geográficas

SO: sudoeste

Te: Depósitos do Terciário

TGS: Teoria Geral dos Sistemas 
Ti: Trecho Inferior

Tm: Trecho médio

TO: Tocantins

Ts: Trecho superior

UEMT - Universidade Estadual do Mato Grosso

UFMS - Universidade Federal do Mato Grosso do Sul

UFMT - Universidade Federal do Mato Grosso

UFP - Universidade Federal do Pará

UFRGS: Universidade Federal do Rio Grande do Sul

UGI: União Geográfica Internacional

UNESCO: Organização das Nações Unidas para a Educação a Ciência e a Cultura.

UNEP: United Nations Environment Programme

UNISINOS - Universidade do Vale do rio dos Sinos

USP - Universidade de São Paulo

UTM: Universal Transversa Mercator

WGS: Word Geodetic System

W: oeste 


\section{LISTA DE ANEXOS}

ANEXO A: Algumas especies da flora e da fauna da bacia hidrográfica do rio dos Sinos __ 291

ANEXO B: Sistema de Clasificación de Tipos de Humedales de Ramsar __ 292

ANEXO C: Criterios para la Identificación de Humedales de Importancia Internacional __ 295

ANEXO D: Resolução No 303, de 20 de março de 2002 __ 297

ANEXO E: Lei Municipal no 6.493 de 17.12.2007__ 302

ANEXO F: Definição de Áreas Inundadas (DIEGUES, 2002).___ 307

ANEXO G: Principais aspectos e impactos ambientais do processo produtivo de curtumes _ 309

ANEXO H: Traçado proposto dos diques e respectivos pôlderes __ 310

ANEXO I: Perfil de dique de terra ___ 311

ANEXO J: Reportagens __ 311

\section{LISTA DE FIGURAS}

Figura 01: Mapa de localização da bacia hidrográfica do rio dos Sinos - RS. __ 10

Figura 02: Taxonomia do relevo. 18

Figura 03: Diferença na resposta espectral do rio no período de vazante (a) 14/06/1990; e no período de cheia (b) 31/05/1985. 37

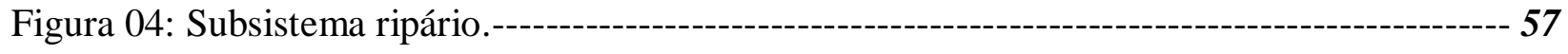

Figura 05: Grandes Estruturas do Território Brasileiro.__ 65

Figura 06: Unidades de Relevo. __ 68

Figura 07: Parte da planície do rio Purus. _ 73

Figura 08: Limite entre as placas Sul - Americana e de Nazca com formação de fossa submarina (a); detalhe da figura a, costa ativa com relevo ondulado (b); cidade de La Serena - Chile (a e b); Plataforma continental da placa Sul - America na face leste, margem passiva (c); planície costeira (d); Laguna - Brasil (c e d). _ 75

Figura 09: Evolução da sedimentação costeira durante fim do Terciário e o__ 78

Quaternário no estado da Bahia.__ 78

Figura 10: Mecanismo de bloqueio do transporte litorâneo de areias devido ao fluxo formado por uma desembocadura fluvial em região costeira.

Figura 11: Perfil esquemático (W- E) transversal aos sistemas deposicionais da Planície Costeira do RS com suas fáceis sedimentares associadas. 81

Figura 12: Lagunas do sistema barreira.__ 83

Figura 13: Transição entre as rochas básico-intermediárias e ácidas. ___ 89 
Figura 14: Evolução pedológica ao longo do tempo. 107

Figura 15: Relação entre a profundidade do planossolo e concentração de argila. 108

Figura 16: Relação entre fator de forma para bacias com mesma área. 123

Figura 17: Relação entre a forma da bacia hidrográfica do rio dos Sinos. 124

Figura 18: Principais padrões de canais fluviais. 126

Figura 19: Localização dos perfis transversais traçados na bacia hidrográfica do rio dos Sinos. 128

Figura 20: Perfil Transversal do trecho superior da bacia hidrográfica do rio dos Sinos. 129

Figura 21: Perfil Transversal do trecho médio da bacia hidrográfica do rio dos Sinos. 130

Figura 22: Perfil Transversal do trecho inferior da bacia hidrográfica do rio dos Sinos. 131

Figura 23: Perfil longitudinal do rio dos Sinos. 134

Figura 24: Padrão meandrante psamítico do trecho superior do rio dos Sinos 135

Figura 25: Padrão meandrante pelítico no trecho inferior do rio dos Sinos. 135

Figura 26: Perfil longitudinal do rio Rolante. 136

Figura 27: Trecho superior do rio Rolante. 136

Figura 28: Trecho inferior do rio Rolante. 137

Figura 29: Perfil longitudinal do rio Paranhana. 137

Figura 30: Sinuosidade do rio Paranhana em seu trecho superior. 138

Figura 31: Padrão de canal irregular do rio Paranhana no seu trecho inferior. 138

Figura 32: Perfil longitudinal do rio da Ilha. 139

Figura 33: Rio da Ilha com baixa sinuosidade em área de planalto dissecado. 140

Figura 34: Rio da Ilha sinuoso configurando um padrão de canal meandrante pelítico 140

Figura 35: Perfil 1 Planícies Interiores-planície fluvial 142

Figura 36: Perfil 1 Planícies Interiores - planície fluviocoluvionar 145

Figura 37: Perfil 2 Planícies Interiores - planície fluviocoluvionar 146

Figura 38: Perfil 1 Domínio das Coxilhas - colinas 148

Figura 39: Perfil 2 Domínio das Coxilhas - colinas 148

Figura 40: Perfil 3 Domínio das Coxilhas - colinas 149

Figura 41: Perfil 1 Domínio das Coxilhas - morros baixos 151

Figura 42: Perfil 2 Domínio das Coxilhas - morros baixos 152

Figura 43: Perfil Domínio das Coxilhas - Morro Testemunho 153

Figura 44: Perfil 1 Planalto Basáltico Tabular 154 Figura 45: Perfil 2 Planalto Basáltico Tabular 155 
Figura 46: Perfil 2 Planalto Basáltico Tabular 156

Figura 47: Perfil Transição entre Planalto Basáltico Tabular e o Planalto Dissecado. 157

Figura 48: Perfil 1 Planalto Basáltico Dissecado - morros altos 160

Figura 49: Planalto Basáltico Dissecado - morros altos 161

Figura 50: Planalto Basáltico Dissecado - morros altos 161

Figura 51: Planalto Basáltico Dissecado - morros médios 162

Figura 52: Planalto Basáltico Dissecado - morros médios 163

Figura 53: Planalto Basáltico Dissecado - morros médios 163

Figura 54: Planalto Basáltico Dissecado - morros baixos 165

Figura 55: Planalto Basáltico Dissecado - morros baixos 165

Figura 56: Tipos principais de drenagem. 169

Figura 57: Lago formado por movimentação tectônica. 169

Figura 58: Formação de lagos vulcânicos. 170

Figura 59: Vários padrões de lagos em planícies de grande extensão fluvial. 171

Figura 60: Formação de lagos em ferradura 171

Figura 61: Lagos formados por barramentos pelo deslocamento de sedimentos. 172

Figura 62: Formação de lagos costeiros formados por barramentos. 172

Figura 63: Processos associados à melhora da qualidade da água proporcionada pelas terras inundáveis

Figura 64: Região Metropolitana de Porto Alegre (RMPA) e os principais centros urbanos a partir do desenvolvimento industrial. 201

Figura 65: Trecho superior do rio dos Sinos. 204

Figura 66: Conurbação no trecho inferior do rio dos Sinos. 205

Figura 67: Inundação 211

Figura 68: Tipos de leito fluvial. 212

Figura 69: Criação de um pôlder. 219

Figura 70: Pôlderes IV e V. 222

Figura 71: Criação de canal artificial 224

Figura 72: Inundações no Vale do rio Sinos e no Vale do rio Caí. 230

Figura 73: Abrangência do Aquífero Guarani. 247 


\section{LISTA DE FOTOGRAFIAS}

Fotografia 01: Subsistema Lacustre. 56

Fotografia 02: Subsistema Palustre. 57

Fotografia 03: Subsistema planície de inundação. 58

Fotografia 04: Predomínio de lagoas na região pantaneira de Paiaguás. 71

Fotografia 05: Escarpa do planalto, município de São Francisco de Paula. 89

Fotografia 06: Morro Testemunho da Formação Botucatu 61

no município de São Leopoldo. 61

Fotografia 07: Relevo suave ondulado da Formação Botucatu 92 no município de São Leopoldo. 92

Fotografia 08: Plantação de arroz irrigado em planossolo no município de Canoas. 109

Fotografia 09: Chernossolo Háplico Órtico com lençol aflorante, município de Taquara. 110

Fotografia 10: Perfil do argissolo vermelho distrófico, município de Campo Bom. 112

Fotografia 11: Perfil do cambissolo húmico alumínico, 114

Fotografia 12: Perfil do neossolo regolítico eutrófico, município de Caraá. 116

Fotografia 13: Planície fluvial do rio da Ilha, município de Taquara. 143

Fotografia 14: Planície fluvial do rio Paranhana, município de Parobé. 144

Fotografia 15: Em primeiro plano, colinas areníticas da Formação Botucatu município de Parobé-

Fotografia 16: Padrão em colinas, município de Taquara. 150

Fotografia 17: Morros baixos da Formação Botucatu, município de Novo Hamburgo. 152

Fotografia 18: Planalto Basáltico Tabular de Cimeira, município de Gramado. 155

Fotografia 19: Suave ondulação do Planalto Basáltico Tabular, 156 município de São Francisco de Paula. 156

Fotografia 20: Cachoeira nas bordas do Planalto Basáltico Tabular, município de São Francisco de Paula. 158

Fotografia 21: Morros altos de topos aguçados, município de Três Coroas. Fotografia 22: Topos de morros convexos e aguçados, município de Caraá. 160

Fotografia 23: Morros baixos da Formação Serra Geral, município 166 de Santo Antônio da Patrulha. 166

Fotografia 24: Lago formado pelo abandono de meandro, município de Taquara. 184

Fotografia 25: Terra inundável do rio da Ilha, próxima à foz, município de Taquara. 185

Fotografia 26: Bacia de amortecimento em Porto Alegre. 209 
Fotografia 27: Rua Ramiro Barcelos, Montenegro (1928).

Fotografia 28: Bairro Rio Branco - Canoas (1937). 215

Fotografia 29: Inundação no centro de Porto Alegre em 1941. 216 Fotografia 30: Município de São Leopoldo, 1965. 217

Fotografia 31: Novo Hamburgo, 1976. 217

Fotografia 32: Comporta do sistema de macrodrenagem. 225

Fotografia 33: Casa de Bombas. 225

Fotografia 34: Dique construído com materiais inconsolidados. 226

Fotografia 35: Dique de cimento no centro de São Leopoldo. 227

Fotografia 36: Casa de bombas, canal artificial e dique no município de Canoas. 228

Fotografia 37: Inundação no trecho inferior do rio dos Sinos. 229 Fotografia 38: Inundação no trecho inferior do rio dos Sinos. 229

Fotografia 39: Moradias irregulares nas bermas de equilíbrio dos diques e sulcos erosivos. 233

Fotografia 40: Construção irregular de rampas de acesso ao dique e 234

Fotografia 41: Despejo irregular dos rejeitos da industria coureira-calçadista. 242

Fotografia 42: Rejeitos da extração do Botucatu, município de Taquara RS. 243

Fotografia 43: Arroio João Correa no município de São Leopoldo. 253

Fotografia 44: Ocupação irregular e presença de lixo. 254 Fotografia 45: Aterro das terras úmidas e construção de condomínio popular. 254

Fotografia 46: Cultivo de gado em Santo Antonio da Patrulha. 262

Fotografia 47: Cultivo de arroz na planície de Santo Antonio da Patrulha. 262

Fotografia 48: Plantio de arroz município de Caraá 264 


\section{LISTA DE GRÁFICOS}

Gráfico 01: Janelas atmosféricas e faixas do espectro de maior absorção da REM. 36

Gráfico 02: Quantidade de água e sua relação com a refletância. 37

Gráfico 03: Dados pluviométricos da bacia hidrográfica do rio dos Sinos (1999). 96

Gráfico 04: Dados pluviométricos da bacia hidrográfica do rio dos Sinos (2000). 97

Gráfico 05: Dados pluviométricos da bacia hidrográfica do rio dos Sinos (2001). 98

Gráfico 06: Dados pluviométricos da bacia hidrográfica do rio dos Sinos (2002). 98

Gráfico 07: Dados pluviométricos da bacia hidrográfica do rio do

Gráfico 08: Dados pluviométricos da bacia hidrográfica do rio dos Sinos (2004). 100

Gráfico 09: Dados pluviométricos da bacia hidrográfica do rio dos Sinos (2005). 100

Gráfico 10: Dados pluviométricos da bacia hidrográfica do rio dos Sinos (2006). 101

Gráfico 11: Dados pluviométricos da bacia hidrográfica do rio dos Sinos (2007). 102

Gráfico 12: Dados pluviométricos da bacia hidrográfica do rio dos Sinos (2008). 102

Gráfico 13: Metais pesados acima da Classe I na bacia hidrográfica do rio dos Sinos. 241

\section{LISTA DE MAPAS}

Mapa 01: Mapa geológico da bacia hidrográfica do rio dos Sinos - RS 85

Mapa 02: Mapa hipsométrico da bacia hidrográfica do rio dos Sinos 118

Mapa 03: Mapa de declividade da bacia hidrográfica do rio dos Sinos. 121

Mapa 04: Mapa Geomorfológico da bacia hidrográfica do rio dos Sinos - RS 167

Mapa 05 : Limite terra inundável trecho um - jusante 174

Mapa 06 : Limite terra inundável trecho dois - jusante 177

Mapa 07 : Limite terra inundável trecho três - jusante 180

Mapa 08 : Limite terra inundável trecho um - médio 183

Mapa 09 : Limite terra inundável trecho um - montante 187

Mapa 10 : Limite terra inundável trecho dois - montante 189

Mapa 11: Uso do solo da terra inundável trecho um - jusante 251 
Mapa 12: Uso do solo da terra inundável trecho dois - jusante 255

Mapa 13: Uso do solo da terra inundável trecho três - jusante 257

Mapa 14: Uso do solo da terra inundável trecho um - médio 259

Mapa 15: Uso do solo da terra inundável trecho um - montante 261

Mapa 16: Uso do solo da terra inundável trecho dois - montante 264

\section{LISTA DE QUADROS}

Quadro 01: Características da câmera CCD. 38

Quadro 02: Principais aplicações das bandas 1,2,3 e 4 dos satélites Landsat 5 e 7. 39

Quadro 03: Proposta de classificação para as áreas úmidas do sistema palustre. 55

Quadro 04: Principais alterações causadas nas terras inundáveis do rio dos Sinos 196

Quadro 05: Fluxos básicos principais de um curtume. 239

Quadro 06: Situações atuais de conflito pelo uso da água e problemas ambientais 244 


\section{SUMÁRIO}

CAPÍTULO 1 - INTRODUÇÃO

1.1 Introdução

1.2 Problematização da pesquisa

1.3 Localização e caracterização geral da área de estudo ------

1.3.1 Aspectos naturais _- 6

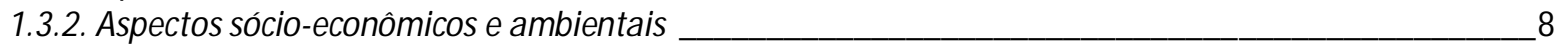

1.4 Objetivos 11

1.4.1 Geral

1.4.2 Específicos

1.4.3. Hipótese _----

CAPÍTULO 2 MÉTODOS

2.1. Teórico - Metodológico

2.1.1 Parâmetros para a análise do relevo

2.1.2 Cartografia geomorfológica

2.1.3 M odelo Sistêmico _

2.1.4 Parâmetros para a análise das alteraçôees nas terras inundáveis

2.2 Operacional 30

2.2.2 Interpolação das imagens de radar e geração de curvas de nível

2.2.2.1 Confecção dos mapas hipsométrico, declividade, MDE e perfis transversais e longitudinais ----- 32

2.2.3 Confecção do mapa geológico e geomorfológico

2.2.4 Confecção dos mapas das terras inundáveis -

2.2.5 Mapeamento do uso e dos recursos hídricos naturais e antropogênicos das terras inundáveis da

bacia hidrográfica do rio dos Sinos 39

2.2.6 Trabalhos de campo

2.2.7 Materiais

2.2.7.1 Softwares:

\section{CAPÍTULO 3 CONSIDERAÇÕES SOBRE O OBJETO DE ESTUDO E RELAÇÃO COM AS PLANÍCIES DE} INUNDAÇÃO

3.1. Breve discussão sobre as várias denominações para o objeto de estudo

3.2 Definições do objeto em questão, convenções e centros de pesquisa que visam à preservação 45

3.3 Considerações sobre alguns sistemas de classificação das chamadas terras úmidas _------- 50

3.4 Definições de planície, formas de classificação e relação com as terras inundáveis _-------- 60

3.5 Macroformas e morfoesculturas do relevo e relação com as planícies de inundação e terras inundáveis

3.5.1 Planícies do pantanal Mato-Grossense e do Guaporé

3.5.2 Planície Amazônica

3.6 Regressão e transgressão marinha e as planícies costeiras

3.6.1 Planícies costeiras do Rio Grande do Sul 
CAPÍTULO 4 - ANÁLISES DOS ASPECTOS FÍSICOS DA ÁREA DE ESTUDO

4.1 Geologia

4.1.1. Cobertura Sedimentar Cenozóica - Depósitos do Terciário e do Quaternário

4.1.2. Vulcanismo e cobertura sedimentar da Bacia do Paraná

4.1.2.1 Formação Serra Geral

4.1.2.2 Formação Botucatu

4.1.2.3 Formação Rosário do Sul _-_- 92

4.2 Características do clima regional e influência no relevo

4.2.1 Análise dos dados pluviométricos _

4.3 Análise pedológica

4.3.1. Planossolos

4.3.2 Chernossolos

4.3.3. Argissolos -- 110

4.3.4 Cambissolos

4.3.5 Associação de solos e afloramentos rochosos -

4.4 Análise da hipsometria

4.5 Análise da declividade 119

4.6 Análise da forma da bacia

4.6.1. Fator de forma

4.6.2 Coeficiente de compacidade

4.6.3 Índice de Circularidade

4.7 Análise do relevo 126

4.7.1 Forma do canal fluvial

4.7.2 Análises dos perfis longitudinais e transversais

4.7.3.1 Análise do perfil transversal do trecho superior da bacia hidrográfica do rio dos Sinos

4.7.3.2 Análise do perfil transversal do trecho médio da bacia hidrográfica do rio dos Sinos - -

4.7.3.3 Análise do perfil transversal do trecho inferior da bacia hidrográfica do rio dos Sinos -

4.7.3.4 Perfil longitudinal

4.7.3.4.1 Análise do perfil Iongitudinal do rio dos Sinos e padrões de canais associados

4.7.3.4.2 Análise do perfil longitudinal do rio Rolante e padrões de canais associados - - ---------- 135

4.7.3.4.3 Análise do perfil longitudinal do rio Paranhana e padrões de canais associados

4.7.3.4.4 Análise do perfil longitudinal do rio da Ilha e padrões de canais associados _-_-_-_-_-_-_ 138

4.7.4 Análise do mapa geomorfológico

4.7.4.1. Morfoescultura Planícies Interiores

4.7.4.1.1. Planície Fluvial

4.7.4.1.2. Planície Fluviocoluvionar

4.7.4.2. Morfoescultura Domínio das Coxilhas

4.7.4.2.1. Padrão em colinas

4.7.4.2.2. Padrão de morros baixos

4.7.4.3 Morfoescultura Planalto das Araucárias

4.7.4.3.1 Planalto Basáltico Tabular de Cimeira

4.7.4.4 Planalto Basáltico Dissecado

4.7.4.4.1. Morros Altos

4.7.4.4.2. Morros médios

4.7.4.4.3. Morros baixos _-- 164

4.7.5 Análise da terra inundável do trecho um de jusante 
4.7.6 Análise da terra inundável trecho dois de jusante

4.7.7 Análise das terras inundáveis do trecho inferior três

4.7.8 Análise da terra inundável do trecho médio

4.7.9 Análise da terra inundável trecho superior um

4.7.10 Análise da terra inundável trecho superior dois

\subsection{Importância, funções e principais impactos causados nas terras inundáveis da área de} estudo

5.2 Relações entre o processo histórico de ocupação e as intervenções nas terras inundáveis

5.2.1 Processo Regional de Urbanização

5.2.1.1 Fase da Imigração

5.2.1.2 Fase Industrial

5.2.1.3. Fase da Metropolização

5.2.1.4 Uso e a ocupação do solo da bacia hidrográfica do rio dos Sinos e problemas relacionados _-_-_ 203

5.3 Inundações 206

5.3.1 Os sistemas de controle de enchentes - Porto Alegre e Vale dos Sinos

5.3.1.1. Riscos associados às obras de controle de enchentes do vale do rio dos Sinos -

5.4 Destinação de resíduos sólidos da bacia hidrográfica do rio dos Sinos _-_-_-_-_-_-_-_ 236

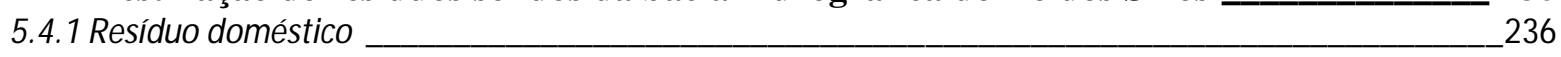

5.4.2. Problemas relacionados ao despejo de curtume

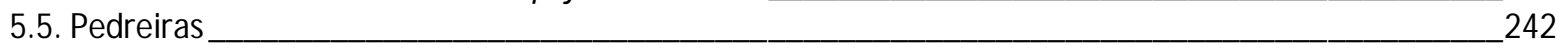

5.6 Problemas relativos à água

5.8 Análises do mapeamento das alterações antrópicas nas terras inundáveis da bacia hidrográfica do rio dos Sinos

5.8.1 Terra inundável trecho um - jusante

5.8.2 Terra inundável trecho dois - jusante

5.8.3 Terra inundável trecho três - jusante

5.8.4 Terra inundável trecho um - médio

5.8.5 Terra inundável trecho um - montante

5.8.6 Terra inundável trecho dois - montante

5.9. DISCUSSÕES FINAIS 


\section{CAPÍTULO 1 - INTRODUÇÃO}

\subsection{Introdução}

A escolha do objeto de estudo desta pesquisa, terras inundáveis, se deu a partir de trabalho anterior, em uma sub-bacia localizada próxima à foz do rio dos Sinos, inserida em grande parte na Região Metropolitana de Porto Alegre - RMPA. A partir de revisão bibliográfica, de análise de fotografias aéreas e de trabalhos de campo referentes ao estudo anterior constatou-se a destruição ou alteração dessas áreas ao longo do tempo mesmo com a importância que possuem.

Sobre o objeto em questão constatou-se que, além dos problemas de ordem ambiental, sendo a área de estudo apenas mais um exemplo do que ocorre em vários locais do mundo, existem problemas de ordem conceitual, que em certo nível contribuem para gerar conflitos quanto à compreensão destas áreas, sendo estes reflexos da complexidade e da variedade que envolvem esses ambientes.

$\mathrm{O}$ primeiro problema de ordem conceitual refere-se à multiplicidade de nomenclaturas, no nível popular, em maior grau, e também no nível científico. Alguns autores como Scott \& Jones (1995) e Maltchik (2006) consideram o primeiro caso como algo que pode gerar confusões, já entre os pesquisadores não se observa a discussão da padronização de termos.

Talvez pela compreensão que não é totalmente clara ou talvez devido às inúmeras designações, há também inúmeras definições referentes ao tema de estudo. Algumas vezes as definições não são abrangentes e estão mais próximas de caracterizações de tipologias, assim não contribuem para o entendimento amplo do que essas áreas são independentemente de fatores espaciais ou geográficos, por exemplo.

'Devido aos problemas verificados, há dificuldades na elaboração de uma legislação específica e, para que seja possível elaborar leis de proteção, é importante propor uma forma de abordagem que possa padronizar e sistematizar os conceitos, além de evitar confusões no que se refere à compreensão, à designação e à definição.

Nesta pesquisa a designação utilizada para o objeto de estudo será terra inundável, sendo a mesma, aqui, definida como o espaço físico que sofre processos de inundação ou permanece ocupado pelas águas, devido ao extravasamento e/ou subida de corpo hídrico superficial ou subterrâneo, responsável pelo fenômeno da inundação. A precipitação pluviométrica compreende 
o input desse sistema. Sua morfologia compreende terras planas ou quase planas e/ou áreas deprimidas. Dependendo do tipo de corpo hídrico aos quais estas estão associadas, podem ser denominadas, em um nível mais específico, como terras inundáveis lacustres, fluviais, fluviomarinhas ou fluviolacustres. Estão comumente inseridas nas planícies de inundação.

Devido à permanência da água por períodos variáveis e devido à deposição de sedimentos, essas áreas desenvolvem solos característicos assim como tendem a desenvolver ao longo do tempo flora e fauna adaptadas.

As intervenções nos corpos hídricos, de forma direta, ou no relevo, que poderá causar alterações nos corpos hídricos de forma direta ou indireta, são capazes de descaracterizar o que se entende por terra inundável.

A forma como essas áreas são designadas e/ou definidas será respeitada ao longo do trabalho, quando forem feitas citações diretas ou indiretas de autores que tratam do tema em questão.

Quanto às legislações brasileiras referentes ao que chamamos de terras inundáveis, elas se encontram difusas dentro de Resoluções, Portarias, Leis, Decretos ${ }^{1}$ e outros atos, tanto Federais como Estaduais, abrangendo aspectos ligados à proteção ambiental e das águas. Os dispositivos para a proteção e gerenciamento dessas áreas não aparecem de forma direta e clara.

Para melhor compreender essas áreas não é possível analisá-las a partir de uma visão pontual, é necessário abordá-las dentro de uma visão sistêmica. Considera-se dentro desta perspectiva que a bacia ou micro - bacia hidrográfica é a unidade de análise mais adequada para o estudo das mesmas.

\footnotetext{
${ }^{1}$ Código das Águas (1934); Código Florestal (1934; 1965); Código das Minas de 1940 e modificado em 1967; Decreto de 1948 onde é aprovada a Convenção para a Proteção da Fauna, Flora e áreas de beleza cênica das Américas; Decreto de 1961 para o controle da contaminação das águas continentais e marinhas; Decreto - lei de 1962 criando a Superintendência de Desenvolvimento da Pesca (SUDEPE); Lei de 1967 proibindo a caça de animais silvestres no Brasil; Lei de 1967 criando o Instituto Brasileiro de Desenvolvimento Florestal (IBDF) responsável pelo estabelecimento e manejo de áreas protegidas; Decreto de 1973 que cria a Secretaria Especial de Meio Ambiente (SEMA) responsável pelas Estações Ecológicas; Decreto de 1975 em que foi aprovada a adesão do Brasil à Convenção sobre Tráfico Internacional de Espécies da Flora e da Fauna em perigo de extinção (CITES); Decreto de 1979 onde é aprovada a adesão do Brasil à Convenção Internacional sobre Contaminação de Petróleo; Criação do IBAMA (1989); Criação do Ministério do Meio Ambiente, Desenvolvimento Urbano e Amazônia; Lei das Águas (1997); Sistema Nacional de Unidades de Conservação - SNUC (2000). Fonte: DIEGUES, 2002.
} 
A bacia hidrográfica é entendida como célula básica da análise ambiental permitindo reconhecer e avaliar seus diversos componentes e os processos de interação que nela ocorrem, devido à possibilidade do estudo dos elementos naturais e sociais que a compõem numa relação de causa e efeito.

Com maior frequiência percebe-se que os estudos relativos às terras inundáveis têm como foco e muitas vezes como ponto de partida a diversidade biológica. Essa é de suma significância e em grande parte justifica a importância que tais áreas possuem. Contudo, partir da diversidade biológica pode não ser a melhor forma para compreender essas áreas, pois questões endêmicas variam muito de um local para o outro e isto pode acarretar inúmeras denominações que se confundem com tipologias sem que seja possível comparar sistemas similares.

Acredita-se que algumas das características dessas áreas, numa análise mais ampla, estão relacionadas às formas de relevo e assim, partir da geomorfologia, tendo como base seus fundamentos conceituais e metodológicos, pode em um nível mais abrangente contribuir para melhor compreender a manifestação das mesmas.

Muitos ramos de pesquisa alegam ser a base essencial na qual se assenta a ocupação humana, como a biologia e a geologia. A pesquisa geomorfológica por seu lado permite a utilização de classificações que tendem a ser genéticas considerando a forma, a composição e os processos geradores/ modificadoras das entidades geomorfológicas (SILVA, 1994).

A análise geomorfológica consiste na identificação e no mapeamento das formas de relevo, baseada no aspecto fisionômico, no significado morfogenético e nas influências estruturais e esculturais (FUJIMOTO, 2008). Assim, partir da geomorfologia para compreender as terras inundáveis perpassa pelo entendimento da gênese e dinâmica dessas áreas, sendo necessário extrapolar os limites espaciais das mesmas para melhor percebê-las.

\subsection{Problematização da pesquisa}

É notório o desenvolvimento de importantes civilizações nos locais onde há abundância de água. As antigas populações do Egito e da Mesopotâmia, por exemplo, desenvolveram-se em áreas ribeirinhas: as margens do rio Nilo, Tigre e Eufrates. As cheias periódicas não 
representavam um problema, mas a renovação da fertilidade dos solos possibilitando uma rica agricultura.

No passado, as populações avançavam em novas áreas por meio dos rios e as cidades se localizavam nas suas margens, o que trazia o beneficio do transporte por barcos, sendo este o meio principal de locomoção. A população entendia o processo da inundação e buscava fixar suas casas em locais mais altos, apesar de serem surpreendidas nas inundações maiores, porém esses eventos eram raros, com recorrência aproximada de 50 anos (METROPLAN, 2001).

A sociedade ao longo do tempo obteve muita sabedoria na convivência com os rios e são raras as igrejas católicas que se localizam em áreas de inundação. São muitos os canais construídos no século XIX onde era previsto um leito para o escoamento, um para a estiagem e outro para as inundações. Atualmente, muitos desses conhecimentos foram renegados no acelerado processo de ocupação do espaço (METROPLAN, 2001).

Apesar das importantes funções ambientais que desempenham as áreas úmidas, muitas vezes, foram consideradas regiões de pouco valor econômico, devido ao fato de estarem encobertas permanentemente ou temporariamente por água e serem vistas como habitat de mosquitos transmissores de enfermidades. Como resultado dessa concepção, milhares de quilômetros quadrados foram drenados e transformados para usos agrícolas, industriais e urbanos, inutilizando funções de grande importância para a sociedade (DIEGUES, 1990).

De acordo com inúmeras estimativas, atualmente a extensão das áreas úmidas está em torno de sete a nove milhões de quilômetros quadrados, ou seja, cerca de $4 \%$ a $6 \%$ de toda a superfície terrestre. Desse valor estimado, mais da metade (56\%) encontra-se em áreas tropicais (2.600.000 $\mathrm{km}^{2}$ ) e subtropicais $\left(2.100 .000 \mathrm{~km}^{2}\right)$. Nas regiões temperadas ocupam uma área de $1.000 .000 \mathrm{~km}^{2}$, e nas regiões polares $200.000 \mathrm{~km}^{2}$ (MITSCH \& GOSSELINK, 2000).

Para Bertolucci (2004), as áreas úmidas variam em tamanho desde muito pequenas a muito grandes, porém todas são importantes para o estabelecimento de plantas raras ou endêmicas. São locais de transição entre o sistema terrestre e aquático, reunindo informações biológicas de ambos os sistemas (JUNK et al., 1989; MITSCH \& GOSSELINK, 2000).

Essas áreas vêm sofrendo um intenso processo de degradação por meio do aterro, construções de canais, dragagens, descargas de pesticidas, fungicidas, poluição urbana e industrial. Como consequência ocorre o empobrecimento biológico, invasão pelo mar, 
deterioração da qualidade da água, sendo que algumas políticas e incentivos que levam à destruição têm sido incrementados (DIEGUES, 1990).

A partir da década de 1960, o governo brasileiro começou a incentivar o plantio em áreas alagadas por meio do programa Pró-Várzea. Com o crescimento do cultivo de arroz no extremo sul do Brasil aumentaram as superfícies desses ambientes aquáticos afetados por obras de irrigação, canalização e dessecação, sem que houvesse qualquer planejamento paralelo no sentido de salvaguardar alguns remanescentes de áreas úmidas naturais para a preservação da fauna e flora (FONTANA et al., 2003).

O Programa PROVARZEAS - Programa Nacional para Aproveitamento Racional de Várzeas Irrigáveis teve início no final de 1980 e início de 1990. O objetivo inicial era o de incorporar áreas de várzea ao sistema produtivo por meio de drenagens, com o cultivo de soja e milho. No Rio Grande do Sul, a maioria do recurso foi utilizada para o cultivo de arroz. Os agricultores receberam vários incentivos, mas deviam se comprometer a fazer rotação de culturas, entre outras medidas (CASTRO, 2003).

Segundo COOPERJA (2010) a implantação de um sistema revolucionário de produtividade e qualidade de arroz começou a mudar o cenário em meados da década de 80. A mudança do cultivo de arroz sequeiro para o cultivo de arroz irrigado no sistema pré-germinado foi o impulso para a definitiva consolidação do sistema de produção de arroz em áreas alagadiças, o sistema Pró-Várzea.

O Rio Grande do Sul foi pioneiro no Brasil na implantação de sistemas de irrigação para agricultura, datando de 1881 o projeto Cadro, que iniciou em 1903 por iniciativa privada e logo após em 1912 no município de Cachoeira do Sul, ambos para o plantio de arroz (CASTRO, 2003).

Dados da Agência Nacional das Águas - (ANA) apontam que até o final de 1980, esse programa, visando à expansão das fronteiras agrícolas, promoveu o aumento da produtividade em várzeas irrigáveis e o maior aproveitamento de solos férteis, irrigando mais de um milhão de hectares no país. Atualmente extinto, o programa empresta sua sigla a uma nova concepção de objetivos conservacionistas: o Projeto de Manejo dos Recursos Naturais da Várzea - Pró-Várzea na bacia amazônica (BRASIL, 2003). 
Em termos regionais, dados de 1998 da Food and Agriculture Organization of the United Nations - FAO indicam as áreas irrigadas no Brasil: Região Norte: 86.660 ha, Região Nordeste: 495.370 ha, Região Sudeste: 890.974 ha, Região Sul: 1.195 .440 ha e a Região Centro Oeste com 201.760 ha. O Rio Grande do Sul é o estado com a maior área irrigada do Brasil com 998.800 ha representando 30\% da área do país LIMA (2000, apud CASTRO, 2003).

Com a crescente necessidade de se obter alimentos vem ocorrendo uma expansão da fronteira agrícola, avançando em locais de grande fragilidade ambiental, colocando em risco a biodiversidade e a própria sobrevivência das populações que ocupam áreas ecologicamente importantes (CHOMENKO, 1995).

A utilização agrícola dessas áreas está associada ao emprego da drenagem ocasionando a completa modificação da hidrodinâmica. Tais alterações interferem na estrutura e funções ecológicas, nos padrões e frequências do hidroperíodo, produzindo a completa transformação e degradação das condições originais (TAVARES, 2007).

A transformação das terras úmidas está ocorrendo numa escala ampla, ao passo que a formulação de leis e diretrizes para a sua proteção ocorre em escalas locais. Dessa forma, é preciso alinhar as duas realidades, analisando-se os impactos cumulativos sobre essas áreas, em uma abordagem abrangente, em termos temporais, espaciais e organizacionais (BEDFORD \& PRESTON, 1988).

A drenagem para a utilização agrícola se constitui em um dos fatores que contribui para o desaparecimento dessas áreas; aliado a isso, ocorre a pressão para a destruição dessas áreas para o avanço urbano e industrial, por meio de iniciativas do governo, de empresas privadas e da população com poucas opções de moradia.

\subsection{Localização e caracterização geral da área de estudo}

\subsubsection{Aspectos naturais}

O rio dos Sinos já teve outras denominações herdadas dos povos indígenas que habitavam a região. Segundo Kayser (2007), os Charruas e os Minuanos chamavam-no de Cururuaí, em referência aos ratões habitantes das terras inundáveis da bacia. Outro nome foi Itapuí, do qual não se sabe exatamente o significado: rio das pedras delgadas ou rio de som de sino, porém, como os 
índios não conheciam sinos, outra interpretação possível é rio das pedras que gritam. O nome utilizado atualmente pode ter derivado da palavra Sinus, que em latim significa seio, enseada ou sinuoso.

O rio dos Sinos está inserido no Complexo Fluvial do Guaíba, também formado pela confluência dos rios Jacuí, Taquarí (afluente do Jacuî), Caí e Gravataí, que formam o delta do rio Jacuí. A porção oeste da bacia hidrográfica do rio dos Sinos, que compreende o trecho médio e inferior da mesma, está situada na Região Metropolitana de Porto Alegre - RMPA.

As nascentes do rio dos Sinos localizam-se no município de Caraá em altitudes superiores a 600 metros. O rio segue no sentido leste-oeste até a cidade de São Leopoldo, onde muda para a direção norte-sul, desembocando no delta do rio Jacuí, no município de Canoas, entre a Ilha Grande, dos Marinheiros e das Garças, numa altitude de apenas 5 metros, (SEMMAM \& COMITESINOS, 2005).

A vegetação da bacia é caracterizada pelo encontro de diversas formações fitogeográficas onde ocorrem a Floresta Ombrófila Mista nas nascentes do rio Rolante (Floresta Nacional de São Francisco de Paula), Savana, Floresta Estacional Decidual, Floresta Estacional Semidecidual e Áreas de Tensão Ecológica. Atualmente a cobertura original está bem reduzida, restando maiores concentrações nas nascentes e nas margens fluviais (COMITESINOS, 2005).

A bacia hidrográfica do rio dos Sinos possui uma rica diversidade biológica (Anexo A). Alguns exemplos da flora são representados pela riccia, planta herbácea flutuante, a ludwigia e o junco, plantas herbáceas emergentes; entre a fauna, a garça branca e o ratão do banhado. Segundo ProSinos (2009), os animais em extinção são a lontra, o jacaré-do-papo-amarelo, o cisne do pescoço preto e o colhecuira.

No que se refere aos aspectos morfológicos da bacia, nos limites ao norte e leste do trecho superior o relevo é pouco dissecado, compreendendo as bordas do planalto basáltico, que faz limite com relevo fortemente dissecado e que atinge parte do limite ao sul e sudeste para o mesmo trecho. A litologia predominante é formada por basaltos da Formação Serra Geral.

No trecho médio, na face norte, o relevo tem a mesma configuração que do trecho superior. Ao longo das áreas adjacentes às planícies afloram colinas areníticas e morros baixos da Formação Botucatu e Serra Geral. 
No trecho inferior predominam as colinas da Formação Botucatu e as planícies fluviais e fluviocoluvionares constituídas por depósitos de cascalho, areia, silte e argila, representando os depósitos do Terciário e do Quaternário.

A formação Rio do Rastro aparece numa pequena porção da face oeste do trecho inferior da bacia configurando um relevo suave formado por colinas.

As áreas de planícies fluviais e de planícies fluviocoluvionares da bacia hidrográfica do rio dos Sinos ganham maior dimensão no trecho inferior, onde predominam áreas de baixa altitude, baixa declividade e relevo suave.

Segundo Maltchik (2003), no trecho superior e médio predominam áreas úmidas de 0.1 a 5 ha; já no trecho inferior, à medida que o canal do rio começa a se expandir e a declividade se torna praticamente nula, essas chegam a aproximadamente 10 ha.

\subsubsection{Aspectos sócio-econômicos e ambientais}

Situada a nordeste do estado do Rio Grande do Sul, a bacia hidrográfica do rio dos Sinos (Figura 01) abrange 30 municípios, sendo oito deles na totalidade e vinte e dois de forma parcial. Possui área aproximada de $3.743 \mathrm{~km}^{2}$ e perímetro de $379,751 \mathrm{~km}$.

Segundo FEPAM (2001), a área total da bacia hidrográfica do rio dos Sinos corresponde a 4,5\% da área total da bacia hidrográfica do Guaíba e a 1,5\% da área total do Estado. Possui população aproximada de 975.000 habitantes, com 90,6\% concentrada na área urbana e 9,4\% em área rural.

Na Região Hidrográfica do Guaíba, onde está inserida a área de estudo, residem mais de 7,1

milhões de habitantes, representando $65,02 \%$ da população do Estado em apenas $30 \%$ da superfície estadual, o que demonstra a concentração populacional desta região. As bacias hidrográficas do Gravataí, Sinos e Lago Guaíba respondem, em conjunto, por quase quatro milhões de habitantes, apresentando as maiores densidades demográficas do Estado. Enquanto a média da Região Hidrográfica do Guaíba é de 84 hab./km², na bacia hidrográfica do rio dos Sinos atinge 359 hab./km² (PRÓ-GUAÍBA, 2004).

A bacia hidrográfica do rio dos Sinos concentra a terça parte das indústrias do estado gerando aproximadamente $40 \%$ da riqueza deste setor. Na região serrana as principais atividades são moveleira, turística e hoteleira, com maior destaque para os municípios de Gramado, Canela 
e São Francisco de Paula. O setor coureiro-calçadista está concentrado nos municípios de Três Coroas, Igrejinha, Novo Hamburgo, Estância Velha e Portão. As indústrias metal-mecânica e petroquímica se destacam em São Leopoldo, Sapucaia do Sul e Canoas (COMITESINOS, 2009). Esta alta concentração populacional e industrial exerce pressão nos recursos naturais, por um lado devido à destruição, por outro, devido ao aumento de demanda. 


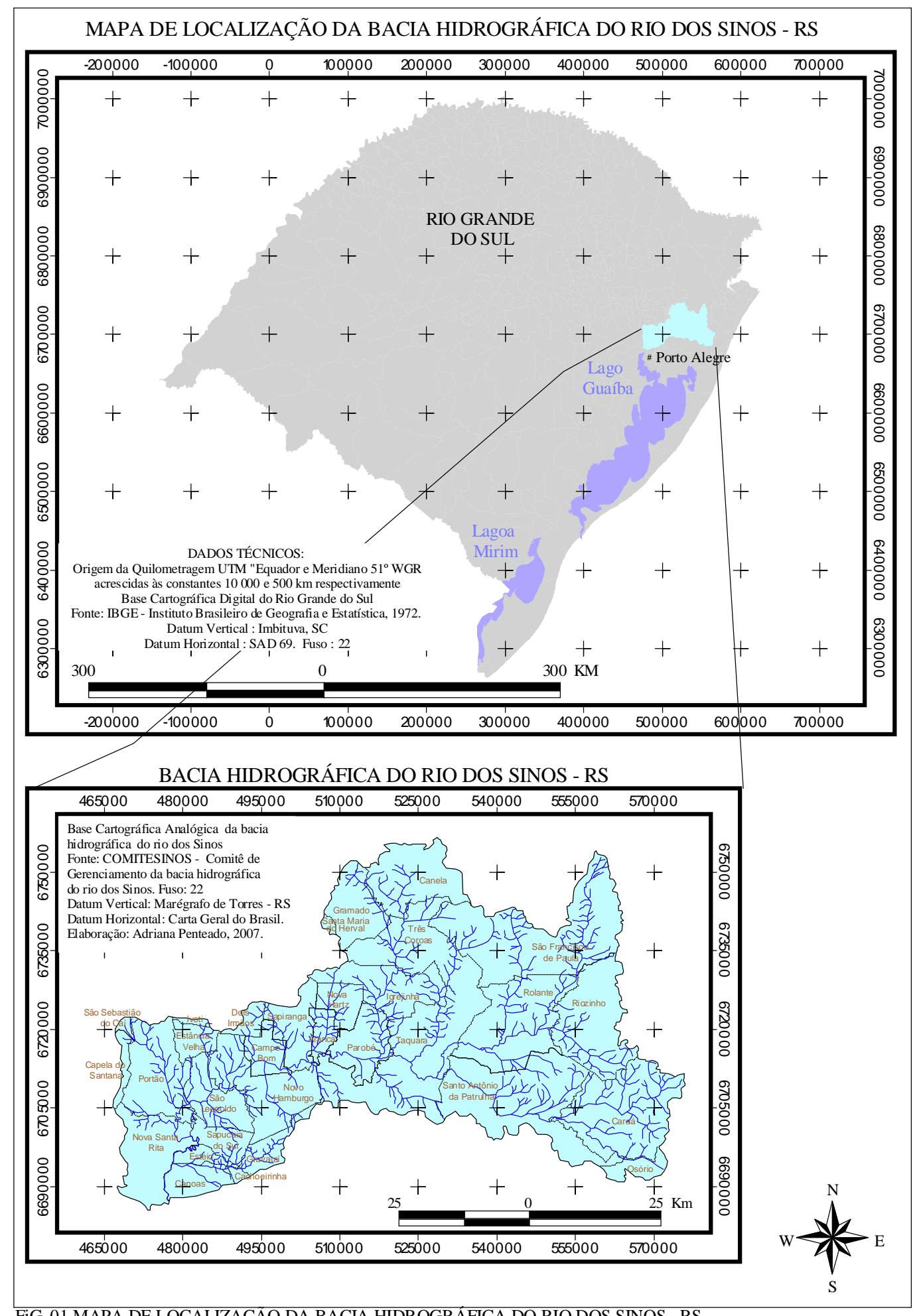

FiG. 01 MAPA DE LOCALIZAÇAO DA BACIA HIDROGRÁFICA DO RIO DOS SINOS - RS

Figura 01: Mapa de localização da bacia hidrográfica do rio dos Sinos - RS.

Fonte: Adriana Penteado, 2007. 
No que se refere ao Índice de Qualidade da Água - IQA, seguindo de montante para jusante no rio dos Sinos, do município de Parobé (trecho médio) a Canoas (foz), a água possui classe quatro, sendo, neste caso, o seu uso recomendado apenas para a navegação e harmonia paisagística. Nos períodos de estiagem com os contínuos despejos industriais e urbanos, a qualidade da água piora e ocorrem problemas para o abastecimento de água potável. Por outro lado, com a alta pluviosidade as inundações atingem a população que se localiza nas margens do rio dos Sinos.

As inundações do rio dos Sinos, na extensão compreendida entre os municípios de Parobé e Campo Bom, oscilam em até $1 \mathrm{~km}$ nas suas margens. Nos municípios de Novo Hamburgo e São Leopoldo, a extensão chega a 2,5 km. Nos municípios de Nova Santa Rita, Esteio e Sapucaia, o rio dos Sinos chegou a extravasar mais ou menos $2 \mathrm{~km}$. No município de Canoas, 3 km, chegando a 6 km no bairro Matias Velho (PROTEGER, 1994).

Os sistemas naturalmente reguladores das inundações e do baixo nível do rio dos Sinos em períodos de estiagem vêm sendo destruídos ao longo do processo de ocupação da área.

A área de estudo escolhida teve o seu processo histórico de ocupação marcado pela proximidade com o rio. Com o passar do tempo, as ocupações se intensificaram e atualmente há uma intensa atividade urbano-industrial na área. Com isso, as terras inundáveis e a rede fluvial sofreram inúmeros impactos, mas ainda é possível encontrar áreas de importância e beleza singular.

\subsection{Objetivos}

\subsubsection{Geral}

O objetivo geral desta pesquisa é o de estudar as terras inundáveis a partir da geomorfologia, abordadas no contexto da bacia hidrográfica na qual se inserem. As discussões e o método de abordagem tentam diminuir as confusões que se dão quanto às definições e às nomenclaturas, e na forma como essas áreas são estudadas. 
Este trabalho tem também por meta identificar as principais intervenções antrópicas causadas às terras inundáveis, pois alteram as características naturais descaracterizando tipologias. Como consequência, a função sócio-ambiental das mesmas pode ser reduzida ou deixar de existir, refletindo em danos para a sociedade.

Devido à existência de terras inundáveis ao longo da bacia hidrográfica do rio dos Sinos, o que contribui para as diferenças tipológicas dessas áreas e a pressão que vêm sofrendo ao longo do tempo, devido à forma de uso e ocupação do solo, a bacia escolhida enquadra-se nos objetivos propostos para esta pesquisa.

\subsubsection{Específicos}

Para alcançar o objetivo geral desta pesquisa os objetivos específicos foram:

- Buscar melhor compreender e definir as terras inundáveis fazendo um paralelo com a definição e formas de classificação das planícies a partir da dinâmica das formas de relevo.

- Análise e discussão de algumas classificações sobre terras inundáveis identificando os parâmetros de classificação e de que forma os mesmos são organizados.

Análises propostas para a bacia hidrográfica em escala regional:

- Uso de imagens de radar para a geração de modelos de elevação do terreno, mapa hipsométrico e de declividade, em escala aproximada de 1:100000.

- Análise do clima, da litologia e da pedologia tendo como base estudos, mapas disponíveis e trabalhos de campo.

- Análise dos dados pluviométricos da bacia hidrográfica do rio dos Sinos.

- Elaboração do mapa geomorfológico da bacia, em escala aproximada de 1:100000, tendo como base os mapas anteriormente citados, além da consulta a imagens do Google.

- Elaboração de perfis transversais e longitudinais ao longo do rio dos Sinos e de seus principais afluentes.

- Análise do processo histórico de ocupação humana na bacia hidrográfica e sua relação com as alterações causadas às terras inundáveis. 
Para as áreas amostrais de terras inundáveis:

- Mapeamento do limite máximo aproximado das terras inundáveis da bacia com base na análise pluviométrica, a partir de imagem de satélite com resolução espacial de 20 metros.

- Análise das terras inundáveis mapeadas identificando tipologias a partir das características dos corpos hídricos identificados.

- Mapeamento e análise do uso do solo das terras inundáveis do rio dos Sinos a partir das imagens disponibilizadas pelo Google Earth.

\subsubsection{Hipótese}

Os estudos referentes às terras inundáveis, em grande parte, dão maior ênfase para fatores biológicos. Outros fatores também são considerados como ponto de partida para os estudos como a origem da água ou características do solo. Esses fatores são analisados pontualmente para cada terra inundável estudada e ora são considerados num primeiro nível de análise, ora são renegados a outros níveis. Isso cria inúmeras caracterizações que se confundem com a noção de tipologias, assim as comparações entre sistemas similares tornam-se difíceis, problema também causado devido à diversidade de designações e definições.

Parte-se do princípio de que as formas e gêneses do relevo determinam as características das terras inundáveis. Assim os estudos referentes ao mesmo podem contribuir para compreender e comparar sistemas similares independente da região na qual estas áreas estão inseridas. De forma a evitar um estudo pontual, essas áreas devem ser estudadas a partir da bacia ou microbacia na qual estão inseridas.

A concentração urbana com o uso e a ocupação inadequada, aliada à falta de conhecimento da importância das terras inundáveis e formas específicas de proteção, tem levado à destruição ou alteração dessas áreas, por meio de aterros, construção de diques, poluição industrial e doméstica.

Neste sentido, a hipótese deste trabalho é a de que analisar as terras inundáveis contextualizadas em uma bacia hidrográfica a partir de parâmetros geomorfologicos pode contribuir na compreensão dessas áreas e diminuir as diversidades de definições e nomenclaturas que se confundem com a noção de tipologias, contribuindo também com a questão metodológica. A partir desse ponto, é possível melhor compreender as possíveis conseqüências causadas pela alteração e/ou destruição desses ambientes devido a ações antrópicas. 


\section{CAPÍTULO 2 MÉTODOS}

\subsection{Teórico - Metodológico}

\subsubsection{Parâmetros para a análise do relevo}

Ross (1991) considera que, no nível regional, quem melhor contribuiu para a geomorfologia brasileira foi Ab'Saber, que sistematizou, organizou e acrescentou conhecimentos que podem ser incorporados de forma quase definitiva na interpretação da gênese do relevo brasileiro. Pode-se afirmar que, de fato, a compartimentação do relevo no território brasileiro torna-se mais compreensível quando se utilizam conceitos de morfoestrutura e morfoescultura.

Compartilhando da afirmativa de Ross, o principal suporte teórico que será utilizado neste trabalho refere-se à proposta metodológica de Ab'Saber (1969), que propõe três níveis básicos de pesquisa em geomorfologia;

Trata-se de uma simbiose conceitual, por meio da qual são reunidos os principais objetivos e enfoques que caracterizam a Geomorfologia contemporânea. Ao sublinhar os níveis de tratamento que consideramos essenciais na metodologia das pesquisas geomorfológicas nos anima apenas a idéia de pôr ordem no caos das postulações pessoais e das controvérsias escolásticas (AB’SÁBER, 1969, p. $01)$.

Em primeiro nível, a Geomorfologia é um campo científico que cuida do entendimento da compartimentação da topografia regional e da caracterização e descrições tão exatas quanto possíveis, das formas do relevo de um dos compartimentos estudados (AB'SÁBER, 1969).

A compartimentação morfológica inclui observações relativas aos diferentes níveis topográficos e características do relevo, que apresentam uma importância direta no processo de ocupação. Nesse aspecto a geomorfologia assume importância ao definir os diferentes graus de risco que uma área possui, oferecendo subsídios ou recomendações quanto à forma de ocupação e uso. (CASSETI, p. 31, 2008). 
Em um segundo nível de tratamento, a Geomorfologia, além dessas preocupações topográficas e morfológicas básicas e elementares, procura obter informações sistemáticas sobre a estrutura superficial das paisagens, referentes a todos os compartimentos e formas dos relevos observados.

Dessa forma, observações geomorfológicas das feições antigas (superfícies aplanadas, relevos residuais) e recentes do relevo (formas de vertentes, pedimentos, terraços, etc.) conduzem a visualização de uma plausível cinemática da paisagem recente (AB’SÁBER, 1969).

A estrutura superficial, ou depósitos correlativos se constitui importante elemento na definição do grau de fragilidade do terreno, sendo responsável pelo entendimento histórico da sua evolução, como se pode comprovar através dos paleopavimentos. Sabendo das características específicas dos diferentes tipos de depósitos que ocorrem em diferentes condições climáticas, torna-se possível compreender a dinâmica evolutiva comandada pelos elementos do clima considerando sua posição em relação aos níveis de base atuais, vinculados ou não a ajustamentos tectônicos (CASSETI, 2008, p. 31).

Em terceiro nível: a Geomorfologia moderna cuida de entender os processos morfoclimáticos e pedogênicos atuais, em sua plena atuação, ou seja, procura entender globalmente a fisiologia da paisagem, por meio da dinâmica climática e de observações mais demoradas e sob controle de equipamentos de precisão (AB’SÁBER, 1969).

Segundo Casseti (2005), a abordagem da fisiologia da paisagem, terceiro nível proposto por Ab Saber (1969), tem por objetivo:

“... compreender a ação dos processos morfodinâmicos atuais, inserindo-se na análise o homem como sujeito modificador. A presença humana normalmente tem respondido pela aceleração dos processos morfogenéticos, como as formações denominadas de tecnogênicas, abreviando a atividade evolutiva do modelado. Mesmo a ação indireta do homem, ao eliminar a interface representada pela cobertura vegetal, altera de forma substancial as relações entre as forças de ação (processos morfogenéticos ou morfodinâmicos) e de reação da formação superficial, gerando desequilíbrios morfológicos ou impactos geoambientais como os movimentos de massa, boçorocamento, assoreamento, dentre outros, chegando a resultados catastróficos, a exemplo dos deslizamentos em áreas topograficamente movimentadas. (CASSETI, 2008, p.31). 
Uma importante base metodológica para os estudos da compartimentação do relevo referese às unidades taxonômicas espaciais e temporais, ou seja, a relação da dimensão espacial da área estudada e os fatores genéticos registrados ao longo do tempo, assim, definindo as variáveis de relevância para a compreensão das formas fisionomicamente semelhantes em seus tipos de modelados.

Para este trabalho será utilizada a proposta de taxonomia do relevo de Ross (1992), que tem sua base teórica nos pressupostos de Penck (1953), Guerasimov (1946), e de Mecerjakov (1968), que desenvolveu os conceitos de morfoestrutura e morfoescultura.

Segundo Ross (1994), o relevo pode ser caracterizado como um dos componentes do meio natural que apresenta uma diversidade enorme de tipos de formas. A sua formação e posterior modificação está condicionada em função das combinações e interferências múltiplas dos demais componentes do estrato geográfico. Essas formas parecem ser estáticas e pouco diferenciadas, porém revelam-se dinâmicas e, a partir das interferências que sofrem, irão mostrar-se de múltiplas maneiras na crosta terrestre. As inter-relações ocorridas podem ser traduzidas pela troca de energia e matéria, sendo geradoras da história atual do relevo e responsáveis, assim, pela evolução e, desse modo, pela gênese do modelado terrestre.

Segundo Penck (1953), o entendimento das atuais formas do relevo terrestre é produto do antagonismo entre as forças endógenas e exógenas. As forças endógenas se revelando de duas formas, a primeira comandada pela dinâmica da crosta terrestre, e a segunda se processando de modo imperceptível através da resistência ao desgaste que a litologia e seu arranjo estrutural oferece a ação de processos exógenos. A ação exógena é também de atuação constante e diferencial no espaço e no tempo, face às características climáticas locais, regionais e sazonais e às mudanças climáticas.

Segundo os princípios de Guerasimov (1946) e Mescerjakov (1968), a morfoescultura se define por processos morfogenéticos comandados por um determinado tipo climático atual, mas também do passado, refletindo a influência da diversidade de resistência da litologia e seu respectivo arranjo estrutural sobre o qual foi esculpida. Já o processo morfoclimático é um produto da ação climática sobre uma determinada estrutura. Dentro desta concepção, os domínios ou zonas morfoclimáticas atuais não são, obrigatoriamente, coincidentes com as unidades morfoesculturais. 
O estudo do relevo da superfície terrestre, objeto da geomorfologia, encerra uma grande complexidade proveniente da sua situação na interface atmosfera/litosfera onde interagem processos endógenos (geológicos) e exógenos (climáticos, biológicos, antrópicos) cujos efeitos são sintetizados na paisagem geográfica.

Por meio dos trabalhos de campo realizados e dos mapeamentos sistemáticos, verifica-se que as variáveis estruturais (litologia, arranjo estrutural, tectônica) têm maior importância na determinação das formas maiores do relevo. Deste modo, os processos endogenéticos são, sem dúvida, os criadores das primeiras formas do relevo (ROSS, 1991).

Com base na proposta de Demek (1967), Mescherikov (1968), e nas experiências do Projeto RADAMBRASIL realizadas entre 1970 e 1980, Ross propôs seis unidades taxonômicas do relevo.

Os táxons do relevo segundo Ross (1992) seguem na sequência, e o desenho esquemático dos mesmos compreende a Figura 02:

- primeiro táxon: caracteriza-se por grandes estruturas do relevo (bacias sedimentares, escudos, cadeias orogênicas), compreendendo a morfoestrutura, onde as suas diferenças são expressas pela estrutura geológica associada a eventos tectônicos.

- segundo táxon: definido como um táxon menor, compreende as unidades morfoesculturais geradas pela ação climática ao longo do tempo geológico. Podem ser identificadas pelas condições topomorfológicas, individualizas por três grandes compartimentos: planaltos, planícies e depressões.

Segundo Casseti (1995), em cada um dos compartimentos são identificados reflexos estruturais (superfície estrutural tabular), paleoerosivos (como as superfícies pediplanadas) e as diferentes formas de dissecação (aguçadas, convexas e tabulares). A identificação desses padrões de formas semelhantes encontra-se associada ao terceiro táxon.

- terceiro táxon: unidades de Padrão de Formas Semelhantes, onde os processos morfoclimáticos atuais começam a ser facilmente notados. Essas unidades guardam entre si elevado grau de semelhança quanto ao tamanho das formas e ao aspecto fisionômico. Exemplo: conjunto de morros e colinas. 
- quarto táxon: compreende as formas do relevo individualizadas dentro de cada unidade de Padrão de Formas Semelhantes. Pode ser formado tanto a partir de processos de agradação quanto de denudação.

- quinto táxon: são as vertentes ou setores de vertentes pertencentes a cada uma das formas individualizadas do relevo. Como exemplo: a forma de uma colina ou morro. Segundo Casseti (2008), no estudo das vertentes os processos morfogenéticos pretéritos e atuais, sobretudo os morfodinâmicos, considerando as derivações antropogênicas, assumem destaque.

- sexto táxon: corresponde às formas menores produzidas pelos processos erosivos atuais ou por depósitos atuais. Ex. voçorocas, cicatrizes de deslizamento, pode-se ainda citar formas antrópicas como corte, aterros.

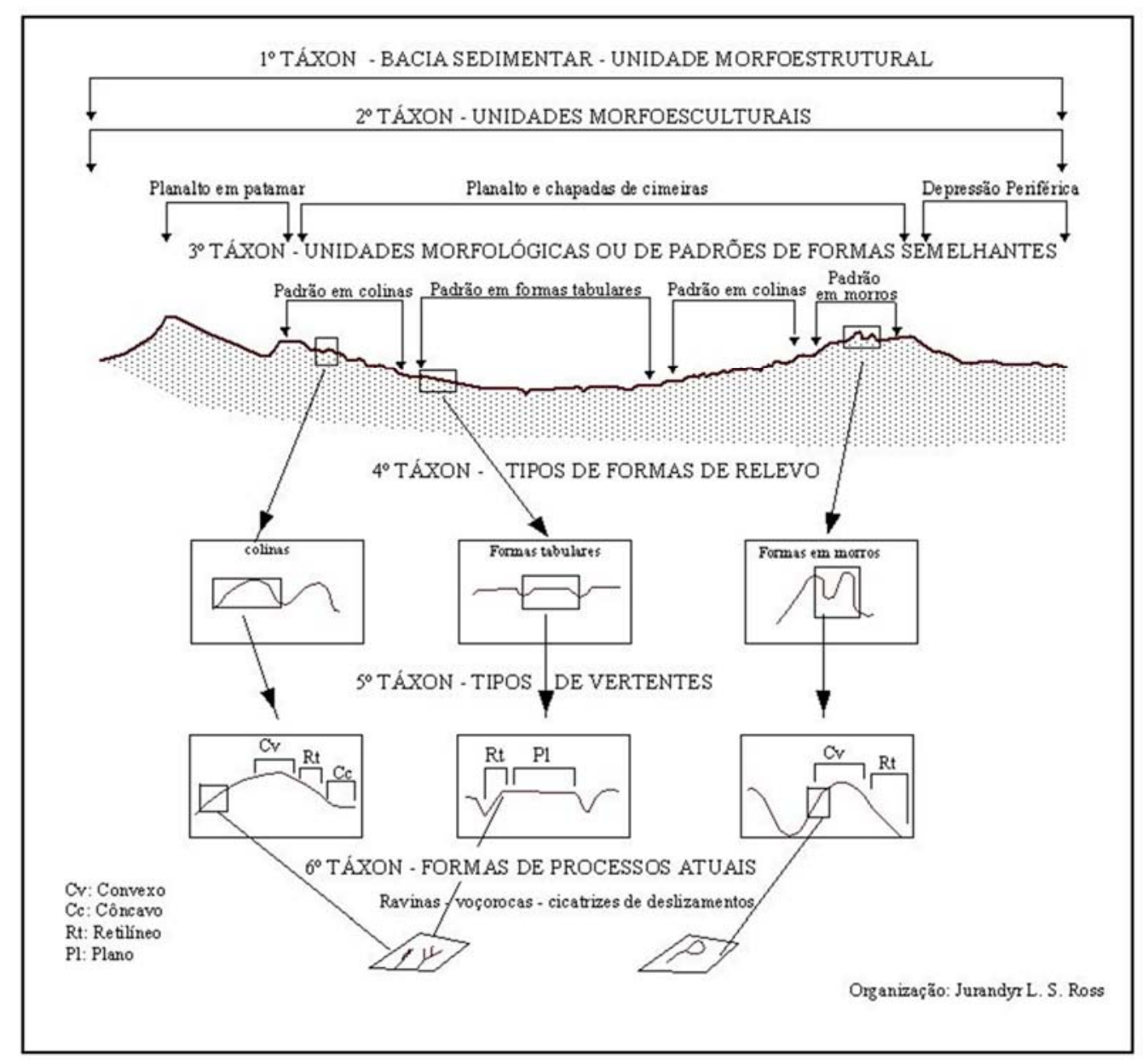

Figura 02: Taxonomia do relevo.

Fonte: Ross (1992). 
O mapa Geomorfológico da bacia hidrográfica do rio dos Sinos será elaborado atingindo o terceiro táxon de detalhamento. Busca-se com este mapa identificar diferenças tipológicas de terras inundáveis para a área de estudo, bem como compreender parte da dinâmica das mesmas.

\subsubsection{Cartografia geomorfológica}

Desde os primórdios da civilização havia interesse no conhecimento espacial dos fenômenos terrestres, buscando conhecer a localização dos mesmos, como se distribuíam e por que ocorriam de tal forma. Atualmente a grande preocupação está concentrada no futuro, buscando identificar como irão ocorrer os fenômenos e como prever soluções que levem à manutenção de um estado de equilíbrio (ARGENTO, 2007).

Dessa forma, torna-se importante ter maior domínio de como os fenômenos se processam para que seja possível, com maior segurança, desenvolver uma melhor base de previsão. A cartografia possui relevante importância como instrumental para tal finalidade, espacializando e permitindo a correlação entre os fenômenos.

A partir de 1909, iniciou-se a tomada de fotografias por aviões, sendo a mesma intensificada na I Guerra Mundial e grandemente desenvolvida na II Grande Guerra. Já em 1960, foram obtidas as primeiras fotografias por satélites tripulados Mercury, Gemini e Apolo. Sendo que a maior contribuição desses satélites foi demonstrar as vantagens e o potencial dessa tecnologia, incentivando o seu avanço (FLORENZANO, 2007).

A partir da década de 1970, a produção de imagens de radar e de satélite permitiu pesquisas em várias áreas: clima, relevo, solo, vegetação, etc. Os avanços tecnológicos permitiram o aprimoramento da cartografia, incluindo aí a cartografia geomorfológica.

A geomorfologia, entendida como o estudo das formas do relevo e dos processos responsáveis pela sua elaboração, tem na cartografia geomorfológica um dos mais importantes veículos de comunicação e análise dos resultados obtidos. Análises das formas, idade e gênese do relevo tornam-se muito mais ricas e lógicas quando acompanhadas de documentos cartográficos (CUNHA, 2001). 
Além dos avanços tecnológicos, o segundo motivo que levou ao avanço da cartografia do relevo foi a necessidade dos países comunistas, sendo os principais deles a antiga URSS, Polônia, Tchecoslováquia e Alemanha Oriental, de demosntrar a utilidade da Geomorfologia como instrumento para o desenvolvimento econômico e social, por meio do mapeamento dos recursos naturais e para o planejamento do território (ROSS, 2005).

No $19^{\circ}$ Congresso da União Geográfica Internacional - UGI, em 1957, dos oito artigos apresentados por diferentes países, constatou-se que os mesmos diferiam no conteúdo e também na maneira de representação. Devido a isso, estabeleceu-se uma subcomissão para o mapeamento geomorfológico com as seguintes tarefas: introduzir um método; adotar um sistema uniforme e principios de preparação para o mapeamento, permitindo assim a comparabilidade; promover a economia nacional por meio dos mapas geomorfológicos, facilitando assim um uso racional da terra (KLIMASZEWSKI, 1982).

Após esse Congresso, muitos artigos foram escritos e várias sessões da subcomissão de mapeamento geomorfológico foram adotadas para realizar as tarefas propostas. Durante as sessões, vários mapas geomorfológicos foram avaliados e, para assegurar a comparabilidade entre os mapas independente do país ou autor, estabeleceram-se escalas de trabalho de detalhe compreendidas entre 1:10000 a 1: 100000, conceito de uma legenda uniforme, principios de uma construção uniforme com o objetivo de faze-lo comparável e legível, estimativa da utilidade dos mapas de detalhe para propósitos práticos (ibid.).

Em 1962, em Kraków, participantes de 15 países concordaram em seguir os seguintes itens para preparar um mapeamento geomorfológico de detalhe:

1) O mapa geomorfológico deve ser o resultado de trabalho de campo, sendo recomendado o uso de fotografias áreas. Atualmente há a possibilidade do uso de imagens de satélite com alta resolução espacial.

2) Os mapas geomorfológicos de detalhe são elaborados em escalas que variam de 1:10000 a 1:100000, pois tais escalas permitem o mapeamento do relevo, e suas peculiariedades podem ser representadas de forma adequada.

3) Um mapa geomorfológico de detalhe dá uma visão completa do relevo, permitindo reconstruir seu passado e prognosticar as tendências de desenvolvimento futuro. Deve incluir dados morfográficos, morfométricos, morfogenéticos e morfocronológicos. 
4) As informações deveriam ser marcadas em um mapa por meio de símbolos em escala. Com o uso de símbolos e cores, a informação é divulgada na perspectiva, tamanho, gênese e idade das formas.

5) Determinar a idade das formas permite introduzir a ordem cronológica no conteúdo do mapa e ajuda a reconstruir o desenvolvimento das formas e prever tendencias futuras de desenvolvimento.

6) Os dados litológicos devem ser marcados com símbolos especiais, de preferência no fundo do mapa.

7) A legenda deve ser elaborada seguindo um ordem genético-cronológica.

8) O mapa geomorfológico de detalhe tem grande importância para o desenvolvimento regional dos territórios que diferem em condições climáticas e de estrutura (KLIMASZEWSKI, 1982).

Os mapeamentos temáticos que identificam os grandes domínios morfoestruturais e as regiões geomorfológicas são condinzentes a escalas iguais ou menores de 1:100000, já os mapeamentos condinzentes com as unidades geomorfológicas devem ser elaborados na escala de até 1:50000 (ARGENTO, 2007).

A cartografação geomorfológica deve mapear concretamente o que se vê e não o que se deduz da análise geomorfológica, portanto em primeiro plano os mapas geomorfológicos devem representar os diferentes tamanhos de formas de relevo, dentro da escala compatível. Em primeiro plano deve-se representar as formas de diferentes tamanhos e em planos secundários, a representação da morfometria, morfogênese e morfocronologia, que têm vínculo direto com a tipologia das formas (ROSS, 1992, p. 25).

O mapeamento geomorfológico tem-se tornado o principal método para o estudo e a pesquisa geomorfológica. Não existe uma definição rígida de quais fatos geomorfológicos podem ser representados em cada escala, isso depende da importância de cada fato para o entendimento geral do relevo da área e dos recursos para o mapeamento (DEMEK, 1967).

Segundo Florenzano (2008), a morfologia, a morfogênese, a morfodinâmica e a morfocronologia são objetos de estudo da geomorfologia e são definidas da seguinte forma:

A morfologia compreende a morfografia que é a descrição qualitativa do relevo, e a morfometria, que se refere caracterização do relevo por meio das variáveis quantitativas. 
A morfografia refere-se aos aspectos descritivos, representados pela forma e aparência do relevo. Exemplos: plano, montanhoso, colinoso. A superfície terrestre constitui-se de elevações e depressões, compreendendo as macroformas que são denominadas de depressões, planícies, planaltos e montanhas.

A morfometria refere-se aos dados quantitativos do relevo, como as medidas de altura, comprimento, largura, superfície, volume, altura absoluta e relativa, declividade, densidade e frequência de suas formas, hipsometria.

A morfogênese refere-se à origem e ao desenvolvimento das formas de relevo, resultado da atuação de processos endógenos e exógenos. Os processos endógenos com origem no interior da Terra, que se manifestam por meio dos terremotos, do vulcanismo, do magmatismo intrusivo e do tectonismo, e os processos exógenos, compreendendo o intemperismo e a erosão que atuam com maior ou menor intensidade dependendo de fatores climáticos.

Morfodinâmica: refere-se aos processos atuais (ativos), endógenos e exógenos, que atuam nas formas do relevo. Os tipos de processos que definem as formas de relevo classificadas de acordo com a sua gênese, podem não corresponder aos que ocorrem nos dias atuais.

A morfocronologia refere-se à idade absoluta e relativa das formas de relevo e aos processos a elas relacionados, sendo essencial distinguir a idade das formas, principalmente fazer a diferenciação entre aquelas recentes e aquelas herdadas de períodos anteriores quando diferentes condições climáticas prevaleciam.

O ser humano passou a ser agente geomorfológico interferindo e intensificando os processos naturais. A forma como o espaço é ocupado e o uso que é feito do mesmo têm causado com frequência danos materiais e humanos. O mapeamento geomorfológico serve como base para o planejamento territorial, permitindo estabelecer quais formas de ocupação e uso são mais adequadas a partir da compreensão da dinâmica das formas de relevo.

A compreensão da dinâmica dos elementos naturais vem ganhando maior relevância na medida em que se intensificam a demanda pelos recursos naturais e também as pressões que causam desequilíbrios. A geomorfologia tem um importante papel neste aspecto, tendo como instrumento de análise e síntese o mapeamento geomorfológico. 


\subsubsection{Modelo Sistêmico}

Com o propósito de compreender as terras inundáveis, além da manifestação espacial de seus limites e da adoção das mesmas a partir de bacia hidrográfica, este trabalho teve também por base a Teoria Geral dos Sistemas - TGS proposta por Bertalanffy (1975).

A Teoria Geral dos Sistemas foi apresentada pela primeira vez por Ludwig Von Bertalanffy, em 1937, no seminário de filosofia de Charles Morris da Universidade de Chicago, sendo publicada somente após a Segunda Guerra Mundial (BERTALANFFY, 1977, p. 127).

Outros estudiosos com suas teorias também contribuíram para a origem do pensamento sistêmico. Segundo Kasper (2000), as 'abordagens sistêmicas fundamentais' são aquelas que estão na origem do pensamento sistêmico:

- Cibernética I, contribuição de Wierner (1970; 1984);

- Cibernética II, que contempla as concepções de Maruyama (1963);

- Cibernética III, que trata da contribuição fundamental de Ashby (1970);

- Dinâmica dos Sistemas, modelo de Forrester (1961; 1990).

O pensamento sistêmico começou a se constituir como movimento no âmbito da ciência em decorrência de três mudanças fundamentais associadas à sociedade industrial: a emergência de uma nova percepção e compreensão da natureza em razão dos desdobramentos na ciência; o desenvolvimento tecnológico impulsionado pela Segunda Guerra Mundial; e a necessidade de administrar estruturas organizacionais cada vez mais complexas, especialmente a partir do pósguerra (KASPER, 2000).

De acordo com Bertalanffy (1975), somente a partir dos anos 1940, como decorrência das grandes transformações tecnológicas impulsionadas pela Segunda Guerra Mundial, criou-se embasamento intelectual e tornou-se propicia a adoção de nova estrutura de referência metodológica.

Com o crescimento da complexidade das organizações humanas, cada vez mais engenheiros e administradores passaram a ser confrontados com situações complexas que envolvem um grande número de elementos, não apenas com as conseqüências relativas às 
interações dos elementos físicos, mas principalmente, com as interações de natureza organizacional envolvendo o fator humano (KASPER, 2000).

A noção de que as interações das soluções eram mais importantes que soluções isoladas levaram a novos campos de investigação. Assim, desenvolveu-se ambiente favorável à emergência das idéias sistêmicas.

Como distinção geral, pode-se afirmar que, enquanto o pensamento tradicional focaliza na análise das partes, o pensamento sistêmico empenha-se em obter sínteses, por meio da totalidade das interações entre as partes relevantes para a existência de um todo (ACKOFF, 1981). Pensar de forma sistêmica é buscar respostas às questões que possuem características que dependem da interpretação de vários fatos.

Podemos declarar como característica da ciência moderna, que este esquema de unidades isoláveis, atuando segundo a casualidade em um sentido único, mostrou-se insuficiente. Daí o aparecimento em todos os campos da ciência de noções tais como totalidade, holístico, organísmico, gestalt, etc., significando todas que, em última instância, temos de pensar em termos de sistemas de elementos em interação mútua (BERTALANFFY, 1975, p. 71 -72).

Bertalanffy explica os principais propósitos futuros da criação da teoria geral dos sistemas:

Acreditamos que a futura teoria geral dos sistemas nos mostrará ser um grande progresso no sentido da unificação da ciência. Pode estar destinada na ciência do futuro a desempenhar um papel semelhante ao da lógica aristotélica na ciência da Antiguidade. A concepção grega do mundo era estática, sendo as coisas consideradas reflexos de arquétipos ou idéias eternas. Por conseguinte, o problema central da ciência era a classificação, cujo organon fundamental é a definição de subordinação e subordinação dos conceitos. Na ciência moderna, a interação da dinâmica parece ser o problema central em todos os campos da realidade. Seus princípios gerais terão de ser definidos pela teoria dos sistemas (BERTALANFFY, 1975, p. 125).

Na década de 1950, Bertalanffy, estudando organismos vivos, observou que estes, embora fossem diferentes em vários elementos, mantinham sempre algumas características comuns que sempre se encontravam presentes independentemente de quais organismos eram estudados. Posteriormente, ele ampliou suas observações a outros tipos de organismos: mecânicos, sociais, etc., e constatou que algumas características se mantinham, não importando a natureza do organismo. 
A mais importante característica que sempre se destacava era a identidade desses organismos. Embora fossem compostos de séries de elementos, percebia-se claramente a interação desses elementos com vistas a atingir um objetivo, que seria a finalidade do organismo (OLIVEIRA, 2007).

O sistema, que seria um termo mais abrangente para organismo, é uma entidade que tem a capacidade de manter certo grau de organização em face de mudanças internas ou externas, composto de um conjunto de elementos em interação, segundo determinadas leis, para atingir um objetivo específico.

Um sistema é uma totalidade integrada, o que implica que a compreensão da sua natureza e de seu funcionamento não pode ser alcançada pela simples análise das partes que o compõem (as propriedades sistêmicas são destruídas quando um sistema é dissecado - física ou teoricamente em elementos isolados). Portanto a abordagem sistêmica enfatiza princípios básicos de organização ao invés de se concentrar nos elementos ou substâncias básicas.

Todo o sistema tem uma natureza orgânica, por meio da qual uma ação que produz mudança em uma das unidades deverá produzir também mudanças em todas as outras unidades, ocorrendo o reajustamento sistemático.

Há uma enorme variedade de sistemas e formas para classificá-los. De acordo com algumas características básicas, os principais tipos são:

Quanto a sua constituição: físico; quando composto de equipamentos, de maquinaria e de objetos e coisas reais. Abstrato; quando composto de conceitos, planos, hipóteses e idéias.

Quanto aos seus elementos: simples: é aquele que possui poucos elementos ou componentes e a relação entre componentes ou elementos não é complicada e direta. Complexo: possui muitos elementos que são altamente relacionados e interconectados. Na realidade, a maioria dos sistemas se situa em um estágio contínuo entre simples e complexo.

Quanto a sua natureza: Aberto: sofre interações com o ambiente onde estão inseridos; fechado: não sofre influência do meio ambiente no qual está inserido, de tal forma que ele se alimenta dele mesmo.

Quanto as suas mudanças: estável: é aquele que mudanças no ambiente resultam em pouca ou nenhuma mudança no sistema; dinâmico: sofre mudanças rápidas e constantes devido à mudança de seu ambiente. 
Quanto ao ambiente: adaptáveis ou não adaptáveis: os conceitos sobre adaptáveis e não adaptáveis estão relacionados à estabilidade e dinâmica. Um sistema adaptável é aquele que responde ao ambiente mutável. Em outras palavras, é aquele que monitora o ambiente e recebe modificações em resposta à mudança do ambiente. O sistema não adaptável é aquele que não muda com o ambiente mutável.

Quanto ao tempo de duração: permanente: é aquele que existe ou existirá por um longo período de tempo, geralmente 10 anos ou mais; temporário: é aquele que existirá por um curto espaço de tempo.

No que se refere aos elementos ou partes componentes de um sistema, destacam-se os seguintes parâmetros:

a) entrada (input) de energia: nenhum organismo é auto-suficiente, pois necessita sempre de entrada e importação de energia do ambiente externo; os sistemas abertos importam energia do ambiente; os animais e vegetais sobrevivem devido à troca constante de energia;

b) transformação de energia: toda a energia que entra no sistema é transformada, formando nova energia que se torna disponível, visando à sobrevivência das espécies;

c) entropia negativa: os organismos do meio ambiente se desgastam e tendem a morrer, por isso é imprescindível que esses sistemas adquiram entropia negativa; para se manter, os sistemas abertos precisam mover-se, a fim de deter o processo entrópico; necessitam adquirir entropia negativa - energia transformada de baixa entropia - visando a evitar a desorganização do sistema; dessa forma, o processo entrópico dos sistemas abertos conduz a desestruturação dos organismos biológicos, sistema aberto, que importa mais energia do meio ambiente do que a desprende, armazena energia e adquire entropia negativa;

d) feedback negativo: todo o sistema aberto, ao receber energia em demasia, emite uma mensagem de feedback negativo com o intuito de manter o sistema na direção correta; os inputs para os sistemas abertos não consistem unicamente em materiais contendo energia, são também de caráter informativo, avisando o sistema sobre a qualidade de energia retroalimentada. O feedback negativo permite aos sistemas abertos corrigir distorções e chegar a um novo estado de equilíbrio, porém quando o feedback é 
interrompido, o seu estado de equilíbrio desaparece, assim, a entropia domina seus mecanismos de retroalimentação, conduzindo-os ao perecimento; energia de baixo aproveitamento;

e) homeostase - consiste num conjunto de elementos auto - reguladores de um sistema aberto que permite manter o estado de equilíbrio do meio ambiente; a energia importada de baixa entropia é utilizada para manter uma constante no sistema; o processo homeostático envolve a manutenção do sistema por intermédio da variabilidade reduzida, decorrente dos efeitos externos; o importante é preservar o caráter estável do sistema.

O excesso de energia entrópica faz com que o sistema não mais suporte o estado de equilíbrio inicial e o conduz a um novo ponto de equilíbrio ou a sua completa deterioração.

A partir das tipologias dos sistemas, uma bacia hidrográfica pode ser caracterizada como física, complexa, aberta, dinâmica e adaptável, com tempo de duração permanente, que pode ser inserido na escala geológica. As terras inundáveis, analisadas dentro da concepção sistêmica, são melhor compreendidas na sua dinâmica e neste trabalho serão consideradas como um subsistema do sistema bacia hidrográfica.

A entrada de energia (input) e massa na forma de água proveniente da precipitação atmosférica e o output por meio da água e de sedimentos que são deslocados por meio dos cursos fluviais e depositados em outras bacias, interferem direta e indiretamente nas terras inundáveis, alterando e ou caracterizando, por exemplo, sua dinâmica hídrica, que por consequiência terá interferência em outros elementos, como o desenvolvimento e/ou a manutenção da biodiversidade característica dessas áreas.

O estudo integrado de bacias hidrográficas teve seu início na década de 1970, alcançando maior relevância com os trabalhos desenvolvidos pela UNESCO e pela UNEP, em 1987, propondo uma metodologia de análise integrada para a avaliação do manejo efetivo e ambientalmente sadio dos recursos hídricos e do patrimônio natural nas bacias hidrográficas. Foi considerado como um sistema não isolado e aberto, dinâmico, explicado pelas constantes trocas de energia e matéria numa relação de entrada e saída. Os estudos sistêmicos, que utilizam como limite de estudo a bacia hidrográfica, têm-se tornado mais importantes para os projetos de 
conservação, planejamento e desenvolvimento sócio-ambiental utilizados nos dias atuais (TORRES, 2008).

A bacia hidrográfica é reconhecida como unidade espacial na Geografia desde o fim de 1960. Na última década, ela foi também incorporada pelas denominadas Ciências Ambientais em seus estudos e projetos de pesquisa. A visão sistêmica e integrada do ambiente está implícita na adoção desta unidade (BOTELHO, 2004).

Ao reconhecermos o estado dos elementos que compõem o sistema de uma bacia hidrográfica (solo, água, ar, vegetação, etc.) e os processos a eles relacionados (infiltração, escoamento, erosão, assoreamento, inundações etc.) é possível avaliar o equilíbrio do sistema.

O sistema aberto é aquele que troca matéria e energia com o seu meio externo (input e output), em construção e destruição de componentes materiais. Em relação à bacia hidrográfica, seu input seria a precipitação e a radiação solar, promovendo a dinâmica no sistema. Seu output seria a água não absorvida pelos organismos e materiais presentes na bacia, esta carregada de elementos como sedimentos, componentes químicos e até mesmo esgoto.

Quando se considera um sistema aberto, é inerente ao sistema a idéia de que, ao alterar um elemento, todo o sistema será afetado, sendo que o mesmo procurará um novo ponto de equilíbrio frente a essa mudança, ou seja, irá procurar produzir um auto-ajuste frente à nova situação.

Sobre os sistemas abertos Bertalanffy (2008) concluiu que estes se mostraram úteis na explicação e na formulação matemática de numerosos fenômenos vitais. O conceito mecanicista da natureza, recentemente predominante, acentuava a resolução dos acontecimentos em cadeias lineares causais e a redução dos processos biológicos às leis conhecidas da natureza inanimada.

Os sistemas naturais não se comportam de forma linear, seus aspectos dinâmicos são altamente organizados no que se refere às trocas de energia e matéria que circulam no sistema natural. A análise geográfica deve ser sistêmica, já que a compreensão das interações entre os elementos é fator de relevância: assim, a análise linear seria, para um Geógrafo, um desvio.

Os sistemas abertos têm a importante propriedade de auto-ajustamento por meio do qual se pode distinguir um estado de equilíbrio dinâmico, onde a importação e a exportação de matéria e energia são equacionadas por meio do ajustamento das formas do sistema (CHORLEY \& KENNEDY, 1971). 


\subsubsection{Parâmetros para a análise das alterações nas terras inundáveis}

O relevo sempre foi percebido pelo ser humano, no conjunto de componentes da natureza, pela sua beleza e forma. É também de grande importância a relação do ser humano com o relevo no sentido que é dado ao mesmo para fixar moradia, execução de estradas, localização para áreas de cultivo e criação de rebanhos.

As significativas alterações promovidas para adaptar o relevo à necessidade de uso muitas vezes causam sérios danos sócio-ambientais, que atualmente podem ter maior proporção devido à grande concentração populacional.

O homem tem a capacidade de alterar os processos de elaboração do relevo, modificando os solos, vegetação, condições hidrológicas, formas de erosão e introduzindo tais modificações no sistema morfológico, que podem conduzir ao desequilíbrio e colapso. A modificação da paisagem é atingida, assim, de maneira indireta através das alterações nas relações de suas variáveis. Numa abordagem geossistêmica, considerando lapsos de tempo na escala do homem, o relevo é considerado como invariante do sistema, enquanto vegetação, solos e atuação dos processos, incluindo a ação do homem, são as variáveis. Para compreender as relações entre relevo e sociedade devemos assimilar que: 1 . O relevo, considerado como invariante do geossistema constitui o espaço morfológico organizado sob as influências climáticas. 2. A ação antrópica deriva ou altera essa organização (ORELLANA, 1981, p. 5).

Segundo Cunha (2001), em relação às estruturas de um sistema, um importante fator referese à interferência efetuada pela ação antrópica nas formas de relevo. Assim, não é possível realizar a análise do relevo sem considerar as estruturas que são controladas por agentes externos.

Para Gregory \& Walling (1973) o ser humano pode promover mudanças de massa e energia nos sistemas em cascata e também instigar mudanças nos sistemas morfológicos e, como consequência, nos sistemas processo-resposta. Considerando que as formas de relevo são o resultado da interação de diversos fatores, verifica-se que as mudanças antrópicas, em qualquer um destes fatores, refletem-se no equilíbrio e nos processos atuantes sobre tais formas.

Nos sistemas abertos, massa e energia que entram, ao transitarem pelo sistema, podem alterar a forma do sistema por meio dos processos que causam. Nesse mesmo contexto está a 
influência antrópica, que pode se processar livremente, já que o sistema aberto recebe energia e massa de qualquer agente externo que possa agir sobre ele (CUNHA, 2001).

O sistema antrópico é capaz de influenciar parte dos sistemas físico-naturais, impondolhes ritmos diferentes e acelerando processos com consequente alteração de suas escalas de tempo de ocorrência (PEREZ FILHO, 2006).

As formas do relevo podem transmitir a idéia de que são componentes independentes na paisagem. Na realidade, elas e os demais componentes do ambiente estão interligados, promovendo ações que, muitas vezes, são induzidas por influências mútuas que em maior ou menor intensidade agem no sentido de criar uma fisionomia que reflete, no todo ambiental ou em suas partes, um ou mais ajustes (CUNHA, 2007).

O modelado constitui-se no substrato físico para a ocupação humana, ele sofre modificações e responde muitas vezes de forma agressiva. Segundo Casseti (1994), mesmo a ação antrópica indireta, ao eliminar a cobertura vegetal, altera de forma substancial as relações entre os processos morfodinâmicos e de reação da formação superficial ou mesmo do substrato, implicando desequilíbrios morfológicos, com os movimentos de massa, vossorocamento, assoreamento, etc.

O propósito para este capítulo é o de fazer um resgate histórico do processo de ocupação da bacia hidrográfica do rio dos Sinos, relacionando este com as principais alterações promovidas nas terras inundáveis e suas consequências. Para isso serão feitas pesquisas bibliográficas, visitas a órgãos competentes e trabalhos de campo.

\subsection{Operacional}

\subsubsection{Clima da área de estudo e análise dos dados pluviométricos}

A caracterização regional do clima da área de estudo foi elaborada a partir de revisão bibliográfica e identificou-se a influência das massas de ar, amplitudes térmicas, média histórica sazonal e anual, temperatura máxima anual média e mínima e a influência do clima na esculturação do relevo. A partir da análise dos dados pluviométricos foi possível reafirmar tendências verificadas pelos autores que foram pesquisados. A estação da qual os dados foram 
analisados localiza-se no município de Sapucaia do Sul e possui código 2951028 junto à Agência Nacional das Águas - ANA.

Os dados pluviométricos foram disponibilizados pela ANA em 2010. Optou-se por fazer um recorte de dez anos para as análises, partindo do ano mais recente com dados disponíveis. O intervalo analisado foi de 1999 a 2008.

A partir dos dados brutos foram elaborados gráficos para cada ano, com o total pluviométrico para cada mês. As análises foram correlacionadas entre os anos, identificando os meses mais e menos chuvosos. Essa análise contribuiu para a escolha das imagens de satélite que foram utilizadas para identificar as terras inundáveis em períodos em que estas atingem limites mais elevados de inundação.

\subsubsection{Interpolação das imagens de radar e geração de curvas de nível}

O projeto SRTM (Shuttle Radar Topographic Mission) advém de cooperação entre a NASA (National Aeronautics and Space Administration) e a NIMA (National Imagery and Mapping Agency), do DOD (Departamento de Defesa) dos Estados Unidos e das agências espaciais da Alemanha e da Itália. O sobrevoo da SRTM ocorreu no período de 11 a 22 de fevereiro de 2000, durante o qual foram percorridas 16 órbitas por dia, num total de 176 órbitas. O sobrevôo foi concluído com a coleta de $12 \mathrm{~TB}$ de dados que vêm sendo processados para a formação de Modelos Digitais de Elevação (MDE). O processamento dos dados coletados visou à formação de um MDE mundial, elaborado continente por continente, iniciado com a América do Norte (VALERIANO, 2004).

A identificação de sistemas terrestres ganha mais objetividade e uniformidade em relação aos métodos tradicionais (qualitativos), quando se adotam métodos paramétricos (quantitativos) que requerem a medição e mapeamento de variáveis do relevo, destacando-se dentre elas a altitude, declividade, curvaturas vertical e horizontal, orientação de vertentes, dentre outras variáveis morfométricas, caracterizando o relevo de forma mais completa (id., 2008).

A abordagem paramétrica pode ser substancialmente facilitada por alternativas como imageamento orbital e geoprocessamento de MDEs, possibilitando a extração automática de 
informações da topografia, amenizando assim a demanda de trabalho manual e a subjetividade dessas atividades.

A imagem SRTM é utilizada em trabalhos científicos como fonte de informações altimétricas de qualidade para escalas entre 1:100000 e 1:250000 (VALERIANO, 2008). A escolha da imagem SRTM, como superfície digital, se fundamenta pela qualidade dos seus dados, além de apresentar a vantagem de ser disponibilizada gratuitamente.

Para o presente trabalho, as imagens utilizadas foram interpoladas pelo método de krigagem, sendo considerado um bom método, pois utiliza o dado tabular e sua posição geográfica para calcular as interpolações.

Segundo o princípio da Primeira Lei de Geografia de Tobler, as unidades de análise mais próximas entre si são mais parecidas do que unidades mais afastadas. A krigagem utiliza funções matemáticas para acrescentar pesos maiores nas posições mais próximas aos pontos amostrais e pesos menores nas posições mais distantes, criando assim os novos pontos interpolados com base nessas combinações lineares de dados (JAKOB, 2002).

As imagens de radar que compõem a área de estudo são: SH-22-X-C e SH-22-V-D. Estas foram recortadas pela área de estudo e posteriormente mosaicadas. A partir da interpolação, os dados com resolução de 90 metros foram reamostrados para 30 metros.

A partir da correção e interpolação das imagens de radar, foi possível gerar no modo automático as curvas de nível cotadas da bacia hidrográfica do rio dos Sinos com intervalo de 10 metros. Essas curvas serviram como base para a elaboração dos mapas de declividade, hipsométrico, modelo de elevação do terreno e perfis transversais e longitudinais.

2.2.2.1 Confecção dos mapas hipsométrico, declividade, MDE e perfis transversais e longitudinais

$\mathrm{Na}$ maioria das vezes a representação do relevo é realizada em duas dimensões (x, y), entretanto, para representar sua forma, que é tridimensional, é necessário utilizar curvas de nível com três dimensões $(x, y, z)$ e, dessa forma, possibilitar a geração de modelos de elevação.

Até a década de 1970 as cartas topográficas convencionais constituíram-se nas ferramentas mais apropriadas para descrever a superfície do terreno. Apesar da sua utilidade, devido à 
comprovada facilidade de percepção visual da superfície topográfica, apresenta algumas limitações quando se pretende realizar análises quantitativas precisas e rápidas das formas das altitudes e, principalmente, quando se busca integrá-las, em sistemas mais complexos, com variáveis climáticas, geomorfológicas, biológicas e antrópicas (GRANELL-PÉREZ, 2004).

Com a maior utilização da informática, a partir de 1980, possibilitou-se descrever numericamente a superfície do terreno com o auxílio do computador e manipular simultaneamente, dentro de um SIG, outras variáveis passíveis de expressão cartográfica, facilitando assim os estudos sistêmicos onde diferentes variáveis integram-se em sistemas de elementos inter-relacionados e interdependentes.

Segundo Granell-Pérez (2004), as cartas topográficas convencionais podem ser entendidas como modelos analógicos do relevo, que representam as variações espaciais de altitude do terreno por meio de símbolos convencionais, e pela análise destes, o relevo pode ser deduzido por analogia. Já os Modelos de Elevação - $\mathrm{MDEs}^{2}$ elaborados em meio digital são modelos simbólicos, com maior grau de abstração, onde o relevo é representado por simbolização matemática.

Segundo Burrough (1986), dentre alguns usos dos MDEs destacam-se:

a) armazenamento de dados de altimetria para gerar mapas topográficos;

b) elaboração de mapas de declividade para apoio à análise de geomorfologia e erodibilidade;

c) análise de variáveis geofísicas e geoquímicas;

d) apresentação tridimensional (em combinação com outras variáveis).

A criação de um modelo numérico do terreno corresponde a uma nova maneira de tratar o problema da elaboração e implantação de projetos. A partir dos modelos (grades) pode-se calcular diretamente e gerar mapas de declividade, gerar fatiamentos nos intervalos desejados e perspectivas tridimensionais.

\footnotetext{
${ }^{2}$ Podemos considerar como sinônimos os conceitos de Modelo Numérico do Terreno - MNT, Modelo Digital do Terreno - MDT e Modelo de Digital de Elevação - MDE, que determinam uma representação matemática da distribuição espacial de uma determinada característica vinculada a uma superfície real. A superfície é, em geral, contínua, e o fenômeno que representa pode ser variado (FELGUEIRAS \& CÂMARA, 2006).
} 
Os Modelos Digitais de Elevação - MDEs e os Sistemas de Informações Geográficas SIGs são atualmente ferramentas que auxiliam na compreensão das relações geográficas na visualização, pesquisa e modelagem dos dados espaciais. Atualmente, um desafio é aprimorar as técnicas de geoprocessamento com o mapeamento geomorfológico.

As curvas de nível digitais e cotadas podem ser manipuladas em modelos digitais e algoritmos de interpolação que permitem a obtenção de informações relativas à declividade, à orientação de vertentes, à geração de modelos tridimensionais, à hipsometria, ao perfil topográfico, entre outras informações morfométricas (CASTRO, 2000).

Em relação ao mapa hipsométrico, este se preocupa em estudar as inter-relações existentes em determinada unidade horizontal de espaço no tocante à sua distribuição em relação às cotas altitudinais, indicando a proporção ocupada por determinada área da superfície terrestre em relação às variações altimétricas a partir de determinada isoípsa base, possibilitando conhecer o relevo (ROSA, 2003).

O mapa hipsométrico da bacia hidrográfica do rio dos Sinos, gerado a partir da triangulação das curvas de nível, foi dividido em nove classes: 0 - 25, 25 - 50, 50 - 150, 150 - 300, 300 450, 450 - 600, 600 - 750, 750 - 850 e 850 a 980 metros. Os intervalos não obedeceram a um padrão regular, pois a melhor adequação de intervalo depende da escala de apresentação de cada trabalho, bem como das características do relevo. Foram elaborados testes para a melhor representação das classes, chegando-se aos intervalos acima. Buscou-se também uma correlação entre as classes e a litologia da área.

O mapa de declividade foi dividido em seis classes: 0 - 2, 2 - 5, 5 - 12, 12 - 24, 24- 45 e > $45 \%$. Estes intervalos não obedeceram a um padrão, pois se buscou separar as áreas planas, de média e alta declividade, correlacionando com os mapas hipsométrico e geológico.

Os mapas de declividade e hipsométrico foram gerados na escala 1: 100000.

A análise topográfica, que diz respeito à altitude e à declividade, é importante por exercer influência na precipitação pluviométrica, na formação de lagos e planícies e na determinação da velocidade do escoamento superficial (VILLELA \& MATTOS, 1979).

A partir do Modelo de Elevação do Terreno - MDT foram gerados três perfis transversais da bacia: nos trechos inferior, médio e superior, perfis longitudinais dos rios Paranhana, da Ilha, Rolante e dos Sinos. Ao longo da bacia foram também gerados perfis ao longo dos 
compartimentos geomorfológicos. A análise dos perfis permite a correlação entre declividade, hipsometria, geologia e formas de relevo.

Os modelos de elevação serviram como apoio para a análise da bacia, não sendo incluídos mapas dos mesmos no trabalho, buscando evitar análises repetitivas.

\subsubsection{Confecção do mapa geológico e geomorfológico}

O mapa geológico foi georreferenciado e digitalizado a partir da escanerização das folhas Caxias do Sul e Gravataí, gerados pelo Serviço Geológico do Brasil - CPRM, de agosto de 1998, na escala 1: 250000 .

O mapa geomorfológico teve como base de elaboração os mapas de declividade, hipsométrico, modelos digitais de elevação e o mapa geológico, assim como consulta de imagens Google Earth. Metodologicamente o mapa foi embasado na taxonomia do relevo proposta por Ross (1992), atingindo o terceiro táxon, que compreende o padrão de formas semelhantes. Foi gerado na escala aproximada de 1: 100000.

\subsubsection{Confecção dos mapas das terras inundáveis}

Por meio do sensoriamento remoto é possível obter imagens e outros tipos de dados da superfície terrestre através da captação e do registro da energia refletida ou emitida pela superfície, sem o contato direto com o alvo, de forma remota.

As técnicas de sensoriamento remoto foram amplamente utilizadas durante a Primeira e a Segunda Guerra Mundial, com fins militares. Porém até então, apenas as fotografias aéreas obtidas à média e baixa altitudes mereciam destaque (ROSA, 1992).

Em 1972, os EUA deram um salto e colocaram em órbita o primeiro satélite de sensoriamento remoto com finalidade civil, destinação e obtenção de dados de forma rápida, confiável e repetitiva dos alvos terrestres.

A partir desse momento, inúmeros outros sistemas de obtenção de dados passivos e ativos foram desenvolvidos e hoje há uma enorme quantidade de informações fornecidas por esses 
sensores, que nos permitem conhecer melhor o planeta, sendo ferramentas fundamentais ao inventário, mapeamento e monitoramento dos recursos naturais.

No Brasil, o sensoriamento remoto ganhou destaque a partir de 1970, com o Projeto RADAMBRASIL $^{3}$, que tinha como objetivo básico fazer um levantamento integrado dos recursos naturais do país.

As primeiras imagens de satélite, que foram do LANDSAT, foram recebidas pelo país em 1973. Atualmente o Brasil gera imagens a partir dos satélites CBERS-2 e CBERS-2B, produto de um programa de cooperação entre o Brasil e a China (FLORENZANO, 2002).

Os dados de sensoriamento remoto são captados por meio da refletividade da radiação eletromagnética, que se propaga por meio de ondas eletromagnéticas com a velocidade da luz, sendo medida pela frequência (hertz-Hz) e comprimento de onda (em unidades de metros).

Porém a radiação eletromagnética não pode chegar diretamente ao sensor em todas as faixas do espectro, pois a transmissividade atmosférica é variável para os diversos comprimentos de onda. Dessa forma, torna-se importante, além do conhecimento da resposta espectral dos alvos que se deseja mapear, a identificação das janelas atmosféricas, que são as faixas onde a radiação sofre menor interferência de gases que causam efeitos de absorção e espalhamento.

No gráfico 01 (eixo x: faixa do espectro eletromagnético e eixo y: porcentagem de absorção), as cores representadas em cinza correspondem à melhor resposta espectral (janelas atmosféricas), e os locais em preto são aqueles onde a radiação eletromagnética sofre maior interferência.

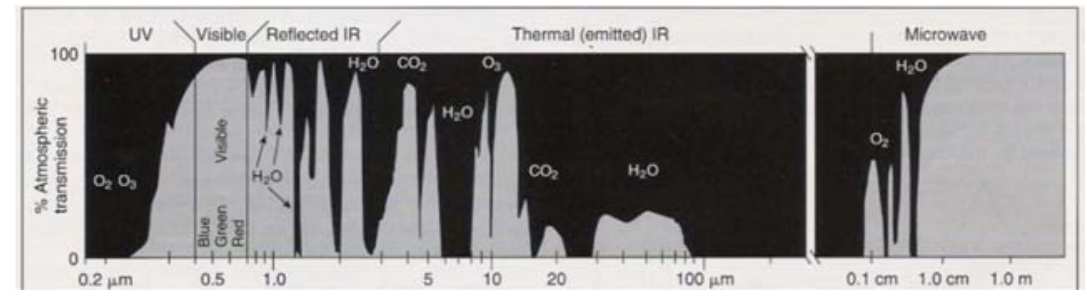

Gráfico 01: Janelas atmosféricas e faixas do espectro de maior absorção da REM.

\footnotetext{
${ }^{3}$ O território brasileiro foi imageado pelo sistema de radar GEMS - Goodyear Environmental Monitoring System. As imagens foram tiradas em dois momentos: 1971/1972 e 1975/1976. No primeiro período cobriu a Amazônia Legal, parte leste dos estados da Bahia e Minas Gerais e norte do Espírito Santo; o segundo cobriu o restante do Brasil. Os mapas resultantes foram publicados na escala 1: 1.000000. Fonte: Florenzano, 2008.
} 
Ao comparamos um mesmo alvo com e sem a presença de umidade, percebe-se que esta sempre interfere na resposta espectral do alvo causando maior absorção da radiação. Dessa forma, os alvos refletem menos energia e se apresentam na imagem em tons mais escuros. $\mathrm{O}$ gráfico 02, demonstra uma relação inversa entre quantidade de água no solo e sua refletância, o que também pode ser verificado na figura 03.

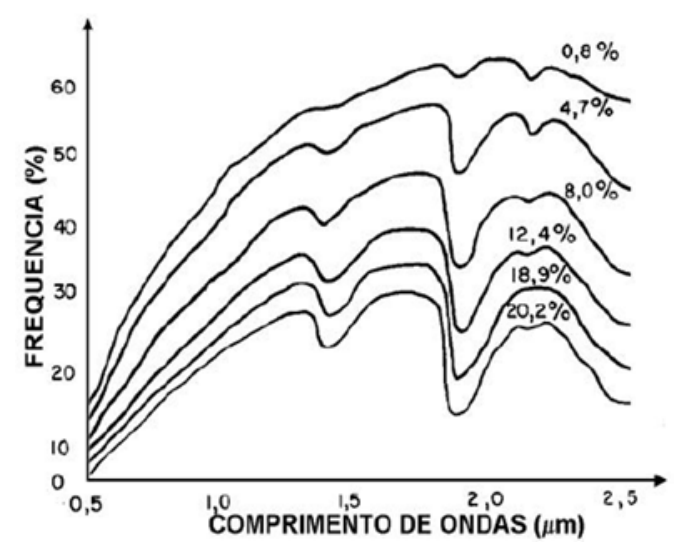

Gráfico 02: Quantidade de água e sua relação com a refletância.

Fonte: INPE, 2007.

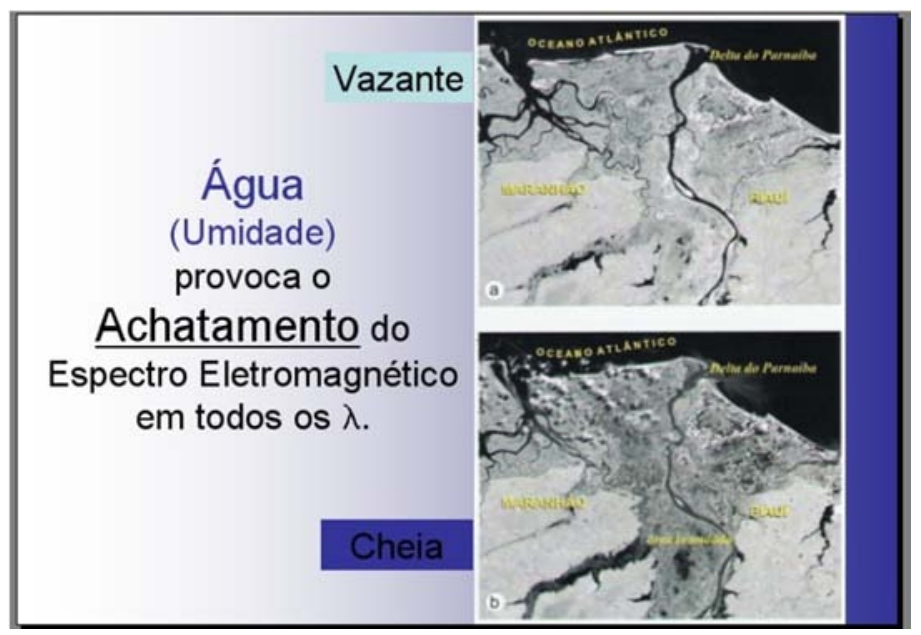

Figura 03: Diferença na resposta espectral do rio no período de vazante (a) 14/06/1990; e no período de cheia (b) 31/05/1985.

Fonte: FLORENZANO, 2002.

Com base na melhor resolução espectral, as melhores imagens disponíveis gratuitamente para serem utilizadas no mapeamento das terras inundáveis, seriam as imagens do Landsat, 
porém estas possuem resolução espacial de 30 metros e isso diminuiria de forma significativa o detalhamento das informações geradas. Optou-se dessa forma pelo uso das imagens CBERS com resolução de 20 metros, também disponibilizadas gratuitamente, mediante cadastro na página do INPE.

Para o mapeamento das terras inundáveis da bacia hidrográfica do rio dos Sinos, foram utilizadas duas imagens de satélite, buscando identificar os limites dessas áreas em período de maior concentração pluviométrica, baseando-se na análise dos dados disponibilizados pela ANA - Agência Nacional da Águas.

As cenas utilizadas foram 157_33 e 156_33, de 07/09/2005 e 16/06/2004 respectivamente, bandas 1, 2, 3 e 4 com resolução espacial de 20 metros, do sensor CBERS_CCD_2, com as características especificadas no quadro 01.

As imagens foram disponibilizadas no sistema de projeção UTM. As mesmas foram convertidas para o sistema WGS-1984, compatível com as demais informações geradas no trabalho.

\begin{tabular}{|c|c|}
\hline \multicolumn{2}{|c|}{ Características da Câmera Imageadora de Alta Resolução CCD } \\
\hline Bandas espectrais & $\begin{array}{l}0,51-0,73 \mu \mathrm{m} \text { (pan) } \\
0,45-0,52 \mu \mathrm{m} \text { (azul) } \\
0,52-0,59 \mu \mathrm{m} \text { (verde) } \\
0,63-0,69 \mu \mathrm{m} \text { (vermelho) } \\
0,77-0,89 \mu \mathrm{m} \text { (infravermelho próximo) }\end{array}$ \\
\hline Campo de Visada & $8,3^{\circ}$ \\
\hline Resolução espacial & $20 \times 20 \mathrm{~m}$ \\
\hline Largura da faixa imageada & $113 \mathrm{~km}$ \\
\hline Capacidade de apontamento do espelho & $\pm 32^{\circ}$ \\
\hline Resolução temporal & $\begin{array}{l}26 \text { dias com visada vertical } \\
\text { (3 dias com visada lateral) }\end{array}$ \\
\hline
\end{tabular}

Os intervalos espectrais do azul (banda 1), do verde (banda 2), do vermelho (banda 3 ) e do infravermelho próximo (banda 4) da câmera CCD do CBERS têm alta proximidade com os 
intervalos das imagens do LANDSAT 5 e 7. Assim o quadro 02 permite saber quais são as principais aplicações das bandas do CBERS, apesar de terem sido geradas para as imagens LANDSAT.

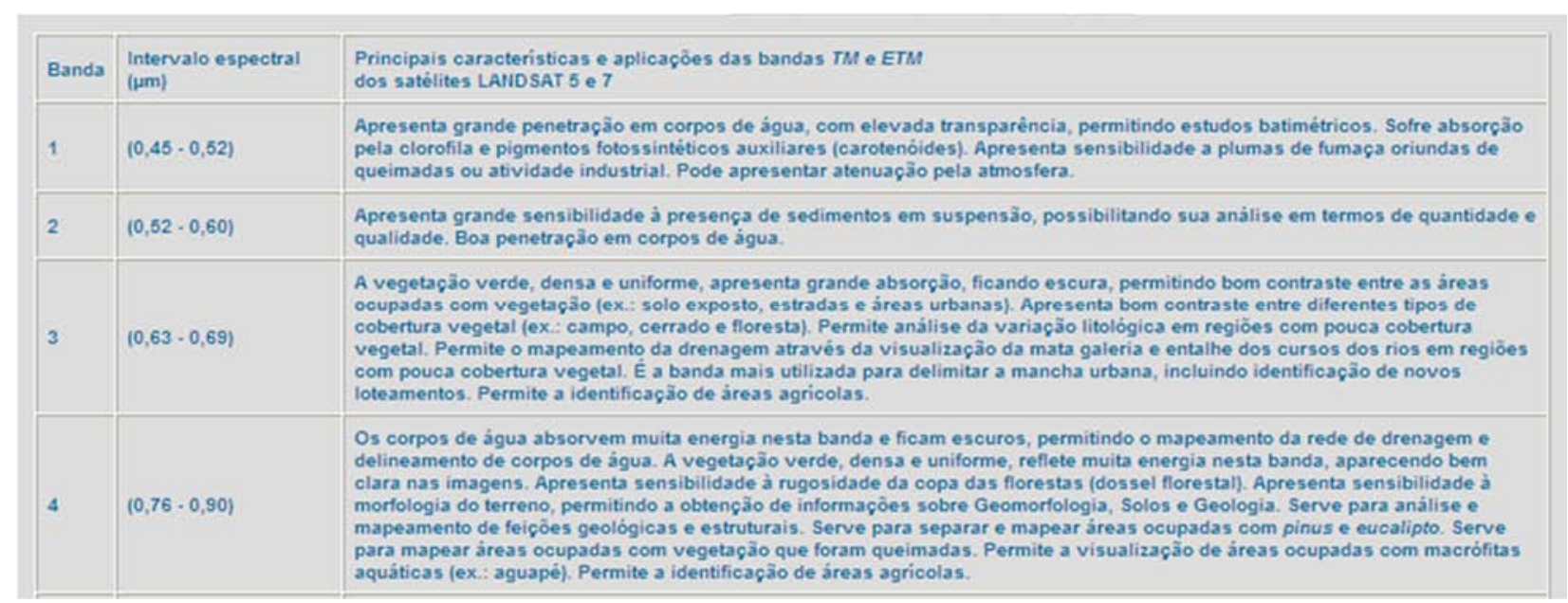

QUADRO 02: Principais aplicações das bandas 1,2,3 e 4 dos satélites Landsat 5 e 7. Fonte: INPE - Instituto Espacial de Pesquisas Espaciais, 2009.

Com base no quadro 02 a melhor banda para o mapeamento das terras inundáveis seria a quatro, porém a mesma isoladamente se apresentaria em tons de cinza, a manipulação com outras bandas permitiu uma composição colorida que facilitou a identificação dos fatores mapeados.

Técnicas de processamento digital de imagens, como a composição colorida e manipulação de contrastes, permitem realçar as feições e os distintos padrões favorecendo uma posterior análise visual e uma melhor distinção de unidades. A cor é um dos principais atributos de reconhecimento do sistema visual humano, que é capaz de distinguir dezenas de milhares de cores diferentes.

\subsubsection{Mapeamento do uso e dos recursos hídricos naturais e antropogênicos das terras} inundáveis da bacia hidrográfica do rio dos Sinos

Os mapas de uso do solo, o refinamento dos limites das terras inundáveis e o mapeamento dos corpos hídricos foram elaborados a partir das imagens disponibilizadas pelo Google Earth.

A vetorização foi elaborada sobre as imagens a partir do comando: adicionar caminho. Posteriormente, os arquivos com extensão kmz foram exportados para o software Spring onde 
foram convertidos para a extensão shp, para que os mesmos pudessem ser editados no programa Arc Gis 9.0.

Não foi necessário refinar o georrefenciamento, que se manteve mesmo com as conversões elaboradas. A partir daí foram elaborados os layouts dos mapas.

\subsubsection{Trabalhos de campo}

Os levantamentos de campo desta pesquisa iniciaram a partir de trabalho anterior desenvolvido em uma sub-bacia pertencente à bacia hidrográfica do rio dos Sinos. Desde então foram feitas observações sobre a dinâmica das terras inundáveis e como estas são percebidas pela população local. O principal apoio recebido para a realização dos levantamentos de campo, para o trabalho anterior, ocorreu por meio do Projeto Monalisa ${ }^{4}$.

Os trabalhos de campo, num primeiro momento, tiveram por objetivo compreender a dinâmica dos aspectos físicos da bacia, buscando corrigir e verificar mapas elaborados, tomadas de fotografias e de registros escritos. Toda a extensão da bacia foi percorrida ao longo do desenvolvimento da pesquisa.

Com o objetivo de encontrar dados históricos foram feitas visitas em museus e bibliotecas que possuem fotografias e reportagens antigas. Outros órgãos, como prefeituras e secretarias de meio ambiente, possuem materiais que ajudaram na pesquisa.

\subsubsection{Materiais}

- Imagens de radar SRTM. Articulação: SH-22-X-C e SH-22-V-D. Resolução Espacial 90 metros.

- Mapa Geológico Integrado da Bacia Hidrográfica do Guaíba. Folhas SH.22.VD, Caxias do Sul (1998); SH.22.X-C/D Gravataí (2000), ambos na escala 1:

\footnotetext{
4 Este projeto tratou dos impactos ambientais causados na bacia hidrográfica do rio dos Sinos e, a partir dos levantamentos, o objetivo era elaborar uma avaliação sobre a capacidade de manutenção das lavouras de arroz e o comprometimento que estas poderão sofrer, bem como outras atividades produtivas, frente à possibilidade de expansão descontrolada das áreas cultivadas.
} 
250000. Disponibilizados em formato analógico pelo Serviço Geológico do Brasil - CPRM.

- $\quad$ Mapa Geológico, Geomorfológico, Pedológico e do Relevo. Folha SH 22 Porto Alegre e parte das folhas SH 21 Uruguaiana e SI 22 Lagoa Mirim. Escala 1:1.000000. Projeto RADAMBRASIL, 1986.

- Dados pluviométricos fornecidos pela Agência Nacional das Águas - ANA (2010), da estação 2951028, localizada no município de Sapucaia do Sul.

- Imagens CBERS_CCD_2, cenas 157_33 e 156_33, de 07/09/2005 e 16/06/2004 respectivamente, bandas 1, 2, 3 e 4 com resolução espacial de 20 metros.

- $\quad$ Imagens disponibilizadas pelo Google Earth.

- $\quad$ GPS Magellan 315.

\subsubsection{Softwares:}

* Envi 4.0: georreferenciamento, mosaicamento e composição das imagens.

* Arc Gis 9.0: interpolação e extração de curvas de nível a partir de imagens de radar, vetorização do mapa geológico, edição da hidrografia, geração dos mapas de declividade, hipsométrico, perfis, geomorfológico, uso do solo. Combinação das informações para análise.

* Spring 5.1 .7

* Google Earth 5.2.1

Os programas que não estão disponíveis gratuitamente foram fornecidos pelo laboratório de SIG, do curso de Engenharia Cartográfica da Universidade Federal do Rio Grande do Sul UFRGS. 


\section{CAPÍTULO 3 CONSIDERAÇÕES SOBRE O OBJETO DE ESTUDO E RELAÇÃO COM AS PLANÍCIES DE INUNDAÇÃO}

\subsection{Breve discussão sobre as várias denominações para o objeto de estudo}

Durante a pesquisa bibliográfica sobre o tema de estudo verificaram-se variadas nomenclaturas e também definições, o que até certo ponto causou dificuldades, em um primeiro momento, para compreender o objeto em questão. Optou-se dessa forma em elaborar uma definição, já estabelecida na parte introdutória do trabalho, bem como designações que buscam ser mais claras.

Acredita-se que nem sempre os limites de outras definiçõos coincidam de forma exata com o que se definiu como terras inundáveis neste trabalho, mas é possível afirmar a grande relação entre as definições, e a busca por parte daqueles que estudam este tema em avançar em relação aos vários desafios que ainda se apresentam sobre o assunto.

Os exemplos aqui colocados, bem como a discussão sobre os mesmos têm por objetivo esclarecer alguns pontos em relação aos termos utilizados por pesquisadores e a população em geral.

Muitos países utilizam terminologias locais para a definição de terras úmidas (SCOTT \& JONES, 1995). A especificidade e a regionalidade dos termos prejudica a identificação correta que, entre outros problemas, dificulta a comparação entre sistemas similares de diferentes regiões geográficas.

A nomenclatura é bastante ampla em relação aos corpos d'água: arroio, riacho, córrego, rio, lago, lagoa, mar, oceano, o que pode variar segundo a escala e/ou a região de trabalho. Tal fato também ocorre em relação às terras úmidas e, tanto um como o outro podem ser classificados como: efêmeros, intermitentes ou perenes (CHRISTOFOLETTI, 1974, p. 52).

No Brasil as leis que tratam da preservação dessas áreas geralmente utilizam termos locais: pântano, brejo, banhado, alagado, igapó, igarapé, corixo, sanga, etc., que nem sempre incluem todas as classes de áreas úmidas de uma região dificultando ações voltadas para a conservação. $\mathrm{O}$ uso dessas terminologias em trabalhos científicos restringe a compreensão e dificulta a comparação entre sistemas similares (MALTCHIK, 2006). 
Abaixo seguem algumas definições ${ }^{5}$ para alguns termos que estão relacionados ou se referem ao objeto de estudo:

Pântano: terreno plano, constituindo baixadas inundadas junto aos rios. Também recebe a denominação de brejo.

Brejo: terreno plano, encharcado, que aparece nas regiões de cabeceira ou em zonas de transbordamento de rios.

Banhado: Termo derivado do espanhol bañado e usado principalmente no sul do Brasil para as extensões de terras baixas inundadas pelos rios. Constituem terras boas para culturas, ao contrário dos pântanos. O banhado é um terreno encharcado de água parada que pode, periodicamente, apresentar-se seco.

Corixo: denominação regional do Pantanal de Mato Grosso para os pequenos riachos permanentes que ligam as "baías".

Igapó: denominação regional da Amazônia para os terrenos que ficam alagados por ocasião do transbordamento dos rios, e onde existe cobertura florestal. O termo do vernáculo corresponde a igapó e lezíria ou lezira.

Lezíria ou Lezira: denominação usada para os trechos de áreas alagadiças por ocasião das cheias, junto a certos rios, isto é na planície de inundação ou leito maior. Esta denominação é pouco usada, preferindo-se as denominações regionais como: igapó, banhado, tremendal, lamaçal, ipueira, ipu, etc. O termo lezíria restringe-se apenas ao campo descritivo da paisagem física do leito maior, onde há depressões que são invadidas pelas cheias.

Lamaçal: diz-se das áreas de terreno encharcado pelas águas das chuvas, ou mesmo pela inundação de zonas marginais a um rio, a um lago, etc. Lamaçal é sinônimo de leziria.

IPU: denominação dada no Ceará a terrenos alagados adjacentes aos serrotes, ou pequenos lagos.

Alagadiço: terreno sujeito a inundações por parte dos rios ou marés, conforme a sua posição em relação ao mar e rios. Os terrenos alagadiços são encharcados apenas periodicamente e, assim, durante certo período podem se transformar em áreas secas.

Mangue: terrenos baixos, junto à costa, sujeitos a inundação das marés. Esses terrenos são, quase na totalidade, constituídos de vasas (lamas) de depósitos recentes, com desenvolvimento de vegetação típica, o manguezal.

\footnotetext{
${ }^{5}$ As definições foram extraídas do Dicionário Geológico - Geomorfológico (GUERRA, 1987).
} 
Sacado: termo utilizado na Amazônia para alças fluviais abandonadas, temporária ou permanentemente, pelo rio (DIEGUES, 2002).

Analisando as definições dos termos acima se conclui que pântano, banhado, igapó e brejo referem-se às terras inundáveis que têm como principal corpo hídrico associado o rio, assim estarão inseridas, ao menos em parte, nas planícies fluviais.

Há proximidade entre o termo brejo e pântano, porém o primeiro é mais abrangente, incluindo áreas de nascente, assim esses termos utilizados como sinônimos podem causar confusão.

O termo corixo não compreende uma designação de terra inundável mas sim um termo regional do Pantanal brasileiro para corpo hídrico.

O termo lamaçal é confuso e muito amplo, não servindo para caracterizar nenhuma área específica. Pode designar áreas associadas a rios e/ou lagos, assim compreendem terras inundáveis inseridas, ao menos em parte, em planícies fluviais, lacustres ou fluviolacustres.

O termo ipu se refere às terras inundáveis inseridas, ao menos em parte, nas planícies lacustres.

O termo alagadiço tem as mesmas características que o termo lamaçal, pois não define nem caracteriza por ser muito abrangente "Sujeito a alagamento dos rios ou mares."

O termo mangue refere-se às terras inundáveis inseridas nas planícies fluviomarinhas.

O termo sacado compreende terras inundáveis de ambiente fluviolacustre com a formação de lagos a partir do abandono de meandros.

Mais termos que servem para designar as chamadas áreas úmidas encontram-se no Anexo $\mathrm{F}$, sendo que a maioria deles se refere às características da vegetação.

Não é possível partir de nomenclaturas regionais para identificar tipologias de terras inundáveis já que estas, muitas vezes, são confusas e/ou muito amplas, porém é importante saber o que significam ou tentam significar, para que seja possível o diálogo entre pesquisadores e a população que vive nestas áreas, que podem ter muito a contribuir na compreensão destas áreas.

No nível científico são usados termos como áreas úmidas, terras úmidas, regiões úmidas, áreas alagadas, áreas alagáveis, etc. 
Os termos áreas, zonas e/ou regiões úmidas podem ser considerados sinônimos e aplicados, por exemplo, às áreas de floresta tropical ou subtropical, sem qualquer relação com o objeto em questão. Já os termos áreas alagadas ou alagáveis podem se referir a qualquer área de acumulação de água, que ocorre devido à precipitação, como uma poça que pode ter duração insignificante, relacionada ao tempo de infiltração de água.

O termo terras úmidas é bastante utilizado e talvez o que dê menor margem para interpretações variadas, isso não significa que o mesmo seja o mais adequado a ser utilizado, pois terra úmida pode se referir a um estado específico do solo, sendo que o mesmo pode ser considerado úmido mesmo com baixas quantidades de água entre as partículas que o compõem.

Com o objetivo, por exemplo, de elaboração de leis específicas de proteção, acredita-se que a designação deveria ser padronizada entre os pesquisadores, evitando variadas interpretações sobre o que são essas áreas, dando margem a não inclusão de alguns sistemas.

Existem peculiaridades quanto aos termos regionais e os que são utilizados por pesquisadores. No primeiro caso, referem-se de certa forma às tipologias e as confusões se dão neste campo; no segundo caso, os termos usados têm caráter geral e podem se confundir com elementos sem nenhuma ou com pouca relação com aquilo que se busca designar.

\subsection{Definições do objeto em questão, convenções e centros de pesquisa que visam à preservação}

Não é possível afirmar o que é causa e o que é efeito, o fato é que além das inúmeras designações há também inúmeras definições e ambos os fatores, aliados a outras variáveis, causam dificuldades para a elaboração de leis de proteção e o diálogo entre os pesquisadores.

As definições variam entre interesses científicos, econômicos e políticos. Essas inúmeras definições são o reflexo da grande diversidade de habitats que compõem essas áreas. Dessa forma, grande parte das leis municipais, estaduais e federais, protege esse ecossistema somente em termos regionais não incluindo necessariamente todas as classes de terras úmidas. Significativas áreas sofrem o risco de desaparecer, ainda hoje vistas como locais insalubres, de difícil acesso e aproveitamento econômico (BERTOLUCCI, 2004). 
Segundo O’Brien (1988), as áreas úmidas são o resultado da conformação fisiográfica do terreno e do balanço hídrico, os quais favorecem a acumulação e retenção de água no solo ou na superfície por um determinado período de tempo. Elas surgem com a presença dos cursos de água correspondendo em abrangência lateral às planícies de inundação. É nesse domínio que ocorrem os maiores fluxos naturais de matéria do ambiente, por meio da circulação das águas superficiais e subterrâneas logo subjacentes e do fluxo de sedimentos nos leitos e nas margens dos rios.

Para Lyon (1993) as wetlands podem ser definidas da seguinte maneira:

A wetland can be described as a mix of characteristics from terrestrial or upland areas and the characteristics of aquatic or water environments. In essence, a wetland is the edge or interphase between uplands and adjacent water areas. The water may be in the form of rivers, lakes, ocean areas, or met spots. As such, wetlands may be found almost anywhere. They will possess characteristics of both upland and aquatic environments and exhibit a mix of soil, plant, and hydrological conditions. The mix the characteristics create a unique habitat for life and earth processes, but the mix also makes wetlands hard to identify (LYON, 1993, p. 58).

O Food Security Act, ato legal que regula a utilização de terras úmidas nos E.U.A. para fins agrícolas, tem por finalidade o aproveitamento agrícola das chamadas wetlands, o que pode ser identificado pela definição que o mesmo propõe:

Wetlands are defined as areas that have a predominance of hydric soils and that are inundated or saturated by surface or ground water at frequency and duration sufficient to support, and under normal circumstances do support, a prevalence of hydrophytes vegetation typically adapted for life in saturated soil conditions, except lands in Alasca, identified as having a high potential for agricultural development and a predominance of permafrost soils (NATIONAL FOOD SECURITY ACT MANUAL, USDA, 1988, p. 27).

Segundo Mello (1998) apud Neiff, Iriondo \& Carignan (1994), as áreas úmidas são definidas da seguinte maneira:

Sistemas de extensão sub-regional, em que a presença espacial e temporal de uma cobertura variável de água origina fluxos biogeoquímicos característicos, solos com acentuado hidromorfismo e uma biota cuja estrutura dinâmica são bem adaptados a uma ampla variação na disponibilidade de água. Podem ser considerados macrosistemas, cuja complexidade aumenta a variabilidade hidro-sedimentológica e com a extensão geográfica (MELLO, 1998, p. 157). 
Atualmente a proposta internacional mais aceita para a definição das chamadas zonas úmidas é a elaborada pela Convenção de Ramsar ${ }^{6}$, a partir de um acordo internacional lançado em 1971, na cidade de Ramsar, no Irã.

Extensões de brejos, pântanos e turfeiras, superfícies cobertas pela água, sejam de regime natural ou artificial, permanentes ou temporárias, estancadas ou correntes, doces, salobras ou salgadas, incluindo as extensões de águas marinhas cuja profundidade da maré não exceda os 6 metros (RAMSAR, 1971, p. 21).

As definições acima se complementam e conseguem contribuir muito para a compreensão do que são as terras inundáveis. A definição da Food Security é voltada para interesses econômicos, as demais abrangem características naturais. A definição de Ramsar (1971) utilizase de termos regionais com definições por vezes confusas.

A Convenção de Ramsar também definiu os critérios para a identificação de zonas úmidas de importância internacional (ANEXO B), os chamados Sítios Ramsar. Existem 1.556 sítios Ramsar reconhecidos mundialmente por suas características, biodiversidade e importância estratégica para as populações locais.

Segundo Vieira (2008):

Por volta de 1960, houve uma grande preocupação com as aves aquáticas existentes nas regiões úmidas, pois as mesmas estavam desaparecendo em grande escala. Daí surgiu à necessidade de se criar um tratado que visasse proteger o habitat natural destas aves aquáticas, sendo este o objetivo inicial da Convenção de Ramsar, que, mais tarde, foi ampliado para a conservação e o uso racional das zonas úmidas, na visão de um ecossistema, e não somente para preservar as aves (VIEIRA, 2008, p. 57).

A preocupação internacional com estas aves teria como motivo principal as migrações periódicas que essas realizam, dessa forma ora estão integradas ao ecossistema de um país, ora de outro. Assim não era suficiente a preservação de um único habitat em determinado território, mas a integração entre os países que possuem terras inundáveis consideradas de importância internacional.

O Brasil ratificou a Convenção em 1994, ficando a partir de então comprometido a indicar pelo menos uma zona úmida de importância internacional, em particular para as aves migratórias. Além do Parque Nacional do Pantanal Mato-grossense (MT), o Brasil possui outras sete áreas

\footnotetext{
${ }^{6}$ Também conhecida como Convenção sobre as Zonas Úmidas de Importância Internacional. Fonte: Vieira, 2008.
} 
classificadas como Sítios Ramsar: Estação Ecológica Mamirauá (AM), Ilha do Bananal (TO), Reentrâncias Maranhenses (MA), Área de Proteção Ambiental da Baixada Maranhense (MA), Parque Estadual Marinho do Parcel de Manoel Luz (MA), Lagoa do Peixe (RS) e a Reserva Particular do Patrimônio Natural SESC Pantanal (MT) ${ }^{7}$.

Atualmente a Convenção tem por objetivo amparar as zonas úmidas de importância internacional em todo o planeta, criando medidas de proteção possíveis para o uso sadio, de forma que cada Estado-membro assuma obrigações específicas a respeito das áreas incluídas pelos mesmos na lista (VIEIRA, 1998).

Segundo a Declaração de Cuiabá (2008), alguns países têm desenvolvido modelos para o gerenciamento das áreas úmidas, mas outros ainda estão muito atrasados, e muitos dos que são signatários da Convenção de Ramsar não realizaram de forma efetiva ações para a regulação de uma política específica, preparando um inventário nacional.

Ser signatário da Convenção de Ramsar não é medida satisfatória para a preservação das terras inundáveis, pois neste caso são consideradas apenas as áreas de importância internacional, desde que sejam incluídas pelos países membros. São também necessárias medidas para a preservação das áreas de importância regional e local, estas comumente inseridas nos grandes centros urbanos e sofrendo grande pressão antrópica.

Segundo Diegues (1992), outras Convenções assinadas pelo Brasil e que de alguma forma referem-se às áreas úmidas são: Convenção Internacional das Espécies de Flora e Fauna Selvagem em Perigo de Extinção (1975); Convenção Relativa à Proteção do Patrimônio Mundial, Cultural e Natural (1987); em 1974 foi estabelecida a Comissão Brasileira do Programa sobre o Homem e a Biosfera; Convenção Internacional Sobre a Responsabilidade Civil por danos causados por poluição de óleo (1977), além da participação na elaboração da Convenção sobre o Direito do Mar (1982).

Muitos países vêm adotando definições de terras úmidas mais complexas do que a proposta pela Convenção de Ramsar, principalmente para incluir as características próprias de suas regiões. Esse é o caso do Canadá, Espanha, Estados Unidos, Austrália, Grécia e da África do Sul,

\footnotetext{
${ }^{7}$ Disponível em: http://www.wwf.org.br/informacoes/questoes_ambientais/areas_umidas/. Acessado em: 05/01/10.
} 
que já possuem grande parte de suas terras úmidas incluídas como reservas biológicas (STERNET, 2003).

Existem poucos levantamentos sobre áreas úmidas no Brasil e os mesmos não são abrangentes. Os mais completos são de Diegues $(1994,2002)$ e listam algumas das áreas úmidas mais conhecidas com informações gerais levantados pela literatura sobre a ecologia, o uso, e os impactos humanos, (Instituto Nacional de Áreas Úmidas, 2008).

Segundo o Programa $^{8}$ de Pesquisa e Conservação de Áreas Úmidas no Brasil - PPCAUB (1990), o país possui grandes extensões e variedades de terras úmidas, de importância tanto biológica quanto socioeconômica; muitas das quais são de grande expressão internacional. Esses ecossistemas podem ser tanto continentais quanto litorâneos.

As áreas alagadas são bastante extensas, sendo que as continentais recebem diversas designações. As maiores extensões encontram-se nas planícies de inundação de grandes rios, como o Amazonas e o Paraná, onde em geral o alagamento ocorre em ciclos anuais. As áreas alagadas associadas a rios menores são também extensas e muito importantes ecologicamente. Os períodos de inundação são mais curtos e os alagamentos podem não ocorrer todos os anos (Instituto Nacional de Áreas Úmidas, 2008).

No Brasil, destacam-se os seguintes centros de pesquisas ecológicas sobre terras inundáveis: Instituto Nacional de Pesquisas da Amazônia - INPA, Universidade Federal do Mato Grosso - UFMT, Centro de Pesquisas do Pantanal - CPT, Universidade Federal do Mato Grosso do Sul - UFMS, Universidade Estadual do Mato Grosso - UEMT, Universidade Estadual do Mato Grosso do Sul - UEMS, Universidade para o Desenvolvimento da Região do Pantanal, Universidade Federal do Pará - UFP (ibid.).

O Núcleo de Apoio à Pesquisa Sobre Populações Humanas em Áreas Úmidas Brasileiras NUPAUB, com sede na Universidade de São Paulo - USP, elaborou inventário destacando

\footnotetext{
${ }^{8}$ Um Programa de importância internacional é o de Conservação das Áreas Úmidas, da União Nacional de Conservação da Natureza (UICN), que tem por objetivo incentivar os governos e as entidades não governamentais a desenvolver programas de uso sustentável e preservação desses ecossistemas. Este programa é representado no Brasil pelo PPCAUB, sediado na Universidade de São Paulo e apoiado pela Fundação Ford. No Brasil, este Programa tem por objetivos estudar as relações entre as comunidades humanas e os ecossistemas de terras úmidas, determinar o valor sócio-econômico dessas áreas e propor alternativas para o manejo sustentado desses recursos.
} 
fatores biológicos e sócio-econômicos. A Universidade do Vale do Rio dos Sinos - UNISINOS desenvolve pesquisas sobre estas áreas no Rio Grande do Sul com ênfase em flora e a fauna.

O programa proposto pelo Instituto Nacional de Áreas Úmidas - INAU pretende implantar estrutura necessária para o levantamento das chamadas áreas úmidas, ampliando o conhecimento ecológico, além de elaborar planos de manejo sustentável incluindo as recomendações da Declaração de Cuiabá. O objetivo do INAU é propor uma classificação que ligue as unidades maiores brasileiras às classificações internacionais.

Em relação às áreas úmidas da região sul do Brasil, essas são insuficientemente conhecidas, o que pode ser percebido pela escassa quantidade de estudos sobre o tema. As pesquisas, de um modo geral, se limitam a grupos específicos de organismos com estudos sobre a biologia das espécies ou das populações. Existem trabalhos de limnólogos abrangendo variáveis bióticas e abióticas. Os estudos sobre aves limícolas, especialmente as migratórias, já são bastante numerosos, com trabalhos realizados em praticamente toda a zona costeira. No entanto, faltam trabalhos sobre a estrutura e a função desses ecossistemas de forma a permitir o uso sustentável dessas áreas (CHOMENKO, 1995).

\subsection{Considerações sobre alguns sistemas de classificação das chamadas terras úmidas}

Um sistema de classificação, de forma geral, tem por objetivo a organização de sistemas similares segundo certos critérios. Porém o mesmo não precisa compreender um elemento final em si e pode ser acompanhado de embasamento explicativo constando itens para a caracterização de uma área sem que os mesmos sirvam necessariamente como parâmetros de classificação.

A classificação de terras inundáveis é importante para que seja feito o levantamento das áreas, sejam estas pequenas ou de grande extensão, sendo assim possível elaborar políticas de preservação e manejo, possibilitando a comparação entre sistemas. As menores áreas costumam sofrer maiores pressões, sendo mais facilmente destruídas, seja pelo aterro ou drenagem.

As áreas úmidas cobrem grandes áreas na América do Sul. Os dados indicados na literatura científica variam bastante, mas todos eles subestimam a área total. Isso se deve a três fatores: não foi determinada uma definição a ser adotada para o seu levantamento, não foi elaborado um 
sistema de classificação geral e não foram feitos esforços sérios para realizar esse levantamento por causa da baixa prioridade dada a tais ecossistemas (INAU, 2008).

Há grandes e famosas áreas consideradas terras úmidas, como o pantanal brasileiro, as planícies dos grandes rios e dos manguezais, mas os diferentes tipos de pequenas terras úmidas, cuja soma atinge centenas de milhares de quilômetros quadrados, não são considerados. Estimase que $20 \%$ da América do Sul esteja coberta por esse ecossistema, mas somente partes são estudadas e manejadas (INAU, 2008).

Segundo Maltichik (2004), as primeiras classificações de áreas úmidas eram regionais e restritas a um determinado tipo de ambiente (SHALER, 1890; DAVIS, 1907; WEBER, 1907) e na sua maioria baseadas na comunidade de plantas (WARMING, 1909; CHRISLER, 1910; SHREVE et al., 1910).

Nos Estados Unidos, foram propostas diversas classificações, porém, muitas delas estavam associadas ao uso da terra e tinham por objetivo a conversão dessas áreas para o cultivo (TINER, 1999).

Atualmente, existem inúmeras classificações com interesses diversificados, mas a maioria está intimamente associada a inventários e propostas de conservação. Alguns exemplos de classificação: a proposta da U.S. Fish and Wildlife Service (COWARDING et al., 1979); para o manejo das terras úmidas dos EUA, Scientific Committee on Problems of the Environment (SCOPE), International Council of Scientific Unions (GOPAL et al., 1990), Convenção de Ramsar (SCOTT \& JONES, 1995); para a proteção de aves aquáticas migratórias, do International Waterfowl and Wetlands Research Bureau - IWRB, do The Nature Conservancy TNC (GROVES et al., 2002).

Como exemplos de classificações nacionais há: EUA (BRINSON, 1993) Canadá (ZOLTAI et al., 1975; TARNOCAI, 1980; WARNER \& RUBEC, 1997), Austrália (PAIMANS et al., 1985; SEMENIUK, 1987), Índia (GOPAL \& SAH, 1995) e China (LU, 1995).

Alguns exemplos de classificações nacionais brasileiras: das matas ripárias (RIBEIRO \& WALTER, 1998; RODRIGUES, 2000), hidromorfológica dos habitats do Rio Paraguai e sua área alagável (WANTZEN et al., 2005), dos habitats do Pantanal (NUNES DA CUNHA \& JUNK, 2006). 
Segundo Maltchik (2004), até o momento não existe um sistema de classificação único para as áreas úmidas brasileiras. As classificações utilizadas nos inventários realizados no Brasil foram baseadas em termos regionais que geralmente informavam pouco sobre as características dos sistemas.

São três os atributos mais utilizados para a classificação de áreas úmidas: vegetação com características hidrófilas, hidrologia e os solos. Para que esses três itens sejam identificados é necessária a permanência da água em tempo suficiente para que ocorra a adaptação biológica (MALTCHIK, 2004).

a) Vegetação: formas biológicas (flutuantes, submersas, emersas, arbustos, árvores), tipos de folhas (largas, estreitas ou aciculares), persistência das folhas (permanentes ou caducifólias), tipos de comunidades (tipos dominantes e tipos de habitats) etc.

Alguns pesquisadores discutem o uso da vegetação como critério de classificação, pois consideram que as características vegetais resultam de fatores hidrológicos e geomorfológicos, e que muitas funções das áreas úmidas são independentes da composição vegetal (MALTCHIK, 2004).

b) Tipos de solos: classificados como hidromórficos, se desenvolvem em condições de excesso d'água, sob influência do lençol freático. Esses solos podem apresentar a cor cinza em virtude da presença de ferro reduzido, ou ausência de ferro trivalente. Ocupam baixadas inundadas ou frequentemente inundáveis. Existem dois tipos principais: os orgânicos e os minerais.

Devido à presença da água, desenvolve-se vegetação típica que se adapta a essa condição. O solo torna-se anaeróbico, assim as raízes de plantas de áreas não úmidas não teriam condições de respirar. O período da inundação, sua profundidade e nutrientes disponíveis determinam as características da vegetação.

c) Características hídricas: influência hídrica (áreas litorâneas, estuarinas ou continentais), presença de lâmina d'água (permanente, intermitente ou ausente), origem da água (precipitação, água subterrânea ou inundações de rios e lagos), velocidade e química da água (salinidade, condutividade e $\mathrm{ph}$ ). 
Segundo Tiner (1999), os sistemas de classificação de terras úmidas podem ser horizontais: quando utilizam termos populares; ou hierárquicos: quando agrupam as terras úmidas em diferentes níveis, partindo de uma divisão mais geral para uma mais detalhada.

O primeiro sistema tem um caráter mais regional e/ou local e tende a causar incompreensões e/ou a necessidade de pesquisas específicas para a compreensão dos termos utilizados. No Brasil, por exemplo, as denominações são muito variadas e, por isso, não devem ser utilizadas em um sistema nacional, ou mesmo regional, de classificação.

O segundo sistema permite uma caracterização mais detalhada e, supostamente, mais consistente. Possibilita a comparação de pesquisas no nível nacional e internacional.

A princípio o sistema hierárquico de classificação se mostra mais eficiente, porém cada proposta tende a ter suas limitações e avanços, assim devem ser analisadas e discutidas para que sejam aprimoradas ao longo do tempo.

Uma das classificações internacionais mais conhecidas foi proposta por Cowardin et al. (1979) adotado pelo U.S. Fish and Wildlife Service dos E.U.A. Nesta classificação são considerados cinco níveis (marinho, estuarino, lacustre, palustre e fluvial), incluindo subdivisões. O primeiro nível é apresentado a seguir:

MARINHO: associados ao mar aberto, que se estendem na costa oceânica, onde a salinidade exceda 30 partes por mil;

ESTUARINO: são sistemas que estão usualmente semifechados por terra, mas conectados, ou esporadicamente conectados com o oceano. Salinidade varia de 0,5 a 30 partes por mil;

LACUSTRE: terras úmidas situadas em depressões topográficas ou rio represado, não contendo árvores, arbustos, emergentes, liquens, com mais de 30\% de área coberta, e onde a área total exceda 8 ha;

PALUSTRE: terras úmidas dominadas por árvores, arbustos, emergentes, liquens, e todos os locais onde a salinidade seja inferior a cinco partes por mil. Incluem todos os sistemas que não se enquadram no outros níveis;

FLUVIAL: terras úmidas que contêm canais, exceto aquelas dominadas por árvores, arbustos, liquens, emergentes, que possuem habitats com salinidade não excedendo cinco partes por mil. 
O primeiro nível hierárquico de classificação proposto por Cowardin et al (1979) foi elaborado a partir de mais de um critério e estes possuem pesos diferenciados para cada sistema. No item marinho e estuarino, por exemplo, predominam questões relativas aos corpos hídricos e à salinidade da água. No sistema lacustre é considerada a geomorfologia, vegetação e a estipulação de área. No sistema palustre predominam questões relativas à vegetação e à salinidade. Já no sistema fluvial a classificação se dá pela exclusão de tipologias de vegetação e pelo teor de salinidade.

Os vários critérios com pesos diferentes no primeiro nível podem tornar esse sistema menos funcional, mesmo servindo ao que se propõe. Acredita-se que cada nível de classificação deve conter os mesmos parâmetros, buscando uma ordenação.

O Inventário de Áreas Úmidas Brasileiras (2002), elaborado pelo NUPAUB - Núcleo de Pesquisas de Áreas Úmidas Brasileiras, não compreende uma proposta de classificação, mas um levantamento geral de vários fatores considerados importantes para o conhecimento e manejo dessas áreas relacionando fatores sociais e ambientais. Este panorama geral pode contribuir em uma proposta que vise à classificação das terras inundáveis brasileiras.

A unidade básica de análise deste inventário foi a bacia hidrográfica. As bacias hidrográficas definidas foram: Bacia Amazônica, Bacia Tocantins - Araguaia, Bacia do São Francisco, Bacia Platina: Uruguai, Paraguai e Paraná; bacias secundárias: bacia do Norte, Bacia do Leste, Bacia do Sudeste e do Sul.

Para cada bacia hidrográfica foram pesquisados os seguintes fatores: descrição geral, flora, fauna, ecossistemas, fluxos migratórios, dados populacionais, características etno-culturais das populações locais, uso do solo e dos recursos naturais e conflitos relacionados, principais atividades econômicas, impactos das atividades humanas e nível de criticidade.

Irgang (1999), a partir de anos de observação sistemática na lagoa dos Patos e Mirim, no Rio Grande do Sul, propôs uma classificação com base nas plantas dominantes em cada terra úmida. Essa classificação é restrita, pois algumas espécies são endêmicas e a nomenclatura fundamenta-se em termos regionais (MALTCHIK, 2004).

No Rio Grande do Sul, destacam-se também os estudos elaborados e orientados por Maltchik em relação às terras inundáveis. Os levantamentos compreendem pesquisas sobre macroinvertebrados com a finalidade de avaliar a distribuição geográfica destes organismos em 
nível de família, comparar a composição e estrutura das comunidades entre as províncias geomorfológicas e regiões hidrográficas e analisar o grau de similaridade entre as diferentes classes de terras inundáveis.

O mesmo pesquisador, em 2004, reconhecendo a importância dos sistemas palustres, assim como o atual estado de conservação e a predominância de áreas úmidas palustres no estado, propôs um sistema de classificação para essas áreas (Quadro 03).

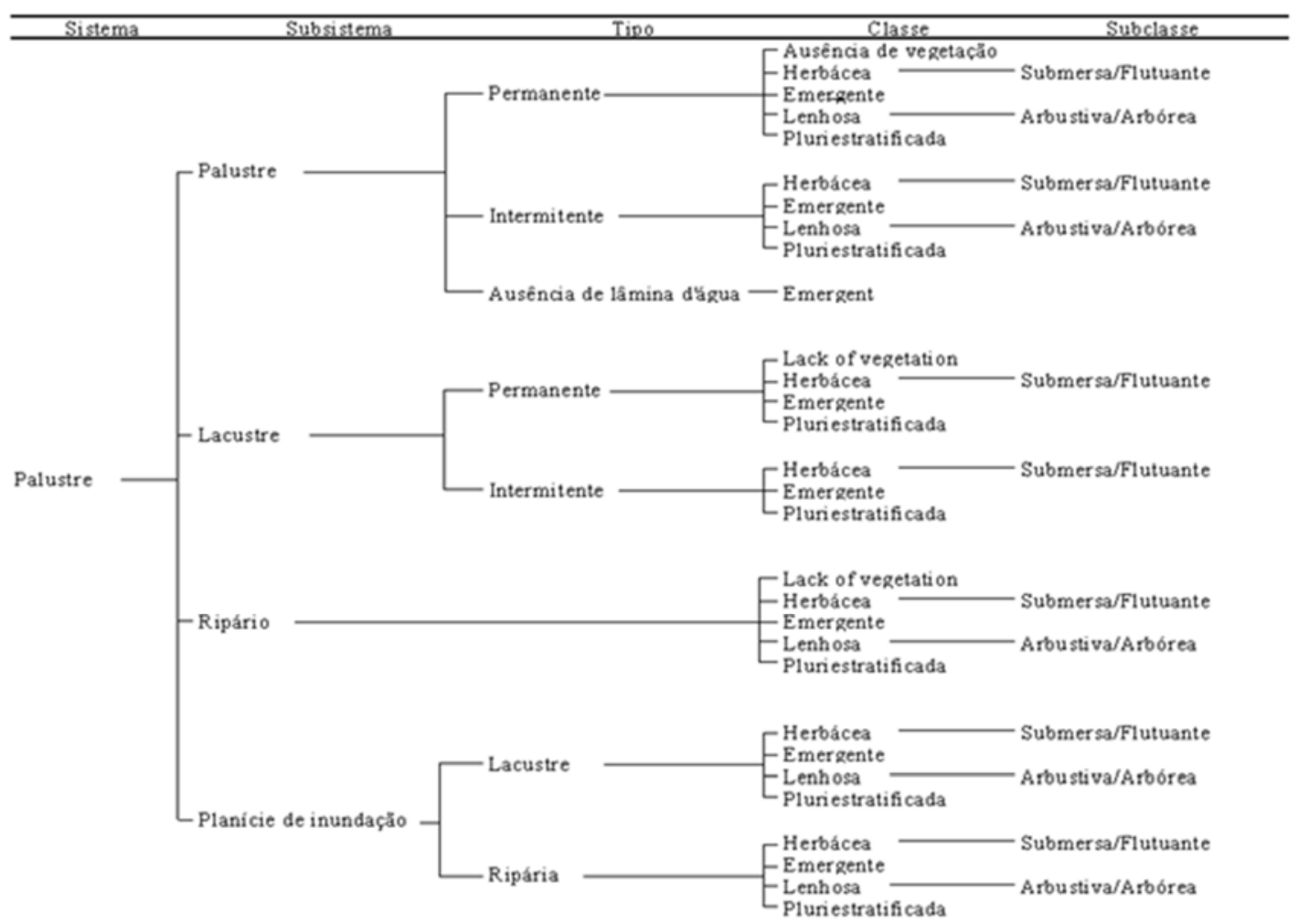

Quadro 03: Proposta de classificação para as áreas úmidas do sistema palustre. Fonte: Maltchik, 2004.

O sistema de classificação é hierárquico e foi adaptado das classificações propostas pela "U.S. Fish and Wildlife Service" (COWARADIN et al., 1979) e pela Convenção de Ramsar (1990). Os sistemas são compostos dos itens: lacustre, ripário, estuário, marinho, artificial e palustre, este último foi o ponto de partida para a proposta de Maltchik.

O primeiro nível do sistema palustre foi definido pela vegetação, área e característica hídrica, o subsistema pelo volume da água e área de drenagem. O terceiro nível baseou-se 
principalmente nas características hídricas. A classe e a subclasse, quarto e quinto nível respectivamente, foram baseadas exclusivamente nas características da vegetação.

Neste trabalho, a proposta de Maltchik será analisa até o terceiro nível (tipo), dado que o quarto e o quinto níveis (classe e subclasse) referem-se às características da vegetação das terras inundáveis, e questões da flora e também da fauna não serão discutidas neste trabalho.

O sistema palustre compreende áreas úmidas sem influência de marés, dominadas por vegetação herbácea ou lenhosa ou áreas úmidas sem vegetação < que 30\% e < que 30 hectares (MALTCHIK, 2004).

Segundo Maltchik (2004), a principal diferença entre o subsistema lacustre (fotografia 01) e o subsistema palustre (fotografia 02) é a relação entre o volume de água e a área de drenagem. No primeiro os limites entre o sistema aquático e terrestre são bem definidos, localizados em depressões topográficas da área da drenagem. Há no subsistema lacustre o aumento do gradiente de profundidade da margem para o centro da chamada terra úmida.

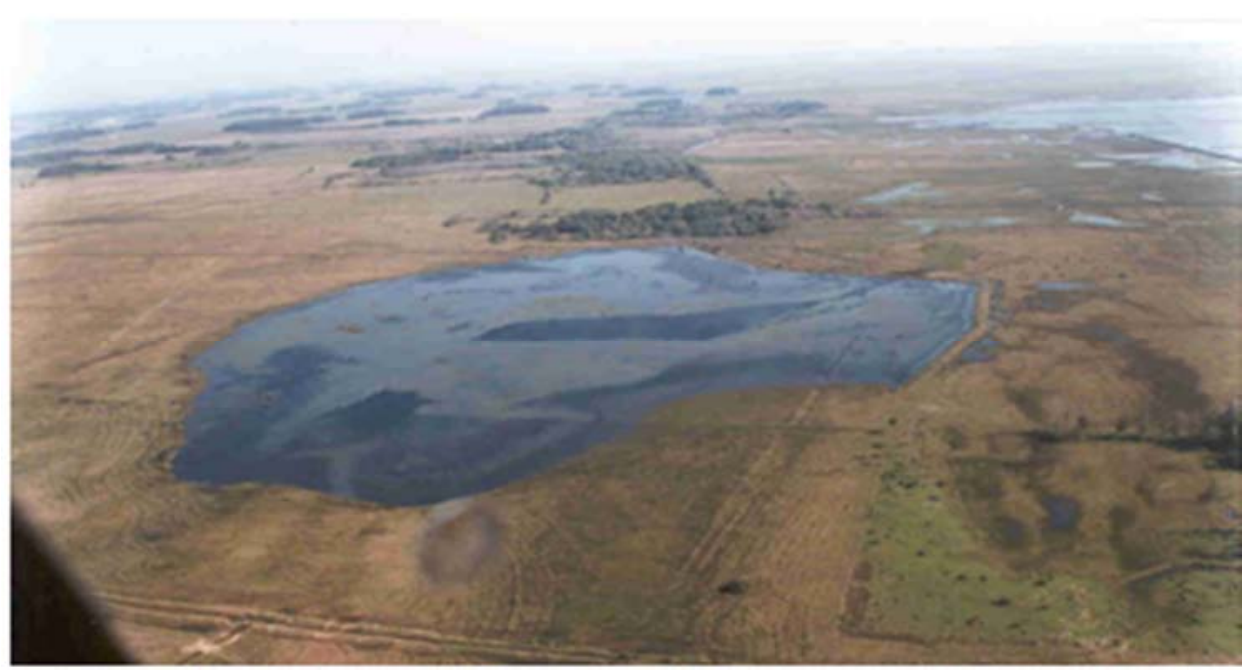

Fotografia 01: Subsistema Lacustre.

Fonte: Maltchik, 2004. 


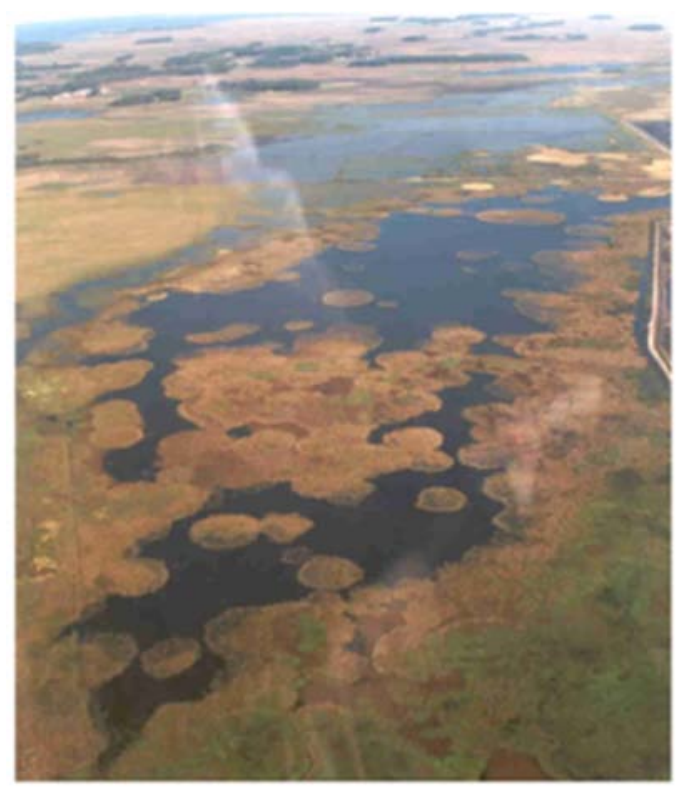

Fotografia 02: Subsistema Palustre.

Fonte: Maltchik, 2004.

O subsistema ripário compreende canais abandonados de rios ou arroios, os quais podem estar isolados ou receber periodicamente influência do canal principal do rio (Figura 04).

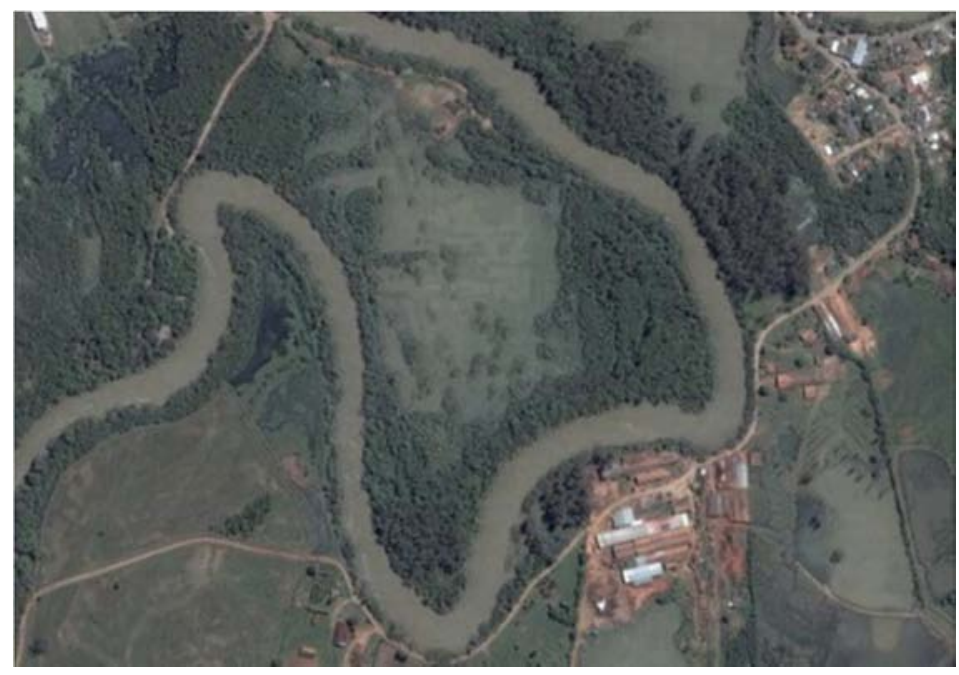

Figura 04: Subsistema ripário.

Fonte: Secretaria de Meio Ambiente de São Leopoldo. 03/2005.

O subsistema planície de inundação compreende áreas periodicamente inundadas pelo extravasamento de rios ou lagos (Fotografia 03). 


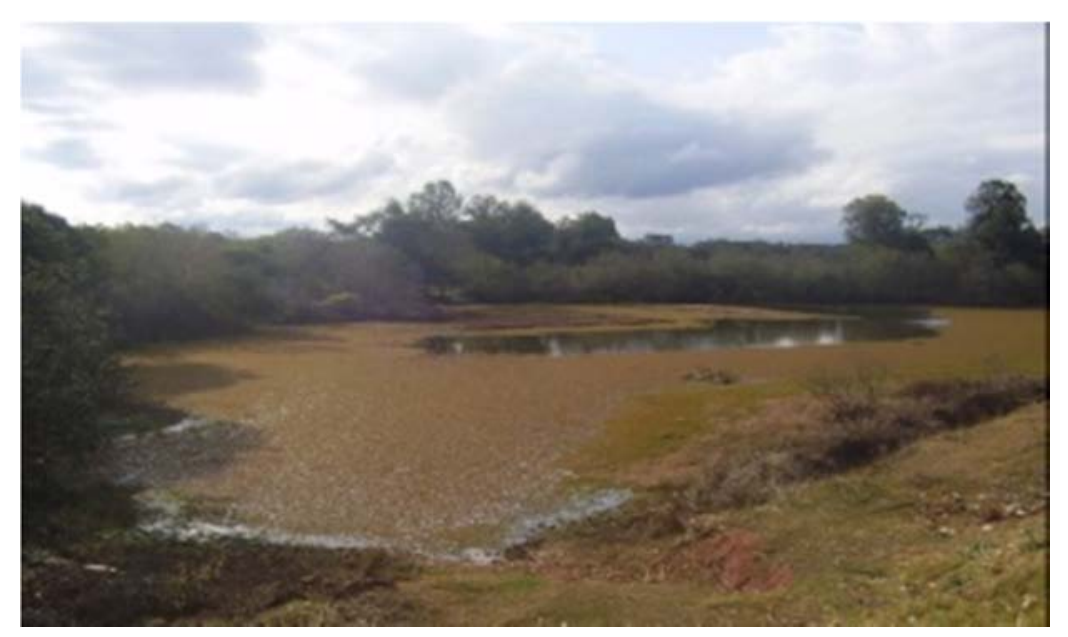

Fotografia 03: Subsistema planície de inundação.

Fonte: Adriana Penteado, 06/2009.

Quanto aos tipos, o subsistema palustre foi divido em três níveis que estão baseados no hidroperíodo ou na origem da água: permanente (a lâmina d'água está presente durante todo o ano), intermitente (presença de lâmina d'água ao menos durante quatro meses do ano) e ausência de lâmina d'água (somente presença de solos saturados).

O subsistema ripário e planície de inundação não precisam compor níveis diferentes de classificação, já que estão inseridos em áreas de planície fluvial. É necessário identificar a existência ou não de lagos. No caso afirmativo, o nome mais adequado seria terras inundáveis fluviolacustres, sem a formação de lagos, terra inundável de ambiente fluvial. Dessa forma é possível evitar uma identificação ou caracterização isolada de parte de um sistema que está interligado, mas que possui peculiaridades, não se apresentando de forma homogênea em toda a sua extensão.

O sistema palustre, primeiro nível de classificação, entre outros parâmetros utiliza-se da referência “< que 30 hectares". Já no subsistema, a principal diferença entre lacustre e palustre é o volume e a área de drenagem, segundo Maltchik (2004).

A noção de escala possui relação com o tamanho e com os processos que atuam nas formas da superfície terrestre, por isso é importante ser considerada para um sistema de classificação de 
terras inundáveis. Acredita-se que o mesmo não se aplica à estipulação de uma área por que impõe limites rígidos.

Devido à dinâmica principalmente antrópica, o tamanho de uma terra inundável pode diminuir ao longo de um espaço de tempo considerado curto. Podem também ser segmentadas ou aterradas de forma parcial, podem ainda ser criadas artificialmente.

Outros inúmeros fatores são importantes e servem de forma mais adequada para uma classificação e podem explicar de forma direta ou indireta o tamanho de uma terra inundável. Este item deve constar como fator de caracterização e não como fator de classificação. Um grande número de classes e subclasses nem sempre tornará uma classificação mais adequada.

É importante propor metodologia que possa ser utilizada para a classificação de qualquer terra inundável, independentemente de características endêmicas, tamanho, se possuem ou não importância internacional. As peculiaridades regionais e locais são inerentes e devem ser caracterizadas na escala de detalhe, inseridas dentro de um sistema hierárquico mais amplo.

Existem confusões entre a noção de classificação e de caracterização. A classificação busca ordenar, e deve partir de um nível abrangente, do maior para o menor. A caracterização está contida dentro da noção de classificação. Muitas confusões são causadas porque se parte da caracterização compreendendo que esta seria por si só uma forma de classificar.

Uma forma de melhor compreender as terras inundáveis é por meio da compreensão da dinâmica das planícies, sendo assim possível estabelecer uma interpretação genética, que perpassa pela análise das formas de relevo. A partir da formação das planícies de inundação, peculiaridades do solo, da flora e da fauna, podem se estabelecer, caracterizando não só um ambiente de deposição de sedimentos, mas um ambiente com uma riqueza e importância singular do ponto de vista biológico e também social. A forma como as planícies de inundação são classificadas pode também contribuir, num primeiro nível, na classificação das terras inundáveis, bem como na designação das mesmas.

Os subcapítulos seguintes do capítulo três têm por finalidade discutir a definição das planícies, formas de classificação, gênese e relação com outras formas de relevo, buscando melhor compreender as terras inundáveis. 


\subsection{Definições de planície, formas de classificação e relação com as terras inundáveis}

A planície, em seu aspecto geral, é uma extensão de terreno mais ou menos plana ou de reduzido desnível, por vezes ondulada, onde os processos de deposição são mais expressivos que os processos erosivos. As constituições das rochas se diferenciam dos planaltos e das depressões por serem formadas por sedimentos recentes, com origem em processos realizados predominantemente no Quaternário. A planície pode ser formada, por exemplo, pela deposição marinha, fluvial, eólica, fluviomarinha e lacustre. Os corpos hídricos compreendem os agentes principais responsáveis pelo transporte de sedimentos, mas os mesmos podem não estar presentes como no caso das planícies eólicas.

Segundo GUERRA (1987) existem planícies que podem estar localizadas a mais de mil metros de altitude que são denominadas planícies de nível de base local. O critério de altitude não pode ser determinante na definição de planícies. É possível caracterizar as planícies que são encontradas em diversas altitudes, onde os vales apresentam grande quantidade de aluviões.

A palavra chave da colocação acima é altitude. É fato que a mesma não pode ser determinante para a definição de planícies. Isso, porém, se aplica às áreas interiores do continente, dado que as planícies costeiras, com influência direta ou indireta do mar, localizam-se em baixas altitudes.

A dinâmica das inundações nas planícies marinhas ou continentais/interiores é diferenciada. Nas áreas continentais, as cheias dos corpos hídricos com extravasamento para as áreas de planície têm relação direta com a pluviosidade que é mais concentrada em certos períodos do ano e a oscilação e/ou permanência entre as fases de cheia e vazante pode variar entre dias, semanas ou meses.

As planícies costeiras sofrem inundação diária devido ao movimento de subida e descida da maré, que compreende a maré alta ou preamar e a maré baixa. Esse fenômeno ocorre num intervalo de tempo de aproximadamente seis horas e ocorre devido à atração que o sol e a lua exercem sobre a Terra. Assim, caracteriza-se por ser mais constante dentro de um intervalo de tempo menor.

Buscou-se identificar algumas das formas de classificar as planícies a partir dos seguintes fatores: localização, agente principal de sedimentação e o tipo de foz do canal fluvial. 
Quanto a sua situação ou localização as planícies são classificadas como: costeiras ou litoraneas, continentais ou interiores, segundo o agente de sedimentação: lago, rio ou mar e, quanto às caracteristicas da foz do rio principal: deltaicas ou estuarinas.

As planícies continentais ou interiores estão situadas no interior do continente sem sofrer ação das águas oceânicas e as planícies costeiras localizam-se nas bordas continentais sofrendo ação direta ou indireta do mar.

É comum o uso do termo planícies marinhas, ora para designar a localização das mesmas, ora pra definir o agente principal de sedimentação, que neste caso é o mar, o mesmo não ocorre em relação ao termo planície continental que se refere estritamente ao primeiro caso. Define-se aqui o primeiro termo, como designação de agente de sedimentação principal, e o termo planície costeira, para a designação locacional.

Nem sempre ocorre um limite claro, fisicamente visível, entre as planícies continentais e costeiras, existindo um ambiente de transição. Este fato é mais comum em áreas onde os limites da bacia sedimentar atingem a costa, fato que ocorre, por exemplo, nas planicies da bacia hidrográfica do rio Amazonas. Assim, quanto à situação, pode-se definir mais um termo para designar as planícies, que pode ser planícies em ambiente de transição continental-costeiro.

Um mesmo rio pode fazer parte da dinâmica de planícies continentais e costeiras, sendo que essa ação se dá no sentido interior do continente - bordas continentais. A quantidade de sedimentos transportados pelo rio até o mar em quantidade inferior ao normal, altera a dinâmica costeira e as faixas de praia podem sofrer retração. Outras modificações em cadeia, por consequência desta, podem se desenvolver. Assim, alterações nos corpos hídricos interiores podem trazer alterações amplas em magnitude e abrangência espacial atingindo, por exemplo, as planícies costeiras.

Segundo o agente de sedimentação predominante, as planícies podem ser classificadas como marinha, fluvial, lacustre ou lagunar (DICIONÁRIO GEOMORFOLÓGICO, 1987):

Planície Marinha: área mais ou menos plana resultante de acumulação marinha, podendo comportar praias, canais de maré, cristas de praia, restingas, ilhas barreira. Ocorre nas baixadas litorâneas sob a influência dos processos de agradação marinhos. 
Planície fluvial: área plana ou quase plana formada pela deposição de sedimentos transportados pelos rios. Estão localizadas no interior do continente e podem estar localizadas em diferentes altitudes.

Planície Coluvio-aluvionar: planície formada pela deposição de materais de áreas mais altas pela ação da gravidade e dos fluxos hídricos.

Quanto às planícies fluviais, o movimento horizontal da água tem grande importância, pois diferenças hidrométricas de poucos centímetros determinam que superfícies de centenas de quilômetros estejam inundadas ou secas. Nas planícies de maior altitude a fase de inundação é mais curta e é produzida com o fluxo torrencial da chuva (NEIFF, 1999). Assim, as terras inundáveis com características peculiares relativas ao solo e a vegetação se desenvolvem, mais comumente, nas planícies de baixas altitudes.

O curso do rio, suas ilhas, cursos secundários e planície de transbordamento formam subsistemas, estrutural e funcionalmente dependentes do fluxo horizontal de água, que formam uma mesma unidade ecológica de funcionamento com o curso do rio (NEIFF, 1999).

Planície Lacustre: Área plana resultante de processos de acumulação lacustre, comportando lagos, cordões arenosos e diques marginais. Ocorre associada aos grandes sistemas fluviais e aos vales de origem neotectônica.

Segundo TUNDISI (2008) apud HUTCHINSON (1957), os lagos podem ser classificados quanto à origem como: tectônica, vulcânica, movimentos de terreno, glaciação, lagos de solução, ação fluvial, por ação do vento, na costa, acumulação orgânica, construídos por organismos e por impactos de meteoritos.

Planície Lagunar: Área plana resultante de processos de acumulação lagunar, contendo lagunas que podem conter água salgada ou salobra e localizam-se nas bordas litorâneas, podendo haver canais entre as mesmas e o mar.

Uma planície de inundação pode estar associada a um tipo de corpo hídrico ou mais de um, caso em que surgem derivações das nomenclaturas descritas anteriormente, como planície fluviomarinha ou fluviolacustre.

Planície Fluviomarinha: área mais ou menos plana, resultante da combinação de processos de acumulação fluvial e marinha sujeita a inundações periódicas, podendo comportar canais 
fluviais, manguezais, cordões arenosos e deltas. Ocorre nas baixadas litorâneas, próximo às embocaduras fluviais.

Planície Fluviolacustre: Área plana resultante da combinação de processos de acumulação fluvial e lacustre, podendo comportar canais anastomosados, paleomeandros (oxbow lakes) e diques marginais. Ocorre em setores sob o efeito de processos combinados de acumulação fluvial e lacustre, sujeitos a inundações periódicas com barramentos, formando lagos.

Podem ainda existir planícies que sofrem influência marinha, fluvial e lacustre ao longo de sua área, de forma simultânea ou não e com intensidades variadas ao longo do espaço - tempo, principalmente em relação à influência marinha e os demais corpos hídricos.

Segundo o agente principal de transporte de sedimentos, uma planície pode também ser definida como planície eólica: tendo o vento como principal agente; glacial: que tem como agente de transporte as geleiras; e planície coluvial, onde o fator determinante é a gravidade.

Um rio pode desaguar em um lago, em uma lagoa, no mar ou em outro rio e, quanto às caracteristicas da sua foz, pode ser definido como estuarino ou deltaico. Esses termos são também utilizados para definir as planícies que estão associadas a estes canais.

$\mathrm{Na}$ foz deltaica, ocorre a construção de uma série de ilhas, braços e canais formando intricada rede potâmica na forma de um leque. O termo delta é em alusão a letra grega de mesmo nome que tem a forma de um triângulo. Para o surgimento de uma foz com essas características são necessárias a coexistência de vários fatores como grande quantidade de material sólido em suspensão, pouca profundida da foz, ausência de fortes correntes marítimas, etc. (GUERRA, 1987).

A planície deltaica pode subdividir-se em superior e inferior, sendo a planície superior de domínio fluvial com sua correspondente planície de inundação que pode estar associada a lagos e pântanos. A planície inferior está situada sobre os lóbulos deltaicos e está sujeita a ação das marés, constituída por canais de distribuição separados por baixadas onde se encontram os manguezais, lagos e canais de marés, segundo o tipo de delta (SALAS - DUEÑAS, 2004).

A foz estuarina compreende a desembocadura de um rio formado por um longo canal de forma afunilada. As áreas planas ou suavemente planas adjacentes ao corpo hídrico compreendem as planícies estuarinas. 
O termo planície de inundação é comumente utilizado como sinônimo de planície fluvial, porém o termo pode ser utilizado para qualquer tipo de planície inundável. O mesmo raciocínio pode ser aplicado ao termo planície marginal de alagamento, que também é utilizado como sinônimo de leito maior.

As planícies fluviais, lacustres, marinhas, etc., e derivações compreendem as áreas onde se manifestam as terras inundáveis, porém estas podem também atingir áreas de terraços. O ponto de intersecção entre as planícies e as terras ínundáveis no que se refere a caracterização e não a definição é que as mesmas compreendem terras planas ou suavemente planas, as maiores localizam-se em baixas altitudes e estão associadas aos corpos hídricos (estes últimos quase sempre no caso das planícies na sua definição geral e sempre em relação às terras inundáveis). Para a planície a dinâmica da água funciona como um agente de transporte, para a terra inundável representa sua essência.

Uma planície em sua gênese pode ter como agente principal de deposição um corpo hídrico, porém alterações de ordem natural ou antrópica podem extinguir esse agente sem, contudo, descaracterizar o que se entende por planície. O mesmo raciocínio não pode ser aplicado às terras inundáveis, que podem ser consideradas efêmeras quando comparadas à noção de planícies.

A chuva pode ser compreendida como o input do ciclo hidrológico e é responsável, entre outros fatores, pela manutenção dos corpos hídricos e, de forma direta ou indireta, das terras inundáveis. A precipitação dissociada de forma mais direta dos corpos hídricos, sem promover sua subida e/ou extravasamento, não forma uma terra inundável, mas áreas alagadas que tendem a desaparecer dependendo da relação quantidade de chuva em certo intervalo de tempo (frações de hora, dia) e capacidade de infiltração. Os fatores que vão influenciar na capacidade de infiltração são o tipo de cobertura do solo.

\subsection{Macroformas e morfoesculturas do relevo e relação com as planícies de inundação e terras inundáveis}

A compreensão das terras inundáveis perpassa pela análise da gênese e das formas de relevo, já que a configuração deste a partir de suas peculiaridades morfológicas estabelecem 
peculiaridades dessas áreas em relação ao tamanho e desenvolvimento de flora e fauna adaptadas devido ao tempo em que essas áreas permanecem inundadas e/ou secas.

As grandes estruturas do relevo - as macroformas - são classificadas para o território brasileiro, segundo Ross (1998), pelas plataformas ou crátons, pelas cadeias orogênicas e pelas bacias sedimentares (Figura 05). Essas grandes unidades de relevo estão relacionadas aos eventos tectônicos responsáveis pelas estruturas geológicas - as morfoestruturas - e correspondem ao primeiro táxon na classificação do relevo (ROSS, 1992). No segundo táxon, que corresponde às unidades morfoesculturais, estão presentes os planaltos, as depressões e as planícies.

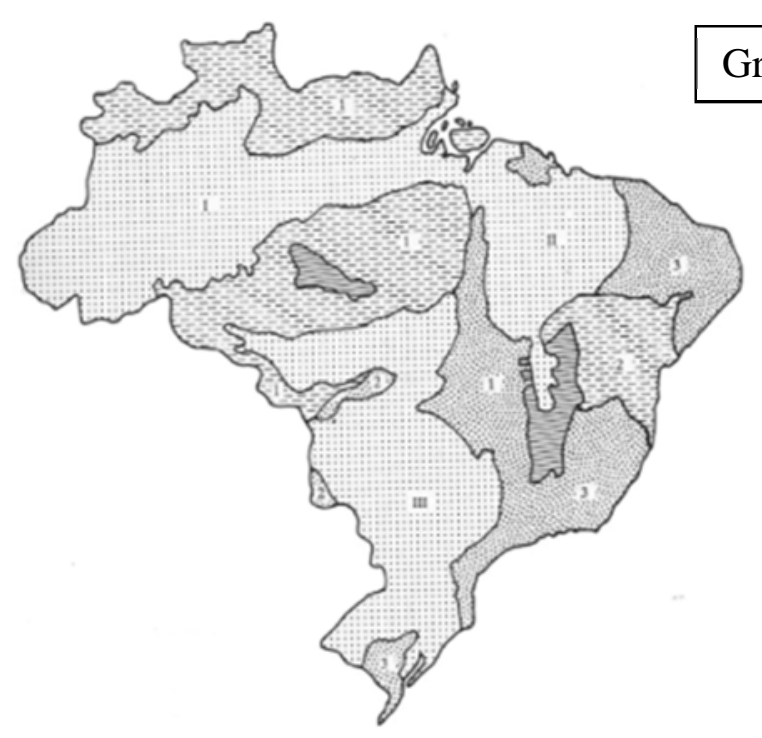

Grandes estruturas do Território Brasileiro

Figura 05: Grandes Estruturas do Território Brasileiro.

Fonte: Ross, 1998.

As plataformas ou crátons correspondem aos terrenos mais antigos cujas idades variam entre 900 milhões e 4,5 bilhões. Desgastados por muitas fases de erosão, caracterizam-se como os terrenos mais retrabalhados pelos procesos erosivos, são também os mais estáveis do ponto de vista tectônico. Guardam características de baixos planaltos ou aspecto de depressões deposicionais às margens das bacias sedimentares (ROSS, 1998). 
As bacias sedimentares ${ }^{9}$ são formadas por espessos pacotes sedimentares em diferentes fases de deposição marinha, glacial ou continental ao longo do Paleozóico, Mesozóico e Cenozóico, nos últimos 600 milhões de anos. Recobrem de forma parcial os crátons ou plataformas ocupando $75 \%$ das terras emersas da Terra. No territorio brasileiro as três grandes bacias sedimentares são: Amazônica, do Maranhão ou Parnaíba e do Paraná. (op. cit).

As cadeias orogênicas correspondem aos terrenos mais elevados da superficie terrestre, geradas pelo efeito de dobramentos acompanhados de intrusões, vulcanismo, abalos sísmicos e falhamentos. São mais recentes que as bacias sedimentares em torno de 100 milhões de anos. A maioria encontra-se situada nas bordas dos continentes, sobretudo no Pacífico, Índico e Mediterrâneo. Nas áreas onde predomina esse tipo de modelado os processos erosivos são mais atuantes que os processos de agradação (GUERRA, 1987).

Inseridas nessas grandes estruturas estão as grandes unidades morfoesculturais que se referem aos grandes traços determinados pela tectônica e eventos morfoclimáticos existentes nas unidades morfoestruturais, que podem, grosso modo, ser identificadas pelas condições topomorfológicas, individualizadas por três grandes compartimentos: planaltos, planícies e depressões (CASSETI, 2010).

Por planalto entende-se a extensão territorial elevada, de diferentes condições geológicas, submetida a processo de dissecação, se caracterizando como fornecedora de sedimentos. A depressão compreende o compartimento embutido em planaltos, posicionada em situação topográfica inferior, também submetida a processo de dissecação, se caracterizando como fornecedora de sedimentos. A planície refere-se ao compartimento receptor de sedimentos de montante, encontrando-se embutida tanto nos planaltos como nas depressões (ibid.).

No mapa do IBGE (2002) (Figura 06), foram mapeadas sete unidades de relevo: planícies, tabuleiros, depressões, chapadas, patamares, planaltos e serras. Este mapa pode ser comparado ao

\footnotetext{
9 Bacia sedimentar a) é uma área deprimida da crosta terrestre, de origem tectônica, na qual se acumularam sedimentos; b) área na qual se acumularam sedimentos em espessura consideravelmente maior que nas regiões adjacentes; c) entidade geológica que se refere ao conjunto de rochas sedimentares que guardam relação geométrica e/ou histórica mútua, cuja superfície hoje não necessariamente se comporta como uma bacia de sedimentação. Sua origem está ligada à cinemática da tectônica de placas. Dicionário Geológico. Disponível em: http://www.geotrack.com.br/pdiciob.htm 2009.
} 
mapa das grandes estruturas do relevo brasileiro (Figura 05) e, a partir disso, é possível fazer algumas relações entre as macroestruturas e as planícies.

As maiores planícies do territorio brasileiro, tanto continentais quanto costeiras, estão inseridas na bacia sedimentar da Amazônia, que atinge a faixa costeira no estado do Pará e, em parte, do Amapá. A bacia hidrográfica de mesmo nome supera os limites da bacia sedimentar, atingindo outras grandes estruturas e nessas áreas se apresentam planícies relativamente menores.

Segundo Guerra (1987), a bacia sedimentar pode, numa análise mais geral, coincidir com a bacia hidrográfica, porém esta última pode ser bem mais extensa e seus ríos podem drenar outros terrenos que vão além da área sedimentar. Aquelas podem ser consideradas como planícies aluviais que se desenvolvem, ocasionalmente, em áreas continentais, ocorrendo uma relação estrita entre a natureza, a estrutura das rochas e as formas de relevo.

Os principais afluentes da bacia hidrográfica do rio Amazonas que se localizam na bacia sedimentar de mesmo nome são: Negro, Madeira, Solimões e Amazonas, aos quais estão associadas as maiores planícies continentais do territorio nacional. O rio Xingu que está inserido na bacia hidrográfica do Amazonas, tem planícies mais expressivas na área compreendida na bacia sedimentar do Paraná. 


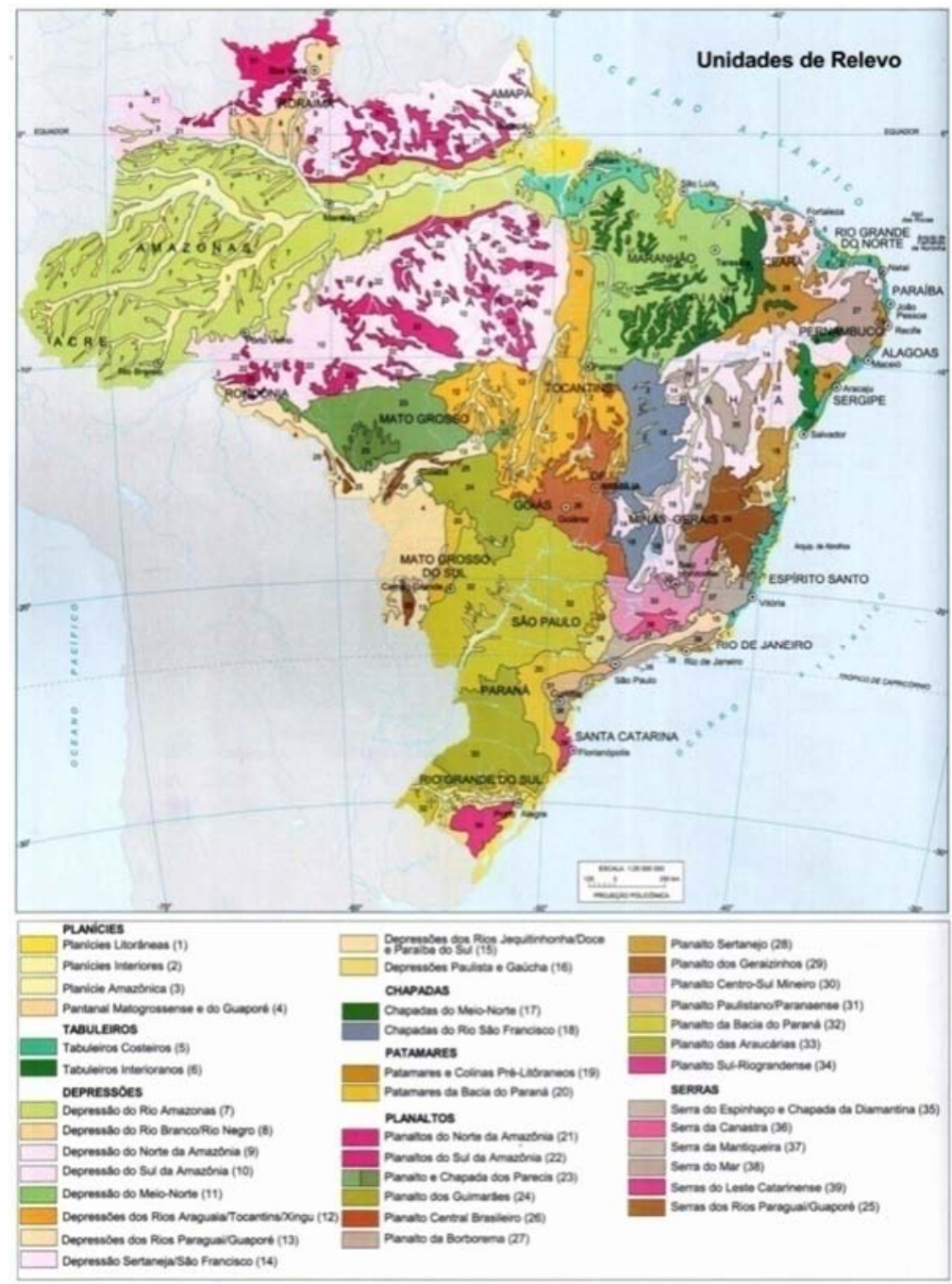

Figura 06: Unidades de Relevo.

Fonte: Atlas Geográfico, IBGE, 2002.

As planícies costeiras associadas à bacia sedimentar do Amazonas estão inseridas na bacia hidrográfica de mesmo nome: sub-bacia do Jari, nas bacias costeiras do norte; Oiapoque; Araguari; e, na bacia hidrográfica do Tocantins, sub-bacia do rio Pará.

Outro exemplo de extensas planícies associadas a uma bacia sedimentar refere-se às planicies do Pantanal Mato-Grossense e do Guaporé, inseridas em grande parte na bacia sedimentar do Paraná. Estas planicies estão inseridas na bacia hidrográfica do rio Paraguai e seus principais afluentes são o rio Miranda, Aquidauana, Itaquira e Cuiabá. 
Considerando as planícies do Pantanal Mato-Grossense e do Guaporé no território brasileiro, encontram-se segmentadas em três, sendo que as duas menores áreas encontram-se localizadas no cráton pré-brasiliano Amazônico.

À bacia sedimentar do Paraná estão também associadas as grandes planícies do rio Paraná e alguns de seus afluentes, planícies da bacia hidrográfica do Guaíba; ríos Vacacaí, Jacuí e Taquari, incluindo o rio dos Sinos, rio Araguaia e Tocantins e alguns de seus afluentes, e rio Ibicuí, inserido na bacia hidrográfica do rio Uruguai.

As maiores planícies da bacia hidrográfica do rio São Francisco estão localizadas na bacia sedimentar do Maranhão e nas coberturas sedimentares correlativas ao brasiliano.

A segunda maior área contínua de planicie litorânea localiza-se nas bordas da bacia sedimentar do Paraná, atingindo grande parte do litoral do Rio Grande do Sul.

Destacam-se também as planícies do rio Grajaú e Turiaçu, na face norte da bacia sedimentar do Maranhão, e algumas das planícies do rio Tocantins na face oeste.

A partir da análise conjunta das figuras 05 e 06 constata-se que as maiores planícies do território nacional, tanto continentais quanto costeiras, estão comumente inseridas em áreas de bacias sedimentares.

Pode-se inferir que há uma estreita relação entre bacias sedimentares e áreas de planície, ambas compreendendo áreas de deposição de sedimentos. A primeira por materiais consolidados ao longo do tempo geológico e a segunda por sedimentos recentes e inconsolidados. O tempo pretérito de uma bacia sedimentar compreende uma planície que ao longo do tempo sofreu soerguimentos, dobras, erosão, vulcanismo etc., possuindo por isso características mais complexas que as planícies. Talvez a estreita relação genética entre planície e bacia sedimentar explique o fato de que as maiores planícies encontram-se inseridas nesta morfoestrutura e, naquelas, as maiores terras inundáveis.

\subsubsection{Planícies do pantanal Mato-Grossense e do Guaporé}

O Pantanal é uma planície aluvial com aproximadamente $200.000 \mathrm{~km}^{2}$, formada no período quaternário, preenchida com depósitos aluviais dos rios da Bacia do Alto Paraguai e em fase de entulhamento. É a maior área inundável do continente americano (SOUZA, 1973). 
O regime da inundação nos pantanais é monomodal com variações no espaço e no tempo. O início da inundação ao norte da planície coincide com o início de chuvas constantes no mês de dezembro, enquanto na parte central e sul da planície podem ocorrer defasagens de até três meses entre o pico das precipitações (fevereiro/março) e o máximo das inundações. Ao longo dos cursos dos rios, a inundação da planície é principalmente garantida pelo transbordamento dos mesmos a partir de canais intermitentes, Penha (1999, apud FANTIN-CRUZ, 2010).

Aproximadamente $100000 \mathrm{~km}^{2}$ da área pantaneira chegam a ficar alagados no período de cheias. Este fato se explica, principalmente, pela baixa altitude do Pantanal: entre 80 e 150 metros acima do nível do mar e pela pequena declividade (NETO, 1992).

Do ponto de vista geológico, é uma área de formação recente, resultante dos processos de soerguimento da cadeia andina, que propiciaram a individualização da bacia sedimentar do Pantanal (GODOY FILHO, 1986).

Engloba zonas de ocorrência de planicies aluviais, flúvio - lacustres, e de inundação. As duas primeiras [...] são caracterizadas por apresentarem diques marginais, ilhas e lagoas. As planicies de inundação situam-se em posição interfluvial em relação à drenagem de maior importância, e por isso comportam "vazantes", "corixos", meandros abandonados, lagos, "baías" e pântanos permantemente alagados; baixos terraços fluviais inundáveis anualmente; altos terraços, diques aluviais, "cordilheiras" (PINTO, 2008, p. 84).

A região chamada Pantanal compreende vários pantanais com diferentes paisagens e formas de ocupação, podendo ser considerados ao menos oito. O pantanal do Poconé é parcialmente inundado pelos ríos Taquari e Cuiabá. O pantanal de Paiaguás (Fotografia 04), localizado na região de Corumbá e ao longo do curso do rio Paraguai, tem área bastante rebaixada, onde predominam as grandes lagoas, além de numerosas baías permantemente cobertas por águas. O Pantanal da Nhecolândia não é alagável como os demais, e por isso é a principal área de pastoreio. Destacam-se ainda os pantanais de Coroa Grande - Jauru, São Lourenço, Miranda - Aquidauana, Jacadigo - Nabileque e Taquari (NETO, 1992). 


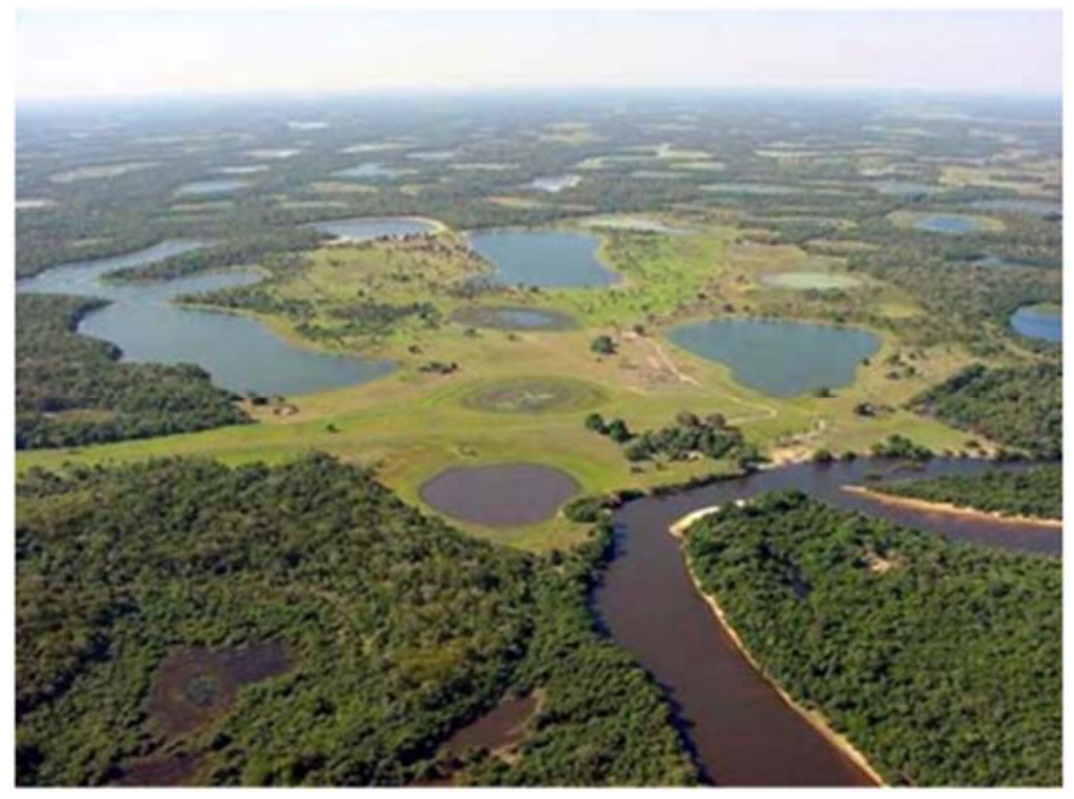

Fotografia 04: Predomínio de lagoas na região pantaneira de Paiaguás.

Fonte: http://www.achetudoeregiao.com.br/ANIMAIS/pantanal.htm

Segundo Neiff (1990, 2000) apud Cunha (2010), referindo-se à planície inundável do Pantanal, as diferenças locais da inundação (intensidade e duração), assim como as variações topográficas, modelam a paisagem e por consequiência a distribuição das unidades fitofisionômicas.

Outros autores partem do princípio de que existe uma relação linear entre cota topográfica e inundação. Variações topográficas determinam diretamente a intensidade e a duração da inundação e esses fatores têm relação direta com a distribuição das espécies vegetais (CUNHA, 2010).

Segundo Cunha (2010), o efeito da geomorfologia sobre o padrão espacial da inundação foi registrado por Poole et al. (2002) na planície de inundação do Nyak (EUA), Casco et al. (2005) na planície de inundação do baixo Paraguai (Argentina) e por Girard et al. (2010) para o Pantanal. 


\subsubsection{Planície Amazônica}

A bacia hidrográfica do rio Amazonas é a maior do mundo, com aproximadamente sete milhões de $\mathrm{km}^{2}$, com 3,8 milhões de $\mathrm{km}^{2}$ inseridos em território brasileiro. $\mathrm{O}$ rio Amazonas, que recebe também outros nomes, percorre aproximadamente $6280 \mathrm{~km}$, sendo o segundo maior do mundo em extensão e o primeiro em vazão de água. Sua largura média é de cinco quilômetros e possui aproximadamente sete mil afluentes.

Segundo Almeida (1989) apud Gibbs (1967), a carga detrítica transportada pelos rios amazônicos em épocas de cheia e vazante fica em torno de $123 \mathrm{~g} / \mathrm{m}^{3}$ e $22 \mathrm{~g} / \mathrm{m}^{3}$, respectivamente. Compreende uma elevada quantidade de sedimentos transportados.

Segundo Silva (2009) a bacia hidrográfica do Amazonas apresenta uma baixíssima declividade $(1 \mathrm{~cm} / \mathrm{km})$ na sua planície aluvial (GUYOT et al. 1993, 1994), onde uma relevante sazonalidade no regime hidrológico é evidenciada. Todos os cursos de água que se juntam ao rio Amazonas entre o leste do Peru e o oceano Atlântico, e ao Rio Negro entre Manaus e Barcelos, caracterizam-se por apresentarem enchentes anuais (WALKER, 1995).

As zonas de inundação da bacia Amazônica constituem uma rede complexa de lagos conectados ao leito principal dos rios, cobrindo superfícies que são estimadas entre $60000 \mathrm{~km}^{2}$ (SIPPEL et al., 1998) e $300000 \mathrm{~km}^{2}$ (JUNK, 1983).

Segundo Guerra (1987), examinando a área sedimentar da Amazônia observa-se que a extensa parte sedimentar denominada "terras firmes" compreende um baixo planalto, enquanto os trechos ribeirinhos e alagados são as verdadeiras planícies da Amazônia. A planície Amazônica e a do pantanal Mato- Grossense possuem grande extensão e compreendem a forma dominante na paisagem.

A origem da planície amazônica e do baixo planalto brasileiro, segundo Orville Derby, citado por Guerra (1987), ocorreu devido ao soerguimento dos Andes que barrou a comunicação franca existente entre o Atlântico e o Pacífico e levou à formação de um grande braço de mar. Com o passar do tempo, esse canal foi totalmente colmatado por aluviões carreadas da cadeia andina e dos maciços velhos e desgastados das Guianas, ao norte, e do Brasileiro, ao sul.

A planície do Amazonas é formada por uma unidade bem menor do que se pensava antigamente, a mesma apresenta cordões mais elevados que margeiam o leito do rio e formam 
diques fluviais com presença de florestas aluviais. Mais afastados encontram-se extensos trechos baixos e planos, onde ocorre maior permanência de água de inundação (ROSS, 1998).

A figura 07 é de parte da planície do rio Purus, afluente da margem sul do rio Solimões. O canal principal mostra-se extremamente sinuoso e a coloração azul clara refere-se à grande quantidade de sedimentos em suspensão na água. Nas áreas adjacentes, nas planícies, há a formação de lagos ao longo da planície do rio Purus, afluente do rio Amazonas.

Assim como nas planícies do Pantanal Mato-Grossense, a permanência dos períodos de inundação tem forte relação com a geomorfologia da área, com predominância de áreas de baixa declividade, planas ou suavemente onduladas. Os processos que levaram ao soerguimento da cadeia andina são considerados preponderantes na formação de ambas as planícies.

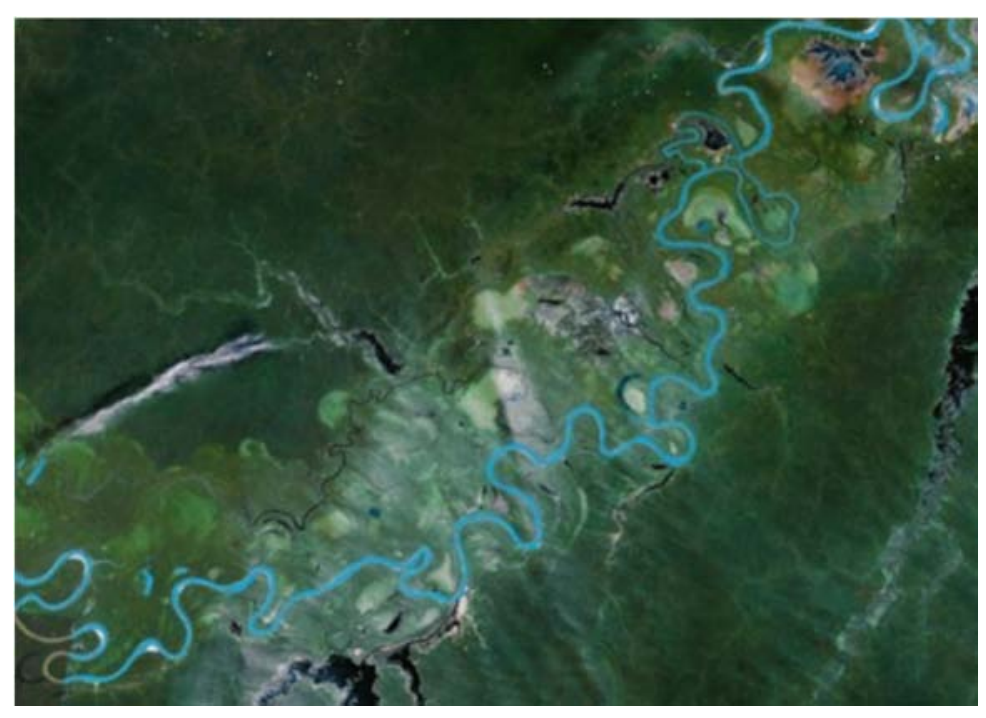

Figura 07: Parte da planície do rio Purus.

Fonte: Google Earth, 29/09/10

As duas maiores áreas de planícies inundáveis brasileiras, do Pantanal e da Amazônia, estão associadas, em grande parte, a rios meandrantes. $\mathrm{O}$ mesmo ocorre em relação às planícies de inundação da bacia hidrográfica do rio dos Sinos. 


\subsection{Regressão e transgressão marinha e as planícies costeiras}

As planícies marítimas ou costeiras, no que se refere à gênese, podem ser classificadas a partir de movimentos tectônicos (epirogênese), e pela eustasia, que se refere à noção teórica ligada às transgressões e regressões marinhas. Os efeitos da eustasia são mais significativos nas costas consideradas passivas devido à maior calma tectônica, propiciando a formação de amplas planícies costeiras.

A figura 08 compreende um exemplo das diferenças na morfologia do relevo nas margens ativas e passivas. A Placa Sul - Americana na sua face oeste é ativa em relação à Placa de Nazca e, na face leste, é passiva em relação à Placa Africana.

Na Figura 08 (letra a, município de La Serena, na costa do Chile) a linha em amarelo representa o limite aproximado entre as placas de Nazca e Sul - Americana. Ocorre neste limite a formação de fossas submarinas devido à subducção da primeira placa. A seta vermelha indica um comprimento aproximado de 100 quilômetros com variação altimétrica oscilando entre zero, na costa, a quase 6000 metros negativos quando atinge as fossas.

Na Figura 08 (letra b, detalhe da figura a), percebe-se o efeito do choque entre as placas nas bordas continentais. A linha em amarelo, que vai da praia até o cume de um morro, representa uma distância de sete quilômetros que varia de 0 a 215 metros de altitude, apresentando um relevo ondulado a forte ondulado bem próximo a costa.

Uma relação inversa pode ser verificada na face leste da placa Sul - Americana onde o relevo se mostra com pouca declividade e pequena variação de altitude.

A Figura 08 (letras c e d, face leste da Placa Sul - Americana) compreende a face oposta da Placa Sul - Americana. Na figura 08 (letra c), a plataforma continental atinge aproximadamente 140 quilômetros de extensão, com altitude variando entre zero a 370 metros.

Na figura d a linha traçada na faixa que vai da linha de costa em direção ao continente é de 28 quilômetros e a variação altimétrica está entre zero e dezesseis metros configurando um relevo plano ou quase. Percebe-se nessa área uma ampla planície e, nesta, vários corpos hídricos causando a inundação, ao menos em parte dessa área. 


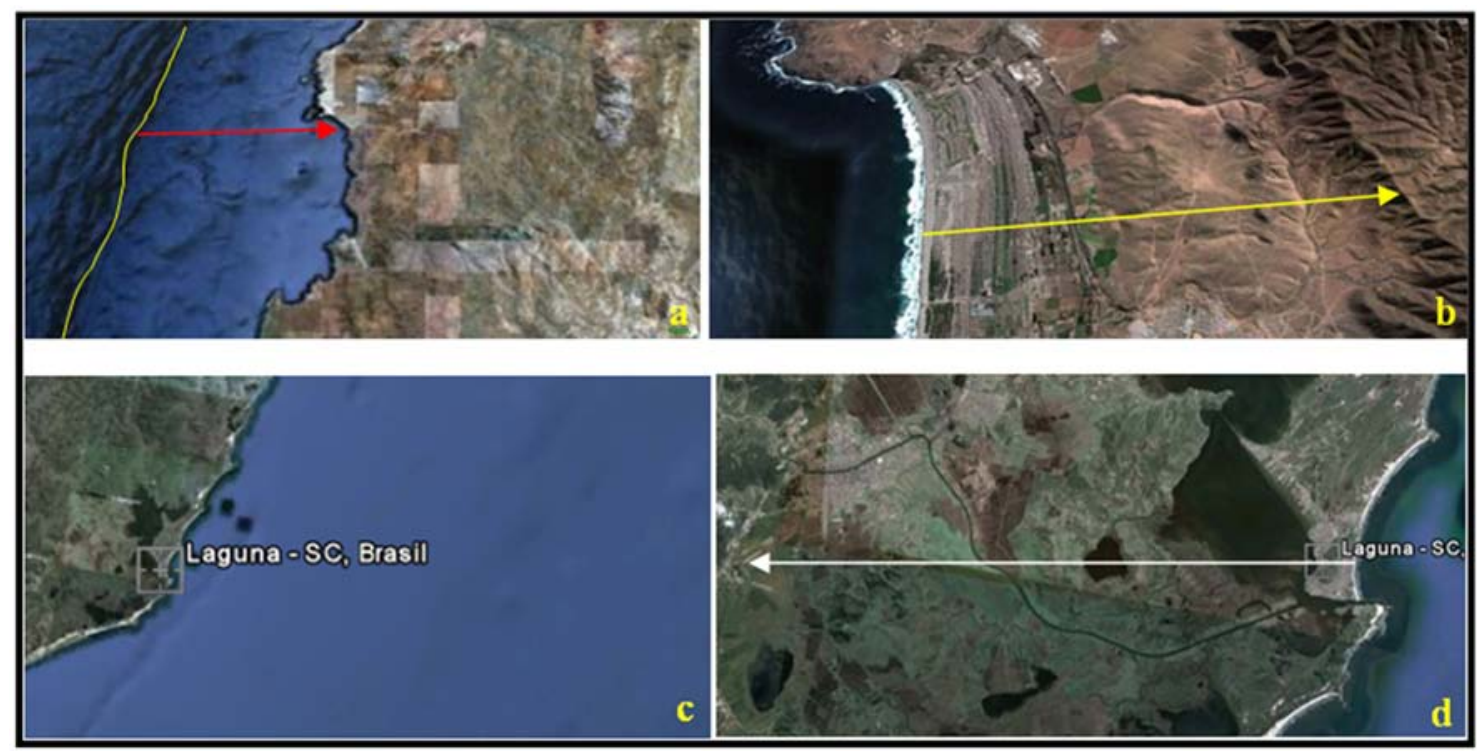

Figura 08: Limite entre as placas Sul - Americana e de Nazca com formação de fossa submarina (a); detalhe da figura a, costa ativa com relevo ondulado (b); cidade de La Serena - Chile (a e b); Plataforma continental da placa Sul - America na face leste, margem passiva (c); planície costeira (d); Laguna - Brasil (c e d).

Fonte imagens: Google Earth, 25/08/2010.

Elaboração: Adriana Penteado, 2010.

A eustasia ou eustatismo refere-se às variações lentas do nível dos mares, que podem ter movimentos positivos - quando as águas invadem as terras, as chamadas transgressões marinhas, ou negativas - quando as águas se afastam da linha litorânea. O congelamento de grande quantidade de água e a sua fusão são os principais fatores que explicam tais movimentos.

O acúmulo de águas sobre os continentes, na forma de gelo, acarretou regressões marinhas importantes ao longo do Quaternário, o que pode ser chamado de eustatismo glacial. Há ainda o abaixamento ou soerguimento lento do fundo da bacia oceânica, ocasionando eustasia de deformação lenta dos fundos oceânicos (GUERRA, 1987).

As flutuações do nível relativo do mar resultam das variações reais do nível marinho (eustasia) e das modificações do nível dos continentes (tectonismo e isostasia). Portanto é evidente que, quando se efetuam reconstruções de antigos níveis marinhos, estes se referem a posições relativas e não absolutas (SUGUIO et al., 1985, p. 01). 
As grandes oscilações do nível do mar ocorreram no Quaternário e exerceram papel fundamental na evolução das linhas de costa, por vezes deixando à mostra parte das atuais plataformas continentais, ou recobrindo-as de forma parcial ou total, formando as atuais planícies costeiras.

Globalmente, a alternância de períodos glaciais e interglaciais ocorridos durante o Quaternário no hemisfério norte e suas consequências indiretas nos oceanos austrais; os movimentos tectônicos cenozóicos; as deformações do geóide terrestre; a acumulação de sedimentos nas bacias oceânicas; entre outras, são causas importantes para explicar a formação dos depósitos emersos e submersos das planícies costeiras e plataformas continentais adjacentes (FILHO, 2003).

As variações na altura do nível do mar compreendem um dos mais eficientes mecanismos de modificação da linha de costa. Oscilações de centenas de metros, decorrentes das glaciações, provocaram migrações de linha de costa de dezenas a mais de centenas de quilômetros, correspondentes a largura da plataforma continental. Esta passou de feição submarina para planície costeira, sendo retrabalhada pela dinâmica fluvial e marinha (MUEHE, 2007).

No Brasil, as oscilações do nível do mar foram de fundamental importância na evolução das planícies costeiras. Os depósitos arenosos quaternários de origem marinha, situados acima da zona atual de deposição equivalente, são evidências marcantes de antigos níveis marinhos mais altos que o atual. Resumidamente, pode-se dizer que, independente das causas, a maior parte do litoral brasileiro esteve em submersão até cerca de 5150 anos A.P. (antes do presente) seguida de emersão até os nossos dias. Essa não é uma situação comum encontrada no mundo inteiro para este intervalo de tempo. (SUGUIO, 1985).

Durante o Holoceno, no final da última grande transgressão (por volta de 5000 A.P.), a maior parte do litoral brasileiro esteve 5 metros acima do nível atual, sendo que o posterior recuo foi responsável pelo desenvolvimento da porção mais recente da planície costeira atual (SUGUIO \& MARTIN, 1987).

O modelo evolutivo mais completo refere-se ao estado da Bahia (Figura 09), sendo válido entre Macaé (RJ) e Recife (PE). Este modelo possui oito estágios evolutivos e demonstra a influência das transgressões e das regressões marinhas na formação de planícies costeiras. 
Os depósitos de sedimentos que são mais intensos nos períodos de regressão marinha são formados pela ação das águas marinhas e fluviais. Com o passar do tempo, os materiais depositados podem sofrer litificação e, assim, algumas feições podem permanecer estáveis ou pouco alteradas em períodos transgressivos, ficando novamente emersas nas regressões. Já os materiais inconsolidados serão facilmente removidos e retrabalhados.

Nos períodos transgressivos, predominam os processos erosivos, e nos regressivos, os processos de deposição. O tempo de atuação de cada fenômeno vai interferir na intensidade de atuação de cada processo.

A alternância de períodos regressivos-transgressivos vai (re) modelando as planícies costeiras e, neste processo desenvolvem-se ambientes propícios ao surgimento de terras inundáveis costeiras. 

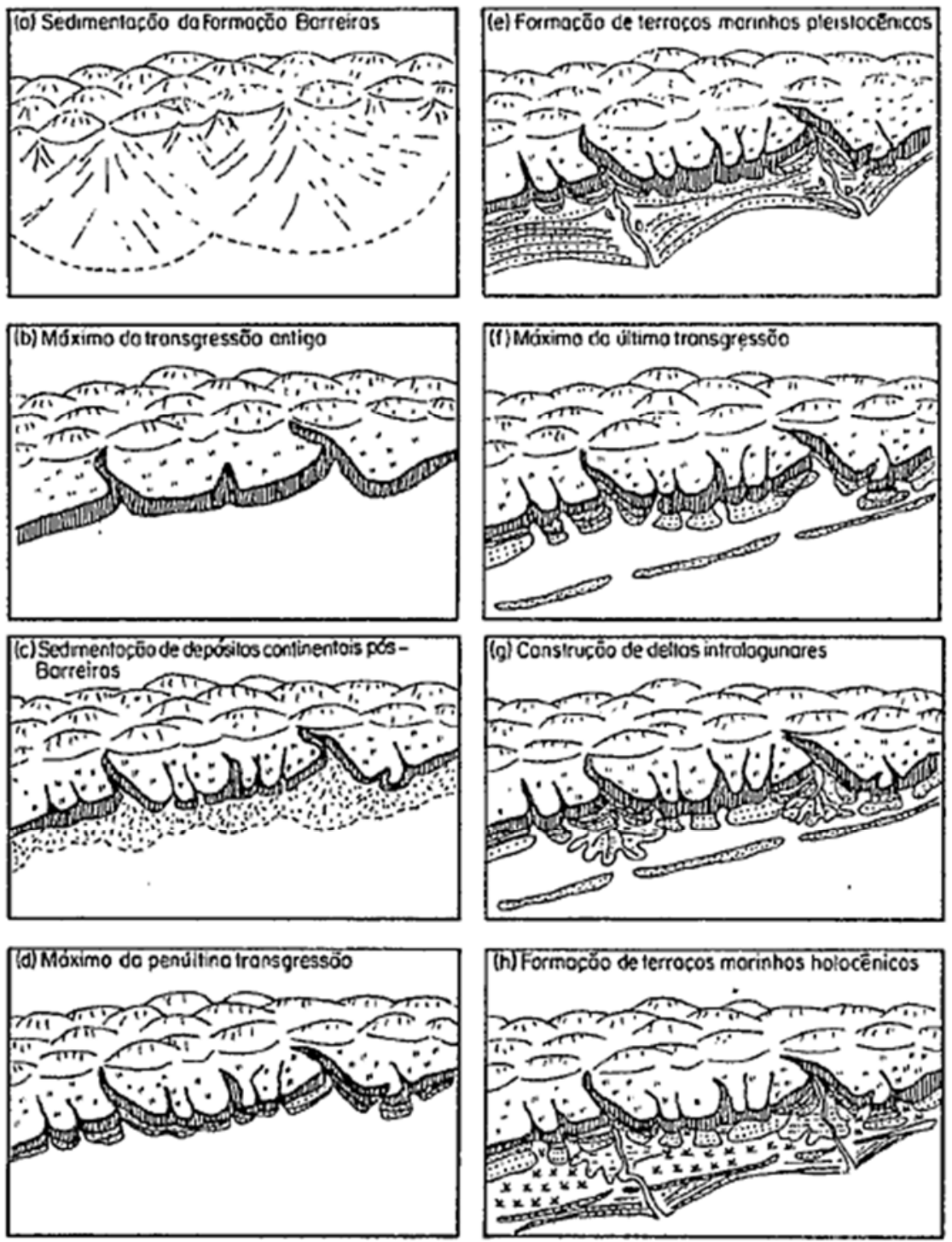

Figura 09: Evolução da sedimentação costeira durante fim do Terciário e o

Quaternário no estado da Bahia.

Fonte: Suguio et al, 1985, p. 282.

Os depósitos arenosos serão mais desenvolvidos onde o trânsito litorâneo sofrer algum tipo de impedimento ocasionando a deposição dos sedimentos. Esses obstáculos podem ser reentrâncias de linhas de costa, ilhas, desembocaduras importantes de rio, etc. (SUGUIO, 2005).

A Figura 10 exemplifica um bloqueio do trânsito litorâneo devido ao alto fluxo fluvial no período de cheia. Esse fluxo irá impedir a passagem dos sedimentos em suspensão trazidos pelas 
ondas, como conseqüência esse material é depositado antes do fluxo que funciona como um molhe artificial. Ocorrerá uma sedimentação a barlamar ${ }^{10}$ e erosão a sota- mar.

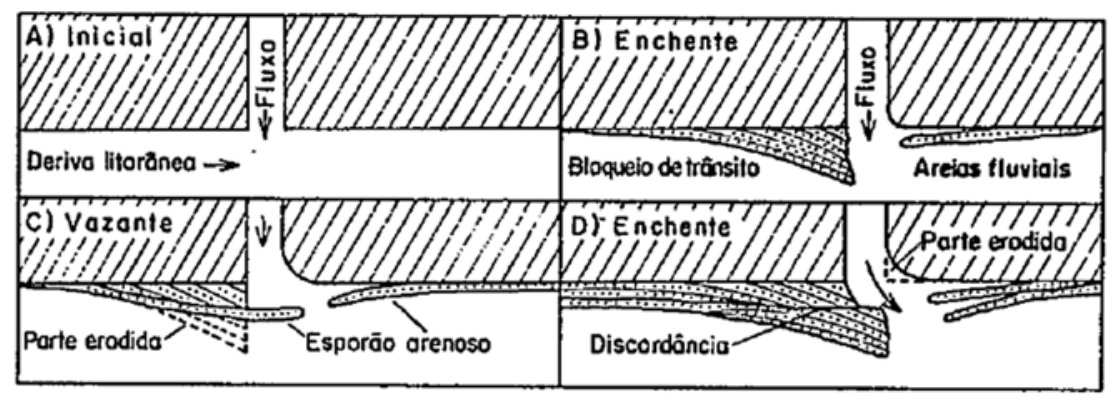

Figura 10: Mecanismo de bloqueio do transporte litorâneo de areias devido ao fluxo formado por uma desembocadura fluvial em região costeira.

Fonte: Suguio et al., 1985, p. 281.

$\mathrm{Na}$ época de baixa vazão, o fluxo do rio já não funciona como uma barreira, ou perde grandemente sua significância nesse sentido. Os sedimentos depositados no período anterior começam a sofrer erosão. O material que é erodido pode originar um pontal arenoso que irá obstruir a desembocadura do canal fluvial. Dependendo da permanência do período de baixa vazão, o pontal construído poderá resistir aos períodos de alta vazão; posteriormente, apenas as extremidades deste serão erodidas, e o barramento poderá causar um deslocamento na foz do rio no sentido da deriva litorânea (SUGUIO et al., 1985).

Este processo deixará sobre a planície costeira linhas de truncamento ziguezagueantes [...]. Acompanhando estas linhas de truncamento será construído, a barlamar, novo sistema de cristas arenosas alimentado por transporte litorâneo paralelo à linha de costa. Uma vez formados, esses pontais e ilhas irão abrigar em seu lado interno zonas protegidas que de lagunas evoluem para lagoas e zonas pantanosas com manguezais (SUGUIO et al, 1985, p. 282).

A planicie litorânea constitui-se das seguintes feições morfológicas: praia, pós-praia, campo de dunas e planície fluviomarinha (VICENTE DA SILVA, 1993):

\footnotetext{
${ }^{10}$ Barlamar: Sentido contrário ao transporte preferencial de sedimentos clásticos litorâneos, movimentados através de correntes longitudinais. Fonte: http://www.geotrack.com.br/pdiciob.htm. Acessado em 19/08/2010.
} 
As praias são formadas por sedimentos arenosos ou rochosos, restos de conchas e cascalhos; há, porém, um predominio quase absoluto de grãos de quartzo. Compreende depósitos de areia acumulada devido à ação das águas marinhas.

A pós-praia corresponde a uma área de transição entre os sedimentos arenosos e outros ecossistemas como as dunas e estuários, podendo por vezes ser limitada por falésias e/ou "beach rocks".

Para a formação de dunas costeiras, é necessária a disponibilidade de grande quantidade de sedimentos que poderão ter origem fluvial ou marinha, assim, nem todo o litoral terá o desenvolvimento de dunas. O vento é um importante agente na remodelação dessas áreas. As dunas podem ser fixas: quando há vegetação nas mesmas tornando-as menos vulneráveis à ação do vento; ou móveis: sem vegetação e que mudam de forma constantemente conforme a direção e intensidade dos ventos.

Elas se formam onde existe um obstáculo. O ângulo da duna a barlavento é suave (inclinação de $5^{\circ}$ a $12^{\circ}$ ), enquanto a sotavento pode alcançar uma declividade que chega a $35^{\circ}$ (GUERRA, 1987).

A planície fluviomarinha está localizada em áreas onde há influência das oscilações da maré e das águas fluviais. Desenvolve-se a partir da combinação de processos continentais e marinhos cujos agentes fluviais, terrestres e oceânicos propiciam a formação de um ambiente lamacento, encharcado, úmido, rico em matéria orgânica, onde se encontram os manguezais que também podem ser denominados de terras inundáveis fluviomarinhas.

\subsubsection{Planícies costeiras do Rio Grande do Sul}

Os principais estudos sobre a formação das planícies costeiras do Rio Grande do Sul (PCRS) foram desenvolvidos pelo Centro de Estudos de Geologia Costeira e Oceânica da UFRGS e pelo Instituto de Meio Ambiente da PUC - RS por Tomazelli \& Villwock.

Os estudos desenvolvidos utilizam como unidade básica de mapeamento e correlação o sistema deposicional (Figura 11). 
O trabalho mostrou que os depósitos aflorantes na PCRS acumularam-se em sistemas deposicionais específicos desenvolvidos na região durante o final do Terciário e, principalmente, durante o Quaternário: (1) um sistema de leques aluviais ocupando uma faixa contínua ao longo da parte mais interna da planície costeira e, (2) quatro distintos sistemas deposicionais transgressivos-regressivos do tipo laguna-barreira (TOMAZELLI \& VILLWOCK, 2005, p. 111).

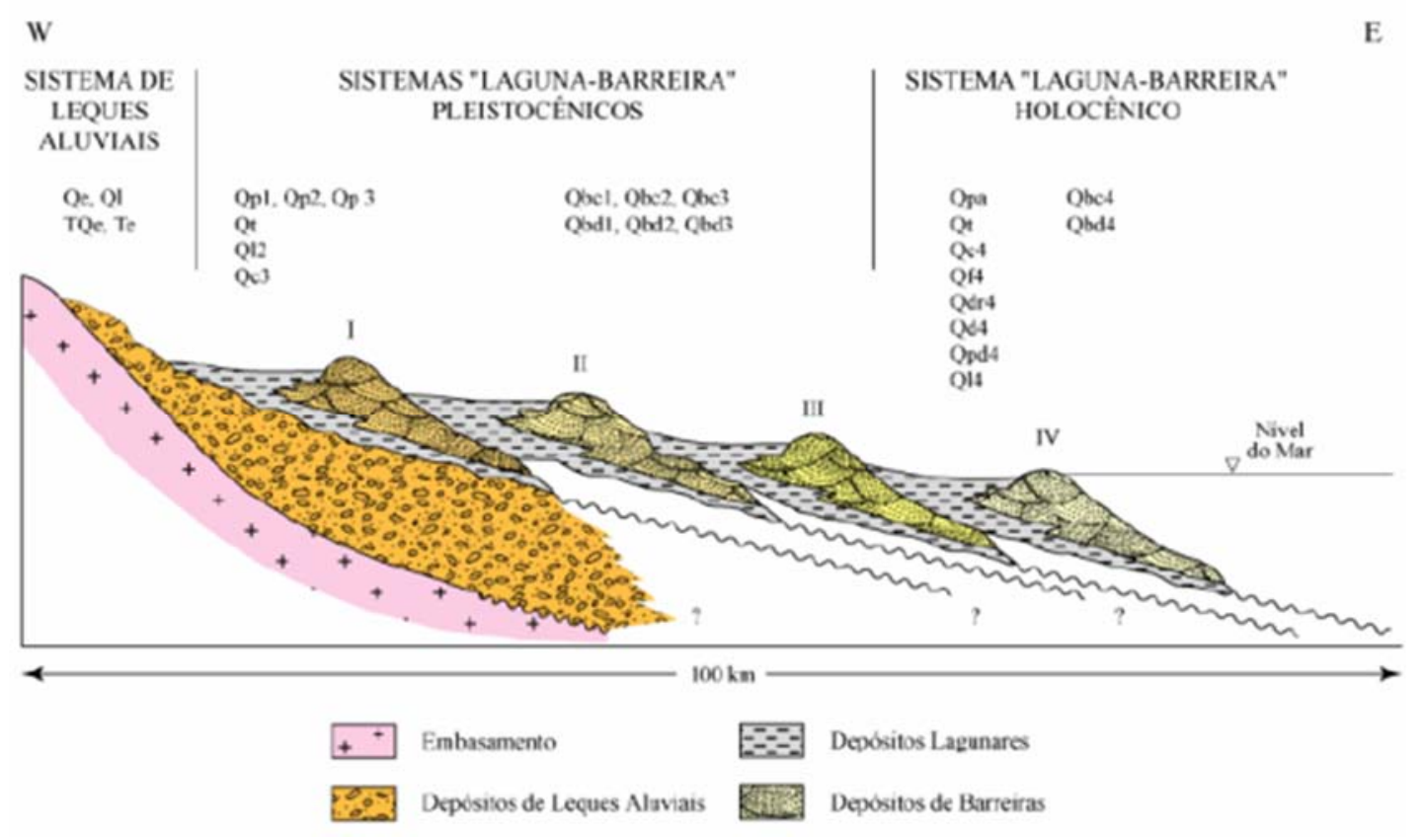

Figura 11: Perfil esquemático (W- E) transversal aos sistemas deposicionais da Planície Costeira do RS com suas fáceis sedimentares associadas.

Fonte: Tomazelli \& Villwock, 2005.

O Sistema Deposicional de Leques Aluviais está associado aos ambientes de encostas de terras altas adjacentes à planície costeira. Os processos deposicionais se iniciaram, provavelmente, no final do Terciário e atuam com menor intensidade até o presente. A intensidade desses processos variou em função das mudanças no clima, alterando o regime pluviométrico e a taxa de cobertura vegetal. (TOMAZELLI \& VILLWOCK, 2005).

O Sistema Laguna Barreira I ocorreu no primeiro evento pleistocênico, sofrendo influência de várias transgressões e regressões marinhas que se sucederam durante o Quaternário, compreendendo o sistema deposicional mais antigo. Seu crescimento ocorreu principalmente a partir de sedimentos eólicos. A cada nova transgressão do mar parte da região era encoberta pela água, havendo assim retrabalhamento dos sedimentos que ali estavam depositados. A diferença 
sedimentológica da área reflete estes diferentes eventos. Os depósitos têm origem aluvial, lagunar, lacustre e paludal de idades diferenciadas (TOMAZELLI \& VILLWOCK, 2005).

O Sistema Laguna Barreira II ocorreu num segundo evento transgressivo - regressivo e o Sistema III está relacionado a um terceiro evento. Este se encontra bem preservado atualmente e foi responsável pela implantação final da Lagoa dos Patos. Os depósitos relativos à barreira III são encontrados de forma quase contínua ao longo de toda a planície costeira do Rio Grande do Sul (ibid.).

O Sistema Deposicional Laguna - Barreira IV compreende o mais recente sistema deposicional e desenvolveu-se durante o Holoceno. Surgiu como consequência da última grande transgressão pós-glacial. No pico máximo desta transgressão o mar estava aproximadamente 3 a 4 metros acima do seu nível atual (ibid.).

Os depósitos ao longo do Terciário e do Quaternário possibilitaram o alargamento da atual planície costeira do Rio Grande do Sul. Os mesmos formaram barreiras que possibilitaram a retenção de água formando lagoas e lagunas, estas associadas a outros corpos hídricos caracterizam um sistema no qual estão inseridas as terras inundáveis costeiras do estado.

A Figura 12, representando parcialmente o município de Cidreira, compreende parte da planície costeira do Rio Grande do Sul. Destacam-se algumas das lagunas do sistema barreira, localizadas no limite entre as dunas costeiras, que estão conectadas entre si e com o mar por canais hídricos. 


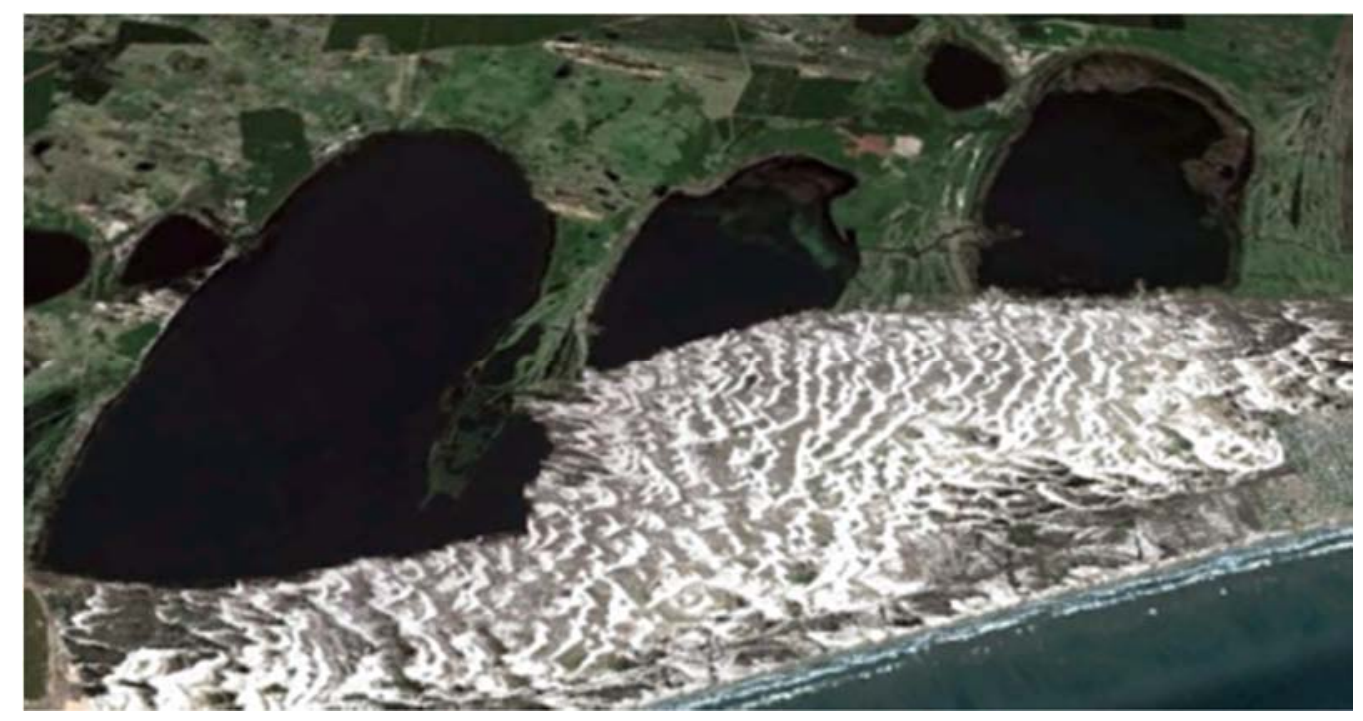

Figura 12: Lagunas do sistema barreira.

Fonte: Google Earth, 2010. 


\section{CAPÍTULO 4 - ANÁLISES DOS ASPECTOS FÍSICOS DA ÁREA DE ESTUDO}

\subsection{Geologia}

Para o entendimento morfoestrutural e morfotectônico de uma região qualquer é de suma importância o entendimento inicial das estruturas geológicas. As estruturas em geral controlam as feições geomorfológicas, as quais posteriormente serão submetidas a processos de "esculturação" pelos fatores climáticos.

No território brasileiro, as estruturas e as formações litológicas são antigas, mas as formas do relevo são recentes. Estas foram produzidas pelos desgastes erosivos que sempre ocorreram e continuam ocorrendo, e com isso estão sendo permanentemente reafeiçoadas. Desse modo, as formas grandes e pequenas do relevo brasileiro têm como mecanismo genético, de um lado, as formações litológicas e os arranjos estruturais antigos, de outro os processos mais recentes associados à movimentação das placas tectônicas e ao desgaste erosivo de climas anteriores e atuais, (ROSS, 1996, p. 45).

As características geológicas, além de influenciarem na morfoestrutura, definem o local de armazenamento da água precipitada; na superfície, por meio do escoamento superficial (rios ou lagos) ou no subsolo (escoamento subterrâneo ou confinamento em aquíferos), segundo VILELLA \& MATTOS, 1979.

A geologia da área de estudo é composta por depósitos do Quaternário e do Terciário, Formação Serra Geral, Formação Botucatu e Formação Rosário do Sul, conforme Mapa Geológico. 
Mapa 01: Mapa geológico da bacia hidrográfica do rio dos Sinos - RS 


\subsubsection{Cobertura Sedimentar Cenozóica - Depósitos do Terciário e do Quaternário}

Os depósitos eluviais e coluviais do Terciário são representados por conglomerados, diamicitos, arenitos conglomeráticos, arenitos e lamitos avermelhados, maciços ou com estruturas acanaladas. Estão presentes no rio Paranhana desde o município de Três Coroas até bem próximo a sua foz, no rio da Ilha em maior proporção no seu trecho médio, assim como no rio Rolante. Está também presente em boa parte da extensão do rio dos Sinos, margeando os depósitos do Quaternário ao longo de pequenos afluentes.

Os depósitos aluvionares do Quaternário são representados por cascalhos, areias grossas e finas e sedimentos síltico-argilosos. Os mesmos preenchem as calhas e planícies de inundação dos maiores rios da bacia de estudo. No rio dos Sinos estes depósitos estão presentes em quase toda a sua extensão, com maior concentração a jusante. Seguidamente se encontram em maior proporção no rio Rolante e da Ilha e em um pequeno trecho do rio Paranhana.

Os depósitos do Quaternário encontram-se de forma predominante em altitudes de até 40 metros, já os depósitos do Terciário chegam a aproximadamente 130 metros de altitude.

\subsubsection{Vulcanismo e cobertura sedimentar da Bacia do Paraná}

Segundo Vieira (1984), a bacia sedimentar do Paraná ocupa uma vasta área sobre a plataforma sul-americana, num total de $1.600000 \mathrm{~km}^{2}$ em terras brasileiras, paraguaias, uruguaias e argentinas. Trata-se de uma bacia de acumulação sedimentar dentro do cráton.

A efusão dos vulcanitos da Formação Serra Geral foi precedida e seguida por intensa tectônica rúptil que se desmembrou em horsts e grabens da sequência sedimentar. Estes movimentos geraram "arcos" e "siclinais" que, de certa forma, influenciaram na deposição dos sedimentos pós-Serra Geral.

Segundo Milani (2000), o Jurássico na Bacia do Paraná foi um período de erosão em grande escala, se refletindo como a mais pronunciada lacuna de seu registro estratigráfico. Considera-se que inexiste uma seção meso a neotriássica em praticamente toda a bacia, com exceção da área de ocorrência da Supersequência Gondwana II tanto no estado do Rio Grande do Sul como no Uruguai. 
A Formação Botucatu, em conjunto com as lavas da Formação Serra Geral, compõe a Supersequência Gondwana II da Bacia do Paraná. Essas unidades litológicas são altamente particulares entre si, a primeira uma seção de arenitos médios a finos de origem eólica compondo um singular blanket (cobertor) em toda a bacia, e a segunda, sucedendo a primeira, compreende rochas magmáticas efusivas que compõem a maior manifestação ígnea continental de toda a terra. Estas duas unidades, apesar das particularidades, estão agrupadas em uma mesma unidade aloestratigráfica em função do íntimo relacionamento entre si (MILANI, 1997).

O contato entre a Formação Botucatu e a Formação Serra Geral não apresenta uma conformidade, mas assume a dimensão de um contato transicional pelo fato de que, existindo uma alternância entre os primeiros derrames e o final das acumulações de eolianitos, pode-se dizer que o campo de dunas conviveu por algum tempo com o vulcanismo ativo, até que o completo soterramento pelas rochas basálticas impediu definitivamente a manutenção do arenito Botucatu.

Devido ao elevado fluxo térmico no interior do continente, condições de subsidência incipiente à nula levaram a abrasão eólica relacionada ao paleodeserto, e grande mobilidade dos ergs arenosos, que não encontravam restrições fisiográficas para a sua fixação definitiva (ibid.).

Com o início do magmatismo, este serviu como um importante fator de modelamentos do substrato da bacia representado pelas massas de lavas, de forma que os campos de dunas que hoje constituem o registro estratigráfico da Formação Botucatu, acumulados a partir do Neojurássico, devem ter se utilizado da nova configuração do substrato, ocorrida em função do magmatismo da Serra Geral (VIEIRA, 1984).

Os planaltos em bacias sedimentares, como na bacia do Paraná, são quase inteiramente circundados por depressões periféricas ou marginais. Essas unidades também se caracterizam por apresentar contatos escarpados por frentes de cuesta (RADAM, 1986).

\subsubsection{Formação Serra Geral}

A designação de Formação Serra Geral (WHITE, 1906) refere-se à província magmática relacionada aos derrames e intrusivas que recobrem $1,2 \times 10^{6} \mathrm{~km}^{2}$ da Bacia do Paraná, (MELFI et al., 1988), abrangendo toda a região centro-sul do Brasil e estendendo-se ao longo das fronteiras do Paraguai, Uruguai e Argentina. Esta unidade está constituída dominantemente por basaltos e 
basalto-andesitos de filiação toleiítica ${ }^{11}$, os quais contrastam com riolitos e riodacitos aflorantes na região dos Aparatos da Serra, e que caracterizam uma associação litológica bimodal (basalto riolito).

A Formação Serra Geral é considerada um registro do mais volumoso episódio de extravasamento intracontinental de lavas do planeta (MILANI et al., 1994). Esta formação está associada aos estágios precoces da ruptura do Gondwana e à abertura do Oceano Atlântico Sul. Possui uma espessura de até 2000 metros de basalto sobre os sedimentos da bacia do Paraná (MISUZAKI, 2004).

A Formação Serra Geral é constituída de magmatitos básicos, dentre os quais se incluem derrames de lavas, soleiras, diques de diabásio e corpos de arenitos intertrapeanos. A origem dessa Formação está associada ao vulcanismo de fissura, com efusão relativamente calma, evidenciada pela ausência de materiais piroclásticos (NISHIYAMAL, 1991). Diques e corpos concordantes de diabásio, encaixados em unidades rochosas mais antigas e relacionadas às efusivas, têm ocorrência generalizada na região de Uruguaiana - folhas Porto Alegre SH. 21 e Porto Alegre SH. 22 (RADAM, 1986).

Leinz (1949) apud RADAM (1986), em detalhado estudo referente à Formação Serra Geral no sul do país, considerou a ascensão dos magmas por meio da abertura de geóclases relacionadas a movimentos ligados à deriva continental, estabelecendo no Rio Grande do Sul duas dessas “zonas produtoras”: Linhas Tectônicas Torres- Posadas e São Gabriel - Santa Maria.

Para a área de estudo a formação Serra Geral está subdividida em rochas básicas intermediárias (Ksgb1) e ácidas (Ksga1). A primeira, em maior proporção, atinge todos os trechos da bacia, com maior incidência nos trechos médio e superior, atingindo a maioria dos municípios.

As rochas vulcânicas ácidas são encontradas nas bordas norte e nordeste da bacia, principalmente nos municípios de Igrejinha, Canela, Gramado, São Francisco de Paula e Riozinho.

Nas bordas do planalto o relevo é fracamente dissecado, caracterizando topos tabulares a suavemente ondulados, representado o limite entre as rochas ácidas e básico-intermediárias. A

\footnotetext{
${ }^{11}$ Toleito: variedade de tipo de magma com ampla distribuição na superfície do globo, sendo encontrado em cadeias oceânicas, vulcões em escudo e regiões continentais relacionadas aos basaltos de platô, como os encontrados na Bacia do Paraná. Fonte: Glossário on line CPRM - Serviço Geológico do Brasil. 16/04/2009.
} 
transição ocorre por meio de escarpas seguidas de relevo fortemente dissecado (Figura 13). O desnível altimétrico das rochas ácidas para as básicas e intermediárias varia de aproximadamente 980 a 300 metros. A Fotografia 05 é do município de São Francisco de Paula, representando as escarpas no limite entre o Planalto Basáltico Tabular e o Planalto Basáltico Dissecado.

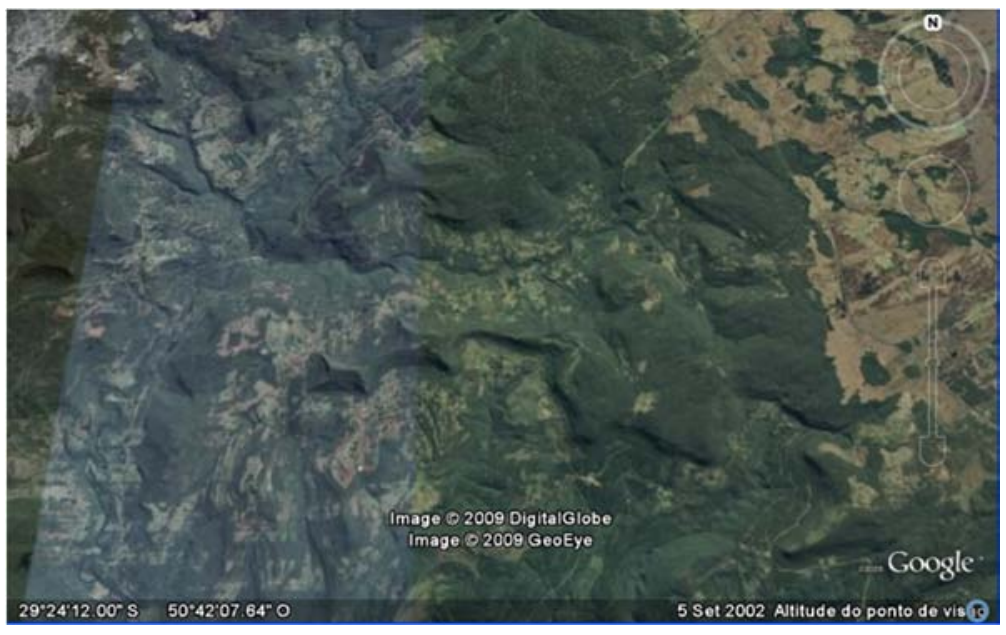

Figura 13: Transição entre as rochas básico-intermediárias e ácidas. Fonte: Google Earth, acessado em 15/06/2009.

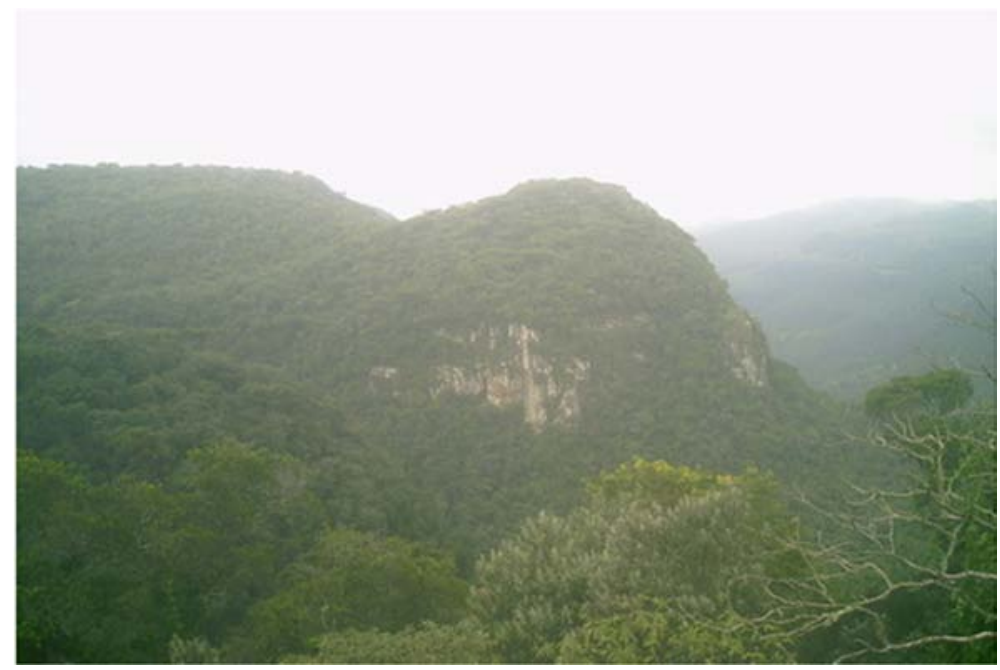

Fotografia 05: Escarpa do planalto, município de São Francisco de Paula. Fonte: Google Earth, acessado em 15/06/2009. 


\subsubsection{Formação Botucatu}

Campos (1889) introduziu na literatura geológica o termo Botucatu para denominar os arenitos que fazem parte da serra de mesmo nome no estado de São Paulo. Essa Formação caracteriza-se pelas estratificações cruzadas, planar ou acanalada, de médio a grande porte (campos de dunas eólicas), com raras intercalações de arenitos com estratificações planoparalelas (interdunas secas), que ocorrem embaixo ou intercaladas as rochas vulcânicas. Além disso, apresenta comumente alternância de lâminas de arenito fino e de arenito médio, o que resulta em bimodalidade textural (ASSINE, 2004).

Segundo Ramos (1975), esses arenitos são predominantemente eólicos de origem, característicos em toda a Bacia do Paraná, compreendendo um dos grandes eventos climáticos ocorridos no Mesozóico. Estes arenitos geralmente apresentam-se com tonalidades de rosa, granulometria que varia de fina a média, possuindo grãos de quartzo bem classificados, levemente feldspáticos, por vezes silicificados (conferindo-lhes maior resistência), ora cimentados com óxido de ferro (tornando-os friáveis e facilmente desagregáveis).

Os espaços que separam uma camada sedimentar de outra são as juntas de estratificação, também denominadas de diáclases ${ }^{12}$ horizontais. Essas diáclases, do ponto de vista morfológico, têm importância por causa da erosão diferencial, isto é, do trabalho desigual da erosão que, quando atua sobre uma camada tenra, age com mais intensidade do que quando trabalha em uma camada mais resistente (GUERRA, 1987).

O contato entre as formações Botucatu e Serra Geral é concordante na base do primeiro derrame vulcânico, com recorrência de arenitos nas camadas inferiores dos basaltos da Serra Geral. Não há grandes superfícies internas na Formação Botucatu no Rio Grande do Sul, que assim representa o registro de um único evento de acumulação eólica na área (SCHERER, 2000).

\footnotetext{
12 Fratura, junta ou fenda, aberturas microscópicas ou macroscópicas que aparecem no corpo de uma rocha, principalmente por causa dos esforços tectônicos, tendo direções variadas. As diáclases são de grande importância no modelado do relevo terrestre. Constituem pontos fracos de ataque, por parte da erosão. As diáclases têm um grande papel na desagregação das rochas e também na erosão elementar. Fonte: Dicionário Geológico - Geomorfológico de Guerra \& Guerra (1987).
} 
Quando silicificados, os arenitos mantêm topografia acidentada, com cotas elevadas, constituindo verdadeiras feições de "cuestas" dissecadas, com frequência "morros testemunhos" nas faces íngremes (RAMOS, 1975).

A Fotografia 06 é de um morro testemunho de arenito Botucatu, localizado no trecho inferior da bacia hidrográfica do rio dos Sinos, entre os municípios de São Leopoldo, Novo Hamburgo e Sapucaia do Sul. O Morro do Paula vem sendo utilizado ao longo do tempo para a extração irregular de arenito, além de ocupações irregulares que vêm se intensificando.

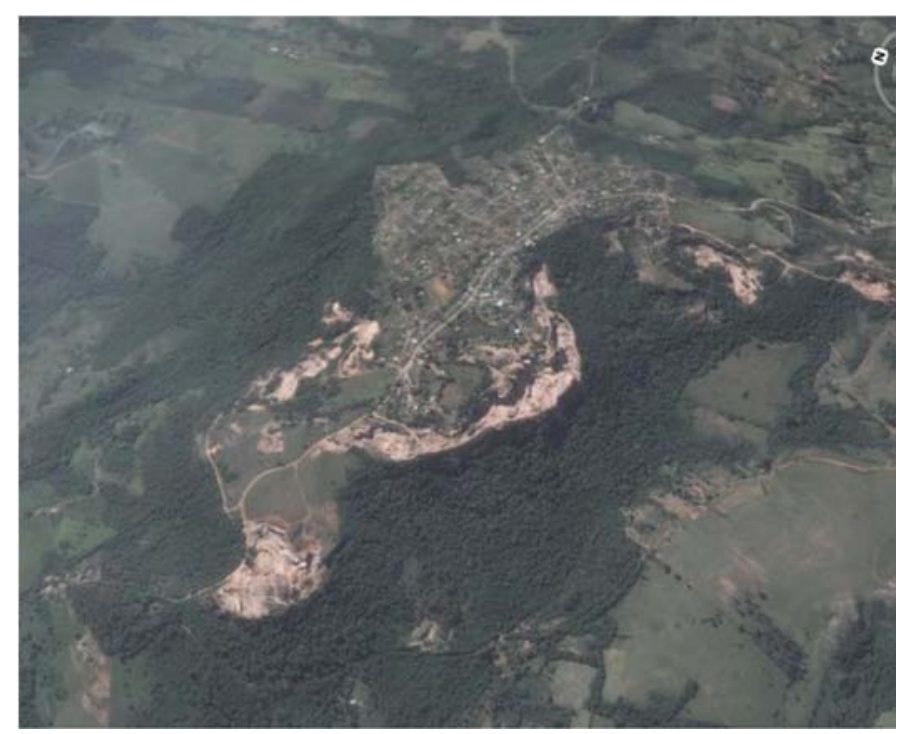

Fotografia 06: Morro Testemunho da Formação Botucatu no município de São Leopoldo.

Fonte: Google Earth, acessado em 15/06/2009.

Quando friáveis, os arenitos da Formação Botucatu são facilmente intemperizados, permitindo o modelado de colinas suaves, de vertentes convexas, arredondadas, de média altitude, determinando paisagens onduladas (RAMOS, 1975) - Fotografia 07. 


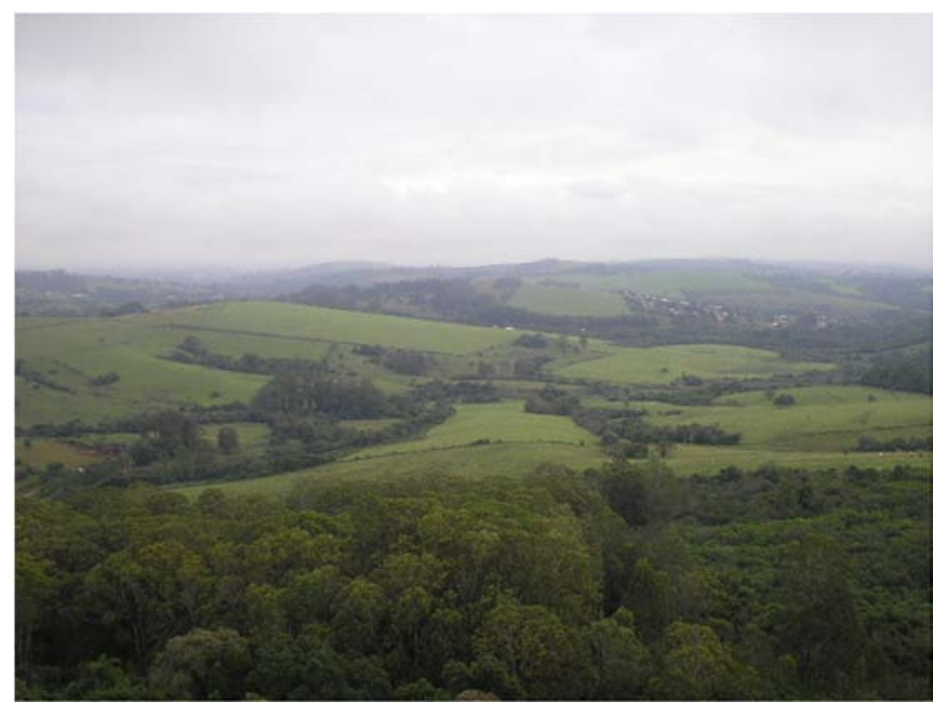

Fotografia 07: Relevo suave ondulado da Formação Botucatu no município de São Leopoldo.

Fonte: Adriana Penteado, 09/2005.

Os arenitos interderrames ocorrem intercalados na sequência básica de maneira eventual, sob a forma de lentes ou camadas de maior continuidade lateral. Ocorrem intercalados nos derrames basálticos, sendo a presença confirmada por meio de perfis geológicos em Novo Hamburgo (presença de rochas de sequência ácida), Caxias do Sul, entre outros municípios, variando suas espessuras desde alguns centímetros até algumas dezenas de metros (RADAM, 1986).

Há considerável ocorrência de diques de diabásio, com espessuras e extensões variadas, nos municípios de Taquara e Novo Hamburgo. Esses diques podem representar, em parte, antigos dutos vulcânicos. (RADAM, 1986).

A Formação Botucatu na área de estudo se concentra nos trechos médio e inferior. Os municípios onde essa formação é predominante são: Taquara, Parobé, Araricá, Campo Bom, Novo Hamburgo e Portão.

\subsubsection{Formação Rosário do Sul}

Considera-se que a sedimentação da Formação Rosário do Sul ocorreu sob regime fluvial, iniciando o assoreamento da bacia sedimentar do Paraná, com transporte dos sedimentos a partir 
de áreas elevadas do Escudo Sul-Riograndense. Esse processo indicaria uma atividade epirogênica marginal à bacia, proporcionado condições especiais para a deposição desses sedimentos, restritos ao Rio Grande do Sul (ASSINE, 2004).

Segundo RADAMBRASIL (1986), a Formação Rosário do Sul é constituída por arenitos médios e finos a muito finos, de cor vermelha, rosa, amarela e esbranquiçada. Os arenitos são sílticos, com matriz argilosa e cimento ferruginoso, localmente calcíferos, apresentando classificação de pobre a moderada. Geralmente são quartzosos, com proporções variáveis de feldspato e argilas, com frequência ocorre a presença de mica. São geralmente friáveis e pouco consolidados.

Os sedimentos arenosos exibem estratificação cruzada tangencial, de porte médio a grande, apresentam-se por vezes de forma maciça, estratificados com siltitos, e com siltitos argilosos, com estratificação plano-paralela ou cruzada de baixo ângulo. As camadas são lenticulares ou tabulares, com contatos irregulares e transicionais entre diversas litologias. As intercalações de sedimentos finos não apresentam grandes espessuras, mostram persistência horizontal pequena. Lateral e verticalmente apresentam proporções maiores de areia, confundindo-se com os termos arenosos. Contatos bruscos verificam-se na passagem de litologias finas para grosseiras (RAMOS, 1975).

Essa formação, em relação às demais, possui pouca expressividade espacial, aparece de forma contínua e de forma predominante no município de Nova Santa Rita e em área pouco significativa no município de Portão.

\subsection{Características do clima regional e influência no relevo}

No aspecto regional, o clima da área de estudo segundo KOPPEN (1948) é subtropical, com períodos de clima temperado, meses com temperatura média inferior a $18^{\circ} \mathrm{C}$ e temperatura mínima superior a - $3^{\circ} \mathrm{C}$. Clima úmido com precipitação pluviométrica bem distribuída durante todo o ano, com verão muito quente e inverno frio.

A partir de pesquisas sobre as condições metereológicas e da dinâmica e circulação atmosférica regional, constatou-se que os climas da região sul são controlados por massas de ar tropical e polares (Massa Tropical Atlântica - MTA, Massa Tropical Continental - MTC, e Massa 
Polar Atlântica - MPA), com predomínio do clima subtropical úmido das costas orientais e subtropicais dominados fortemente por massa tropical marítima (MENDONÇA, 2007).

O clima da região sul também sofre a influência das Massas Tropicais Marítimas - MTMs, úmidas e instáveis, que alcançam as costas orientais do continente e deslocam-se para o interior. Carregam o calor e a umidade ao longo das frentes quentes e frias, onde o ar tropical encontra o ar polar. No verão, sob domínio das bordas ocidentais das células de altas pressões oceânicas, essas massas de ar geram fortes chuvas e temperaturas e umidades elevadas. A precipitação é abundante durante todo o ano. No inverno, os avanços frequentes de massas polares e as perturbações ciclônicas geram temperaturas baixas, com amplitude térmica de moderada magnitude e chuvas frequentes (ibid.).

Os estudos realizados pela Secretaria de Energia, Minas e Comunicações - SEMC (2002), que analisaram séries climatológicas do Rio Grande do Sul, reafirmam uma das principais características do clima temperado subtropical do sul brasileiro, que são as chuvas bem distribuídas ao longo de todo o ano. As flutuações inter-regionais dentro do Estado são de pequena magnitude, podendo-se notar tendência de precipitações anuais crescentes no sentido Sul-Norte, variando entre $1200 \mathrm{~mm}$ e $2500 \mathrm{~mm}$ anuais.

Por situar-se na extremidade sul do Brasil, o Rio Grande do Sul apresenta as maiores amplitudes térmicas anuais, atingindo temperaturas próximas ou abaixo de $0^{\circ} \mathrm{C}$ durante o inverno, e nos dias quentes acima de $30^{\circ} \mathrm{C}$, com umidade no verão. A região mais fria, naturalmente, está situada nas maiores altitudes dos campos do alto da serra, enquanto a região mais quente está no extremo oeste do Estado (SECRETARIA DE ENERGIA, MINAS E COMUNICAÇÕES - SEMC, 2002).

No estado, a média histórica sazonal, entre 1961 e 2001 , no verão, foi de $20,1^{\circ}$ a $22^{\circ}$ C; outono e primavera, $16,1^{\circ}$ e $18^{\circ}$; e no inverno $<14^{\circ}$ C. A média histórica anual está entre $16^{\circ}$ e $18^{\circ} \mathrm{C}$. Os índices térmicos anuais inferiores a $19^{\circ} \mathrm{C}$ são acentuados pela ação das serras gaúchas e catarinenses (MENDONÇA, 2007).

A temperatura máxima anual média está entre $20^{\circ}$ a $22^{\circ} \mathrm{C}$. Já as médias históricas anuais se apresentam no verão entre $22,1^{\circ}$ a $24^{\circ} \mathrm{C}$; outono e primavera entre $20^{\circ}$ a $22^{\circ} \mathrm{C}$; e no inverno < $20^{\circ}$. A temperatura mínima anual média está entre $12,1^{\circ}$ a $14^{\circ} \mathrm{C}$, considerando as estações no verão está entre $16,1^{\circ}$ a $18^{\circ} \mathrm{C}$; outono e primavera entre $12,1^{\circ}$ a $14^{\circ}$; e no inverno $<10^{\circ} \mathrm{C}$ (ibid.). 
Segundo Vieira (1984), que analisou o regime térmico e pluviométrico no Rio Grande do Sul, no período entre 1912 e 1942, a diferenciação climático-sazonal é bem significativa, principalmente quando se analisa a média do mês mais quente e a média do mês mais frio. Esse parâmetro terá forte repercussão na ação dos processos morfogenéticos.

A ação do clima sobre as morfoestruturas se dá de forma direta e indireta. A ação direta ocorre por meio da intensidade de elementos do clima, principalmente pela temperatura, umidade, precipitação e ventos. A ação indireta se processa por meio da vegetação e dos solos (VALERIANO, 2007).

As morfoesculturas correspondem ao modelado de formas geradas sobre diferentes estruturas e sob a ação de fatores exógenos. O conceito de morfoestrutura está relacionado com as feições do relevo produzidas na Terra pela ação do clima atual e passado ao longo do tempo geológico da morfoestrutura (SUERTEGARAY, 2004).

O estudo dos processos morfogenéticos demonstra a importância do fator climático para a esculturação das formas do relevo. Dois conceitos básicos estão implicitamente envolvidos: que processos morfogenéticos diferentes produzem relevos de formas diferentes e que as características do modelado devem refletir, até certo ponto, as condições climáticas sob as quais se desenvolveu a topografia (CHRISTOFOLETTI, 1974).

No Rio Grande do Sul a condição morfoclimática é definida pela natureza morfoestrutural do relevo e pelas manifestações do clima. Da interação entre ambas desenvolve-se a morfogênese, ou seja, tem origem a evolução das formas que caracterizam o modelado do relevo a partir das estruturas geotectônicas. Os processos morfogenéticos, responsáveis pela morfodinâmica, se desencadeiam e atuam com maior ou menor intensidade devido ao clima. Devido às características climáticas do estado predomina o intemperismo químico, este produzindo feições particularizadas sobre o relevo a partir da natureza litológica dos grandes quadros morfoestruturais (VIEIRA, 1984). 


\subsubsection{Análise dos dados pluviométricos}

Os dados pluviométricos da bacia hidrográfica do rio dos Sinos foram disponibilizados pela ANA em 2010. A estação localiza-se em Sapucaia do Sul, entre as coordenadas 5109' 40" W e $29^{\circ}$ 49' 12" S, código 2951028.

O recorte para análise foi do ano mais atual, a partir dos dados disponíveis, para anos anteriores, fechando o intervalo de uma década entre 1999 e 2008. Analisou-se a pluviosidade total para cada mês, a média e o total de cada ano, a correlação entre os anos e a identificação dos meses mais e menos chuvosos.

No ano de 1999 (Gráfico 03), os meses mais chuvosos foram julho (170,3 mm), abril $(136,2)$ e junho $(129,5 \mathrm{~mm})$, e os meses mais secos foram maio $(58,6 \mathrm{~mm})$, janeiro $(65,9 \mathrm{~mm})$, fevereiro e março $(70,1 \mathrm{~mm})$. A média anual foi de $102,85 \mathrm{~mm}$ e o valor total para o ano foi de $1234,2 \mathrm{~mm}$.

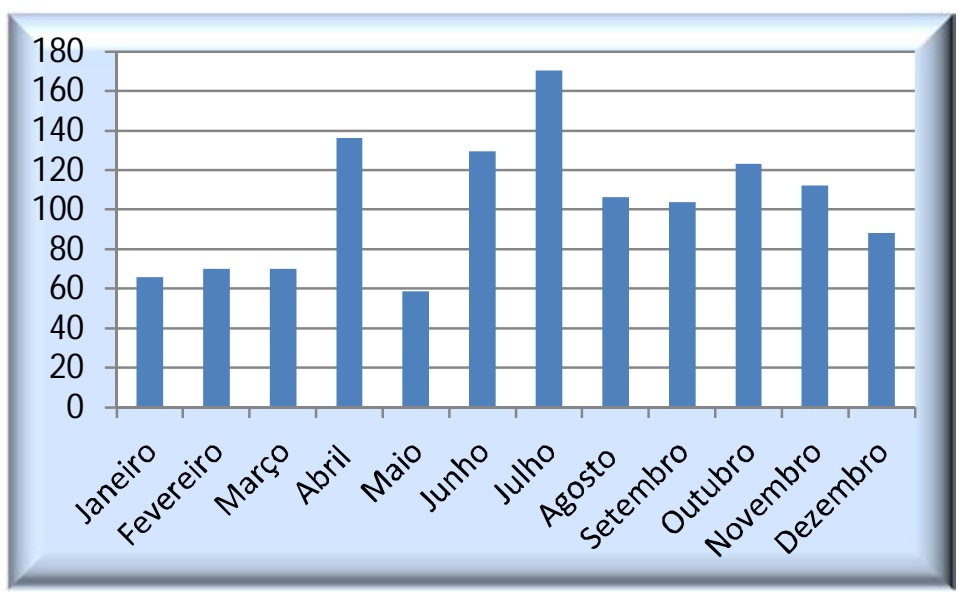

Gráfico 03: Dados pluviométricos da bacia hidrográfica do rio dos Sinos (1999).

Fonte: Agencia Nacional da Águas (2010).

Elaboração: Adriana Penteado, 2010.

Para o ano de 2000 (Gráfico 04), outubro foi o mês mais chuvoso com 246,5 mm, seguido dos meses de abril (214,7 mm) e junho (187,4 mm). Assim como no ano de 1999, abril e junho estiveram entre os meses mais chuvosos. Os meses mais secos foram maio $(50,2 \mathrm{~mm})$, janeiro $(62,2 \mathrm{~mm})$ e fevereiro $(62,5)$. Assim com no ano anterior os meses de janeiro e fevereiro 
apresentaram-se como os mais secos. A média anual do ano foi de 131,183 mm e o total pluviométrico foi de 1574,2 $\mathrm{mm}$, com aumento de $340 \mathrm{~mm}$ em relação ao ano anterior.

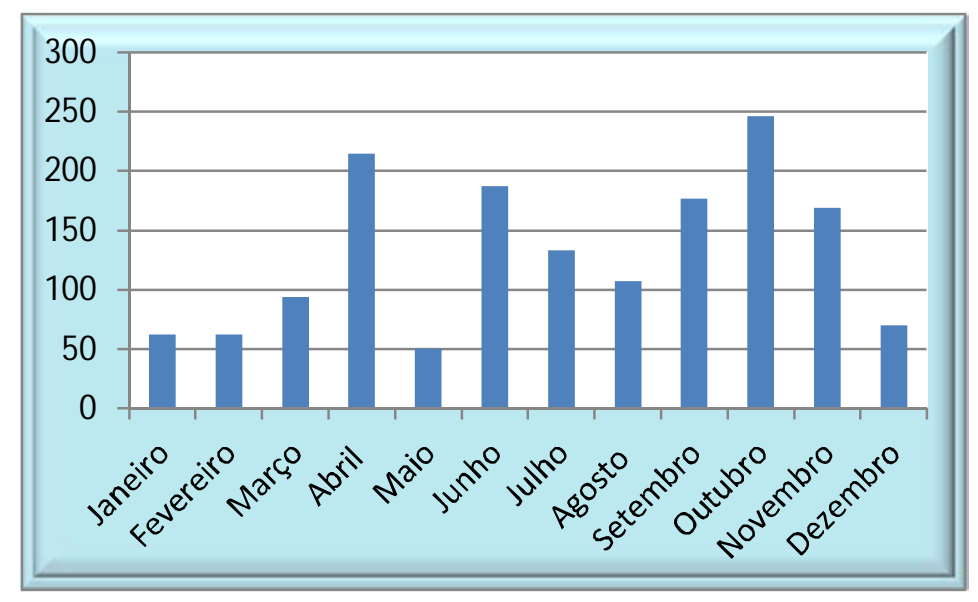

Gráfico 04: Dados pluviométricos da bacia hidrográfica do rio dos Sinos (2000).

Fonte: Agencia Nacional da Águas (2010).

Elaboração: Adriana Penteado, 2010.

Para o ano de 2001 não foram registrados os dados dos meses de maio, junho e julho, prejudicando parcialmente a análise deste ano, bem como a correlação com os demais anos considerados.

Com base nos dados disponíveis para o ano de 2001 (Gráfico 05) os anos mais chuvosos foram janeiro (241,9 mm), abril (241,6 mm) e outubro (203, $8 \mathrm{~mm})$. Os meses mais secos foram agosto $(27,6 \mathrm{~mm})$, março $(98,7 \mathrm{~mm})$ e dezembro $(100,5 \mathrm{~mm})$.

Pelo terceiro ano consecutivo o mês de abril esteve entre o mais chuvoso, seguido do mês de outubro em 2000 e 2001. A média do ano foi de 144,188 mm e o total foi de 1297,7 mm, com aumento de 63,5 em relação ao ano de 1999, mesmo sem o registro de três meses. 


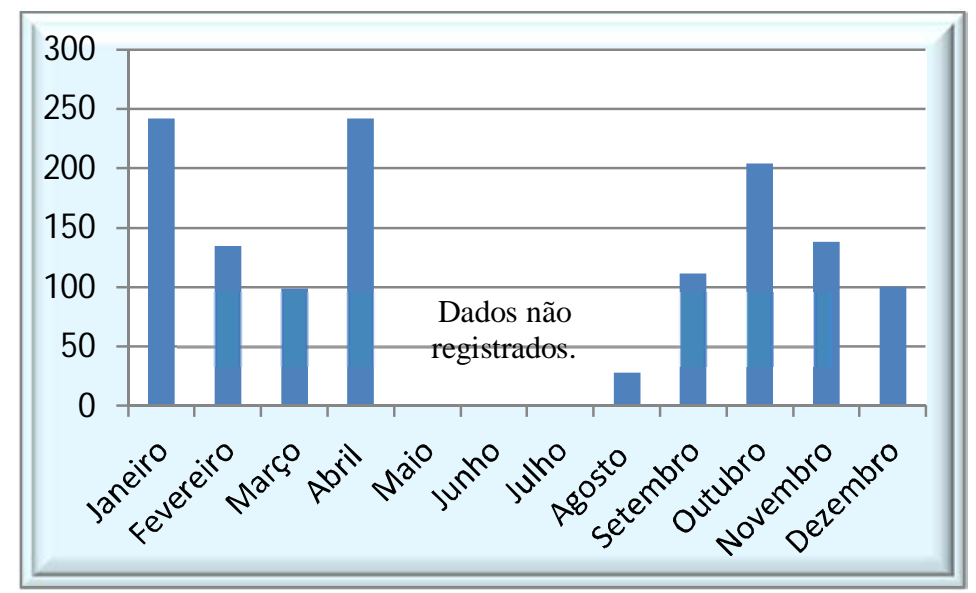

Gráfico 05: Dados pluviométricos da bacia hidrográfica do rio dos Sinos (2001).

Fonte: Agencia Nacional da Águas (2010).

Elaboração: Adriana Penteado, 2010.

Em relação aos anos anteriores, de 1998 a 2001, o ano de 2002 apresentou os maiores índices pluviométricos do ano, com 1986,8 mm, com aumento de 412,6 mm em relação ao ano de 2000, que foi o segundo mais chuvoso em relação aos dados até aqui analisados.

Os meses mais chuvosos para 2002 (Gráfico 06) foram outubro $(287,1 \mathrm{~mm})$, julho $(231,7$ $\mathrm{mm})$ e setembro $(213,4 \mathrm{~mm})$. Os meses mais secos foram fevereiro $(75,7 \mathrm{~mm})$, janeiro $(93,6 \mathrm{~mm})$ e novembro com $124 \mathrm{~mm}$. A média do ano ficou em 165, $566 \mathrm{~mm}$.

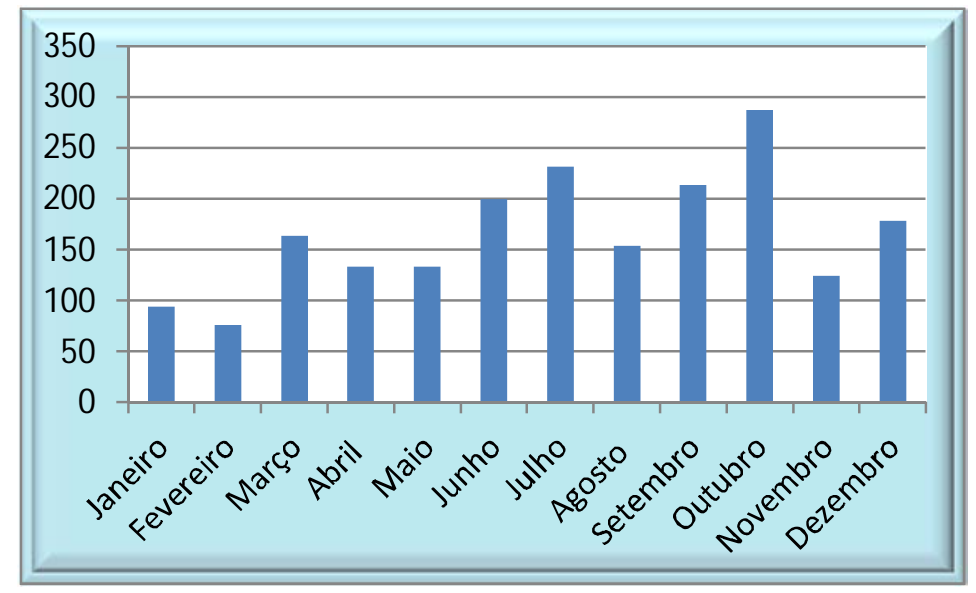

Gráfico 06: Dados pluviométricos da bacia hidrográfica do rio dos Sinos (2002).

Fonte: Agencia Nacional da Águas (2010).

Elaboração: Adriana Penteado, 2010. 
Para o ano de 2003 (Gráfico 07) os meses mais secos foram setembro (52,8 mm), maio $(59,6 \mathrm{~mm})$ e agosto $(91,5 \mathrm{~mm})$. O mês de maio, no intervalo de cinco anos até agora analisado, está pela terceira vez entre os meses mais secos. Os meses mais chuvosos foram dezembro $(232,4$ $\mathrm{mm})$, novembro (196,4 mm) e junho (143,4 mm).

O mês de junho está entre os mais chuvosos nos mesmos anos em que maio esteve entre os mais secos, que foi em 1999, 2000 e 2003. A média para este ano foi de 132,83 mm e o total anual 1, $594 \mathrm{~mm}$.

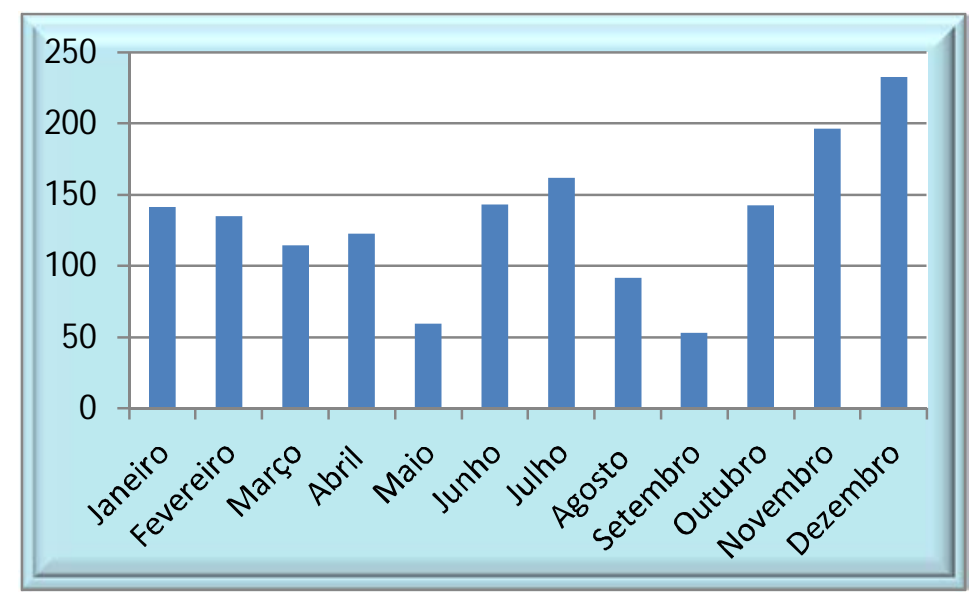

Gráfico 07: Dados pluviométricos da bacia hidrográfica do rio dos Sinos (2003).

Fonte: Agencia Nacional da Águas (2010).

Elaboração: Adriana Penteado, 2010.

O ano de 2004 (Gráfico 08) com média pluviométrica de 99,375 mm e total de 1192, $5 \mathrm{~mm}$ anuais, foi o ano mais seco em relação aos anos até aqui analisados.

Os meses menos chuvosos foram dezembro $(28,1 \mathrm{~mm})$, janeiro $(43,6 \mathrm{~mm})$ e março com $62,3 \mathrm{~mm}$. O mês de janeiro se apresentou como o mais seco pela quarta vez, incluindo os anos de 1999, 2000, 2002. Os meses com maior índice pluviométrico foram setembro (211,1 mm), julho $(189,9 \mathrm{~mm})$ e maio com $154,2 \mathrm{~mm}$. 


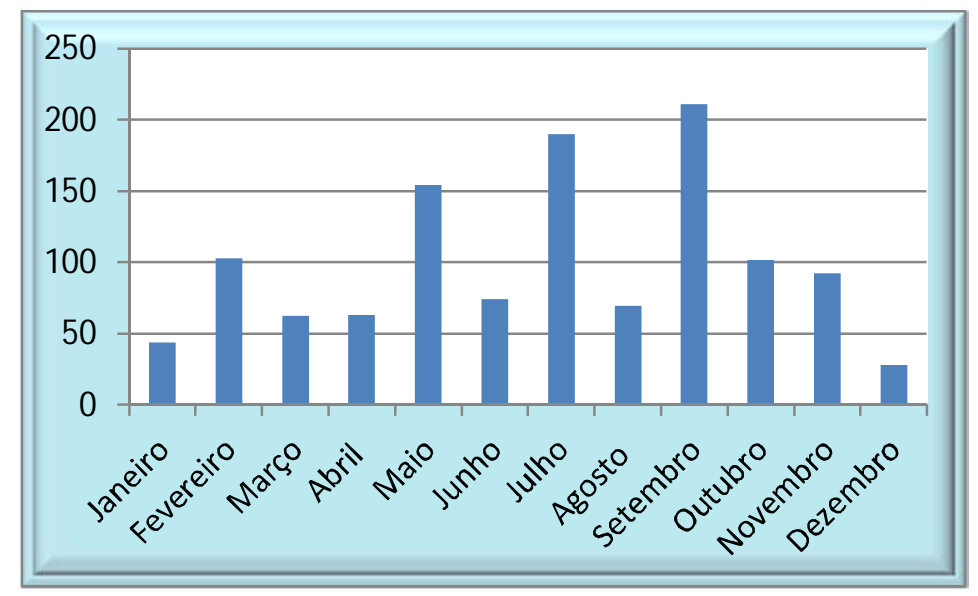

Gráfico 08: Dados pluviométricos da bacia hidrográfica do rio dos Sinos (2004).

Fonte: Agencia Nacional da Águas (2010).

Elaboração: Adriana Penteado, 2010.

O ano de 2005 (Gráfico 09) em geral teve índice pluviométrico dos meses abaixo de 200 $\mathrm{mm}$, exceto no mês de outubro, que foi o mais chuvoso, com índice de 326, $7 \mathrm{~mm}$. A média para o ano foi de $121,125 \mathrm{~mm}$ e o total anual foi de $1,453 \mathrm{~mm}$. Os meses mais secos foram janeiro (32, $5 \mathrm{~mm})$, junho $(42,9 \mathrm{~mm})$ e fevereiro $(43,3 \mathrm{~mm})$.

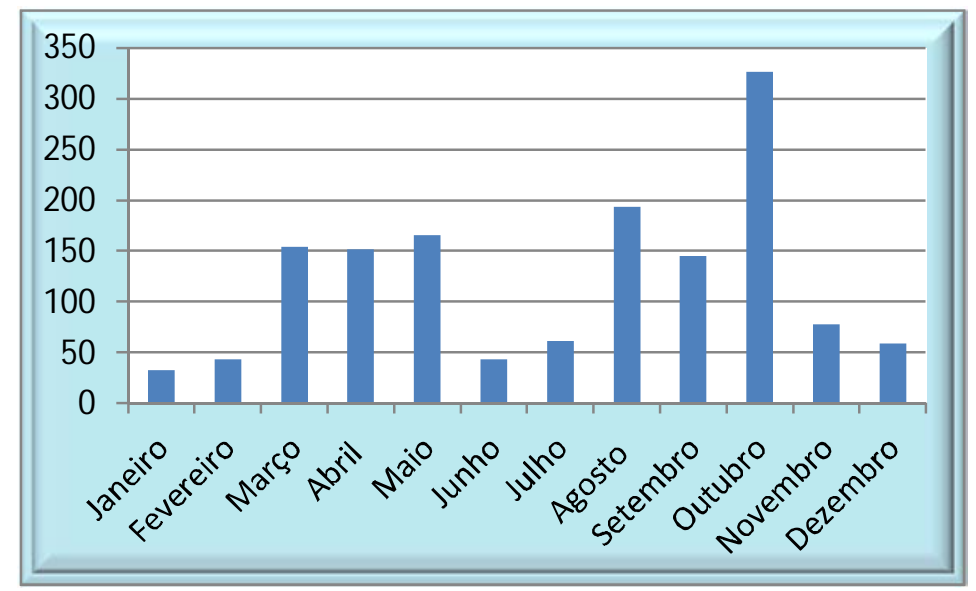

Gráfico 09: Dados pluviométricos da bacia hidrográfica do rio dos Sinos (2005).

Fonte: Agencia Nacional da Águas (2010).

Elaboração: Adriana Penteado, 2010. 
O ano de 2006 possui as maiores falhas em relação aos registros, com quatro meses sem dados: abril, maio, julho e agosto (Gráfico 10). Devido a isso, o total pluviométrico para o ano apresentou o valor mais baixo em relação aos dez anos analisados, com 788, $2 \mathrm{~mm}$. A média anual, considerando os oito meses com dados disponíveis, foi de 98,52 mm, sendo também o valor mais baixo.

Os meses mais chuvosos foram janeiro $(198,90)$, novembro $(125,6 \mathrm{~mm})$ e setembro $(100,1$ $\mathrm{mm})$. Os meses mais secos foram março $(53,1 \mathrm{~mm})$, outubro $(67 \mathrm{~mm})$ e fevereiro $(69,1 \mathrm{~mm})$

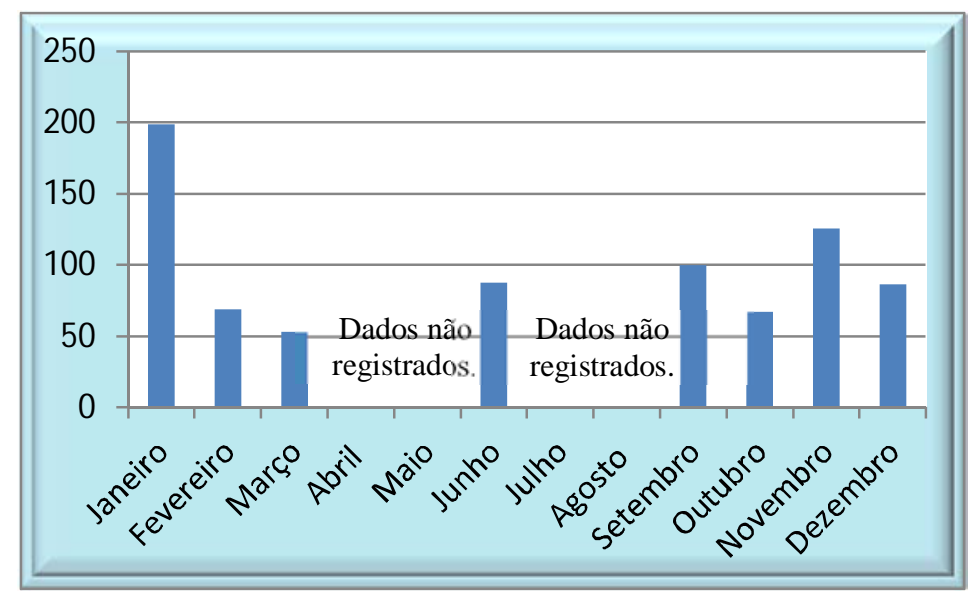

Gráfico 10: Dados pluviométricos da bacia hidrográfica do rio dos Sinos (2006).

Fonte: Agencia Nacional da Águas (2010).

Elaboração: Adriana Penteado, 2010.

Para o ano de 2007, gráfico 11, não há registros para os meses de setembro, outubro e novembro, mesmo assim, apresentou total pluviométrico maior que o ano de 2004 que possui dados completos. O valor ficou em $1225 \mathrm{~mm}$, com média de 136,11 mm.

Apresentando uma tendência quando comparados aos anos anteriores, os meses de janeiro e fevereiro estiveram entre os mais secos com 61,7 mm e $91 \mathrm{~mm}$ respectivamente, logo após o mês de abril com 42,4 mm. Os meses mais chuvosos foram julho $(213,7 \mathrm{~mm})$, junho $(197,1 \mathrm{~mm}) \mathrm{e}$ maio $(178 \mathrm{~mm})$. 


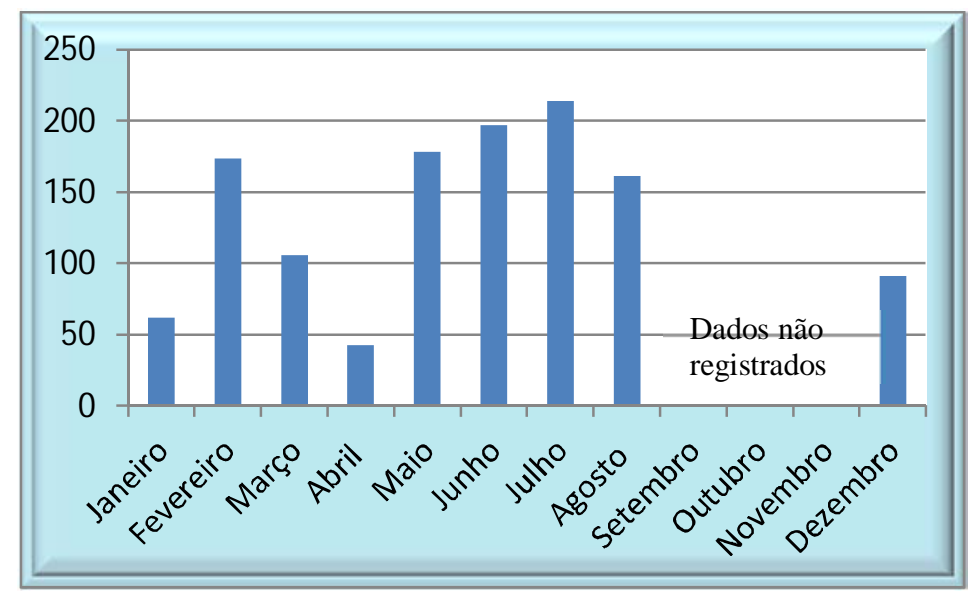

Gráfico 11: Dados pluviométricos da bacia hidrográfica do rio dos Sinos (2007).

Fonte: Agencia Nacional da Águas (2010).

Elaboração: Adriana Penteado, 2010.

O ano de 2008, gráfico 12, teve total pluviométrico muito próximo ao ano de 2000 (1574, 2 $\mathrm{mm}$ ) com valor de $1583,1 \mathrm{~mm}$ e média anual de 131,92 $\mathrm{mm}$. Os meses mais chuvosos foram outubro (252,2 mm) e maio com $199 \mathrm{~mm}$. Os meses mais secos foram novembro e março, $(31,9$ $\mathrm{mm}$ e $47,3 \mathrm{~mm})$.

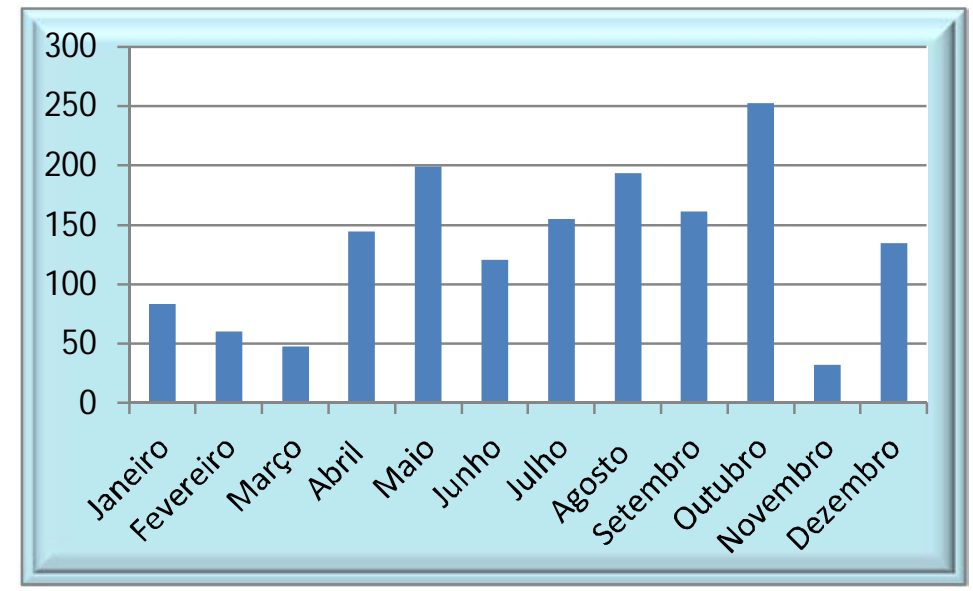

Gráfico 12: Dados pluviométricos da bacia hidrográfica do rio dos Sinos (2008).

Fonte: Agencia Nacional da Águas (2010).

Elaboração: Adriana Penteado, 2010.

Considerando todos os dados analisados, o mês que apresentou maior frequência em anos com os menores índices pluviométricos foi janeiro em 1999, 2000, 2002, 2004, 2005 e 2007, 
seguido do mês de fevereiro em 1999, 2000, 2002, 2005, 2006 e 2008 e março em 1999, 2001, 2006 e 2008. Apesar de janeiro estar entre os meses mais secos, em 2001 e 2006 esteve entre os meses mais chuvosos.

$\mathrm{O}$ mês com maior frequência em anos com maior índice pluviométrico foi outubro em 2000, 2001, 2002, 2005 e 2008, maio em 2004, 2005, 2007 e 2008, junho em 1999, 2000, 2003 e 2007 e julho em 1999, 2002, 2004 e 2007. Para a década analisada a alta pluviométrica se concentrou na primavera, no outono e no início do inverno.

Os únicos meses com dados completos para os dez anos são janeiro, fevereiro, março e dezembro, para os demais há falhas de um a três anos.

A partir da soma dos dados disponíveis para cada ano analisado, em relação aos meses, o mais chuvoso foi outubro com $1750 \mathrm{~mm}$, sem registro de dados em 2006, seguido do mês de julho com $1317 \mathrm{~mm}$, sem os dados de 2001 e 2006, e setembro com 1275,4, este sem registro para o ano de 2007. Os meses com menores índices pluviométricos foram fevereiro com 926,4 mm, março com 963,6 mm, e janeiro com 1024, 8 mm, com dados completos para todos os anos.

O ano com maior índice pluviométrico foi 2002 com 1986,8 mm. Já em relação ao ano com menor índice é necessário desconsiderar os anos de 2001, 2006 e 2007, já que não foram registrados os dados dos meses de maio, julho e julho para o primeiro caso, abril, maio, julho e agosto para o segundo e setembro, outubro e novembro para o terceiro. Considerando os anos com dados completos para todos os meses, o ano mais seco foi 2004, com 1192,5 mm.

Os dados analisados - entre 1999 e 2008 - indicaram tendência de estiagem no verão, nos meses de janeiro, fevereiro e março, e maior pluviosidade nos meses de outubro, maio, junho e julho.

A tendência, dentro de um contexto geral, indica um possível comportamento dentro de um padrão conhecido. Quando dados específicos são analisados dentro de uma escala de tempo suficiente, por exemplo, demonstram as características climáticas de uma região. Mesmo com a tendência temporal (climática) já conhecida para uma área de estudo, é necessária a análise dos dados pluviométricos para que seja possível determinar quais os meses mais adequados para escolha de imagens para delimitar as terras inundáveis.

As variações pluviométricas se refletem na mudança espacial das terras inundáveis e indicam: os meses mais apropriados para definir os limites aproximados maiores e também menores que essas áreas atingem; a variação entre estes dois itens que pode ser mensurável; a 
identificação das áreas que se apresentam secas causando uma segmentação natural e temporária, sendo necessária, além dos dados pluviométricos, a análise de imagens de satélite ou fotografias aéreas para estabelecer esta relação.

Um parâmetro eficaz para a descrição das chamadas áreas úmidas é por meio da descrição da elasticidade do macrossistema, definido como o quociente entre a área ocupada durante o período de maior inundação e a área ocupada no período de máxima seca. Este valor é influenciado pelas características geomorfológicas, capacidade de armazenamento de água no solo e subsolo, precipitação, evapotranspiração, infiltração e a variabilidade de aportes de água nas planícies de inundação (MELLO, 1998 apud NEIFF, IRIOND \& CARIGNAN (1994).

Quando se coloca limite aproximado maior ou menor das terras inundáveis, considera-se que não é possível determinar um limite fixo, pois os índices pluviométricos variam em pequena e grande proporção, neste último caso quando da ocorrência de eventos excepcionais. A intensidade da chuva pode produzir comportamentos diferentes quando a mesma ocorre em um pequeno intervalo de tempo, em relação a um intervalo maior, considerando o mesmo total pluviométrico. Outros fatores, como a capacidade de infiltração do solo, podem ser alterados ao longo do tempo e do espaço em uma bacia hidrográfica, causando mudanças no nível dos corpos hídricos e na área das terras inundáveis. Reafirma-se assim o termo limite aproximado maior ou menor, que sofre tanto influencia de fatores naturais como antrópicos.

Com base na análise dos dados pluviométricos entre 1999 e 2008, o mês e o ano mais apropriado para a delimitação das terras inundáveis, com base em imagens de satélite ou fotografias aéreas, considerando um limite aproximado máximo, seria o mês de outubro em 2005, que registrou $326,7 \mathrm{~mm}$, preferencialmente próximo ao final do mesmo, havendo assim aproximação do acúmulo precipitado do mês, mesmo com os processos naturais de evaporação e infiltração da água. Antecedendo este mês, no mesmo ano, os meses de agosto e setembro também tiveram índices relativamente altos de pluviosidade, o primeiro com 193,7 mm e o segundo com 144,8 mm.

Não só a escolha do mês de maior pluviosidade é importante para delimitar o limite aproximado máximo das terras inundáveis, mas a situação precedente recente, pois situações anteriores de estiagem vão influenciar também na distribuição da água da chuva, sendo que boa parte da mesma poderá servir para o reabastecimento do lençol freático, que realimentará os cursos hídricos sem que haja extravasamento. Assim, é importante considerar para este caso mês 
anterior em que não tenha ocorrido estiagem, o que é adequado quando o objetivo é mapear o limite mínimo aproximado das terras inundáveis.

Em relação ao mês mais seco para a delimitação aproximada menor das terras inundáveis, considerando a década analisada, foi agosto em 2001, com 27,6 mm. Para os meses anteriores do mesmo ano não há registros, não sendo possível definir se tratava-se de um período mais seco ou mais chuvoso. Porém, os meses de junho e julho se apresentaram, ao longo dos anos com dados disponíveis, como meses com tendência a alta pluviosidade.

O segundo mês, e que possivelmente seja o mais adequado para a delimitação do limite aproximado menor das terras inundáveis, seria fevereiro de 2005, com 43,3 mm. O mesmo foi antecedido de dois meses secos que foram dezembro de 2004, com 28,1 mm, e janeiro de 2005, com $32.5 \mathrm{~mm}$. Este dado não foi gerado neste trabalho e a elucidação desse comportamento busca auxiliar em uma metodologia de mapeamento que possa delimitar com certa precisão a elasticidade do sistema terras inundáveis.

Com base nesses dados, foram pesquisadas as imagens disponíveis para o período de maior pluviosidade. As imagens do CBERS disponibilizadas mais adequadas foram de 07/09/2005 e 16/02/2004, cenas 157_33 e 156_33, respectivamente. Não foi possível gerar um mosaico com imagens de mesma data, por não haver disponibilização de dados.

A imagem de 07/09/2005 cobre grande parte da bacia do rio dos Sinos e para o mês de setembro, segundo dados da ANA (2010), o dia mais chuvoso foi 11 de setembro, com 38,6 mm. $\mathrm{O}$ dia seis, que antecede a geração da imagem, teve índice pluviométrico de $32,2 \mathrm{~mm}$. Os meses antecedentes, agosto e julho, apresentaram, respectivamente, 193, $7 \mathrm{~mm}$ e 61,3 mm, o primeiro com alto indice pluviométrico e o segundo com baixo.

A imagem de 16/02/2004 cobre parte do extremo oeste da bacia. Para o mês de fevereiro do ano referido, segundo a mesma fonte anteriomente citada, o dia 15 foi o mais chuvoso, com 40,1 mm, antecendo a data da geração da imagem gerada e utilizada neste trabalho. O período foi antecedido de um mês seco, janeiro, com 43,6 mm e pré-antecedido por um mês com maior pluviosidade, dezembro de 2003, com 232,4 mm. Pela lógica até aqui colocada, a imagem de 16/02/2004 não seria a mais adequada a ser utilizada, porém é a mais adequada considerando aquilo que está disponível para o uso.

Nos casos onde a estação pluviométrica é localizada em áreas mais a montante da bacia, é importante considerar o tempo de retardo da inundação, ocorrendo aproximadamente três dias 
após um evento chuvoso concentrado nas cabeceiras, para bacias com forma mais alongada. No caso dos dados pluviométricos utilizados nesta pesquisa, a estação localiza-se no baixo curso do rio dos Sinos.

A delimitação aproximada maior é o dado mais importante a ser considerado para fins de planejamento e gestão das terras inundáveis.

A preservação dos rios é prevista, em certo grau, pela proteção de sua mata ciliar. Para as terras inundáveis também deve ser respeitada uma zona de amortecimento de impactos que deve ultrapassar seus limites físicos.

\subsection{Análise pedológica}

O solo pode ser definido como a camada superficial constituída de partículas minerais e orgânicas, distribuídas em horizontes de profundidade variável, resultante da ação conjunta de agentes intempéricos sobre as rochas e da adaptação destas às condições de equilíbrio do meio em que se encontram expostas, geralmente diferentes daquele que condicionou sua gênese, apresentando variabilidade espacial (MEDEIROS, 2006).

Os agentes responsáveis pelo intemperismo dos solos são: água, vegetação, topografia, homem e outros animais, conjuntamente associados ao fator tempo e ao clima. Os solos conservam as características das rochas de origem, sendo que apenas alguns centímetros de solo levam décadas para a sua formação. Regiões quentes e com muitas chuvas costumam ter solos mais profundos que regiões mais secas (ibid.).

A Figura 14 mostra a influência do tempo na formação dos solos. A rocha exposta sofre intemperismo e forma um solo pouco desenvolvido, formando solos classificados como neossolos, que são solos jovens, com formação de horizonte A. Com o passar do tempo, a vegetação se desenvolve e passa também a influir no intemperismo por meio de suas raízes que ajudam na desagregação das partículas minerais. O cambissolo compreende um solo em estágio intermediário de desenvolvimento com presença de horizonte incipiente $\mathrm{Bi}$, abaixo do horizonte A. No estágio de desenvolvimento dos solos o argissolo, é considerado um solo bem desenvolvido, apresentando horizontes A, E, Bt e C. 


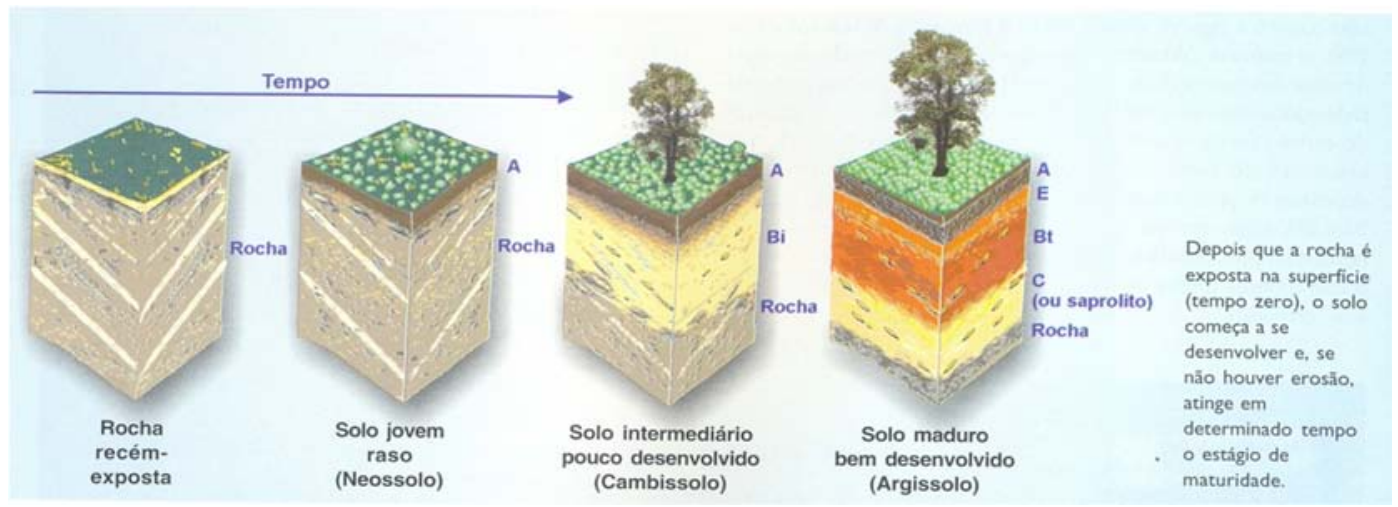

Figura 14: Evolução pedológica ao longo do tempo.

Fonte: Lepsch, 2002.

Para a área de estudo não há um mapeamento de detalhe ou semidetalhe dos solos, permitindo apenas uma localização geral dos mesmos. Com base no mapa de solos elaborado pela Emater/RS (2007), os solos encontrados na bacia hidrográfica do rio dos Sinos são: planossolo háplico eutrófico, chernossolo háplico órtico, argissolo vermelho distrófico, argissolo vermelho-amarelo distrófico, cambissolo húmico alumínico, além de afloramentos rochosos associados a solos como o neossolo regolítico eutrófico e distrófico, argissolo brunoacinzentado alumínico e o luvissolo háplico órtico.

\subsubsection{Planossolos}

Compreendem solos minerais, imperfeitamente ou mal drenados, de textura mais leve, que contrasta abruptamente com o horizonte B imediatamente subjacente, adensado e geralmente com acentuada concentração de argila, com permeabilidade lenta ou muito lenta, constituindo por vezes um horizonte "pã”, que é responsável pela detenção do lençol d'água sobreposto (suspenso), de existência periódica e presença variável durante o ano. Podem apresentar qualquer tipo de horizonte A, horizonte E, nem sempre horizonte E álbico, seguidos de horizonte B plânico, tendo sequência de horizontes $\mathrm{A}, \mathrm{AB}$, ou A, E (álbico ou não) ou Eg, seguidos de Bt, Btg, Btm ou Btmg (IBGE, 2007). 
A figura 15 mostra, de forma geral, o grande incremento de argila do horizonte A para o horizonte B textural ou plânico. Nos primeiros dez centímetros a concentração de argila é de $20 \%$, chegando a aproximadamente $60 \%$ quando atinge $80 \mathrm{~cm}$ de profundidade. Essa característica do planossolo permite uma infiltração vertical mais rápida nos horizontes superiores mais arenosos e a gradativa diminuição da velocidade da infiltração na medida em que aumenta a concentração de argila.

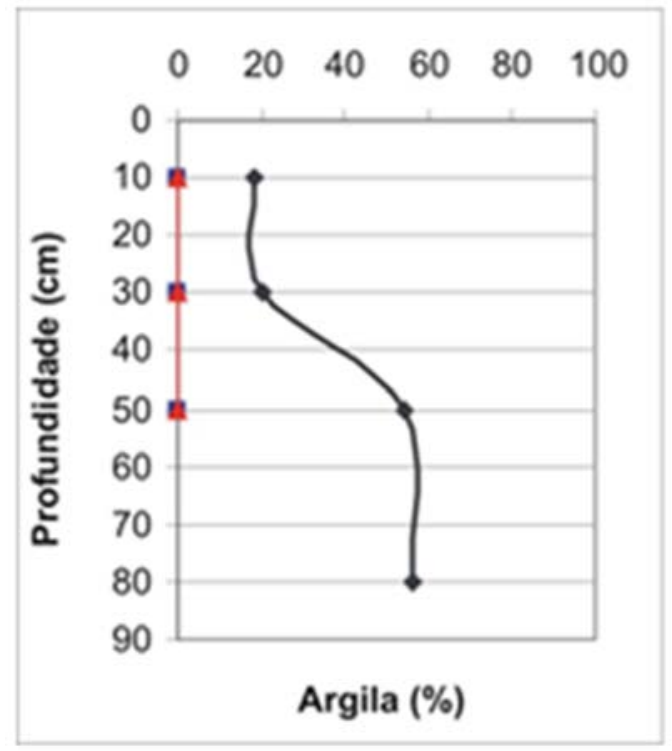

Figura 15: Relação entre a profundidade do planossolo e concentração de argila. Fonte: Prado, 2010.

Esses solos têm grande expressão no sul do Rio Grande do Sul, principalmente na depressão central gaúcha e em menores proporções na encosta superior do nordeste. São comumente utilizados para o plantio de arroz e pastagens e encontrados em relevo plano ou suave ondulado nas planícies de rios e/ou lagos. A fertilidade natural é variável (STRECK, 2008).

$\mathrm{Na}$ área de estudo é encontrado o Planossolo Háplico Eutrófico (Fotografia 08) arênico com alta saturação por bases $\geq 50 \%$, com horizontes $\mathrm{A}$ ou $\mathrm{A}+\mathrm{E}$ de textura arenosa com espessura de 50 a $100 \mathrm{~cm}$ até o início do horizonte B. Esses solos originados de sedimentos aluviais possuem menos nutrientes que outros planossolos. Pelo fato de serem mais arenosos têm melhores condições de drenagem da camada superficial, horizonte A, a taxa de decomposição da matéria orgânica é mais elevada. São utilizados há décadas no cultivo de arroz irrigado (ibid.). 
Esse solo é encontrado nos municípios de Canoas (foz do rio dos Sinos), Esteio, Nova Santa Rita, Sapucaia do Sul, São Leopoldo, Novo Hamburgo e Campo Bom. Verifica-se grande concentração urbana na área de ocorrência desses solos, principalmente nos municípios de Canoas, Esteio, Sapucaia do Sul e São Leopoldo.

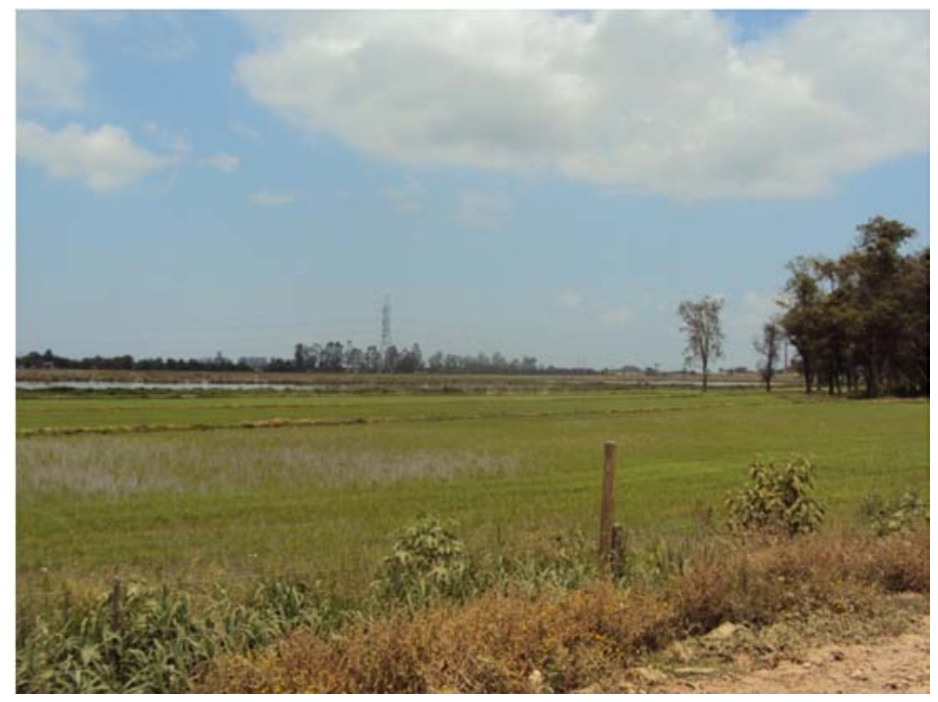

Fotografia 08: Plantação de arroz irrigado em planossolo no município de Canoas. Fonte: Adriana Penteado, 07/2010.

\subsubsection{Chernossolos}

Solos de pequena e média espessura que se caracterizam pela presença de um horizonte superficial A do tipo chernozêmico, teores consideráveis de matéria orgânica, cores escurecidas e boa fertilidade, sobre horizontes subsuperficiais avermelhados ou escurecidos com argila de alta atividade (IBGE, 2007).

Estes solos apresentam material orgânico mal ou não decomposto. Situam-se em parte das planícies do rio dos Sinos e seus afluentes. O chernossolo encontra-se em relevo plano a suavemente ondulado. Possui potencial alto para culturas anuais, com risco de inundação ocasional. O chernossolo háplico órtico, presente na área de estudo, diferencia-se do chernossolo ebânico, que apresenta predomínio de cores escuras também no horizonte B e do chernossolo 
argilúvico quando possui horizonte B textural ou acumulação de argila no horizonte B (Klamt, 2008).

Aproximadamente a partir do município de Parobé, de jusante para montante, o chernossolo começa a ganhar expressão na planície do rio dos Sinos e de seus principais afluentes: rio Rolante, Paranhana e da Ilha. Localiza-se também nas planícies de alguns afluentes localizados nos municípios de Taquara (Fotografia 09), Santo Antônio da Patrulha e de parte do município de Caraá.

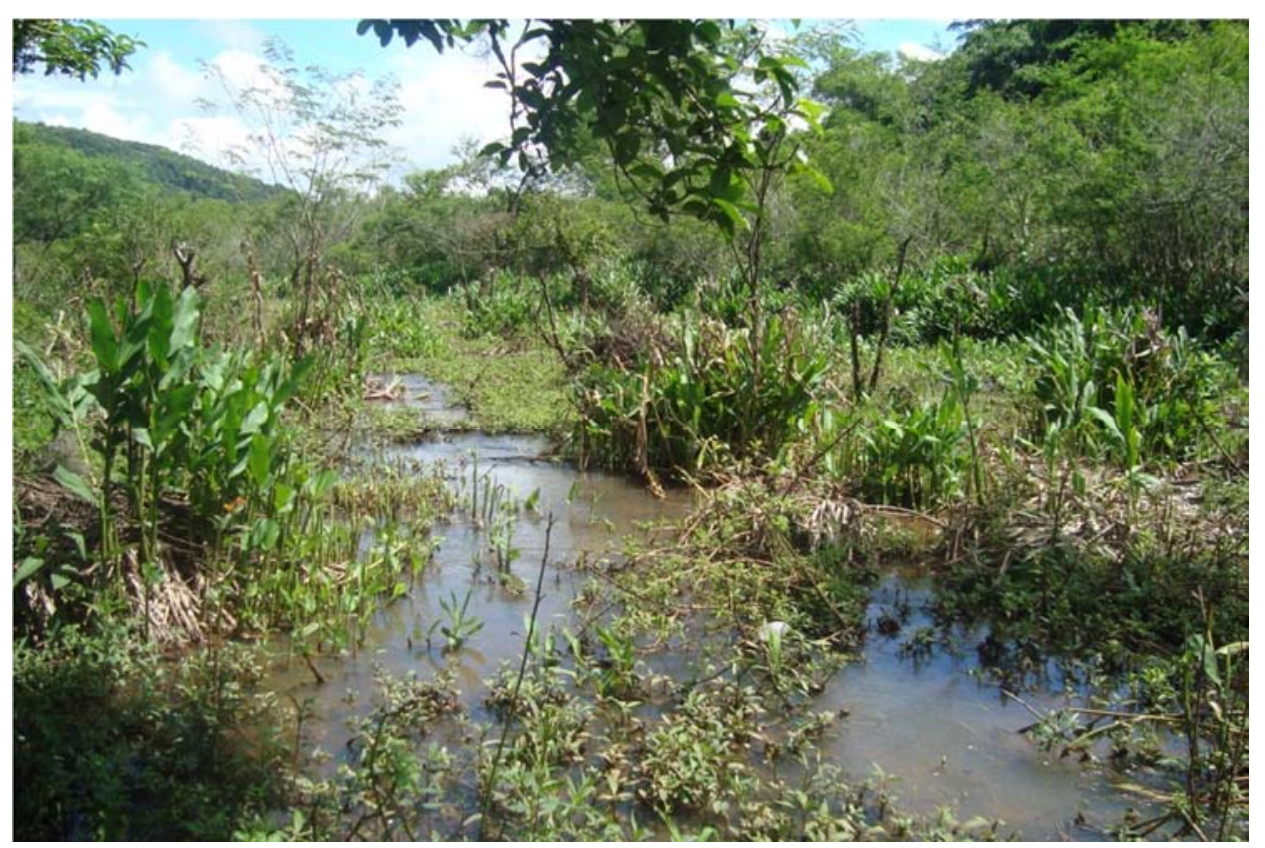

Fotografia 09: Chernossolo Háplico Órtico com lençol aflorante, município de Taquara. Fonte: Adriana Penteado, 01/2011.

\subsubsection{Argissolos}

A profundidade dos argissolos é variável, mas em geral são pouco profundos. São, juntamente com os latossolos os solos mais expressivos do Brasil, sendo verificados em praticamente todas as regiões do país (IBGE, 2005).

Uma das características mais importantes desse solo refere-se à presença do horizonte B textural. Devido à diferença textural entre o horizonte $\mathrm{A}$, mais arenoso, e o horizonte $\mathrm{B}$, mais argiloso, a água consegue facilmente percolar pelo primeiro horizonte, mas quando alcança o 
segundo horizonte, ocorre uma resistência para a infiltração devido à presença da argila, funcionando de certa forma como uma barreir: isto vai propiciar o escoamento lateral da água entre um e outro horizonte, provocando num primeiro momento a erosão do horizonte A. Devido a essas características naturais, este solo é muito susceptível à erosão (EMBRAPA, 1999).

O horizonte A constitui um horizonte superficial e concentra boa parte da matéria orgânica do solo, bem como a maioria das propriedades necessárias ao desenvolvimento das plantas. A perda desse horizonte causa uma perda da fertilidade do solo (ibid.).

Esses solos variam de bem a imperfeitamente drenados, com horizonte Bt do tipo B textural. Apresenta tipicamente um perfil com gradiente textural, onde o horizonte B é mais argiloso que os horizontes A e E. Esse solo pode se originar de diversos tipos de materiais, como o basalto, granito, arenito, argilito e siltito, podem ocorrer em relevo suave ondulado a fortemente ondulado (STRECK, 2008).

Segundo EMBRAPA (1999), para a área de estudo os argissolos apresentam minerais formados essencialmente por compostos inorgânicos em vários estágios de intemperismo. Apresentam mudança textural abrupta referente a um considerável aumento no teor de argila dentro de uma pequena distância na zona de transição entre o horizonte A ou E e o horizonte B subjacente.

$\mathrm{Na}$ área de estudo é encontrado o argissolo vermelho distrófico e o argissolo vermelhoamarelo distrófico, caracterizando solos de baixa fertilidade natural, sendo assim necessária a fertilização dos mesmos para o uso agrícola. As cores vermelhas e amarelas indicam a presença de óxido de ferro, que quando aparecem de forma homogênea no perfil, indicam que há boa condição de drenagem.

Os argissolos vermelhos distróficos são encontrados margeando, em grande parte, os limites de ocorrência dos planossolos e dos chernossolos na área de estudo. Nessas áreas, a litologia predominante é o arenito Botucatu. O relevo se apresenta suavemente ondulado.

A fotografia 10 é de um perfil do argissolo vermelho distrófico localizado no município de Campo Bom, onde predominam as colinas areníticas da Formação Botucatu. 


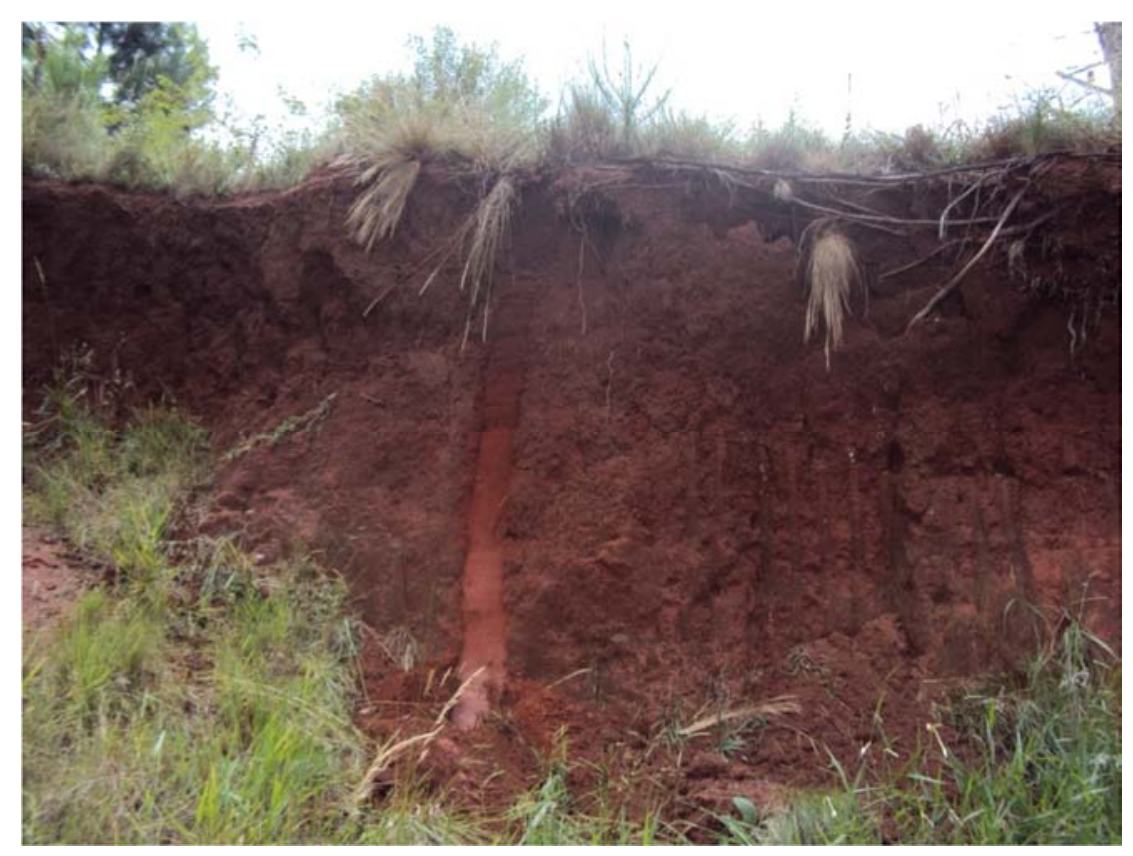

Fotografia 10: Perfil do argissolo vermelho distrófico, município de Campo Bom. Fonte: Adriana Penteado, 01/2011.

Os argissolos vermelho-amarelos distróficos têm maior incidência nos limites ao sul da bacia, nos trechos médio e inferior, e no trecho superior próximo à nascente do rio dos Sinos. Esses solos, para a área de estudo, ocorrem em menor proporção que os argissolos vermelhos distróficos. Esses solos estão mais comumente associados à litologia da formação Serra Geral. Próximo às nascentes do rio dos Sinos, onde se encontra esse solo, o relevo se apresenta mais ondulado.

\subsubsection{Cambissolos}

Os cambissolos são solos que apresentam grande variação de profundidade, podendo ser rasos ou profundos, além de apresentarem grande variabilidade também em relação às demais características. A drenagem varia de acentuada a imperfeita e podem apresentar qualquer tipo de horizonte A sobre um horizonte B incipiente (Bi), também de cores diversas. Muitas vezes são pedregosos, cascalhentos e mesmo rochosos. Ocorrem disseminados preferencialmente em regiões serranas ou montanhosas. São solos em processo de transformação, assim não possuem 
características suficientes para serem enquadrados em classes de solos mais desenvolvidos (IBGE, 2007).

A província geomorfológica do Planalto Rio-Grandense, compreendendo, entre outras, a região fisiográfica dos Campos de Cima da Serra, que se situa a nordeste do RS, se constitui numa superfície aplainada com cotas acima dos 900 metros. Ao sul seu limite compreende o município de São Francisco de Paula. Constitui uma das regiões mais frias e chuvosas do estado. Predominam rochas vulcânicas ácidas e o relevo varia de suave a fortemente ondulado. Devido às condições climáticas os solos que predominam são ácidos, correspondendo às classes dos cambissolos húmicos alumínicos (STRECH, 2008).

O cambissolo húmico alumínico é mais rico em matéria orgânica no horizonte superficial e extremamente ácido. Ocorre em ambientes onde a alta pluviosidade e as baixas temperaturas favorecem a acumulação de matéria orgânica. Os cambissolos em áreas de maior altitude ocorrem devido às características climáticas, com geadas tardias e baixas insolações que apresentam restrições para culturas de verão, sendo mais apropriados para frutas de clima temperado, silvicultura e pastagens. $\mathrm{O}$ uso desse solo para a agricultura exige altos investimentos em corretivos e fertilizantes, além da necessidade de práticas conservacionistas (KLAMT, 2008).

A incidência deste solo é predominante no compartimento geomorfológico Planalto Basáltico Tabular que atinge até 980 metros de altitude. Localiza-se na porção nordeste da bacia do rio dos Sinos de forma predominante no município de São Francisco de Paula. Na Fotografia 11 é possível verificar a alta concentração de matéria orgânica no horizonte A, o que se reflete na coloração escura. O mesmo não apresentou pedregosidade. 


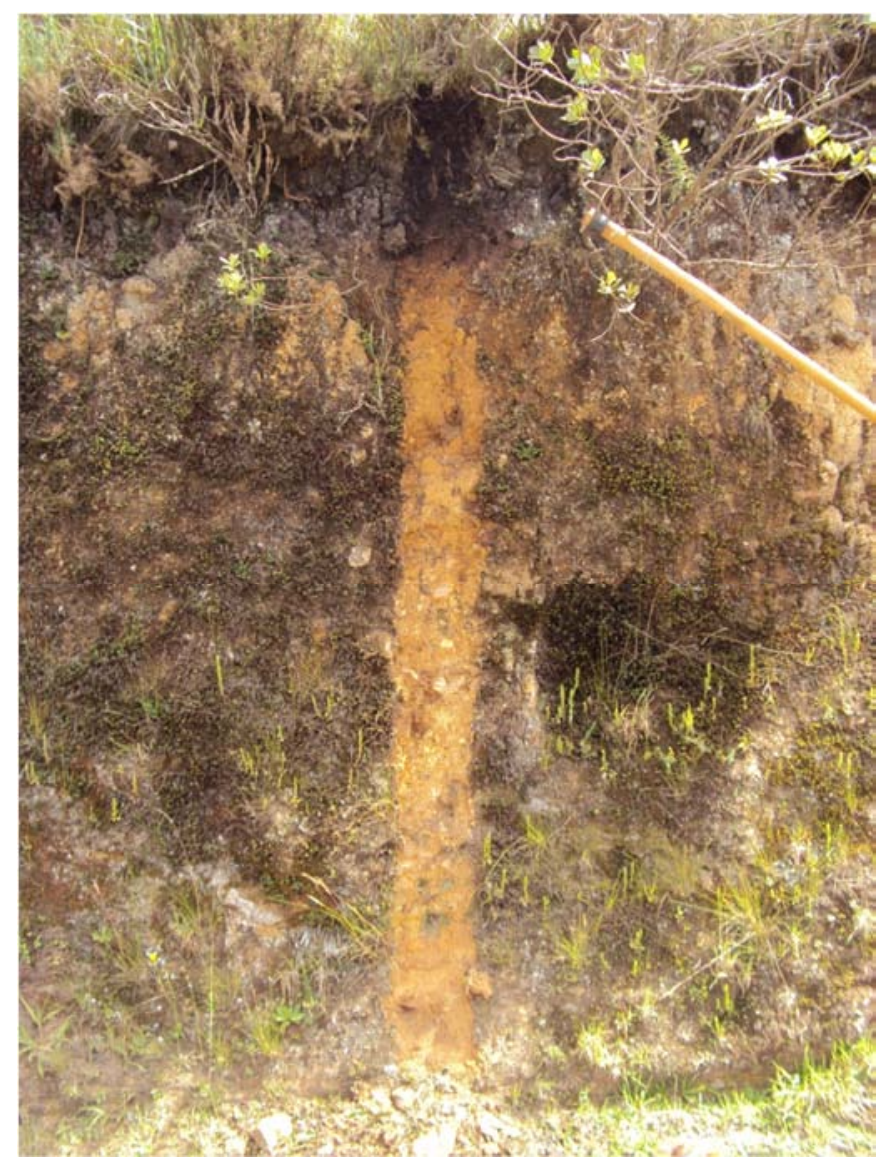

Fotografia 11: Perfil do cambissolo húmico alumínico, município de São Francisco de Paula.

Fonte: Adriana Penteado, 01/2011.

\subsubsection{Associação de solos e afloramentos rochosos}

Há, para a área de estudo, dois tipos distintos de afloramentos rochosos associados a solos em geral pouco desenvolvidos. O primeiro deles e de menor incidência compreende o neossolo regolítico distrófico/cambissolo húmico alumínico/argissolo brunoacinzentado alítico, associado às rochas da Formação Serra Geral.

Os neossolos se caracterizam por serem solos pouco desenvolvidos. São solos de formação recente, se desenvolvem a partir de variados tipos de rochas e podem ser encontrados em diversas condições de relevo e drenagem. Apresenta o horizonte A assentado diretamente sobre a rocha totalmente alterada e contato lítico em profundidade maior que $50 \mathrm{~cm}$, admitindo horizonte $\mathrm{Bi}$ com espessura menor que $10 \mathrm{~cm}$. Em relação ao grupo dos neossolos, os regolíticos são os de 
maior incidência no Rio Grande do Sul, os distróficos de baixa fertilidade natural e os eutróficos com saturação de bases maior que 50\% (KAMPF, 2008).

As características do cambissolo húmico alumínico já foram descritas anteriormente, assim como as características do argissolo, com a diferença de que, para a primeira associação de solos com afloramentos rochosos, este apresenta a característica alítica, que representa um argissolo com saturação por alumínio maior que $50 \%$.

Essa primeira associação de solos e rochas é encontrada no município de Canela e de Gramado, compreendendo uma pequena área em relação à bacia estudada.

O segundo tipo de associação, e com grande incidência, na bacia compreende o Neossolo Regolítico Eutrófico/Cambissolo Háplico Eutrófico/Luvissolo Háplico Órtico, também associados aos afloramentos da Formação Serra Geral.

O cambissolo háplico eutrófico possui menor incidência de matéria orgânica que o húmico e sua saturação por base é maior que $50 \%$.

O luvissolo apresenta acumulação superficial de argila, são solos geralmente pouco profundos, bem a imperfeitamente drenados, apresentando no perfil uma sequência de horizontes A-Bt-C, onde o horizonte Bt é do tipo textural. Estes solos têm alta atividade de argila, o que caracteriza maior absorção de água, e alta saturação por bases (STRECH, 2008).

O segundo tipo de associação de rochas e solos é encontrado na face norte-nordeste da bacia do rio dos Sinos. Alguns municípios onde se verifica tal associação são Caraá, Riozinho, Rolante, Três Coroas e norte do município de Taquara.

A Fotografia 12 é de um perfil do neossolo regolítico eutrófico localizado no município de Caraá, em área de incidência de morros médios da Formação Serra Geral pertencente ao compartimento geomorfológico Planalto Basáltico Dissecado. O mesmo apresenta alta pedregosidade logo abaixo do horizonte superficial. 


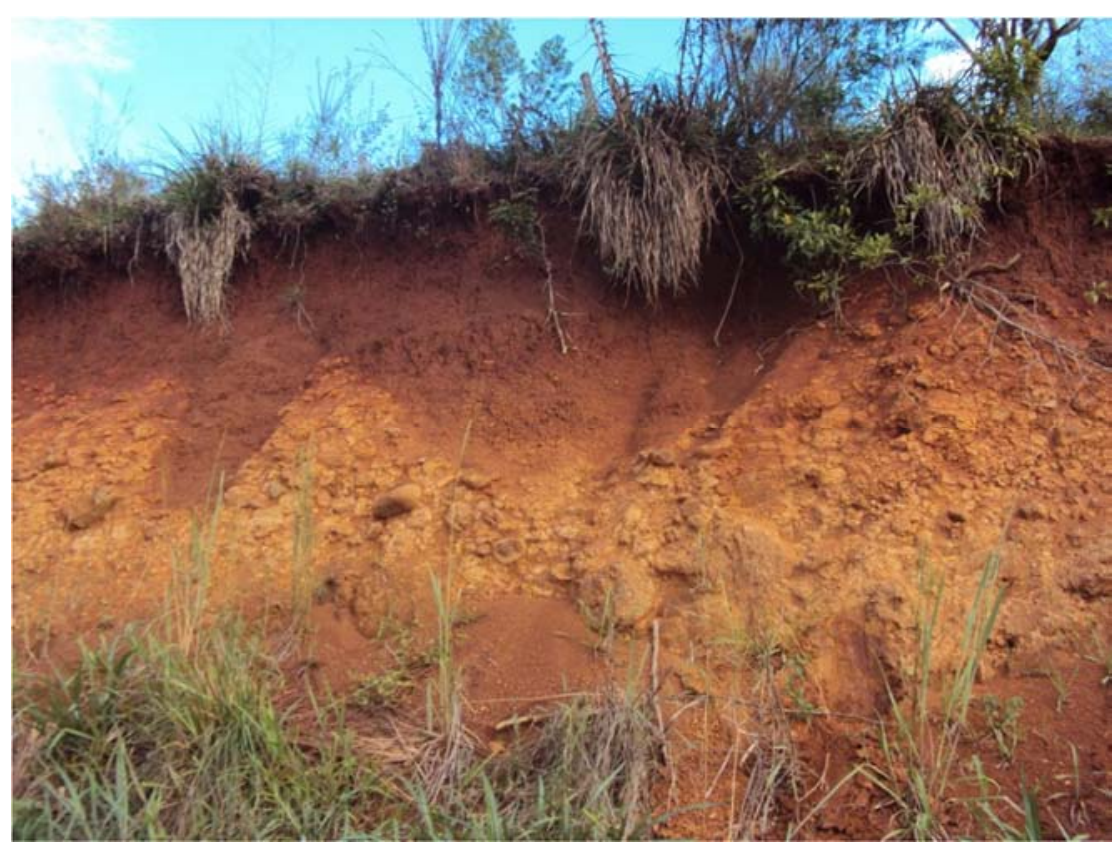

Fotografia 12: Perfil do neossolo regolítico eutrófico, município de Caraá. Fonte: Adriana Penteado, 01/2011. 


\subsection{Análise da hipsometria}

A bacia hidrográfica do rio dos Sinos atinge altitude máxima de aproximadamente 980 metros. As áreas mais altas localizam-se na porção leste-nordeste e as mais baixas ao sul e a oeste (Mapa 02).

As maiores altitudes, variando entre 750 a 980 metros, estão presentes em maior proporção nos municípios de Canela, Riozinho e São Francisco de Paula. Em menor proporção são encontradas em parte dos municípios de Gramado, Rolante, Caraá e Santo Antonio da Patrulha. Correspondem tais intervalos altimétricos, em sua maioria, às áreas de incidência de rochas vulcânicas ácidas da Formação Serra Geral.

Os intervalos entre 300 e 750 metros concentram-se nos trechos superior e médio, na porção norte-leste. Predominam nos municípios de Gramado, Três Coroas, Igrejinha, nordeste de Taquara, Rolante, oeste de Riozinho e sudoeste de São Francisco de Paula. Neste trecho predominam as rochas intermediárias e básicas da Formação Serra Geral.

Os intervalos entre 50 a 300 metros de altitude se concentram na face sul da bacia, predominando a sul e a oeste de Santo Antônio da Patrulha, sul de Taquara, sudeste de Novo Hamburgo, leste de Sapucaia e ao longo do município de Gravataí. Compreende o intervalo dos morros baixos da Formação Serra Geral e Botucatu e das colinas areníticas.

As altitudes entre 25 e 50 metros se distribuem ao longo de parte das planícies dos rios Rolante, da Ilha, Paranhana e outros afluentes menores. A montante da bacia este intervalo se inicia a oeste do município de Caraá e sua área aumenta quando o mesmo atinge o município de Santo Antônio da Patrulha, no qual possui extensão de 12 quilômetros. Para o intervalo descrito predominam os depósitos do Terciário.

$\mathrm{O}$ intervalo entre 0 e 25 metros de altitude, de montante para jusante, se inicia em Santo Antônio da Patrulha e segue de forma contínua até o município de Canoas, que possui os menores valores altimétricos de toda a bacia em relação aos demais municípios, predominando o intervalo acima descrito. Este intervalo altimétrico corresponde, em grande parte, à planície de inundação do rio dos Sinos. Em Santo Antônio da Patrulha a extensão desse intervalo, a partir de um corte transversal, é de aproximadamente 1,5 quilômetros, atingindo 12,5 quilômetros entre Nova Santa Rita e Canoas. Para este intervalo predominam os depósitos do Quaternário. 
Mapa 02: Mapa hipsométrico da bacia hidrográfica do rio dos Sinos 


\subsection{Análise da declividade}

Nas bordas do planalto da Formação Serra Geral, ao norte da bacia, a declividade é baixa não ultrapassando os 5\%, caracterizando um relevo pouco dissecado. Verifica-se próximo a essas áreas declividades entre 24 a $45 \%$, representando parte das escarpas do planalto e a transição para um relevo fortemente dissecado. Essa transição se localiza na face norte dos municípios de Gramado, Canela, Três Coroas, São Francisco de Paula e norte-leste do município de Riozinho. Geologicamente corresponde, em grande parte, à transição de rochas mais ácidas para intermediárias e básicas. As declividades acima de $45 \%$ são quase inexistentes e encontram-se intercaladas entre as declividades de 24 a $45 \%$ para o trecho descrito.

São também verificadas declividades entre 24 e $45 \%$ a nordeste do município de Caraá, onde se localizam as nascentes do rio dos Sinos, e em Santo Antônio da Patrulha em pequena proporção a nordeste. No trecho médio, ocorrem nos municípios de Igrejinha, Nova Hartz e Araricá a noroeste, e em Santa Maria do Herval a sudeste. No trecho inferior, em pequena proporção, nos municípios de Sapiranga, Novo Hamburgo e Gravataí.

As declividades entre 12 a $24 \%$ estão mais concentradas ao norte e nordeste da bacia do rio dos Sinos e são encontradas em todos os municípios acima descritos e em maior proporção em Canela, Gramado, São Francisco de Paula, Riozinho e Rolante. Este intervalo de declividade não foi verificado em apenas quatro municípios que são Canoas, Nova Santa Rita, Esteio e Cachoeirinha.

O intervalo entre 5 e $12 \%$ se distribui ao longo de toda a bacia, com maior concentração no trecho superior e médio onde predominam as rochas intermediárias e básicas da Formação Serra Geral.

As declividades entre 2 e 5\% são encontradas em toda a bacia, com maior incidência no trecho inferior, seguido do trecho médio. Nesses locais predominam os arenitos da Formação Botucatu. Essas classes de declividade são também predominantes na área de incidência da Formação Rosário do Sul, que ocupa a metade oeste do município de Nova Santa Rita. A maior incidência desse intervalo, considerando a área dos municípios inseridos na bacia, ocorre em Portão, que se localiza no extremo oeste da área de estudo. 
As declividades entre $0 \%$ e $2 \%$ ocorrem em maior proporção ao longo do rio dos Sinos, rio Rolante, Paranhana e da Ilha e alguns outros afluentes menores. Predominam nos municípios de Canoas, Cachoeirinha e Esteio. 
Mapa 03: Mapa de declividade da bacia hidrográfica do rio dos Sinos. 


\subsection{Análise da forma da bacia}

A bacia hidrográfica do rio dos Sinos possui área aproximada de $3743 \mathrm{~km}^{2}$, perímetro de $379,751 \mathrm{~km}$, e o comprimento máximo de $123874 \mathrm{~km}$. Estes dados foram mensurados a partir de base digitalizada e georrefenciada.

A área total inclui todos os pontos situados a altitudes superiores à da saída da bacia e dentro do divisor topográfico que separa duas bacias adjacentes; o perímetro é o comprimento linear do divisor de águas; e o comprimento máximo refere-se à distância da foz até a cabeceira mais distante.

A maior parte das características de uma bacia está correlacionada, de algum modo, com sua área, o que a priori justifica a importância da adequada delimitação para posterior cálculo de área. Como exemplo dessa relação, temos que, quanto maior for a bacia, maior será o seu potencial de geração de sedimentos.

A forma é uma das características físicas mais difíceis de ser expressa em termos quantitativos, assim como o arranjo da rede de drenagem. É influenciada por algumas características, sendo a principal delas a geologia. A forma da bacia pode também atuar nos processos ou no comportamento hidrológico da mesma.

Neste trabalho foram aplicados três índices com o objetivo de definir a forma da bacia estudada: Fator de forma - Ff (CHRISTOFOLETTI, 1969, TAVARES \& QUEIROZ, 1981); Coeficiente de compacidade - Kc (VILLELA \& MATTOS, 1980); Índice de circularidade Ic, (MILLER, 1953 apud CHRISTOFOLETTI, 1974).

\subsubsection{Fator de forma}

O Fator de forma - Ff é a relação da forma da bacia com um retângulo, compreendendo a razão entre a largura média e o comprimento máximo.

O fator de forma varia entre zero e um, sendo que quanto mais próximo do valor um, mais arredondada será a forma da bacia, o que indica maior tendência de ocorrência de enchentes de forma brusca; quanto mais próximo do número zero, mais alongada será a forma, com melhor escoamento da água em relação às bacias mais arredondadas. A Figura 16 busca demonstrar esSa relação. 


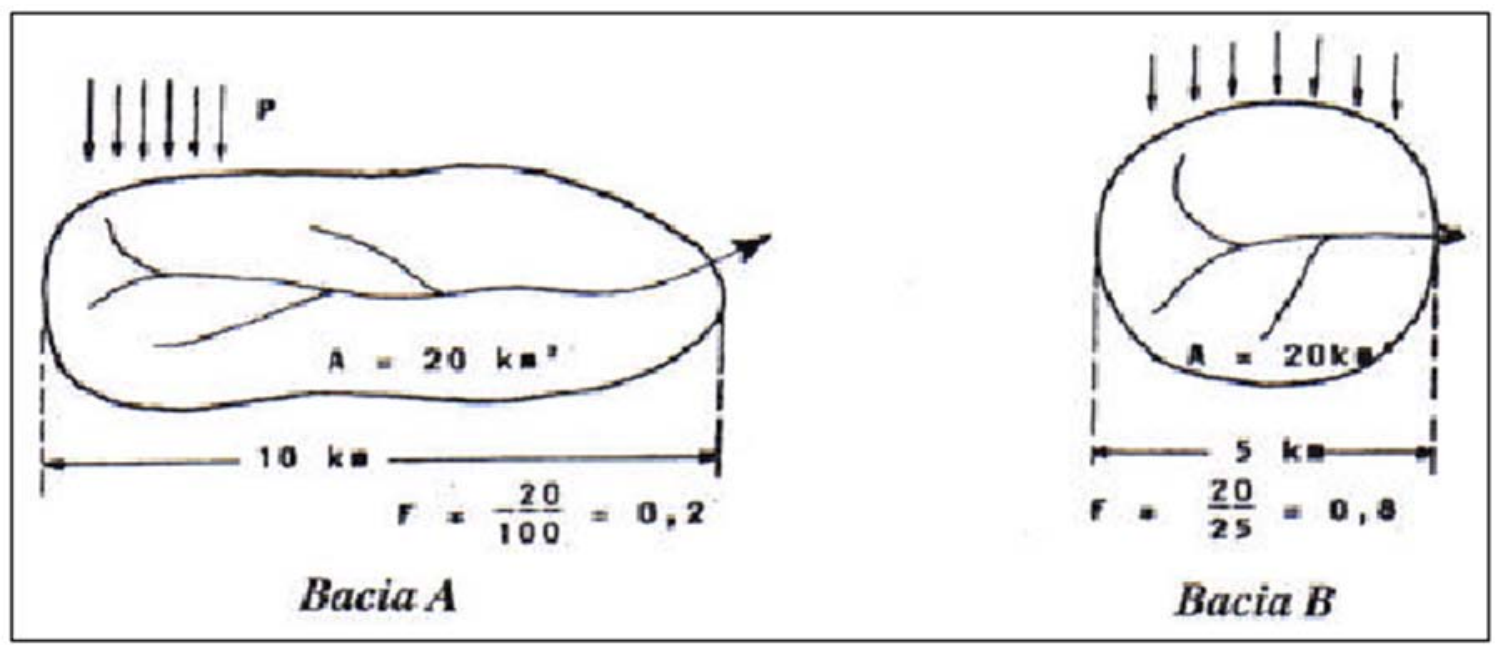

Figura 16: Relação entre fator de forma para bacias com mesma área. Fonte: Lima, 2010.

$\mathrm{Na}$ bacia $\mathrm{A}$, a água da chuva não se concentra de forma tão rápida com na bacia $\mathrm{B}$. As bacias mais longas e estreitas (A) possuem menores chances de serem atingidas em toda sua extensão por chuvas intensas. Comparando as duas bacias A e B, a bacia com fator de forma maior tem maiores chances de sofrer inundações bruscas do que a bacia com Ff menor.

A fórmula para o cálculo do Ff é a seguinte:

$$
\mathrm{Kf}=\frac{\mathrm{A}}{\mathrm{L}^{2}}
$$

Onde:

$\mathrm{Kf}=$ fator de forma, $\mathrm{A}=$ área $\left(\mathrm{km}^{2}\right)$ e $\mathrm{L}=$ comprimento máximo da bacia $(\mathrm{km})$.

Aplicando a fórmula para a bacia hidrográfica do rio dos Sinos temos:

$$
\begin{gathered}
\mathrm{Kf}=3743 / 102,61^{2}=0,35 \\
\mathbf{K f}=0,35
\end{gathered}
$$

A bacia do rio dos Sinos possui um fator de forma baixo, o que indica que a mesma tem uma forma mais alongada. Com o objetivo de demonstrar essa relação, foi elaborada a Figura 17, onde o limite da bacia foi combinado a um triângulo, tentando demonstrar o resultado obtido pela fórmula acima. 


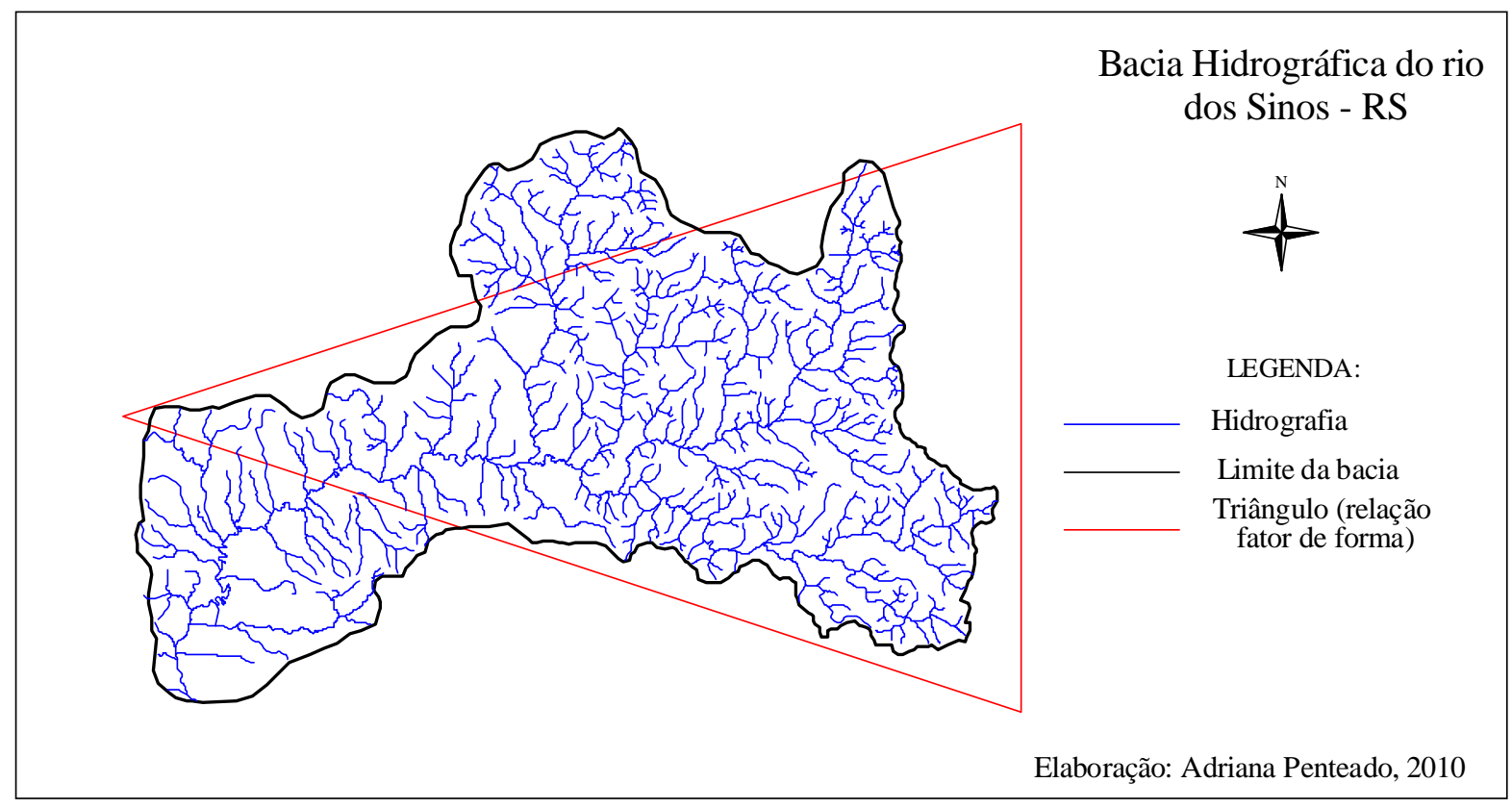

Figura 17: Relação entre a forma da bacia hidrográfica do rio dos Sinos.

Fonte: Adriana Penteado, 2010.

Analisando-se a Figura 17 percebe-se que a bacia hidrográfica do rio dos Sinos, no seu trecho, inferior dista do padrão alongado "ideal". O rio curvo nesse trecho, a baixa declividade e o acúmulo das águas das áreas adjacentes favorecem o aumento de volume das águas e o escoamento lento. Nesse local as inundações têm maior intensidade.

\subsubsection{Coeficiente de compacidade}

O coeficiente de compacidade $(\mathrm{Kc})$ relaciona a forma da bacia com um círculo. Constitui a relação entre o perímetro da bacia e a circunferência de um círculo de área igual a da bacia.

De acordo com Villela e Mattos (1975), esse coeficiente é um número adimensional que varia com a forma da bacia, independentemente de seu tamanho. Quanto mais irregular for a bacia, maior será o coeficiente de compacidade. A fórmula para obter o coeficiente é:

$$
K c=0,28 \frac{P}{\sqrt{A}}
$$

Para a área de estudo: 
$\mathrm{Kc}=$ Coeficiente de compacidade, $\mathrm{P}=$ Perímetro $(\mathrm{m})$ e $\mathrm{A}=$ área $\left(\mathrm{km}^{2}\right)$.

Aplicando para a área de estudo temos:

$\mathrm{Kc}=0,28 \times 379,751 /$ raiz quadrada $3743=1,73$

$$
\mathbf{K c}=1,73
$$

O resultado demonstra a irregularidade da forma da bacia e que a mesma não se aproxima de uma forma circular.

\subsection{3 Índice de Circularidade}

Simultaneamente ao coeficiente de compacidade, o índice de circularidade tende para a unidade à medida que a bacia se aproxima da forma circular e diminui à medida que a forma torna alongada. Para isso, utilizou-se a seguinte equação:

$$
I C=\frac{12,57 * A}{p^{2}}
$$

Para a área de estudo:

$\mathrm{IC}=$ Índice de circularidade, $\mathrm{A}=$ Área $\left(\mathrm{Km}^{2}\right), \mathrm{P}=$ perímetro $(\mathrm{km})$.

Aplicando temos: $\mathrm{IC}=12,57 \times 3743 / 379751^{2}=0,3262$

$$
\mathbf{I C}=0,3262
$$

Os três índices aplicados possuem resultados coerentes entre si, e estes demonstram que a bacia de estudo, devido a sua forma mais alongada, não é naturalmente susceptível a inundações bruscas que ocorrem seguidamente a um evento chuvoso extremo.

Alguns fatores externos relativos à área estudada, embora externos, influenciam no escoamento das águas internas: o influxo do rio Guaíba, relacionado, em parte, ao vento Minuano que circula no sentido sudoeste-nordeste, por exemplo. O rio Guaíba tem o fluxo de suas águas próximo à confluência com o rio dos Sinos, no sentido nordeste-sul.

As chuvas bruscas nas cabeceiras terão resposta à jusante, no caso da bacia hidrográfica do rio dos Sinos, entre dois e três dias após a ocorrência do evento pluviométrico. 


\subsection{Análise do relevo}

\subsubsection{Forma do canal fluvial}

A sinuosidade é o principal parâmetro utilizado para classificar os canais fluviais. A mesma resulta da combinação de fatores como descarga, fluxo hidráulico, gradiente do terreno, natureza e granulometria dos sedimentos transportados - e, principalmente, da relação entre a carga de fundo e o material em suspensão. Por meio desses elementos o clima, o tipo de relevo, a litologia e seu arcabouço estrutural interferem no traçado dos canais de uma rede de drenagem (IBGE, 2009).

Quanto à forma do canal fluvial, existem três definições mais usuais: canais retilíneos, anastomosados e meandrantes (Figura 18), definidos segundo CHRISTOFOLETTI (1981):

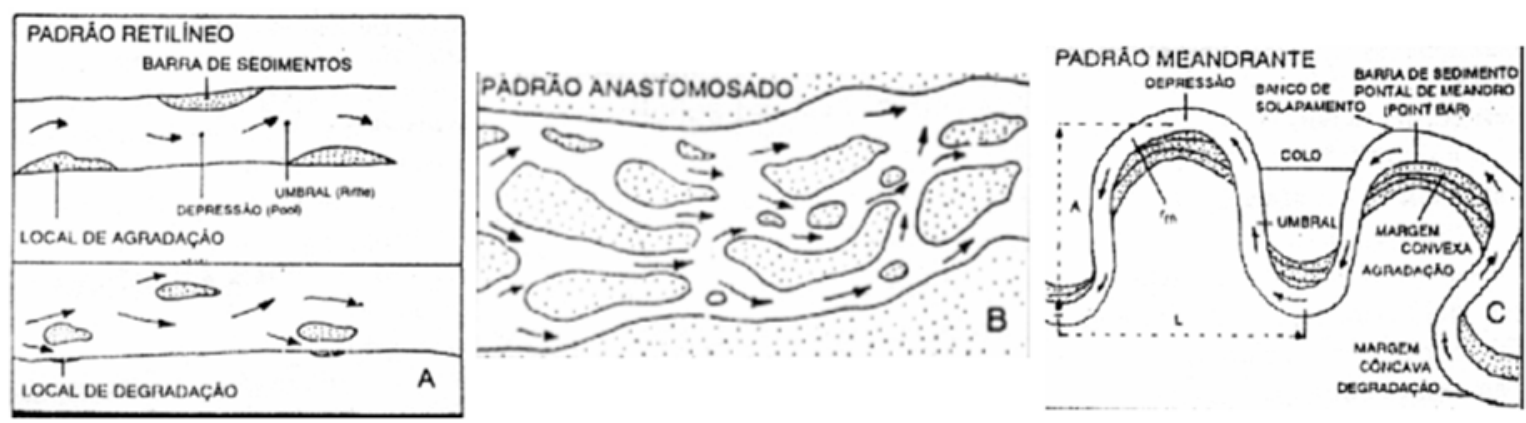

Figura 18: Principais padrões de canais fluviais.

Fonte: Cunha, 2007.

Os canais retilíneos são aqueles em que um rio percorre um trajeto reto, sem se desviar significativamente de sua trajetória normal. Os canais verdadeiramente retilíneos são extremamente raros na natureza, existindo principalmente quando o rio é controlado por linhas tectônicas (CUNHA, 2007).

Os canais anastomosados são caracterizados por apresentar grande volume de carga de fundo que, conjugado com as flutuações das descargas, ocasionam sucessivas ramificações, ou múltiplos canais que se subdividem e se reencontram, separados por ilhas assimétricas e barras arenosas.

Os canais meandrantes são encontrados, com frequência, nas áreas úmidas cobertas por vegetação ciliar, descrevem curvas sinuosas harmoniosas e semelhantes entre si. A formação da 
sequência de depressões (pools) e umbrais (riffles) ao longo do leito fluvial, definindo margens de erosão e deposição, representa estágio inicial do meandramento (ibid.).

Entre os tipos de canais há também o de padrão entrelaçado, que é comum em ambientes glaciais e está associado a leques aluviais ou relevos sujeitos a movimentos tectônicos. É característico em ambientes de elevada carga sedimentar, assim como alta capacidade de transporte, erosão e deposição. Há controvérsias entre este padrão e o anastomosado. Porém o entrelaçado pode ser diferenciado pelo número elevado de barras de canal no padrão entrelaçado (IBGE, 2010).

Existem dois sistemas distintos de padrão meandrante, o psamítico e o pelítico (IBGE (2010) apud Bigarella (2003):

O padrão psamítico está associado à natureza do ambiente, cujo canal se estabelece em regiões de maior declive, apresentando descarga menos uniforme, além de maior proporção de carga de fundo. As curvas dos meandros são mais suaves, apresentando um perfil transversal quase simétrico e mais escavado no fundo.

Na ocorrência desse padrão, as planícies de inundação, em relação às áreas mais à jusante, são mais estreitas, e as feições associadas são mais discretas em função da largura do vale. Compreende situações comuns em planaltos dissecados localizados a montante da bacia hidrográfica.

O padrão pelítico esta associado a extensas planícies de gradiente muito baixo, constituídas predominantemente por sedimentos mais finos. A sinuosidade do canal é bastante elevada e sua capacidade de migração se eleva à medida que o rio procura adaptar seu curso às variações de descarga, aproveitando a amplidão lateral que a extensa planície oferece. Em virtude disso, surgem inúmeras feições correlacionadas à migração dos canais, que são o resultado tanto de processos erosivos como de processos de acumulação.

Para a área de estudo, os principais padrões de canais fluviais serão identificados conjuntamente com as análises do perfil longitudinal do rio dos Sinos e de seus principais afluentes: rio Rolante, Paranhana e da Ilha. 


\subsubsection{Análises dos perfis longitudinais e transversais}

As análises de perfis de um rio e de uma bacia hidrográfica permitem estabelecer relações entre fatores como a altimetria, a declividade, a geologia e as formas de relevo, possibilitando uma interpretação integrada desses fatores. Pode-se também perceber desajustes que podem ocorrer devido a fatores humanos ou naturais. Devido a isso, a análise dos perfis compreende importante método de análise.

A Figura 19 localiza os perfis traçados na bacia hidrográfica do rio dos Sinos. Os transversais por meio de linhas perpendiculares ao rio principal, e os longitudinais pela nomenclatura dos rios.

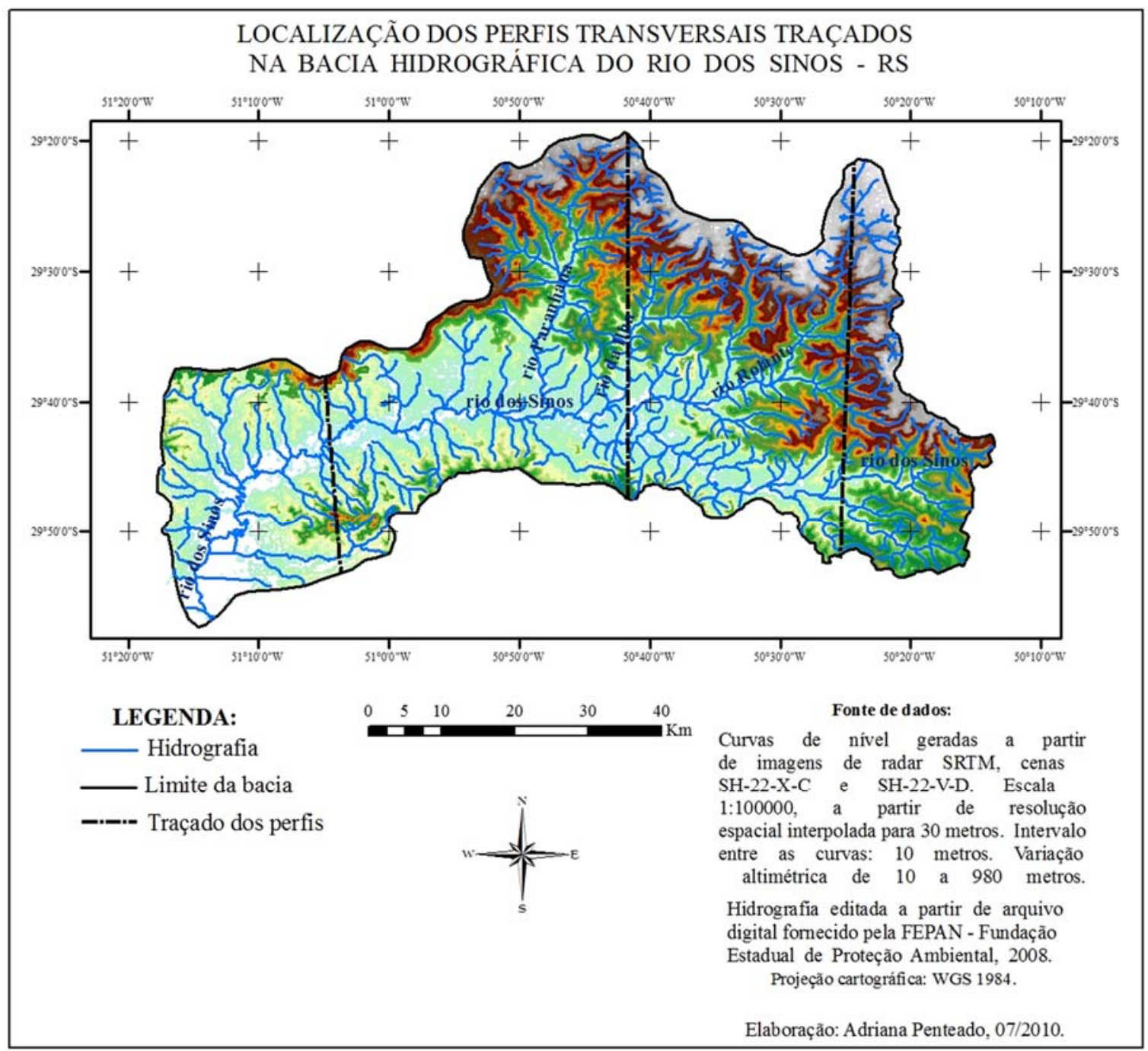

Figura 19: Localização dos perfis transversais traçados na bacia hidrográfica do rio dos Sinos. Elaboração: Adriana Penteado, 2010. 
4.7.3.1 Análise do perfil transversal do trecho superior da bacia hidrográfica do rio dos Sinos

Por meio da análise do perfil transversal do trecho superior da bacia hidrográfica do rio dos Sinos (Figura 20), observa-se, de forma predominante, relevo fortemente ondulado. O desnível altimétrico nesse trecho é acentuado, variando aproximadamente de 900 para 240 metros, em 50 quilômetros de distância no sentido norte-sul.

O relevo menos dissecado corresponde à área das nascentes do rio Rolante no Planalto Basáltico Tabular, na face extremo norte do perfil, atingindo altitude que ultrapassa os 900 metros, considerando seu trecho intermitente.

Em geral predominam altas declividades e vales encaixados, característicos de ação erosiva vertical. Pequenas depressões com fundo plano podem ser observadas nos pontos a, b, c (rio dos Sinos) e d, onde correm os rios de maior vazão.

Os primeiros pontos (a e b) localizam-se em altitudes mais altas, 630 e 230 metros, respectivamente; já os pontos c e d estão próximos de 40 metros. Os fundos de vale mais planos caracterizam processo erosivo do sentido horizontal e onde começam se a configurar áreas de planície.

Há, para a área representada neste perfil, predominância das rochas da Formação Serra Geral.

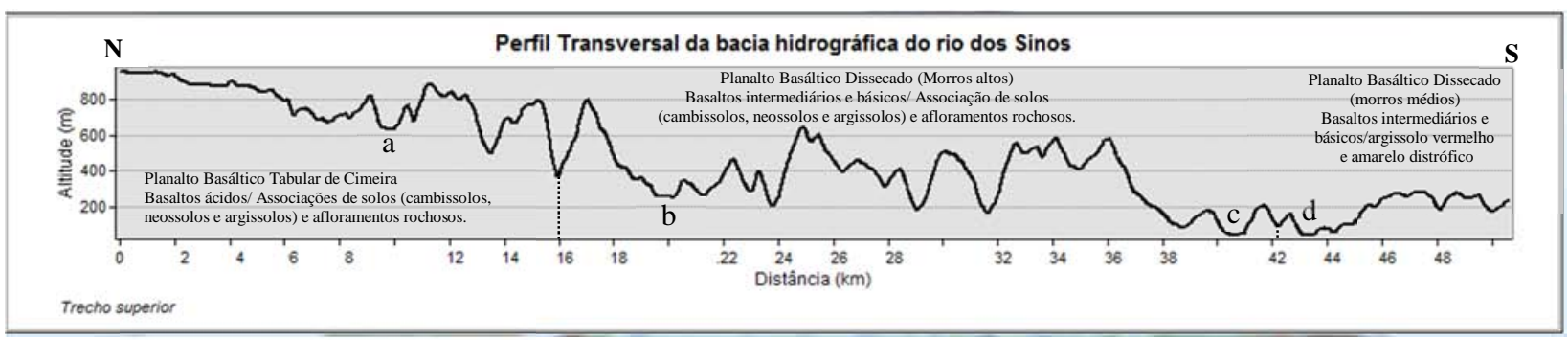

Figura 20: Perfil Transversal do trecho superior da bacia hidrográfica do rio dos Sinos. Elaboração: Adriana Penteado, 2010. 


\subsubsection{Análise do perfil transversal do trecho médio da bacia hidrográfica do rio dos Sinos}

No perfil transversal do trecho médio da bacia hidrográfica do rio dos Sinos (Figura 21), a planície de inundação tem um grande alargamento em relação ao perfil do trecho superior. A mesma está situada a aproximadamente 30 metros de altitude.

O leito menor do rio dos Sinos tem extensão aproximada de cinco quilômetros (área indicada entre as setas vermelhas). É composto por depósitos de planícies e canais fluviais; cascalhos, areias grossas e finas e sedimentos síltico-argilosos inconsolidados. As suaves elevações nas margens do leito menor indicam diques marginais.

O leito maior do rio dos Sinos encontra-se com o leito maior do rio da Ilha que está indicado pela seta azul seguido da letra c. O leito maior, conjugado entre os dois rios, possivelmente atinge as marcas em verde, que delimitam uma área aproximada de treze quilômetros.

Os vales apresentam-se menos encaixados e com fundo plano. Com a menor declividade, $o$ desgaste do canal se acentua no sentido horizontal, se distanciando da forma em $\mathrm{V}$ e se aproximando da forma em $\mathrm{U}$.

Há ainda, para este perfil, predominância da Formação Serra Geral, e nas áreas mais baixas e mais planas, depósitos do Quaternário e do Terciário.

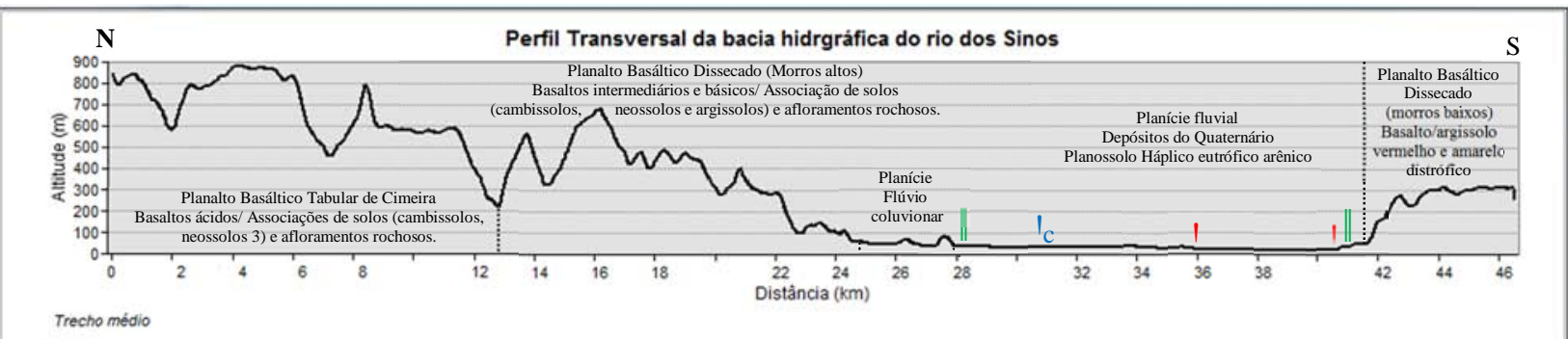

Figura 21: Perfil Transversal do trecho médio da bacia hidrográfica do rio dos Sinos.

Elaboração: Adriana Penteado, 2010. 


\subsubsection{Análise do perfil transversal do trecho inferior da bacia hidrográfica do rio dos Sinos}

No perfil transversal do trecho inferior da bacia hidrográfica do rio dos Sinos (Figura 22) o relevo apresenta-se suave ondulado predominando como modelado às planícies fluviais. Assim, os processos de deposição são mais acentuados que os processos erosivos.

A Formação Serra Geral é representada pelo morro no extremo norte do perfil. Tem seu pico um pouco acima de 400 metros de altitude compreendendo a maior elevação para esse trecho.

As colinas da Formação Botucatu, na face norte do perfil, atingem aproximadamente 100 metros. Na face sul há presença de colinas e morros baixos, estes atingindo altitude de até 300 metros.

O leito menor do rio dos Sinos (delimitado pelas linhas em vermelho) teve um deslocamento de sul para norte em relação ao perfil do trecho médio, sem aumento significativo de largura. Nas demais áreas planas correm rios de menor vazão (representados pelas setas).

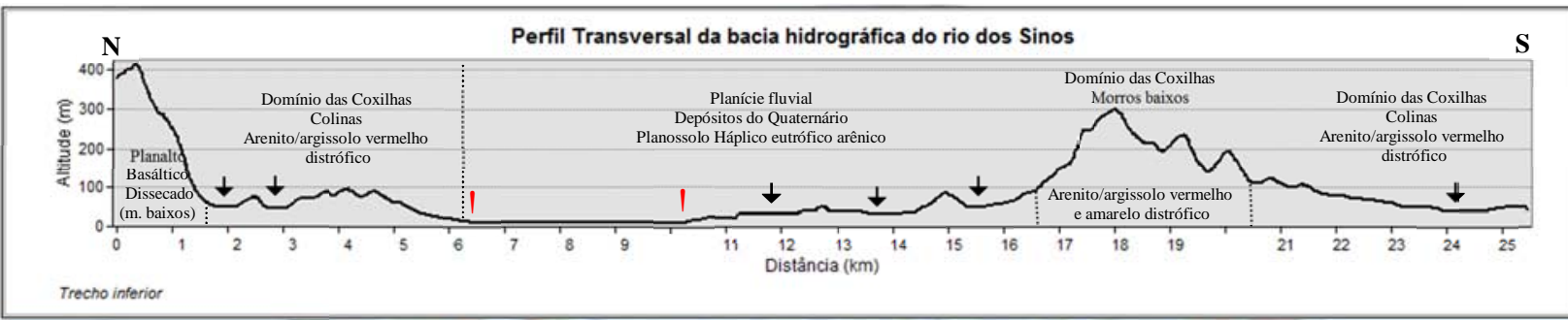

Figura 22: Perfil Transversal do trecho inferior da bacia hidrográfica do rio dos Sinos. Elaboração: Adriana Penteado, 2010.

\subsubsection{Perfil longitudinal}

O perfil longitudinal de um rio mostra a relação da sua altimetria com o comprimento de seu curso hídrico, desde a nascente até a foz. Quando o rio encontra-se em equilíbrio, o perfil descreverá uma linha côncava ascendente. 
Um rio em equilíbrio é aquele que atingiu a estabilidade, de modo que, sobre determinado período de tempo, a água e a carga detrítica que entram no sistema são compensadas pelas que dele saem (MORISAWA, 1968).

A abordagem sistêmica voltada aos estudos da dinâmica fluvial utiliza-se do termo estabilidade quando há o equacionamento das entradas (input) e das saídas (output) de matéria e energia.

Os rios podem ser analisados como um sistema aberto em termos de entrada e saída de matéria e energia e como sistemas de processo-resposta. O funcionamento desse sistema é controlado pela magnitude e frequência de inputs. Progressivas mudanças na morfologia e operação do sistema podem ocorrer se mudanças nos inputs ou degradação interna do sistema ocorrerem, auto-regulação ou trocas negativas (feedback) podem ocorrer, criando um novo estado de equilíbrio entre as formas e os processos (SILVA, 2005).

O curso de água assume o seu perfil de equilíbrio, onde a declividade, a velocidade e a descarga se combinam para transportar toda a sua carga sedimentar, sem que exista nem erosão, nem sedimentação. Alterações no nível de base desestabilizam o perfil de equilíbrio (GUERRA, 1987).

O nível de base pode ser definido como um ponto limite, sendo que abaixo deste a erosão das águas correntes deixa de atuar. O nível de base geral de todos os rios é o nível do mar. Existem também vários níveis de base locais ou regionais, em função dos quais os rios realizam o escavamento do perfil de equilíbrio (ibid.).

Qualquer ponto de um rio pode ser considerado nível de base local para os demais trechos que se encontram a montante. Assim, não seriam apenas as alterações altimétricas em relação ao oceano que poderiam responder por reativação da rede de drenagem, mas também modificações ocorridas no nível de base local, pertencentes a qualquer ponto do interior de uma bacia (COTTON, 1948).

À medida que o leito do rio é aprofundado há um incremento da ação erosiva nas partes altas da bacia, caracterizando a compensação fluvioerosiva (CHRISTOFOLETTI, 1981). A carga de fundo de um sistema fluvial tem relação direta com a geometria hidráulica do canal e quaisquer alterações envolvendo essa variável podem acarretar no desequilíbrio do perfil longitudinal (LEOPOLD et al., 1964). 
Normalmente, ao longo do curso de um rio há trechos em equilíbrio e trechos em desequilíbrio. Os trechos ajustados apresentam inclinações suaves e constantes ao longo do perfil longitudinal, e os trechos em desequilíbrio apresentam deformações e/ou irregularidades.

As alterações no perfil longitudinal de um rio podem ocorrer devido às variações no escoamento e na carga sólida, confluência dos tributários, variações no processo erosivo devido às diferenças litológicas, deformações tectônicas e aumento brusco da erosão devido a alterações no nível de base local (ibid.).

Os desajustes podem ocorrer devido a fatores naturais e/ou antrópicos. Como exemplo de fatores naturais há as quedas de água, e de fatores antrópicos, a construção de hidrelétricas e a extração mineral no canal. 
4.7.3.4.1 Análise do perfil longitudinal do rio dos Sinos e padrões de canais associados

No perfil longitudinal do rio dos Sinos (Figura 23), de leste para sudoeste há uma queda relevante de altitude em uma distância aproximada de 30 quilômetros a partir da sua nascente. Após esse trecho assume certa estabilidade altimétrica e se concentra abaixo de 40 metros de altitude até a sua foz, onde atinge cota próxima a zero. A partir dessa transição as planícies de inundação começam a atingir proporções mais significativas.

Ao longo do perfil longitudinal do rio dos Sinos estão localizados os pontos de intersecção dos perfis transversais traçados na bacia por meio das abreviaturas $\mathrm{Ts}$, $\mathrm{Tm}$ e $\mathrm{Ti}$, que significam respectivamente trecho superior, trecho médio e trecho inferior.

As irregularidades ao longo do perfil longitudinal, algumas indicadas pelas setas em preto, representam desajustes no canal.

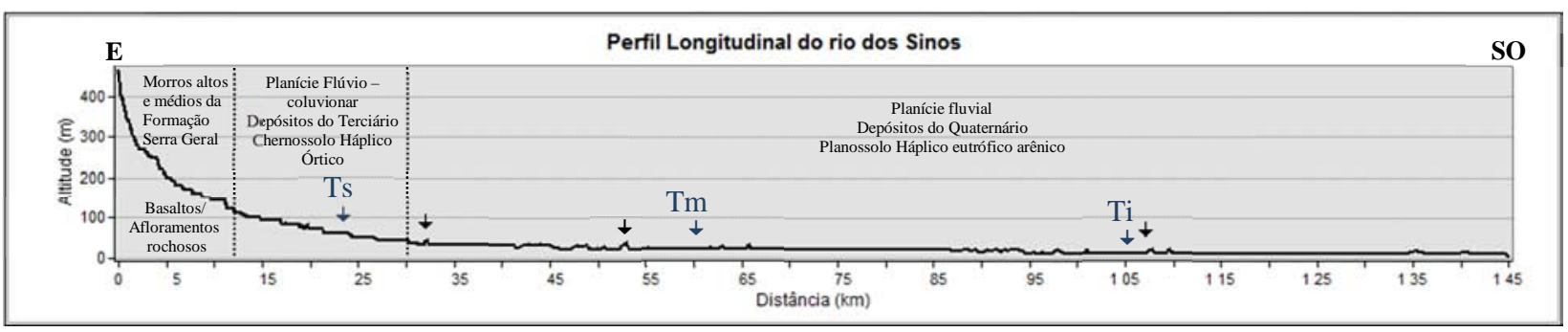

Figura 23: Perfil longitudinal do rio dos Sinos.

Elaboração: Adriana Penteado, 2010.

Nas áreas mais altas no Planalto Dissecado, o rio dos Sinos apresenta certa sinuosidade, com padrão que pode ser definido como meandrante psamítico (Figura 24). A sinuosidade aumenta para jusante caracterizando canal meandrante pelítico. Provavelmente, devido às alterações muito próximas ao rio, para a área demonstrada na Figura 25, não se verificam feições correlacionadas à migração do canal. O padrão meandrante demonstra estabilidade do canal, havendo, dessa forma, certo ajustamento entre a declividade, largura e profundidade, velocidade dos fluxos, vazão, carga detrítica e rugosidade. 


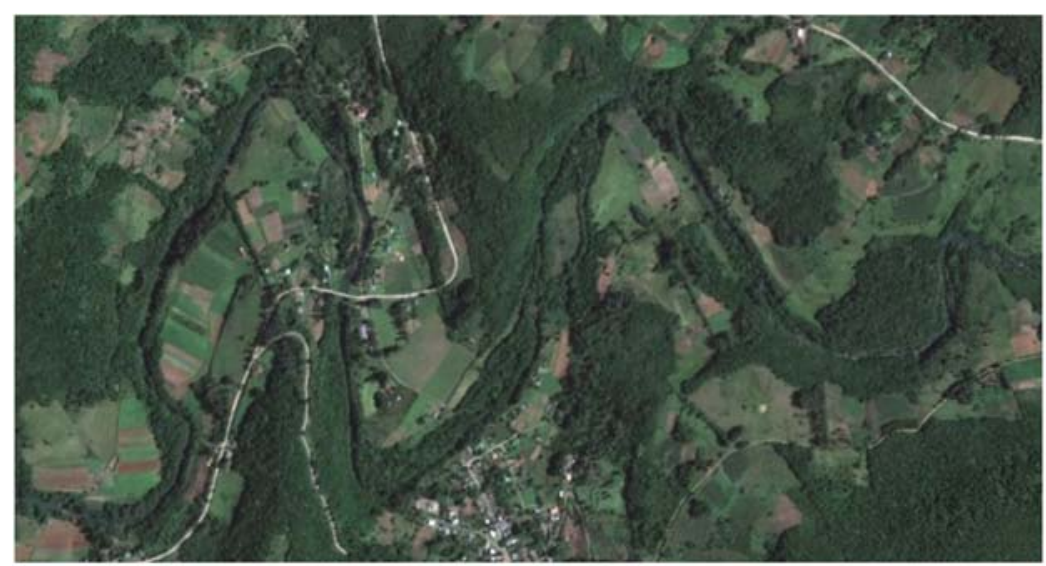

Figura 24: Padrão meandrante psamítico do trecho superior do rio dos Sinos Fonte: Google Earth, 26/07/10.

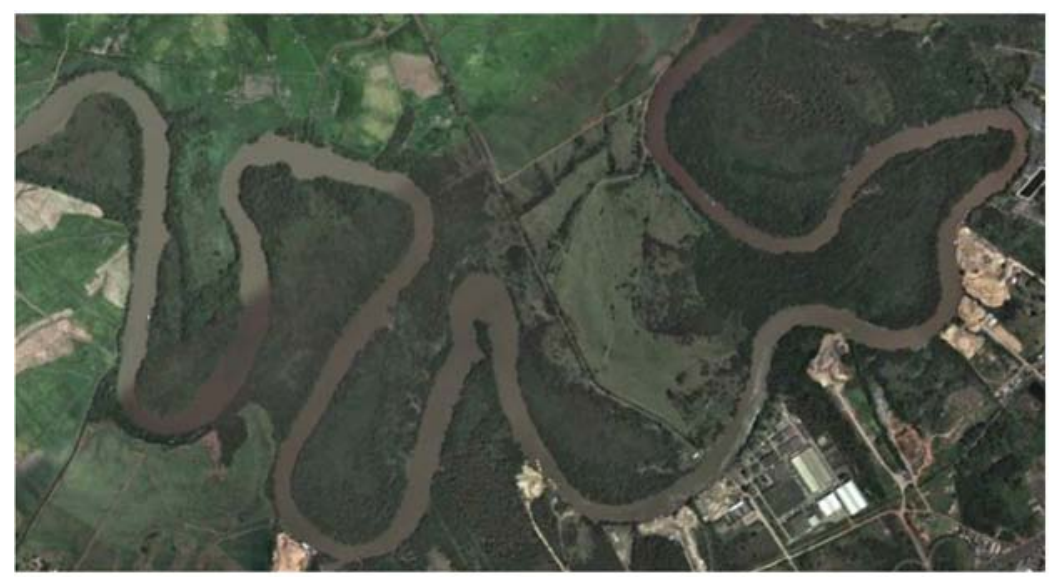

Figura 25: Padrão meandrante pelítico no trecho inferior do rio dos Sinos. Fonte: Google Earth, 26/07/10.

4.7.3.4.2 Análise do perfil longitudinal do rio Rolante e padrões de canais associados

O rio Rolante nasce no município de São Francisco de Paula, no Planalto Basáltico Tabular da Formação Serra Geral. Em extensão é o mais importante afluente do rio dos Sinos. Corre no sentido norte-sudoeste, desaguando no rio dos Sinos, que funciona como seu nível de base, numa altitude aproximada de 20 metros, entre a divisa dos municípios de Parobé e Taquara.

Os topos planos na face norte do perfil (Figura 26) representam os patamares da Serra Geral e a declividade entre uma e outra cota é acentuada. Essa morfologia possibilita a existência de cachoeiras. Nesse trecho, o rio desce aproximadamente 400 metros em 14 quilômetros, configurando uma média de queda de 28 metros de altitude para cada quilômetro, porém em 
alguns trechos a queda é mais abrupta. $\mathrm{Na}$ área indicada pela seta verde identifica-se desnível de 100 metros quase em ângulo reto. Esse desajuste no perfil compreende um fator natural e indica a escarpa do planalto. Já o desajuste indicado pela seta em preto pode ter origem antrópica.

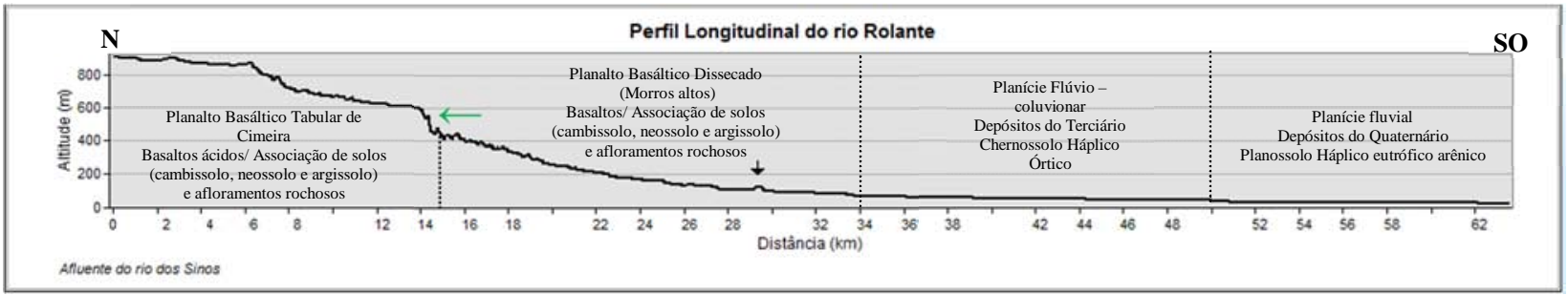

Figura 26: Perfil longitudinal do rio Rolante.

Elaboração: Adriana Penteado, 2010.

Muito próximo à sua nascente, o rio Rolante apresenta canal com padrão irregular (Figura 27), inserido em área de Planalto Tabular, de fraca dissecação do relevo.

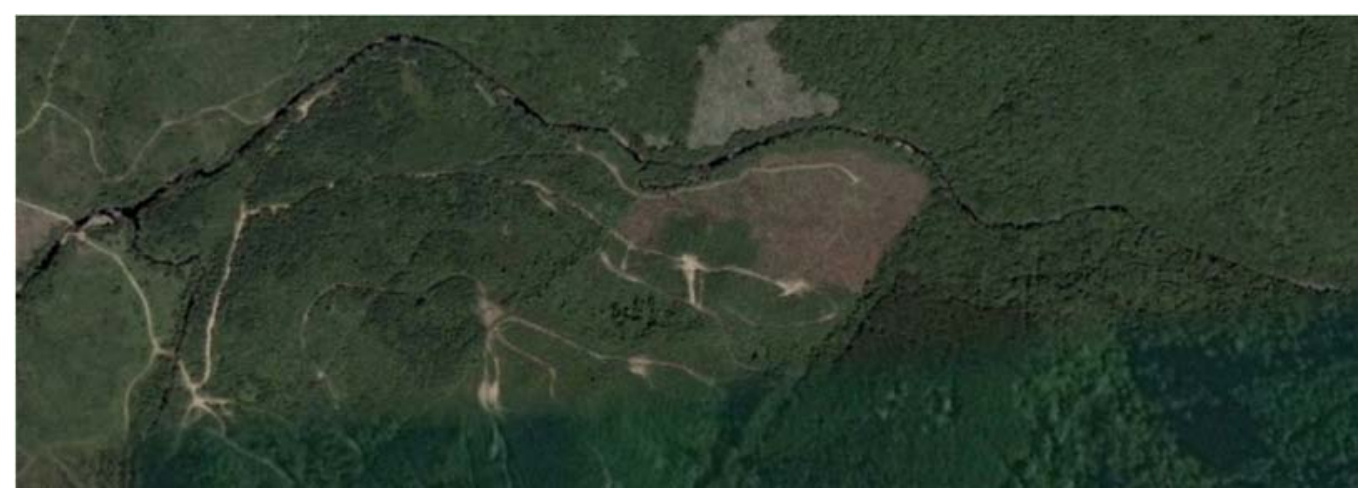

Figura 27: Trecho superior do rio Rolante.

Fonte: Google Earth, 26/07/10.

Aproximadamente a partir dos seus últimos quinze quilômetros, o rio Rolante apresenta-se sinuoso e em sua planície fluvial há sinais de divagação do canal (setas em vermelho), dinâmica própria de rios meandrantes, havendo presença de paleocanais. O paleocanal da extrema direita configura um lago em forma de ferradura. Há também sinais de agradação (margem convexa) e de erosão (margem côncava) no canal (Figura 28). 


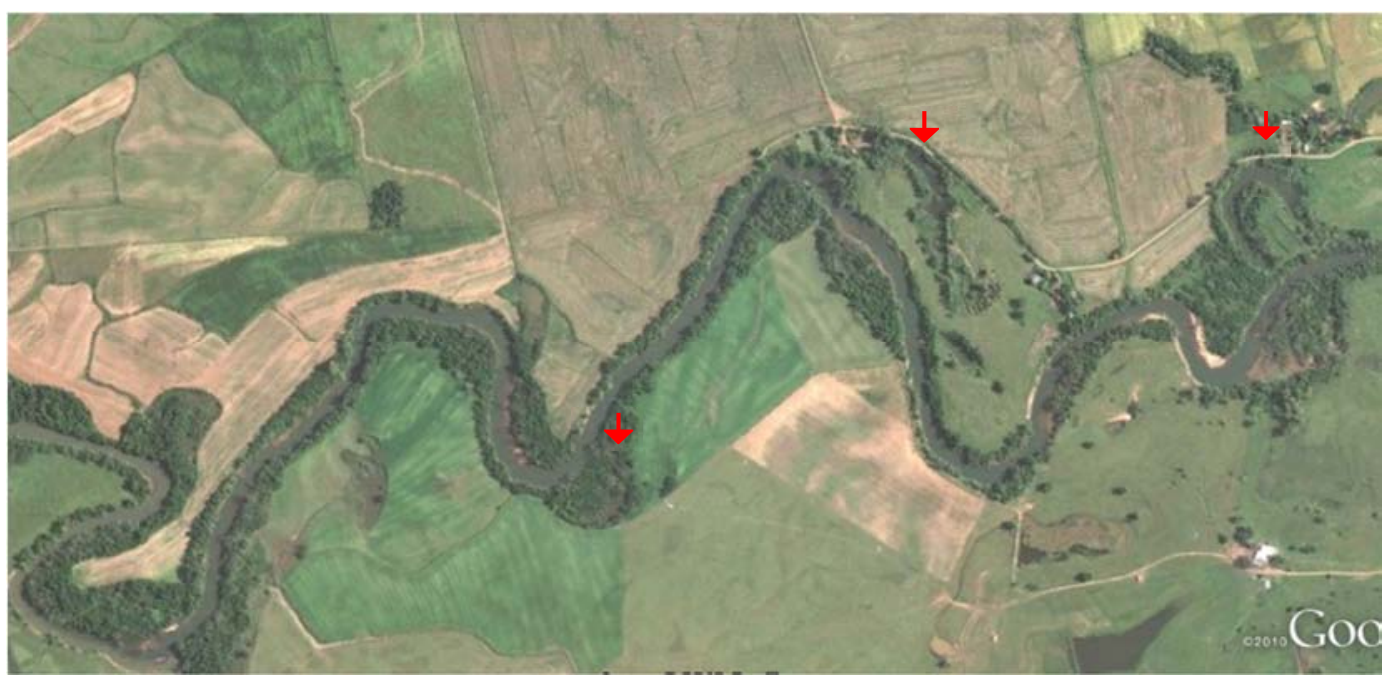

Figura 28: Trecho inferior do rio Rolante.

Fonte: Google Earth, 26/07/10.

4.7.3.4.3 Análise do perfil longitudinal do rio Paranhana e padrões de canais associados

Em extensão, o rio Paranhana é o segundo maior afluente do rio dos Sinos, correndo no sentido nordeste-sul. Sua nascente encontra-se localizada no município de Canela, na denominada Serra Gaúcha, nas bordas do Planalto Basáltico Tabular.

Seu maior desnível altimétrico (Figura 29) ocorre numa extensão aproximada de oito quilômetros, variando de aproximadamente 800 metros até a cota 200 no sentido nordeste-sul. Sua planície assume maior expressividade espacial no ponto especificado pela seta em preto. Deságua no rio dos Sinos numa altitude aproximada de 20 metros, que representa seu nível de base local, na divisa entre os municípios de Taquara e Santo Antônio da Patrulha.

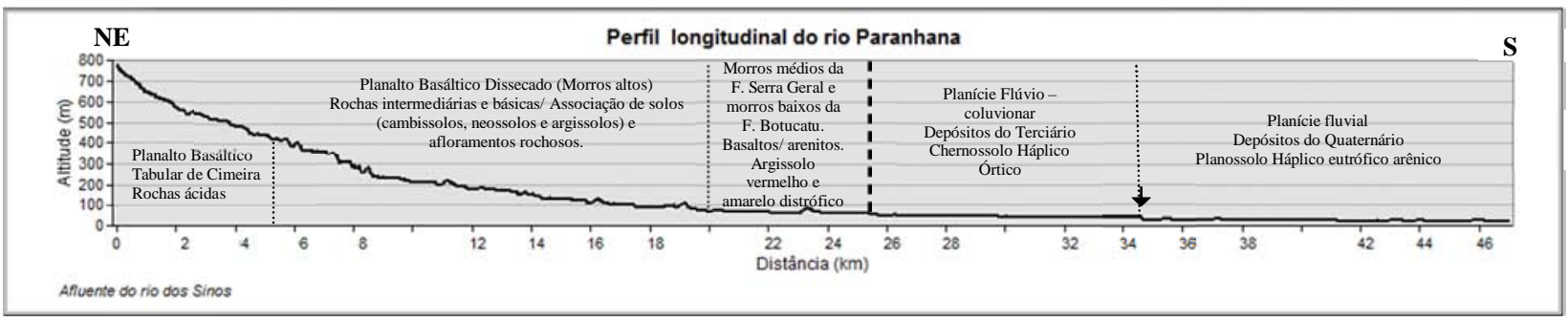

Figura 29: Perfil longitudinal do rio Paranhana.

Elaboração: Adriana Penteado, 2010. 
Próximo à sua nascente, em área do Planalto Dissecado, o rio Paranhana apresenta trechos com médio grau de sinuosidade, configurando padrão meandrante psamítico (Figura 30). Nos seus 3,5 quilômetros finais sua sinuosidade diminui, mas em algumas margens é possível verificar processo de erosão e de agradação (Figura 31).

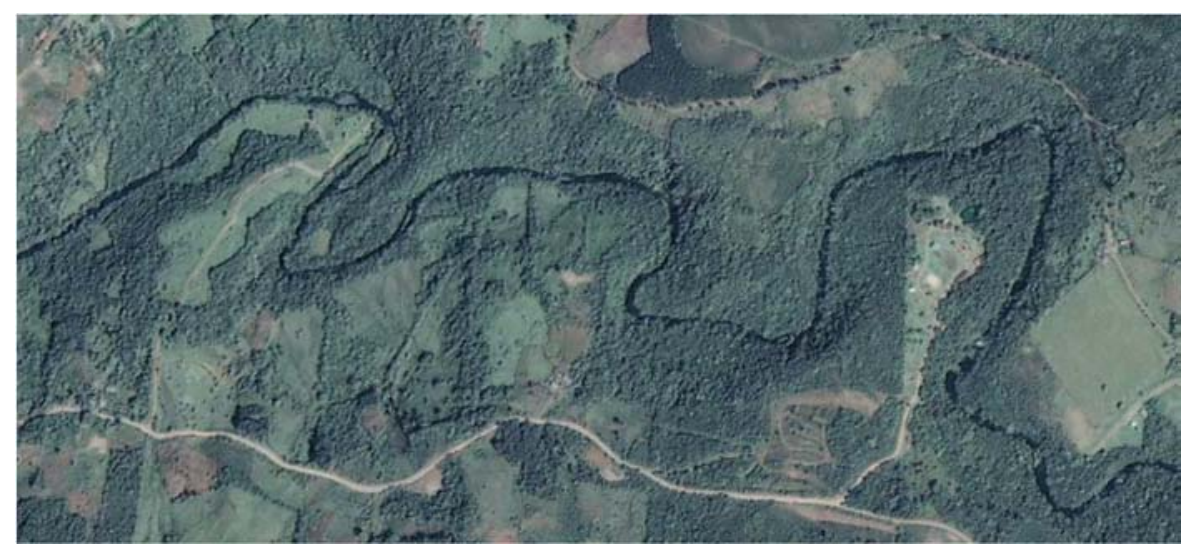

Figura 30: Sinuosidade do rio Paranhana em seu trecho superior.

Fonte: Google Earth, 26/07/10.

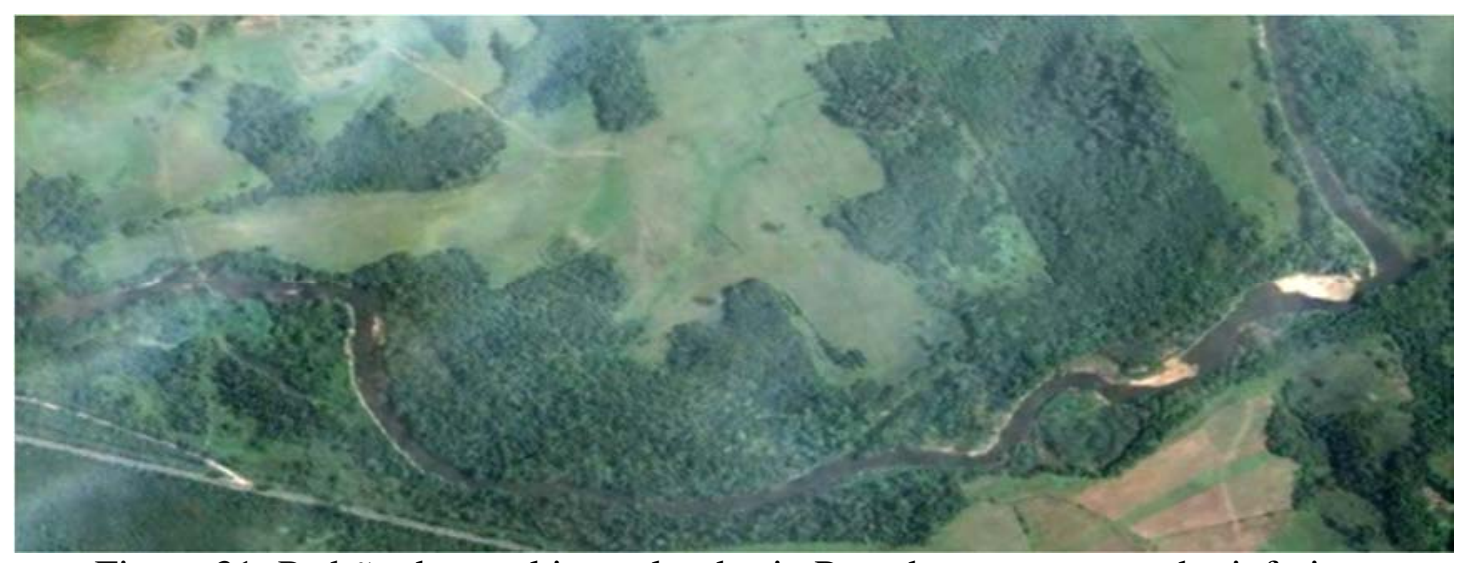

Figura 31: Padrão de canal irregular do rio Paranhana no seu trecho inferior. Fonte: Google Earth, 26/07/10.

4.7.3.4.4 Análise do perfil longitudinal do rio da Ilha e padrões de canais associados

O rio da Ilha é o terceiro principal afluente do rio dos Sinos, possuindo aproximadamente 30 quilômetros de extensão. Nasce, assim como o rio Rolante, no município de São Francisco de 
Paula, em altitude aproximada de 800 metros nas bordas do Planalto Tabular ao norte da bacia, seguindo em direção sudoeste onde deságua no rio principal da bacia.

Segue pelo mesmo município numa distância aproximada de 8,5 quilômetros, onde o planalto apresenta-se fortemente dissecado. Desde a nascente até o ponto descrito, configura-se o seu maior desnível altimétrico, que é de aproximadamente 700 metros. Posteriormente atinge o município de Taquara, onde se localiza sua foz, em nível altimétrico de 20 metros. A seta em preto indica a transição dos limites municipais (Figura 32).

Sua planície começa a ganhar expressão espacial a partir dos seus últimos 14 quilômetros em direção a sua foz, em altitude aproximada de 55 metros. A partir dos seus últimos 2,5 quilômetros sua planície atinge a planície do rio dos Sinos (indicado pela seta em vermelho).

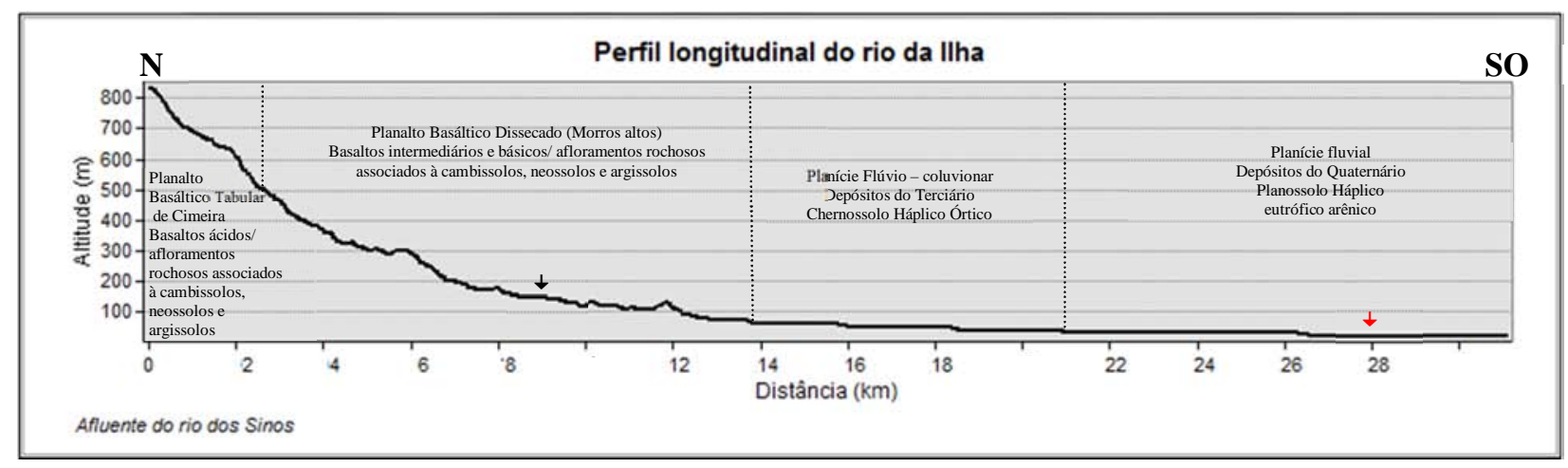

Figura 32: Perfil longitudinal do rio da Ilha.

Elaboração: Adriana Penteado, 2010.

No trecho superior, no Planalto Dissecado, o rio da Ilha apresenta canal de baixa sinuosidade com padrão mais próximo do irregular (Figura 33). Já em sua foz a sinuosidade aumenta, configurando um padrão de canal meandrante pelítico (Figura 34). 


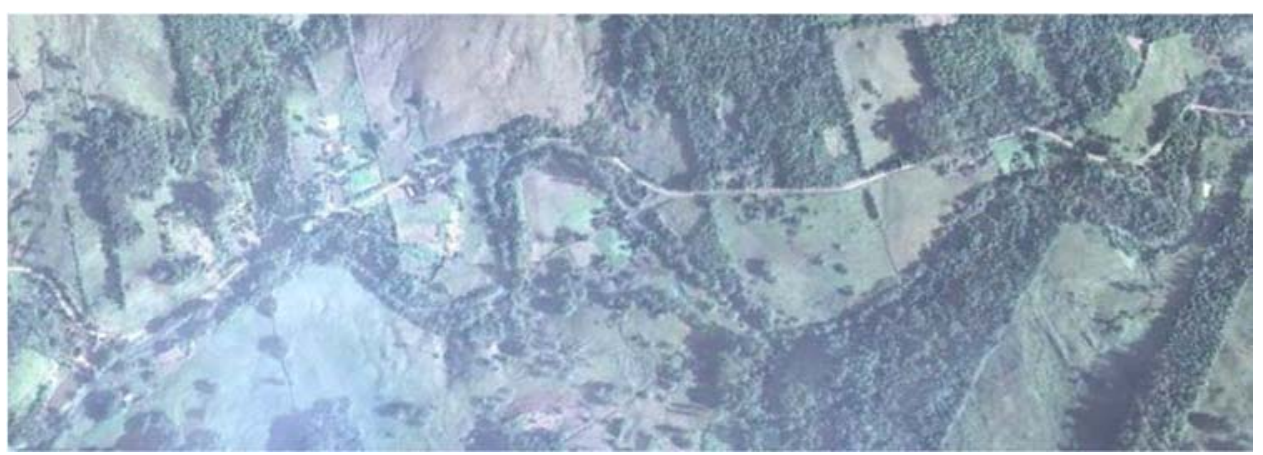

Figura 33: Rio da Ilha com baixa sinuosidade em área de planalto dissecado. Fonte: Google Earth, 18/04/10.

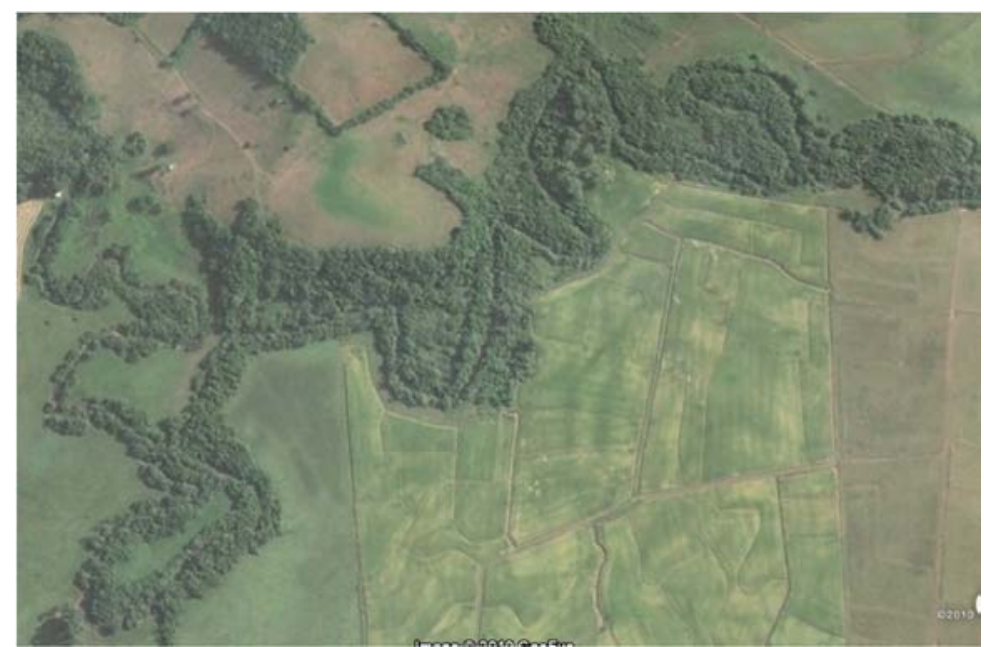

Figura 34: Rio da Ilha sinuoso configurando um padrão de canal meandrante pelítico Fonte: Google Earth, 18/04/10. 


\subsubsection{Análise do mapa geomorfológico}

O mapa geomorfológico da bacia hidrográfica do rio dos Sinos foi elaborado com detalhamento até o terceiro táxon, que compreende o padrão de formas semelhantes. A morfoestrutura da área compreende a Bacia Sedimentar do Paraná. A partir da ação do clima ao longo do tempo geológico na morfoestrutura, foram esculpidas formas menores denominadas de morfoesculturas. Para a área de estudo foram definidas três morfoesculturas: Planícies Interiores, Planalto das Araucárias e a Depressão Central Gaúcha.

Segundo Casseti, 2008:

A compartimentação topográfica corresponde à individualização de um conjunto de formas com características semelhantes, o que leva a se admitir que tenham sido elaboradas em determinadas condições morfogenéticas ou morfoclimáticas que apresentem relações litoestratigráficas ou que tenham sido submetidas à eventos tectodinâmicos. A interpenetração das diferentes forças ao longo do tempo leva à caracterização das formas de relevo, da situação topográfica ou altimétrica e da existência de traços genéticos comuns como fatores de individualização do conjunto, (CASSETI, 2008, p. 02).

As planícies Interiores foram subdivididas em planícies fluviais e fluviocoluvionares, estas compreendendo os modelados de acumulação da bacia.

O Planalto das Araucárias, segundo táxon, compreendeu os modelados do Planalto Basáltico Tabular de Cimeira e o Planalto Basáltico Dissecado, onde foram identificados os seguintes padrões de formas: morros tabulares, morros altos, morros médios e morros baixos. Esses modelados foram esculpidos a partir das rochas efusivas básico-intermediárias e ácidas da Formação Serra Geral.

A morfoestrutura Depressão Central Gaúcha compreende o modelado Domínio das Coxilhas, onde foram identificadas as formas em colinas e morros baixos. A litologia compreende os arenitos da Formação Botucatu e da Formação Rosário do Sul. 


\subsubsection{Morfoescultura Planícies Interiores}

\subsection{Planície Fluvial}

As planícies fluviais do rio dos Sinos e de seus afluentes localizam-se a uma altitude, predominantemente, de até 35 metros, e declividades de até $2 \%$. Caracterizam-se geologicamente pelos depósitos do Quartenário, que compreendem os cascalhos, areias grossas a finas e sedimentos síltico-argilosos inconsolidados. Predominam, nas áreas adjacentes a este modelado, as colinas areníticas da Formação Botucatu.

De Santo Antônio da Patrulha até o município de Parobé, o solo predominante é o chernossolo háplico órtico. A partir de Campo Bom em direção a Canoas, o solo predominante é o planossolo háplico eutrófico. O relevo é plano a suave ondulado e predominam os processos de agradação de sedimentos.

As planícies fluviais do rio dos Sinos, de montante para jusante, se iniciam no município de Santo Antonio da Patrulha (Figura 35). Nas margens sul e sudeste afloram os morrotes basálticos da Formação Serra Geral. Na margem norte e nordeste as colinas areníticas da Formação Botucatu. A distância aproximada da nascente do rio dos Sinos até este trecho é de aproximadamente 30 quilômetros. A largura máxima da planície neste município ultrapassa, em alguns trechos, os três metros.

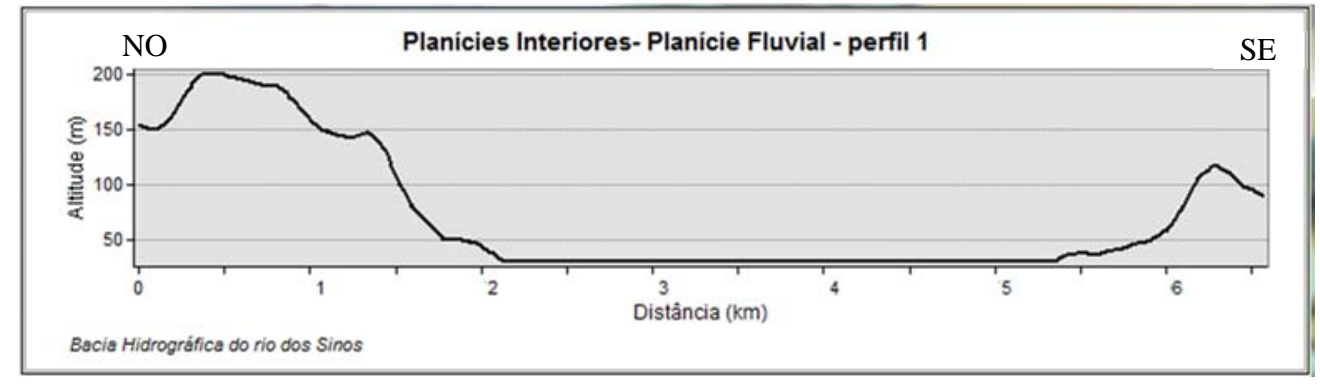

Figura 35: Perfil 1 Planícies Interiores-planície fluvial

Elaboração: Adriana Penteado, 2010.

Seguindo em direção à jusante, na divisa municipal entre Santo Antônio da Patrulha e Taquara, a leste, a planície do rio Rolante encontra as planícies do rio dos Sinos. As planícies do 
rio da Ilha (Fotografia 13), na parte central de Taquara e, na sua divisa com Parobé, do rio Paranhana (Fotografia 14).

No trecho descrito predominam, nas margens das planícies, as colinas areníticas. A extensão das planícies fluviais dos três principais afluentes do rio principal, da foz em direção à nascente, é de aproximadamente 12 quilômetros.

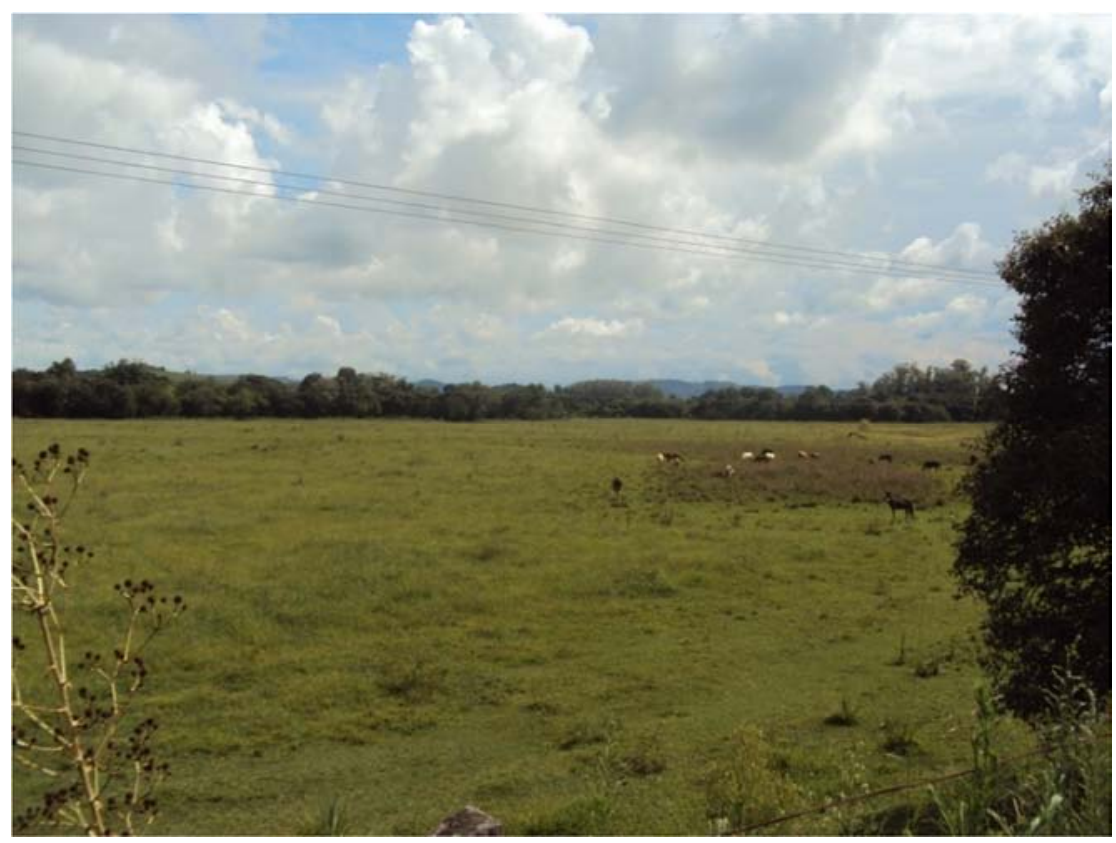

Fotografia 13: Planície fluvial do rio da Ilha, município de Taquara. Fonte: Adriana Penteado, 01/11. 


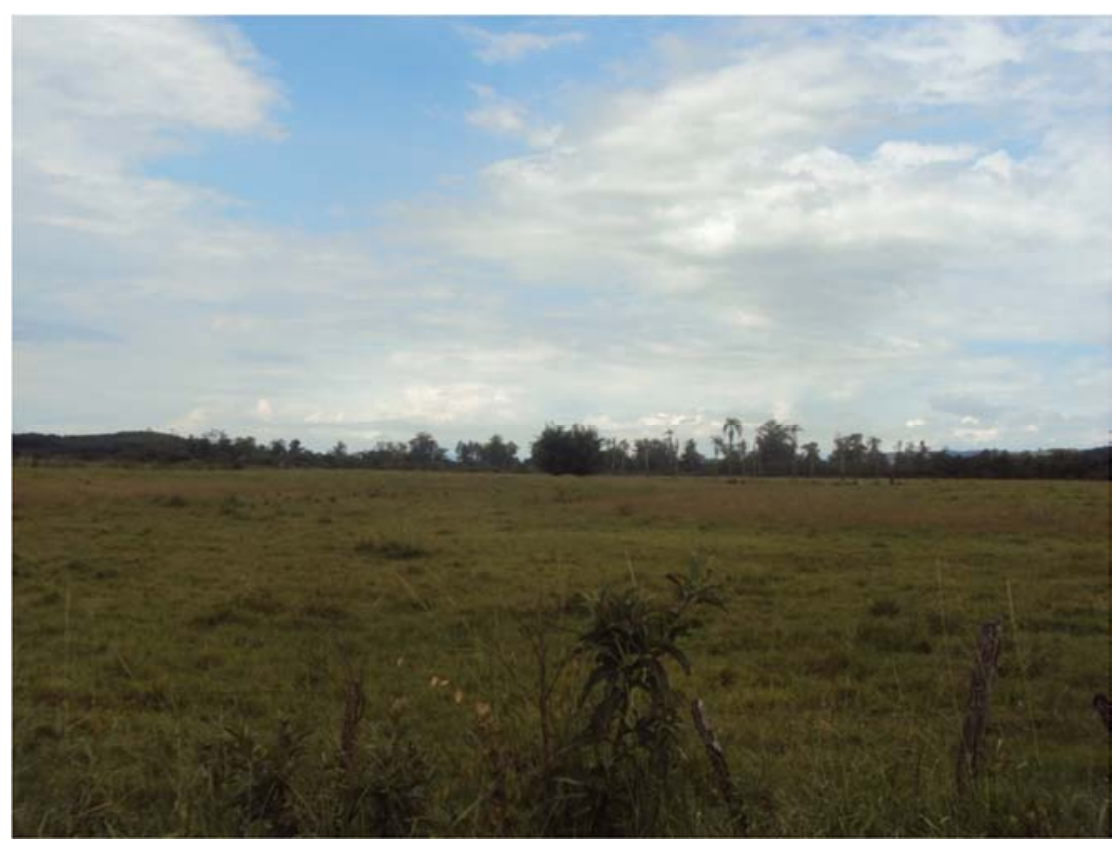

Fotografia 14: Planície fluvial do rio Paranhana, município de Parobé. Fonte: Adriana Penteado, 01/11.

Em média as planícies dos três rios descritos, de Santo Antonio da Patrulha até a divisa com Campo Bom e Novo Hamburgo, têm em torno de dois quilômetros de largura. A partir desse ponto expandem aproximadamente um metro nas laterais, e próximo à foz possui largura que ultrapassa, em alguns trechos, os oito metros.

\subsection{Planície Fluviocoluvionar}

As planícies fluviocoluvionares estão localizadas, de forma predominante, acima de 40 metros de altitude e abaixo de $145 \mathrm{~m}$. A declividade varia entre 0 e 5\%. Predominam nestas áreas os depósitos do Terciário, que são constituídos por conglomerados, diamicitos, arenitos conglomeráticos, arenitos e lamitos avermelhados, maciços ou com estruturas acanaladas. Onde há desenvolvimento pedológico, o solo predominante é o chernossolo háplico órtico.

Localizam-se em áreas que variam de relevo fortemente dissecado a suave ondulado, predominando a pequena expressividade espacial. Surgem, em continuidade, as planícies fluviais nas áreas mais altas e de maior declive. Aparecem de forma descontínua ao longo da bacia e em 
geral com largura menor que 1,4 quilômetros. Nesse modelado predomina o processo de agradação com sedimentos mais grosseiros do que os que estão presentes nas planícies fluviais.

Após nove quilômetros da nascente do rio dos Sinos, no município de Caraá, em direção a sua foz, configuram-se as planícies fluviocoluvionares, nos limites entre o Planalto Basáltico Dissecado de morros altos, na face norte do rio dos Sinos, e de morros médios do mesmo modelado. A largura da planície nesse trecho é de aproximadamente 200 metros. Chegando próximo a um quilômetro já no município de Santo Antônio da Patrulha, onde o relevo adjacente caracteriza-se pela presença de morros baixos da Formação Serra Geral.

Na Figura 36, no município de Caraá, a seta em vermelho representa a planície fluviocoluvionar do rio dos Sinos. Na face sul, os morros médios da Formação Serra Geral, e na face norte, os morros altos.

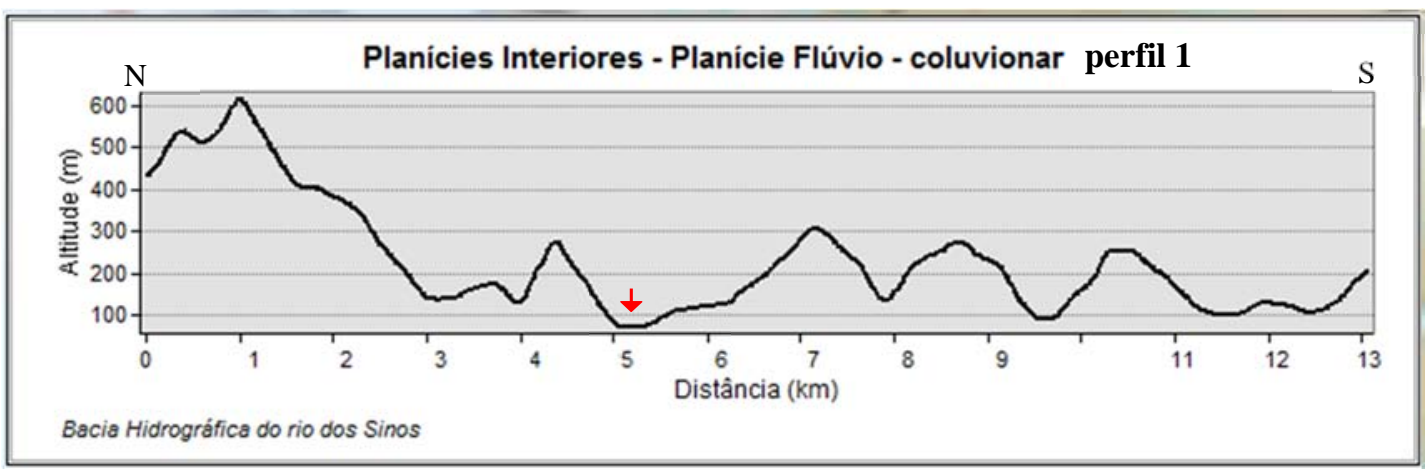

Figura 36: Perfil 1 Planícies Interiores - planície fluviocoluvionar Elaboração: Adriana Penteado, 2010.

A segunda área analisada, de incidência de planície fluviocoluvionar e de expressão espacial semelhante à que se localiza em Caraá, se inicia aproximadamente após 25 quilômetros de distância da nascente do rio Rolante em direção a sua foz, no compartimento geomorfológico Planalto Basáltico Dissecado. Nas áreas adjacentes predominam os morros altos da Formação Serra Geral.

A Figura 37 compreende perfil traçado entre os municípios de Rolante e Riozinho em área de incidência dos morros altos do Planalto Basáltico Dissecado. O fundo de vale que se inicia a 
quatro quilômetros do perfil é onde se localiza parte da planície fluviocoluvionar do rio Rolante, com 250 metros de largura, localizada a aproximadamente 90 metros de altitude.

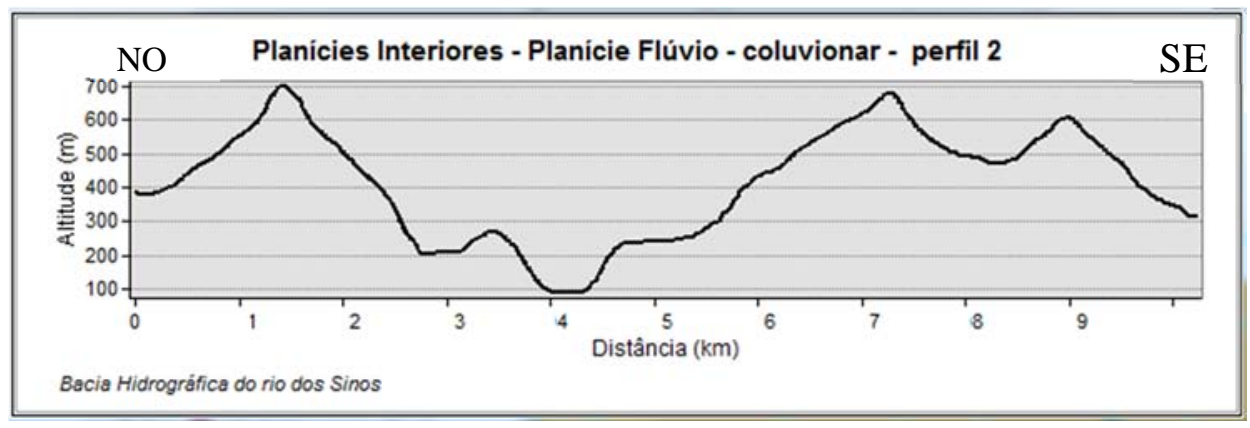

Figura 37: Perfil 2 Planícies Interiores - planície fluviocoluvionar Elaboração: Adriana Penteado, 2010.

A planície fluviocoluvionar do rio Rolante chega a atingir 1,4 quilômetros de extensão, próxima à confluência com a planície fluvial, onde o relevo nas áreas adjacentes se constitui na margem norte pelos morros baixos da Formação Botucatu, e na margem sul, pelos morros baixos da Formação Serra Geral.

Há ainda duas áreas expressivas de planícies fluviocoluvionares. Uma delas, ao longo do rio Paranhana, a 18,6 quilômetros de distância de sua cabeceira, no município de Três Coroas, seguindo em direção ao município de Igrejinha, onde atinge largura máxima aproximada de 900 metros. Nas áreas adjacentes há presença de colinas areníticas.

A outra área, mais a oeste, localiza-se entre os municípios de Nova Hartz e Araricá em afluente da margem norte do rio dos Sinos.

No trecho inferior da bacia do rio dos Sinos, as planícies fluviocoluvionares apresentam-se muito segmentadas e em pequenos trechos, predominando nas áreas adjacentes as colinas areníticas. 


\subsubsection{Morfoescultura Domínio das Coxilhas}

\subsection{Padrão em colinas}

O padrão de formas em colinas encontra-se, predominantemente, em áreas da Formação Botucatu e da Formação Rosário do Sul. Está mais concentrado ao longo de todo o trecho inferior e médio da bacia e, em pequena proporção, no trecho superior. A declividade atinge $12 \%$ e predomina a altimetria entre 50 a 150 metros, predominando o relevo suave ondulado com fraca dissecação.

Em relação aos rios principais, o padrão encontra-se nas áreas mais à jusante e adjacentes ao rio da Ilha, Rolante e Paranhana, com maior incidência em relação ao ultimo rio. Em relação às áreas adjacentes ao rio dos Sinos, de montante para jusante, é possível verificar a presença de colinas a partir do município de Santo Antônio da Patrulha, que seguem em direção ao trecho inferior da bacia.

Entre os principais municípios com presença de colinas estão Taquara, Igrejinha, Parobé, Sapiranga, Campo Bom, Estância Velha, Portão, Nova Santa Rita, São Leopoldo, Novo Hamburgo, Araricá e Nova Hartz.

A Figura 38 é do primeiro perfil traçado para o padrão de formas em colinas. Localiza-se entre Sapucaia do Sul e São Leopoldo, com aproximadamente 2,74 quilômetros de extensão. A maior colina atinge 120 metros de altitude e a menor 90 metros. O fundo do vale que se localiza mais ao sul do perfil possui fundo plano e altitude de 60 metros; o que se encontra mais ao norte está acima dos 70 metros. Nesses vales correm afluentes da margem leste do rio dos Sinos. Os topos das colinas se apresentam convexos. 


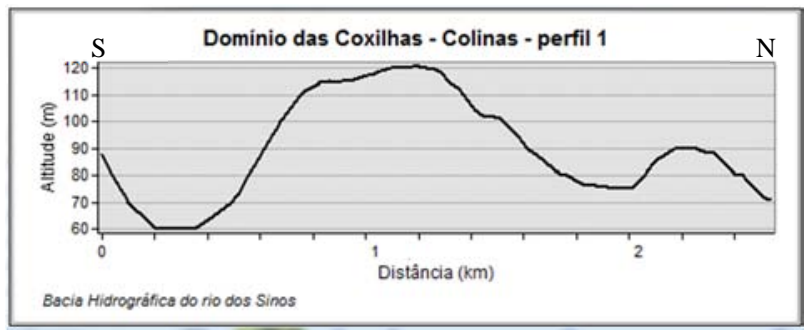

Figura 38: Perfil 1 Domínio das Coxilhas - colinas

Elaboração: Adriana Penteado, 2010.

O segundo perfil (Figura 39) para a análise das colinas foi traçado no município de Parobé e possui extensão aproximada de 3,3 quilômetros. As colinas mais altas chegam próximas a 140 metros de altitude, a menor delas fica próxima a 120 metros. É possível verificar que os fundos de vale têm a forma em $\mathrm{U}$, o que demonstra um alargamento do canal. Os dois primeiros a 80 metros de altitude, e o que se encontra mais a nordeste, a 71 metros. Nesses vales correm afluentes do rio dos Sinos. Novamente, os topos das colinas se apresentam convexos.

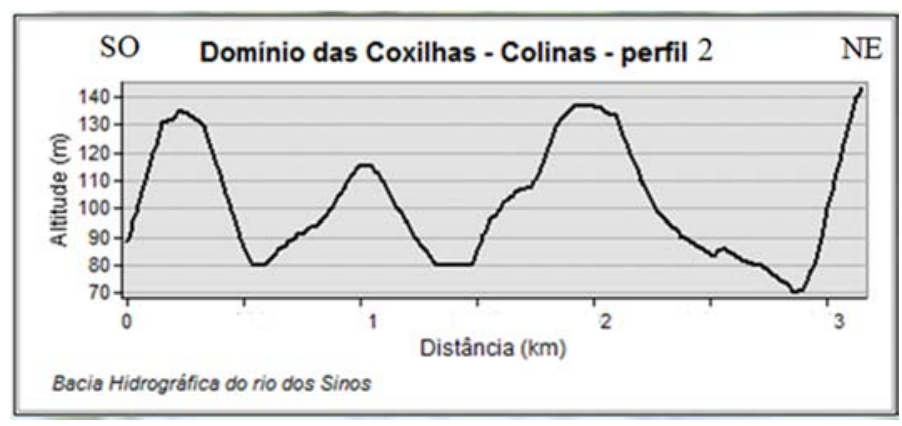

Figura 39: Perfil 2 Domínio das Coxilhas - colinas

Elaboração: Adriana Penteado, 2010.

A fotografia 15 que não representa o exato local da Figura 39, é de parte do município de Parobé, onde se verifica, em segundo plano, as colinas areníticas da Formação Botucatu. Esse padrão de relevo é predominante em todo o município. 


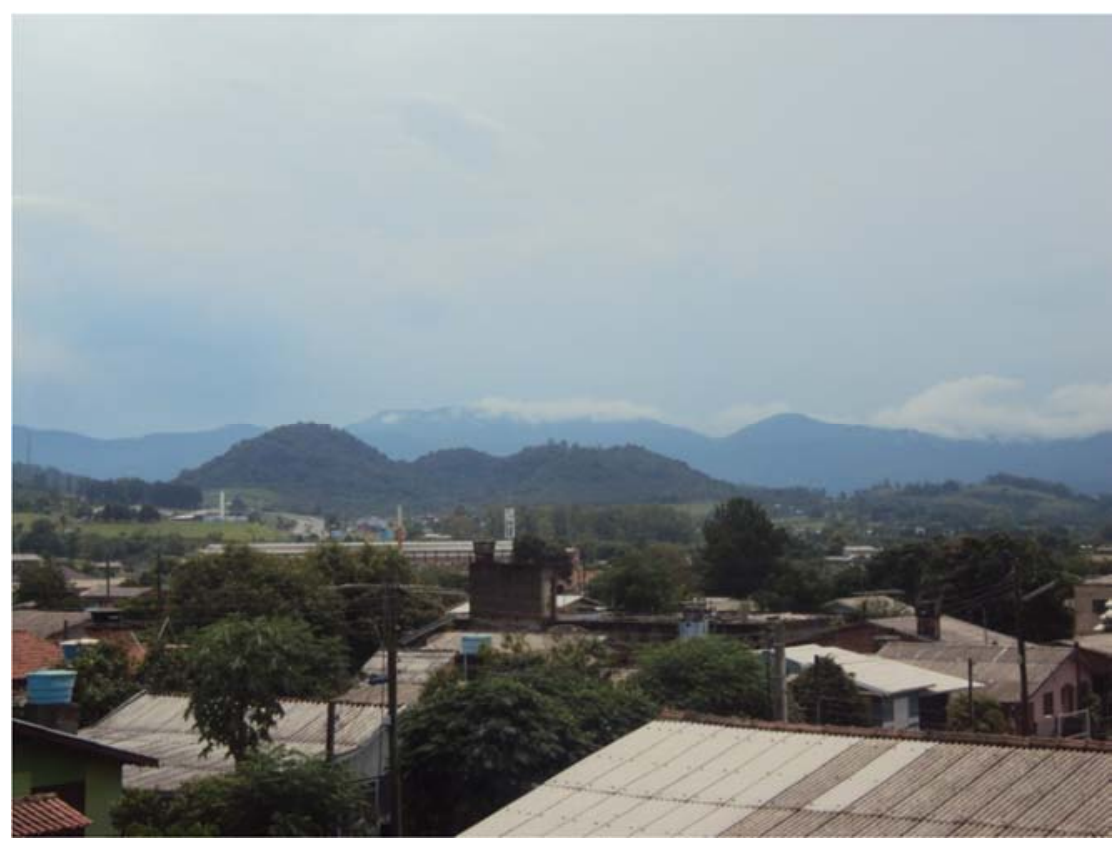

Fotografia 15: Em primeiro plano, colinas areníticas da Formação Botucatu, município de Parobé.

Fonte: Adriana Penteado, 01/11.

O terceiro perfil (Figura 40) foi traçado no município de Taquara e possui extensão de 2,9 quilômetros. As altitudes das duas maiores colinas chegam a 122 e 140 metros respectivamente. O fundo plano, na parte central do perfil, compreende talvegue onde escoa um dos afluentes do rio Paranhana. Os topos das colinas se apresentam convexos.

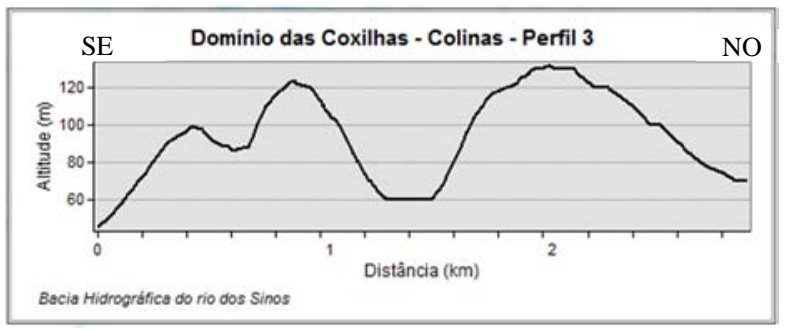

Figura 40: Perfil 3 Domínio das Coxilhas - colinas Elaboração: Adriana Penteado, 2010.

Na Fotografia 16 vemos a margem sul do rio dos Sinos, obtida no município de Taquara. No vale, de fundo plano, o solo característico é chernossolo háplico órtico, onde ocorrem as 
terras inundáveis deste município, sendo estas margeadas, em boa parte, pelo padrão de formas em colinas.

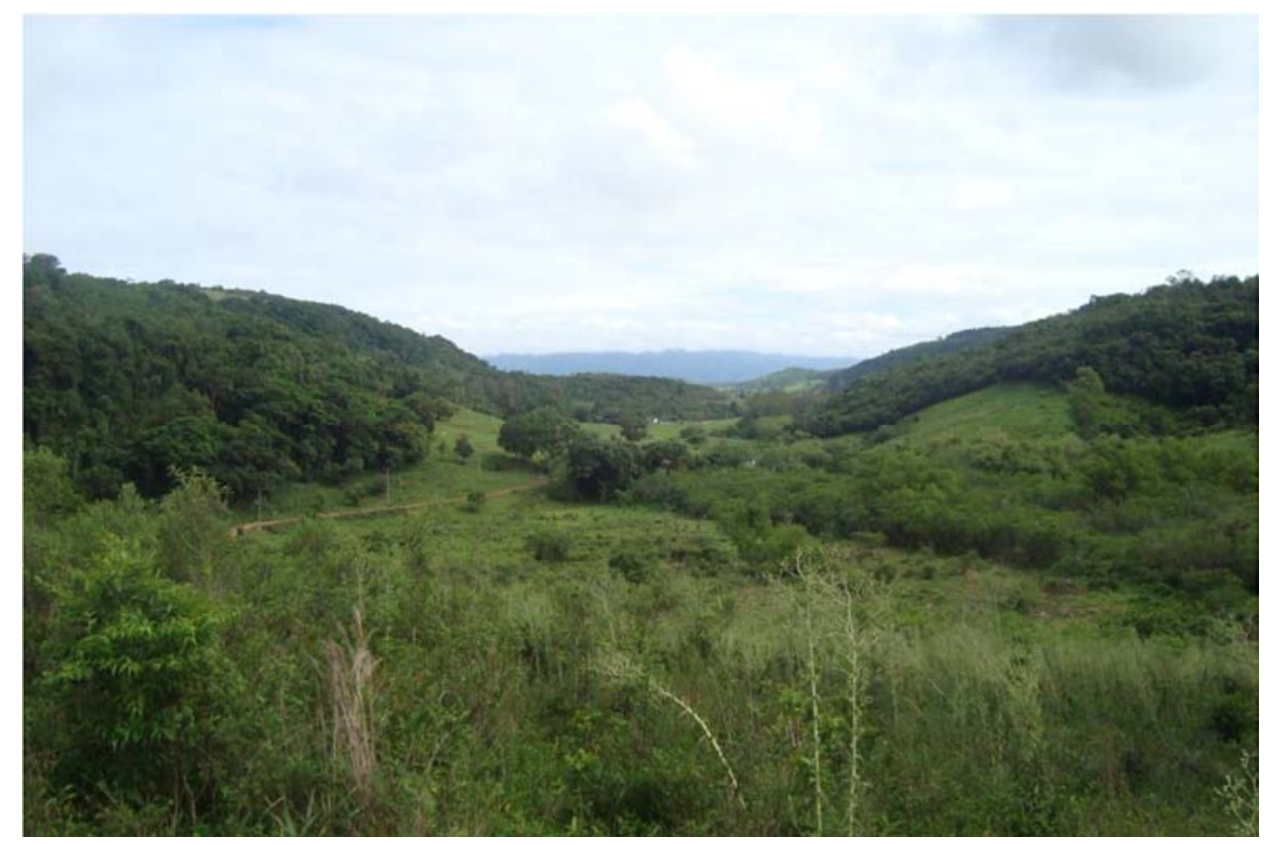

Fotografia 16: Padrão em colinas, município de Taquara. Fonte: Adriana Penteado, 06/2010.

Os solos mais comuns para a área de incidência do padrão em colinas são os argissolos vermelhos distróficos, que devido às características naturais, com diferença textural do horizonte A, mais arenoso, para o horizonte $\mathrm{B}$, mais argiloso, possui susceptibilidade natural à erosão. A preservação da vegetação compreende um fator que pode inibir esse processo. Não foram verificados acentuados processos erosivos para as áreas de incidência de colinas. Em locais onde a vegetação foi retirada e o solo se encontra exposto, observa-se casos isolados de formação de sulcos e ravinas.

\subsection{Padrão de morros baixos}

O padrão de morros baixos do Domínio das Coxilhas ocorre em dois segmentos na área de estudo. O primeiro e maior deles no trecho inferior da bacia, abrangendo os municípios de 
Sapucaia do Sul, Gravataí, São Leopoldo, Novo Hamburgo e Taquara. O segundo e menor segmento ocorre no trecho médio da bacia hidrográfica do rio dos Sinos, entre os municípios de Taquara e Rolante. Os morros baixos ocorrem na área de incidência de afloramentos dos arenitos da Formação Botucatu, onde se verifica formação de alguns morros testemunhos.

A declividade predominante do padrão do trecho inferior está entre 0 e $12 \%$, e mais a oeste atinge as classes entre 12 a $24 \%$. Na área do trecho médio a declividade se concentra entre 5 a $12 \%$ e atinge em alguns pontos declividades entre 12 a $24 \%$.

A altimetria para este padrão de formas está entre 150 e 300 metros, podendo atingir limite inferior mais baixo, mas não ultrapassando o limite mais alto. $\mathrm{O}$ solo predominante para o padrão de relevo de morros baixos, localizados na área de incidência da Formação Botucatu, é o argissolo vermelho distrófico.

O primeiro perfil de morros baixos do domínio das Coxilhas (Figura 41) foi traçado entre Sapucaia do Sul e Novo Hamburgo, com extensão de 4,12 quilômetros. São identificados três morros baixos com altitudes entre 260 e 280 metros. Nos vales com altitudes que variam de 155 a 178 metros de altitude correm afluentes do rio dos Sinos. Os topos têm a forma convexa.

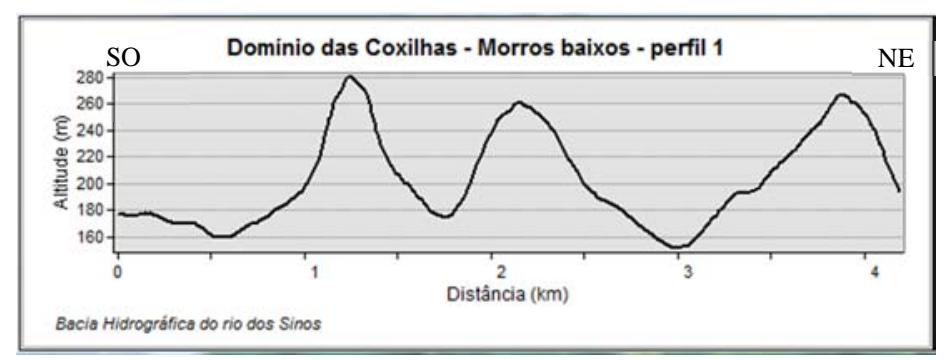

Figura 41: Perfil 1 Domínio das Coxilhas - morros baixos Elaboração: Adriana Penteado, 2010.

O segundo perfil foi traçado entre Taquara e Rolante e possui aproximadamente 7,2 quilômetros de extensão. O morro mais alto ultrapassa os 250 metros de altitude e o segundo fica entre 240 e 250 metros de altitude. O fundo do vale a noroeste apresenta fundo em forma de $\mathrm{U}$, demonstrando um alargamento do mesmo. Em todos os vales representados na figura 42 correm afluentes do rio Rolante. Os topos dos morros se apresentam convexos. 


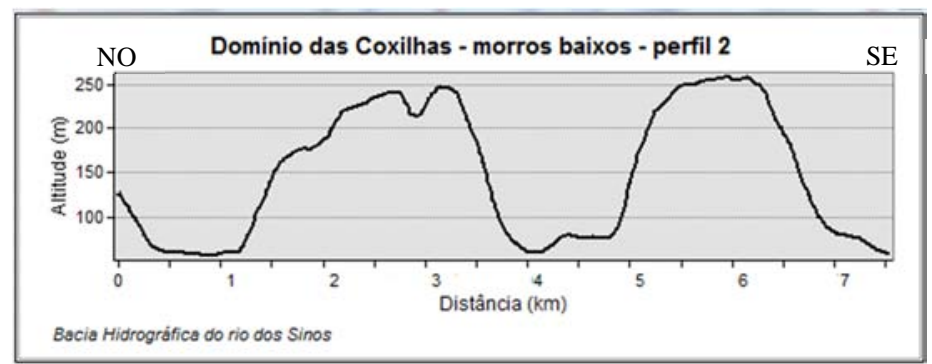

Figura 42: Perfil 2 Domínio das Coxilhas - morros baixos Elaboração: Adriana Penteado, 2010.

A Fotografia 17 foi retirada na margem sul do rio dos Sinos no município de Novo Hamburgo. Em primeiro plano encontram-se as terras inundáveis com presença de juncos e maricás. Em segundo plano, ao fundo, visualizam-se os morros baixos da Formação Botucatu.

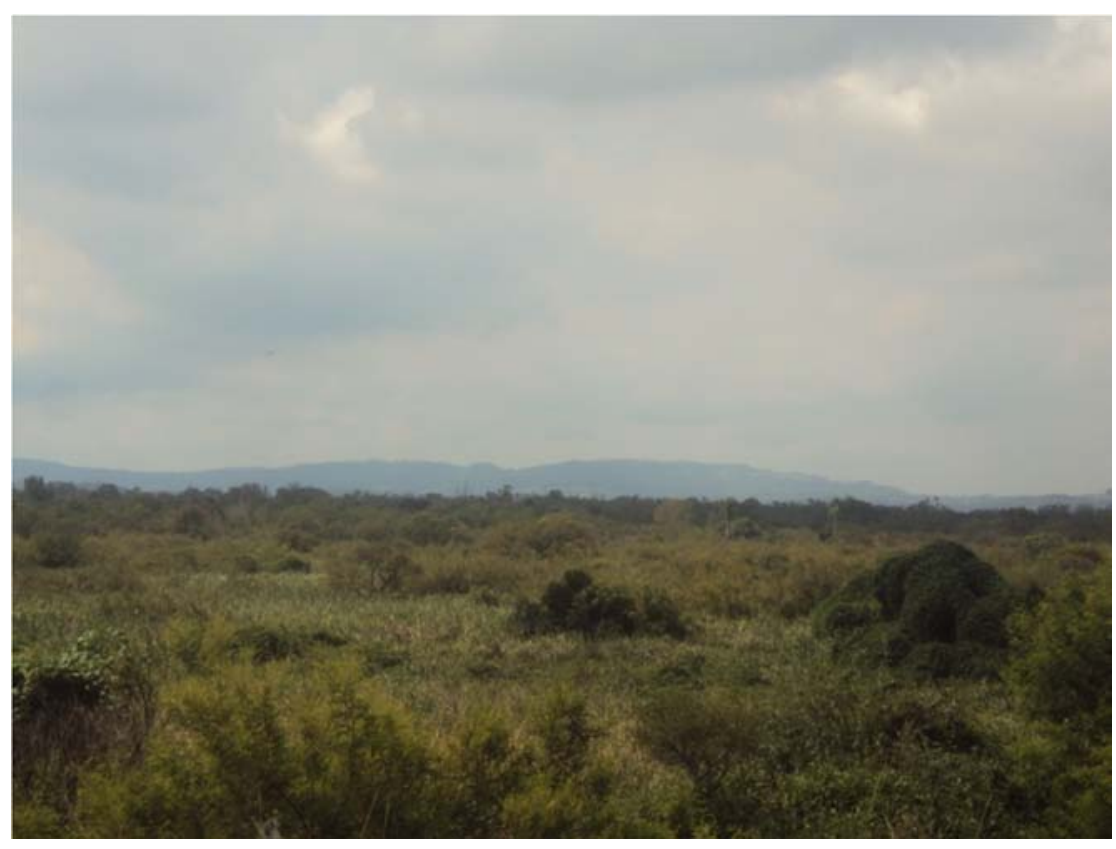

Fotografia 17: Morros baixos da Formação Botucatu, município de Novo Hamburgo. Fonte: Adriana Penteado, 01/11.

A Figura 43 compreende um morro testemunho da Formação Botucatu, atingindo cerca de 290 metros de altitude. Seu topo se apresenta, a oeste, plano, e a leste, convexo. Sua extensão, no sentido sudoeste-nordeste, é de aproximadamente 1,5 quilômetros. Localiza-se entre São Leopoldo, Sapucaia do Sul, Novo Hamburgo e Gravataí. 
Nas áreas de afloramento do arenito Botucatu verificam-se lavras para a extração de lajes, localmente chamadas de pedra grés. O material residual é comumente jogado nas encostas, causando destruição da vegetação e assoreamento dos cursos de água e terras inundáveis. Fato que também ocorre no morro testemunho representado pela figura 43, denominado Morro do Paula.

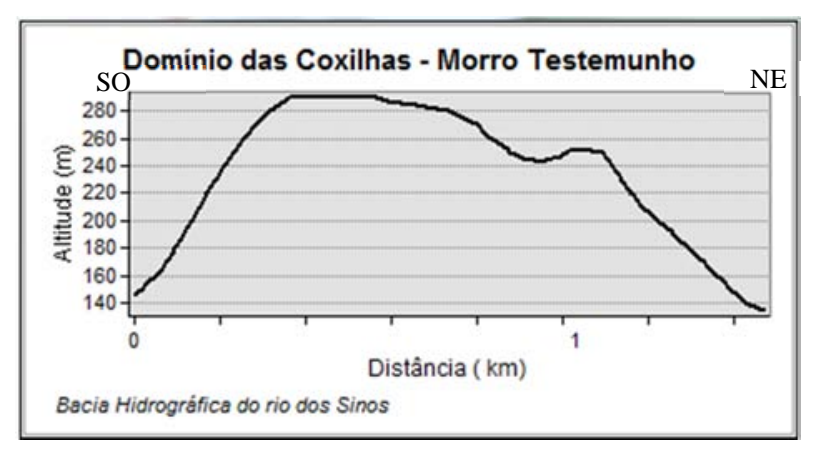

Figura 43: Perfil Domínio das Coxilhas - Morro Testemunho

Elaboração: Adriana Penteado, 2010.

$\mathrm{Na}$ área de estudo, para a morfoescultura Depressão Central Gaúcha, na qual se insere o modelado do Domínio das Coxilhas, predominam as baixas altitudes e fraca à média dissecação do relevo, com topos convexos e vales, em geral, amplos. As colinas e morros baixos da Formação Botucatu e Rosário do Sul margeiam, em grande parte, a planície do rio dos Sinos e de seus principais afluentes.

\subsubsection{Morfoescultura Planalto das Araucárias}

Segundo Almeida (1956), a área do Planalto da Araucárias engloba relevos conservados e dissecados de planaltos e bordas escarpadas, onde a cobertura vegetal apresenta ou apresentava a constante presença da Araucaria angustifolia.

As características geomorfológicas da Região Geomorfológica Planalto das Araucárias são bastante heterogêneas, variando desde formas de relevo amplas e aplanadas até o nível mais profundo de entalhamento (RADAM, 1986). 


\subsection{Planalto Basáltico Tabular de Cimeira}

O Planalto Basáltico Tabular de Cimeira encontra-se nas faces nordeste e leste da bacia hidrográfica do rio dos Sinos de forma contínua. Está inserido nas rochas da Formação Serra Geral com predomínio das efusivas vulcânicas ácidas. Neste compartimento se concentram as maiores altitudes, entre 750 e 980 metros. A declividade está entre $0 \%$ a $45 \%$ e, onde a mesma é mais acentuada, há formação de escarpas erosivas.

A rede de drenagem apresenta média densidade e é onde estão inseridas as nascentes dos principais afluentes do rio dos Sinos: rio Paranhana, rio da Ilha e rio Rolante. Os municípios inseridos nesse compartimento são Gramado, Canela, São Francisco de Paula, Riozinho e Caraá.

O primeiro perfil do Planalto Basáltico Tabular (Figura 44) localiza-se em Canela e possui aproximadamente 4,5 quilômetros de extensão. A altitude do morro ultrapassa os 850 metros e o topo do mesmo se apresenta plano. No vale, que se apresenta pouco profundo, escoa uma nascente intermitente do rio Paranhana.

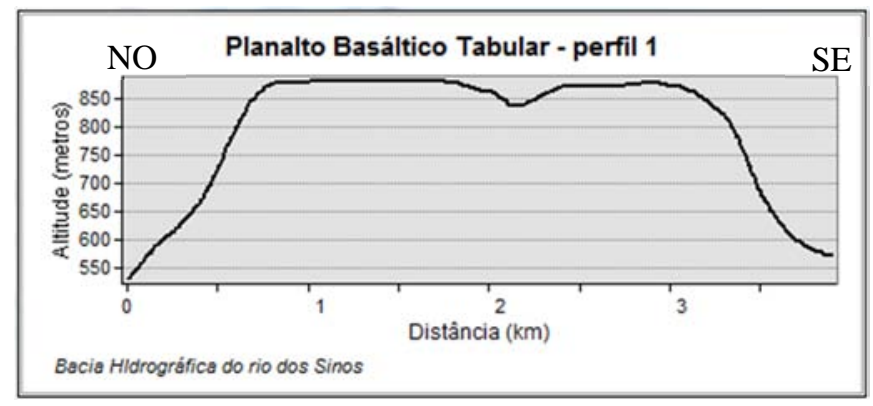

Figura 44: Perfil 1 Planalto Basáltico Tabular Elaboração: Adriana Penteado, 12/10

A Fotografia 18 é do município de Gramado em área de incidência do Planalto Basáltico Tabular. Verifica-se o topo plano dos morros e a vertente íngreme, por vezes caracterizando escarpas. 


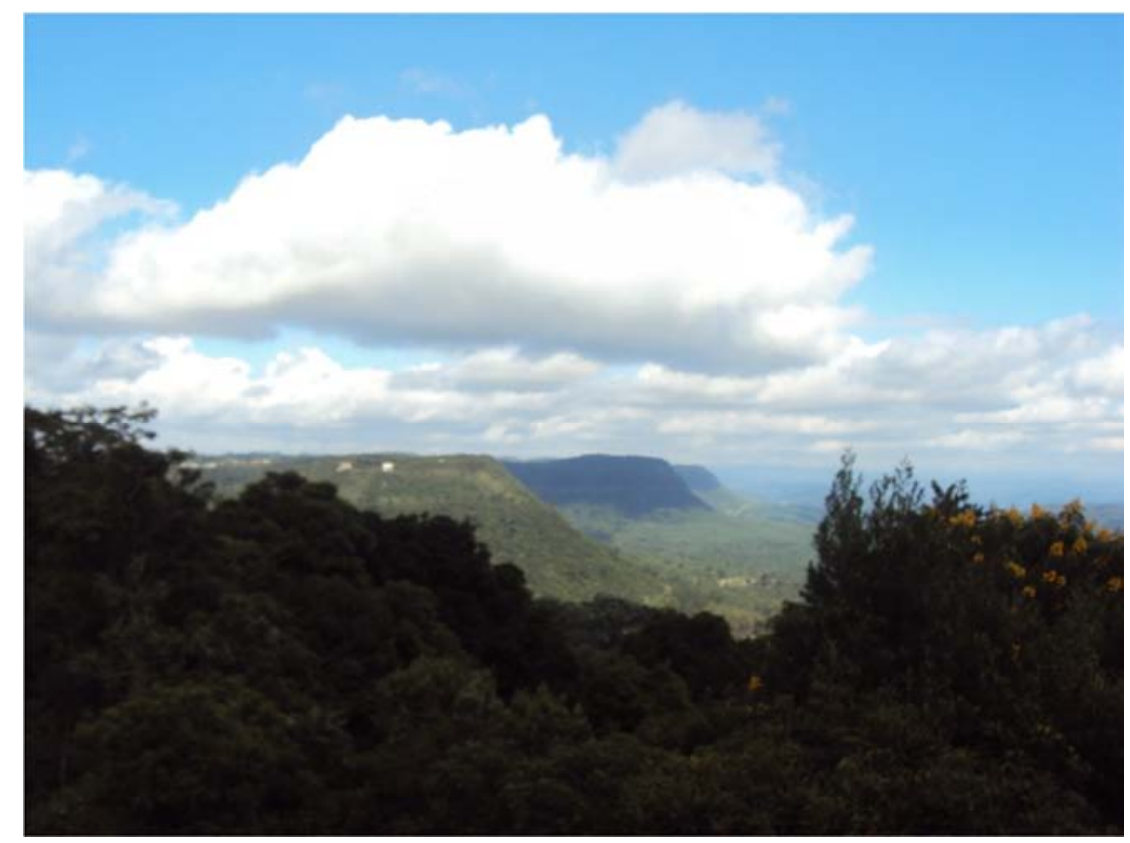

Fotografia 18: Planalto Basáltico Tabular de Cimeira, município de Gramado. Fonte: Adriana Penteado, 01/11.

O segundo perfil (Figura 45) foi traçado em São Francisco de Paula e possui extensão de 7,53 quilômetros. Os topos dos morros se apresentam planos ou suaves ondulados, com altitudes próximas a 900 metros. O vale mais profundo, ao centro, atinge 220 metros. Nos três vales referentes ao segundo perfil correm afluentes do rio Paranhana.

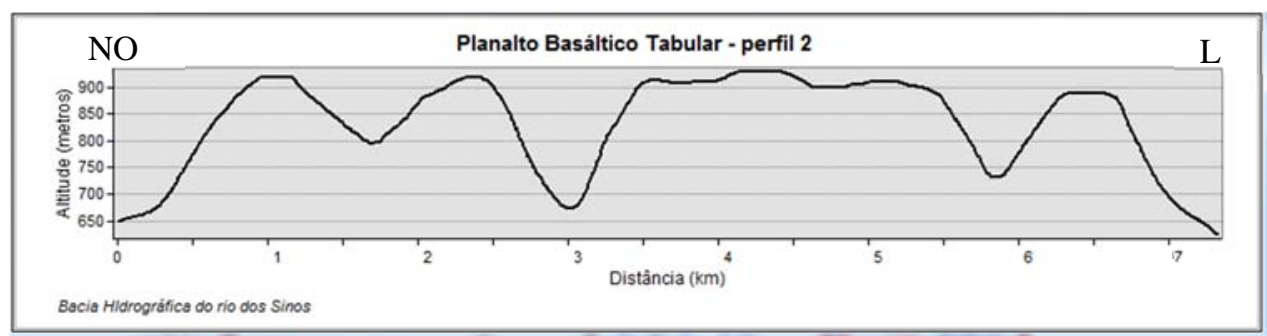

Figura 45: Perfil 2 Planalto Basáltico Tabular

Elaboração: Adriana Penteado, 12/10

A Fotografia 19 foi retirada no município de São Francisco de Paula e representa a suave ondulação de parte do Planalto Basáltico Tabular. 


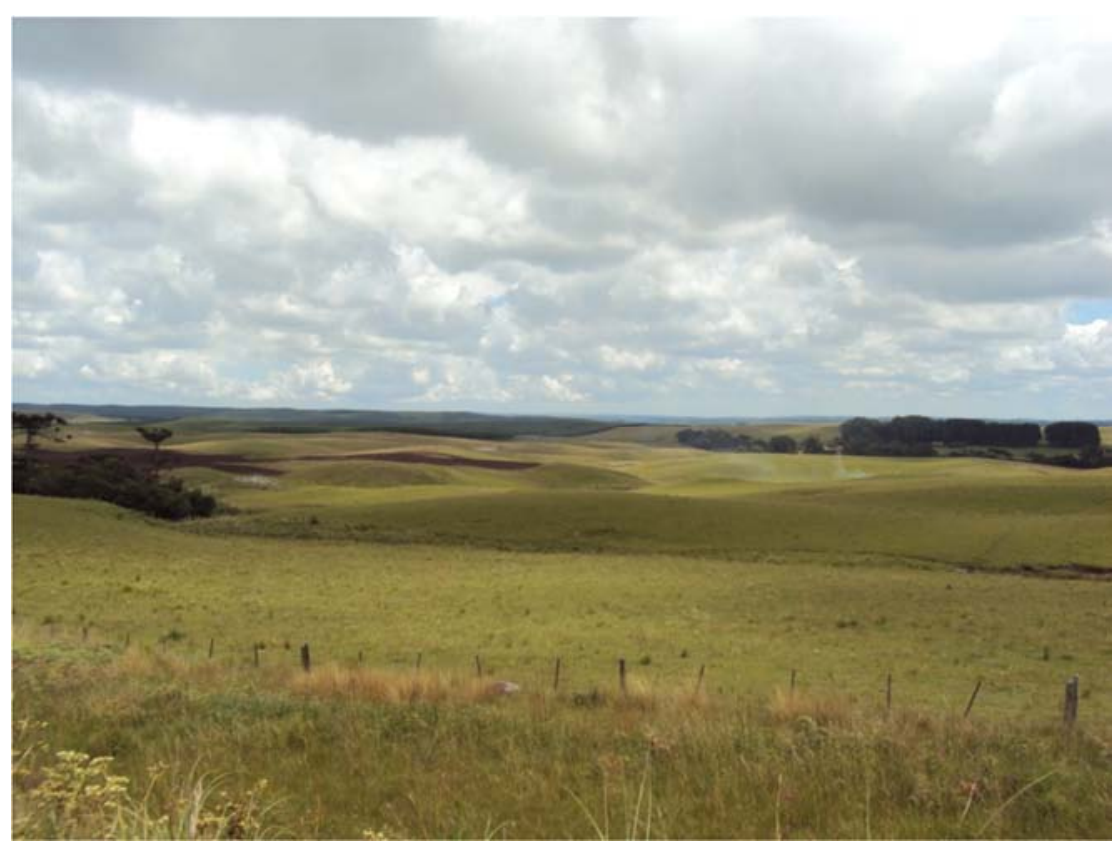

Fotografia 19: Suave ondulação do Planalto Basáltico Tabular, município de São Francisco de Paula.

Fonte: Adriana Penteado, 01/11.

O terceiro perfil (Figura 46) foi traçado no município de Riozinho e possui 5,5 quilômetros de extensão. O morro possui dois desníveis principais com variação de aproximadamente 100 metros de altitude. A análise do perfil permite perceber, em um mesmo morro, parte do topo suave ondulado, com variação menor que 40 metros, e a continuidade do mesmo na direção sul, mais suave. No vale no extremo sul do perfil, a 650 metros de altitude, escoa uma das nascentes do rio Rolante.

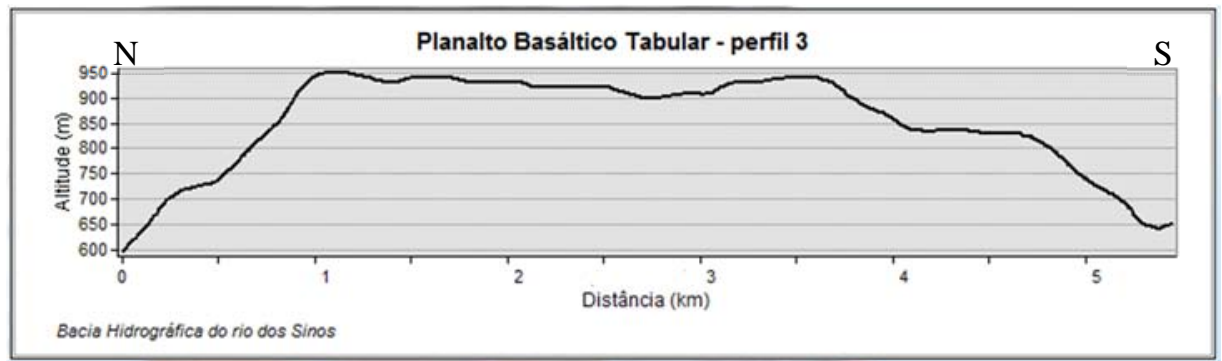

Figura 46: Perfil 2 Planalto Basáltico Tabular

Elaboração: Adriana Penteado, 12/10 
As escarpas do Planalto Basáltico Tabular representam, em parte, os limites desse compartimento e inicio do compartimento geomorfológico Planalto Basáltico Dissecado, considerando a área de estudo. A litologia muda nessa transição de rochas efusivas ácidas para intermediárias e básicas, ambas da Formação Serra Geral.

A Figura 47 representa a transição entre o Planalto Basáltico Tabular e o Planalto Dissecado. O perfil foi traçado no município de São Francisco de Paula e possui aproximadamente 8,7 quilômetros de extensão. O desnível entre um e outro compartimento (???) chega próximo a 300 metros de altitude. Devido aos limites abruptos entre os compartimentos geomorfológicos, formando desníveis no relevo, com altas declividades e altitudes, há formação de cachoeiras (Fotografia 15) com quedas de água que podem ultrapassar os 100 metros.

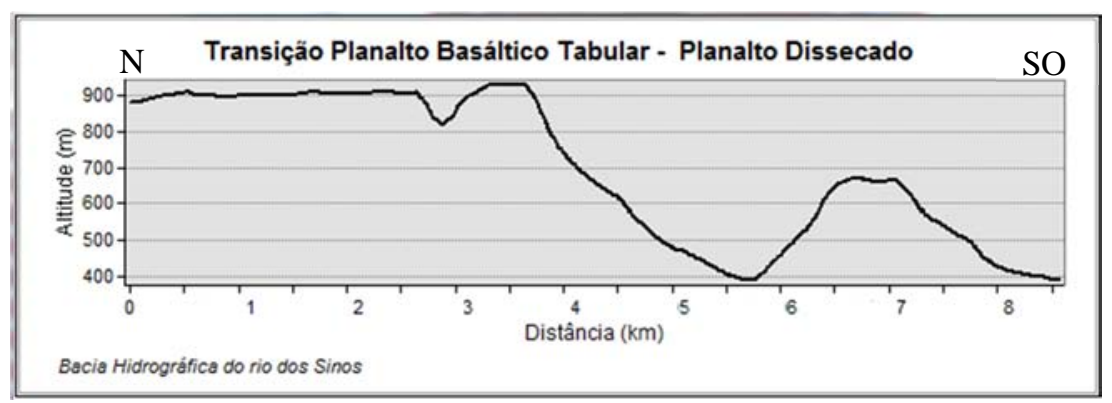

Figura 47: Perfil Transição entre Planalto Basáltico Tabular e o Planalto Dissecado. Elaboração: Adriana Penteado, 12/10 


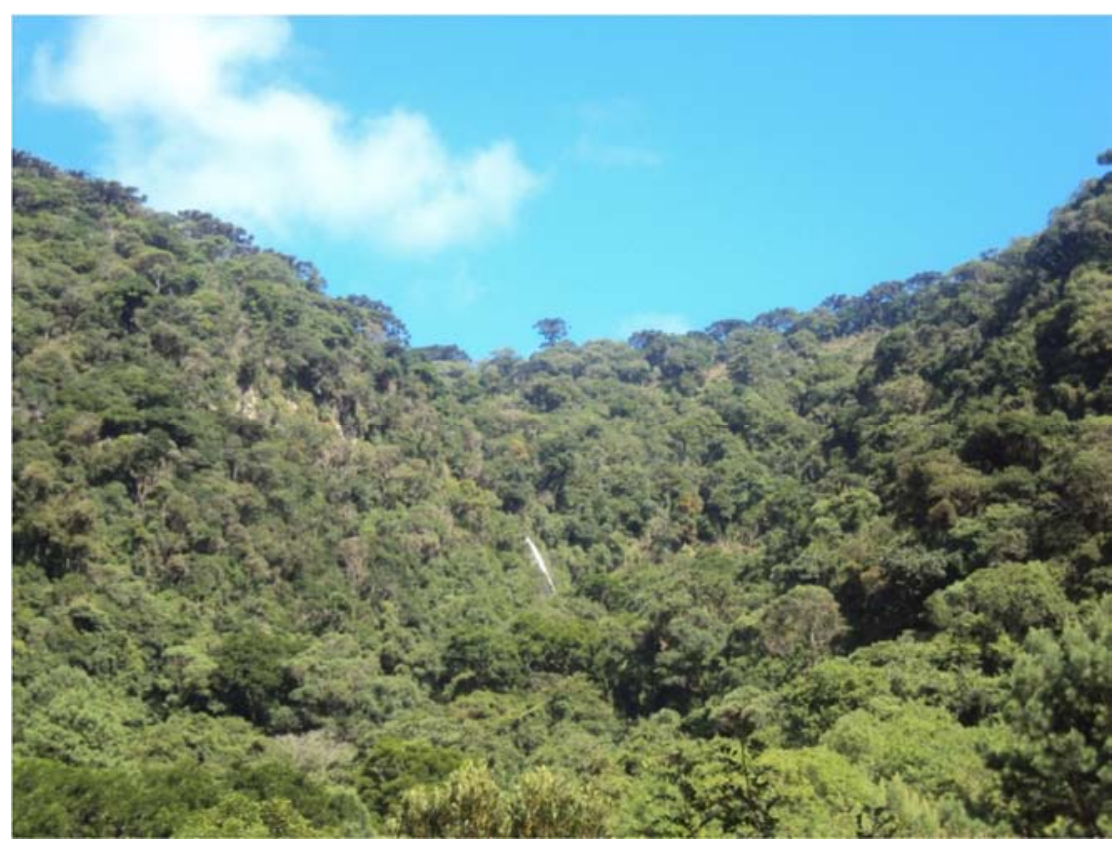

Fotografia 20: Cachoeira nas bordas do Planalto Basáltico Tabular, município de São Francisco de Paula.

Fonte: Adriana Penteado, 01/2011.

O solo predominante no Planalto Basáltico Tabular é o cambissolo húmico alumínico, que é um solo extremamente ácido e, por isso, pobre para fins agrícolas. A ocorrência de geadas e a baixa insolação favorecem a formação desse solo na região. Predomina no município de São Francisco de Paula. Nos municípios de Gramado e Canela, na parte inserida no Planalto Basáltico Tabular, há presença de solos como o neossolo regolítico eutrófico, cambissolo húmico alumínico e argissolo brunoacinzentado alítico associados a afloramentos rochosos.

\subsubsection{Planalto Basáltico Dissecado}

O planalto Basáltico Dissecado foi subdivido em três unidades semelhantes de relevo, que são os morros baixos, médios e altos. A litologia dessa morfoestrutura compreende as rochas intermediárias e básicas da Formação Serra Geral. O relevo se apresenta de forte a medianamente ondulado, predominando os processos erosivos em relação aos processos de deposição. 
Unidade geomorfológica Serra Geral constitui-se, de forma geral, nos terminais escarpados abruptos nas bordas sul e leste, desenvolvidas, em especial, a partir de rochas efusivas básicas. A borda sul é conhecida popularmente como "Região Serrana". Constitui-se de um relevo escarpado mais rebaixado, com cotas altimétricas que caem gradacionalmente para oeste. Esta área apresenta-se mais festonada, dado que sofre ação erosiva de rios de grande porte (VILLELA \& MATTOS, 1979).

\subsection{Morros Altos}

O compartimento geomorfológico Planalto Dissecado de morros altos ocorre em segmento ao Planalto Tabular, em parte das faces norte e leste da bacia, a oeste do município de Riozinho, norte de Rolante e Taquara, noroeste de Igrejinha e Nova Hartz, em pequena proporção em Araricá, Sapiranga e Santa Maria do Herval, sudoeste de São Francisco de Paula, sul de Canela e Gramado e de forma predominante em Três Coroas.

A leste e a oeste deste compartimento há ocorrência de declividades entre 24 e $45 \%$. De forma predominante, as declividades estão concentradas entre 12 e $24 \%$. A altimetria predomina entre 450 e 750 metros. $\mathrm{O}$ relevo se apresenta fortemente dissecado com presença predominante de morros de topos aguçados, vales encaixados, alta densidade de drenagem, com muitos cursos intermitentes. As escarpas também estão presentes no Planalto Basáltico Dissecado, contudo sem representar um elemento de transição ou limite entre compartimentos.

O primeiro perfil de morros altos do Planalto Dissecado (Figura 48) foi traçado no município de Três Coroas e possui aproximadamente 4,90 quilômetros de extensão. As altitudes dos topos dos morros variam entre 370 e 440 metros. Os vales representam os canais onde escoam afluentes do rio Paranhana, o primeiro a 250 metros de altitude, e o segundo a aproximadamente 100 metros, com fundo plano e aproximadamente 200 metros de extensão. Os topos dos morros se apresentam aguçados. 


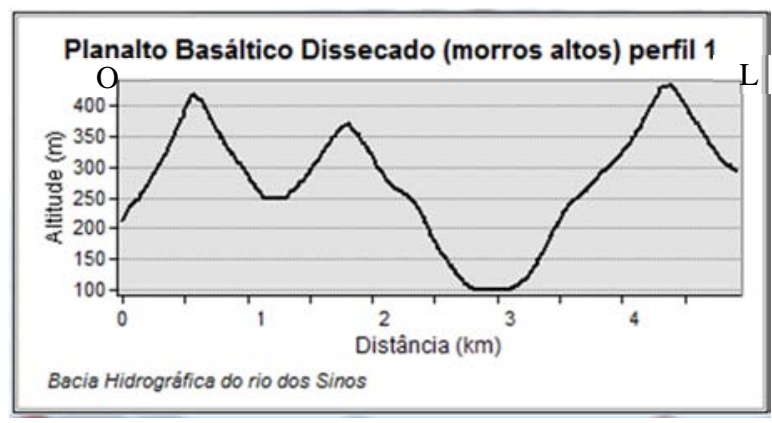

Figura 48: Perfil 1 Planalto Basáltico Dissecado - morros altos

Elaboração: Adriana Penteado, 2010.

A Fotografia 16 é do município de Três Coroas, onde se visualiza, em segundo e terceiro planos, morros altos de topos aguçados.

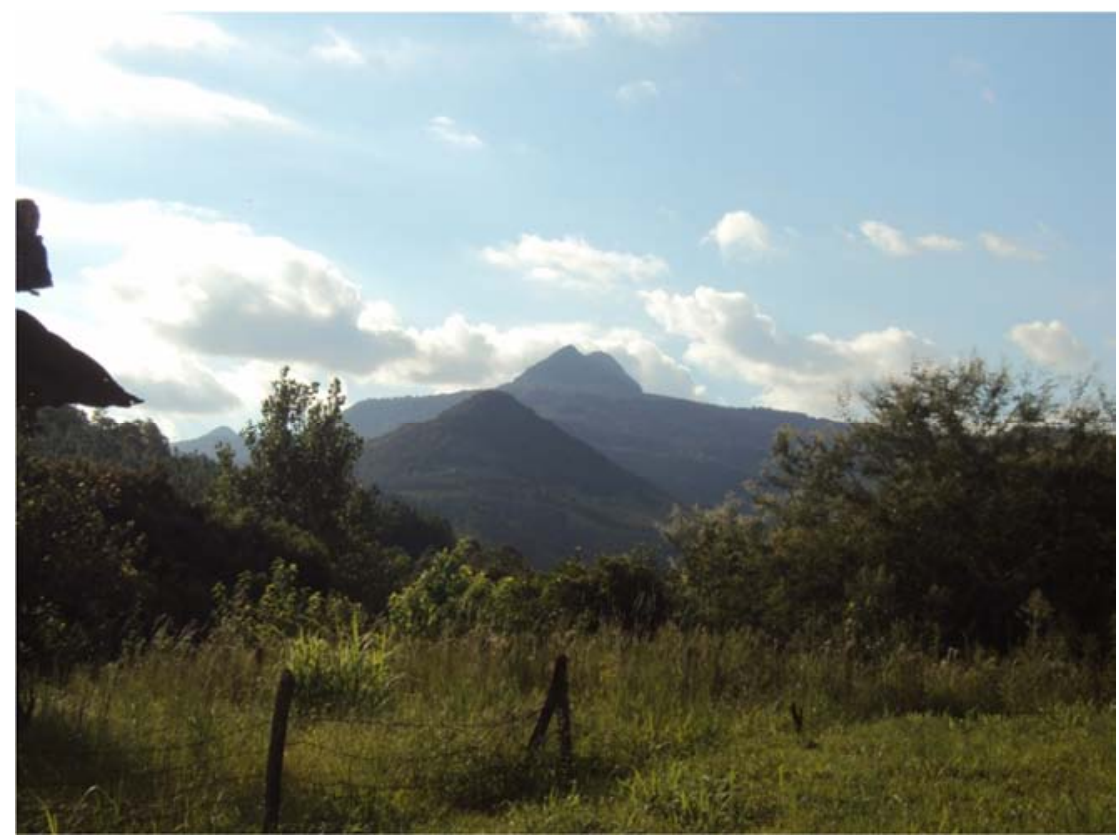

Fotografia 21: Morros altos de topos aguçados, município de Três Coroas. Fonte: Adriana Penteado, 01/11.

O segundo perfil (Figura 49) foi traçado entre os municípios de Taquara e São Francisco de Paula, com extensão de 6,2 quilômetros. Os topos dos morros estão entre 420 e 510 metros e se apresentam novamente aguçados. Os vales, que atingem entre 320 e 200 metros de altitude de noroeste a sudeste na linha do talvegue, compreendem áreas onde escoam afluentes do rio da Ilha. 


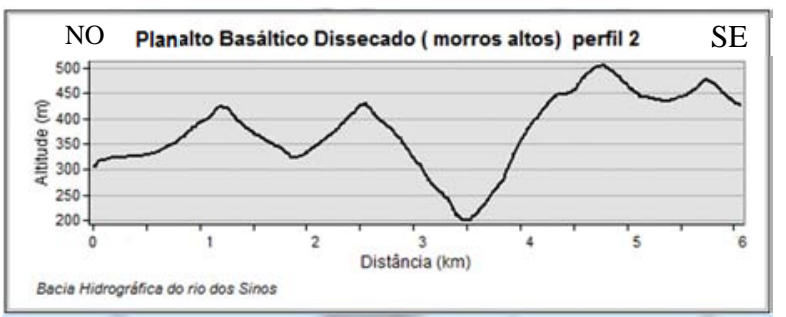

Figura 49: Planalto Basáltico Dissecado - morros altos Elaboração: Adriana Penteado, 2010.

O terceiro perfil de morros altos (Figura 50) foi traçado entre Riozinho e Caraá e possui extensão aproximada de 6,08 quilômetros. Os topos dos morros se apresentam aguçados e variam de 700 a 530 metros de altitude. O vale mais profundo atinge desnível de quase 300 metros. Nos fundos dos vales escoam alguns afluentes do rio Rolante.

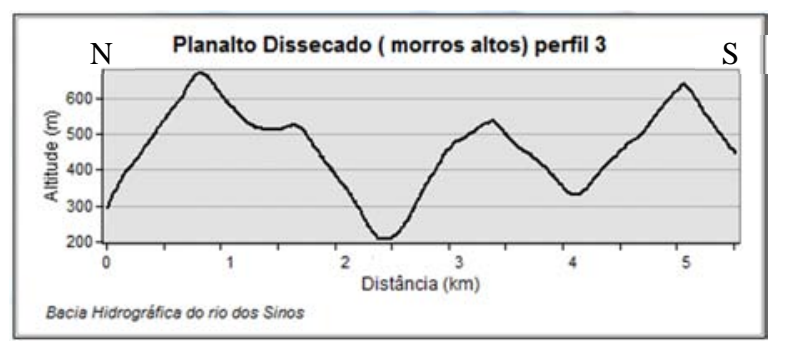

Figura 50: Planalto Basáltico Dissecado - morros altos Elaboração: Adriana Penteado, 2010.

Os solos predominantes aparecem associados a afloramentos rochosos. A primeira associação ocorre nos municípios de Gramado e Canela e são representados pelo neossolo regolítico distrófico/cambissolo húmico alumínico/argissolo brunoacinzentado alítico. O segundo tipo de associação de solos com afloramentos da Formação Serra Geral são o neossolo regolítico eutrófico e o cambissolo háplico eutrófico, presentes em Taquara, Riozinho, Rolante, Três Coroas e Igrejinha. 


\subsection{Morros médios}

Os morros médios da morfoestrutura Planalto Basáltico Dissecado ocorrem nos trechos médio e superior da bacia hidrográfica do rio dos Sinos, nos municípios de Três Coroas, Igrejinha, Taquara, Rolante, Santo Antônio da Patrulha, Caraá e Osório e em pequena proporção em Santa Maria do Herval, Nova Hartz, Araricá e Sapiranga. As altitudes concentram-se entre 300 e 450 metros. As declividades concentram-se entre 12 e 24\%. Compreende transição entre os morros altos e baixos, com particularidades em relação aos topos dos morros.

O perfil 1 morros médios (Figura 51) da morfoestrutura Planalto Basáltico Dissecado foi traçado no município de Igrejinha e possui aproximadamente 9 quilômetros de extensão. Alguns topos de morro ultrapassam os 400 metros de altitude, o mais baixo possui cota de 340 metros. É possível verificar morros de topos aguçados e convexos simultaneamente no mesmo perfil. Nos vales representados no perfil escoam afluentes do rio Paranhana. Os vales se apresentam encaixados ou com fundo plano, sem grande expressividade espacial no sentido transversal do talvegue.

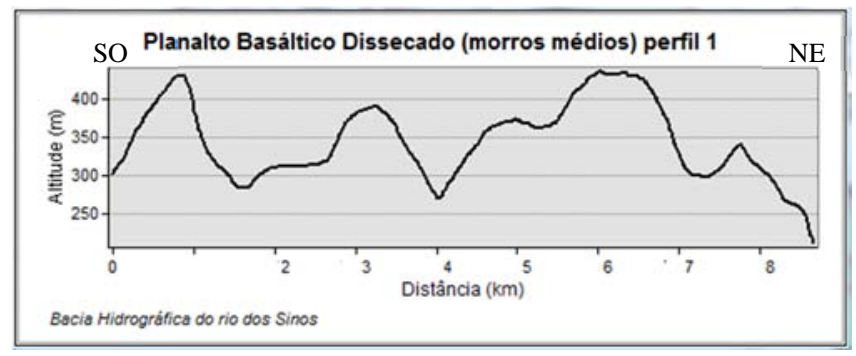

Figura 51: Planalto Basáltico Dissecado - morros médios

Elaboração: Adriana Penteado, 2010.

O segundo perfil (Figura 52) foi traçado entre os municípios de Rolante e Santo Antônio da Patrulha e possui 8,45 quilômetros de extensão. Os topos dos morros estão entre 390 e 450 metros de altitude e, assim como no perfil anterior, apresentam formas convexas ou aguçadas. Nos vales com aproximadamente 250 metros de entalhamento correm afluentes do rio Rolante. 


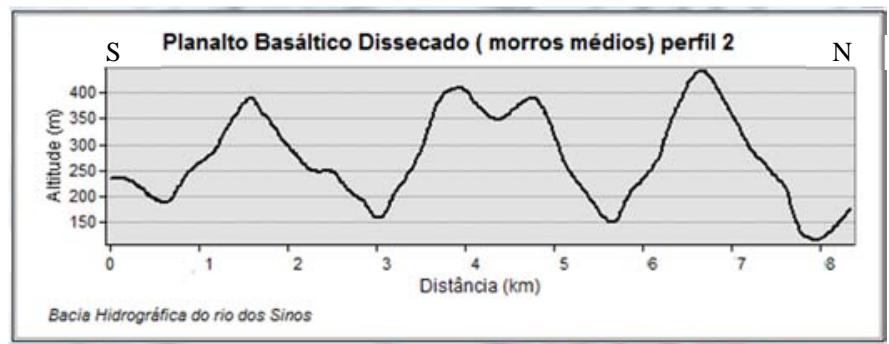

Figura 52: Planalto Basáltico Dissecado - morros médios

Elaboração: Adriana Penteado, 2010.

O terceiro perfil (Figura 53) foi traçado entre Santo Antônio da Patrulha, Caraá e Osório, no extremo sudeste do trecho superior da bacia, e possui extensão de 10 quilômetros. Os topos dos morros estão entre 300 e 360 metros de altitude com formas aguçadas ou convexas. Nos fundos de vale escoam afluentes de uma microbacia que desemboca na margem sul do rio dos Sinos. Novamente se percebe a pouca expressividade do fundo dos vales, sem presença significativa, por esse motivo, de planícies neste compartimento geomorfológico.

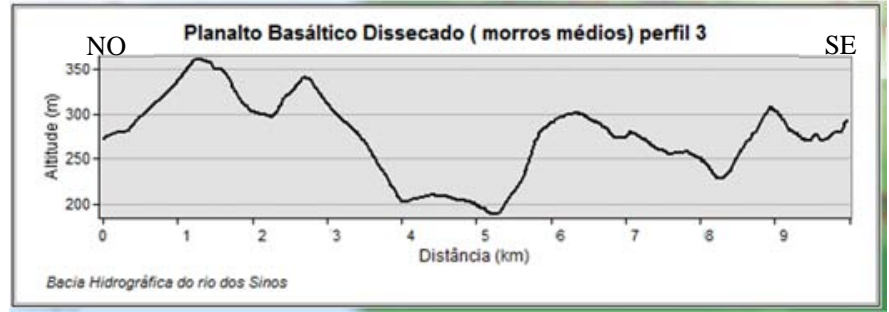

Figura 53: Planalto Basáltico Dissecado - morros médios

Elaboração: Adriana Penteado, 2010.

A Fotografia 17 foi retirada no município de Caraá. Em primeiro plano observa-se planície de afluente da margem sul do rio dos Sinos; em segundo e terceiro planos, morros de topos convexos e aguçados. 


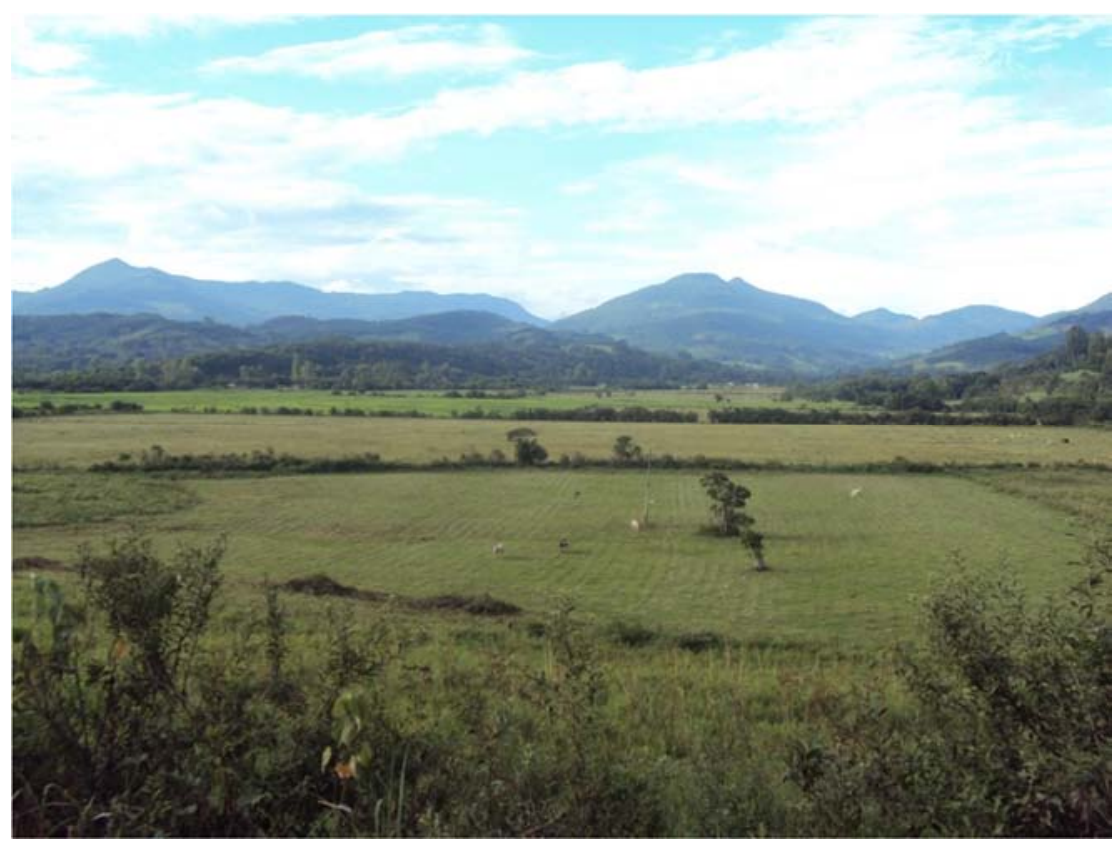

Fotografia 22: Topos de morros convexos e aguçados, município de Caraá. Fonte: Adriana Penteado, 01/11.

Nos municípios de Caraá, Osório e extremo sudeste de Santo Antônio da Patrulha, para a área compreendida no compartimento de morros médios, o solo predominante é o argissolo vermelho distrófico. Para as demais áreas que seguem em direção à jusante predomina o argissolo vermelho-amarelo distrófico.

\subsection{Morros baixos}

Os morros baixos do Planalto Dissecado ocorrem ao longo de toda a bacia em áreas descontínuas e relativamente pequenas. Os municípios onde se encontram tais formas são Portão, Estância Velha, Ivoti, Dois Irmãos, Novo Hamburgo, Campo Bom, Sapiranga, Nova Hartz, Igrejinha, Parobé, Taquara, Santo Antônio da Patrulha, Rolante e Caraá. A altimetria se concentra entre 150 e 300 metros de altitude. Em uma pequena área localizada entre Taquara e Parobé a declividade concentra-se em 5\%. Nas demais áreas, predomina o intervalo entre 5 e $12 \%$.

O primeiro perfil para os morros baixos (Figura 54) foi traçado no extremo sul do município de Taquara e possui 4,2 quilômetros de extensão. Os topos dos morros possuem a forma convexa. O fundo de vale está um pouco acima dos 50 metros de altitude e é onde escoa 
um afluente da margem sul do rio dos Sinos. O fundo do vale possui aproximadamente 200 metros de extensão no sentido transversal e altitude próxima a 60 metros.

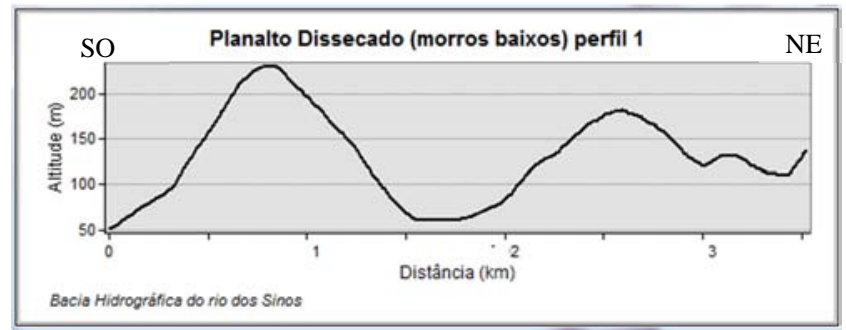

Figura 54: Planalto Basáltico Dissecado - morros baixos Elaboração: Adriana Penteado, 2010.

O segundo perfil para os morros baixos da Formação Serra Geral (Figura 55) foi traçado entre Santo Antônio da Patrulha e Caraá, com extensão de 6,65 quilômetros. Assim como no perfil anterior, os topos dos morros têm a forma convexa e variam entre 220 e 280 metros de altitude. Nos fundos de vale correm afluentes da margem sul do rio dos Sinos.

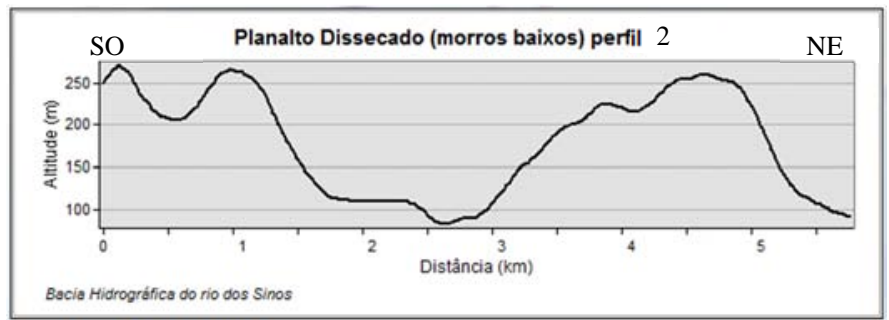

Figura 55: Planalto Basáltico Dissecado - morros baixos

Elaboração: Adriana Penteado, 2010.

A Fotografia 18 é do município de Santo Antônio da Patrulha. Em primeiro plano a planície do rio dos Sinos, em segundo plano os morros baixos da Formação Serra Geral com topos convexos. 


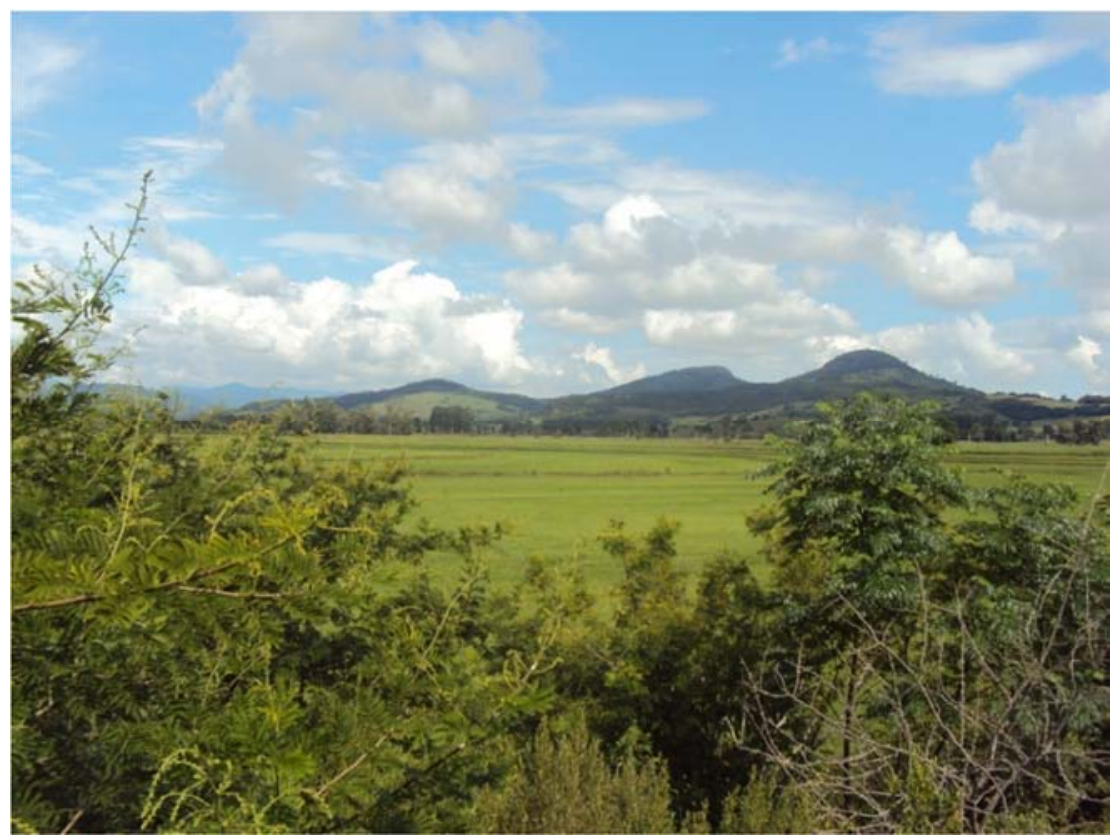

Fotografia 23: Morros baixos da Formação Serra Geral, município de Santo Antônio da Patrulha.

Fonte: Adriana Penteado, 01/11.

Os solos predominantes para o padrão de formas de morros baixos da Formação Serra Geral são o argissolo vermelho distrófico e o argissolo vermelho-amarelo distrófico.

Em relação ao compartimento morfoestrutural Planalto Basáltico Dissecado, verificou-se que, para os morros altos, predominam os topos aguçados; para os morros médios, topos aguçados ou convexos; e para os morros baixos, topos convexos. Para os morros altos predominam solos associados a afloramentos rochosos, para o demais predominam os argissolos.

Apesar da diferença litológica entre os morros baixos da Formação Serra Geral e da Formação Botucatu, os perfis demonstraram similaridades entre as formas. 
Mapa 04: Mapa Geomorfológico da bacia hidrográfica do rio dos Sinos - RS 


\subsubsection{Principais tipologias de drenagens e lagos}

As terras inundáveis do rio dos Sinos estão associadas, além do corpo hídrico definido como rio, a lagos que possuem sua formação a partir da interação das características físicas e devido à ação antrópica.

São aqui apresentados, em um primeiro momento, os principais tipos de lagos, estejam estes localizados na costa ou no interior do continente. Posteriormente busca-se identificar as características daqueles que foram mapeados na bacia do rio dos Sinos.

Lagos, represas, áreas alagadas e rios funcionam como ecossistemas complexos, com interações permanentes e dinâmicas com a bacia hidrográfica na qual estão inseridos. O estudo geomorfológico dos lagos contribui consideravelmente para o conhecimento da origem e para o entendimento da dinâmica dos processos de formação dos mesmos (TUNDISI, 2008 apud SWANSON, 1980).

Os padrões de drenagem são importantes para caracterizar os tipos de evolução regional das redes de rios e as inter-relações entre fatores climáticos, as rochas, a natureza dos terrenos, além de informarem sobre a formação de lagos no contexto regional, sendo que em uma mesma bacia podem ocorrer processos genéticos distintos, criando, assim, tipologias diferenciadas.

Os principais tipos de drenagem nas bacias hidrográficas, segundo Ab'Saber (1975), são: paralela, dendrítica, baioneta, angular, retangular, radial, meândrica, anastomosada e anular (Figura 56). 

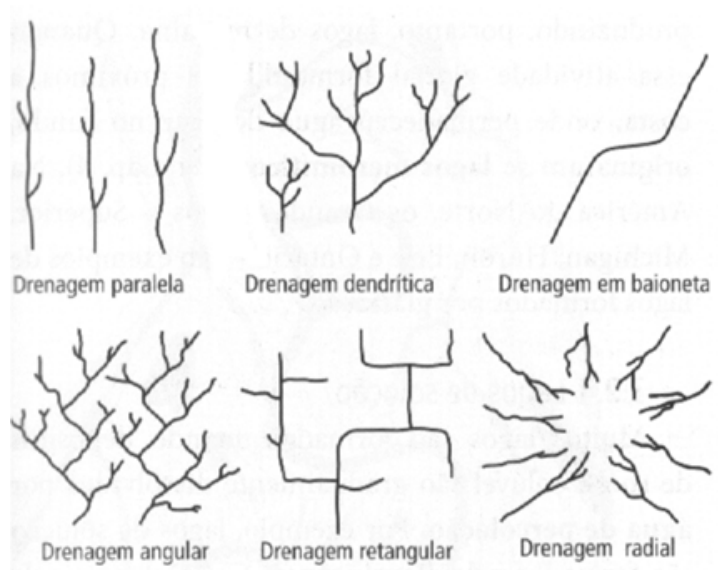

Drenagem dendritica

Drenagem em baioneta
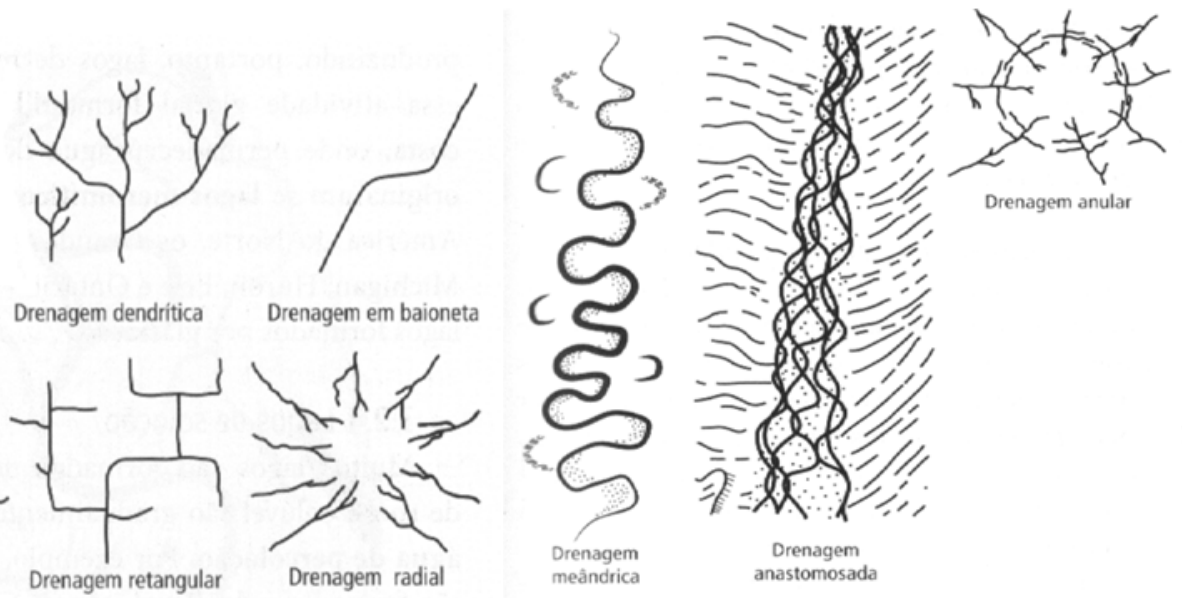

Figura 56: Tipos principais de drenagem.

Fonte: Ab'Saber (1975).

Em 1957 Hutchinson identificou 76 tipos de lagos agrupados em 11 agentes de formação: tectônica, vulcânica, movimentos do terreno, glaciação, lagos de solução, ação fluvial, ação do vento, na costa, acumulação orgânica, construídos por organismos e por impactos de meteoritos.

Os mecanismos mais comuns que dão origem aos lagos, segundo Tundisi (2008) são:

Tectônica: o lago é formado por movimentos da crosta terrestre, como falhas que ocorrem em depressões, formam-se nas fossas tectônicas (graben), Figura 57.

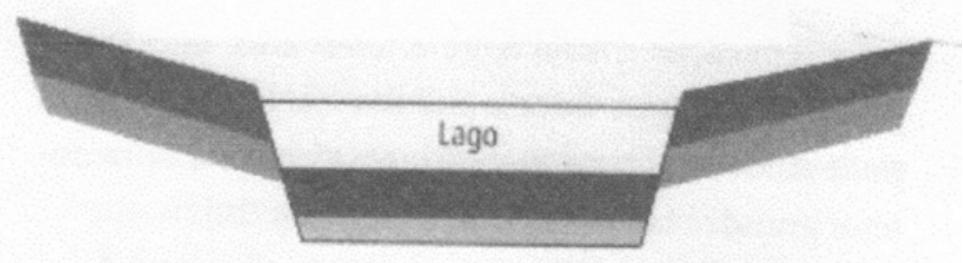

Figura 57: Lago formado por movimentação tectônica.

Fonte: Tundisi, 2008.

Vulcânica: A formação de depressões ou concavidades não drenadas naturalmente produz uma série de lagos de origem vulcânica. A lava expelida por um vulcão pode barrar um rio dando assim origem a um lago, Figura 58 


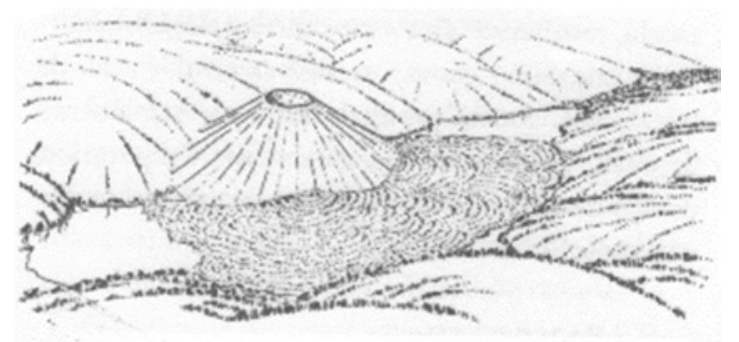

Figura 58: Formação de lagos vulcânicos.

Fonte: Tundisi, 2008.

Glaciação: Os movimentos das geleiras que podem ser catastróficos provocam corrosão ou deposição das massas de gelo, com subsequente degelo. A grande glaciação no Pleistoceno e a posterior regressão, por exemplo, formaram um grande número de lagos. Em alguns casos, o transporte de rochas e sedimentos pelo gelo bloqueou vales e depressões, produzindo lagos de moraina.

Lagos de solução: Formados quando depósitos de rocha solúvel são gradualmente dissolvidos por água de percolação. Como exemplo, os lagos formados pela dissolução de CaCO3. Esses lagos são encontrados nas regiões cársticas.

Lagos formados pela atividade fluvial: os rios têm, em sua dinâmica, uma capacidade obstrutiva, de deposição de sedimentos, e uma capacidade erosiva, de transporte dos sedimentos. Muitos lagos laterais são formados a partir dessa atividade. Em regiões com intensa sedimentação, a água tende a fluir ao redor dos sedimentos formando um padrão em U. Lagos em ferradura são formados por esse tipo de sistema. Os lagos fluviais estão relacionados com o processo de erosão e sedimentação dos rios (Figura 59 e Figura 60). 


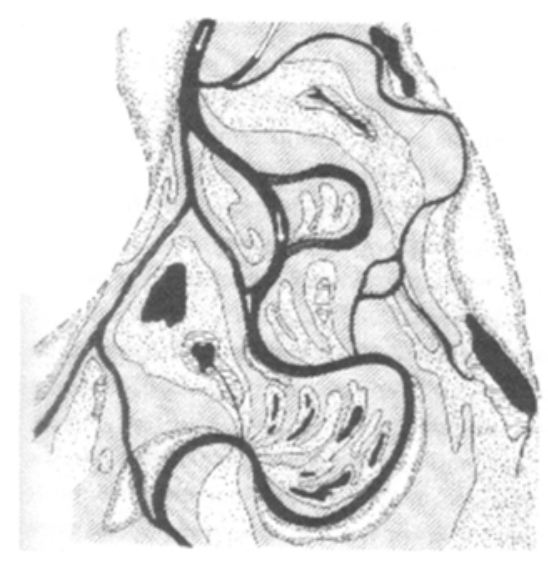

Figura 59: Vários padrões de lagos em planícies de grande extensão fluvial.

Fonte: Tundisi, 2008.

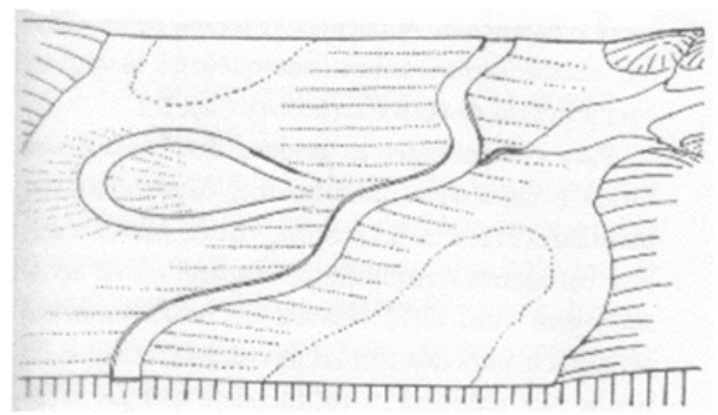

Figura 60: Formação de lagos em ferradura

Fonte: Tundisi, 2008.

Lagos formados pela ação do vento: A formação de depressões pelo vento ou o bloqueio pelo acúmulo de dunas pode formar lagos. Esses lagos são efêmeros, uma vez que as concavidades com essa gênese reservam água durante períodos chuvosos, tornando-se progressivamente salinas com a evaporação durante a seca, até seu desaparecimento.

Lagos formados por depósitos de origem orgânica: O desenvolvimento de plantas e os detritos associados podem causar barramento em pequenos rios e depressões. Barragens artificiais produzidas por castores ou pela ação humana podem também acumular matéria orgânica e plantas, produzindo lagos.

Deslizamentos: Movimento de rochas e solo em grande quantidade, resultado de eventos pluviométricos acima do normal ou por ação dos terremotos. Pode produzir lagos por barramento 
de vales. Os mesmos geralmente são temporários, devido à ação da erosão em grande intensidade no material inconsolidado.

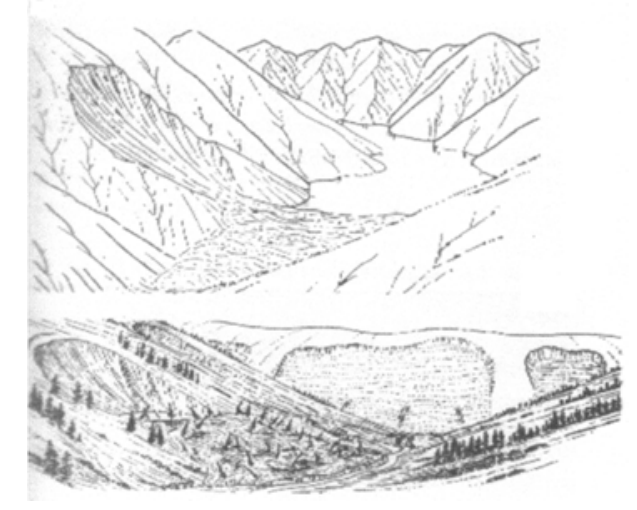

Figura 61: Lagos formados por barramentos pelo deslocamento de sedimentos. Fonte: Tundisi, 2008.

Lagoas costeiras: formadas pela deposição de sedimentos na costa, produzido em regiões onde há baías e reentrâncias.

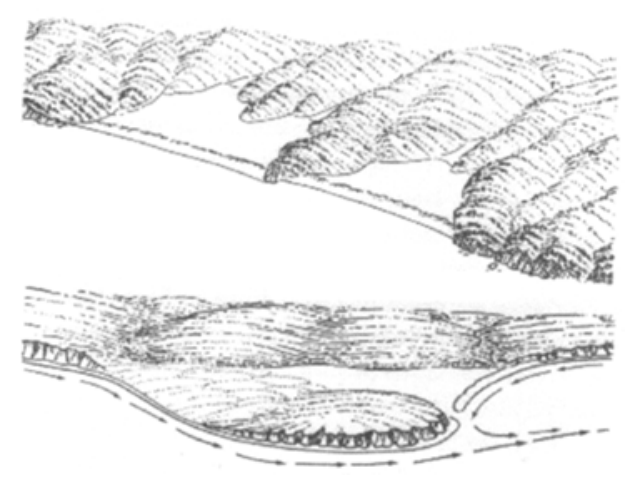

Figura 62: Formação de lagos costeiros formados por barramentos.

Fonte: Tundisi, 2008.

Lagos de origem meteorítica: Um meteoro atingindo a Terra pode formar uma depressão, esta acumulando água forma um lago.

Podem ser incluídos, na classificação de Tundisi, lagos de origem antropogênica, tais como os chamados açudes, muito comuns em toda a extensão da bacia hidrográfica do rio dos Sinos. 


\subsubsection{Análise da terra inundável do trecho um de jusante}

A terra inundável do trecho um de jusante (Mapa 05) é a que se encontra nos últimos 17 quilômetros do rio dos Sinos, possui área de $58,80 \mathrm{~km}^{2}$ e localiza-se entre os municípios de Nova Santa Rita, segmentada em duas partes, Esteio, Canoas e Sapucaia do Sul.

Não há sinais visíveis de migração do rio dos Sinos mesmo no seu trecho mais sinuoso, o que pode ser explicado pelo alto grau de alteração antrópica também na área interna desta terra inundável. A maior parte da mesma é utilizada para a agricultura predominando a rizicultura.

Pela análise de imagens do Google Earth verificou-se que o canal não apresentou sinais de assoreamento ou erosão marginal. Pela forma de uso o mais provável é que ocorra erosão laminar das áreas adjacentes ao rio, sendo necessário um monitoramento em campo para constatar a ocorrência de tal processo.

O padrão meandrante tortuoso (Cunha 2007 apud Kellershals et. al., 1976) ocorre somente no trecho mais ao norte, o restante do canal possui um padrão irregular.

A declividade desta área está entre 0 e $5 \%$ e a altimetria varia entre 0 e 25 metros, caracterizando um relevo plano. A litologia predominante corresponde a cascalhos e areias, em corpos tabulares isolados, síttico argilosos, compreendendo os depósitos do quaternário. O solo característico é o planossolo háplico eutrófico. Essa área pode ser designada como terra inundável fluvial. 
Mapa 05 : Limite terra inundável trecho um - jusante 


\subsubsection{Análise da terra inundável trecho dois de jusante}

A terra inundável do trecho dois de jusante possui $20,13 \mathrm{~km}^{2}$ e dista apenas 1,4 quilômetros da terra inundável do mapa 05. Está localizada entre os municípios de Sapucaia do Sul, Portão, São Leopoldo, neste onde se verifica a maior área e em Nova Santa Rita, onde se localiza a menor. (Mapa 06).

O rio dos Sinos apresenta no trecho mapeado padrão de meandros tortuosos Kellershals et. al. (1976 apud CUNHA, 2007). A extensão do canal é de aproximadamente de 14 quilômetros. Verifica-se também a presença de paleocanais ao longo da planície de inundação, caracterizando registro de divagação de canal.

A morfologia dos lagos é muito variada, Tundisi (2008) apud Hutchinson (1957), apresentou uma série de tipologias, as principais são: circular: lagos vulcânico, especialmente lagos em antigas crateras, subcircular: forma ligeiramente modificada em relação a circular, pela ação do vento e transporte de material, elíptico: lagos árticos, alongado sub - retangular: lagos de origem glacial em vales cavados, com forma aproximada de retângulo, dentríticos: lagos originados a partir de vales submersos bloqueados por sedimentação, com muitos afluentes e baías, forma triangular, forma irregular: em regiões onde ocorre fusão de bacias e com forma irregular, formas de crescente: alguns lagos com forma de meia lua em valas de inundação ou em regiões vulcânicas.

Segundo Ab Saber (2006), em 1958 Wilhelmy em visita ao pantanal reconheceu na área que visitou dois tipos de lagos: os de barragem fluvial, que são originados devido à inundação de lóbulos internos dos meandros e os que são encarcerados por diques marginais. A mesma tipologia pode ser verificada em alguns trechos do rio dos Sinos.

A nordeste do mapa 06 no município de São Leopoldo é possível verificar, segundo a classificação de Wilhelmy (1958), um lago de barragem fluvial no lóbulo interno do meandro, possui pequena extensão e localiza-se mais próximo do atual canal do rio dos Sinos. Pela classificação tipológica pode ser definido como subcircular.

A leste do primeiro lago descrito verifica-se um lago que possui uma de suas extremidades retilínea, o que se explica devido à parte de um dique construído para evitar as inundações em 
São Leopoldo, o mesmo determinando também uma extremidade retilínea mais abaixo do lago, compreendo parte do limite da terra inundável mapeada.

Quanto aos demais lagos, com formas muito próximas de um meandro, é possível verificar um lago em forma de crescente a noroeste do lago natural alterado. O mesmo possui aproximadamente 27 metros de extensão.

Em São Leopoldo há ainda um meandro abandonado com extensão aproximada de 1,2 quilômetros. O mesmo tem a forma de uma ferradura e é onde se localiza o lago subcircular.

Seguindo o rio dos Sinos no sentido nordeste-sul no município de Sapucaia do Sul verificase um pequeno paleocanal com forma entre subcircular e irregular.

Os meandros abandonados compreendem registro da divagação do rio dos Sinos para ambas as margens.

A sudeste do município de Portão há um canal artificial ligado ao rio dos Sinos. O mesmo foi criado com a escavação no terreno criando forma parecida a um canal hídrico.

A declividade desta terra inundável está entre 0 e 5\%, não ultrapassando os 25 metros de altitude, caracterizando uma área plana. O solo é classificado como planossolo háplico eutrófico e a litologia é caracterizada por depósitos do quaternário.

Devido às características naturais essa área pode ser designada como terra inundável flúviolacustre. 
Mapa 06 : Limite terra inundável trecho dois - jusante 


\subsubsection{Análise das terras inundáveis do trecho inferior três}

O mapa das terras inundáveis do trecho três - jusante (Mapa 07) representa duas áreas que distam entre si aproximadamente 1,2 quilômetros. A maior área possui $41,83 \mathrm{~km}^{2} \mathrm{e}$ a menor 5,59 $\mathrm{km}^{2}$.

A maior terra inundável localiza-se entre São Leopoldo, Novo Hamburgo e Campo Bom. O rio dos Sinos neste trecho apresenta extensão de 27 quilômetros com canal com trechos meandrantes tortuosos, meandrantes irregulares e irregulares. Para a menor área mapeada o rio dos Sinos apresenta um padrão irregular, com 3,2 quilômetros de extensão no município de Sapiranga. Apesar destas áreas se localizarem no trecho inferior do rio dos Sinos, onde há concentração urbana alta, o mesmo ainda apresenta sinais de divagação ao longo de sua planície.

Em São Leopoldo verificam-se três paleocanais que se localizam na margem sul do rio principal. Devido à forma longilínea dos mesmos sugere-se como designação o termo longilíneo tortuoso. $\mathrm{O}$ menor deles pode ser definido com subcircular.

Em Novo Hamburgo há cinco lagos, o maior deles pode ser definido, quanto à forma, como circular. Um deles tem ainda fortes sinais mórficos de meandro abandonado, tendo o mesmo, em parte, forma subcircular. Os demais lagos possuem formas irregulares.

Em Campo Bom também se verifica um meandro abandonado, este mais próximo ao rio principal, compreendendo também um paleocanal e um lago em forma de meia lua ou subcircular. Há também dois lagos de forma subcircular, o menor deles podendo ser designado como de lóbulos internos de meandro. O maior apresenta-se mais alongado e encontra-se próximo ao limite externo da terra inundável.

A terra inundável menor em Sapiranga dista aproximadamente 1,2 quilômetros da área maior. Nesta área se verifica sinal de paleocanal que não compreende no presente a formação de um lago devido ao avançado estado de colmatação. O canal abandonado possui mais de um meandro, contendo ao menos dois. A extensão do mesmo é de aproximadamente 3,7 de extensão. Pela expressividade lateral e longitudinal do mesmo se pode inferir que o rio dos Sinos manteve sua migração de forma mais intensa em sua margem sul, possibilidade que ganha maior força pela expressividade dos paleocanais encontrados em São Leopoldo, também na margem sul do rio dos Sinos, fato que não ocorre na margem norte com a mesma expressividade. Este padrão 
ocorre em toda a bacia. Perfurações e analises sedimentológicas podem confirmar ou refutar a hipótese.

Para as duas áreas mapeadas a declividade está entre 0 e $5 \%$ e a altimetria chega a 25 metros. Predominam os depósitos do quaternário e o planossolo háplico eutrófico.

As duas áreas mapeadas podem ser definidas como terras inundáveis flúviolacustres. 
Mapa 07 : Limite terra inundável trecho três - jusante 


\subsubsection{Análise da terra inundável do trecho médio}

No trecho médio do rio dos Sinos as terras inundáveis atingem além deste rio, seus três principais afluentes: Paranhana, da Ilha e Rolante. As áreas mapeadas estão quase restritas ao município de Taquara, excluindo apenas a área na margem oeste do rio Paranhana, que se localiza em Parobé. As terras inundáveis apresentam-se segmentadas em duas áreas e, excluindo a área inserida no rio da Ilha, em todas elas há presença de paleocanais nas planícies. A maior delas possui área de $42,83 \mathrm{~km}^{2}$ e a menor, onde estão inseridos trechos do rio da Ilha, Rolante e Sinos, possui área de $5,59 \mathrm{~km}^{2}$.

O rio Paranhana no trecho inundável tem 5,5 quilômetros de extensão, o rio da Ilha 5,4 quilômetros e o rio Rolante 8,4 quilômetros.

No rio Paranhana há dois lagos de pequena expressividade espacial, o menor com cinco metros de extensão e o maior com aproximadamente 14 metros. A distância entre o lago que se encontra mais longe do rio em questão, e que é o maior, é de apenas 10 metros. Seguindo em direção a montante não se verifica pelas imagens analisadas sinais de divagação do rio. Dentro desta lógica, coloca-se a pequena e improvável possibilidade de migração deste rio para além dos 15 metros dentro da escala geológica do período do terciário e do quaternário, a mesma ocorrendo com maior expressividade na margem leste e localizada aproximadamente entre o último quilometro do mesmo, no encontro com o rio dos Sinos.

$\mathrm{O}$ rio da Ilha apresenta canal com padrão meandrante irregular no seu trecho inferior e padrão de canal irregular em direção a montante, não há na terra inundável para este trecho a formação de paleocanais. A falta de registro de divagação do rio da Ilha pode ser explicado por que, segundo mapa geomorfológico elaborado, o mesmo localiza-se na margem e próximo aos limites do depósito do Quaternário, fazendo o mesmo, limite neste trecho com as colinas areníticas da Formação Botucatu.

A não divagação para leste não poderia seguir o mesmo raciocínio já que a planície neste sentido tem largura favorável. Pela largura média do rio da Ilha no trecho a jusante, que é de um metro, e dos rios principais que estão paralelos a este, Paranhana e Rolante com média de três metros de largura, acredita-se que o rio da Iha seja um rio mais jovem e ainda em processo de escavação e alargamento do seu leito principal. Talvez isso explique a não divagação do mesmo. 
O rio Rolante, para o trecho mapeado, possui padrão meandrante irregular e dois registros de paleocanais, um deles com forma subcircular e o outro mais próximo ao circular. A divagação é no sentido oeste e localiza-se aproximadamente a 1,7 quilômetros do encontro do mesmo com o rio dos Sinos e seguindo em direção montante.

O rio dos Sinos para o trecho mapeado apresenta padrão irregular e meandrante tortuoso. Um total de nove paleocanais, a maioria deles com forma subcircular e distribuída ao longo de ambas às margens.

Para este trecho mapeado verificou-se processos de agradação e erosão, o primeiro processo prevalecendo no rio Paranhana e o segundo ao longo do rio dos Sinos com maior incidência próxima ao encontro com o rio Rolante.

Para os quatro rios citados, a declividade está entre 0 a $5 \%$ e altitude de até 25 metros. O solo característico é o chernossolo háplico órtico e a litologia compreende os depósitos do quaternário.

As duas áreas mapeadas podem ser designadas como terras inundáveis flúviolacustres. 
Mapa 08 : Limite terra inundável trecho um - médio 
A Fotografia 19 foi tirada no município de Taquara próxima ao limite com o município de Santo Antônio da Patrulha. Compreende lago formado pelo abandono de meandro. Em relação ao mapa, localiza-se, de oeste para leste, na quinta área mapeada e compreende o segundo lago. Próximo ao ponto de obtenção da Fotografia 24 ocorre o encontro entre o rio dos Sinos e o rio Rolante, não sendo possível estabelecer um limite entre as terras inundáveis de ambos.

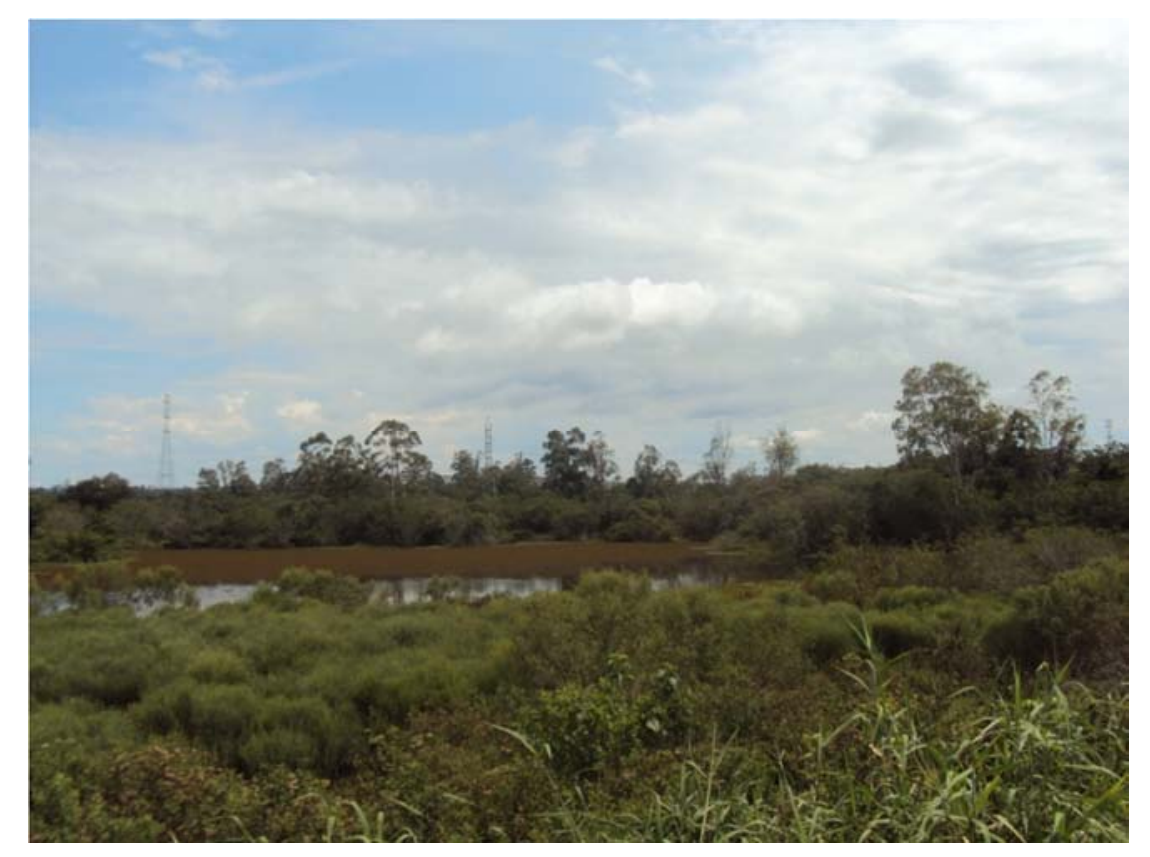

Fotografia 24: Lago formado pelo abandono de meandro, município de Taquara. Fonte: Adriana Penteado, 01/11.

A Fotografia 20 é da terra inundável do rio da Ilha, próxima à foz do mesmo, que deságua no rio dos Sinos, no município de Taquara. Não foi possível identificar o paleocanal que se localiza entre as terras inundáveis dos dois rios, possivelmente pela submersão do mesmo pela água. 


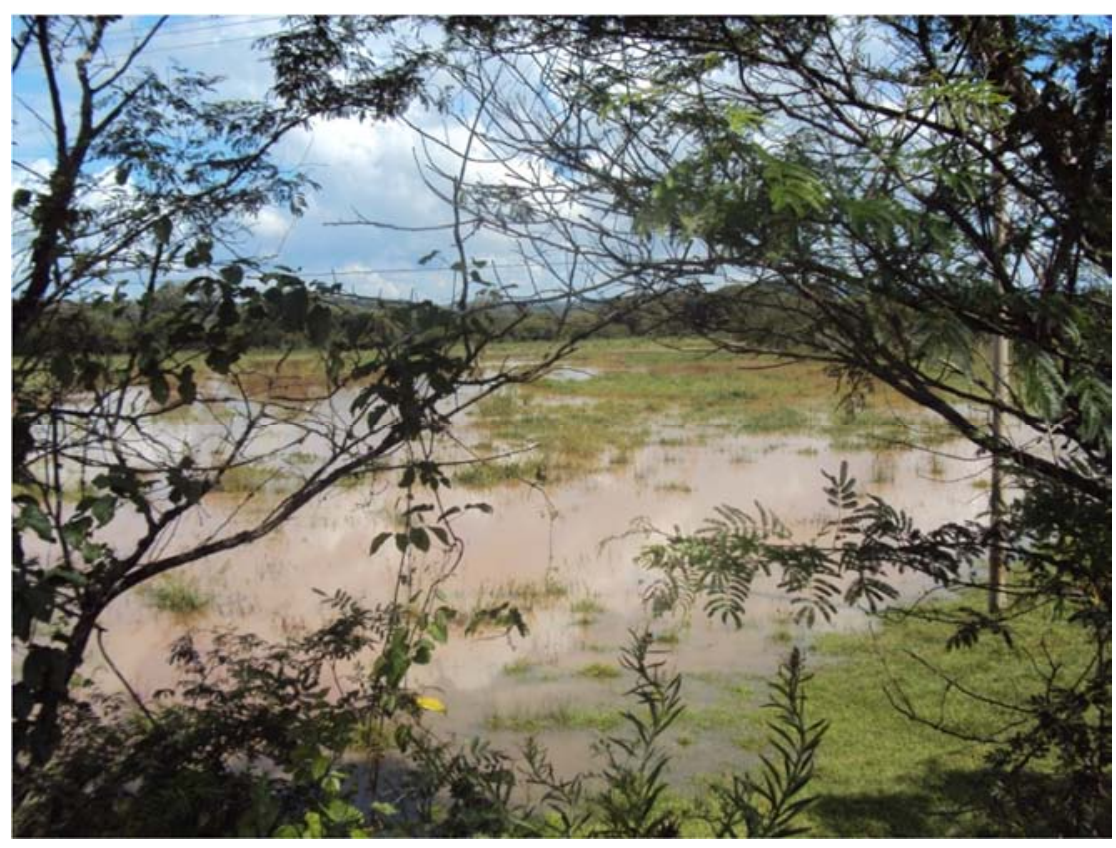

Fotografia 25: Terra inundável do rio da Ilha, próxima à foz, município de Taquara. Fonte: Adriana Penteado, 01/11.

\subsubsection{Análise da terra inundável trecho superior um}

A terra inundável do trecho um - montante possui $18,75 \mathrm{~km}^{2}$ e localiza-se no município de Santo Antonio da Patrulha, na área central do mesmo (Mapa 09). A concentração urbana deste município, que é de baixa densidade, localiza-se a 10 quilômetros da extremidade a sudeste da área mapeada.

Na terra inundável mapeada há presença de um único paleocanal localizado próximo a área central da terra inundável. O rio dos Sinos neste trecho tem extensão de aproximadamente 20 quilômetros, apresentando trechos sinuosos e retilíneo na parte mais a montante, este último sendo resultado de processo antrópico.

No extremo oeste do mapa localiza-se um meandro que está em processo de estrangulamento faltando apenas 4 metros de extensão de solo para ser removido para que o mesmo se desligue do rio dos Sinos. Pela extensão acredita-se que este processo poderá ser presenciado num tempo aproximado de 10 anos, formando mais um lago na área.

Verificou-se no extremo oeste do mapa processo erosivo e no extremo leste retificação do canal. 
A declividade deste trecho está entre 0 e $5 \%$ e a altimetria não ultrapassa os 25 metros de altitude, caracterizando um relevo plano. Nas áreas adjacentes há presença de colinas areníticas e morros baixos basálticos. A litologia compreende os depósitos do quaternário. O solo característico para essa área é o chernossolo háplico órtico, com risco de inundação ocasional.

Esta terra inundável pode ser designada como flúviolacustre. 
Mapa 09 : Limite terra inundável trecho um - montante 


\subsubsection{Análise da terra inundável trecho superior dois}

No mapa 10 as terras inundáveis apresentam-se segmentadas em três, com as seguintes áreas, de oeste para leste; $11,04 \mathrm{~km}^{2}, 0,85 \mathrm{~km}^{2}$ e $6,42 \mathrm{~km}^{2}$ totalizando $18,31 \mathrm{~km}^{2}$. Somente a área mais a leste localiza-se entre Santo Antônio da Patrulha e Caraá, as demais estão restritas ao primeiro município descrito. Não há segmentação natural em relação à área do mapa anterior. A mesma foi representada separadamente por questões de ordem cartográfica.

$\mathrm{O}$ rio dos Sinos apresenta de forma predominante padrão irregular, em alguns trechos mais a oeste padrão meandrante sinuoso.

Para a área maior há três paleocanais sendo que o que se localiza mais a leste não compreende um lago e tem extensão de 0,4 metros. A forma dos paleocanais que formam lagos pode ser definida como longilínea tortuosa. Há também um canal em processo de estrangulamento com uma das extremidades já desconectada do rio dos Sinos. Pela forma atual infere-se que formará um lago subcircular.

A altimetria desta área está entre 25 e 50 metros e a declividade em alguns trechos atinge 12\%. O solo característico é o chernossolo háplico órtico. Quanto à litologia compreende os depósitos do quaternário. De oeste para leste das áreas mapeadas há a transição de morros médios para morros altos da formação Serra Geral.

As áreas mapeadas podem ser designadas como terras inundáveis flúviolacustres. 
Mapa 10 : Limite terra inundável trecho dois - montante 
A partir da análise dos mapas das terras inundáveis do rio dos Sinos constatou-se que estas se localizam de forma predominante em declividades de até $5 \%$ e altitudes de até 25 metros. Somente na área do trecho dois - montante a declividade atinge $12 \%$ e a altitude 50 metros, havendo neste caso transição das áreas adjacentes de morros baixos da Formação Botucatu, para morros médios da Formação Serra Geral.

A terra inundável maior é a do trecho um - jusante com $58,8 \mathrm{~km}^{2}$ e a menor a do trecho dois - montante com 13,71 km². A resolução espacial para o mapeamento destas áreas foi de 20 metros e foi necessária a utilização de imagens com maior resolução para refinar os limites. $\mathrm{O}$ período das imagens escolhidas influenciou nas áreas das terras inundáveis mapeadas. Para a década analisada a imagem escolhida é a segunda mais adequada, assim as terras inundáveis mapeadas atingem áreas maiores do que as que foram representadas e é possível que em alguns trechos onde se verificou a segmentação natural não ocorra em períodos mais chuvosos.

Nas áreas do trecho inferior o solo característico é o planossolo háplico eutrófico e nas áreas do trecho médio e superior, o chernossolo háplico órtico.

As áreas mapeadas não apresentaram continuidade ao longo da bacia, sendo que não é possível que apresentem mesmo com maiores índices pluviométricos, devido, por exemplo, ao município de São Leopoldo que possui adensamento urbano nas planícies do rio dos Sinos e construiu junto ao rio obras de contenção contra enchentes.

Somente na terra inundável do trecho inferior - um não se verificou presença de paleocanais. Possivelmente esta área não apresenta tais características devido ao alto grau de alteração em praticamente toda a área inundável, além da provável desconstituição natural de paleocanais e lagos com a aragem do solo e drenagem das águas.

Os paleocanais para a área de estudo, nem sempre representam lagos, dependendo do nível de colmatação dos mesmos. Foi possível verificar processos onde há formação de novos lagos pelo estrangulamento de meandro. As formas dos paleocanais estão entre subcircular, circular, irregular e como proposto aqui, longilíneo tortuoso.

Os paleocanais se encontram em maior número e extensão total, com maior incidência na margem sul ou leste, dependendo da direção do rio dos Sinos. Assim, o rio dos Sinos ao longo do tempo geológico teve sua migração com maior intensidade para norte e oeste.

Entre a primeira área mapeada e a segunda, de jusante para montante, a segmentação ocorre por uma distância de 1,4 quilômetros, possivelmente devido ao total pluviométrico que não foi 
capaz de inundar essa área. De forma geral percebeu-se que as terras inundáveis maiores localizam-se nas áreas mais a jusante, demonstrando a influência do relevo na extensão dessas áreas.

As terras inundáveis se formam a partir do extravasamento de rios e/ou lagos e da subida do lençol freático, a chuva faz parte do input de todo o sistema que é bacia hidrográfica do rio dos Sinos, que compreendo um sistema aberto, respondendo as entradas no sistema, as alterações internas, e ambas se refletem no output do mesmo. 


\section{CAPÍTULO 5 - ASPECTOS ANTRÓPICOS}

\subsection{Importância, funções e principais impactos causados nas terras inundáveis da área de estudo}

As terras inundáveis localizadas em áreas isoladas têm como principal importância a manutenção da vida adaptada a este tipo de ambiente. Já quando as ocupações humanas se aproximam dessas áreas, outras importâncias ganham mais relevância.

As ocupações e os usos nas cidades alteram e/ou criam diversos ambientes relacionados com o maior ou menor grau de intervenção. Como consequência, há impactos negativos e para minimizar estes efeitos obras de engenharia muitas vezes são vistas como a solução.

Porém, com as alterações de uso e ocupação continuadas e, no mesmo tom, inadequadas, as obras ao longo do tempo podem se tornar insuficientes ou obsoletas e novas obras podem se tornar necessárias. Assim, as alterações ao longo do tempo na natureza se traduzem em prejuízos também de ordem econômica. As intervenções mais significativas no que se refere às obras de engenharia nas terras inundáveis compreendem sistemas de controle de inundações, construção de estradas, hidrelétricas, retificação de canais, etc.

Em escala menor, as intervenções mais comuns compreendem a impermeabilização dos solos, retiradas de vegetação, despejo de esgoto sem tratamento, aterros, assoreamento, drenagem, segmentação, etc. Essas ações podem ser consideradas de menor importância se analisadas pontualmente, porém somadas causam também alterações significativas.

As áreas mais planas são mais requisitadas para a ocupação, pois, por exemplo, demandam menores custos com fundações. As ocupações em terras inundáveis podem de certo modo ser facilitadas nos períodos em que essas áreas têm aspecto de terra firme, e quando as mesmas inundam pode haver danos materiais e até humanos. Nas áreas urbanas, além da ocupação residencial, há também a ocupação por indústrias e para a produção agrícola. Assim, de várias formas e por variados motivos, essas áreas são modificadas ou destruídas.

Aproximadamente 50\% das terras úmidas do planeta desapareceram nos últimos 100 anos, principalmente devido à agricultura e ao desenvolvimento urbano (SHINE \& KLEMM, 1999). 
As principais funções dessas áreas são a despoluição de águas, a regulação do nível de enchentes, recarga de aquíferos, grande variedade de cadeias alimentares, além de se constituirem em habitat único para animais e plantas.

Atualmente a população humana está cada vez mais concentrada nas áreas urbanas. Há uma grande necessidade de conservação da água, sua purificação e seu uso para a recreação, ao mesmo tempo em que aumenta a poluição e diminuem os ambientes naturais que possuem a capacidade de abastecer a população.

Quanto à purificação da água, as terras inundáveis têm a capacidade de remover eficientemente altos níveis de nutrientes como nitrogênio e fósforo, comumente associados ao escoamento da água utilizada na agricultura. Também diversas espécies de plantas encontradas nestes ecossistemas possuem a capacidade de remover substâncias tóxicas provenientes de descargas industriais e atividades de mineração. Macrófitas como Eichhornia crassipes e Typha $s p$ têm sido utilizadas para tratar efluentes que contêm altas concentrações de metais pesados (VEIGA, 2005).

Esses sistemas apresentam importante papel no aprisionamento e reprocessamento de nutrientes e contaminantes, podendo, dessa forma, contribuir para a melhora da qualidade da água de forma natural, funcionando como um sistema depurador, reciclando elementos e tratando cargas poluentes (MITSCH \& GOSSELINK, 2000 apud BENASSI, 2006). A Figura 63 busca exemplificar esse processo. 


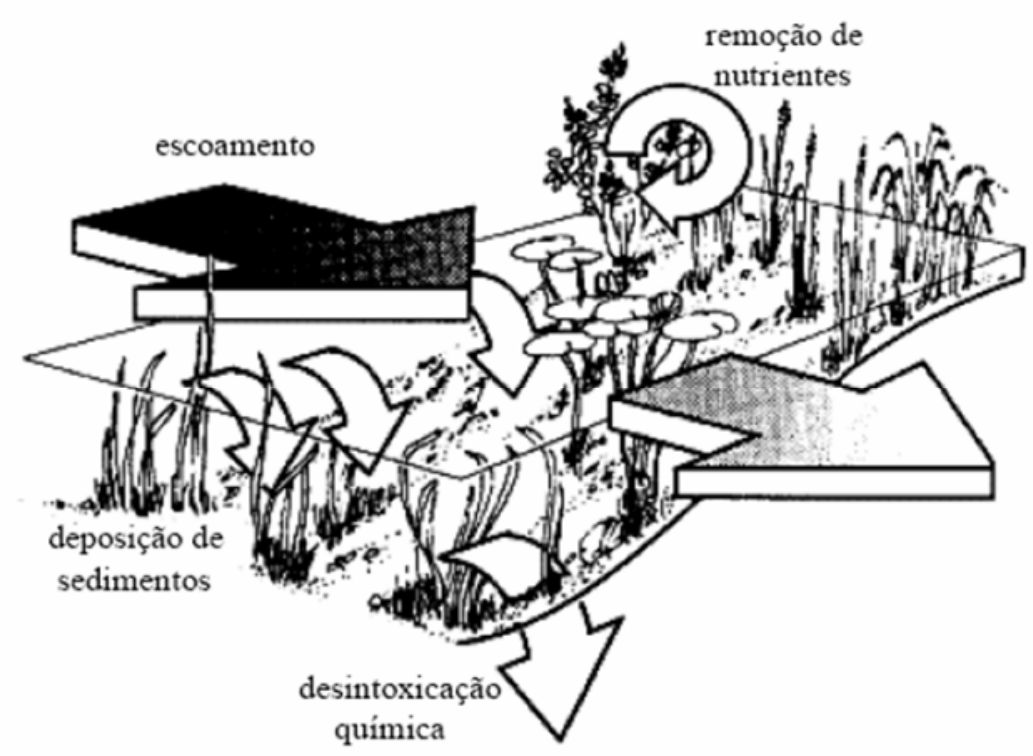

Figura 63: Processos associados à melhora da qualidade da água proporcionada pelas terras inundáveis

Fonte: BENASSI (2006) adaptado de USEPA (2000).

Estudos realizados por Ferreira $(1998,2000)$ constataram que na lagoa de Imboassica, no Rio de Janeiro, houve remoção de nitrogênio e fósforo acima de $90 \%$, havendo nesta área presença de macrófitas aquáticas; nos efluentes que atingem as áreas alagadas do rio Atibaia, em São Paulo, houve redução de nitrogênio em $80 \%$ e de fósforo em $60 \%$.

Segundo Odum (1983), as áreas alagadas ocupam aproximadamente 2\% da área total do globo terrestre; estima-se que estas contenham de 10 a $14 \%$ do carbono total do planeta. A estratificação aeróbia/anaeróbia dos sedimentos desses ambientes possui grande relevância em relação ao desempenho de ciclagem dos compostos como enxofre, nitrogênio, fósforo e carbono.

As terras inundáveis têm também a capacidade de armazenamento de água e regulação dos níveis de enchentes. Com o extravasamento lateral do rio nos períodos de cheia, devido à maior pluviosidade, as terras inundáveis armazenam grande quantidade de água e, à medida que o nível do rio desce, as áreas que foram inundadas vão cedendo água para o rio, evitando dessa forma, o baixo nível hídrico. Com a destruição desses reguladores, o nível do rio aumenta e diminui rapidamente e, como consequência, ocorre o agravamento das inundações e dos períodos de estiagem, neste caso prejudicando o abastecimento público. 
A capacidade do ambiente natural em fornecer bens e serviços que, direta ou indiretamente, satisfazem a necessidade humana, compreende a função ambiental desses sistemas. Existindo quatro categorias: funções de regulação; capacidade dos ecossistemas de manter e regular os processos ecológicos essenciais, funções de suporte; capacidade de fornecer espaço e substrato adequado às atividades humanas, funções de produção; capacidade de fornecimento de matérias primas e energia, funções de informação; capacidade para desenvolver oportunidades para o desenvolvimento cognitivo e recreação. Segundo Mello (1998) apud Grott (1986), as chamadas áreas úmidas estão entre os ambientes de maior desempenho dessas funções.

A relevância das áreas úmidas consiste no fato de que elas podem constituir, de forma única, exemplos de fenômenos biológicos ou geológicos. Podem também ter grande importância para a preservação de espécies da flora e da fauna e serem incomparáveis do ponto de vista visual e por sua raridade (MELLO, 1998 apud SHULDINER, COPE \& NEWTON, 1979).

As terras inundáveis também contribuem para diminuir os efeitos das ilhas de calor nas áreas de adensamento urbano-industrial, as quais se manifestam principalmente pela retirada da vegetação, impermeabilização do solo, tipos de materiais utilizados nas construções, disposição de prédios que podem alterar ou dificultar a circulação do vento e, por consequência, impedir a dispersão de poluentes presentes no ar.

\subsection{Relações entre o processo histórico de ocupação e as intervenções nas terras inundáveis}

O Quadro 04 buscou resumir e relacionar o processo de ocupação da área de estudo com as principais intervenções causadas nas terras inundáveis e as consequências relacionadas. Posteriormente, os processos serão explicados ao longo do texto. 


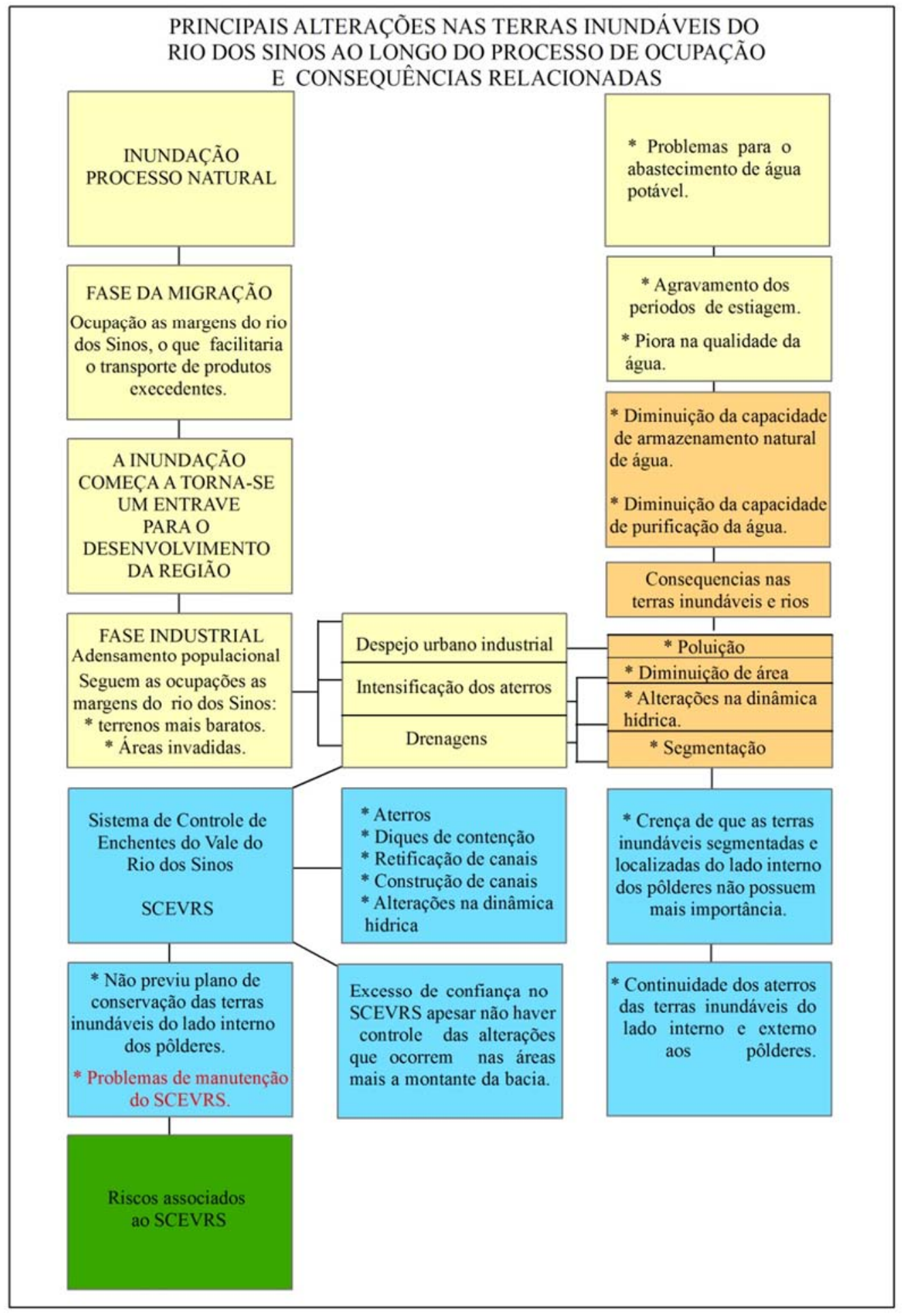

Quadro 04: Principais alterações causadas nas terras inundáveis do rio dos Sinos e consequências relacionadas.

Elaboração: Adriana Penteado, 2010. 


\subsubsection{Processo Regional de Urbanização}

O processo de ocupação da bacia hidrográfica do rio dos Sinos está fortemente relacionado ao processo histórico de ocupação de Porto Alegre e sua região metropolitana. Este processo coincide mais intensamente com os trechos médio e inferior da bacia, justamente onde estão localizadas as terras inundáveis maiores e que sofreram as intervenções mais significativas.

Souza (1997) classificou o processo de urbanização de Porto Alegre em cinco fases: ocupação do território-formação do núcleo, o trigo na região, imigração ítalo-germânica, industrialização e o processo de metropolização.

Os processos aqui descritos serão aqueles que possuem relação direta com o processo de urbanização da região metropolitana, dessa forma serão descritos os processos de imigração, industrialização e, por fim, a metropolização.

\subsubsection{Fase da Imigração}

O processo migratório, tanto de Porto Alegre como de outros municípios do território nacional, ocorreu principalmente por três motivos: (1) crescimento capitalista na Europa, onde as máquinas substituem a trabalho humano e, nesse sentido, promovem um excedente de mão de obra; (2) interesse capitalista em financiar o desenvolvimento de colônias em países "novos" por meio desses imigrantes; por fim, (3) a consciência dos países de economia colonial, de que era necessário diversificar o sistema de produção para tornarem-se independentes economicamente. Essas questões, entre outras, vão propiciar a vinda de imigrantes para o Brasil (SOUZA, 1997).

O início do processo migratório praticamente coincidiu com o período do Império no Brasil. Houve a decisão da Coroa em promover a vinda de imigrantes para ocupar as terras do sul, não dadas como sesmarias para a criação de gado, por acharem-se cobertas de matas e por isso não se prestarem facilmente àquela atividade (ibid.).

Segundo RADAMBRASIL (1986), a partir do século XIX, as imigrações se acentuaram efetivamente, iniciando um novo ciclo de povoamento no Brasil. Assim os alemães ocuparam os vales dos rios dos Sinos e Jacuí e a borda da Serra Geral, enquanto os italianos se estabeleceram no vale do rio das Antas. Dessas ocupações surgiram cidades que guardam traços culturais dos 
imigrantes que as fundaram, como Novo Hamburgo, São Leopoldo, Caxias do Sul, Bento Gonçalves e Garibáldi, de origem alemã e italiana. Porto Alegre, a capital gaúcha, é de origem açoreana, tal como Rio Grande, Osório, Taquari e Rio Pardo.

Para Porto Alegre, um fato de suma importância no seu crescimento refere-se ao processo migratório, ocorrido entre 1820 a 1890. A primeira leva de imigrantes de origem alemã chegou ao norte de Porto Alegre entre os anos de 1824 e 1825 num total de 1032 pessoas, e entre os anos de 1826 a 1829, mais 3823 desembarcaram. Finalmente, entre 1844 e 1853 completa-se o número, com a entrada de mais 2636 imigrantes Deutschtum (1924 apud SOUZA, 1997).

As colônias de imigrantes aqui instaladas passaram pelas seguintes fases: a) desmatamento e agricultura de subsistência; b) expansão agrícola e exportação de excedentes e c) especialização agrícola, tendo como meta o comércio.

Os imigrantes alemães instalaram-se, inicialmente, ao norte de Porto Alegre, no ano de 1824 em São Leopoldo. Até mais ou menos 1860 a capital gaúcha se constituía apenas em um mercado para o consumo dos excedentes produzidos na colônia alemã.

Do norte de Porto Alegre, os imigrantes seguiram ocupando as áreas ao longo do rio dos Sinos e, saindo de sua margem direita, subiram a Encosta da Serra. A partir de 1850, com a chegada de uma nova leva de imigrantes alemães, novas áreas foram necessárias para a ocupação. $\mathrm{O}$ acesso a elas se fez através dos principais rios que confluem próximo a Porto Alegre para formar o lago Guaíba: os rios dos Sinos, Caí e o conjunto Jacuí/Taquari (MÜLLER ,1997).

O rio dos Sinos foi o principal motivo para a ocupação dos imigrantes alemães nas suas margens, pois representava um local ideal para a instalação de um porto, estreitando assim os laços com Porto Alegre e facilitando o acesso aos produtos que produziam.

Os produtos cultivados nas colônias alemãs eram transportados por embarcações fluviais via rio dos Sinos. Nesse sentido, o rio dos Sinos foi o grande facilitador de comunicação entre as comunidades, favorecendo a ocupação para além de seu curso e afluentes, atingindo a região banhada pela bacia hidrográfica do Guaíba.

De 1824 a 1950, a região do vale do rio dos Sinos passou de uma base agrícola para uma muito mais ampla, abrangendo áreas como artesanato, comércio e indústrias. Foi por meio dessas atividades que a região conquistou relevância no desenvolvimento regional do Rio Grande do Sul. 
Segundo Müller (1997), a ocupação das áreas antes praticamente desocupadas e sua incorporação à economia do estado, através da agricultura diversificada, foram de fundamental importância para o crescimento de Porto Alegre e região. Aquela vocação portuária inicial de Porto Alegre agora recebe forte impulso, pois os rios, ao longo dos quais se instalou a nova economia, trazem naturalmente a produção. Estabeleceu-se, assim, sob o comando de Porto Alegre, a coleta da produção, sua exportação, bem como a importação dos bens requeridos pelas novas populações.

A partir de 1860, os alemães começam a mostrar sua força, favorecendo comercialmente Porto Alegre. Nesse período, melhoramentos urbanos começam a ser introduzidos na cidade, que ressurgirá com a função comercial graças à colonização ítalo-germânica.

Em 1875, chegam ao Rio Grande do Sul os imigrantes italianos, ocupando as terras que permaneceram desocupadas, ou seja, os divisores de água e as encostas mais íngremes que os alemães deixaram de ocupar. O centro de imigração ocorre em Caxias do Sul, os imigrantes ocupam-se primeiramente da agricultura. Assim Porto Alegre se beneficia do aumento da produção agrícola e da ampliação de seu mercado pelo aumento da população, com 60 mil imigrantes italianos.

Um mercado suficientemente amplo permitirá a transformação de métodos de produção artesanal para uma produção industrial com o objetivo de atendimento do mercado regional.

\subsubsection{Fase Industrial}

Segundo Souza (1997), em Porto Alegre o processo de industrialização ocorreu no período entre 1890 a 1945. Um fator que ajudou no crescimento industrial da cidade foi o estrangulamento da importação de produtos manufaturados durante as duas grandes guerras mundiais, forçando a aceitação do produto nacional.

Em Porto Alegre, observa-se a mesma tendência à industrialização que no resto do país e no interior do estado. Comparado às outras cidades rio-grandenses, ressalta-se em Porto Alegre a sua diversidade industrial, com destaque ao ramo metalúrgico.

Ao elevado surto industrial de Porto Alegre associa-se um significativo incremento populacional, sendo que a maior taxa do decênio 1900-1910 chegou a aproximadamente 6\%. 
Segundo Fujimoto (2000), o início da industrialização como principal atividade econômica e a forma pela qual a sociedade se apropria da natureza e a transforma, marcou o processo de urbanização.

No que se refere à questão industrial da Grande Porto Alegre, podemos distinguir, de forma geral, quatro zonas, segundo a ordem cronológica de desenvolvimento. A primeira e mais antiga situa-se junto às instalações portuárias e à via férrea, como continuidade ao estabelecimento de um comércio atacadista. Essa primeira zona corresponde ao bairro Navegantes, onde está localizada a travessia do lago Guaíba (MOLD, 1973).

A segunda zona industrial ocorre ao longo da BR 116, ligando as cidades de Canoas, Esteio, São Leopoldo e Novo Hamburgo. O desenvolvimento comercial e industrial de Novo Hamburgo e São Leopoldo criou laços com os municípios vizinhos, correspondendo à continuidade dos espaços urbanos no limite norte da região metropolitana.

Devido ao baixo custo, os terrenos alagadiços às margens dos rios dos Sinos e Gravataí, no município de Canoas, atraíram grande quantidade de operários. No período de cheia dos rios as inundações formam um contingente de flagelados (MOLD ,1973).

Na direção NE, ao longo do eixo viário que conecta os municípios de Gravataí e Cachoeirinha, estrada que dá acesso a São Paulo pelo litoral, estabeleceu-se a terceira zona industrial da cidade, acompanhada de loteamentos, e surgimento de vilas pobres, cujo limite de expansão compreende a várzea do rio Gravataí.

Já a sudoeste encontra-se a quarta zona industrial, de surgimento recente e que se estabeleceu também ao longo da BR 116, porém após a travessia do Guaíba. As restrições de urbanização nesse local também estão ligadas à presença de terrenos alagadiços. É fato na cidade de Guaíba o surgimento de vilas tendendo a aproximar-se das estradas, provocando uma expansão do crescimento nessa direção.

O intuito da Figura 64 é possibilitar a visualização geral do crescimento dos principais centros urbanos da região metropolitana, a partir dos quatro eixos industriais definidos por Mold (1973). 


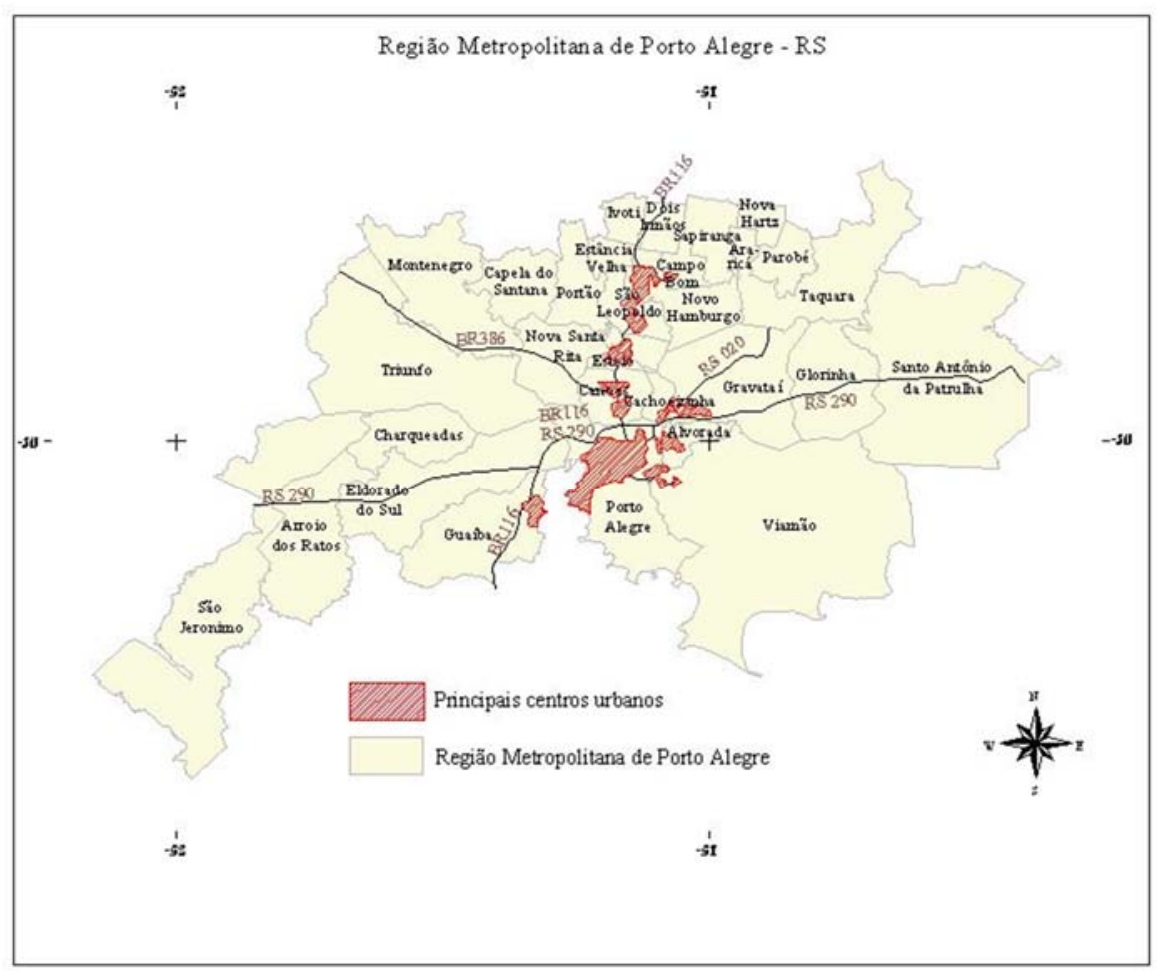

Figura 64: Região Metropolitana de Porto Alegre (RMPA) e os principais centros urbanos a partir do desenvolvimento industrial.

Elaboração: Adriana Penteado, 2006.

\subsubsection{Fase da Metropolização}

A fase de metropolização da Grande Porto Alegre compreende o período de 1945 até a atualidade. O Rio Grande do Sul entra nesse período com a pecuária extensiva em moldes tradicionais e com uma agricultura que até então significava um mercado suficiente para os produtos da indústria de Porto Alegre. Já na década de 1960 a situação entra em colapso, devido às terras muito subdivididas e os solos esgotados pela falta de práticas conservacionistas (MÜLLER, 1997).

Em 17 de novembro de 1967, o Governo do Estado nomeou uma Comissão para realizar estudos para a delimitação da Área Metropolitana de Porto Alegre. Os critérios utilizados foram os seguintes: continuidade dos espaços "urbanizados", medidos através de fotografias aéreas; os 
fluxos de transporte, fundamentalmente de passageiros (migrações pendulares); e as funções exercidas pelos centros urbanos periféricos nos espaços urbanizados da capital do estado.

Em 1968, é definida a Região Metropolitana de Porto Alegre, inicialmente constituída por 14 municípios e, atualmente, com 31 municípios.

Das áreas rurais com maiores problemas partem correntes migratórias aos centros urbanos, em especial para a capital. Surge então a mão de obra menos qualificada ou subempregada, concentrada, vias de regra, em vilas de sub-habitação ou mesmo em sub-habitações nas "frestas" das áreas residenciais legalmente constituídas.

Os que desejavam permanecer no setor primário se dirigiram para áreas menos densas do estado e, como nestas áreas a disponibilidade de terra é limitada, migraram para outros estados ou, até mesmo, para países vizinhos, estendendo as fronteiras agrícolas.

Pouca atenção foi dada ao setor agrícola, que se encontra a uma distância estratégica da capital e que contava com um significativo mercado que necessitava ser atendido. Altos percentuais de produtos primários provêm, atualmente, de outros estados.

O setor industrial, que no início do século participava da produção industrial quase ao lado de São Paulo, rapidamente foi perdendo sua posição. Por esse motivo foram criados incentivos para a vinda de novas indústrias, sendo que algumas, de relativo porte, foram atraídas. São também tomadas medidas com o intuito de suprir o déficit energético que representava um obstáculo a uma industrialização mais intensa.

Segundo Souza (1997), tais fatos se refletem no aumento da população de Porto Alegre. Na década de 1940-1950, a população sobe de 263 mil habitantes para 380 mil, e nas décadas de 1950-1960, para 626 mil. Já nas décadas de 1960-1970 o ritmo de crescimento é menor, alcançando 885 mil. Na década de 1960 evidencia-se que os problemas que se apresentam não podem ser resolvidos no âmbito da jurisdição municipal. O uso do solo precisava ser disciplinado, os transportes e a infraestrutura necessitavam de integração, o saneamento apresentava problemas.

Significativa parcela da população morava em municípios vizinhos, embora trabalhasse em Porto Alegre. Enfim, a cidade não mais funcionava em sua circunscrição administrativa, Porto Alegre e seus municípios vizinhos passaram a integrar um todo orgânico que reclamava iniciativas e soluções conjuntas: entra-se na fase da metropolização. 
Com a construção da BR 116 a industrialização segue seu traçado, inclusive saindo dos limites de Porto Alegre em direção norte por Niterói-Canoas-Esteio até Sapucaia do Sul, sendo acompanhada por expressivo contingente de moradias populares.

Posteriormente, com o desenvolvimento da BR 101 em direção ao litoral, poucas indústrias localizam-se ao longo da BR 116. As novas implantações se fazem em Cachoeirinha e outros municípios em direção leste. As vilas populares se estabelecem, preferencialmente, ao longo da Avenida Assis Brasil e seus prolongamentos e da Avenida Bento Gonçalves em direção a Viamão, compreendendo ainda o município de Alvorada. Dessa forma é importante destacar que a expansão urbana se dá pelos acessos mais dinâmicos.

A região metropolitana equipa-se também para assumir o papel terciário, porém neste quesito Porto Alegre tem grande preponderância sobre os demais, seja na infra-estrutura administrativa ou financeira. Os serviços de educação e pesquisa, embora fortemente situados em Porto Alegre, encontram-se também disseminados em outros municípios, como Canoas, São Leopoldo e Novo Hamburgo.

Desde o início do século, verificou-se a tendência de as indústrias acompanharem as vias de acesso de longo curso, como a Avenida Voluntários da Pátria, a Avenida Farrapos, a BR 116, a Avenida Cristóvão Colombo, a Avenida Benjamin Constant, a Avenida Assis Brasil e, atualmente, a orientação leste, acompanhando a Free Way (BR 290).

Essa tendência definiu a Zona Norte de Porto Alegre como uma área industrial, prolongando-se nos municípios vizinhos da região metropolitana, numa primeira fase ao longo da BR 116 e, atualmente, na direção leste.

Atualmente as indústrias, por suas necessidades de expansão e pelos incentivos financeiros oferecidos, tendem preferencialmente a localizar-se fora de Porto Alegre, na região metropolitana.

\section{$\underline{\text { 5.2.1.4 Uso e a ocupação do solo da bacia hidrográfica do rio dos Sinos e problemas relacionados }}$}

Na Região Metropolitana de Porto Alegre - RMPA, historicamente as áreas urbanas e eixos de colonização desenvolveram-se a partir dos cursos de água, junto às margens, pois esses eram os caminhos naturais de comunicação entre diferentes regiões. Assim, o padrão da ocupação foi 
determinado pela hidrografia. Com o passar do tempo, os eixos hidrográficos foram substituídos pelos rodoviários, porém manteve-se a mesma distribuição espacial de ocupação urbana e circulação. Os eixos rodoviários aceleraram o processo de ocupação de grandes contingentes populacionais, que ocuparam principalmente as planícies de inundação dos cursos de água (PROTEGER, 2004).

Berço do primeiro Comitê de Gerenciamento de Bacia Hidrográfica do Brasil, o rio dos Sinos é considerado o mais poluído da região ${ }^{13}$, pois tem o maior parque industrial, com destaque para as indústrias coureiro-calçadistas, petroquímicas e metalúrgicas. O setor primário é pouco desenvolvido, com agricultura e pecuária somente no seu curso superior (ibid.).

Segundo COMITESINOS (2005), as áreas altas (Figura 65) e médias da bacia hidrográfica do rio dos Sinos são dominadas pela agropecuária; nas áreas mais íngremes, em pequenas propriedades existe agricultura de subsistência de grãos e hortifrutigranjeiros. Os solos do médio vale são muito utilizados como pastagens destinadas à pecuária. Finalmente, nas zonas mais baixas do rio dos Sinos, são encontradas áreas planas e alagáveis em parte não urbanizadas, geralmente cultivadas com arroz irrigado. Já no trecho entre Três Coroas e o município de Canoas predominam áreas urbanizadas com alto grau de industrialização (Figura 66).

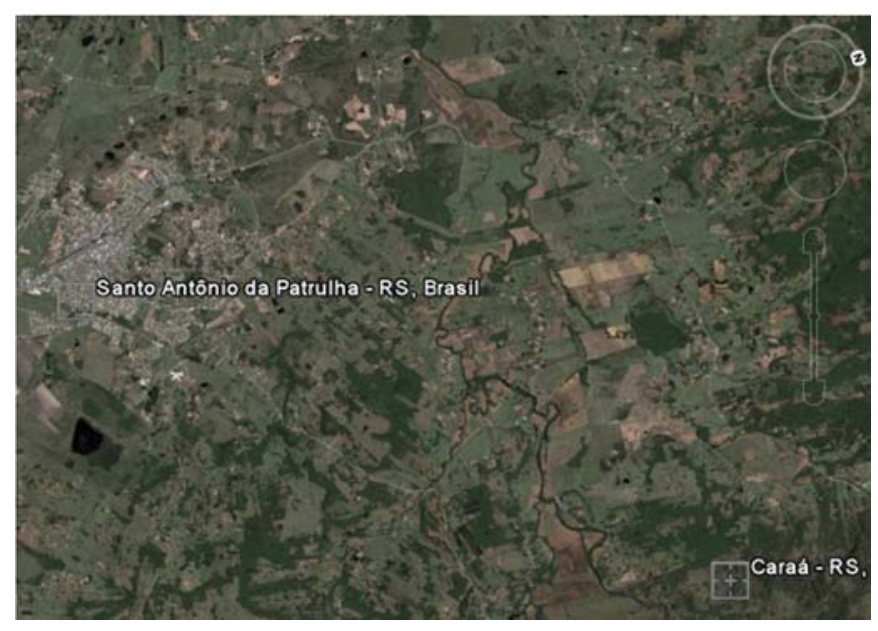

Figura 65: Trecho superior do rio dos Sinos.

Fonte: Google Earth, 04/02/2009.

\footnotetext{
13 A bacia hidrográfica do rio dos Sinos está inserida na região hidrográfica do Guaíba, que é formada pelas seguintes bacias hidrográficas: Vacacaí-Mirim, Alto Jacuí, Baixo Jacuí, Taquari-Antas, Caí, Gravataí, Guaíba, Pardo.
} 


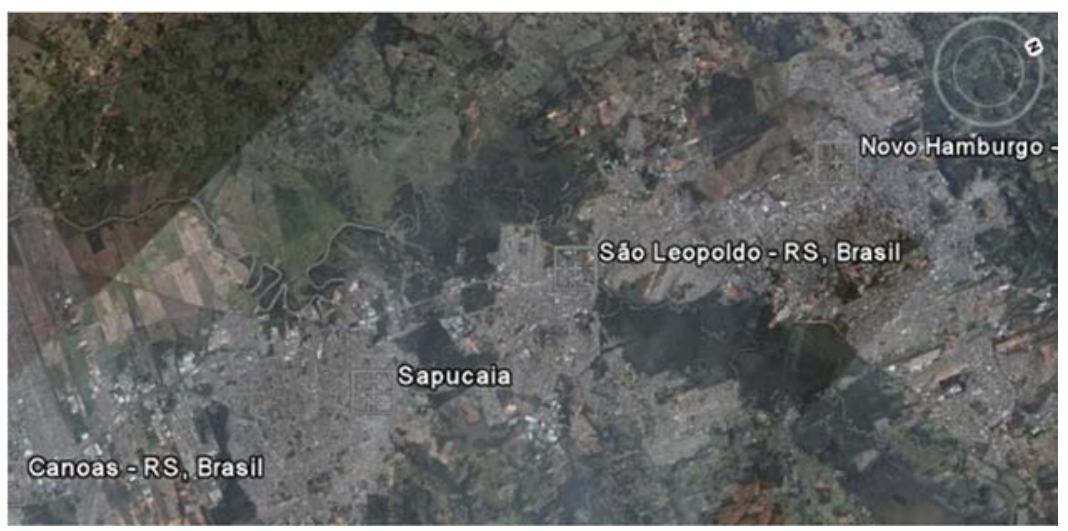

Figura 66: Conurbação no trecho inferior do rio dos Sinos. Fonte: Google Earth, 04/02/2009.

O Projeto de Educação Ambiental da bacia hidrográfica do rio dos Sinos (2007) dividiu a mesma em três macrozonas, traçando um panorama geral sobre a ocupação e as principais alterações:

Na macrozona terras altas (Caraá, Santo Antônio da Patrulha, Nova Hartz - parcial, Riozinho, Rolante), nas proximidades da nascente principal do rio dos Sinos, vivem índios guaranis. Além deles e de pequenos núcleos de origem alemã, a cultura que predomina na região é a dos descendentes da imigração italiana. Eles se dedicam às plantações de fumo, verduras e milho, além da agropecuária. Já é possível verificar sinais de destruição, por meio do desmatamento e da poluição.

Na macrozona terras onduladas coxilhas (Dois Irmãos (parcial), Araricá, Campo Bom parcial, Estância Velha, Parobé, Novo Hamburgo -parcial, Portão - parcial, Sapiranga, Taquara), a população é formada por alemães e poloneses. As atividades giram em torno da agropecuária, dos arrozais e das pastagens. Nessa macrozona, as alterações são bem mais intensas, há muitos desmatamentos, desvios de cursos do rio para irrigação, dragas que fazem a extração de areia para a comercialização. Nessa região, o rio já apresenta vestígios de poluição industrial e residencial.

A macrozona terras baixas (Esteio, Nova Santa Rita, São Leopoldo) foi colonizada por descendentes alemães, atualmente, conta com uma população cada vez mais diversificada, devido ao avançado processo de industrialização dos últimos 30 anos. Destacam-se as indústrias coureiro-calçadista e metalúrgica. Nessa área ocorre intenso processo erosivo, desmatamento e 
substituição, por eucaliptos, da vegetação nativa das matas ao longo do rio. Além disso, intensa poluição do solo e da água. Presença de grande quantidade de lixo industrial e doméstico, tendo como consequência águas com alto grau de contaminação.

A bacia hidrográfica do rio dos Sinos tem sofrido as consequências da intensa utilização dos seus recursos hídricos com práticas agropecuárias inadequadas na parte superior e a industrialização e a urbanização desordenada nas regiões médias e inferiores, enfrentando, entre outros problemas, a escassez de água para o abastecimento de sua comunidade (CASSARTELLI, 1999).

\subsection{Inundações}

Segundo estudos da Pesquisa Nacional de Saneamento Básico - PNSB (2000), as inundações atingem com frequência algumas cidades brasileiras e a intensidade dos danos possui, geralmente, relação direta com o maior grau de adensamento urbano. Dos 4327 municípios com serviço de drenagem urbana, 1235 (28,5 \%) sofreram com as inundações entre os anos de 1998 e 2000.

Entre 1979 a 1989, as fortes chuvas e consequentes inundações no país foram responsáveis pela morte de aproximadamente cinco mil pessoas, com 3,6 milhões de desabrigados, 111770 casas danificadas e 101000 casas totalmente destruídas. Em 1983, os prejuízos decorrentes das inundações na região sul do Brasil atingiram total de US\$ 1,3 bilhões. Em 1984 e 1985, grandes inundações no Nordeste causaram imensos prejuízos materiais e perdas significativas de vida (DIEGUES, 2002).

Para minimizar a ocorrência e a intensidade desse problema, uma das medidas seria aumentar a retenção de água nas bacias por meio da infiltração, com a conservação e a recuperação das áreas de retenção natural das águas como as planícies de inundação.

O que ocorre com maior frequência é a artificialização gradual do sistema hidrológico, com alterações significativas nos cursos hídricos e em suas planícies. Essas ações têm onerosos custos, que podem ser permanentes ao longo do tempo. Com o processo de uso e ocupação inadequados, muitas das obras realizadas tornam-se insuficientes ou obsoletas. Projetam-se então novas e 
onerosas obras que nunca deixam de estar em pauta, pois o motivo que as tornam "necessárias" continua existindo.

O processo de aumento da capacidade dos canais nas cidades tornou-se insustentável economicamente. Um exemplo é o canal do rio Tamanduateí e Meninos na cidade de São Paulo, que chegou a custos de US\$ 50 milhões/km (METROPLAN, 2001).

No caso acima, o plano de drenagem não analisou a bacia como um todo, nem buscou recuperar as condições de infiltração, isso gerou os seguintes prejuízos: os investimentos em canalizações que com frequência chegam a ser 10 vezes mais caros que o Controle local além do aumento das inundações para jusante. É necessário pensar na conservação dos remanescentes dos ambientes naturais reguladores das inundações (ibid.).

As áreas urbanizadas em relação às não urbanizadas possuem o escoamento superficial das águas 10 a 30\% maior; a água subterrânea diminui entre 32 e 50\% e, aproximadamente, $43 \%$ das precipitações são evacuadas das áreas urbanas pelo sistema de drenagem ${ }^{14}$ (PICKETT et al., 2001).

Os principais efeitos da urbanização sobre o ciclo hidrológico são (TUCCI, 2003):

* Aumento do escoamento superficial e redução do tempo de escoamento, que provocam aumento nas vazões máximas e antecipam os picos de cheias;

* Redução do escoamento subterrâneo que causa rebaixamento do nível do lençol freático;

* Redução nos processos de evapotranspiração;

* Redução da infiltração da água no solo.

As conseqüências da urbanização sobre a hidrologia são mais diretas e referem-se ao crescimento das vazões máximas de cheias causando inundações e a redução das vazões mínimas no período de estiagem (TUCCI, 1995). Em muitos casos, a hidrologia apresenta pouco das suas características naturais.

\footnotetext{
${ }^{14}$ Os sistemas de drenagem são classificados, de acordo com suas dimensões, em: sistemas de microdrenagem, também denominados de sistemas iniciais de drenagem; e de macrodrenagem. A microdrenagem inclui a coleta e afastamento das águas superficiais ou subterrâneas através de pequenas e médias galerias, fazendo ainda parte do sistema todos os componentes do projeto para que tal ocorra. A macrodrenagem inclui, além da microdrenagem, as galerias de grande porte ( $\mathrm{D}>1,5 \mathrm{~m}$ ) e os corpos receptores, tais como canais e rios canalizados. Os sistemas de drenagem urbana são essencialmente preventivos de inundações, principalmente nas áreas mais baixas das comunidades, sujeitas a alagamentos, ou áreas marginais de cursos naturais de água. É evidente que, no campo da drenagem, os problemas agravam-se em função da urbanização desordenada. Fonte: Fernandes, 2002.
} 
As condições hidrológicas que produzem a inundação podem ser classificadas como naturais ou artificialmente derivadas. As naturais são aquelas cuja ocorrência é propiciada pelas entradas de energia e matéria e pelas características da bacia, independentemente do tipo de uso do solo que é empregado: tipo de fenômeno meteorológico definindo a intensidade e a duração da precipitação, relevo, cobertura vegetal e capacidade de drenagem (COLLISCHONN, 2007).

Segundo Andrade (2005) um dos grandes desafios para os planejadores do espaço urbano está em conciliar densidade urbana com ciclo hidrológico, tentando reter o maior tempo possível a água onde ocorre a precipitação. O objetivo é retardar a liberação para as áreas mais baixas ou favorecer a infiltração no solo das águas da chuva, por meio da criação de bacias de captação e espaços verdes e da limitação de superfícies impermeabilizadas.

No Brasil, principalmente no século XX, as ações baseadas na adaptação da hidrografia aos sistemas de vias urbanas causaram drásticas intervenções, como a retificação de meandros dos rios. O objetivo de tais ações era o de recuperar terrenos impróprios para a ocupação. Assim, estas áreas retificadas e "saneadas" deram lugar à urbanização. Os fundos de vale se transformaram em locais passíveis de loteamentos ou áreas comercializáveis, abrigando também as vias marginais, tão comuns nas mais diversas cidades (FELÍCIO, 2009).

Apesar dos inúmeros casos de inundações ao longo do tempo, trazendo prejuízos materiais e humanos, no Brasil não existe nenhum programa sistemático de controle deste fenômeno que envolva seus diferentes aspectos. O que se observa são ações isoladas por parte de algumas cidades. Um exemplo é o município de Estrela, no Rio Grande do Sul, que implantou dentro de seu Plano Diretor, a legislação de zonas de uso especial, definidas pela restrição de ocupação e de construções abaixo de determinadas cotas, estabelecidas no zoneamento de inundação previamente elaborado. O município prevê, na legislação, a troca de área de inundação por índice de ocupação em zonas valorizadas, como uma forma de adquirir áreas de risco para uso público (REZENDE \& TUCCI, 1979).

Os reservatórios de amortecimento de cheias vêm sendo executados há décadas em países como Austrália, Canadá, Estados Unidos, França, tornando-se uma prática na concepção de projetos de drenagem. No Brasil, algumas cidades vêm atuando na regulação e legislação no que tange à obrigatoriedade de execução de reservatórios de amortecimento em empreendimentos e loteamentos novos, públicos ou privados, a partir de um valor mínimo de área impermeabilizada 
(FONSECA et al., 2006). Curitiba, Guarulhos, Porto Alegre, Rio de Janeiro e São Paulo são exemplos de cidades que atualmente estão adotando práticas nesse sentido.

Para diminuir a impermeabilização estão sendo empregados dispositivos que promovam a infiltração ou o armazenamento temporário das águas pluviais, tais como os planos ou superfícies de infiltração, as valas ou trincheiras com poços de infiltração, a utilização de pavimentos porosos e ou permeáveis.

A Fotografia 26 é de uma bacia de amortecimento do sistema de contenção de cheias do município de Porto Alegre. Esta obra busca simular umas das funções das terras inundáveis, que é a de reter a água da chuva quando ocorre precipitação pluviométrica elevada.

Esta bacia de amortecimento, que é impermeabilizada, dificulta o retorno da água para o rio quando o nível deste fica baixo. Uma obra menos artificial poderia ser mais útil do ponto de vista ambiental e econômico, além de ter melhor aspecto visual.

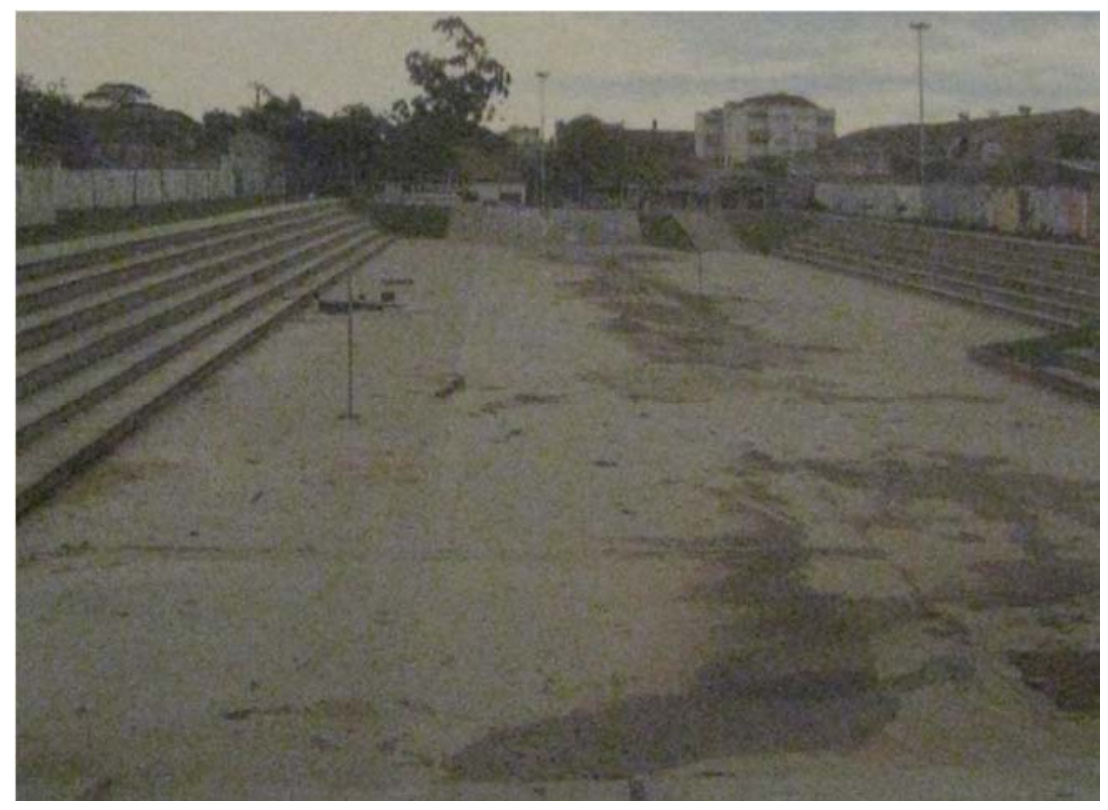

Fotografia 26: Bacia de amortecimento em Porto Alegre.

Fonte: Metroplan, 2001.

Atualmente, as inundações são cada vez mais causadas pela combinação de fatores naturais e sociais. Têm origem natural porque estão associadas com a ocorrência de fenômenos atmosféricos, com dinâmica e extensão espacial própria. Observa-se, porém, que se registram cada vez mais eventos que foram induzidos, acelerados ou ampliados pela intervenção humana 
relacionados a processos como desmatamento, desestabilização de vertentes, degradação de ecossistemas, mudanças no padrão de uso do solo agrícola, crescimento urbano sem planejamento adequado e sem provisão de infraestrutura de drenagem. Assim, os lugares de grande concentração urbana apresentam, na atualidade, maior suscetibilidade a que ocorra esse tipo de evento (COLLISCHONN, 2009).

Em condições naturais, parte da chuva fica retida nos troncos e folhas das plantas. O escoamento superficial é retido por obstáculos naturais gerando maior infiltração e retardando a chegada da água nos cursos de água. Quando a cobertura vegetal é retirada, não há resistência ao escoamento e a água atinge os rios com maior facilidade e rapidez, contribuindo também com o assoreamento dos rios, pois, sem a cobertura vegetal, os sedimentos são carregados pela água e acabam depositados no fundo dos leitos dos rios. Esse fato é agravado quando há impermeabilização do solo (ibid.).

$\mathrm{O}$ aumento da precipitação pluviométrica promove o extravasamento do rio para além do seu canal normal ou menor, atingindo o leito maior: esse processo compreende a inundação (Figura 67).

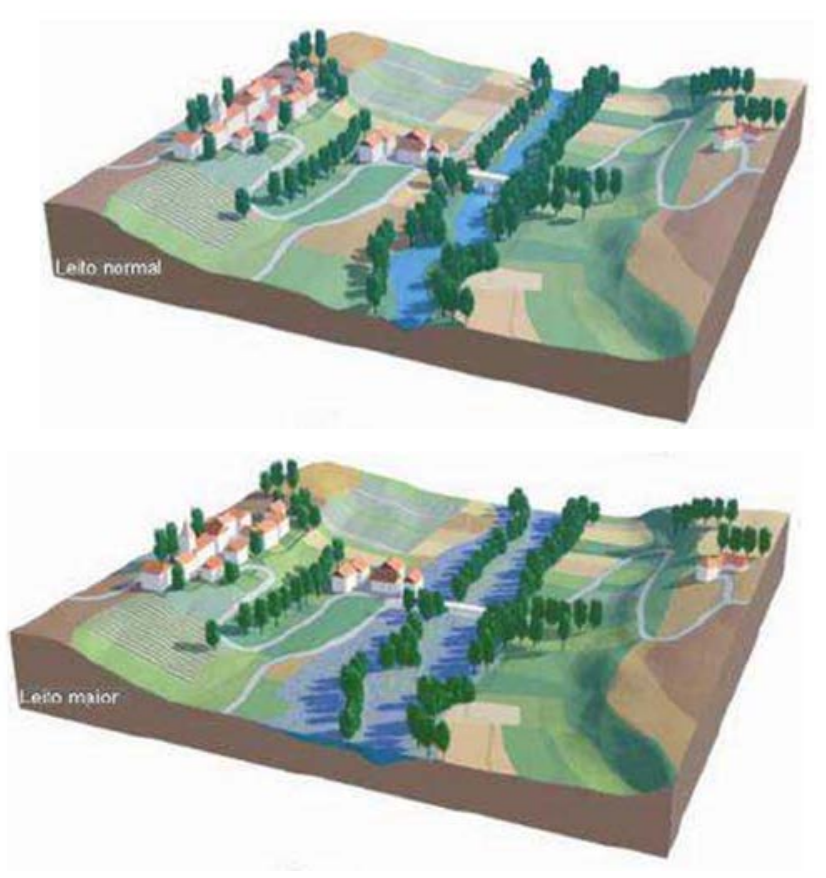




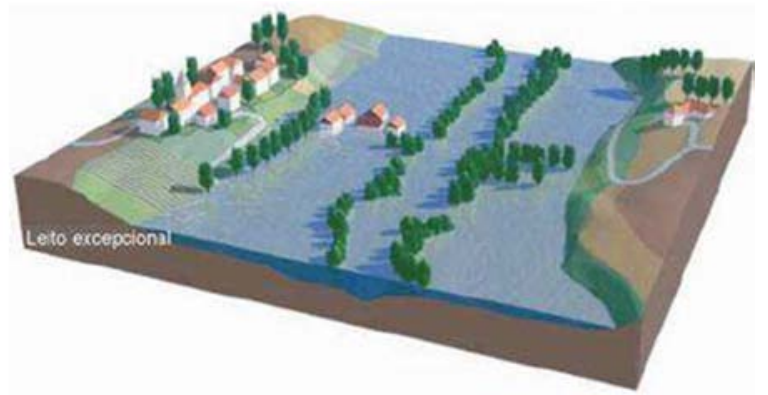

Figura 67: Inundação

Fonte: Prim.net - Cito, 2008 apud Collischonn, 2009.

As ocupações se consolidam nas áreas de planície de inundação que em certos períodos do ano permanece com aspecto de terra firme. As ocupações com o passar do tempo vão se consolidando e torna-se cada vez onerosa a ampliação de sistemas de drenagem e, na medida em que a impermeabilização aumenta agravam-se as inundações.

Um dos principais parâmetros que influenciam as inundações, analisado conjuntamente com a geomorfologia, é a declividade, pois permite mapear as áreas naturalmente mais susceptíveis. Segundo Dias et al. (2004), declividades entre 0 e 5\% são as que mais influenciam nas áreas de inundações, pois representam as planícies e os terraços fluviais.

Segundo Paiva (2005):

O declive constitui, por si só, um factor agravante em situação de inundação urbana, de cariz bastante rápido, uma vez que aumenta a velocidade de escorrência ao longo das vertentes, mais ou menos inclinadas, e favorece a estagnação e acumulação das águas em locais planos. Este processo é tanto mais grave quanto mais impermeabilizada estiver a vertente, diminuindo as perdas por infiltração e aumentando a disponibilidade hídrica à superfície. p. 151.

A Figura 68 exemplifica os tipos de leito fluvial por meio de um perfil transversal. 


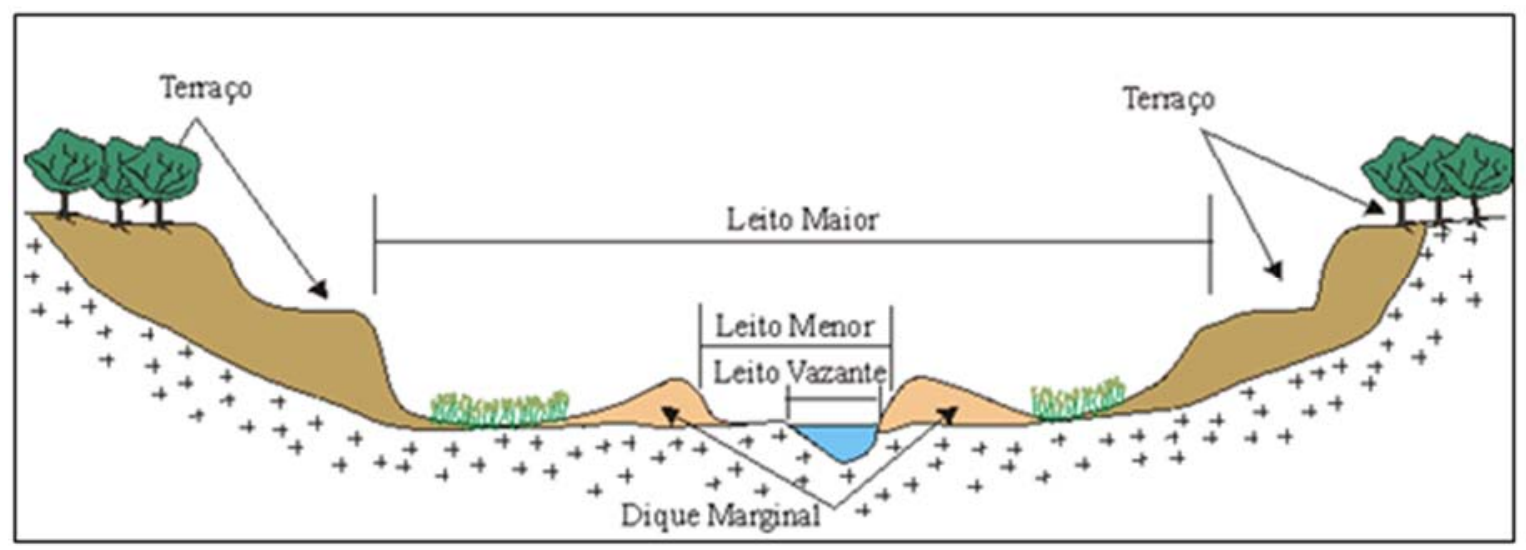

Figura 68: Tipos de leito fluvial.

Fonte: Silva, 2009.

No leito menor, definido pelos diques marginais, o escoamento da água é constante, daí por que não há crescimento da vegetação. O leito de vazante, encaixado no leito menor, compreende o talvegue e é onde o rio escoa nos períodos de estiagem. O leito maior corresponde ao leito menor mais a planície de inundação, sendo esta geralmente utilizada para a ocupação.

As obras de contenção das inundações buscam impedir o extravasamento natural do rio para o seu leito maior; são então estabelecidas barreiras que separam o rio de sua planície.

Na subsuperfície, a troca de água pode permanecer, mesmo com as obras, e as planícies podem manter sua dinâmica, embora de forma alterada. Mesmo que não ocorra troca de água pela subsuperfície, dependendo das características da obra, a alimentação hídrica das planícies continua a ocorrer pela subida do lençol freático e pela precipitação.

As áreas do lado externo dos pôlderes ficam mais propícias à destruição, pois estas, não sendo mais alimentadas diretamente pelo rio, podem ter seu período de inundação diminuído e/ou com lâmina de água mais rasa, facilitando o aterro ou a drenagem.

No caso das planícies que estão localizadas do lado interno, ainda em contato direto com o rio, nos períodos de maior chuva estas tendem a ter o nível de lâmina de água mais alto, pois sua área normal de extravasamento, no sentido horizontal, foi diminuída, havendo uma compensação natural no sentido vertical. 
Dragagens são necessárias ao longo do tempo para aumentar a profundidade do rio e diminuir o risco de o mesmo superar a altura das barreiras artificiais invadindo áreas supostamente protegidas por obras.

O município de Porto Alegre, bem como sua região metropolitana, já sofreu grandes prejuízos materiais e humanos ao longo dos séculos devido às inundações. Atualmente os danos são menores, mas ainda compreendem um problema. Essa problemática da RMPA se insere no contexto do estado do RS e tem relação com as alterações ou ocupações em áreas de terras inundáveis.

As terras úmidas do Rio Grande do Sul estão distribuídas principalmente na Planície Costeira, Depressão Central e Fronteira Oeste. Estimativas sobre a perda dessas áreas são desconhecidas, embora alguns pesquisadores calculem valores próximos a 90\%. Apenas um pequeno percentual se mantém ainda em condições naturais, tipificando ecossistemas extremamente frágeis e ameaçados. De um total de aproximadamente 5.300000 ha, aproximadamente 3.000000 ha são utilizados para culturas de arroz irrigado (CHOMENKO, 1995).

A Câmara de Vereadores de Porto Alegre, no período entre 1824 e 1983, registrou grandes inundações na Região Metropolitana de Porto Alegre ocorridos nos anos de 1833, 1873, 1897 , 1905, 1912, 1914, 1921, 1926, 1928, 1936, 1937, 1941, 1954, 1956, 1964, 1965, 1967, 1970, 1976 e 1983. Os municípios de São Leopoldo e Novo Hamburgo, quase sempre, eram os mais atingidos, principalmente nas inundações de 1941, 1965 e 1967, as maiores já registradas, com dezenas de milhares de desabrigados na região (METROPLAN, 2001).

Na bacia hidrográfica do rio dos Sinos, inserida em boa parte na RMPA, segundo Ramos (1975), as cheias ocorrem principalmente no inverno e têm como causa principal o influxo do Guaíba. As cheias do Guaíba são provenientes de um conjunto de fatores, entre os quais o de ter um dos maiores índices pluviométricos do Rio Grande do Sul no Planalto Meridional, aliado ao fato de receber praticamente todos os contribuintes da bacia do rio Jacuí. O escudo SulRiograndense e o litoral representam um obstáculo ao escoamento das águas até o oceano Atlântico, por isto elas são acumuladas no Guaíba. Na grande inundação de 1941 o lago Guaíba subia três centímetros e meio por hora, atingindo quase cinco metros acima do seu nível normal. 
O agravamento das cheias periódicas no rio dos Sinos e em todo o estado do Rio Grande do Sul possui relação direta com a diminuição dos ambientes reguladores - as terras úmidas - e com o desmatamento na margem dos rios. $\mathrm{O}$ volume de água da precipitação, que antes ficava retido pela vegetação e era absorvido gradativamente pelos solos antes de chegar aos cursos de água, flui rapidamente para os rios, transportando, assim, sedimentos (BERTÊ, 2004).

No ano de 1881 ocorreu a Exposição Brasileira Alemã em Porto Alegre e, devido à grande chuva na abertura do evento, o jornal o Século tentou descrever o panorama:

O barracão de exposição representava uma ilha. Era um mundo de água, por todos os lados! Atravessava-se de canoa, pernas-de-pau ou a nado. Isto só fazia os corajosos. Uma pobre senhora foi vítima, quis atravessar a pé e submergiu na lama. Quando a tiraram do precipício já era cadáver! Coitada! Morrer assim num dia tão chuvoso, e duma morte tão prosaica... E chovia a cântaros! Mas que a exposição abriu-se é o que não padece dúvida alguma. Se ainda estamos a sentir o cheiro das lingüiças... (METROPLAN, 2001, p. 17).

Em 1928, fortes chuvas causaram inundações em vários municípios como Novo Hamburgo, Campo Bom, São Leopoldo e Montenegro (Fotografia 27), sendo estas cidades localizadas no Vale do rio dos Sinos, além de Porto Alegre, Gravataí e São Jerônimo.

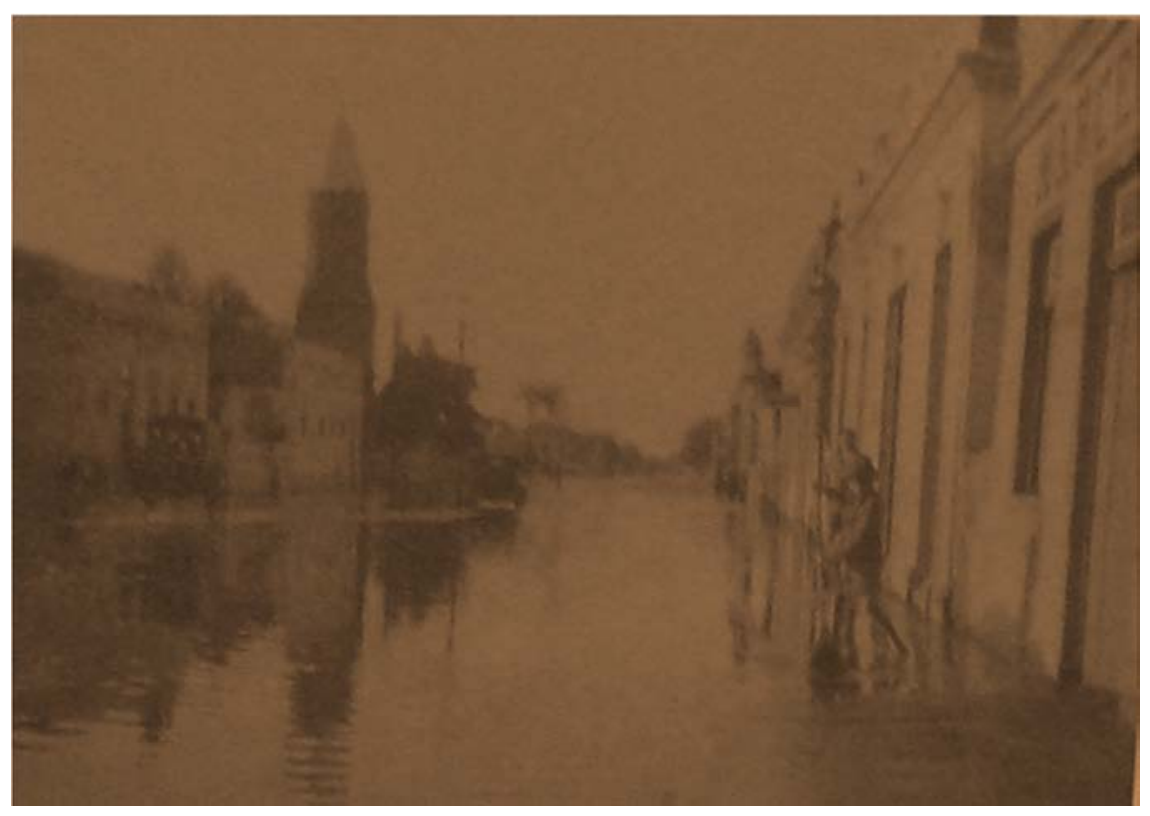

Fotografia 27: Rua Ramiro Barcelos, Montenegro (1928).

Fonte: METROPLAN, 2001, p.23 
Em 1936, em São Leopoldo, o rio dos Sinos extravasou os limites do seu leito menor, inundando várias ruas da cidade. Devido à gravidade do evento, as estradas estavam impossibilitadas de utilização, o município ficou isolado e mais de 300 pessoas ficaram desabrigadas.

O município de Canoas em 1937 (Fotografia 28), na época distrito de Porto Alegre, ficou isolado devido às inundações. As emergências deveriam ser atendidas por barcos do governo, por meio do rio dos Sinos e Gravataí, estabelecendo contato com outras localidades próximas. No município de Montenegro, que foi novamente atingido, muitas casas construídas em áreas de planície foram abandonadas.

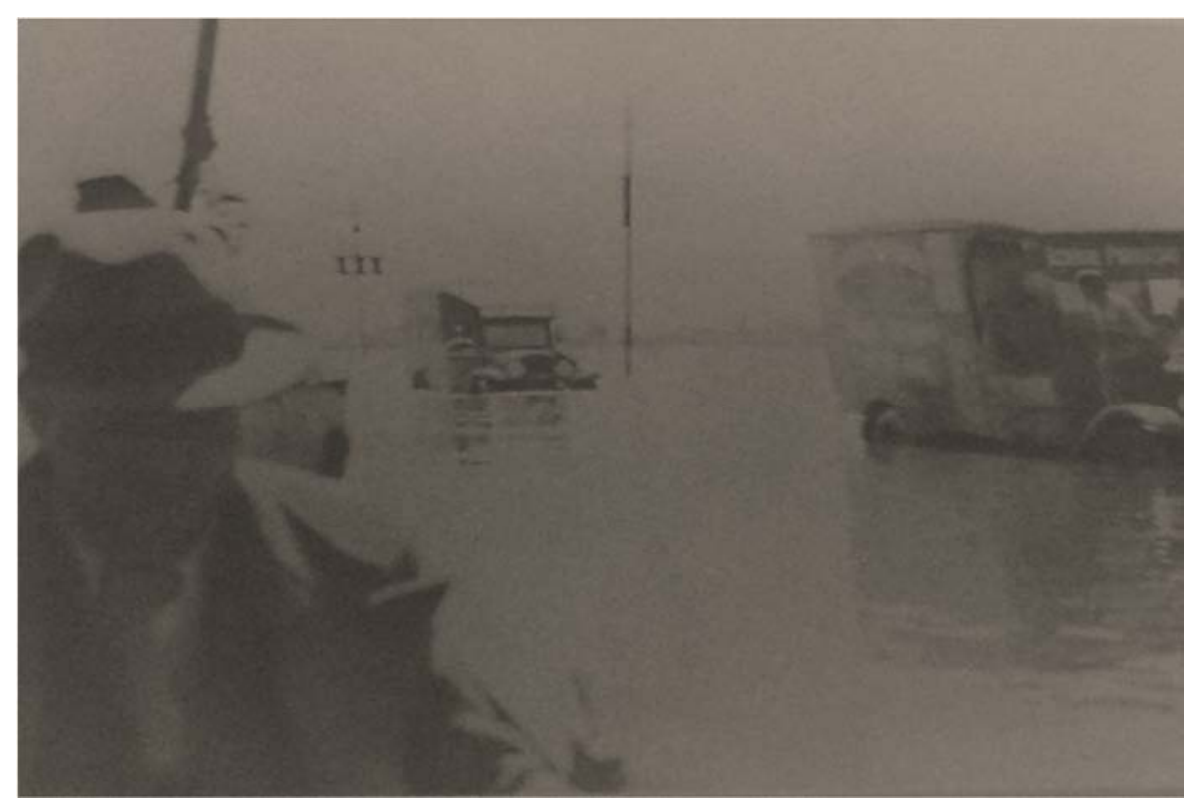

Fotografia 28: Bairro Rio Branco - Canoas (1937).

Fonte: METROPLAN, 2001, p.29

Uma das piores inundações que extravasou os limites da bacia do rio dos Sinos ocorreu em 1941 (Fotografia 29), castigando praticamente todo o estado do Rio Grande do Sul. O chamado "lago" Guaíba atingiu 4,75 metros acima de seu nível normal.

Vários fatores contribuíram para a calamitosa situação: a chuva intensa que durou duas semanas somada às descargas de águas vindas dos rios afluentes do Guaíba - Gravataí, Caí, Sinos 
e Jacuí - e o Minuano ${ }^{15}$, soprando em sentido contrário, impedindo a vazão das águas para a Lagoa dos Patos. Assim, mesmo quando a chuva cessou, as águas continuaram subindo.

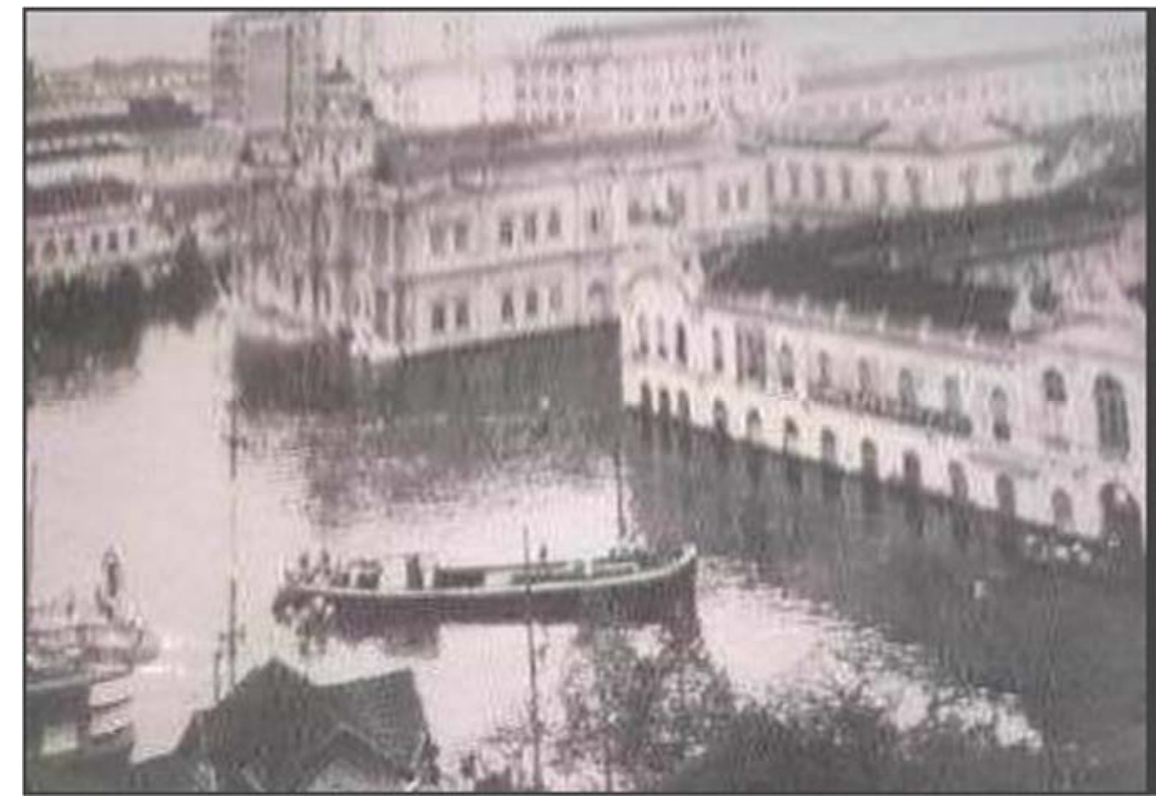

Fotografia 29: Inundação no centro de Porto Alegre em 1941. Fonte: www.portoalegre.rs.gov.br/metroclima

As Fotografias 30 e 31 exemplificam parte do problema causado pela inundação do rio dos Sinos em São Leopoldo em 1965 e, em Novo Hamburgo em 1976.

\footnotetext{
${ }^{15}$ Vento minuano, ou simplesmente minuano, é o nome dado à corrente de ar que tipicamente acomete os estados brasileiros do Rio Grande do Sul e região sul de Santa Catarina. É um vento frio de origem polar (massa de ar polar atlântica), de orientação sudoeste, algumas vezes também classificado como cortante. Ocorre após a passagem das frentes frias de outono e inverno. Fonte: http://pt.wikipedia.org/wiki/Vento_minuano. Acessado em 19/09/2009.
} 


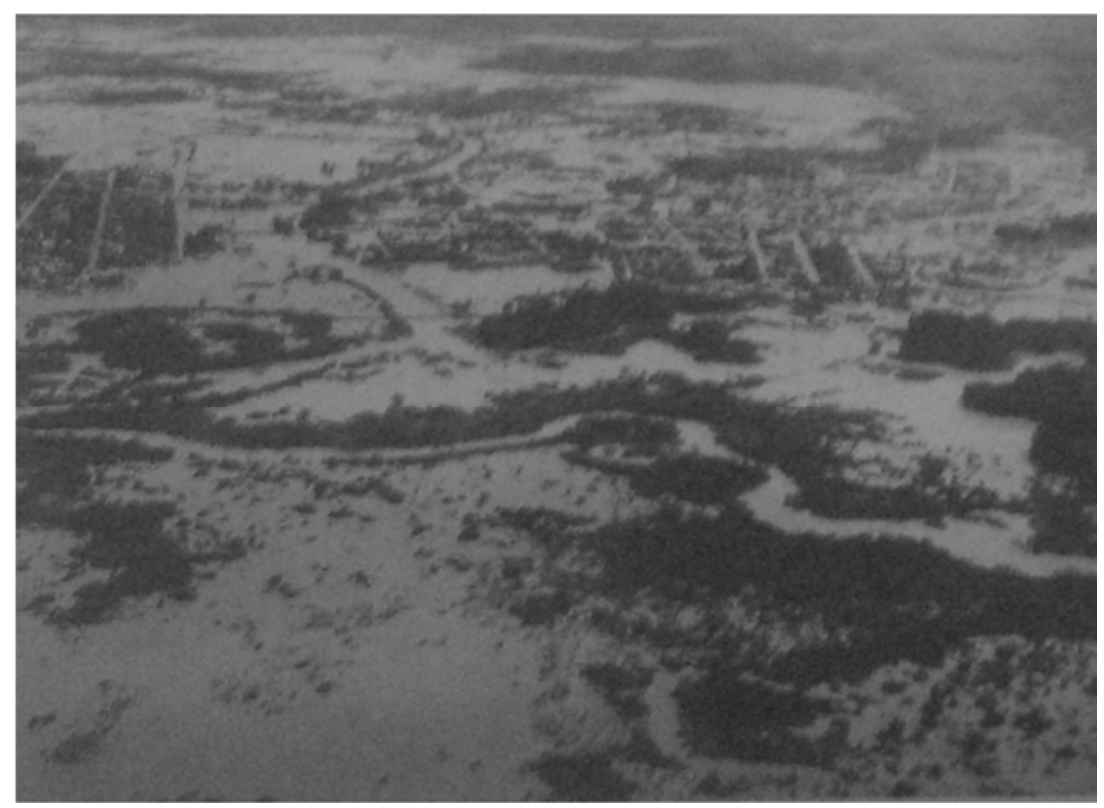

Fotografia 30: Município de São Leopoldo, 1965.

Fonte: METROPLAN, 2001, p. 44

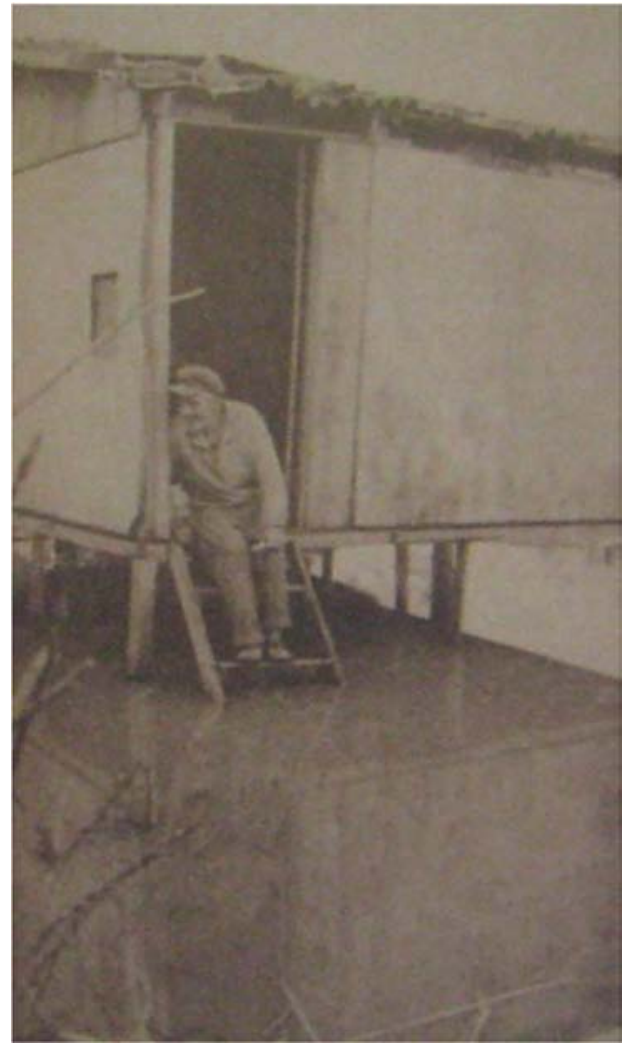

Fotografia 31: Novo Hamburgo, 1976.

Fonte: METROPLAN, 2001, p. 53 
Devido à susceptibilidade natural de ocorrência de inundações em Porto Alegre e parte dos municípios de sua região metropolitana, implantaram-se sistemas de controle de enchentes. A bacia hidrográfica do rio dos Sinos, com seus trechos médio e inferior inseridos na RMPA, é uma área com alto grau de adensamento urbano e industrial, assim os danos causados pela dinâmica natural do rio, agravados pela ação antrópica, podem trazer muitos danos.

As obras do Sistema de Controle de Enchentes do Vale do Rio dos Sinos causaram alterações na dinâmica hídrica dos rios e das terras inundáveis, segmentação entre o rio e suas planícies de inundação, canalizações e criação de canais artificiais.

\subsubsection{Os sistemas de controle de enchentes - Porto Alegre e Vale dos Sinos}

Após a grande enchente de 1941, o governo passou a acelerar os estudos para a implantação do sistema de controle de enchentes de Porto Alegre e Região Metropolitana. Em meados de 1940 o DNOS - Departamento Nacional de Obras e Saneamento enviou engenheiros do Rio de Janeiro para o Rio Grande do Sul para dar início aos trabalhos. Devido ao contexto da Segunda Guerra Mundial, tudo se desenvolvia mais lentamente (METROPLAN, 2001).

O projeto elaborado previa a construção de um anel de diques capaz de suportar enchentes como a ocorrida em 1941. As obras se iniciaram em Porto Alegre e o primeiro pôlder foi construído na região do aeroporto, concluído em 1949. Simultaneamente ocorria a obra do saneamento da estação rodoviária.

Um pôlder é uma porção de terrenos baixos e planos que constituem uma entidade hidrológica artificial, incluída entre aterros conhecidos como diques, utilizados para a agricultura ou moradia. Para esgotamento das águas pluviais, os pôlderes devem ser drenados por meio de canais com comportas e/ou de bombas, a fim de impedir a subida excessiva da água no interior da área ensecada pelos diques.

A necessidade da construção de um pôlder ocorre devido à ocupação em áreas naturalmente ocupadas pelas águas, seja de forma permanente ou temporária. Primeiramente, promovem-se alterações como a construção de quadras para o loteamento modificando os cursos hídricos. $\mathrm{O}$ alagamento periódico, que tende a se intensificar, passa a ser um problema e traz prejuízos materiais e humanos. 
Num primeiro momento, são criados diques que funcionam como barreiras à entrada da água pelo extravasamento natural dos rios ou pela maré alta, mas com a precipitação pluviométrica a água fica represada na área protegida, infiltrando lentamente. Então são também necessários sistemas de bombeamento dessa água para fora do pôlder. O exemplo simplificado na figura 69 é de um pôlder que utiliza sistema para bombeamento da água por meio de pás que podem ser acionadas também com o vento, exemplo utilizado na Holanda, país situado às margens e abaixo do nível do mar.

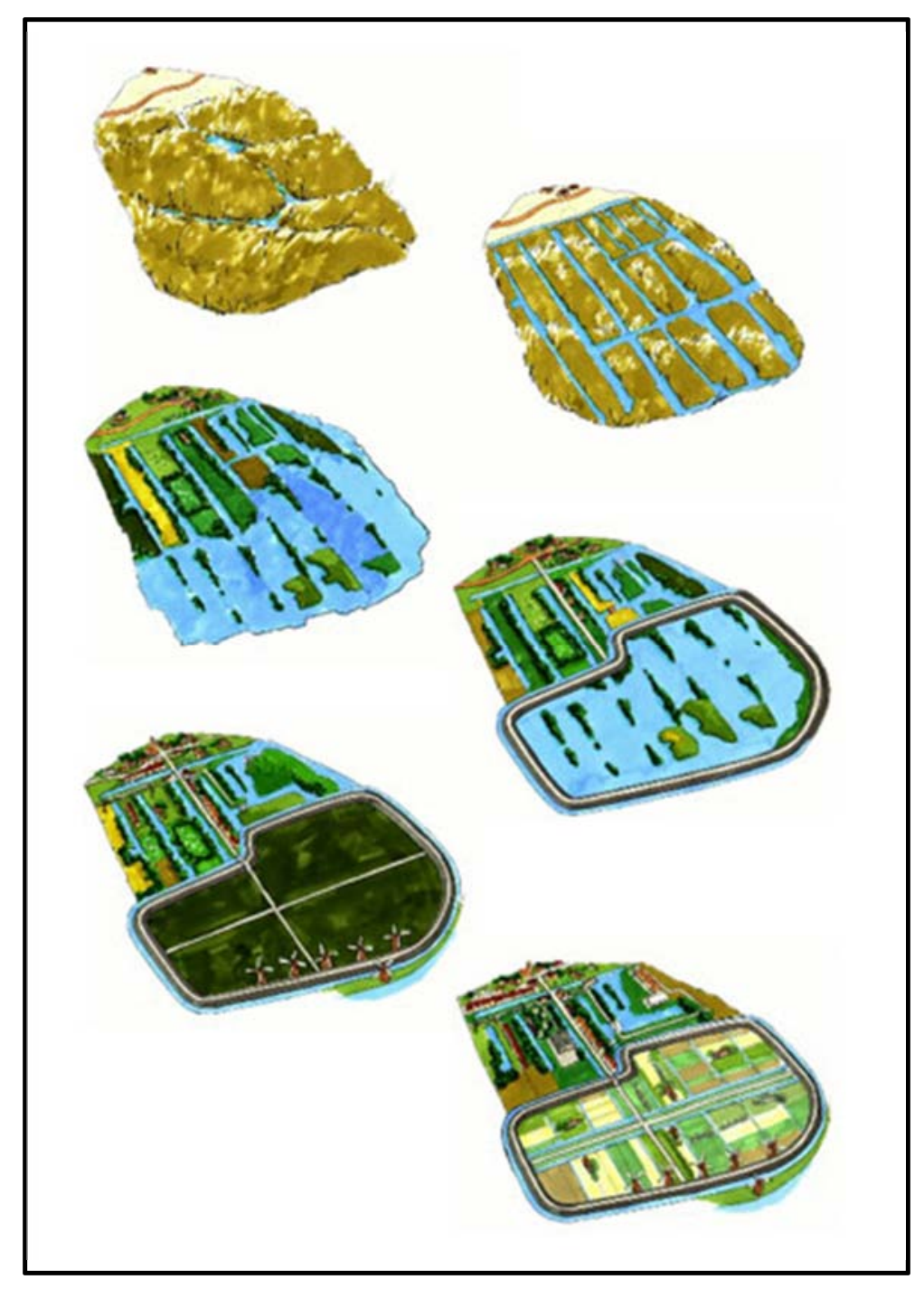

Figura 69: Criação de um pôlder.

Fonte: static.nai.nl/polders/e/hoe_e.html. Acessado 28/06/2010. 
Os sistemas de proteção contra cheias de Porto Alegre e Região Metropolitana se prolongam desde a zona sul da capital gaúcha até São Leopoldo, passando por Alvorada, Esteio, Viamão, Cachoeirinha e Novo Hamburgo. Dessas cidades, além da capital, somente Alvorada e Viamão não estão localizadas na bacia hidrográfica do rio dos Sinos.

Para a implantação do sistema contra inundações no Vale do Rio dos Sinos foram elaborados estudos específicos por técnicos alemães e brasileiros a partir de um acordo afirmado em 30 de novembro de 1963, entre Brasil e Alemanha.

O principal documento elaborado foi o Plano Diretor Geral Hidrológico além do Estudo Socioeconômico, do Plano Geral de Proteção Contras as Cheias e o Estudo da Viabilidade Econômica. Esses documentos, que contam também com peças cartográficas, fazem parte do projeto do Sistema de Proteção Contra Enchentes no Vale do Rio dos Sinos - SCEVRS.

O trabalho, editado em vários volumes, considerou fatores naturais como o clima e a pedologia, além de questões sociais e econômicas. No entanto não se observou relato sobre a importância da preservação dos remanescentes de terras inundáveis. Isso pode ser em parte explicado pelo que disse Paiva (2005) a respeito da questão.

O que ocorre freqüentemente no caso das planícies aluviais é uma exagerada confiança na tecnologia de regularização das bacias hidrográficas (barragens, açudes, diques), o que incute uma falsa sensação de segurança na sociedade em geral, levando a que se permita a construção, e se construa efectivamente, em áreas desaconselháveis do ponto de vista do risco de inundação. (PAIVA, 2005, p. 29)

As características naturais da área facilitaram a ocupação: da sua foz até Campo Bom o rio dos Sinos possui uma depressão com largura variando entre 5 a $8 \mathrm{~km}$. A reduzida declividade dessa área é de aproximadamente três metros entre Campo Bom e São Leopoldo, e um metro entre São Leopoldo e sua foz. As inundações são vistas como um entrave ao maior desenvolvimento da região do Vale, que representa um importante pólo industrial do Rio Grande do Sul (SEMA, 2004).

Segundo relatório do SCEVRS, a prevenção contra as enchentes nestas áreas só seria possível com a construção de diques ao longo do rio dos Sinos, sendo que o extravasamento hídrico pode ocorrer pela elevação das águas do Guaíba, por vazões excessivas no rio dos Sinos, ou pela conjunção de ambos os fatos. 
Os estudos tiveram início em maio de 1967 e foram concluídos após dois anos. Entre as entidades responsáveis estava a firma de Consultoria Alemã, de Essen, com o apoio da Secretaria de Obras Públicas do estado do Rio Grande do Sul e da Faculdade de Economia de São Leopoldo. Inicialmente, a execução das obras foi prevista de Canoas até Campo Bom.

O Departamento Nacional de Obras Públicas - DNOS que trabalhava há longa data em defesa contra as inundações, ficou responsável pela execução das obras participando com 50\% dos recursos nacionais; os outros $50 \%$ foram financiados pelo governo do Rio Grande do Sul. Foi prevista a construção de seis pôlderes, sendo eleitos como prioritários os pôlderes IV e V (Figura 70) pela maior importância socioeconômica.

Verifica-se na figura 70 o adensamento urbano muito próximo ao canal principal do rio dos Sinos, herança da colonização alemã, que teve seu início em 1824, em São Leopoldo. No local onde os diques estão paralelos ao rio, num trecho aproximado de 160 metros, o leito maior foi suprimido, ocorrendo um estrangulamento do rio e, por consequência, o maior represamento das águas nas áreas a montante. Na seção transversal do rio, no mesmo trecho, há três pontes que limitam a altura da água dificultando o escoamento. 


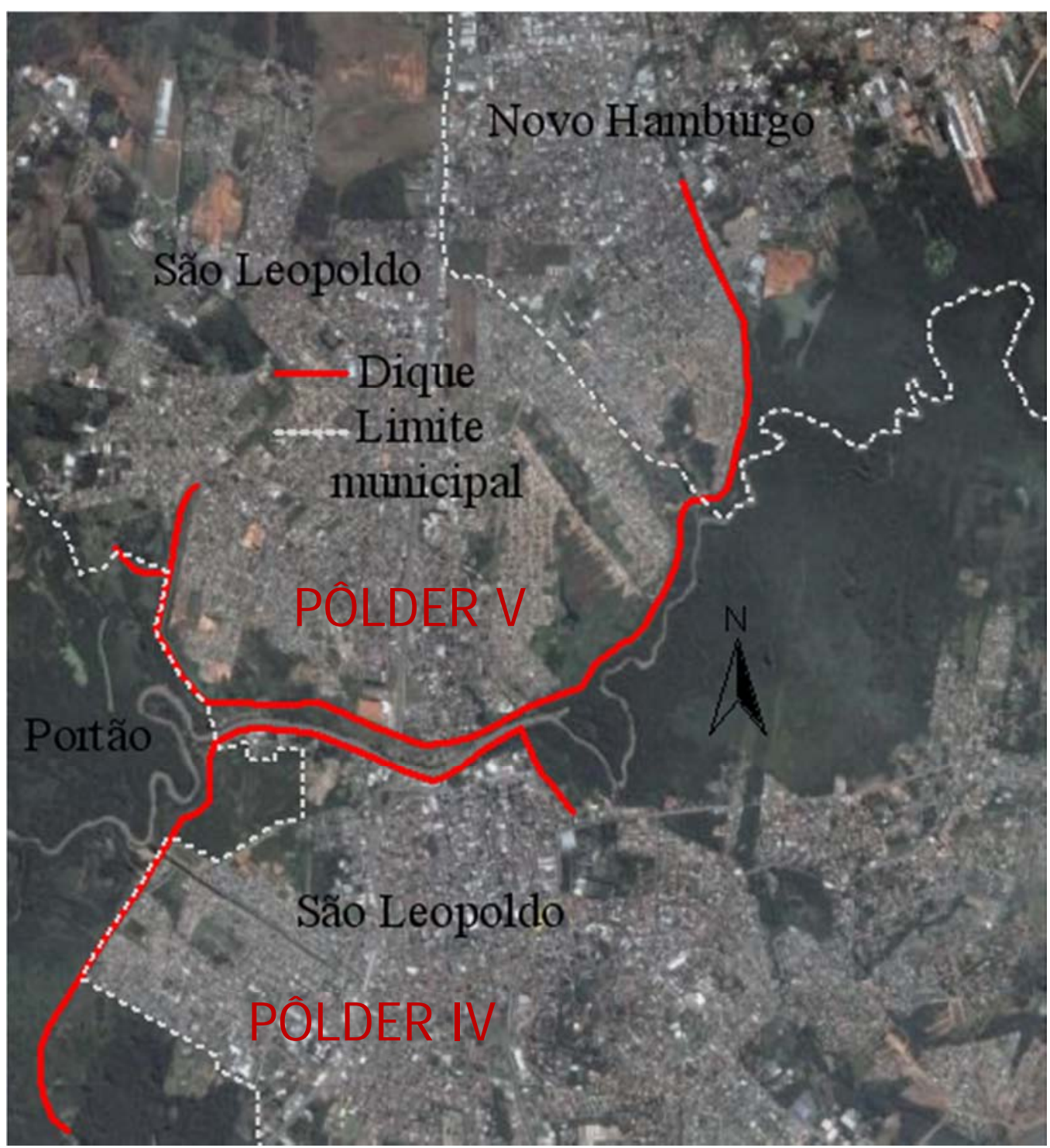

Figura 70: Pôlderes IV e V.

Elaboração: Adriana Penteado, 21/09/09.

Devido à configuração atual as terras inundáveis a montante da área de estrangulamento assumem maior importância na retenção das águas que escoam das cabeceiras do rio dos Sinos até esse ponto. As mudanças na cobertura do solo, como o desmatamento, causam erosão e aumentam a quantidade de sedimentos em suspensão nos rios. Com o conseqüente assoreamento as terras inundáveis vão perdendo a capacidade de armazenamento do volume de água que tende a se espraiar cada vez mais lateralmente, aumentando as inundações. O segmento entre os pôlderes IV e V é um dos mais críticos e os sistemas de controle das inundações devem ser 
pensados em conjunto com a preservação dos remanescentes naturais, a fim de evitar a necessidade de mais obras a montante.

Em vista da criticidade dessa área foram necessários ensaios em modelo para simular situações e formas ótimas sob o ponto de vista técnico-hidráulico. A partir dessa simulação foi também possível verificar a relação da velocidade da água com a erosão do leito do canal.

Para a execução do modelo, o DNOS contratou o Instituto de Pesquisas Hidráulicas - IPH da Universidade Federal do Rio Grande do Sul - UFRGS. Dois modelos reduzidos foram estudados, o primeiro considerou possíveis ampliações das pontes e afastamentos entre os diques da margem esquerda e direita. A partir dos resultados obtidos optou-se pelo segundo modelo, pois necessitava de menor custo e o investimento poderia ser aplicado em um espaço de tempo maior que no primeiro modelo.

Na execução do segundo modelo foi criado um canal lateral que desvia a descarga de água não absorvida pelo leito principal e nas seções das pontes, reintegrando-se novamente ao leito natural a jusante das pontes da BR 116, transformando a zona central em ilha (Figura 71). 


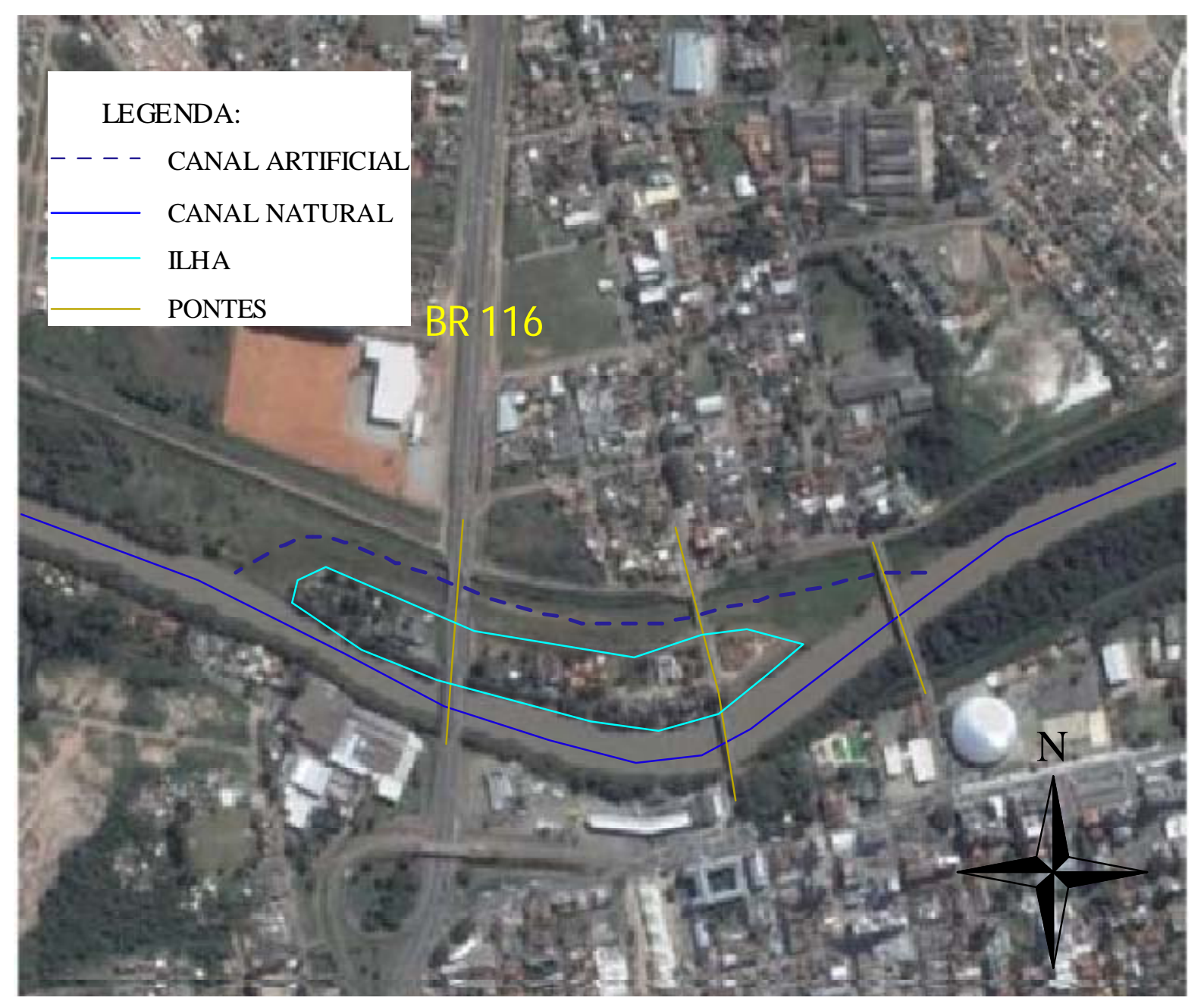

Figura 71: Criação de canal artificial

Fonte: Google Earth, adaptação Adriana Penteado, 02/2010.

A drenagem dos pôlderes do SCEVRS é feita por canais abertos e casas de bombas utilizando sifões para a travessia das estradas. A alguns canais de macrodrenagem estão associadas comportas (Fotografia 32) que abrem com a elevação do nível de água e a partir daí, as casas de bombas (Fotografia 33) bombeiam a água para o rio dos Sinos. As casas de bombas possuem capacidade diferenciada: nas que possuem duas bombas, o potencial é de $1 \mathrm{~m} / \mathrm{s}$, já nas com sete bombas a capacidade é de $18,20 \mathrm{~m} / \mathrm{s}$. 


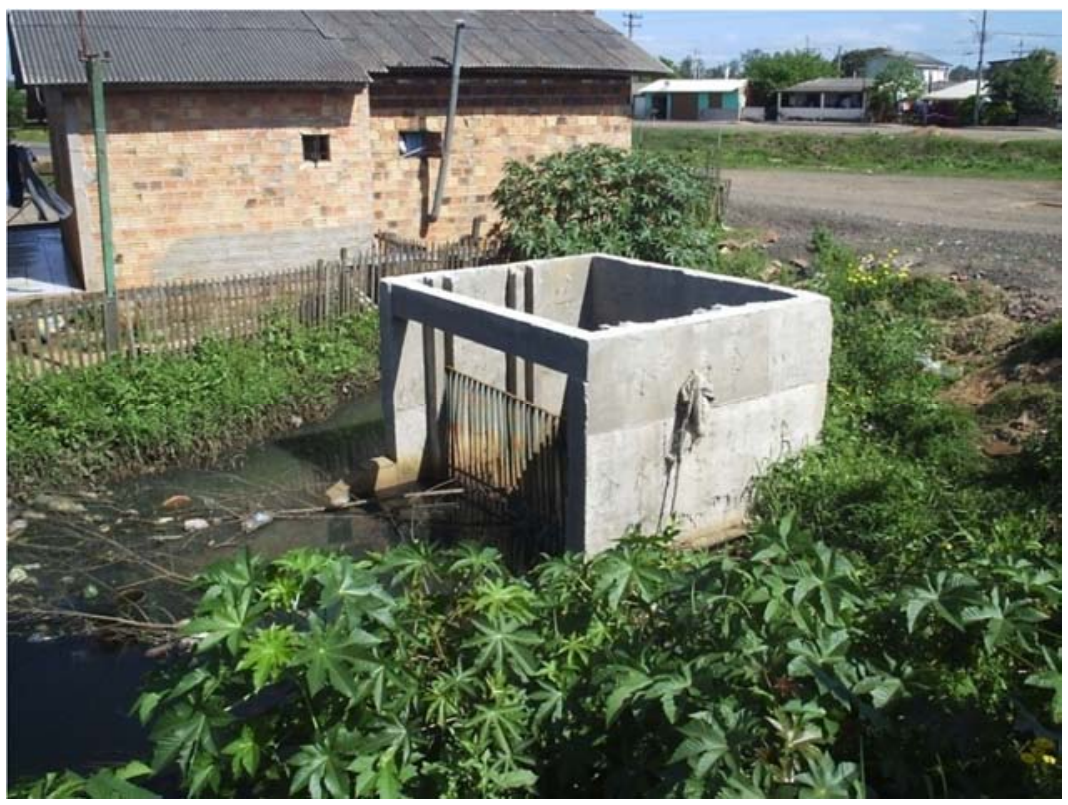

Fotografia 32: Comporta do sistema de macrodrenagem.

Fonte: Adriana Penteado, 09/2009.

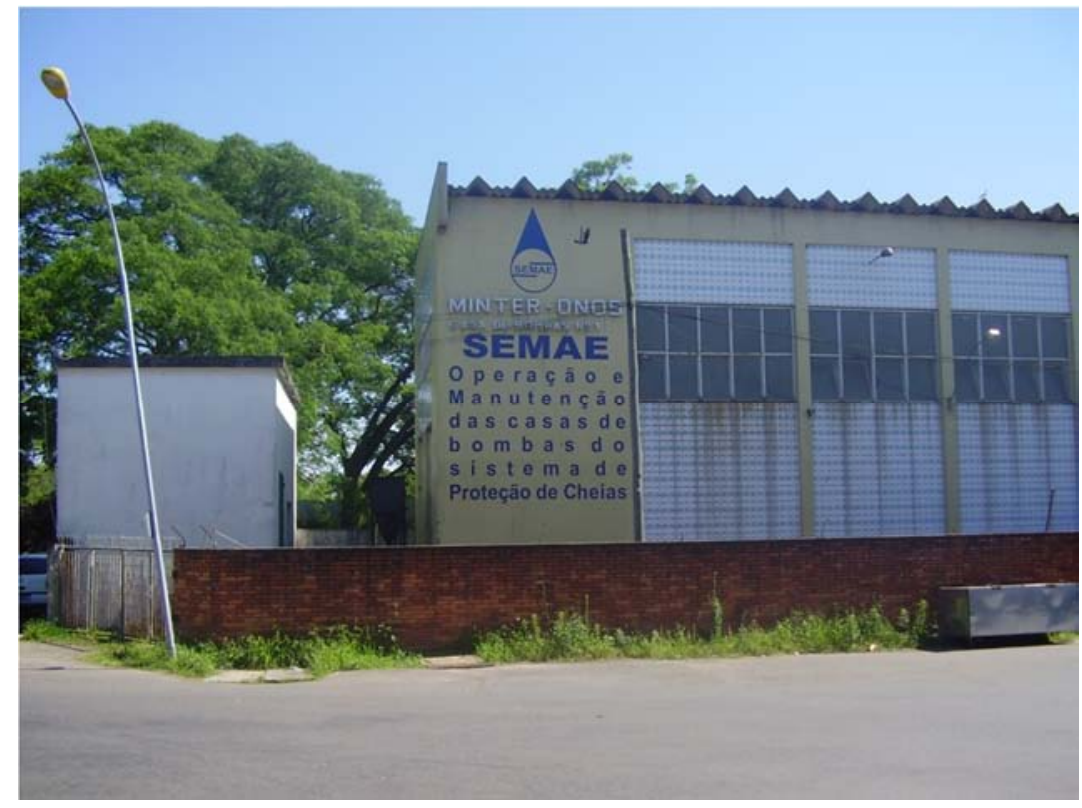

Fotografia 33: Casa de Bombas.

Fonte: Adriana Penteado, 10/2009.

O SCEVRS compreende também os diques (Fotografia 34), que tiveram seu traçado baseado em estudos hidráulicos. Os principais possuem altura de 6 metros, inclinação dos taludes 
de 1:2 nas faces voltadas para o rio e 1: 1, 75 nas faces voltadas para o pôlder, com largura de 4,5 metros (Anexo G).

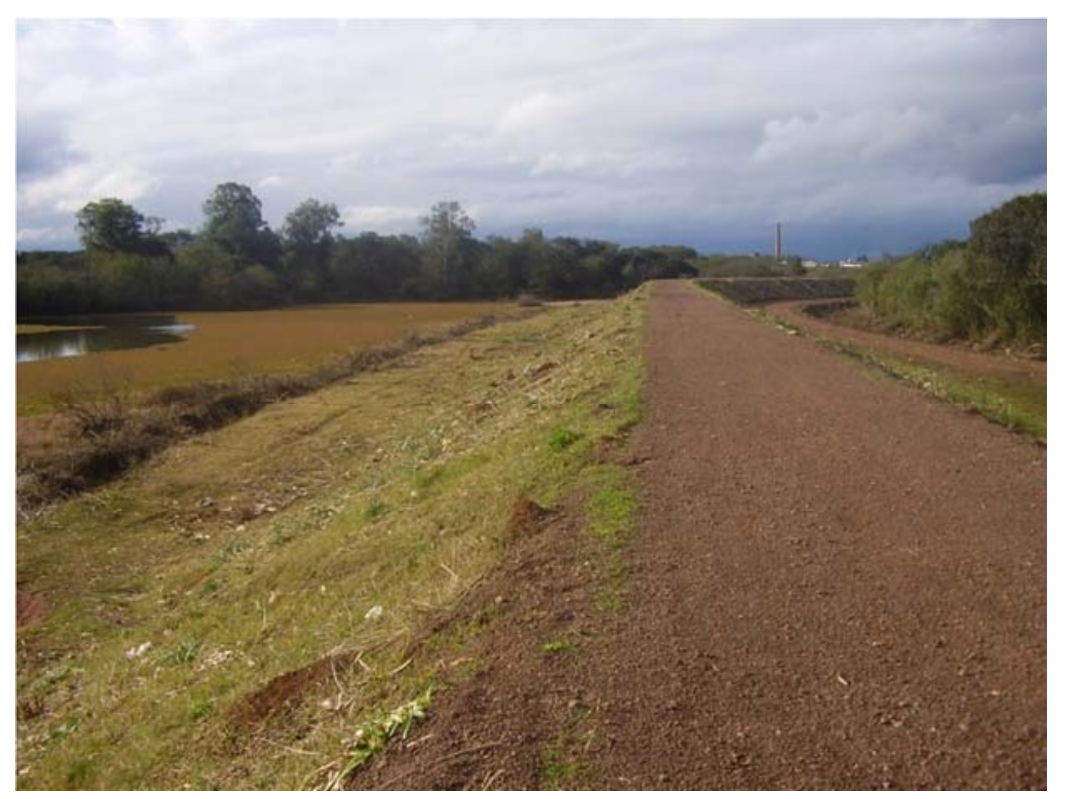

Fotografia 34: Dique construído com materiais inconsolidados.

Fonte: Adriana Penteado, 16/08/09.

Nas áreas onde o rio dos Sinos sofre estrangulamento e/ou em áreas com alto grau de adensamento urbano-industrial, foram também construídos muros de arrimo (Figura 35), cortinas ou muro em L, canalizações e alterações na altura e/ou na localização de pontes. 


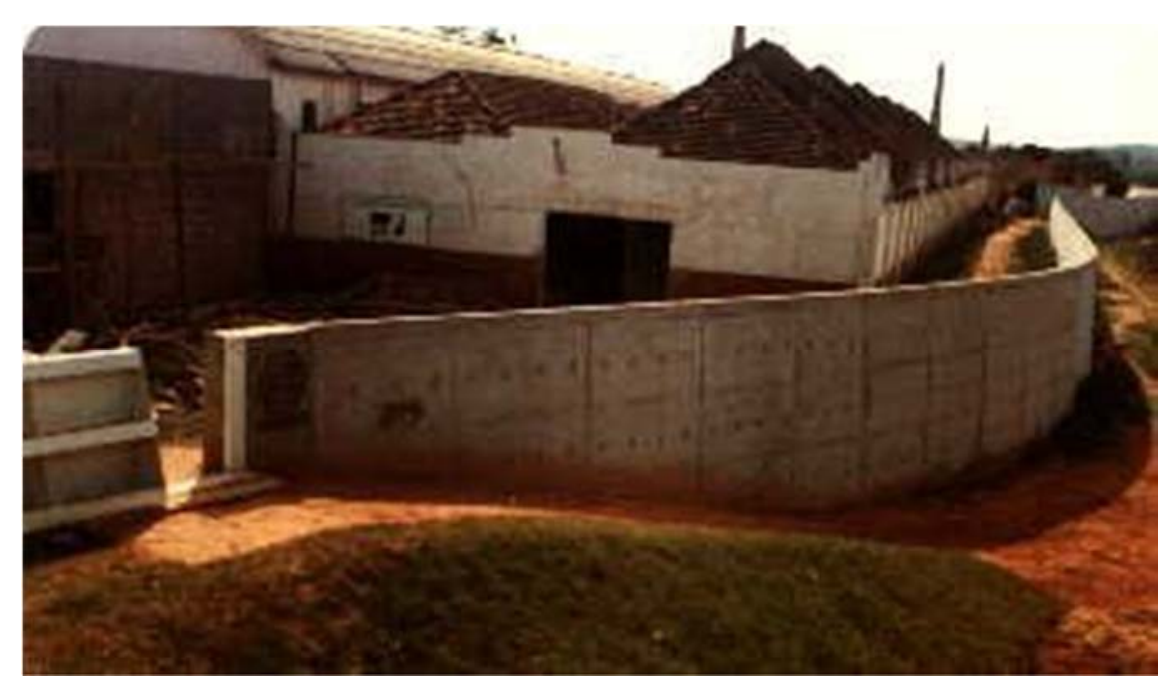

Fotografia 35: Dique de cimento no centro de São Leopoldo. Fonte: Projetos - Rio dos Sinos 09/2009.

O SCEVRS previa a construção de seis pôlderes, porém segundo relatório do projeto, o número seis não foi executado devido aos altos custos e a pequena área que recuperaria. $\mathrm{O}$ tamanho de cada pôlder bem como a localização dos mesmos pode ser visualizado no Anexo $\mathrm{H}$.

O DNOS foi extinto em 1992, desde então o planejamento e as atividades relativas aos sistemas de drenagem, meso e macro, em nível regional, não estão sendo desenvolvidos. Há carência de um ou mais órgãos que assumam esse papel (METROPLAN, 2001).

Os diques laterais e os muros de arrimo são responsáveis pela segmentação das terras inundáveis, somadas a essas alterações, a criação de canais laterais e as canalizações alteram a dinâmica hídrica do rio e de suas terras inundáveis.

Na Fotografia 36 a construção ao fundo compreende a casa de bombas do SCEVRS localizada no município de Canoas. O rio na fotografia foi criado artificialmente para captar as águas que antes eram naturalmente inundadas pela dinâmica natural do rio e acompanha a linha do dique que pode ser visto, coberto por vegetação rasteira, na margem esquerda da fotografia. 


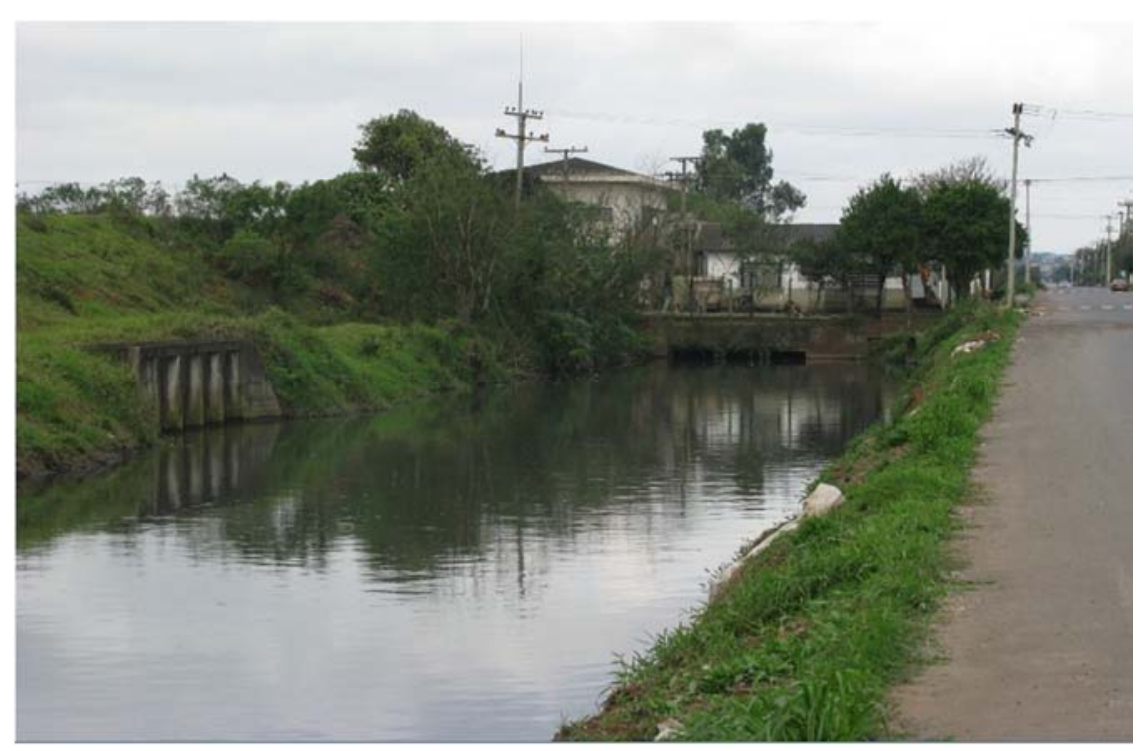

Fotografia 36: Casa de bombas, canal artificial e dique no município de Canoas. Fonte: Adriana Penteado, 09/2010.

Dentre as alterações no solo que contribuem para agravamento das inundações está a canalização dos rios. Tucci (1995) definiu os estágios de transferência de enchentes por canalização, que compreendem, de forma resumida, as seguintes características:

* no primeiro momento a bacia começa a ser urbanizada de maneira distribuída, sendo que a maior intensificação se dá a jusante, aparecendo assim, no leito natural, os locais de inundação, devido aos estrangulamentos naturais ao longo do seu curso;

* no segundo momento, ocorrem as canalizações a jusante com base na urbanização atual. Ocorre ainda um controle pelas áreas que inundam a montante, considerando que a bacia não está totalmente ocupada;

* no terceiro e último momento, com a maior densificação da área, a pressão social faz com que os administradores públicos continuem o processo de canalização para montante e, assim, quando o processo se completa, ou mesmo antes, as inundações retornam para jusante, devido ao aumento da vazão máxima, que não possui condições de ser ampliada. As soluções acabam muitas vezes convergindo para o aprofundamento do canal.

Mesmo com o Sistema de Controle de Enchentes, as inundações continuam ocorrendo, seja por transferência do problema para outras áreas, seja porque a dinâmica da inundação permanece em virtude da subida do lençol freático e da precipitação. 
A Fotografia 37 e a Fotografia 38 registram a inundação no ano de 2008 em São Leopoldo, sendo um problema frequente nesta área. Nesse caso, os três fatores naturais: precipitação (input do sistema), subida do lençol freático e extravasamento do rio dos Sinos, foram os responsáveis pelo ocorrido.

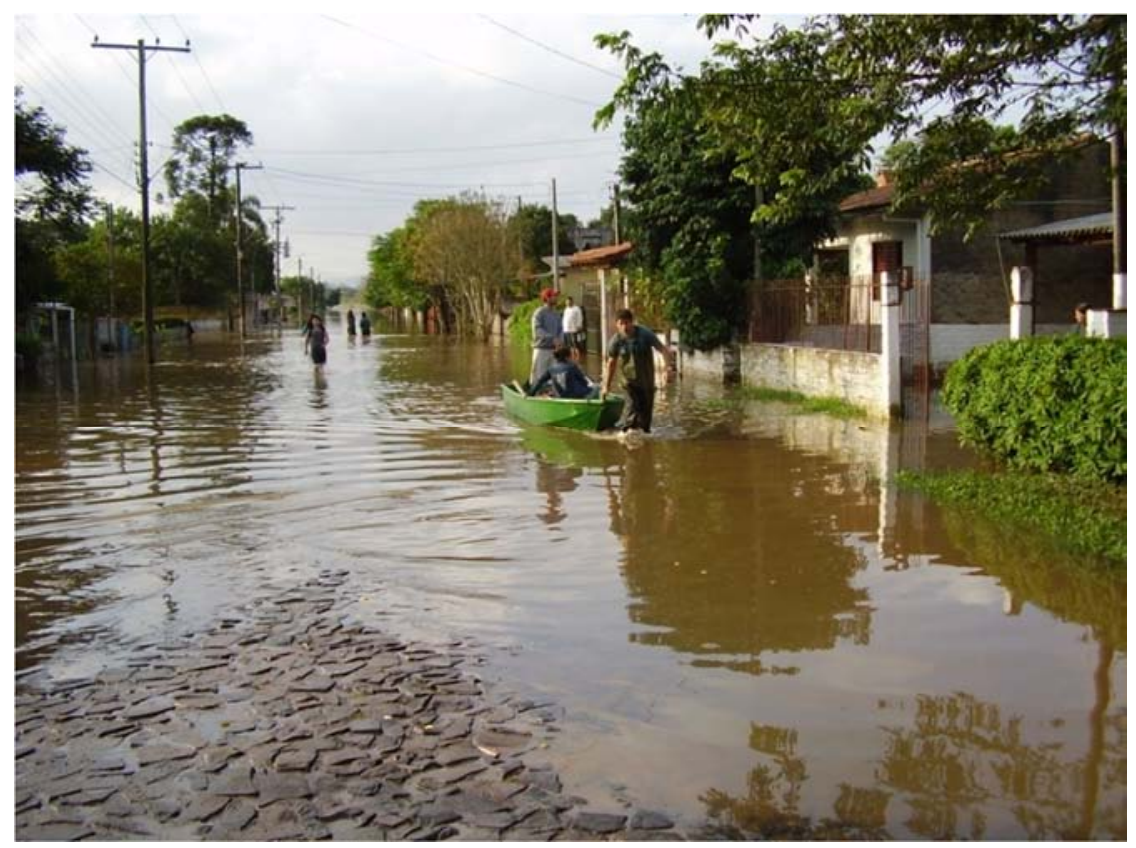

Fotografia 37: Inundação no trecho inferior do rio dos Sinos. Fonte: Adriana Penteado, 04/2008.

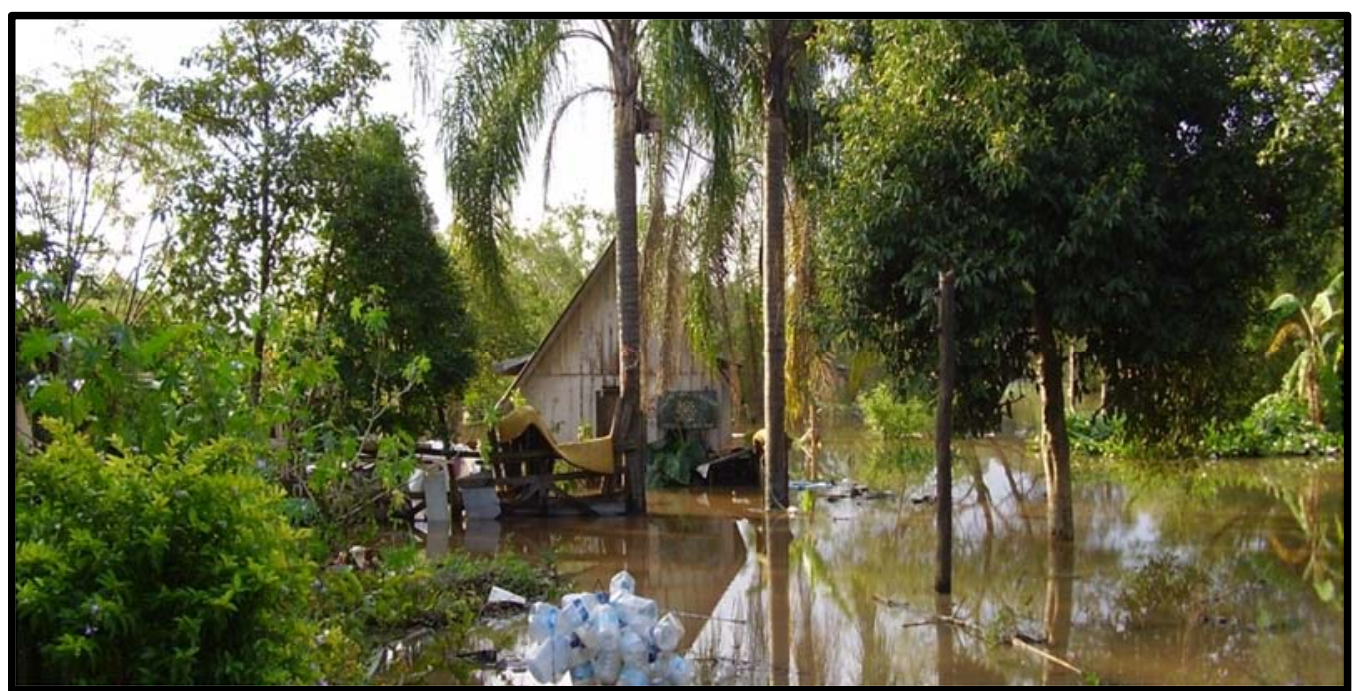

Fotografia 38: Inundação no trecho inferior do rio dos Sinos. Fonte: Adriana Penteado, 04/2008. 
A reportagem do Jornal VS de 2009 (Figura 72) mostra a preocupação e os estragos causados pela subida do nível do rio. A intensidade das chuvas tem levado a índices recordes o nível do rio dos Sinos. Segundo a reportagem, no município de Taquara o rio subiu 3,9 m, atingindo 7,8 m; em Campo Bom, subiu 2,4 m atingindo 7,2 m; em Novo Hamburgo subiu 3,22m atingindo 6,72 m. Em São Leopoldo, segundo a Defesa Civil, o rio deveria chegar a $7 \mathrm{~m}$.

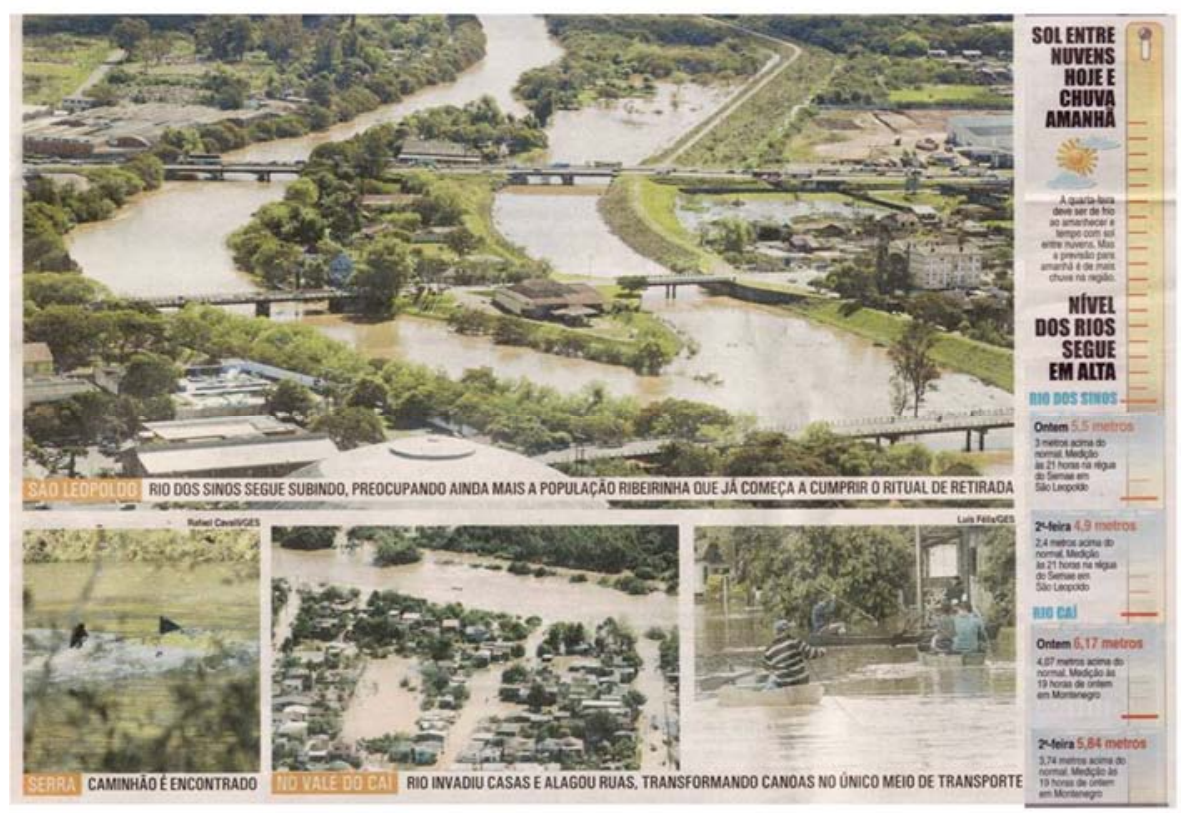

Figura 72: Inundações no Vale do rio Sinos e no Vale do rio Caí.

Fonte: Jornal VS, 09/2009.

A explicação para as mudanças bruscas no tempo é que períodos muito secos costumam ser seguidos por eventos extremos de chuva. O ano de 2009 começou com o fenômeno La Niña ${ }^{16}$, que trouxe a estiagem do começo do ano; já o segundo semestre foi influenciado pelo El Niño ${ }^{17}$, que resultou em excesso de chuva (METSUL, 2009).

\footnotetext{
${ }^{16}$ La Niña corresponde ao resfriamento atípico das águas do Oceano Pacífico e também desempenha considerável impacto nas atividades humanas. Este fenômeno se efetiva quando a porção leste do Pacífico (Taiti) fica sujeita ao aumento de suas pressões, geralmente elevadas. Fonte: Mendonça, 2007.

${ }^{17}$ El Niño é um fenômeno que se caracteriza pelo aquecimento incomum das águas superficiais na porção central e leste do oceano Pacífico, nas proximidades da América do Sul, mais particularmente na costa do Peru. A corrente de águas quentes circula, em geral, na direção sul no início do verão. Somente recebe este nome quando a anomalia térmica é elevada $\left(1^{\circ} \mathrm{C}\right)$ ou muito elevada $\left(\right.$ de $4^{\circ}$ a $\left.6^{\circ} \mathrm{C}\right)$. Fonte: Mendonça, 2007.
} 


\subsubsection{Riscos associados às obras de controle de enchentes do vale do rio dos Sinos}

De forma geral, as obras de contenção contra cheias necessitam de constante manutenção para que não haja rompimento ou falhas que comprometam a segurança do sistema. Segundo Tucci (1995), o controle das inundações urbanas é um processo permanente que deve ser mantido pelas comunidades, visando à redução do custo social e econômico dos impactos.

As medidas adotadas para este problema quase sempre apresentam caráter localizado. Os trechos dos canais ampliados reduzem os prejuízos das áreas afetadas, porém, devido à transferência das vazões, as inundações agravam-se para jusante e as planícies utilizadas pelos rios ou córregos nas cheias, suprimidas pelas obras de urbanização, serão sempre requeridas a jusante (CANHOLI, 2005).

As inundações ocorridas no Vale do rio dos Sinos em 1983, 1984, 1985, 1987 e 1989, atingiram cotas muito superiores ao que seria esperado pelo volume de água precipitado. Atribuiu-se a esse fato a dificuldade de escoamento causado por obstáculos e pelo represamento devido à antiga ponte da estrada de ferro em São Leopoldo (SECRETARIA DO DESENVOLVIMENTO DO GOVERNO DO RIO GRANDE DO SUL, 1992).

Os diques de terra são compostos basicamente de areia, argila e silte. O corpo do dique é composto de argila muito arenosa e pouco siltosa, facilitando a infiltração da água. Na base são utilizadas argila e brita compactada para evitar a formação de depressões. Os diques foram projetados com base na grande inundação de 1941, quando o rio dos Sinos atingiu cota máxima de 6,25 metros. O que contribuiu para tal fato foi o represamento das águas devido ao aterro das obras da BR 116 que estava em construção na época.

O Manual de Operação e Manutenção do Sistema de Proteção, elaborado pela Consultoria Alemã, alerta para os perigos da má conservação dos diques de terra e canais de macrodrenagem. Destacando os seguintes pontos: 
* O coroamento de saibro, que compreende a parte superior do dique, não pode ter depressões que permitam o acúmulo de água.

* Deve ser efetuada a retirada da vegetação arbustiva alta, pois suas raízes podem desestabilizar os taludes em épocas de cheia.

* É necessário o controle da erosão dos taludes dos diques, que é provocada pela passagem de pedestres e animais.

* Só deverá ser permitido o tráfego de bicicletas e motos sobre os diques.

* Não devem ser construídas casas e rampas nos maciços e nas bermas de equilíbrio dos diques.

* O enleivamento dos taludes do maciço das bermas deve ser mantido raso e homogêneo.

* Deve ser impedida a construção de casas nas faixas de domínio dos diques e canais de macro drenagem.

A partir de trabalhos de campo, foi possível constatar que o Sistema encontra-se com manutenção deficiente. Na Fotografia 39 visualizaram-se construções irregulares na bermas de equilíbrio do dique e próximas aos canais laterais de macrodrenagem. Com o constante acesso de pessoas para a parte superior do dique, criaram-se caminhos que suprimiram a vegetação de gramíneas, e isso levou a formação de sulcos erosivos. 


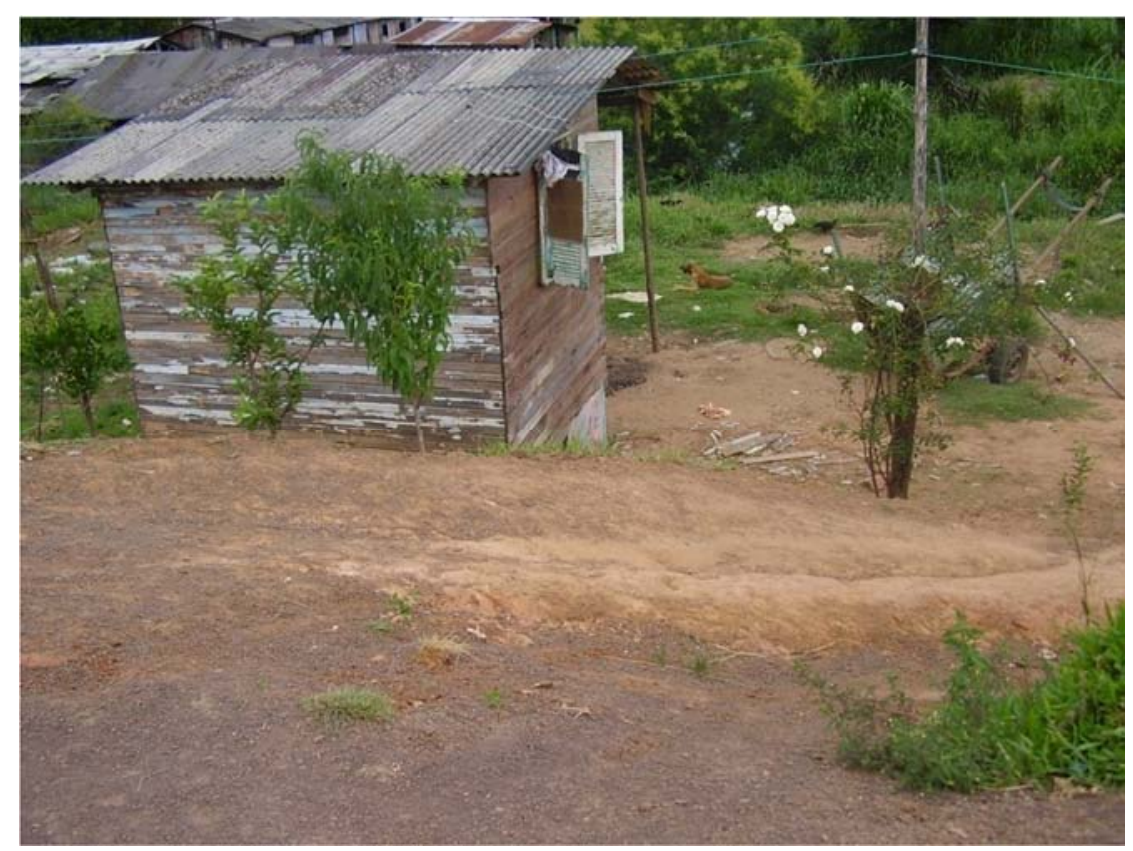

Fotografia 39: Moradias irregulares nas bermas de equilíbrio dos diques e sulcos erosivos. Fonte: Adriana Penteado, 10/2010.

Também foram encontradas árvores de médio-grande porte, que podem ter sido plantadas pelos moradores das ocupações irregulares ou que nasceram naturalmente e não foram retiradas devido à falta de manutenção do Sistema. É necessária a existência de gramíneas ou vegetação arbustiva de pequeno porte para que o material do dique não fique exposto e, por consequência, sofra erosão. Já a vegetação de maior porte fragiliza o Sistema devido à profundidade que atingem as raízes. $\mathrm{Na}$ época de cheia do rio, a força da água em movimento sobre a vegetação arbórea potencializa o problema.

A parte superior dos diques pode servir para o deslocamento das pessoas desde que estas não utilizem veículos como carros e tratores (Fotografia 35), pois o peso destes pode formar depressões na parte superior do dique promovendo o acúmulo de água e desestabilização do mesmo. Na Fotografia 40, além de um trator, é também possível verificar corte do talude do dique para a construção de uma rampa de acesso para o tráfego de veículos pesados. Grande quantidade de material do corpo do dique foi removido. 


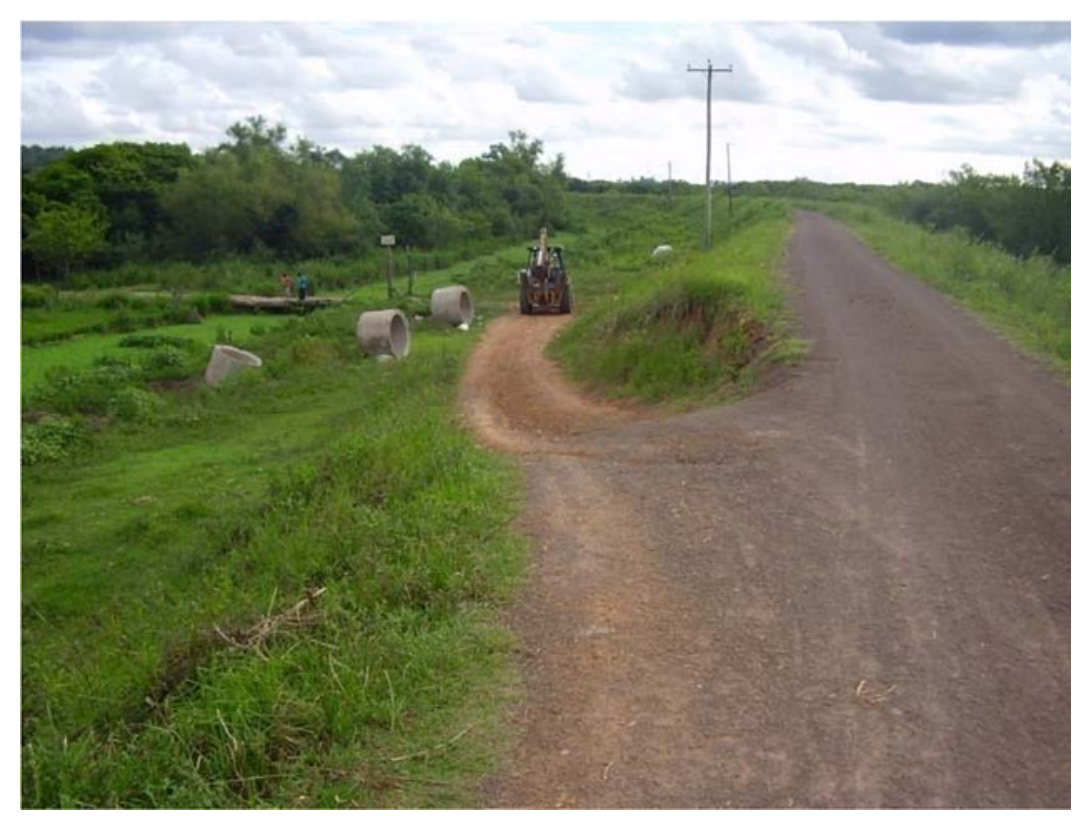

Fotografia 40: Construção irregular de rampas de acesso ao dique e tráfego de veículo pesado.

Fonte: Sandro Petry, 01/2010.

Aterros também foram verificados nas planícies do rio dos Sinos causando perda de profundidade do mesmo e contribuindo para a possível necessidade de dragagem, que além do custo econômico, causaria danos à biodiversidade da área.

Segundo relatório técnico do SCEVRS (2005), as obras de manutenção das Valas de Macrodrenagem encontram dificuldades de execução, pois em alguns trechos já não é mais possível dragar devido à localização de casas irregulares nas faixas de domínio e nas áreas reservadas para o trânsito dos equipamentos ao longo de todo o Sistema de Controle e, até mesmo, nos diques.

A partir dessa situação, o sistema de proteção teve que executar os serviços de dragagem utilizando-se o passeio interno e a berma de equilíbrio para o trânsito dos equipamentos e para a deposição resultante da dragagem, comprometendo a estabilidade dos diques.

Quanto à manutenção dos equipamentos do SCEVRS, o Ministério das Cidades transferiu para o Ministério da Integração Nacional 24 milhões de reais. As prioridades serão as reformas das casas de bombas dos diques, sendo que a casa que se encontra em estado mais crítico está localizada no bairro Santo Afonso, em Novo Hamburgo (JORNAL VS, 2009). 
O processo de degradação do sistema de controle das inundações teve início mais ou menos em 1990, quando o DNOS foi extinto e as obras foram paralisadas.

Segundo Relatório Técnico do SCEVRS (2005), as obras de contenção contra cheias com manutenção inadequada e danos significativos em sua estrutura são piores do que não ter obra alguma, pois, nesse caso, as inundações ocorrem gradativamente, ao contrário daquelas obras que possam romper provocando ondas de grandes dimensões.

Diante dos prejuízos e entraves que as ocupações irregulares têm causado, percebe-se que a remoção destas casas e o impedimento da instalação de novas moradias é um caso de segurança pública no que tange à população residente próxima aos diques.

Com as ocupações já estabelecidas e mesmo com a construção de sistemas de proteção contra inundações, a manutenção do sistema é tão importante quanto à preservação dos ambientes naturais que ainda restam, pois no caso de um evento pluviométrico extremo e falhas no sistema de controle de enchentes, os sistemas naturais servirão como zonas de amortecimento das inundações.

Em inúmeros pontos e de variadas formas, na área de estudo é possível registrar a destruição e/ou a alteração das terras inundáveis, mesmo com as inundações causando danos e mesmo com os riscos de desabastecimento de água potável em períodos de estiagem. As omissões ou ações isoladas com reflexos cumulativos têm consequências em todo o sistema hídrico da bacia hidrográfica do rio dos Sinos.

Com o passar do tempo as concepções humanas podem se alterar e evoluir e com isso novas formas de abordagem surgem. Quando o SCEVRS foi implantado, as obras eram vistas como a melhor e talvez a única forma de resolver o problema das inundações, não tendo sido considerada a possibilidade de renaturalização, ao menos em parte, dos recursos hídricos e de suas planícies.

As obras tiveram apoio técnico dos alemães que, com o passar do tempo, após a conclusão das obras, inseridos numa concepção ideológica européia, adotaram uma visão ambientalista quanto aos problemas causados pelas intervenções nos recursos hídricos. Foram iniciadas ações no sentido de renaturalizar os rios europeus.

A aplicação desta proposta possui muitas limitações, principalmente quando se trata de zonas urbanas e vias de transporte; porém a partir do entendimento entre as interações antrópicas 
e a natureza, permite-se que sejam consideradas novas estratégias, valorizando as condições naturais dos cursos hídricos e das baixadas inundáveis (Rios e Córregos, Preservar, Conservar e Renaturalizar, $1998^{18}$ ).

Na maioria dos países da Europa, durante a primeira metade do século passado, e mais atualmente no Brasil, muitos rios e córregos foram retificados com o objetivo de proteger zonas urbanas, vias de transporte e terras agrícolas contra cheias. As considerações ambientais não receberam prioridade e, nesse sentido, os maiores prejuízos referem-se à perda da diversidade da biota.

\subsection{Destinação de resíduos sólidos da bacia hidrográfica do rio dos Sinos}

\subsubsection{Resíduo doméstico}

Segundo Silva (2008), dos 32 municípios que compõem a bacia do rio dos Sinos, considerando as Licenças de Operação vigentes na data da pesquisa junto à FEPAM, apenas 10 possuem aterros. Segundo a fonte: Aterro Sanitário ${ }^{19}$ de Resíduos Sólidos Urbanos: Canoas (no Bairro Guajuviras) e Sapucaia do Sul (na localidade de Costa do Morro); Central de Triagem com Aterro de Resíduos Sólidos Urbanos: Dois Irmãos (na localidade de Picada Verão), Nova Hartz e

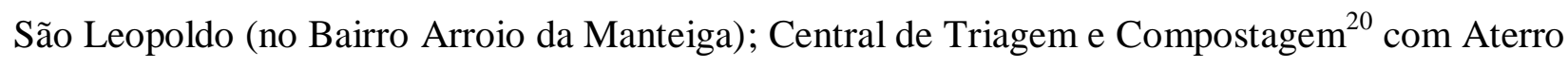
de Resíduos Sólidos Urbanos: Campo Bom (no Bairro Mônaco), Rolante (na localidade de Morro da Glória), Sapiranga (na localidade de Fazenda Leão) e Taquara (na localidade de Moquém); e somente Gravataí possui “Aterro Controlado de Resíduos Sólidos Urbanos” ${ }^{21}$, na localidade de Costa do Ipiranga.

\footnotetext{
${ }_{18}^{18}$ Revista traduzida do alemão para o português.

19 Aterros sanitários de resíduos sólidos urbanos consistem na técnica de disposição destes resíduos sobre solo, sem causar danos ou riscos à saúde pública e à segurança, minimizando os impactos ambientais, método este que utiliza os princípios de engenharia para confinar os resíduos sólidos ao menor volume permissível, cobrindo-os com uma camada de terra na conclusão de cada jornada de trabalho ou em intervalos menores se for necessário (Associação Brasileira de Normas Técnicas - ABNT).

${ }^{20}$ A triagem compreende a técnica de separação e reaproveitamento de resíduos, já a compostagem consiste na utilização da matéria orgânica para a produção de adubo.

${ }^{21}$ Os aterros chamados de controlados são geralmente antigos lixões que passaram por um processo de remediação da área do aterro. Possuem sistemas de controle simplificados, nos quais a disposição do lixo sobre o solo é feito em valas, em camadas, cobertas com uma camada de terra ou material inerte. Devem ser ser isolados e conter drenagem
} 
Um total de quatorze municípios (São Francisco de Paula, Canela, Gramado, Santa Maria do Herval, Três Coroas, Taquara, Araricá, Parobé, Dois Irmãos, Estância Velha, Novo Hamburgo, São Sebastião do Caí, Capela do Santana, Portão) destinam seus resíduos à empresa SL Soluções Ambientais, que implantou, em 1992, um aterro sanitário no município de Minas do Leão, localizado a uma distância aproximada de $80 \mathrm{~km}$ a sudoeste, em linha reta, da foz do rio dos Sinos.

Os municípios que não possuem aterro licenciado ou destino do lixo identificado são: Caraá, Osório, Riozinho, Santo Antônio da Patrulha, Igrejinha, Glorinha, Nova Santa Rita, Esteio e Cachoeirinha. Tanto os municípios que constam com aterros ambientalmente licenciados, como os que não constam, podem apresentar inúmeros focos clandestinos de disposição de lixo (pela população em geral), como também centrais de triagem, reciclagens, entrepostos de resíduos sólidos etc., tolerados ou mesmo promovidos pelo poder público, que não estão enquadrados dentro de normas adequadas.

As terras inundáveis ainda são vistas como locais que dificultam o avanço das ocupações, assim os aterros são vistos como uma solução. Os rejeitos urbanos muitas vezes são utilizados para aterrar essas áreas, seja para a moradia ou para evitar o custo da destinação adequada. Dependendo do tipo de material utilizado, pode ocorrer a poluição dos solos e do lençol freático.

Nas pesquisas de campo na área de estudo, verificou-se a destinação inadequada de rejeitos industriais e domésticos despejados nas margens do rio dos Sinos e de seus afluentes.

\subsubsection{Problemas relacionados ao despejo de curtume}

O Brasil é um dos líderes mundiais na exportação de couros, porém com pouca agregação de valor a esses produtos. Do total comercializado no exterior, $80 \%$ são em estágio primário de curtimento e apenas $20 \%$ como produto inteiramente manufaturado (ASSOCIACAO BRASILEIRA DAS INDUSTRIAS DE CALÇADOS - ABICALÇADOS, 2004).

superficial. O aterro controlado é uma melhor prática do que os lixões, mas deve ser encarado como solução provisória, por ser precário do ponto de vista sanitário e ambiental.

Fonte: http://www.portalsaofrancisco.com.br/alfa/meio-ambiente-reciclagem/aterro-controlado.php. 23/02/2010. 
As indústrias de couros e peles, um dos ramos produtivos com maior potencial poluidor, correspondem juntamente com o setor calçadista, à atividade industrial predominante no Rio Grande do $\mathrm{Sul}^{22}$. Durante décadas, consideráveis volumes de efluentes líquidos das empresas de couros e peles, com elevada carga poluidora orgânica e inorgânica, foram lançados in natura nos rios do Estado, sendo os resíduos sólidos depositados diretamente no solo, geralmente nas margens dos rios ou em áreas consideradas improdutivas, como terrenos alagáveis (KRIEGER, 2000 apud RODRIGUES, 2007). Mesmo com leis para o controle desses efluentes, muitos poluentes originários dos curtumes ainda estão presentes na água e nos sedimentos prejudicando a vida aquática e a saúde humana.

A poluição gerada nos curtumes é resultado das próprias peles e dos produtos químicos que não são totalmente absorvidos durante o curtimento, sendo várias as substâncias químicas que podem ser adicionadas às peles até a transformação em couro.

O despejo de curtume contém grande quantidade de material putrescível (proteínas, sangue, fibras musculares) e de substâncias tóxicas (sais de cromo, sulfeto de sódio, cal livre e compostos arsenicais), que geram com facilidade gás sulfídrico, podendo tornar a água dos corpos receptores imprópria para fins de abastecimento público, usos industriais, agrícolas e recreacionais (BRAILE \& CAVALCANTE, 1993).

Segundo Rodrigues (2007) o processo de fabricação de couro consiste no tratamento da pele bruta em banhos sucessivos em diferentes composições químicas para remover materiais indesejáveis, evitar a putrefação e obter as propriedades e características do couro. O cromo é o principal material utilizado para o curtimento (no mundo $80 \%$ e no Brasil ultrapassando os $90 \%$ ).

Os dois estados de oxidação do cromo mais estáveis são: Cr (III) (óxido de cromo), existindo naturalmente na natureza, e o $\mathrm{Cr}$ (VI) (hexavalente), em geral produzido por processos industriais. Eles são drasticamente diferentes em suas propriedades físico-químicas e bioquímicas. O primeiro é elemento essencial e o segundo é elemento tóxico no metabolismo de vários organismos vivos (ibid.).

\footnotetext{
${ }^{22}$ As principais fábricas de calçados do Vale do Rio dos Sinos estão localizadas nas cidades de Sapiranga, Campo Bom, Dois Irmãos, Ivoti e Novo Hamburgo. Esta última sediou, no final do século XIX, as primeiras grandes indústrias e até hoje é conhecida como capital nacional do calçado. Numa área de 140 quilômetros, a região do Vale abriga um número estimado de 1700 fábricas de calçados e de componentes, indústrias de máquinas e equipamentos e curtumes. (ASSOCIACAO BRASILEIRA DAS INDUSTRIAS DE CALÇADOS - ABICALÇADOS, 2004).
} 
O Cr (III) é oligoelemento e participa na permeabilidade dos vasos sanguíneos, a sua falta absoluta favorece o diabetes, pois o cromo é necessário para assimilar o açúcar dos alimentos. Já o Cr (VI) (cromatos, dicromatos) é cancerígeno ao ser humano. Lesões renais e hepáticas são também relatadas (VAITSMAN et al., 2001).

O Cr (VI) penetra facilmente nas membranas biológicas formando complexos com o DNA, tendo ainda potencial ação oxidante sobre o mesmo. Altera a função de enzimas, os parâmetros químicos do sangue, diminui a resistência a agentes patogênicos e causa alterações de comportamento, perda de apetite, alterações histopatológicas, inibição da fotossíntese e alterações populacionais. No ecossistema pode ter efeitos tóxicos entre moderados e agudos sobre plantas, aves, peixes, mamíferos, etc. Não degrada facilmente, havendo um grande potencial para sua acumulação em peixes (COMISSÃO INTERNA DE SEGURANÇA QUÍMICA, 2004).

O Quadro 05 (IPPC, 2003 apud CETESB, 2005, p. 24) apresenta um esquema, em quantidades médias, com as principais entradas e saídas do processo produtivo convencional para couro bovino salgado, com curtimento com cromo, até o produto final.

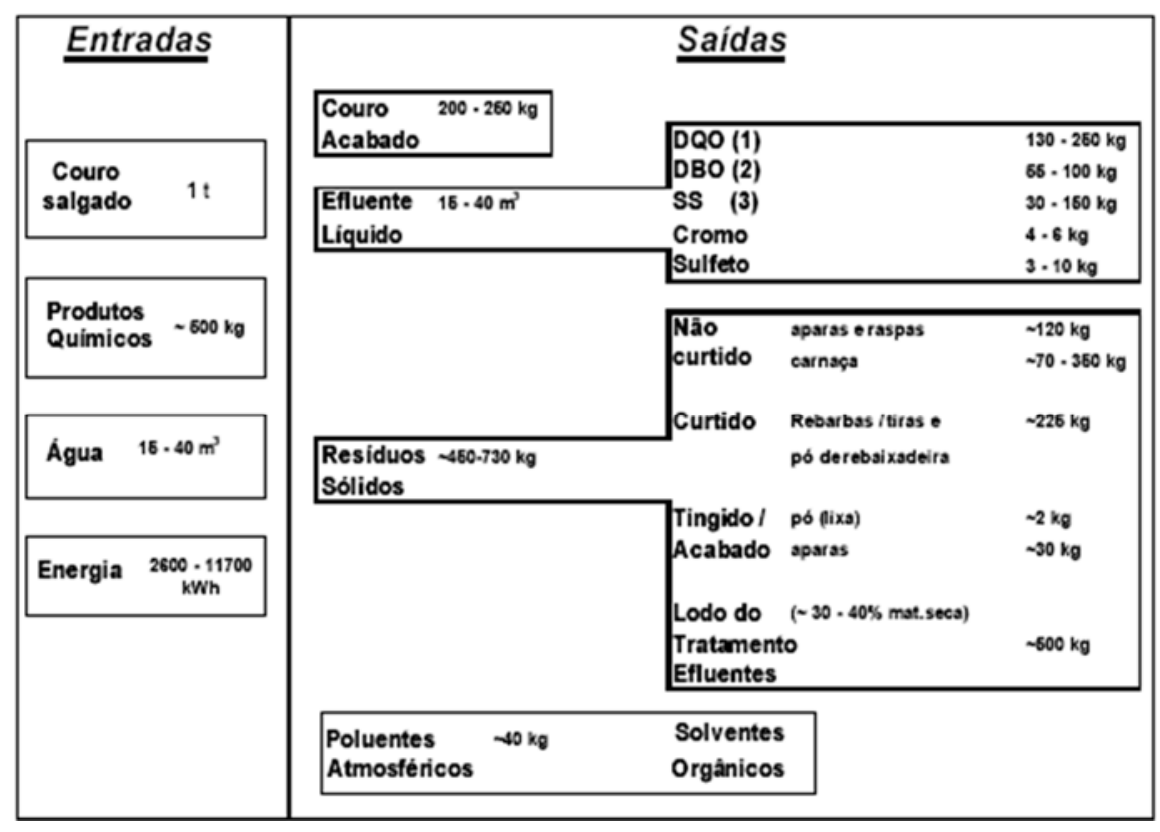

Quadro 05: Fluxos básicos principais de um curtume.

Fonte: Integrated Pollution Prevention and Control - IPPC (2003). 
Analisando-se o Quadro 05 se verifica que uma tonelada de peles gera somente de 200 a 250 quilos de couro, já os rejeitos produzidos nesse processo são de aproximadamente 600 quilos, o que demonstra a grande produção de resíduos nesse processo.

A atual Resolução CONAMA n 357/05, publicada em 18/03/2005, revoga a Resolução

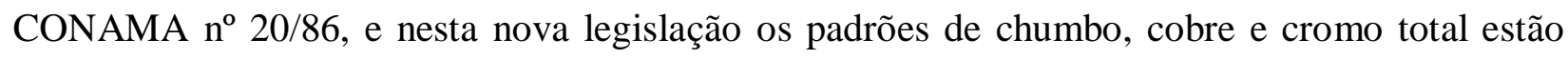
agora bem mais restritivos.

Os dados do Gráfico 13 foram gerados pela Rede de Monitoramento da FEPAM ${ }^{23}$, em operação mensal desde 1990. Para os dados coletados, é possível verificar que o ponto de coleta denominado Novo Hamburgo, localizado na cidade de mesmo nome, é o que se encontra com maior concentração de metais pesados, com altos índices de cobre, chumbo, cromo e níquel. Posteriormente, o ponto com maior poluição é o canal João Correa, localizado no município de São Leopoldo, com alta concentração de cromo.

23 Foram também utilizados dados gerados pela Companhia Rio-grandense de Saneamento (CORSAN) e Departamento Municipal de Águas e Esgotos de Porto Alegre (DMAE), que juntamente com a FEPAM participaram da Rede Integrada de Monitoramento do Rio dos Sinos - Comitesinos, que operou de 1990 a junho de 1996. Fonte: FEPAM, 2009. 


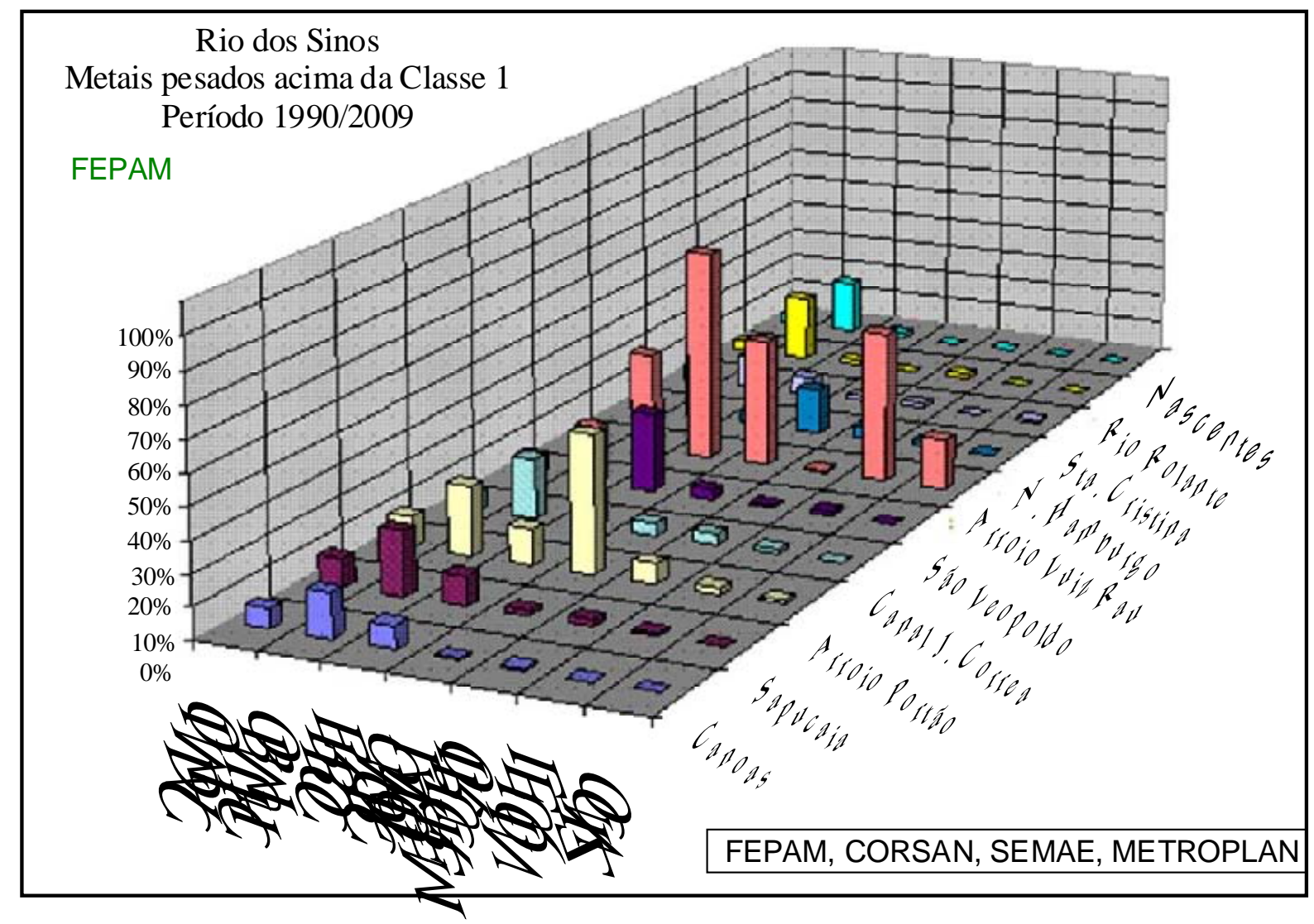

Gráfico 13: Metais pesados acima da Classe I na bacia hidrográfica do rio dos Sinos. Fonte: FEPAM, CORSAM, SEMAE, METROPLAN (2009).

Além dos despejos químicos de substâncias tóxicas para a saúde humana e o meio ambiente, é comum encontrar aterros clandestinos dos restos da indústria coureirO-calçadista. Depositados inadequadamente, liberam por décadas substâncias que poluem o solo e a água do lençol freático

Em alguns casos, esses rejeitos são colocados em sacos plásticos e jogados em terrenos baldios. Esses materiais de pequenos tamanhos e variadas cores poderiam ser utilizados para a produção de artesanato: bolsas, pulseiras, almofadas, tapetes, etc. Os despejos de retalhos de couro (Fotografia 41) foram encontrados durante trabalho de campo em Novo Hamburgo, às margens de um dos afluentes do rio dos Sinos. 


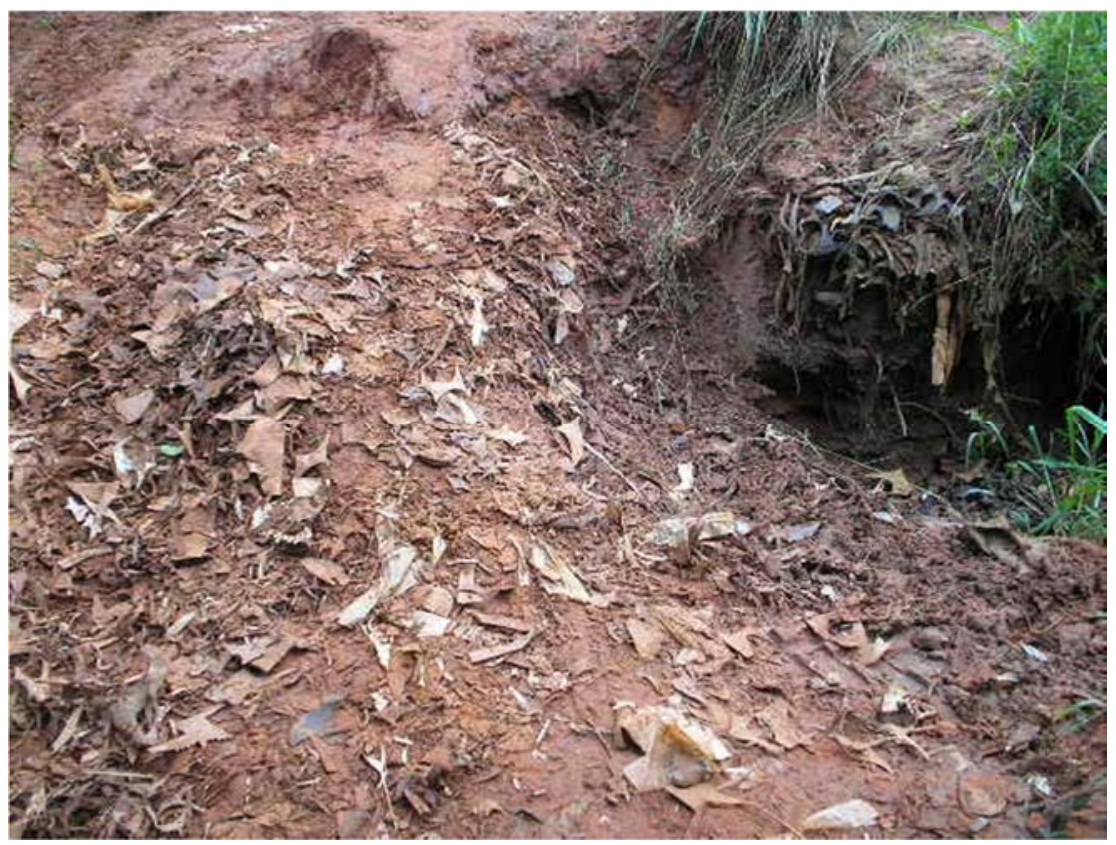

Fotografia 41: Despejo irregular dos rejeitos da industria coureira-calçadista.

Fonte: Adriana Penteado, 05/2009.

\subsection{Pedreiras}

Segundo Collaço (1995), são graves os problemas gerados pela extração do arenito. A flora, os recursos hídricos e paisagísticos são permanentemente atingidos pela atividade de mineração, e a mata nativa que se estende sobre as escarpas é constantemente agredida pelos rejeitos.

É comum a exploração mineral nessa formação para a extração de lajes denominadas pedras grés, utilizadas na construção civil, esta sendo comercializada em muitos municípios do Rio Grande do Sul e em menor quantidade em Santa Catarina e Paraná.

O impacto ambiental dessa atividade extrativa causa alterações no meio físico e na biota por meio da erosão e do assoreamento, causando modificação na qualidade das águas circundantes (RODRIGUES, 2007), supressão da vegetação para limpeza e abertura das bancadas e o impacto visual causado pela retirada do arenito.

A Fotografia 42, no município de Taquara, trecho médio da bacia hidrográfica do rio dos Sinos, demonstra o aterro de terras inundáveis devido à destinação incorreta dos rejeitos 
produzidos pela extração da pedra grés. Em todo o município é possível identificar várias lavras, sendo que muitas delas não estão regularizadas.

Geralmente os donos destas áreas arrendam as pedreiras para terceiros que fazem a extração mineral. Segundo o Ministério Público do Rio Grande do Sul, aproximadamente 500 frentes de lavra foram identificadas no município de Taquara.

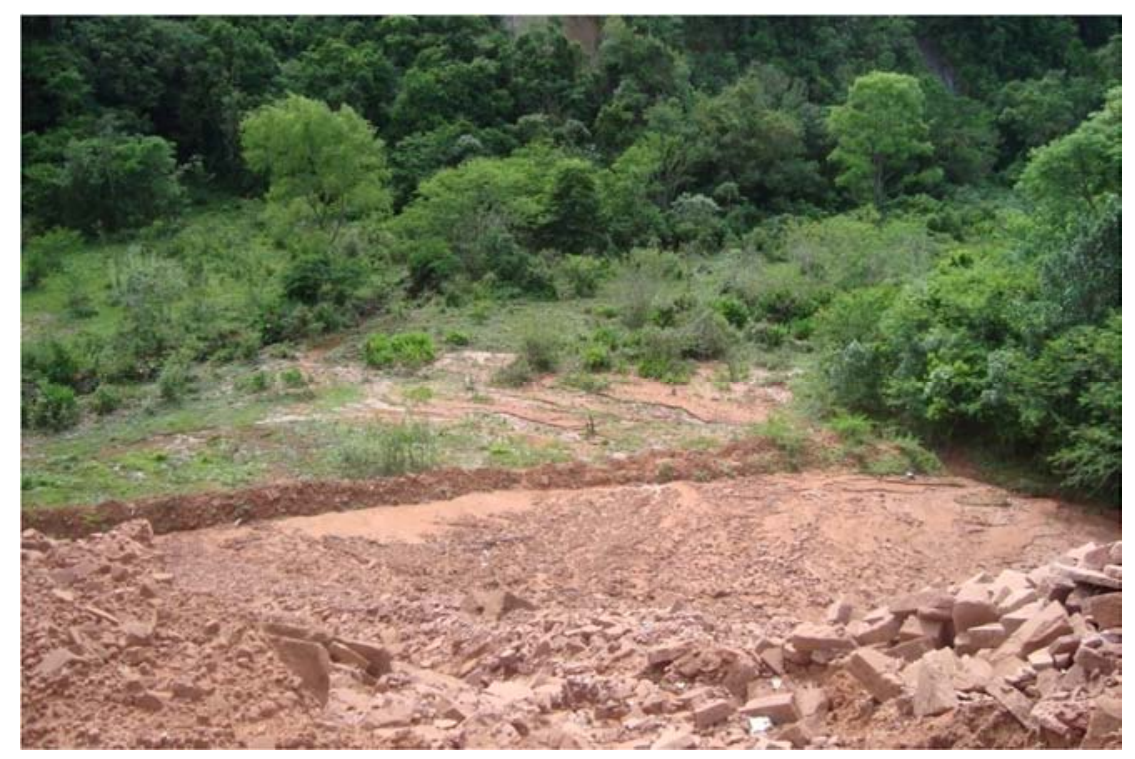

Fotografia 42: Rejeitos da extração do Botucatu, município de Taquara RS. Fonte: Adriana Penteado 12/2009.

As atividades mineradoras que existem em grande número visam a atender a demanda da construção civil e do desenvolvimento urbano local. Estas não apresentam planejamento, o que as tornam predatórias. Frequentemente são abandonadas de forma precoce e sem nenhum cuidado (CPRM, 2008).

A falta de uma metodologia e de um planejamento técnico durante a extração implica no aumento da produção de rejeitos na medida em que as direções de melhor aproveitamento não são seguidas. Também a falta de técnico responsável que oriente a extração durante a atividade acarreta maior desperdício do produto extraído em função da ausência de controle nas direções preferenciais de extração. Nem sempre é possível modificar a direção da lavra de modo que o erro é mantido por longo tempo ou até que se inviabilize aquela direção (CPRM, 2008). 
Uma alternativa menos agressiva para essas áreas seria o turismo ecológico, para o qual muitas têm potencial. O mesmo requer maior investimento que o arrendamento de pedreiras, porém ao longo do tempo possibilita maior retorno econômico e ambiental, pois não se constitui em uma atividade predatória dos recursos naturais, desde que seja adequadamente planejada e gerida.

Para as áreas que mantiverem a atividade de extração mineral é necessário o cuidado com a flora e fauna circundante, procurando causar o menor dano possível.

\subsection{Problemas relativos à água}

Nas nascentes do rio dos Sinos as águas ainda são cristalinas e a vegetação é diversificada e exuberante. Na medida em que o rio segue a jusante começam a aparecer os problemas ambientais: agrotóxicos, desmatamento, erosão, dragas e represas são as alterações mais frequentes no trajeto por terras agrícolas. Quando o rio dos Sinos chega às cidades da região metropolitana recebe os detritos industriais e urbanos de um dos principais pólos fabris do Estado e, poluído, deságua no delta do rio Jacuí (PROJETO EDUCAÇÃO AMBIENTAL SINOS, 2007).

Segundo o Relatório anual da situação dos recursos hídricos da bacia do rio dos Sinos (2003), os principais problemas relativos ao meio ambiente referentes à água são (Quadro 06):

Quadro 06: Situações atuais de conflito pelo uso da água e problemas ambientais

\begin{tabular}{|l|}
\hline - Insuficiência hídrica nos meses de verão. \\
\hline - Lançamento de esgotos domésticos pouco ou não tratados, comprometendo a \\
qualidade das águas principalmente em situações de baixas vazões no leito do rio, no trecho \\
médio-baixo.
\end{tabular}


Fonte: Relatório Anual Sobre a Situação dos Recursos Hídricos no Estado do Rio

Grande do Sul, 2003.

Nos períodos de estiagem a vazão do rio dos Sinos chega a ser vinte vezes menor do que em períodos normais. Medidas realizadas no município de Campo Bom mostraram que a vazão normal do rio dos Sinos é de $65 \mathrm{~m}^{3} / \mathrm{s}$, já no período de estiagem é de $2,9 \mathrm{~m}^{3} / \mathrm{s}$. No município de São Leopoldo a vazão normal é de $71 \mathrm{~m}^{3} / \mathrm{s}$ e atinge $2,9 \mathrm{~m}^{3} / \mathrm{s}$ no período de estiagem. No verão de 2003 para 2004, ocorreu a maior estiagem da última década no Rio Grande do Sul, com volume de pluviosidade de apenas $1 / 3$ do que é considerado normal para esse período. Com a redução do nível do rio, aumenta a concentração de carga orgânica e diminui o oxigênio diluído na água (COMITESINOS, 2000).

No vale do rio dos Sinos os impactos mais significativos sobre a rede hidrográfica são causados pela grande concentração de indústrias instaladas na região. De forma geral, a poluição hídrica é provocada principalmente pela inexistência ou subdimensionamento das estações de tratamento de efluentes líquidos das indústrias, não respeitando os parâmetros expressos na legislação. Com isso efluentes contendo metais pesados e altas cargas orgânicas são lançados nos rios (SEMMAM, 2005).

O esgoto doméstico é também despejado diretamente no rio, sendo raros os casos em que esses dejetos passam por estações de tratamento. As águas subterrâneas, que alimentam os poços artesianos, também apresentam contaminação.

Segundo Sincler Gonçalves ${ }^{24}$, técnico em Tratamento de Resíduos da Estação de Tratamento de Esgoto de São Leopoldo, na estação entra cerca de 100 1/s de água, esta com Classe $4^{25}$ e, após o tratamento, a água continua na mesma Classe, pois a quantidade de coliformes fecais, nitrogênio e fósforo são iguais, havendo apenas a diminuição dos valores de

24 Entrevistado em dezembro de 2008.

25 A Resolução CONAMA n 003 de 05 de junho de 1984, estabeleceu a classificação das águas doces, salobras e salinas do Território Nacional, de acordo com a Resolução no 20, de 18 de junho de 1986. Esta classificação estabelece os usos da água a partir da qualidade da mesma. Dentro da classificação Águas Doces, existem cinco subdivisões; Classe Especial, Classe 1, 2, 3 e 4. As águas de Classe 4 devem ser destinadas à navegação, harmonia paisagística e aos usos menos exigentes. Constituindo- se dentro deste parâmetro a água de pior qualidade. 
Demanda Bioquímica de Oxigênio (DBO) ${ }^{26}$ e da Demanda Química de Oxigênio (DQO) ${ }^{27}$ em mais ou menos $80 \%$ e $70 \%$, respectivamente.

O tratamento de água está cada vez mais complexo. Os percentuais de cloro e sulfato de alumínio, além de crescerem com o tempo, apenas desinfetam as águas e separam as partículas. A região do Vale do Rio dos Sinos tem apenas 5\% do esgoto sanitário coletado e tratado. O município de Novo Hamburgo trata 5\% e São Leopoldo 20\% (PROJETO EDUCAÇÃO AMBIENTAL SINOS, 2007).

O rio dos Sinos apresenta IQA variando entre Bom-Regular para o trecho compreendido entre as suas nascentes e a localidade de Santa Cristina. Deste ponto até a foz, a faixa predominante de IQA é Regular. Junto à foz dos arroios Luiz Rau e Portão registram-se as piores situações, com IQA variando de Ruim a Muito Ruim (COMITESINOS, 2000).

Segundo Zanini ${ }^{28}$ (2009), o rio dos Sinos sofre conflitos de uso. Um exemplo refere-se ao manejo irregular das lavouras agrícolas, com destaque para a rizicultura. Os períodos de estiagem coincidem com os períodos de irrigação da cultura de arroz. Isso reduz de forma drástica o nível do rio dos Sinos. A retirada clandestina de água, somada à liberação dos efluentes das lavouras, prejudica o abastecimento público.

Segundo Altenhoffen ${ }^{29}$ (2006), problemas como a forte poluição da água do rio dos Sinos e o uso de grande volume desta água pelos arrozeiros não chegam a representar um dano tão grave quanto o que se tem feito em relação às terras úmidas. A partir do momento em que os arrozeiros

\footnotetext{
${ }^{26}$ DBO - Quantidade de oxigênio necessária para oxidar a matéria orgânica por decomposição microbiana aeróbia para uma forma inorgânica estável. Os maiores acréscimos em termos de DBO num corpo de água são provocados por despejos de origem predominantemente orgânica. A presença de um alto teor de matéria orgânica pode induzir à completa extinção do oxigênio na água, provocando o desaparecimento de peixes e outras formas de vida aquática.Um elevado valor da DBO pode indicar um incremento da microflora presente e interferir no equilíbrio da vida aquática, além de produzir sabores e odores desagradáveis e, ainda, pode obstruir os filtros de areia utilizadas nas estações de tratamento de água. Pelo fato da DBO somente medir a quantidade de oxigênio consumido num teste padronizado, não indica a presença de matéria não biodegradável, nem leva em consideração o efeito tóxico ou inibidor de materiais sobre a atividade microbiana (UNIVERSIDADE DA ÁGUA, 2006).

${ }^{27}$ DQO - É a quantidade de oxigênio necessária para oxidação da matéria orgânica através de um agente químico. Os valores da DQO normalmente são maiores que os da DBO, sendo o teste realizado num prazo menor e em primeiro lugar, servindo os resultados de orientação para o teste da DBO. O aumento da concentração de DQO num corpo de água se deve principalmente a despejos de origem industrial. (UNIVERSIDADE DA ÁGUA, 2006).

${ }^{28}$ Darci Zanini é secretario da Secretaria Municipal de Meio Ambiente de São Leopoldo. 06/2010.

${ }^{29}$ Rafael Altenhofen é formado em biologia pela Universidade do Vale do rio dos Sinos - UNISINOS. Desenvolveu trabalho de dissertação sobre "Relações ecológicas, percepções e representações de populações humanas ribeirinhas: subsídios para conservação de áreas úmidas na Bacia Hidrográfica do Rio dos Sinos, RS." Reportagem concedida ao jornal ABC Domingo de 2005.
} 
diminuam o bombeamento de água, o seu volume e a sua qualidade melhoram, porém a destruição das terras úmidas tem caráter irreversível.

A bacia hidrográfica do rio dos Sinos está inserida na área de abrangência do Aquífero Guarani, que cobre uma área superior a $1.500000 \mathrm{~km}^{2}$, situada entre o Paraguai, Uruguai, Argentina e Brasil (Figura 73). Possui um volume estimado de 37 mil quilômetros cúbicos de água com qualidade. Porém, segundo SCHERER et al., 2000, por ser altamente permeável, o aquífero demonstra alta fragilidade à contaminação por atividades antrópicas.

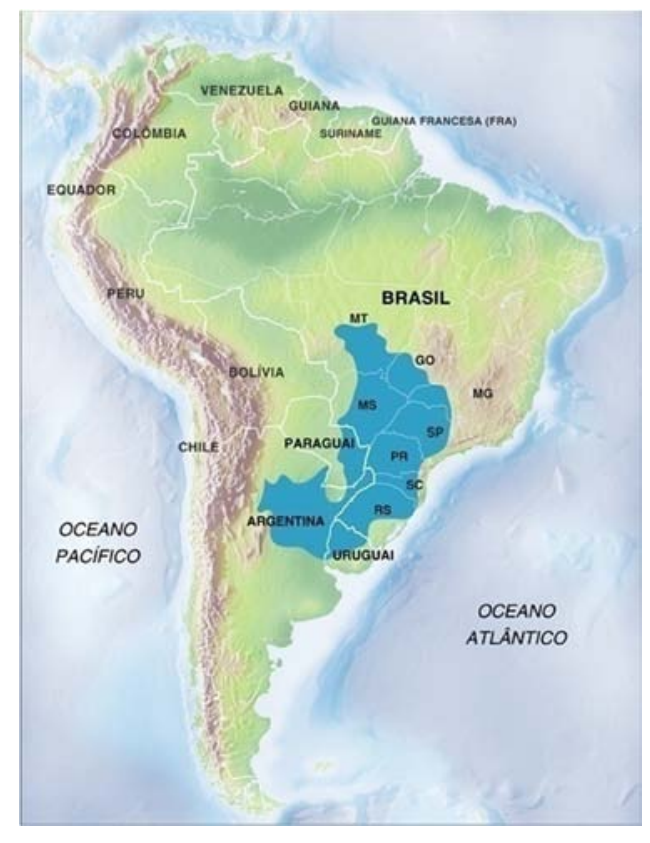

Figura 73: Abrangência do Aquífero Guarani.

Fonte: www.moderna.com.br/.../projeto/2006/1/aqǘfero/

Acessado: 14/12/2009.

O Aquífero Guarani é constituído de várias rochas predominantemente arenosas, que foram sedimentadas em ambiente fluviolacustre e eólico do Triássico e do Jurássico. Os estratos do Triássico encontram-se na base do aquífero e correspondem às unidades correlatas às Formações Pirambóia e Rosário do Sul, no Brasil, e Buena Vista, no Uruguai. Os estratos do Jurássico encontram-se no topo do aquífero e correspondem às unidades correlatas da Formação Botucatu, no Brasil, Misiones, no Paraguai, e Tacuarembó, no Uruguai e na Argentina (BORGUETTI et al., 2008). 
Os principais municípios ao longo das áreas de recarga do aquífero Guarani na bacia hidrográfica do rio dos Sinos, inseridos, segundo a classificação de Gomes et al. (2006), na Serra Gaúcha/encosta nordeste são: Portão, Parobé, Taquara, Santo Antônio da Patrulha, Novo Hamburgo e São Leopoldo, os dois últimos sendo altamente industrializados.

No Rio Grande do Sul o Comitê do rio dos Sinos, que se antecipou a Lei Federal 9433 de 1997 (cuja finalidade é diminuir os conflitos referentes aos usos da água), foi criado em 1988 com o objetivo de apontar caminhos viáveis para que os municípios que utilizam as águas do rio dos Sinos possam usufruir do rio sem continuar poluindo. Possui também informações sobre a demanda e a vazão do rio e estuda a necessidade de construção de barragens.

Apesar dos 20 anos de trabalho do Comitê, buscando ampliar a visão políticoadministrativa do território municipal para o âmbito da bacia (composta por 32 municípios), na prática, cada município se preocupa somente com as suas prioridades, dificultando um planejamento integrado e com a amplitude necessária.

A bacia hidrográfica do rio dos Sinos, com disponibilidade média de $84 \mathrm{~m} / \mathrm{s}$, apresenta um consumo médio de $4,4 \mathrm{~m}$ 3/s, distribuído entre o abastecimento humano (58\%), a irrigação de arroz (19\%) e o abastecimento industrial (18\%) (COMITESINOS, 2000). Há variação na qualidade e na quantidade da água ao longo da bacia e ao longo do tempo, dependendo de fatores como a quantidade de chuva, demanda e despejo de efluentes não tratados. O Comitê prevê a importância da preservação das terras inundáveis. 


\subsection{Análises do mapeamento das alterações antrópicas nas terras inundáveis da bacia hidrográfica do rio dos Sinos}

\subsubsection{Terra inundável trecho um - jusante}

A partir do mapeamento do uso do solo da terra inundável do trecho um de jusante (Mapa 11), constata-se que o uso predominante compreende a agricultura com incidência nos municípios de Esteio, Nova Santa Rita e Canoas. Predomina nesta área, em relação a todos os usos mapeados, o cultivo de arroz irrigado.

A concentração urbana de alta densidade encontra-se a leste e nordeste desta terra inundável, nos municípios de Canoas, Esteio e Sapucaia do Sul. A concentração urbana de baixa densidade localiza-se em parte do município de Canoas, a leste, e em Nova Santa Rita, a oeste.

A permanência e/ou avanço da alta concentração urbana em Canoas foi possível devido a construção de um dique de proteção. Ao longo do mesmo verificaram-se moradias de baixo padrão, sem encanamento de água e tratamento de esgoto. As pessoas que ocupam essas áreas, em boa parte, trabalham com a reciclagem de lixo. O material que sobra é jogado ou deixado em parte das poucas áreas onde há vegetação natural.

Os municípios em situação mais crítica considerando a proximidade com a terra inundável e a alta concentração urbana são Esteio e Sapucaia do Sul.

As áreas de capoeira possuem pequena expressividade, sendo que das duas áreas mapeadas, apenas uma localiza-se no interior da terra inundável de jusante um. A extração mineral, que neste caso refere-se à retirada de areia nas margens ou dentro do rio dos Sinos é encontrada em três municípios, com dois pontos em Sapucaia do Sul, dois em Esteio e um em Canoas.

Esta terra inundável apresenta pouco de suas características naturais, pois a dinâmica hídrica foi alterada e quase toda a vegetação natural suprimida, é possível também que tenha ocorrido à supressão de lagos, naturalmente formados, devido à aragem da terra para a agricultura ou aterro para a ocupação urbano-residencial. A vegetação natural apresenta-se em pequenas proporções com maior densidade em Nova Santa Rita, município que não apresenta alta concentração urbana. 
A possibilidade de recuperação desta terra inundável é boa, dado que predomina na mesma a agricultura, assim a maior parte do solo não se encontra impermeabilizado e não seria necessário o deslocamento de um grande contingente populacional para outras áreas, o que demandaria um custo material muito alto.

É fato a necessidade de produção de alimentos para o abastecimento humano, assim, algumas áreas precisam ser alteradas em sua dinâmica natural. No caso da área discutida nem mesmo a vegetação ciliar prevista no Código Florestal foi preservada. Propor uma recuperação total desta área é uma idéia um pouco utópica, mas é possível e necessário, sem grandes prejuízos de ordem econômica, recuperar e manter algumas das características naturais.

Considerando os aspectos naturais e antrópicos, esta terra inundável pode ser definida como uma terra inundável fluvial com alto grau de alteração de suas características naturais, porém, também com alto grau de possibilidade de recuperação. 
Mapa 11: Uso do solo da terra inundável trecho um - jusante 


\subsubsection{Terra inundável trecho dois - jusante}

A partir do mapeamento do uso do solo na terra inundável do trecho dois - jusante da bacia hidrográfica do rio dos Sinos, constatou-se o predomínio da vegetação natural. Apesar disso, em relação a vegetação ciliar, atinge, no melhor dos casos, $10 \%$ daquilo que é previsto pelo Código Florestal de 1965 (30 metros de mata ciliar para rios com até 10 metros de largura).

Entre São Leopoldo e Sapucaia do Sul verifica-se uma área de reflorestamento, que possui continuidade para além dos limites do mapa. A mesma aqui mapeada, possui $1,5 \mathrm{~km}^{2}$ de área. Localiza-se no denominado Parque do Trabalhador. Encontra-se entre a vegetação natural, mas está de forma predominante. Acredita-se que o plantio feito teve por objetivo secar a área do parque que se encontra naturalmente, em área de terra inundável, hoje alterada e por isso não totalmente alagável, porém ainda compreende planície do rio dos Sinos e uma terra inundável.

As áreas de alta concentração urbana são quatro, três delas em São Leopoldo e uma em Sapucaia do Sul. A mais crítica refere-se a que se localiza mais próximo ao dique de proteção, compreendendo uma área frágil no caso de falha no sistema de contenção de enchentes. Fato que agrava este problema são as ocupações, próximas a essa área e que se localizam no corpo do dique. As mesmas dificultando a manutenção do sistema de controle de enchentes e também danificando o sistema, fato já discutido no subitem 5.3.1.1 deste trabalho.

Há cinco pontos de extração mineral, sendo que quatro destes referem-se a extração de areia no rio dos Sinos ou em sua planície. Três destes pontos localizam-se em Sapucaia do Sul.

A reciclagem de resíduos sólidos domiciliares ocorrem em dois pontos, o menor em uma distância de apenas 1,3 metros do rio dos Sinos, a segunda a uma distância de 2,7 metros.

A agricultura e a capoeira localizam-se na margem oeste do rio dos Sinos e apenas em São Leopoldo não se verifica, para este trecho, cultivo da terra.

A fotografia 43 é do arroio João Correia que deságua no rio dos Sinos. Este rio foi canalizado na década de 1980, atualmente funciona como escoadouro de esgoto urbano e industrial e é altamente poluído e é representando no mapa pela avenida paralela ao mesmo.

A seta em vermelho indica a localização do dique de terra. Abaixo da seta as águas barrentas compreendem as terras ínundáveis que ainda possuem ligação direta com o rio dos Sinos. Acima da mesma seta a mata ao lado de um campo representa parte das terras inundáveis 
que ficaram isoladas do rio. No lado direito da fotografia a seta em amarelo indica ocupações irregulares, sendo que as mais ao sul, considerando a posição da fotografia, localizam-se no corpo do dique. Ao norte desta área localiza-se o Parque do Trabalhador. Essas áreas ainda sofrem com a inundação pois apesar de não serem mais inundadas pelo rio, a subida do lençol freático, juntamente com a chuva, mantem mesmo que alterada, a dinâmica da área.

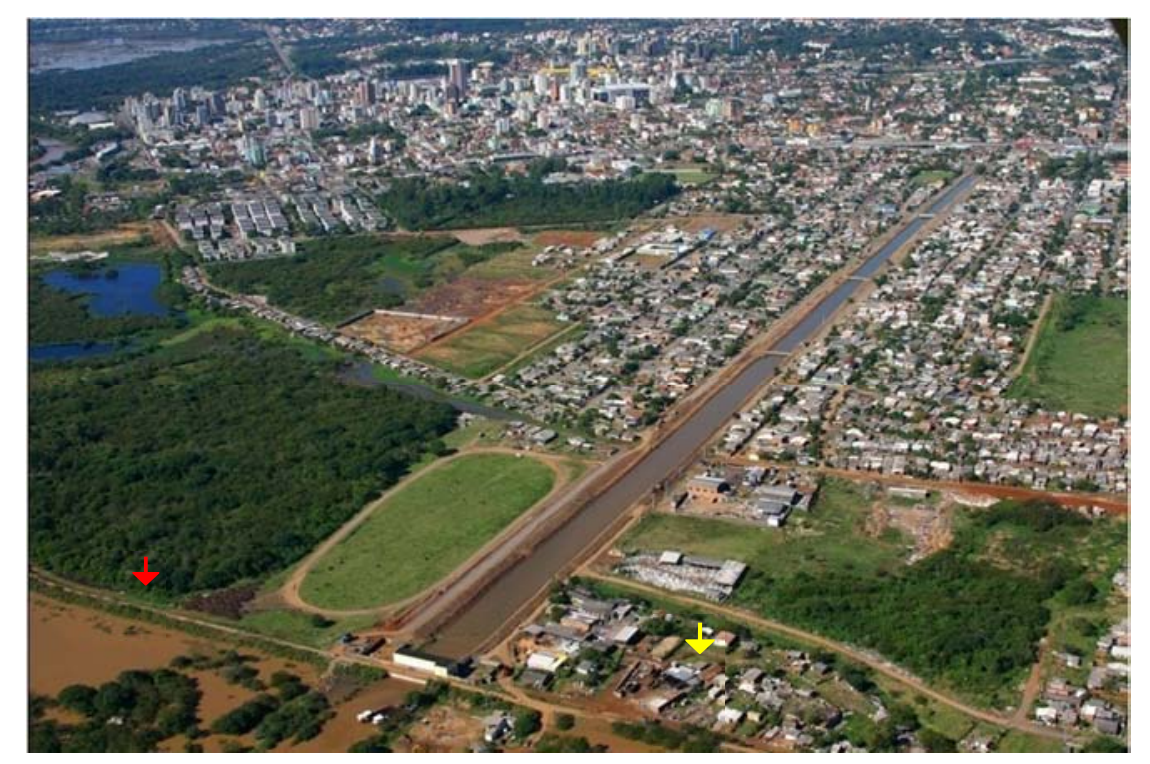

Fotografia 43: Arroio João Correa no município de São Leopoldo. Fonte: Secretaria de Meio Ambiente de São Leopoldo, 2009.

A fotografia 44 mostra uma ocupação irregular em área teoricamente protegida por compreender o que sobrou da planície no que se refere a sua dinâmica natural, a mesma localizase a oeste do dique de terra. Observou-se a grande presença de lixo doméstico. Em pesquisa feita com a família que morava no local, descobriu-se que o antigo morador tinha um criadouro de porcos e solicitava o despejo de resíduos dos caminhões de lixo para servir de alimento para os animais e também como forma de aterrar a área.

No local é intenso o mau cheiro e a presença de moscas. O chorume liberado polui a água que é utilizada para o abastecimento público. No período de cheia do rio, esses moradores, que residem do lado externo dos pôlderes ficam ilhados. 
A fotografia 45 é de uma aérea de aterro com restos de cerâmica. A cota do terreno foi alterada em aproximadamente 1 metro.

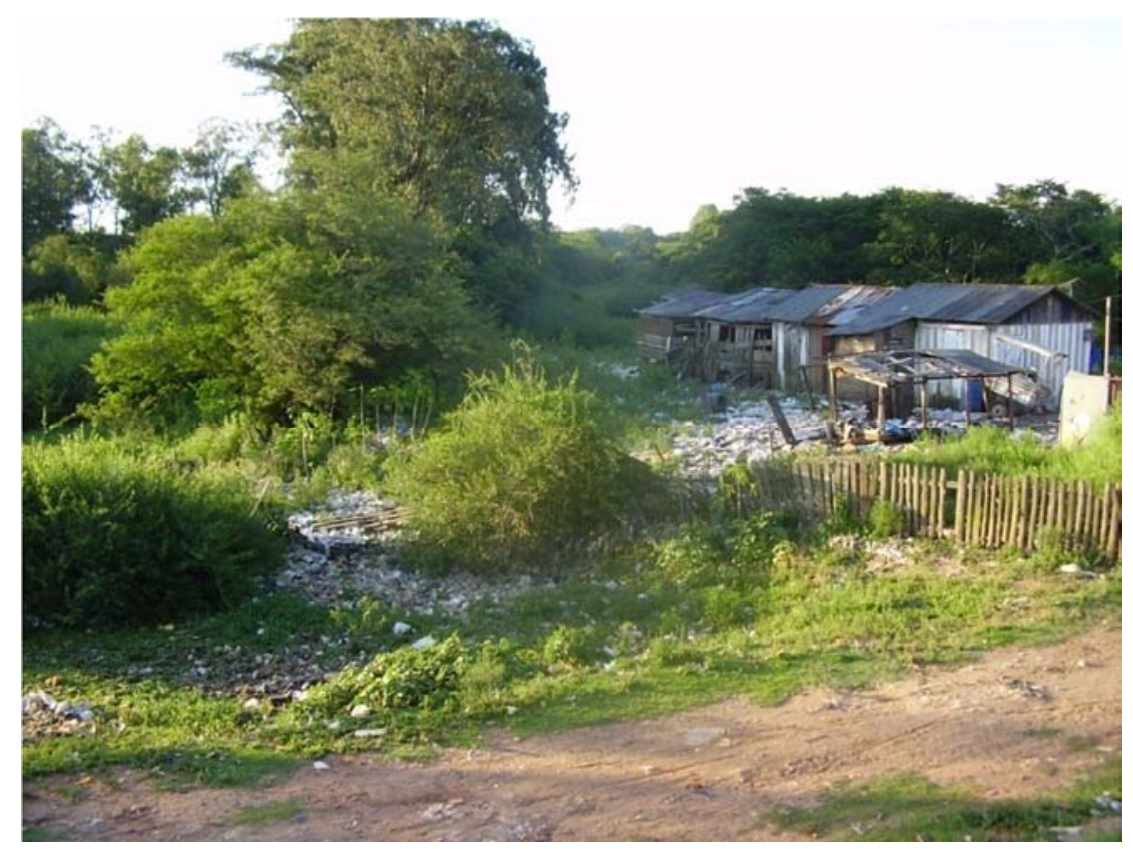

Fotografia 44: Ocupação irregular e presença de lixo.

Fonte: Adriana Penteado, 2007.

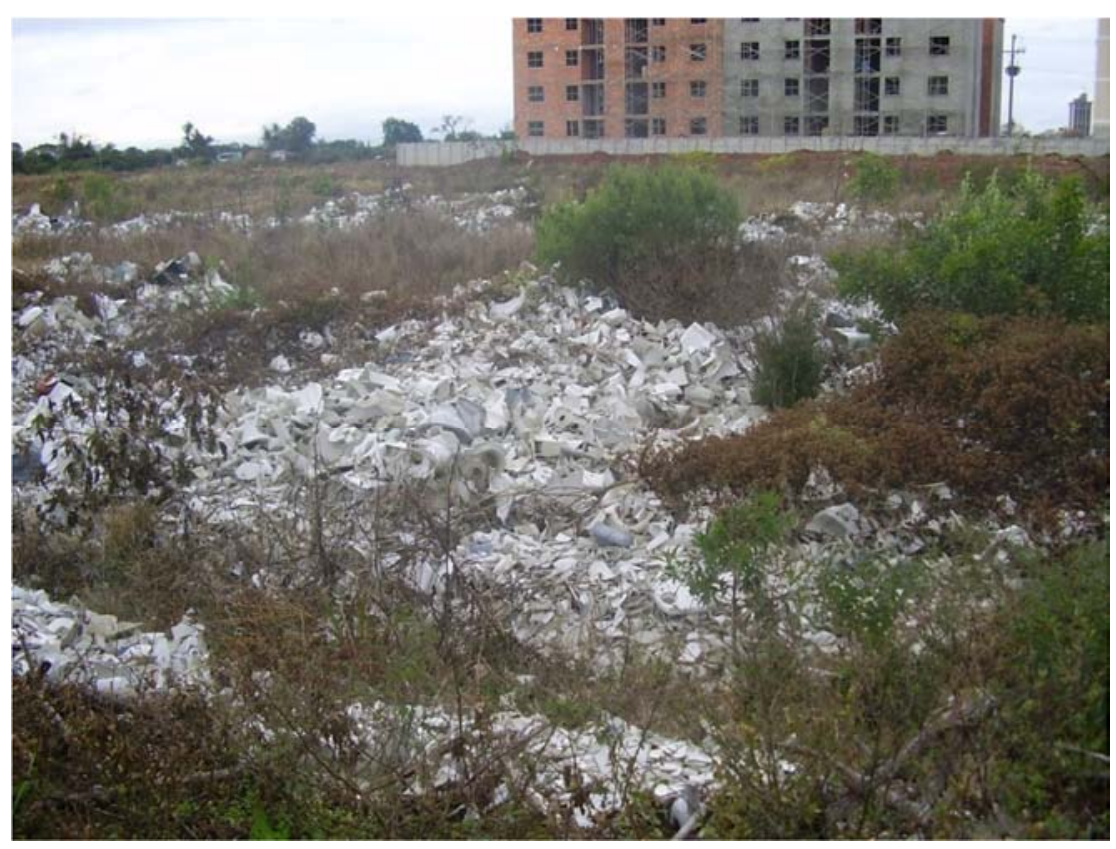

Fotografia 45: Aterro das terras úmidas e construção de condomínio popular. Fonte: Adriana Penteado, 07/2009. 
Mapa 12: Uso do solo da terra inundável trecho dois - jusante 


\subsubsection{Terra inundável trecho três - jusante}

A partir da análise do uso do solo do mapa 13, verifica-se que para a terra inundável maior, predomina dentro de seus limites a vegetação natural, porém há um alto adensamento urbano a norte e sudoeste da área, referentes aos municípios de São Leopoldo, Novo Hamburgo e Campo Bom. Em relação à área total mapeada o florestamento não possui grande significância para este caso.

A maior incidência do uso do solo para a agricultura, assim como área de capoeira, está mais concentrada, para a área maior mapeada, a leste. Também se percebe a grande incidência de açudes, em geral, em áreas muito próximas ao rio dos Sinos.

Há duas estações de tratamento de esgoto, uma dentro do limite da terra inundável e a outra ao sul desta. Por meio de entrevista com funcionário da Estação de Tratamento de São Leopoldo, pode ser constatado a criticidade no que se refere ao tratamento de esgoto na RMPA, incluindo a área de estudo parcialmente.

Foi encontrado apenas um ponto de mineração no município de Novo Hamburgo a uma distância menor que 1,5 metros do rio dos Sinos, na margem sul.

Para a menor área de terra inundável predomina a vegetação natural e, em segundo lugar, a agricultura. A leste da mesma constatou-se a pequena incidência de florestamento.

A maior área sofre um grande risco de destruição porque ao norte e ao sul da mesma, a alta concentração urbana pressiona a construção de estradas ligando esses dois setores. A construção de estradas neste sentido, mas também no sentido leste - oeste causará uma segmentação da terra inundável e isso facilitará sua destruição.

Para o ano 2011 está sendo construída a estrada dos Municípios, entre Campo Bom e Novo Hamburgo. A mesma possui aproximadamente 10 metros de largura permitindo o tráfego de carros e caminhões. Sua construção teve também por objetivo funcionar como dique, impedindo o avanço da inundação para norte em relação à mesma, onde se concentra o alto adensamento de Novo Hamburgo e Campo Bom.

Outra estrada, ainda não asfaltada, mas que corta a terra inundável no sentido norte - sul é a Leopoldo Petry e liga o alto adensamento urbano de Novo Hamburgo, ao norte, com áreas de capoeira, agricultura e florestamento, ao sul, no mesmo município. 
Mapa 13: Uso do solo da terra inundável trecho três - jusante 


\subsubsection{Terra inundável trecho um - médio}

O mapa de uso do solo trecho um - médio compreende duas áreas. A que se encontra a oeste possui grande parte de sua vegetação natural preservada. Ao longo do rio Paranhana ocorre à maior incidência de capoeira. A leste desta área está a concentração urbana do município de Taquara.

A área mais a leste possui predomínio de agricultura e pequena incidência de vegetação natural. 
Mapa 14: Uso do solo da terra inundável trecho um - médio 


\subsubsection{Terra inundável trecho um - montante}

Para a terra inundável do trecho um - montante (Mapa 15) predomina como uso a agricultura e a capoeira. A mesma localiza-se de forma integral no município de Santo Antonio da Patrulha. Não há alto adensamento urbano próximo a essa área. A vegetação natural está presente, mesmo que de forma insuficiente, ao longo de quase todo o rio dos Sinos.

O florestamento compreende uma pequena área que circunda um lago de origem antropogênica. No extremo leste da área há retificação do canal com aproximadamente 1,3 metros de extensão. A erosão localiza-se as margens do canal, a oeste, onde a vegetação natural foi suprimida, predominando a vegetação rasteira e ou arbustiva, aqui denominada como capoeira. 
Mapa 15: Uso do solo da terra inundável trecho um - montante 
A fotografia 46 é da margem sul do rio dos Sinos, no município de Santo Antônio da Patrulha, onde há criação de gado. A fotografia 49 é do plantio de arroz na margem norte para a mesma área.

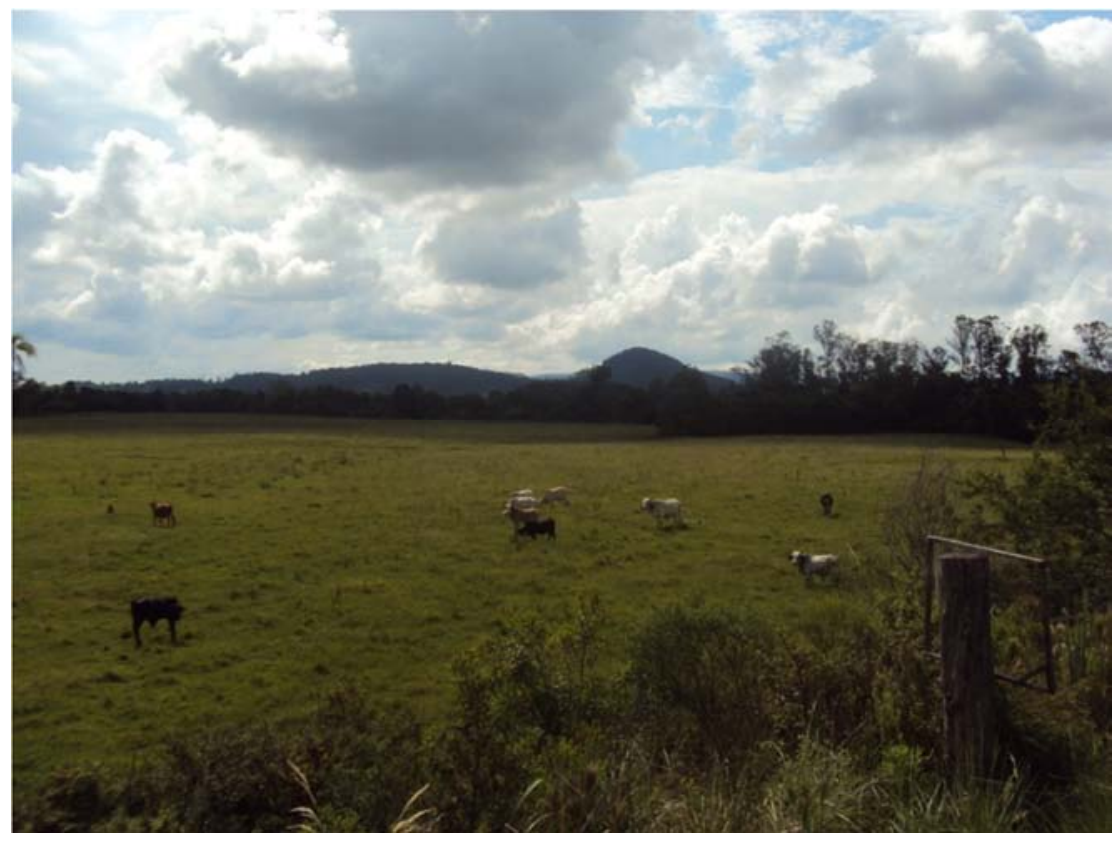

Fotografia 46: Cultivo de gado em Santo Antonio da Patrulha. Fonte: Adriana Penteado, 01/11.

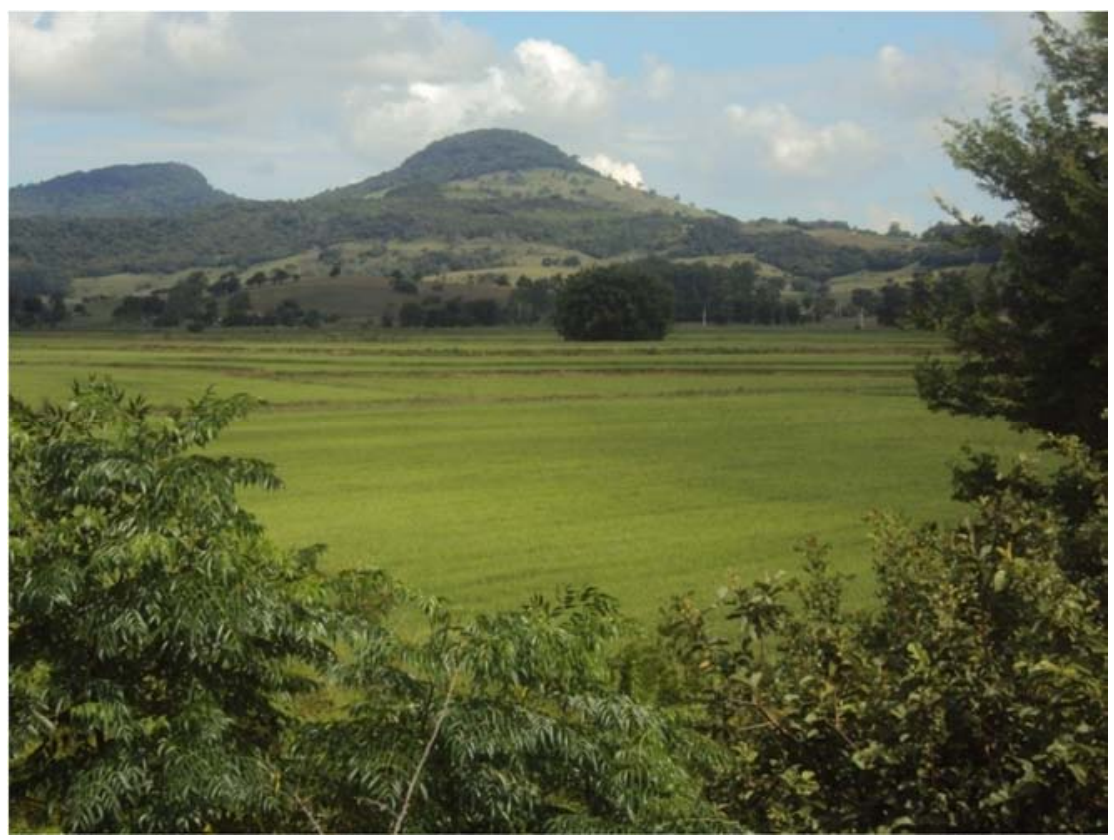

Fotografia 47: Cultivo de arroz na planície de Santo Antonio da Patrulha. Fonte: Adriana Penteado, 01/11. 


\subsubsection{Terra inundável trecho dois - montante}

Em continuidade ao mapa 15, está à área representada pelo mapa 16. A mesma localiza-se no município de Santo Antonio da Patrulha e avança para o município de Caraá. Não há naturalmente a segmentação das duas áreas, tendo sido mapeadas separadamente por questões de ordem cartográfica.

A vegetação natural foi quase totalmente suprimida, predominando em maior concentração a oeste da maior área mapeada. Predomina a agricultura para este mapa e em todas as três áreas mapeadas.

Não há para as áreas mapeadas alto ou médio grau de adensamento urbano, prevalecendo à ocupação dispersa e em baixa concentração. Verificou-se também a utilização destas áreas para criação bovina. 
Mapa 16: Uso do solo da terra inundável trecho dois - montante 
A fotografia 48 é de parte da terra inundável localizada em Caraá, onde a mesma é utilizada para o plantio de arroz.

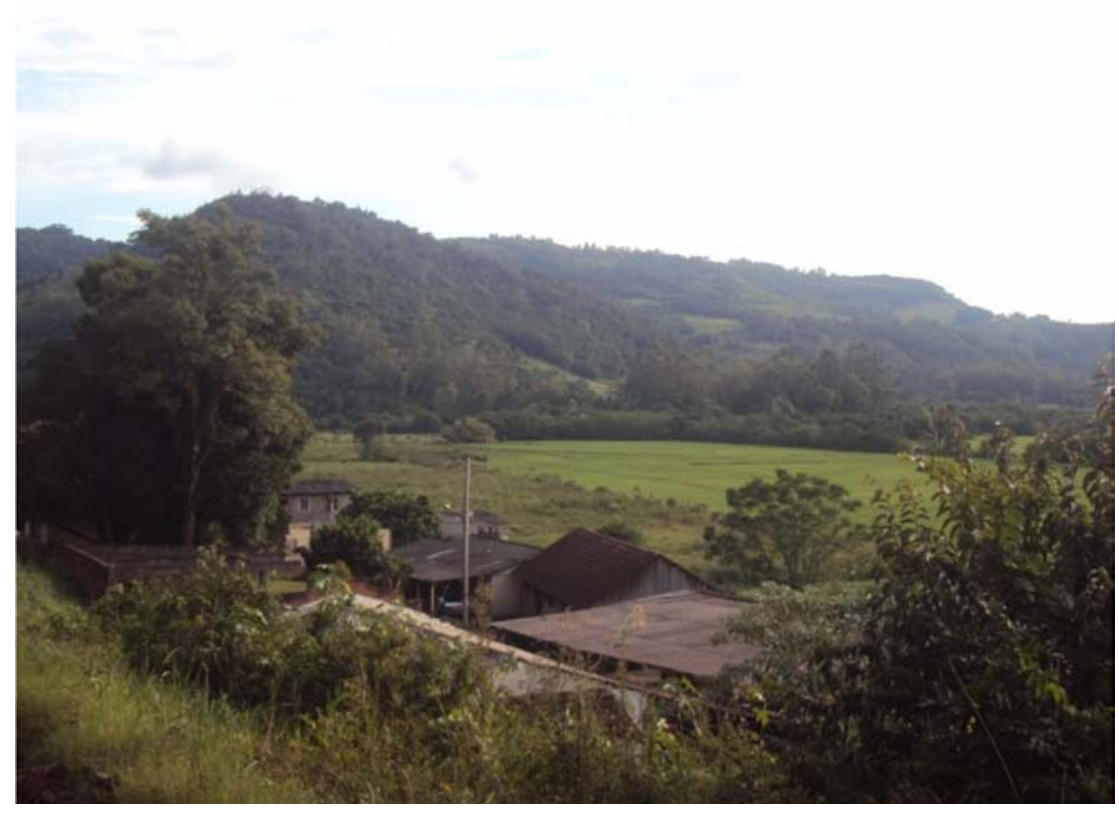

Fotografia 48: Plantação de arroz em terra inundável do município de Caraá. Fonte: Adriana Penteado, 01/11.

Em relação ao uso do solo das terras inundáveis do rio dos Sinos, nas áreas do médio e montante predomina como uso a agricultura e a vegetação ciliar em geral é pequena ou inexistente contribuindo para acionar processos erosivos. O adensamento urbano concentrado só foi verificado para o caso do município de Taquara.

Em relação aos mapas de uso dos trechos um, dois e três - jusante, verificou-se a maior diversificação de atividades. As áreas do trecho dois e três são as que possuem maior incidência de vegetação preservada.

Considera-se como frágeis em relação as alterações antrópicas que irão influenciar no nível das inundações, os municípios de Novo Hamburgo, São Leopoldo e Campo Bom e no trecho mais a jusante Sapucaia do Sul e Esteio.

Considerando a bacia hidrográfica como um sistema aberto e as terras inundáveis como um subsistema da mesma, as alterações nas áreas mais a montante terão maiores reflexos nos 
municípios que se encontram mais a jusante, com o agravamento de enchentes e dos períodos de estiagem. A supressão da vegetação, causando assoreamento, poluição acima da capacidade de depuração das terras inundáveis, rios e lagos, aterramento das terras inundáveis, impermeabilização dos solos, segmentação das terras inundáveis, etc são fatores que vem ocorrendo ao longo da bacia e a resposta para isto compreenderá a somatória destes fatores, porém sentidos em maior proporção em alguns municípios. O agravamento da situação pode se estender para áreas atualmente não atingidas. 


\subsection{DISCUSSÕES FINAIS}

O estudo das terras inundáveis compreende tema latente na atualidade devido ao maior reconhecimento da importância que estas áreas possuem. Algumas questões têm dificultado de certa forma, as pesquisas sobre o tema. As principais se referem às variadas nomenclaturas, definições e metodologias de estudo que entre outros aspectos possuem visões pontuais e voltadas para as características da flora e da fauna.

Esse trabalho buscou por meio da Geomorfologia discutir as principais definições existentes para terras inundáveis e propor uma definição baseando-se na forma como as planícies inundáveis são classificadas, considerando as características e/ou existência de tipologias de corpos hídricos. Existe um ponto de intersecção entre estes ambientes, estão intimamente relacionados, mas por definição são diferentes.

Também foram definidos os limites maiores aproximados das terras inundáveis, embasados primeiramente em dados pluviométricos e posteriormente na escolha de imagens de satélite. Mapearam-se os corpos hídricos presentes dessa forma criando uma denominação para essas áreas em nível mais específico.

No âmbito geral se propôs o estudo destas áreas a partir do recorte espacial de uma bacia hidrográfica, estudando variados aspectos físicos desta, permitindo assim a correlação entre as terras inundáveis, importância das mesmas a partir da situação espacial na bacia de forma correlacionada, contextualização física destas a partir de dados referentes à geologia, geomorfologia, clima e pedologia. Acredita-se que o esforço aqui empreendido traçou um esboço metodológico para o estudo dessas áreas.

Para as terras inundáveis amostrais foram mapeados e analisados os corpos hídricos presentes, bem como as alterações antrópicas. Muitas foram as formas de lagos encontradas sendo necessário definir nomenclatura, pois não foi encontrado suporte na literatura pesquisada. Um único termo foi proposto designado como longilíneo tortuoso para alguns paleocanais que não se enquadram nas definições propostas.

Constatou-se que imagens com resolução espacial de vinte metros não são adequadas para delimitar as terras inundáveis com boa precisão e também para a identificação dos corpos hídricos menores, sendo necessária a utilização de imagens de alta resolução espacial. $\mathrm{O}$ refinamento dos limites deve ser feito a partir de imagens de alta resolução que não precisam ter 
equiparação temporal com as imagens de baixa resolução utilizadas. A combinação entre as imagens pode ser necessária, a de baixa resolução por que registra os dados pluviométricos definidos a partir da análise destes, como os mais adequados, e a imagem de alta resolução que pode ser de um período diferente, para o refinamento dos limites. Para estabelecer se alguns lagos têm origem natural ou antropogênica foi necessária a análise de imagens históricas.

Considerou-se relevante mapear as principais alterações causadas a essas áreas a partir do mapeamento de uso do solo, podendo assim dar uma visão não romântica sobre a situação atual, sendo possível também definir qual a importância de cada uma delas e como essas alterações podem ter efeito em cadeia de forma negativa para as áreas localizadas a jusante.

As terras inundáveis da bacia hidrográfica do rio dos Sinos são, em sua maioria, flúviolacustres. A dinâmica das planícies pode alternar a condição de fluviolacustre para lacustre e vice e versa. A segmentação ocorre em alguns pontos devido a fatores antrópicos como em São Leopoldo, e possivelmente também devido a fatores naturais. Os mapas analisados não foram o resultado do máximo pluviométrico registrado para a área, assim a segmentação das áreas pode compreender um estado temporário em alguns casos. Assim, áreas classificadas como fluviais apenas, e que possuem este aspecto de fato em alguns momentos, podem ser em eventos pluviométricos maiores do que o estudado, classificadas como terras inundáveis fluviolacustres. Isso dependerá da extensão da inundação abrangendo ou não os lagos.

Este trabalho foi focado nas terras inundáveis continentais ou interiores. Breves considerações foram feitas sobre as terras inundáveis costeiras, talvez com pequenos equívocos pela falta de conhecimento sobre este sistema. De qualquer forma considerou-se importante discutir o tema independente de fatores relativos à localização, isso em um aspecto abrangente e geral. Considerações mais aguçadas precisam ser feitas, porém, acredita-se que houve um pequeno avanço também nesse sentido.

Alguns apontamentos podem aqui ser lançados como orientações para novos trabalhos, um deles seria estudar a evolução da dinâmica de divagação das planícies do rio dos Sinos a partir dos registros de paleocanais e como isso influenciou, ou não, no deslocamento das terras inundáveis, relacionando estes acontecimentos a eventos geológicos e climáticos. Uma segunda questão seria buscar a resposta para o paleocanal localizado em Caraá, no trecho superior da bacia hidrográfica analisada. Por ultimo, a partir do que pode ser constatado, buscar o porquê da 
não existência, na atualidade ou de forma permanente, de terras inundáveis em áreas planas e baixas entre o trecho médio e inferior da bacia.

Com base em pressupostos metodológicos teóricos e operacionais da Geomorfologia e de outros ramos que serviram como ferramenta, acredita-se que a hipótese lançada neste trabalho pôde ser atestada ao longo do desenvolvimento do mesmo.

A motivação para este trabalho se deu, de fato, pela beleza que estas áreas possuem, pela nostalgia que causam aos mais sensíveis, e por estarem sendo destruídas. A racionalização da questão veio mais adiante, buscando descobrir a importância que estas áreas possuem e como seria possível por meio da Geomorfologia estudá-las. Felizmente, ou não, há muitos problemas a serem resolvidos em relação ao objeto que foi escolhido.

Acreditava-se ter em mãos grande responsabilidade, pois se buscou abraçar um tema novo para o nosso campo de conhecimento. Crises, delírios, divagações e conversas com amigos e pesquisadores contribuíram para a realização deste trabalho. 


\section{CAPÍTULO VI - REFERÊNCIAS BIBLIOGRÁFICAS}

ABREU, A. A. A teoria geomorfológica e sua edificação: análise crítica. Revista IG. v. 4 , no 1- 2, São Paulo, 1983.

ABREU, A. A. Surell e as leis da morfologia fluvial. Craton \& Intracraton escritos e documentos $n^{\circ}$ 7. UNESP, 1980.

AB'SABER, A. N. Um conceito de geomorfologia a serviço das pesquisas sobre o Quaternário. Geomorfologia nº 18. Igeog - USP, São Paulo, 1969, p. 1 a 23.

AB'SABER, A. N. Brasil: Paisagens de Exceção. O litoral e o Pantanal-Matogrossense. Patrimônios Básicos. São Paulo, 2006.

ACKOFF, R. L. Systems, Organization, and Interdsciplinary Research (1960). In: EMERY, F. E. (Ed). Systems Thinking. Pequim Books Ltda, 1969.

Agência Nacional das Águas - ANA. Dados pluviométricos, estação 2951028. Disponível: http://www2.ana.gov.br/Paginas/servicos/informacoeshidrologicas/infor. aspx

ALMEIDA, W. S. Metodologia de sensoriamento remoto no monitoramento de modificações no canal fluvial e atualização de cartas náuticas. INPE - Instituto Nacional de Pesquisas Espaciais. São José dos Campos. 1989. 198p.

ALTENHOFEN, R.J. Relações ecológicas, percepções e representações de populações humanas ribeirinhas: subsídios para conservação de áreas úmidas na bacia hidrográfica do rio dos Sinos, RS. Dissertação de Mestrado. Universidade do Vale do Rio dos Sinos - UNISINOS. São Leopoldo, 2007. 
AMORIN, J. M.; REGO, H. N. A. de A. Impacto das águas pluviais sobre o meio ambiente no espaço urbano. UFU, 2008.

ASSINE, M. L., PIRANHA, J. M., CARNEIRO, C. D. R. Os paleodesertos Pirambóia e Botucatu. Capítulo V. In: Geologia do Continente Sul - Americano. Evolução da Obra de Fernando Marques de Almeida. São Paulo, Beca, 1994.

Associação Brasileira das Indústrias de Calçados - ABICALÇADOS. http://www.abicalcados.com.br/polos-produtores.html. 12/12/2009

ATLAS EÓlICO DO RIO GRANDE DO SUL. Disponível em: http://www.semc.rs.gov.br/atlas/INDEX_geral.htm

BAIERLE, S. Lutas Urbanas em Porto Alegre: entre a revolução e o transformismo. Porto Alegre: Cadernos da Cidade, 2005.

BEDFORD, B. L. \& PRESTON, E. M. Developing the scientific basis for assessing cumulative effects of wetland loss and degradation on landscape functions: status, perspectives, and prospects. Enviromental Management. Vol.12, n.5, 1988.

BENASSI, R. F. Dinâmica espaço-temporal de um sistema de áreas alagáveis na planície de inundação do rio Jacupiranga, Vale do Ribeira de Iguape, SP. São Carlos, 2006. 204p.

BERTALANFFY, L. Teoria Geral dos Sistemas. Petrópolis: Vozes, 1975.

BERTOLUCI, V. D. M. Inventário, Biodiversidade e conservação de área úmidas do município de São Leopoldo. UNISINOS. Programa de Pós-Graduação em Biologia: Diversidade e Manejo de Vida Silvestre. Dissertação de Mestrado. São Leopoldo, 2004. $70 \mathrm{p}$. 
BIGARELla, J.J., MOUSINHO, M.R. Considerações a respeito dos terraços fluviais, rampas de colúvio e várzeas. Bol. Paranaense de Geografia, Curitiba, n. 16-17, p. 117$153,1965$.

Boletim Mensal da Comissão Interna de Segurança Química. Ano I Número 10. Junho 2004. Disponível em: http://www.qca.ibilce.unesp.br/prevencao/BMCISQ1204.html. Acessado em $17 / 12 / 2009$.

BORGuEtTI, N. R. B., BORGUETTI, J. R., FILHO, E. F. R. Aquífero Guarani. A verdadeira integração dos países da América do Sul. 2008. 214p. Disponível resumo: http://www.oaquiferoguarani.com.br/index_02.htm

BRAILE, P.M. \& CAVALCANTE, J.E.W.A. Manual de tratamento de águas residuárias industriais, São Paulo: CETESB, 1993.

CARDOSO, C. A.; DIAS, H. C.H.; SOARES, C. P. B. S.; MARTINS, S. V. Caracterização morfométrica da bacia hidrográfica do rio Debossan, Nova Friburgo, RJ. Revista Árvore vol. $30 \mathrm{n}^{\mathrm{o}} .2$ Viçosa Mar./Abr. 2006

CASARtelli, M. R. O. Estudo do Fluxo de Metais Pesados na Bacia Hidrográfica do Rio dos Sinos - RS. Programa de Pós-Graduação em Geologia. Universidade do Vale do rio dos Sinos- UNISINOS. São Leopoldo, 1999. 167p.

CASSETI, Valter. Elementos de Geomorfologia. Goiânia, Editora UFG, 2001, 137 p.

CASSETI, V. Geomorfologia. Disponível: http://www.funape.org.br/geomorfologia/ Acessado em: 09/10/2006.

CASTRIOTA, L. B. (org.). Urbanização Brasileira - Redescobertas, Belo Horizonte: C/Arte, 2003. 303 p. 
CASTRO, J. F. M. - A importância da cartografia nos estudos de bacias hidrográficas. In: XXX Semana de Estudos Geográficos "O Homem e as Águas", Minicurso, CAEGE/IGCE/UNESP, 2000.

CEPSRM - Centro Estadual de Pesquisas em Sensoriamento Remoto e Meteorologia. Disponível em: http://www6.ufrgs.br/engcart/PDASR/fusao.html\#. Acessado em 24/06/2009.

CETESB - Companhia de Tecnologia de Saneamento Ambiental. CURTUMES. Série P +L. São Paulo, 2005.

CHOMENKO, L. - Conservação da biodiversidade: aspectos econômicos e planejamento dos recursos naturais. , Porto Alegre, Texto do II Curso de Manejo Sustentado na Área da Mata Atlântica, 1995, 29 p.

CHORLEY, R.J. A geomorfologia e a teoria dos Sistemas. Notícia Geomorfológica. Campinas, v.11, n.21, 1971.

CHORLEY, R. J.; KENNEDY, B. A. Physical geography - A systems approach. London: Prentice Hall International, 1971.

CHRISTOFOLETTI, A. Geomorfologia Fluvial. Edgard Blucher. São Paulo. 1981.

CHRISTOFOLETTI, A. Geomorfologia. 2ed. São Paulo: Edgard Blucher Ltda, 1974. 188 p.

CBERS 2. In: INSTITUTO NACIONAL DE PESQUISAS ESPACIAIS-INPE. São José dos Campos, [2005]. Disponível em: <http://www.dgi.inpe.br/CDSR>. Acesso em: maio 2009.

COLLAÇO, D. L. Caracterização geológico-geotécnica do município de São Leopoldo para fins de planejamento como subsídio ao Plano Diretor. Dissertação de Mestrado. EESC/USP, São Carlos/SP. 2003. 
COLLISCHONN, E. Inundações em Venâncio Aires/RS: Interações entre as dinâmicas natural e social na formação de riscos socioambientais urbanos. Tese de doutorado apresentada ao Programa de Pós-Graduação em Geografia, da Universidade Federal de Santa Catarina - UFSC, Florianópolis, 2009. 327p.

COWARDIN, L.M., CARTER, V., GOLET, F.C. \& LAROE, E.T. Classification of wetlands and deepwater habitats of the United States. Department of the Interior, Fish and Wildlife Service, Washington, D.C., 1979. 131 p.

CPRM (2008) Programa Geologia do Brasil. Levantamentos Geológicos Básicos. Geologia da Folha Gravataí. SH.22-X-C-V. Escala 1: 100000. Porto Alegre. 78p.

CUNHA, C.M.L. A cartografia do Relevo no contexto da Gestão Ambiental. Tese de Doutorado. Rio Claro: IGCE, UNESP, 2001. 128p.

CUNHA, C.M.L.; MENDES, I. A. Proposta de Análise Integrada dos Elementos Físicos da Paisagem: Uma Abordagem Geomorfológica. Estudos Geográficos, Rio Claro, 3(1): 111-120 jan-jun - 2005. www.rc.unesp.br/igce/grad/geografia/revista.htm

DAVIDOVICH. F. Considerações sobre a urbanização no Brasil. In: BECKER, B. K. et. al. (Orgs). Geografia e Meio Ambiente no Brasil. Rio de Janeiro: Hucitec, 1995.

DAVIS, T. J.; BLASCO, D. \& CARBONEL, M. Manual de la Convencion de Ramsar. Una guia a la Convencion sobre los humedales de importancia internacaional. Gland, Oficina de Convenção de Ramsar, 211p. 1996.

DEMEK, J. (ed.) Progress made in geomorphological mapping. Brno: IGU Commission on Applied Geomophology, 1967.

DIAS, J. E. et al. Geoprocessamento aplicado à análise ambiental: o caso do município de Volta Redonda/RJ. In: SILVA, J. X. da, ZAIDAN, R. T. Geoprocessamento e análise ambiental: aplicações. Rio de Janeiro: Bertrand Brasil, 2004. p. 143-177. 
DIEGUES, S. C. Programa de Pesquisa e Conservação de Áreas Úmidas no Brasil. USP/UICN/F. FORD. Inventário de Áreas Úmidas do Brasil. Versão Preliminar. São Paulo, 1990.

ENOMOTO, C. F. Método para elaboração de mapas de inundação: estudo de caso na bacia do rio Palmital, Paraná. 2004. Dissertação (Mestrado em Engenharia de Recursos Hídricos e Ambiental) - Setor de Tecnologia, Universidade Federal do Paraná, Curitiba, 2004.

Felgueiras, C. A.; CÂMARA, G. Modelagem Numérica do Terreno. Disponível em: http://www.dpi.inpe.br/gilberto/livro/introd/cap7-mnt.pdf. Acessado em 07 set. 2008.

FELICIO, B da C.; SILVA, R. S. Ações antrópicas nas áreas lindeiras a corpos d'água. In: XIII Encontro da Associação Nacional de Pós-Graduação e Pesquisa em Planejamento Urbano e Regional urbanos. Florianópolis, 2009.

FEPAM - Fundação Estadual de Proteção Ambiental. Qualidade das águas do Rio dos Sinos. Departamento de qualidade ambiental. Divisão de planejamento e diagnóstico. Monitoramento da qualidade da água. 1999.

FERNANDES, C. - MICRODRENAGEM - Um Estudo Inicial, DEC/CCT/UFPB, Campina Grande, 2002, 196p.

FIERZ, M. S. M. As abordagens sistêmica e do equilíbrio dinâmico na análise da fragilidade ambiental do litoral do estado de São Paulo: contribuição à geomorfologia das planícies costeiras. Tese apresentada à Universidade de São Paulo - USP. Faculdade de Filosofia Letras e Ciências Humanas. São Paulo, 2008.

FILHO, P. W. M. S. Costa de manguezais de macromaré da Amazônia: cenários morfológicos, mapeamento e quantificação de áreas usando dados de sensores remotos. Revista Brasileira de Geofísica. Vol.23 nº. 4. São Paulo Oct./Dec. 2005. 
FINLAYSON, C.M. \& VAN DER VALK, A.G. Wetland classification and inventory: A summary - Vegetatio 118: 185-192.1995.

FLOREnZANO, T. G. (Org.). Geomorfologia, conceitos e tecnologias atuais. Oficina de Textos, São Paulo, 2008. 318p.

FLORENZANO, T. G. Imagens TM-Landsat E HRV-Spot na elaboração de cartas geomorfológicas de uma região do rio Taquari, MS. Pesq. agropec. bras., Brasília, v.33, Número Especial, p.1721-1727, out. 1998

FONSECA, P. L.; NASCIMENTO, E. A.; LONGO, O. C., Gestão ambiental de bacias hidrográficas: medidas não convencionais no controle de cheias urbanas - principais aspectos, considerações e ações integradas. XIII SIMPEP - Bauru, São Paulo, 2006.

FONTES, M. Password. English Dictionary for Speakers of Portuguese. São Paulo, 2001. 783p.

FUjIMOTO, N. S. V. M. Análise Ambiental Urbana da área Metropolitana de Porto Alegre - RS: Sub-bacia Hidrográfica do arroio Dilúvio. Tese de Doutorado. São Paulo: USP, 1991, $236 \mathrm{p}$.

FUNCEME - Fundação Cearense de Meteorologia e Recursos Hídricos. Utilização de imagens CBERS para mapeamento dos espelhos d'água do Brasil. Disponível em: http://www.funceme.br/revistaeletronica/Utiliz_Imagens_CBERS_Espelho_DERAM_2007 .pdf Acessado em: 29/06/09.

GILMAN, K. Hydrology and Wetland Conservation. Institute of Hydrology. Ed.Wiley. Oxon, England, 1994. 101p. 
GIOVANNINI, E. Características do solo e vegetação, e proposta de método para o delineamento de terras úmidas do Rio Grande do Sul. Tese de Doutorado. Universidade Federal do Rio Grande do Sul, Porto Alegre, 2003.

GONÇALVES. A. R.; Lehugeur. L. G. O.; Castro, J. W. A.; Pedroto, A. E. S. Classificação das feições eólicas dos lençóis maranhenses - Maranhão - Brasil. Revista de Geografia da UFC, ano 2, número 03, 2003. 14p.

GODOY FILHO, J. D. Aspectos geológicos do Pantanal Mato-grossense e de sua área de influência. In: Simpósio

governo DO ESTADO DO RIO GRANDE DO SUl. Plano Diretor da Região Hidrográfica do Guaíba. Porto Alegre, 2005.

GRAU, E.R. Regiões Metropolitanas - Regime Jurídico. São Paulo: José Bushatsky, 1974.

GUERASIMOV, I. P, MECERJAKOV, J. A. Morphoestructure. FAIRBRIDGE, R. W. (ed). The Encyclopedia of Geomorphology, Reinhold Book, NY, 1968.

GUERRA, A.T. Dicionário Geológico-Geomorfológico. $4^{\mathrm{a}}$ ed. Rio de Janeiro: Secretaria de Planejamento da Presidência da República, Fundação Instituto Brasileiro de Geografia e Estatística, 1975. 439p.

GUERRA, A.T., CUNHA, S. B. (Orgs.) Geomorfologia. Uma atualização de bases e conceitos. Bertrand Brasil, Rio de Janeiro, 2007. 472p.

GOMES, M. A. F., FILIZOLA, H. F., SPADOTTO, C. A. Classificação das áreas de recarga do sistema aqǘ́fero Guarani no Brasil em domínios pedomorfoagroclimáticos subsídio aos estudos de avaliação de risco de contaminação das águas subterrâneas. Revista do Departamento de Geografia, 18 (2006) 67-74. 
GOPAL, B. \& SAH, M. Inventory and classification of wetlands in India.Vegetatio 118: 3948.1995 .

HAUSMAM, A. Aspectos da Geografia Urbana de Porto Alegre: Crescimento Urbano. In: Boletim Geográfico do Estado do Rio Grande do Sul. Porto Alegre: v.8, nº. 13. 1963.

HAUSMAM, A. Aspectos da Geografia Urbana de Porto Alegre. In: Boletim Geográfico do Estado do Rio Grande do Sul. Porto Alegre: v.6, nº. 12. 1961.

HERRMANN, M. L. P., CRISTO, S. S. V. Mapeamento e análise de áreas susceptíveis a riscos naturais de enchentes e deslizamentos no setor leste da bacia hidrográfica do rio Itacorubi, Florianópolis, SC - Brasil. In: Revista Ciência e Natureza. Santa Maria, 2004.

HORTON, R. E. Erosional development of estremas and their drainage basins; hydrophysical approach to quantitative morphology. Bulletin of the Geological Society of America. New York: Geological Society of America, v. 56, n. 3, p. 275-370, mar. 1945.

IBGE - Fund. IBGE. Manual Técnico de Geomorfologia. Departamento de Recursos Naturais. Rio de Janeiro, 1995.175 p.

IBGE - Fund. IBGE. Manual Técnico de Pedologia. Diretoria de Geociências. Coordenação de Recursos Naturais e Estudos Ambientais. Rio de Janeiro, 2007. 316p.

IDE, C., 1984. Qualidade da drenagem pluvial urbana. Porto Alegre: UFRGS-Curso de PósGraduação em recursos Hídricos e Saneamento 137f. Dissertação (mestrado).

INFANTI JUNIOR, N. \& FORNASARI FILHO, N. Processos de Dinâmica Superficial. In: OLIVEIRA, A.M.S. \& BRITO, S.N.A. (Eds.). Geologia de Engenharia. São Paulo: Associação Brasileira de Geologia de Engenharia (ABGE), 1998. cap. 9, p.131-152. 
Instituto Nacional de Pesquisas Espaciais - INPE. Imagem CBERS_CCD_2, cena 157_33, de 07/09/2005. Disponível: http://www.cbers.inpe.br/

[IPPC] INTEGRATED POLLUTION PREVENTION AND CONTROL - Joint Research Centre - European Commission. Reference document on best available techniques for the tanning of hides and skins. Sevilha, 2003.

Disponível em: http://www.jrc.es/pub/english.cgi/0/733169

Instituto Nacional de Áreas Umidas - INAU. Projeto de Implantação. Coordenador: Wolfgang Junk, 2008.

IRGANG, B.E. Comunidade de macrófitas aquáticas da Planície Costeira do Rio Grande do Sul-Brasil: um sistema de classificação. 1999, 140p. (Tese de doutorado).

JAKOB, A. A. E. A Krigagem como Método de Análise de Dados Demográficos. In: XIII Encontro da Associação Brasileira de Estudos Populacionais, Ouro Preto, Minas Gerais, 2002.

Jornal Vale dos Sinos (2009). Disponível em: http://www.jornalvs.com.br/site/principal/capa.asp Acessado em: 17/01/2010.

JUNIOR, P. T. S. VIII Conferência Internacional de Áreas Úmidas. http://www.cppantanal.org.br/intecol/eng/sections.php?id_section=5. Cuiabá. Mato Grosso, 2008.

JUNK, W. J., WANTZEN, K. M. Flood pulsing, and the development and maintenance of biodiversity in floodplains. In: Ecology of freshwater and estuarine wetlands, University of California Press, Berkeley, 2006. p. 407-435

JUNK, W. J., WANTZEN, K. M., Nunes da Cunha, C., PETERMANN, P., STRUSSMANN, C., MARQUES, M., ADIS, J. Comparative biodiversity value of large wetlands: the Pantanal of Mato Grosso, Brazil. Aquatic Sciences, 63, 278-309. 2006. 
KAYSER. Arno Leandro. O Nome do Rio dos Sinos. Disponível em:

http://www.comitesinos.com.br/site/index.php?option=com_content\&task=view\&id=12\&It emid=26. Acesso em 14 de outubro de 2008.

KAMPF, N. Metodologia para classificação de solos quanto à resistência a impactos ambientais decorrentes da disposição final de resíduos. Fepam em Revista, Porto Alegre, v.2, n.1, p.11-17, jan./dez. 2008.

KASPER, H. O processo de pensamento sistêmico: Um estudo das principais abordagens a partir de um quadro de referência proposto. Dissertação de Mestrado apresentada ao Programa de Pós-Graduação em Engenharia de Produção. UFRGS. Porto Alegre, 2000, 308 p.

KRIEGER, E.I.F. Avaliação da contaminação de águas subterrâneas na área de influência da Usina de Tratamento de Resíduos S/A - UTRESA, em Estância Velha (RS). Dissertação de Mestrado. Universidade Federal do Rio Grande do Sul, Porto Alegre, 2000. 142p.

KOPPEN, W. Climatologia: com un estudio de los climas de la tierra. Fondo de Cultura Economica. México, 479 p. (1948)

LOMBARDO, M. A. Qualidade Ambiental e planejamento urbano: considerações de método. Tese de livre docência. São Paulo: USP, 1996.

LYON, J. G. Practical Handbook for Wetland Identification and Delineation. Ed. Lewis Publishers, Florida, EUA, 1993. 157p.

MACEDO, E. S.; OGURA, T.; CANIL, K. ALMEIDA FILHO, G.S.; GRAMANI, M. F.; SILVA, F. C.; CORSI, C.; MIRANDOLA, F. A. Modelos de fichas descritivas para areas 
de risco de escorregamento, inundação e erosão. In: Anais do Simpósio Brasileiro de Desastres Naturais 1, Florianopolis: GEDN/UFSC, 2004, p.892-907.

\section{MACHADO, J. L. F.; FACCINI, U. F. INFLUÊNCIA DOS FALHAMENTOS REGIONAIS NA ESTRUTURAÇÃO DO SISTEMA AQÜÍFERO GUARANI NO ESTADO DO RIO GRANDE DO SUL}

MALTCHIK, L.; COSTA, E. S.; BECKER, C.G. \& OLIVEIRA, A. E. Inventory of wetlands of Rio Grande do Sul (Brazil). Pesquisas, Botânica 53: 79-88. 2003a

MALTCHIK, L.; ROLON, A. S. Áreas palustres: classificar para proteger. In: Revista Ciência Hoje. Vol. 38 nº. 228. São Leopoldo, 2006.

MALTCHIK, L. (Org.). Biodiversidade e Conservação de Áreas Úmidas da Bacia do Rio dos Sinos. São Leopoldo: UNISINOS, 2003.

MALTCHIK, L.; STERNET, C. Áreas úmidas da bacia do rio dos Sinos: diretrizes para programas de conservação. In: Acta Biológica Leopoldensia. Vol. 25 nº. 1. São Leopoldo 2003.

MANTESSO-NETO...[ et al,] (org.) Geologia do Continente Sul - Americano. Evolução da Obra de Fernando Marques de Almeida. São Paulo, Beca, 1994. 647p.

MANTZAVELAS, A.; ZALIDIS, G. GERAKIS, P. A. \& DAFIS, S. (eds.) 1995. Criteria for Wetland Identification. Thessaloniki, EKBY, 19p.

MECERJAKOV, J. P. Les concepts de morphostruture et morphoesculture: um nouvel instrument del'analyse geomorphologique. Annales de Geographie, nº 423. Paris, 1968.

MEDEIROS, J. C; CARVALHO, M. C. S; FERREIRA, G. B. Sistemas de Produção 3. Cultivo de Algodão Irrigado. Revista Eletrônica. 2006. 
MELFI, A. J.; PICCIRILLO, E. M.; NARDY, A. J. R. Geological and magmatic aspects of the Parana Basin: an introduction. In: PICCIRILLO E. M. \& MELFI, A. J. (Eds.). The Mesozoic Flood Volcanism of the Parana Basin: petrogenetic and geophysical aspects. São Paulo: USP, 1988. p. 1-14.

MENDES, J.C. Elementos de estratigrafia. São Paulo: T.A. Queiroz \& Editora da Universidade de São Paulo, 1984. 566p.

METROPLAN - Fundação Estadual de Planejamento Metropolitano. Os rios na cidade: as enchentes na evolução urbana da região metropolitana de Porto Alegre. Porto Alegre. 2001.96 p.

MILANI, E. J. Comentário sobre a origem e a evolução tectônica da bacia do Paraná. Capítulo XVI. In: Geologia do Continente Sul - Americano. Evolução da Obra de Fernando Marques de Almeida. São Paulo, Beca, 1994.

MIRANDA, E. E. de; (Coord.). Brasil em Relevo. Campinas: Embrapa Monitoramento por Satélite, 2005. Disponível em: 〈http://www.relevobr.cnpm.embrapa.br>. Acesso em: 13 fev. 2009. Imagens: SRTM SH-22-Y-D, SH-22-Y-B.

MITSCH, W. J., GOSSELINK, J. G., Wetlands. Ed. Van Nostrand Reinhold, New York, USA, 1986. 537p.

MIZUSAKI, A. M. P., FILHO, A. T. O magmatismo Pós-Paleozóico no Brasil. Capítulo XVII. In: Geologia do Continente Sul - Americano. Evolução da Obra de Fernando Marques de Almeida. São Paulo, Beca, 1994.

MOLD, Z. M., Urbanização na Área Metropolitana de Porto Alegre: - Um Enfoque Espacial. Monografia PROPUR - Programa de Pós - Graduação em Planejamento Urbano e Regional. Departamento de Urbanismo/ Faculdade de Arquitetura da UFGRS, Porto Alegre, 1973. 
MONTEIRO, C.A.F. Teoria e Clima Urbano. In: MONTEIRO, C.A.F.; MENDONÇA, F. A. (Org.). Clima urbano. São Paulo, Ed. Contexto, 2003. p.9-67.

MONTEIRO, L. H. U.; SOUZA, G. M.; MAIA, L. P. Evolução das áreas de manguezal do litoral nordeste brasileiro entre 1978 e 2004.

NEIFF, J.J. El régimen de pulsos en ríos y grandes humedales de Sudamérica. Pp. 97-145. In: Malvarez, A I \& P Kandus (eds.): Tópicos sobre grandes humedales sudamericanos. ORCYT-MAB (UNESCO) 224 p. 1999.

NETO, J. L. S; PORTELA F. O Pantanal. Editora Ática. 1992, São Paulo. 48 p.

NISHIYAMA, L. Mapeamento geotécnico preliminar da Quadrícula de São Carlos. Dissertação (Mestrado) - Departamento de Engenharia Civil, EESC, Universidade de São Paulo. 266p, v.1. 1991.

NOTA TÉCNICA DO PROJETO DE CONTROLE DE ENCHENTES NO VALE DO RIO DOS SINOS (2008). São Leopoldo.

NUNES, J. O. R.; ROCHA, P. C. Geomorfologia aplicação e métodos. Ed. Expressão Popular. São Paulo, 2008.

O'BRIEN, A. L. Evaluating the cumulative effects of alteration on New England Wetlands. Environmental Management, Vol. 12, n. 5. 1988.

ODUM, E.P. Ecologia. Edt. Guanabara, Rio de Janeiro, 1983, 434p. 
OLIVEIRA, G. G., PENTEADO, A. F. Mapeamento e análise da distribuição das áreas inundáveis na bacia do rio dos Sinos/RS. XIII Simpósio Brasileiro de Sensoriamento Remoto. Natal, 2010.

ORTIZ, L.S. Avaliação do incremento potencial de risco toxicológico associado às concentrações de metais pesados de origem antrópica nas águas do Rio Caí, RS, Brasil. Dissertação de Mestrado. Universidade Federal do Rio Grande do Sul, 2000. 111p.

PAIVA, I. M. R. Risco de inundação em Coimbra. Factores físicos e acção antrópica. As Inundações Urbanas e as Cheias do Mondego (1950/51 - 2003/04). Universidade de Coimbra, Faculdade de Letras. Dissertação de Mestrado. Coimbra, 2005. 206 p.

PAULA, C. C. Caracterização ambiental da bacia de drenagem do rio dos Sinos. Curso de Mestrado em Geologia, área de concentração em geologia sedimentar. São Leopoldo, 1995. 138p. Unisinos.

PENCK, W. Morphological analysis of landforms: a contribution to physical geology. London: MacMillan, 1953.

PENTEADO, A. F. Análise Ambiental da bacia hidrográfica do arroio Kruze - Região Metropolitana de Porto Alegre - RS. Instituto de Geociências. Programa de Pós Graduação em Geografia. UFRGS. 2006. 210p.

PENTEADO, M. M. O. A Geomorfologia no contexto social. In: Geografia e Planejamento. São Paulo: Universidade de São Paulo - Instituto de Geografia, nº 34, p. 1-25, 1981.

Pesquisa Nacional de Saneamento Básico - PNSB (2000) Disponível em: http://www.ibge.gov.br/home/estatistica/populacao/condicaodevida/pnsb/default.shtm Acessado em: 10/01/2010. 
PICKETT, S. T.; CARDENASSO, M. L.; GROVE, J. M.; NILON, C. H.; POUYAT, R. V.; ZIPPERER, W. C.; CONSTANZA, R. Urban Ecological System: Linking Terrestrial, Ecological, Physical and socioeconomic Components of Metropolitan Areas. Annual Review of Ecology and Systematics, 33, 2001.

PINHO, C. M. D. ; RENNÓ, C. D.; KUX, H. J. H. Avaliação de técnicas de fusão aplicadas à imagem Quickbird. INPE - Instituto Nacional de Pesquisas Espaciais. São José dos $\begin{array}{lllll}\text { Campos } & - & \text { SP, } & 2005 . & \text { Disponível }\end{array}$ http://marte.dpi.inpe.br/col/ltid.inpe.br/sbsr/2004/11.22.20.14/doc/4225.pdf. Acesso em: 08/12/2007.

PINTO, M. N. Geormofologia do Pantanal Matogrossense. Disponível em: http://marte.dpi.inpe.br/col/dpi.inpe.br/marte@80/2008/07.22.19.16/doc/078-085.pdf Acessado em 27/08/2010.

Prefeitura de São Leopoldo. Projeto de Controle de Enchentes no Vale do Rio dos Sinos. Estudo de escoamento de vazões críticas no canal central do rio dos Sinos localizado entre a antiga ponte férrea da Av. Mauá e a Casa de Bombas no 04 - Polder V - São Leopoldo - RS. Relatório Final. 2008.

PROJETO PLANAGUA/GTZ de Cooperação Técnica Brasil - Alemanha. Rios e Córregos. Preservar - Conservar - Renaturalizar a recuperação de rios. Possibilidades e Limites da Engenharia Ambiental. 1998.

PROJETO RADAMBRASIL. Folha SH 22. Porto Alegre e parte das folhas SH 21 Uruguaiana e SI 22 Lagoa Mirim. Rio de Janeiro: IBGE, 1986. 791 p.

PROJETOS - RIO DOS SINOS. Fotografia do muro de arrimo no centro de São Leopoldo. Disponível:

http://www.wittler.com.br/engenharia/site/default.asp?TroncoID=906480\&SecaoID $=707260$ Acessado: 09/2009. 
PROTEGER - Programa Técnico para o Gerenciamento da Região Metropolitana de Porto Alegre. Áreas de inundação, Alagamento e Banhados. Metroplam, CPRM - Serviço Geológico do Brasil, 1994. 50p.

PRÓSINOS - Programa de Educação Ambiental da bacia hidrográfica do rio dos Sinos. Disponível em: http://www.portalprosinos.com.br/ Acessado em 10/12/2009.

RAMOS, E. M. Aspectos Geográficos e Geológicos da Região Metropolitana de Porto Alegre (Norte). Dissertação de Mestrado. Porto Alegre: UFRGS, 1975. 106 p.

REBELO, F. Risco e crise nas inundações rápidas em espaço urbano. Alguns exemplos portugueses analisados a diferentes escalas. Territorium, 4, Edições Minerva, Coimbra, pp. 2948. 1997.

REZENDE, B. e TUCCI, C. E. M., 1979. Análise das Inundações em Estrela: relatório técnico. Estrela: Prefeitura Municipal de Estrela, 30p.

RIO GRANDE DO SUL. Secretaria da Coordenação e Planejamento. Baía das todas as águas: Preservação e Gerenciamento Ambiental na bacia hidrográfica do Guaíba. Porto Alegre: Secretaria Executiva do Pró Guaíba, 1998.

ROCHE, J. A colonização alemã e o Rio Grande do Sul. Porto Alegre: Globo, 1969.

RODRIGUES, M. L. K. Origem, distribuição e mobilidade potencial de metais pesados em ambiente fluvial impactado por curtumes. Tese de doutorado. Universidade Federal do Rio Grande do Sul, Porto Alegre, 2007. 256p.

ROSA, R; BRITO, J. L. S. Mapa hipsométrico e de declividade do terreno da bacia hidrográfica do rio Araguari - MG. In: II Simpósio Regional de Geografia "Perspectivas para o cerrado no século XXI". Universidade Federal de Uberlândia - Instituto de Geografia. Minas Gerais, 2003. 
ROSS, J. L. S. (Org.). Geografia do Brasil. Edusp. São Paulo: 1996.

ROSS, J. L. S. Geomorfologia: ambiente e planejamento. São Paulo: Contexto, 1992.

ROSS, J. L. S. O registro cartográfico dos fatos geomorfológicos e a questão da taxonomia do relevo. Revista do Departamento de Geografia. São Paulo: FFLCH/USP, nº 6, 1992.

SCHNEIDER, M.J.; BELLON, O. R. P.; ARAKI, H. Experimentos em fusão de imagens de alta resolução. Bol. Ciênc. Geod., sec. Artigos, Curitiba, v. 9, no 1, p.75-88, 2003.

SCOTT, D.A. \& JONES, T.A. Classification and inventory of wetlands: A global overview. Vegetatio 118: 3-16.1995.

Secretaria de Meio Ambiente - SEMA. Relatório Anual Sobre a Situação dos Recursos Hídricos no Estado do Rio Grande do Sul. Departamento de Recursos Hídricos - DRH, Porto Alegre. 2007.

Secretaria das Obras Públicas e Saneamento do Rio Grande do Sul. Cartilha da Região Metropolitana. Porto Alegre: 1999. 33 p.

Secretaria do Desenvolvimento Regional da Presidência da República. Governo do Rio Grande do Sul. Relatório Técnico do Projeto de Controle de Enchentes no Vale do Rio dos Sinos. São Leopoldo, 1992.

Secretaria de Habitação, Saneamento e Desenvolvimento Urbano do RS.

Disponível em http://www.habitacao.rs.gov.br/portal/index.php?acao=servico\&cod=corsan Acessado em: 21/12/2009.

Secretaria de Planejamento Municipal de Porto Alegre. Plano Diretor de Desenvolvimento Urbano Ambiental. Lei complementar 434/99. Porto Alegre: 1999. 165 p. 
SEMENIUK, C.A. \& SEMENIUK, V. A geomorphic approach to global classification for inland wetlands. Vegetatio 118: 103-124.1995.

SEMMAM - Secretaria Municipal de Meio Ambiente. Subsídios para o Diagnóstico Técnico sobre o município de São Leopoldo. Primeira etapa do Plano Diretor. Aspectos Ambientais. São Leopoldo: SEMMAM, 2006. 59 p.

SHINE, C.; KLEMM, C. Wetlands, water and the law. Using law to advance wetland concervation and mise use. Ramsar Convention Bureau, Gland, 1999.

SILVA, M. P.; MAURO, R.; MOURÃO, G. COUTINHO, M. Distribuição e quantificação de classes de vegetação do Pantanal através de levantamento aéreo. Revista Brasileira de Botânica. Vol.23 n.2 São Paulo, 2000.

SILVA, T. I., RODRIGUES, S. C., TUTORIAL DE CARTOGRAFIA GEOMORFOLÓGICA ARC GIS 9.2 e ENVI 4.0. Universidade Federal de Uberlândia Instituto de Geografia. Uberlândia, 2009. 66p.

SILVA, V. Dinâmica da Paisagem: Estudo Integrado de Ecossistemas Litorâneos em Hauva (Espanha) e Ceará (Brasil). Tese (Doutorado em Geografia Física), Universidade Estadual Paulista - UNESP, Rio Claro (SP), 1993.

SINGER, P. Desenvolvimento econômico e evolução Urbana: análise da evolução econômica de São Paulo, Blumenau, Porto Alegre, Belo Horizonte e Recife. São Paulo: Nacional, $2^{\text {a }}$ ed., 1977.

SMAM - Secretaria Municipal de Meio Ambiente de Porto Alegre. Programa de Áreas de Risco. Preservando a vida e a natureza. Porto Alegre: 2004. 23 p. 
SOUZA, C. F.; MULLER, D. M. Porto Alegre e sua evolução urbana. Porto Alegre: Editora da Universidade, 1997. 127 p.

STRECK, E. V,; et al. Solos do Rio Grande do Sul. Porto Alegre: EMATER/RS, 2008. 222p.

SUGUIO, K; MARTIN, L; BIITENCOURT, A. C.S.P.; DOMINGUEZ, J. M.L.; FLEXOR, J. M.; AZEVEDO, A. E.G.; Flutuações do nível relativo do mar durante o Quaternário Superior ao longo do litoral Brasileiro e suas implicações na sedimentação costeira. Revista Brasileira de Geociências. 1985.

TAVARES, V.E.Q.; DUARTE da Silva, P. A. Preservação de Áreas Úmidas. II Congresso Brasileiro de Agroecologia, 2007.

TINER, RW. Wetland indicators. Lewis. New York, USA, 1999.

TNC: Planejamento Ecorregional do Pantanal: Relatório Final. - The Nature Conservancy, Brasília - Distrito Federal. 2003.

TOMAZELli, L. J.; VILlWOCK, J. A. Mapeamento Geológico das Planícies Costeiras: o Exemplo da Costa do Rio Grande do Sul. Revista Gravel. Número 3. Porto Alegre, 2005.

TORRES, A. P.; ALMEIDA, R. A. Esboço sócio-ambiental da bacia hidrográfica do rio Passa Vaca, SSA-BA. GeoTextos, vol. 4, n . 1 e 2, 2008.

TUCCI, C. E. M. (Org.) Hidrologia. Ciência e Aplicação. ABRH. Ed. UFRGS, 2009. 943 p.

TUCCI, C. E. M. Regionalização de Vazões. Ed. da Universidade. UFRGS, 2002. 256 p.

TUCCI, C.E.M., Controle de Enchentes, in: Tucci, C. (org.). Hidrologia ciência e aplicação. Porto Alegre: Ed. da Universidade: ABRH cap. 16, p621-658.: 952p, 1993 b. 
TUCCI, C. E. M.; PORTO, R. L. L.; BARROS, M. T. de (Orgs.). Drenagem Urbana. ABRH Associação Brasileira de Recursos Hídricos. Porto Alegre: UFRGS, 1995. 428 p.

TUNDISI, T. M.; TUNDISI, J. G. Limnologia. Ed. Oficina de Textos. São Paulo, 2008. 631 p.

WIKIPÉDIA. Definição de pôlder. Acessado em: 01/02/2010. Disponível em: http://pt.wikipedia.org/wiki/P\%C3\%B4lder

WHITE, I.C. (1908) Relatório Final da Comissão de Estudos das Minas de Carvão de Pedra do Brasil. Rio de Janeiro: DNPM, 1988. Parte I; Parte II, p. 301-617. (ed. Fac-similar)

WITTLER. H. C. P.; BARTH, M. Projeto de Proteção Contra Inundações no Vale do rio dos Sinos. Ministério do Interior. Departamento Nacional de Obras de Saneamento. X Congresso Brasileiro de Engenharia Sanitária e Ambiental. Manaus, 1979. 22p.

VAITSMAN, D. S.; AFONSO, J. C.; DUTRA, P.B. (2001) Para que servem os elementos químicos. Editora Interciência, 67-70 p.

VALERIANO, M. M. Modelo digital de elevação com dados SRTM disponíveis para a América do Sul. São José dos Campos: INPE, 2004. 72 p. (INPE-10550-RPQ/756). Disponível em: <http://urlib.net/sid.inpe.br/sergio/2004/06.30.10.57>. Acesso em: 13 fev. 2009.

VENTURINI, L. A. B. Os diferentes significados do relevo no ensino da Geomorfologia. In: V Simpósio Nacional de Geomorfologia. I Encontro Sul - Americano de Geomorfologia. Santa Maria: UFSM, 2004. 10 p.

VIEIRA, E. F. Rio Grande do Sul Geografia Física e Vegetação. Porto Alegre: Sagra, 1984.

VIEIRA, R.dos S.: Legislation and the use of Amazonian floodplains. - In: JUNK, W.J., OHLY, J., PIEDADE, M.T.F. \& SOARES, M.G.M: The Central Amazon Floodplain: 
Actual Use and Options for a Sustainable Management. - Backups Publishers b.v., Leiden: 505-533. 2000.

VILLELA, S.M.; MATTOS, A. Hidrologia Aplicada. São Paulo: McGraw - Hill do Brasil, 1979, 245p.

VITTE, A. C; GUERRA, A. J. T. (ORG.). Reflexões sobre a Geografia Física no Brasil. Rio de Janeiro: Bertrand Brasil, 2004.

ZANINI, D. Peixes agonizam no rio dos Sinos entre Sapucaia do Sul e Esteio. 25/10/2006. Reportagem página prefeitura municipal de São Leopoldo. Disponível:

https://www.saoleopoldo.rs.gov.br/home/show page.asp?id SHOW noticia=1885\&user=\&id CONTEU $\mathrm{DO}=\&$ codID $\mathrm{CAT}=2 \&$ imgCAT $=$ tema prefeitura.jpg\&pagina $=25 \&$ editorial=Meio\%20Ambiente \& categoria $=$ Not\%EDcias

ZASSO L. A. A alteração na deriva litorânea e no balanço de sedimentos em costas arenosas. Estudo de caso: Molhes do rio Mampituba e praias adjacentes. Pontifícia Universidade Católica do Rio Grande do Sul. Faculdade de Geografia. Porto Alegre, 2007. $67 \mathrm{p}$. 
ANEXO A

Algumas especies da flora e da fauna da bacia hidrográfica do rio dos Sinos

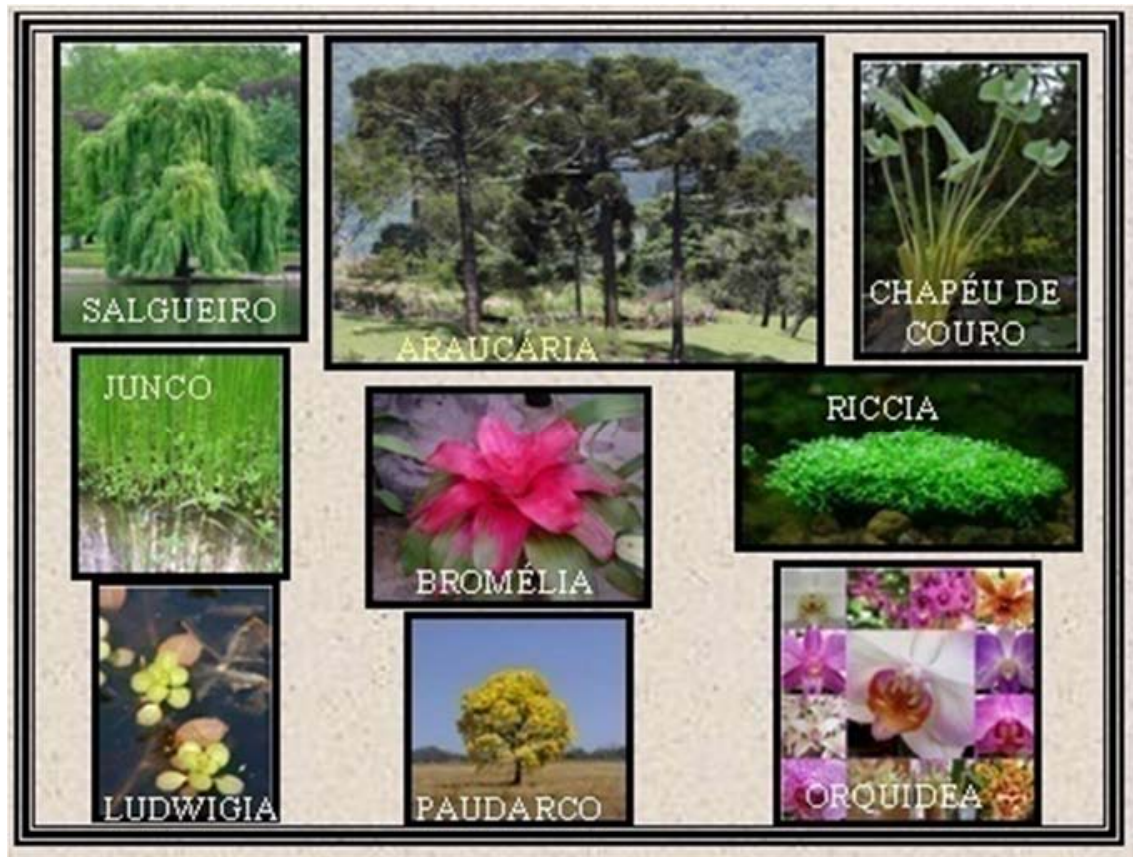

Fonte: PRÓSINOS, 2009. Org.: Adriana Penteado, 2009.

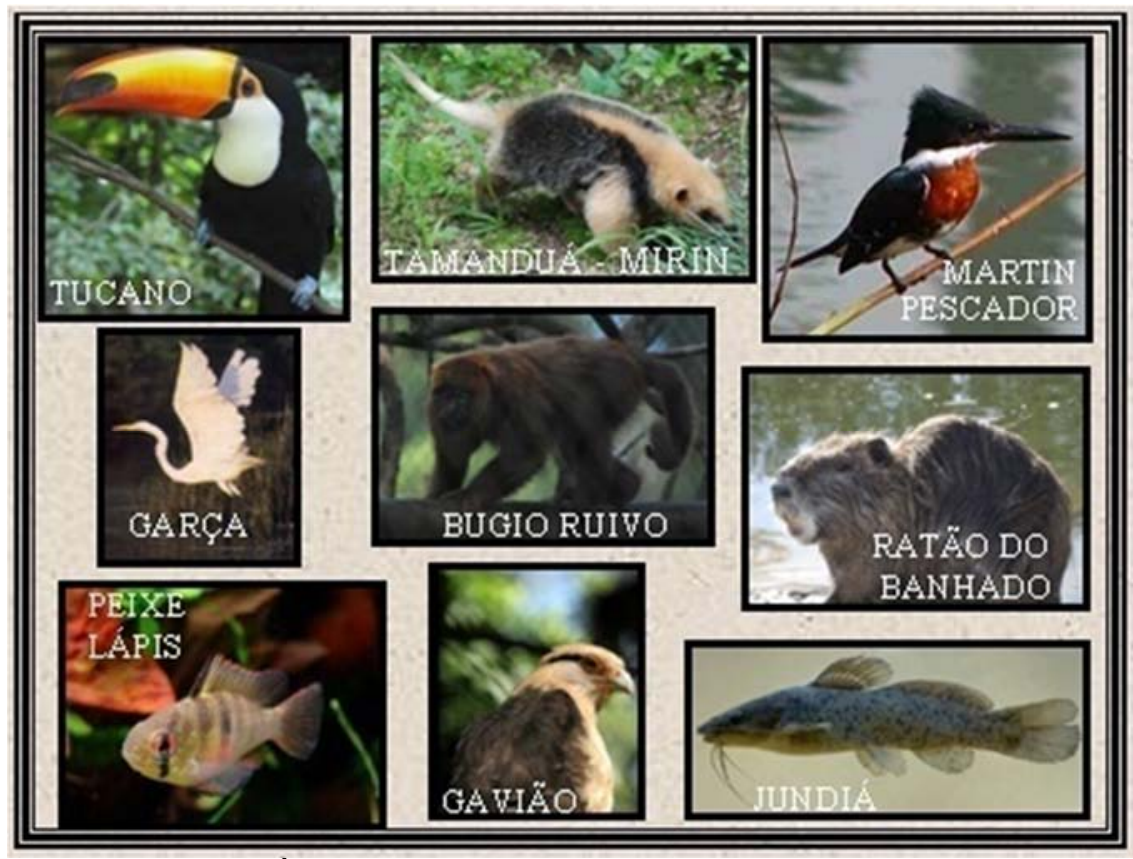

Fonte: PRÓSINOS, 2009. Org.: Adriana Penteado, 2009 


\section{ANEXO B: \\ Sistema de Clasificación de tipos de Humedales de Ramsar}

Los códigos se basan en el Sistema de Clasificación de Tipos de Humedales aprobado en la Recomendación 4.7, enmendada por las Resoluciones VI.5 y VII.11 de la Conferencia de las Partes Contratantes. Las categorías enumeradas a continuación sólo tienen por objeto aportar un marco muy amplio que facilite la identificación rápida de los principales hábitat de humedales representados en cada sitio.

Con objeto de asistir en la determinación de los tipos correctos de humedales para su enumeración en la sección 19 de la FIR, la Secretaría proporciona a continuación, para los humedales marinos y costeros y los humedales continentales, una clasificación con algunas de las características de cada tipo de humedal.

\section{Humedales marinos y costeros}

A -- Aguas marinas someras permanentes, en la mayoría de los casos de menos de seis metros de profundidad en marea baja; se incluyen bahías y estrechos.

B -- Lechos marinos submareales; se incluyen praderas de algas, praderas de pastos marinos, praderas marinas mixtas tropicales .

\section{C -- Arrecifes de coral.}

D -- Costas marinas rocosas; incluye islotes rocosos y acantilados.

E -- Playas de arena o de guijarros; incluye barreras, bancos, cordones, puntas e islotes de arena; incluye sistemas y hondonales de dunas.

F -- Estuarios; aguas permanentes de estuarios y sistemas estuarinos de deltas.

G -- Bajos intermareales de lodo, arena o con suelos salinos ("saladillos").

H -- Pantanos y esteros (zonas inundadas) intermareales; incluye marismas y zonas inundadas con agua salada, praderas halófilas, salitrales, zonas elevadas inundadas con agua salada, zonas de agua dulce y salobre inundadas por la marea.

I -- Humedales intermareales arbolados; incluye manglares, pantanos de "nipa", bosques inundados o inundables mareales de agua dulce.

J -- Lagunas costeras salobres/saladas; lagunas de agua entre salobre y salada con por lo menos una relativamente angosta conexión al mar.

K -- Lagunas costeras de agua dulce; incluye lagunas deltaicas de agua dulce.

Zk(a) -- Sistemas kársticos y otros sistemas hídricos subterráneos, marinos y costeros. 


\section{Humedales continentales}

L -- Deltas interiores (permanentes).

M -- Ríos/arroyos permanentes; incluye cascadas y cataratas.

N -- Ríos/arroyos estacionales/intermitentes/irregulares.

O -- Lagos permanentes de agua dulce (de más de 8ha); incluye grandes madre viejas (meandros o brazos muertos de río).

P -- Lagos estacionales/intermitentes de agua dulce (de más de 8ha); incluye lagos en llanuras de inundación.

Q -- Lagos permanentes salinos/salobres/alcalinos.

R -- Lagos y zonas inundadas estacionales/intermitentes salinos/salobres/alcalinos.

Sp -- Pantanos/esteros/charcas permanentes salinas/salobres/alcalinos.

Ss -- Pantanos/esteros/charcas estacionales/intermitentes salinos/salobres/alcalinos.

Tp -- Pantanos/esteros/charcas permanentes de agua dulce; charcas (de menos de 8 ha), pantanos y esteros sobre suelos inorgánicos, con vegetación emergente en agua por lo menos durante la mayor parte del período de crecimiento.

Ts -- Pantanos/esteros/charcas estacionales/intermitentes de agua dulce sobre suelos inorgánicos; incluye depresiones inundadas (lagunas de carga y recarga), "potholes", praderas inundadas estacionalmente, pantanos de ciperáceas.

U -- Turberas no arboladas; incluye turberas arbustivas o abiertas ("bog"), turberas de gramíneas o carrizo ("fen"), bofedales, turberas bajas.

Va -- Humedales alpinos/de montaña; incluye praderas alpinas y de montaña, aguas estacionales originadas por el deshielo.

Vt -- Humedales de la tundra; incluye charcas y aguas estacionales originadas por el deshielo.

W -- Pantanos con vegetación arbustiva; incluye pantanos y esteros de agua dulce dominados por vegetación arbustiva, turberas arbustivas ("carr"), arbustales de Alnus sp; sobre suelos inorgánicos.

Xf -- Humedales boscosos de agua dulce; incluye bosques pantanosos de agua dulce, bosques inundados estacionalmente, pantanos arbolados; sobre suelos inorgánicos.

Xp -- Turberas arboladas; bosques inundados turbosos.

Y -- Manantiales de agua dulce, oasis.

Zg -- Humedales geotérmicos.

Zk(b) -- Sistemas kársticos y otros sistemas hídricos subterráneos, continentales.

Nota: "llanuras de inundación" es un término utilizado para describir humedales, generalmente de gran extensión, que pueden incluir uno o más tipos de humedales, entre los que se pueden encontrar R, Ss, Ts, W, Xf, Xp, y otros (vegas/praderas, savana, bosques inundados estacionalmente, etc.). No es considerado un tipo de humedal en la presente clasificación.

\section{Humedales artificiales}


1 -- Estanques de acuicultura (por ej. estanques de peces y camaroneras)

2 -- Estanques artificiales; incluye estanques de granjas, estanques pequeños (generalmente de menos de 8ha).

3 -- Tierras de regadío; incluye canales de regadío y arrozales.

4 -- Tierras agrícolas inundadas estacionalmente; incluye praderas y pasturas inundadas utilizadas de manera intensiva.

5 -- Zonas de explotación de sal; salinas artificiales, salineras, etc.

6 -- Áreas de almacenamiento de agua; reservorios, diques, represas hidroeléctricas, estanques artificiales (generalmente de más de 8 ha).

7 -- Excavaciones; canteras de arena y grava, piletas de residuos mineros.

8 -- Áreas de tratamiento de aguas servidas; "sewage farms", piletas de sedimentación, piletas de oxidación.

9 -- Canales de transportación y de drenaje, zanjas.

Zk(c) -- Sistemas kársticos y otros sistemas hídricos subterráneos, artificiales.

Clasificación de las características de los tipos de humedales

Humedales marinos/costeros:

\begin{tabular}{|c|c|c|c|}
\hline \multirow{5}{*}{ Agua salina } & \multirow{3}{*}{ Permanente } & $<6 \mathrm{~m}$ de profundidad & A \\
\hline & & Vegetación submarina & B \\
\hline & & Arrecifes de coral & C \\
\hline & \multirow[b]{2}{*}{ Costas } & Rocosas & $\mathrm{D}$ \\
\hline & & $\begin{array}{l}\text { Playas de arena o } \\
\text { guijarros }\end{array}$ & E \\
\hline \multirow{5}{*}{$\begin{array}{l}\text { Agua salina o } \\
\text { salobre }\end{array}$} & \multirow{3}{*}{ Intermareal } & $\begin{array}{l}\text { Bajos (lodo, arena o } \\
\text { con suelos salinos) }\end{array}$ & G \\
\hline & & Pantanos y esteros & $\mathrm{H}$ \\
\hline & & Bosques & I \\
\hline & \multicolumn{2}{|l|}{ Lagunas } & $\mathrm{J}$ \\
\hline & \multicolumn{2}{|l|}{ Estuarios } & $\mathrm{F}$ \\
\hline $\begin{array}{l}\text { Agua salina, } \\
\text { salobre o dulce }\end{array}$ & \multicolumn{2}{|l|}{ Subterránea } & $\mathrm{Zk}(\mathrm{a})$ \\
\hline Agua dulce & \multicolumn{2}{|l|}{ Lagunas } & $\mathrm{K}$ \\
\hline
\end{tabular}


Humedales continentales:

\begin{tabular}{|c|c|c|c|c|}
\hline \multirow{16}{*}{ Agua dulce } & \multirow{4}{*}{$\begin{array}{l}\text { Corrientes de } \\
\text { agua }\end{array}$} & \multirow{3}{*}{ Permanentes } & Ríos, arroyos & $\mathrm{M}$ \\
\hline & & & Deltas & $\mathrm{L}$ \\
\hline & & & Manantiales, oasis & $\mathrm{Y}$ \\
\hline & & Estacionales/intermitentes & Ríos, arroyos & $\mathrm{N}$ \\
\hline & \multirow{4}{*}{ Lagos y lagunas } & \multirow{2}{*}{ Permanentes } & $>8 \mathrm{ha}$ & $\mathrm{O}$ \\
\hline & & & $<8 \mathrm{ha}$ & $\mathrm{Tp}$ \\
\hline & & Estacionales/intermitentes & $>8 \mathrm{ha}$ & $\mathrm{P}$ \\
\hline & & & $<8$ ha & Ts \\
\hline & \multirow{4}{*}{$\begin{array}{c}\text { Pantanos sobre } \\
\text { suelos inorgánicos }\end{array}$} & Permanentes & $\begin{array}{l}\text { Dominio de la } \\
\text { vegetación }\end{array}$ & $\mathrm{Tp}$ \\
\hline & & \multirow{2}{*}{$\begin{array}{l}\text { Permanentes/ } \\
\text { estacionales/intermitentes }\end{array}$} & $\begin{array}{l}\text { Dominio del } \\
\text { arbusto }\end{array}$ & $\mathrm{W}$ \\
\hline & & & $\begin{array}{l}\text { Dominio del } \\
\text { árbol }\end{array}$ & Xf \\
\hline & & Estacionales/intermitentes & $\begin{array}{l}\text { Dominio de la } \\
\text { vegetación }\end{array}$ & Ts \\
\hline & \multirow{2}{*}{$\begin{array}{l}\text { Pantanos sobre } \\
\text { suelos de turba }\end{array}$} & \multirow{2}{*}{ Permanentes } & No arboladas & $\mathrm{U}$ \\
\hline & & & Arboladas & $\mathrm{x}_{\mathrm{p}}$ \\
\hline & \multirow{2}{*}{$\begin{array}{l}\text { Pantanos sobre } \\
\text { suelos inorgánicos } \\
\text { o de turbera }\end{array}$} & \multicolumn{2}{|l|}{ Gran altitud (alpino) } & $\mathrm{Va}$ \\
\hline & & \multicolumn{2}{|l|}{ Tundra } & $\mathrm{Vt}$ \\
\hline \multirow{4}{*}{$\begin{array}{l}\text { Agua salina, } \\
\text { salobre o } \\
\text { alcalina }\end{array}$} & \multirow{2}{*}{ Lagos } & \multicolumn{2}{|l|}{ Permanentes } & Q \\
\hline & & \multicolumn{2}{|l|}{ Estacionales/intermitentes } & $\mathrm{R}$ \\
\hline & \multirow{2}{*}{$\begin{array}{l}\text { Pantanos, esteros } \\
\text { y charcas }\end{array}$} & \multicolumn{2}{|l|}{ Permanentes } & Sp \\
\hline & & \multicolumn{2}{|l|}{ Estacionales/intermitentes } & Ss \\
\hline \multirow{2}{*}{$\begin{array}{l}\text { Agua fresca, } \\
\text { salina, salobre } \\
\text { o alcalina }\end{array}$} & \multicolumn{3}{|l|}{ Geotérmica } & $\mathrm{Zg}$ \\
\hline & \multicolumn{3}{|l|}{ Subterránea } & $\mathrm{Zk}(\mathrm{b})$ \\
\hline
\end{tabular}

\section{Anexo C:}

Criterios para la Identificación de Humedales de Importancia Internacional

$$
\text { y lineamientos para su aplicación }
$$

Aprobados por la Conferencia de las Partes Contratantes en sus Reuniones $7^{\text {a }}$ (1999) y 9a (2005) en sustitución de losCriterios aprobados previamente por la COP en sus Reuniones $4^{\mathrm{a}}$ y $6^{\mathrm{a}}$ (1990 y 1996), para orientar la aplicación del artículo 2.1 de la Convención sobre designación de sitios Ramsar

Grupo A de los Criterios - Sitios que comprenden tipos de humedales representativos, raros o únicos

Criterio 1: Un humedal deberá ser considerado de importancia internacional si contiene un ejemplo representativo, raro o único de un tipo de humedal natural o casi natural hallado dentro de la región biogeográfica apropiada. 
Grupo B de los Criterios - Sitios de importancia internacional para conservar la diversidad biológica

Criterios basados en especies y comunidades ecológicas

Criterio 2: Un humedal deberá ser considerado de importancia internacional si sustenta especies vulnerables, en peligro o en peligro crítico, o comunidades ecológicas amenazadas.

Criterio 3: Un humedal deberá ser considerado de importancia internacional si sustenta poblaciones de especies vegetales y/o animales importantes para mantener la diversidad biológica de una región biogeográfica determinada.

Criterio 4: Un humedal deberá ser considerado de importancia internacional si sustenta especies vegetales y/o animales cuando se encuentran en una etapa crítica de su ciclo biológico, o les ofrece refugio cuando prevalecen condiciones adversas.

Criterios específicos basados en aves acuáticas

Criterio 5: Un humedal deberá ser considerado de importancia internacional si sustenta de manera regular una población de 20.000 o más aves acuáticas.

Criterio 6: Un humedal deberá ser considerado de importancia internacional si sustenta de manera regular el $1 \%$ de los individuos de una población de una especie o subespecie de aves acuáticas.

Criterios específicos en base a peces

Criterio 7: Un humedal deberá ser considerado de importancia internacional si sustenta una proporción significativa de las subespecies, especies o familias de peces autóctonas, etapas del ciclo biológico, interacciones de especies y/o poblaciones que son representativas de los beneficios y/o los valores de los humedales $\mathbf{y}$ contribuye de esa manera a la diversidad biológica del mundo.

Criterio 8: Un humedal deberá ser considerado de importancia internacional si es una fuente de alimentación importante para peces, es una zona de desove, un área de desarrollo y crecimiento y/o una ruta migratoria de la que dependen las existencias de peces dentro o fuera del humedal.

Criterios específicos basados en otros taxones

Criterio 9: Un humedal deberá considerarse de importancia internacional si sustenta habitualmente el 1\% de los individuos de la población de una especie o subespecie dependiente de los humedales que sea una especie animal no aviaria. 


\section{ANEXO D: \\ Resolução nº 303, de 20 de março de 2002}

Edição Número 166 de 28/08/2003

RESOLUÇÃO No 303, DE 20 DE MARÇO DE 2002

RESOLUÇÃO CONAMA nº 302, de 20 de março de 2002

RESOLUÇÃO CONAMA nº 302, de 20 de março de 2002

Publicada no DOU nos 90, de 13 de maio de 2002, Seção 1, páginas 67-68

Correlações:

Complementa a Resolução no 303/02

Dispõe sobre os parâmetros, definições e limites de Áreas de Preservação Permanente de reservatórios artificiais e o regime de uso do entorno.

O CONSELHO NACIONAL DO MEIO AMBIENTE-CONAMA, no uso das competências que lhe são conferidas pela Lei ${ }^{\circ}$ 6.938, de 31 de agosto de 1981, regulamentada pelo Decreto $n^{\circ}$ 99.274, de 6 de junho de 1990, e tendo em vista o disposto nas Leis nos 4.771, de 15 de setembro de 1965, 9.433, de 8 de janeiro de 1997, e o seu Regimento Interno, e Considerando a função sócio-ambiental da propriedade prevista nos arts. 5o, inciso XXIII, 170, inciso VI, 182, § 2o, 186, inciso II e 225 da Constituição e os princípios da prevenção, da precaução e do poluidorpagador;

Considerando a necessidade de regulamentar o art. 2o da Lei $\mathrm{n}^{\circ} 4.771$, de 15 de setembro de 1965, no que concerne às Áreas de Preservação Permanente;

Considerando as responsabilidades assumidas pelo Brasil por força da Convenção da Biodiversidade, de 1992, da Convenção Ramsar, de 1971 e da Convenção de Washington, de 1940, bem como os compromissos derivados da Declaração do Rio de Janeiro, de 1992;

Considerando a conveniência de regulamentar os arts. 2o e 3o da Lei no 4.771, de 15 de setembro de 1965, no que concerne às Áreas de Preservação Permanente; (considerando acrescentado pela Resolução n 341/03)

Considerando ser dever do Poder Público e dos particulares preservar a biodiversidade, notadamente a flora, a fauna, os recursos hídricos, as belezas naturais e o equilíbrio ecológico, evitando a poluição das águas, solo e ar, pressuposto intrínseco ao reconhecimento e exercício do direito de propriedade, nos termos dos arts. 5o, caput (direito à vida) e inciso XXIII (função social da propriedade), 170, VI, 186, II, e 225, todos da Constituição Federal, bem como do art. 1.299, do Código Civil, que obriga o proprietário e posseiro a respeitarem os regulamentos administrativos; (considerando acrescentado pela Resolução $n^{\circ}$ 341/03) 
Considerando a função fundamental das dunas na dinâmica da zona costeira, no controle dos processos erosivos e na formação e recarga de aqüíferos; (considerando acrescentado pela Resolução n 341/03)

Considerando a excepcional beleza cênica e paisagística das dunas, e a importância da manutenção dos seus atributos para o turismo sustentável; (considerando acrescentado pela Resolução n 341/03)

Considerando que as Áreas de Preservação Permanente e outros espaços territoriais especialmente protegidos, como instrumentos de relevante interesse ambiental, integram o desenvolvimento sustentável, objetivo das presentes e futuras gerações, resolve:

Art. 1o Constitui objeto da presente Resolução o estabelecimento de parâmetros, definições e limites referentes às Áreas de Preservação Permanente.

Art. 2o Para os efeitos desta Resolução, são adotadas as seguintes definições:

I - nível mais alto: nível alcançado por ocasião da cheia sazonal do curso d’água perene ou intermitente;

II - nascente ou olho d água: local onde aflora naturalmente, mesmo que de forma intermitente, a água subterrânea;

III - vereda: espaço brejoso ou encharcado, que contém nascentes ou cabeceiras de cursos d’água, onde há ocorrência de solos hidromórficos, caracterizado predominantemente por renques de buritis do brejo (Mauritia flexuosa) e outras formas de vegetação típica;

IV - morro: elevação do terreno com cota do topo em relação a base entre cinqüenta e trezentos metros e encostas com declividade superior a trinta por cento (aproximadamente dezessete graus) na linha de maior declividade;

V - montanha: elevação do terreno com cota em relação a base superior a trezentos metros;

VI - base de morro ou montanha: plano horizontal defi nido por planície ou superfície de lençol d’água adjacente ou, nos relevos ondulados, pela cota da depressão mais baixa ao seu redor;

VII - linha de cumeada: linha que une os pontos mais altos de uma sequiência de morros ou de montanhas, constituindo-se no divisor de águas;

VIII - restinga: depósito arenoso paralelo à linha da costa, de forma geralmente alongada, produzido por processos de sedimentação, onde se encontram diferentes comunidades que recebem influência marinha, também consideradas comunidades edáficas por dependerem mais da natureza do substrato do que do clima. A cobertura vegetal nas restingas ocorre em mosaico, e encontra-se em praias, cordões arenosos, dunas e depressões, apresentando, de acordo com o estágio sucessional, estrato herbáceo, arbustivo e arbóreo, este último mais interiorizado;

IX - manguezal: ecossistema litorâneo que ocorre em terrenos baixos, sujeitos à ação das marés, formado por vasas lodosas recentes ou arenosas, às quais se associa, predominantemente, a vegetação natural conhecida como mangue, com influência flúvio-marinha, típica de solos limosos de regiões estuarinas e com dispersão descontínua ao longo da costa brasileira, entre os estados do Amapá e Santa Catarina;

X - duna: unidade geomorfológica de constituição predominante arenosa, com aparência de cômoro ou colina, produzida pela ação dos ventos, situada no litoral ou no interior do continente, podendo estar recoberta, ou não, por vegetação; 
XI - tabuleiro ou chapada: paisagem de topografia plana, com declividade média inferior a dez por cento, aproximadamente seis graus e superfície superior a dez hectares, terminada de forma abrupta em escarpa, caracterizando-se a chapada por grandes superfícies a mais de seiscentos metros de altitude;

XII - escarpa: rampa de terrenos com inclinação igual ou superior a quarenta e cinco graus, que delimitam relevos de tabuleiros, chapadas e planalto, estando limitada no topo pela ruptura positiva de declividade (linha de escarpa) e no sopé por ruptura negativa de declividade, englobando os depósitos de colúvio que localizam-se próximo ao sopé da escarpa;

XIII - área urbana consolidada: aquela que atende aos seguintes critérios:

a) definição legal pelo poder público;

b) existência de, no mínimo, quatro dos seguintes equipamentos de infra-estrutura urbana:

1. malha viária com canalização de águas pluviais,

2. rede de abastecimento de água;

3. rede de esgoto;

4. distribuição de energia elétrica e iluminação pública;

5. recolhimento de resíduos sólidos urbanos;

6. tratamento de resíduos sólidos urbanos; e

c) densidade demográfica superior a cinco mil habitantes por km2.

Art. 3o Constitui Área de Preservação Permanente a área situada:

I - em faixa marginal, medida a partir do nível mais alto, em projeção horizontal, com largura mínima, de:

a) trinta metros, para o curso d'água com menos de dez metros de largura;

b) cinqüenta metros, para o curso d'água com dez a cinqüenta metros de largura;

c) cem metros, para o curso d'água com cinqüenta a duzentos metros de largura;

d) duzentos metros, para o curso d'água com duzentos a seiscentos metros de largura;

e) quinhentos metros, para o curso d'água com mais de seiscentos metros de largura;

II - ao redor de nascente ou olho d'água, ainda que intermitente, com raio mínimo de cinqüenta metros de tal forma que proteja, em cada caso, a bacia hidrográfica contribuinte;

III - ao redor de lagos e lagoas naturais, em faixa com metragem mínima de:

a) trinta metros, para os que estejam situados em áreas urbanas consolidadas;

b) cem metros, para as que estejam em áreas rurais, exceto os corpos d’água com até vinte hectares de superfície, cuja faixa marginal será de cinqüenta metros;

IV - em vereda e em faixa marginal, em projeção horizontal, com largura mínima de cinqüenta metros, a partir do limite do espaço brejoso e encharcado; 
V - no topo de morros e montanhas, em áreas delimitadas a partir da curva de nível correspondente a dois terços da altura mínima da elevação em relação a base;

VI - nas linhas de cumeada, em área delimitada a partir da curva de nível correspondente a dois terços da altura, em relação à base, do pico mais baixo da cumeada, fixando-se a curva de nível para cada segmento da linha de cumeada equivalente a mil metros;

VII - em encosta ou parte desta, com declividade superior a cem por cento ou quarenta e cinco graus na linha de maior declive;

VIII - nas escarpas e nas bordas dos tabuleiros e chapadas, a partir da linha de ruptura em faixa nunca inferior a cem metros em projeção horizontal no sentido do reverso da escarpa;

IX - nas restingas:

a) em faixa mínima de trezentos metros, medidos a partir da linha de preamar máxima;

b) em qualquer localização ou extensão, quando recoberta por vegetação com função fixadora de dunas ou estabilizadora de mangues;

X - em manguezal, em toda a sua extensão;

XI - em duna;

XII - em altitude superior a mil e oitocentos metros, ou, em Estados que não tenham tais elevações, a critério do órgão ambiental competente;

XIII - nos locais de refúgio ou reprodução de aves migratórias;

XIV - nos locais de refúgio ou reprodução de exemplares da fauna ameaçados de extinção que constem de lista elaborada pelo Poder Público Federal, Estadual ou Municipal;

$\mathrm{XV}$ - nas praias, em locais de nidificação e reprodução da fauna silvestre.

Parágrafo único. Na ocorrência de dois ou mais morros ou montanhas cujos cumes estejam separados entre si por distâncias inferiores a quinhentos metros, a Área de Preservação Permanente abrangerá o conjunto de morros ou montanhas, delimitada a partir da curva de nível correspondente a dois terços da altura em relação à base do morro ou montanha de menor altura do conjunto, aplicando-se o que segue:

I - agrupam-se os morros ou montanhas cuja proximidade seja de até quinhentos metros entre seus topos;

II - identifica-se o menor morro ou montanha;

III - traça-se uma linha na curva de nível correspondente a dois terços deste; e

IV - considera-se de preservação permanente toda a área acima deste nível.

Art. 4o O CONAMA estabelecerá, em Resolução específica, parâmetros das Áreas de Preservação Permanente de reservatórios artificiais e o regime de uso de seu entorno.

Art. 5o Esta Resolução entra em vigor na data de sua publicação, revogando-se a Resolução CONAMA no 4, de 18 de setembro de 1985 . 
JOSÉ CARLOS CARVALHO - Presidente do Conselho

Este texto não substitui o publicado no DOU, de 13 de maio de 2002.

\author{
ANEXO E: \\ Lei municipal ${ }^{\circ} 6.493$ de 17.12 .2007

\section{PREFEITURA MUNICIPAL DE SÃO LEOPOLDO \\ Estado do Rio Grande do Sul}

(Lei Municipal no 6.493, de 17.12.2007

Anexo A - Aspectos Relevantes dos Banhados

Para o embasamento desta proposta, salientamos que os órgãos gestores de todo a política proposta, a saber, a SEMMAM e o SEMAE, representam São Leopoldo nos seguintes sistemas:

SEMMAM:

I - Sistema Nacional do Meio Ambiente - SISNAMA - Lei n. ${ }^{\circ}$ 6.938, de 31 de agosto de 1981;

II - Sistema Nacional de Gerenciamento de Recursos Hídricos - Lei n. ${ }^{\circ}$ 9.433, de 08 de janeiro de 1997;

III - Sistema Estadual de Proteção Ambiental - SISEPRA - Lei n. ${ }^{\circ}$ 10.330, de 27 de dezembro de 1994;

IV - Sistema Estadual de Recursos Hídricos - Lei n. ${ }^{\circ}$ 10.350, de 30 de dezembro de 1994;

V - Sistema Estadual de Saneamento - SESAN - Lei n. ${ }^{\circ}$ 12.037, de 19 de dezembro de 2003.

SEMAE:

I - Sistema Nacional de Recursos Hídricos - Lei n. ${ }^{\circ}$ 9.433, de 08 de janeiro de 1997;

II - Sistema Estadual de Recursos Hídricos - Lei n. ${ }^{\circ}$ 10.350, de 30 de dezembro de 1994;

III - Sistema Estadual de Saneamento - SESAN, conforme Lei Estadual n. ${ }^{\circ}$ 12.037, de 19 de dezembro de 2003.

Cabe aqui ressaltar a incorporação das premissas do SEMAE, criado pela Lei Municipal 1.648, de 31 de dezembro de 1971. 
Também, como motivação para este código cabem as justificativas abaixo. Ainda que o código não legisle apenas sobre as áreas úmidas, são preservação é vital à qualidade de vida em nossa cidade:

1) Os banhados, bastante ameaçados, são terrenos caracterizados pela presença de água, a qual cobre parte significativa de sua área total, saturando os sedimentos e criando condições de solo encharcado, geralmente, em um ambiente redutor, que permite apenas o desenvolvimento de espécies vegetais adaptadas a essas condições. Como existe variação geográfica do tipo principal de vegetação dominante nesses ambientes, ocorre grande variedade de tipos de sistemas alagados e de nomes atribuídos aos mesmos. Em inglês, são conhecidas como wetland, que pode ser traduzida como área úmida ou zona úmida, e é o termo internacional que denomina o conjunto dos diversos tipos de sistemas úmidos existentes.

2) A palavra banhado provém do termo espanhol bafiado, sendo utilizada principalmente no Rio Grande do Sul, onde esses ecossistemas ocupam grandes extensões na zona costeira, em regiões mais interiores e em São Leopoldo.

3) Na maior parte do país, esses ambientes são conhecidos como "brejos", embora sejam chamados também de "pântanos", "pantanal", "charcos", "varjões" e "alagados", entre outros. Na classificação de vegetação do projeto RADAMBRASIL (IBGE, 1996) os banhados aparecem como Áreas Pioneiras de Influência Fluvial.

4) A relevância destes terrenos está na existência de funções ecológicas importantes para a manutenção do equilíbrio das regiões em que se desenvolvem. Essas funções incluem a produção de alimentos, a conservação da biodiversidade, a sustentação das atividades pesqueiras, a contenção de enchentes, o controle da poluição e o potencial como áreas de recreação. Tendo, como processos ambientais mais importantes a geração de solo, a produção vegetal (produção primária) e a estocagem de nutrientes e carbono, água e biodiversidade.

5) Nos banhados do Rio dos Sinos, registra-se a presença de 141 espécies vegetais, pertencentes a 61 famílias. Estas espécies se distribuem no ambiente ao longo de uma sucessão vegetal que acompanha, de maneira geral, a topografia do terreno e as condições de solo.

6) algumas espécies típicas de banhados são a capivara (Hydrochaerus hidrochaeris), graxaim (Dusicyon sp), ratão-do-banhado (Myocastor coypus), rã-comum (Leptodactylus ocellatus), sapo-cururu (Bufo arenarum), cobra-campeira (Mastigodryas bifossatus), traíra (Hoplias malabaricus), lambaris (Astyanax spp), biguá (Phalacrocorax o/ivaceous), tacha (Chauna torquata), garça branca (Casmerodius 
alba), frangos d'água (Fulica sp.), marrecas (Família Anatidae) e gavião-caramujeiro (Rostrhamus sociabilis).

Impactos sobre os banhados:

A interrupção do padrão natural de vazão afeta o aporte de nutrientes e conseqüentemente a produção primária local. A retirada de água interfere na exportação de materiais (sedimentos, detritos, nutrientes, zooplâncton e vegetação) para fora do sistema natural. Ocorre alteração da composição da flora e da fauna, uma vez que as espécies regulam seu ciclo de vida a partir dos níveis de água. A retenção exagerada de água pode contribuir para a alteração da qualidade do solo. A drenagem do sistema pode promover a acidificação do solo local.

Estes impactos ocorrem por meio de:

I - degradação dos cursos de água que abastecem os banhados;

II - retirada de água para uso agrícola, doméstico e industrial;

III - construção de diques, barragens e represas;

IV - drenagem para implantação de atividades agrícolas.

Recomendações: Impedir qualquer tipo de alteração do padrão hidrológico natural do ambiente.

\section{Contaminação da água}

O uso de grandes quantidades de herbicidas e fertilizantes é acompanhado do perigo de contaminação dos animais (domésticos e silvestres) e dos vegetais, além de apresentarem efeitos negativos sobre microorganismos do solo e a organismos de sangue frio. Isto contribui para distúrbios na cadeia alimentar e para o desequilíbrio dos ecossistemas. A pulverização de algum desses produtos por aviões, assim como o destino das embalagens, que geralmente são enterradas, tendem a agravar o quadro, contaminando o lençol freático (água subterrânea).

Recomendações: Identificar, avaliar e monitorar os possíveis índices de contaminação da água, o solo e dos organismos, assim como estabelecer um programa a fim de monitorar tais parâmetros ambientais.

Também é sugerido um programa de educação ambiental com as comunidades do entorno dos banhados, visando resolver o problema do destino das embalagens dos produtos. 


\title{
PREFEITURA MUNICIPAL DE SÃO LEOPOLDO \\ Estado do Rio Grande do Sul
}

\begin{abstract}
$\underline{\text { Urbanização }}$
A ocupação urbana em áreas de banhado é realizada por meio de loteamentos, construção de moradias e implantação de indústrias. O processo de ocupação humana se inicia com a remoção da vegetação nativa. Há um posterior aterramento das áreas, sendo acompanhado freqüentemente pela disposição inadequada de resíduos sólidos (lixo), que atingem os banhados por meio do lançamento direto e/ou do carreamento pelas chuvas. Ocorre também o lançamento de efluentes (esgotos) domésticos e industriais. A urbanização das áreas de banhados agrava as enchentes nas áreas urbanas.

Recomendações: os banhados devem ser considerados áreas não edificantes. Deve haver fiscalização sobre os pontos de lançamentos de efluentes e resíduos e o monitoramento da qualidade da água.
\end{abstract}

\section{$\underline{\text { Caça e Pesca }}$}

A caça tende a afetar as comunidades de animais silvestres. Já a pesca predatória, seja pela quantidade de recursos extraídos, pelos apetrechos de pesca utilizados, pelas espécies capturadas ou pela época de realização da atividade (períodos de defeso), pode provocar alterações significativas na ictiofauna.

Recomendações: Sugere-se a proibição total da caça nesses ambientes, assim como uma maior fiscalização dos órgãos competentes aliada ao reforço dos programas de educação ambiental.

\section{Desmatamentos}

O desmatamento retira dos ecossistemas os principais organismos produtores (geradores de matéria orgânica e nutrientes), prejudicando a produtividade de todo o ambiente. É importante destacar que algumas espécies de aves têm uma especificidade tão grande por certas árvores que, não encontrando 
árvore ou material adequado para a construção de seus ninhos, nem sequer realizam acasalamento, podendo vir a desaparecer.

Além disso, o solo desprotegido de sua cobertura vegetal é carregado pela erosão, causando assoreamento dos corpos hídricos e redução da fertilidade das terras. Existe também, em algumas áreas de banhado, a extração ilegal de orquídeas silvestres e de plantas ornamentais e o comércio clandestino dessas espécies.

Recomendações: Ampliar a fiscalização dos órgãos competentes, assim como programas de educação ambiental.

\section{Introdução de Espécies Exóticas}

Espécies vegetais exóticas, como Pinus sp. e o Eucalipto sp, que apresentam crescimento rápido e alto consumo de água, quando plantadas nas proximidades dos banhados, provocam o rebaixamento do lençol freático.

Além disso, esses florestamentos inibem o desenvolvimento das populações típicas da fauna e da flora. Quando abandonados ou manejados de forma inadequada, podem expandir-se rapidamente, ocupando novas áreas. Também o desenvolvimento de aqüicultura com espécies exóticas, em áreas vizinhas aos banhados, pode facilitar a introdução de espécies que prejudiquem a biota nativa.

Recomendações: Impedir o plantio massivo de espécies exóticas nas adjacências desses ecossistemas. Fiscalizar as atividades de aqüicultura desenvolvidas.

\section{Competência Legal}

A competência legal e o encaminhamento das questões relativas à preservação e manejo dos banhados no Brasil estão nas esferas municipais, estaduais e federal.

No âmbito federal, estas questões estão sob supervisão do IBAMA; no âmbito estadual, sob supervisão dos órgãos de meio ambiente estaduais e, no âmbito municipal, sob responsabilidade das secretarias municipais de meio ambiente.

(Lei Municipal nº 6.493, de 17.12.2007.

\section{PREFEITURA MUNICIPAL DE SÃO LEOPOLDO}

Estado do Rio Grande do Sul 
As atividades, nestes sistemas, dependem de prévio licenciamento pelo órgão estadual competente, sem prejuízo de outras licenças exigíveis, os quais analisam, licenciam, propõem e orientam diversas formas de pesquisas, usos e manejos nos banhados.

(Lei Municipal n 6.493, de 17.12.2007.

\section{ANEXO F: \\ Definição de Áreas Inundadas (DIEGUES, 2002).}

Nomes regionais que designam áreas inundadas:

Águas emendadas: fenômeno que ocorre quando o divisor de águas de duas bacias é indefinido, permitindo a livre passagem das águas de uma bacia para outra. Como exemplo, há a ligação entre os rios Tocantins e São Francisco, entre o rio Guaporé e Paraguai, etc.

Aningais: formações vegetais ribeirinhas, arbustivas ou arborescentes isoladas ou em conjunto com manguezais.

Baías: lagos que se comunicam com um rio (pantanal).

Baixios: bancos de areia de afloram com a maré ou com a vazante

Bocainas: baías profundas e extensas (Maranhão).

Buraco ou abismo: caverna com desenvolvimento vertical.

Cacimba: cova que recolhe água de terrenos pantanosos.

Chapeirão: recife isolado em forma de árvore ou chapéu. O chapeirão, via de regra, não é posto a descoberto nem pelas marés baixas.

Couxos: canais de escoamento de lagoas (Pantanal).

Cuvetas de maré: depressões costeiras - rochosas ou não - escavadas pelo mar e descobertas à maré baixa.

Furo: comunicação natural entre rios ou entre o rio e lago (Baixo Amazonas).

Gruta ou lapa: caverna com desenvolvimento horizontal.

Igapó: denominação dada aos pequenos rios da região Amazônica.

Jundu: vegetação formada à retaguarda de restingas consolidadas (Costa Leste, de São Paulo a Santa Catarina).

Olhos de água: nascentes redondas isoladas ou à beira-rio, provenientes de insurgêngia do lençol freático. Parcel: recife ou escolho que afloram com determinadas marés, formando ilhas. 
Rias: Costa de submersão caracterizada por apresentar vales muito largos, com barra em forma de trombeta (Pará, Maranhão).

Rio de Pororoca: rios sujeitos a macaréu (onda de alguns metros) ou a benzeiro (ondas de menor porte).

Salões: baixios de argila vermelha e dura provenientes de escarpas a pique de ruíram (Amazônia).

Teso: elevação em várzea inundada, a salvo das águas (Amazonas, Amapá e Maranhão).

Tombo-das-águas: encontro de marés opostas em braços de estuário (Lagamar de Cananéia).

Várzea: planície fluvial.

Veredas: cabeceiras vizinhas de cursos de água, orlados de marimbu, buritizais. 


\section{ANEXO G:}

Principais aspectos e impactos ambientais do processo produtivo de curtumes

\begin{tabular}{|c|c|c|}
\hline $\begin{array}{c}\text { Etapa Básica do } \\
\text { Processo }\end{array}$ & Poluição & $\begin{array}{c}\text { Aspecto Ambiental - } \\
\text { Emissão }\end{array}$ \\
\hline $\begin{array}{c}\text { Conservaçăo e } \\
\text { Armazenamento } \\
\text { das Peles - "barraca" }\end{array}$ & $\begin{array}{l}\text { 1. Ar } \\
\text { 2. Hidrica } \\
\text { 3. Solo / Residuos } \\
\text { Solidos }\end{array}$ & $\begin{array}{l}\text { 1. } \mathrm{NH}_{3} \text { e COVs (1) } \\
\text { 2. eventuais liquidos eliminados pelas } \\
\text { peles } \\
\text { 3. alguns pedaços / apêndices de peles } \\
\text { e sal com matéria orgânica }\end{array}$ \\
\hline Ribeira & $\begin{array}{l}\text { 1. Ar } \\
\text { 2. Hidrica } \\
\text { 3. Solo / Residuos } \\
\text { Solidos }\end{array}$ & $\begin{array}{l}\text { 1. } \mathrm{H}_{S} \mathrm{~S}(1), \mathrm{NH}_{5} \text { e COVs } \\
\text { 2. banhos residuais de tratamento das } \\
\text { peles e águas de lavagens } \\
\text { intermediárias - carga orgânica e } \\
\text { produtos químicos (sulfeto, sais } \\
\text { diversos e outros). } \\
\text { 3. camaça, pêlos, aparas / recortes e } \\
\text { raspas de peles, sem e com produtos } \\
\text { químicos }\end{array}$ \\
\hline Curtimento & 1. Hidrica & $\begin{array}{l}\text { 1. banho residual de curtimento das } \\
\text { peles - carga orgânica e produtos } \\
\text { químicos (cromo, taninos, sais diversos } \\
\text { e outros). }\end{array}$ \\
\hline Acabamento & $\begin{array}{l}\text { 1. Ar } \\
\text { 2. Hidrica } \\
\text { 3. Solo / Residuos } \\
\text { Solidos }\end{array}$ & $\begin{array}{l}\text { 1. COVs - dos solventes dos produtos } \\
\text { aplicados } \\
\text { 2. banhos residuais de tratamento dos } \\
\text { couros - carga orgânica e produtos } \\
\text { químicos (cromo, taninos, corantes, } \\
\text { óleos e outros). } \\
\text { 3. po / farelo / serragem de } \\
\text { rebaixadeira, recortes de couros } \\
\text { curtidos, semi-acabados e acabados, } \\
\text { pó de lixa, residuos de produtos de } \\
\text { acabamento (tintas, resinas e outros) }\end{array}$ \\
\hline
\end{tabular}

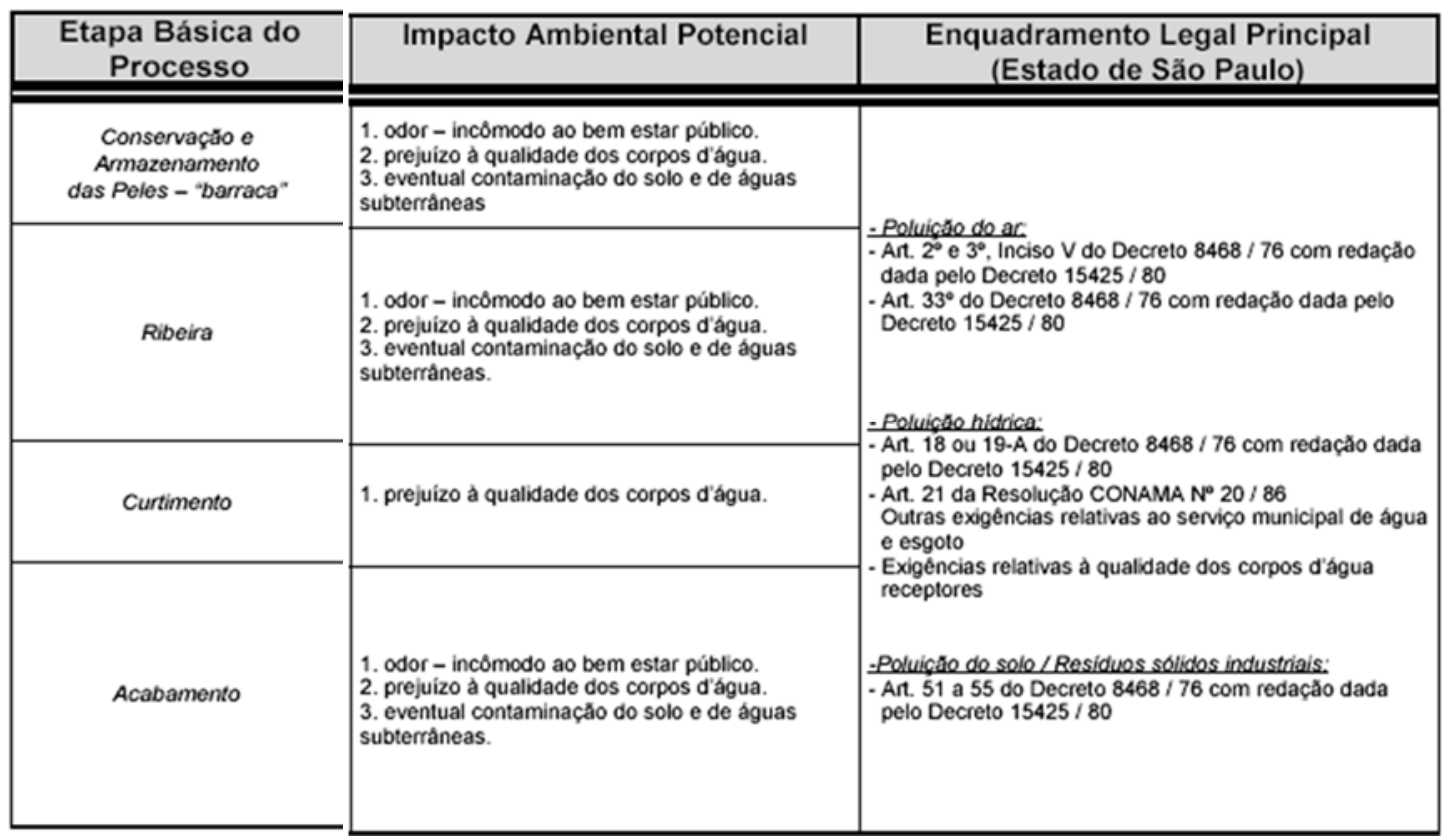

(1) NH3 = gás amônia / COVs = compostos orgânicos voláteis / H2S = gás sulfídrico

Fonte: Companhia de Tecnologia de Saneamento Ambiental-CETESB, 2005. 


\section{ANEXO H:}

Traçado proposto dos diques e respectivos pôlderes

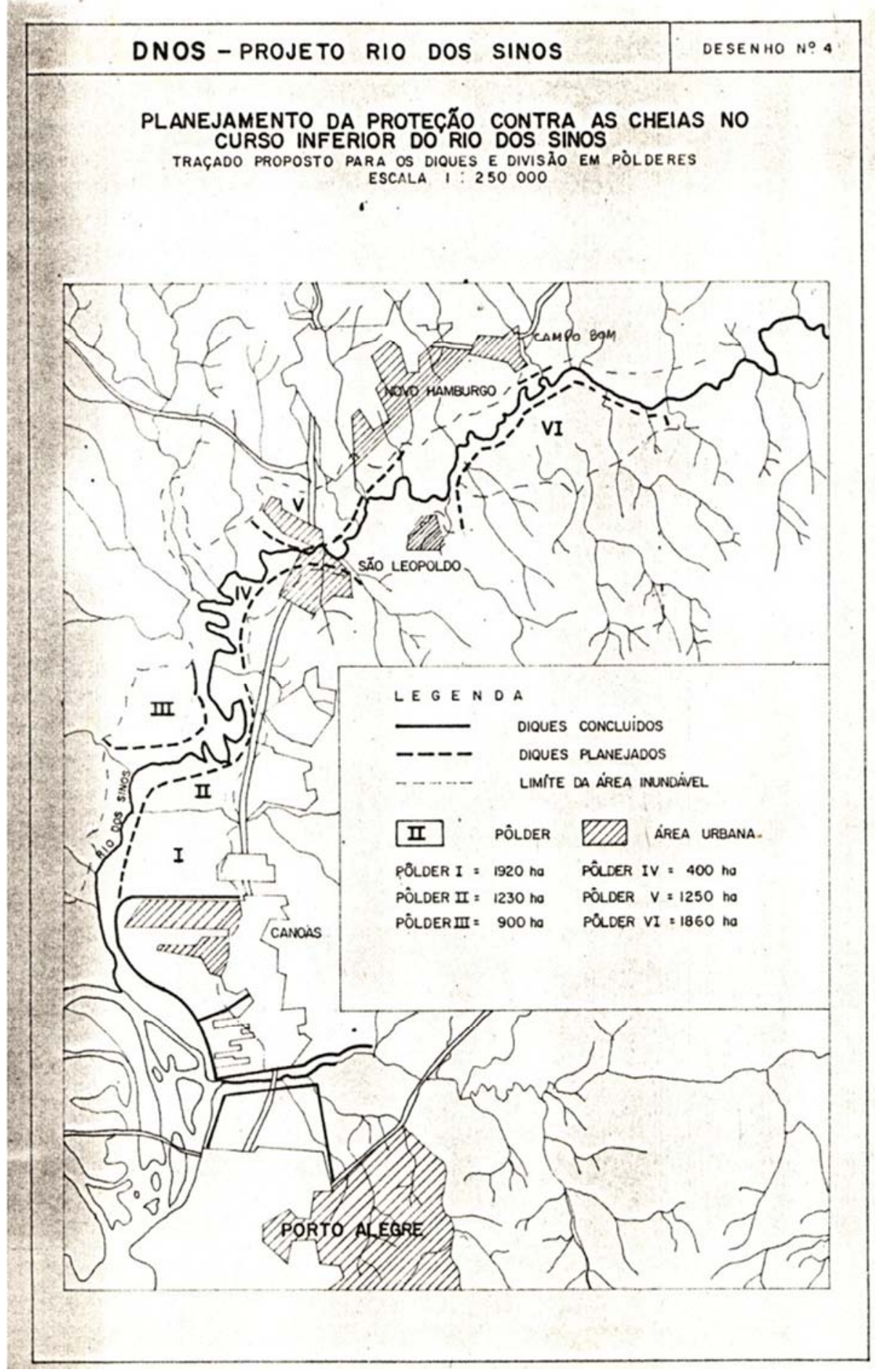

Fonte: Prefeitura municipal de São Leopoldo, 2009 


\section{ANEXO I:}

Perfil de dique de terra

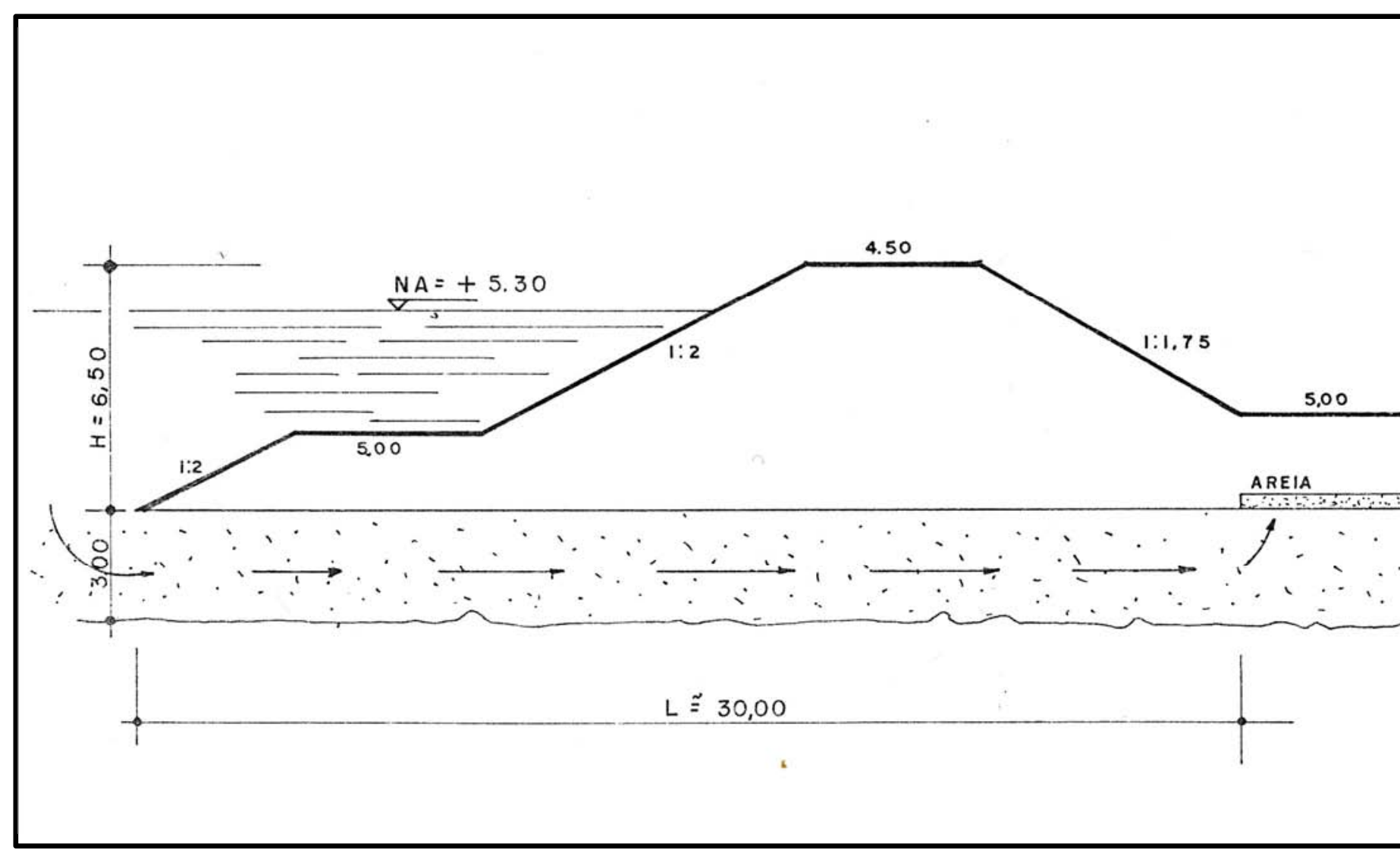

Fonte: Prefeitura municipal de São Leopoldo, 2009.

\section{ANEXO J:}

Reportagens 


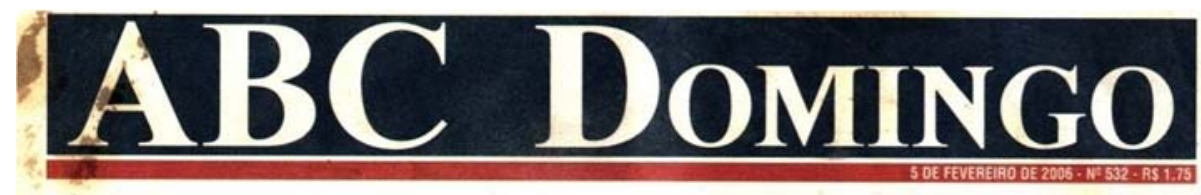

'Omissão ameaça

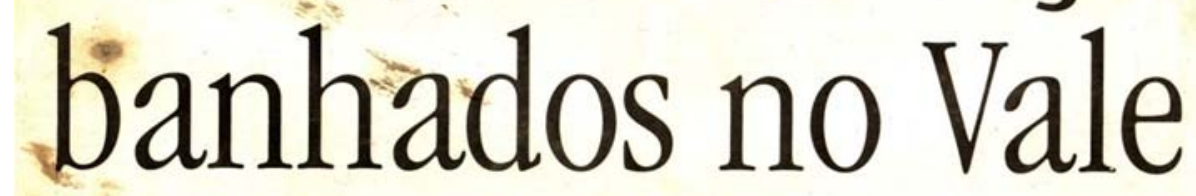

D Ministério Público reage contra indiferença de prefeituras. Páginas 2 e 3

Fonte: Jornal ABC Domingo 05/02/2006.

\section{Moradores da Rua das Camélias pedem ajuda para a Prefeitura}

Lofeamenio esłá consiruído em uma área de preservação e sofre com enchentes

lem do problema
enchente que atio
giu as cassas da R das Camélias pela segunda
vez neste ano, os moradores enfrentam um outro impasse. A área onde moram é de preservacaio ambiental rada para a construção de um loteamento. $\mathrm{O}$ impasse deve ser encaminhado pelos moradores a Ministenio Publico nos proximos dias, ja que as propostas feitas respostas. Conforme a secrettiria de Habitação, lsa. bela Albrecht, as sugestōes dos moradores podem ser estudadis, Uma delas - que ca construçio de um dique - for considerada inviavel pelo prefeito Ary Vanazsi, cilo. A outra seria a remocio das familias para uma área seguna ou ajuda de custo pa. ra construirem casas mais

elevadas.

Segundo informaç̋̄es da Prefeitura, a autorizaçio

para construçáo de um lo-

Rio dos Sinos foi dada em

1970. Na cpoca, com pre-

cos atrativos, muitos mo- de Igor comprou quatro lotes no local, sem imaginar que dali para frente haveri uma rotina com as enchentes. "Pagamos pelos terre-
nos, temos escritura, paga mos IPTU (Imposto Prediti e Territorial Urbano) e passamos por essa situacio de enchente, o que niao ć justo." Se a altemativa de remocaìo for aceita, implicar em análise do valor das car sas da Rua das Camelias.

UUTA - Conforme o morador, as reunióes dos moratcom a Prefcitura passam por diferentes govemos, hal mais de 15 anos, e nada de
concreto foi feito até agora. "O rio está baixando, mas há previstio de mais chuva a partir de sexta. Minha es. posa e filho, de 1 ano, ainda estaio na casa de parentes" no sentido Sul, provocan- de ontem, parte da carga 35 Astuacio de pelo menos do o represamento dos nios. de trigo transportada pela te. $\mathrm{O}$ autốnom $\mathrm{e}$ semelhan- Com isso, o Sinos - que Aménca Latina Logistica Paulo da Silva, 34, vive no tros e ontem à noite o ni- queada enquanto era feilocal há cinco anos. "Dessa vel era de 5,9 metros na ré-. ta a transposição de uma veza enchente foi pequena, gua do Semae-, Gravataí composição para outra. entrou um metro de agua na e Caí devem voltar a subir, A medida foi adotada por minha casa, mas já chegou trazendo novamente ala- causa do alagamento que
a entrar dois metros", con- gamentos, Ontem, em Ca. dificulta a passagem do ta Silva. (a)
Secretarias reunirão toda a comunidade A secretária municipal sugestões dos moradore de Habitacaa, Isabela Al- podem ser estudadas, mento foi aprovado pe- to a construção $\mathrm{cm}$ elevalo poder público $\mathrm{em}$ uma da, pois 6 metros acima siderada a localização. do, quanto a recolocação ram seus terrenos", con- luções com a comunidade, firma a secretária. Como em conjunto com várias tes na Rua das Caméliass. Eecretanas problema recorrenPoder Publico vai procurar te que nåo pode ficar sem

Rio dos Sinos poderá voltar a subir e ventos serẩo fortes

Entre a madrugada de regiốes ribieirinhas ainda hoje $e$ amanhă deve con- sentiam as consequências
tinuar chovendo no Esta- da chuva que comecou na do, contudo, e o vento que seman preocupa. A previsio da no domingo, 13. Porem, as Mestar Meteorologia e de familias que dexiaram suas Mecher

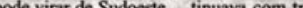
gas, empresas casas nas trem.

Fonte: Jornal VS, 16/09/2009. 

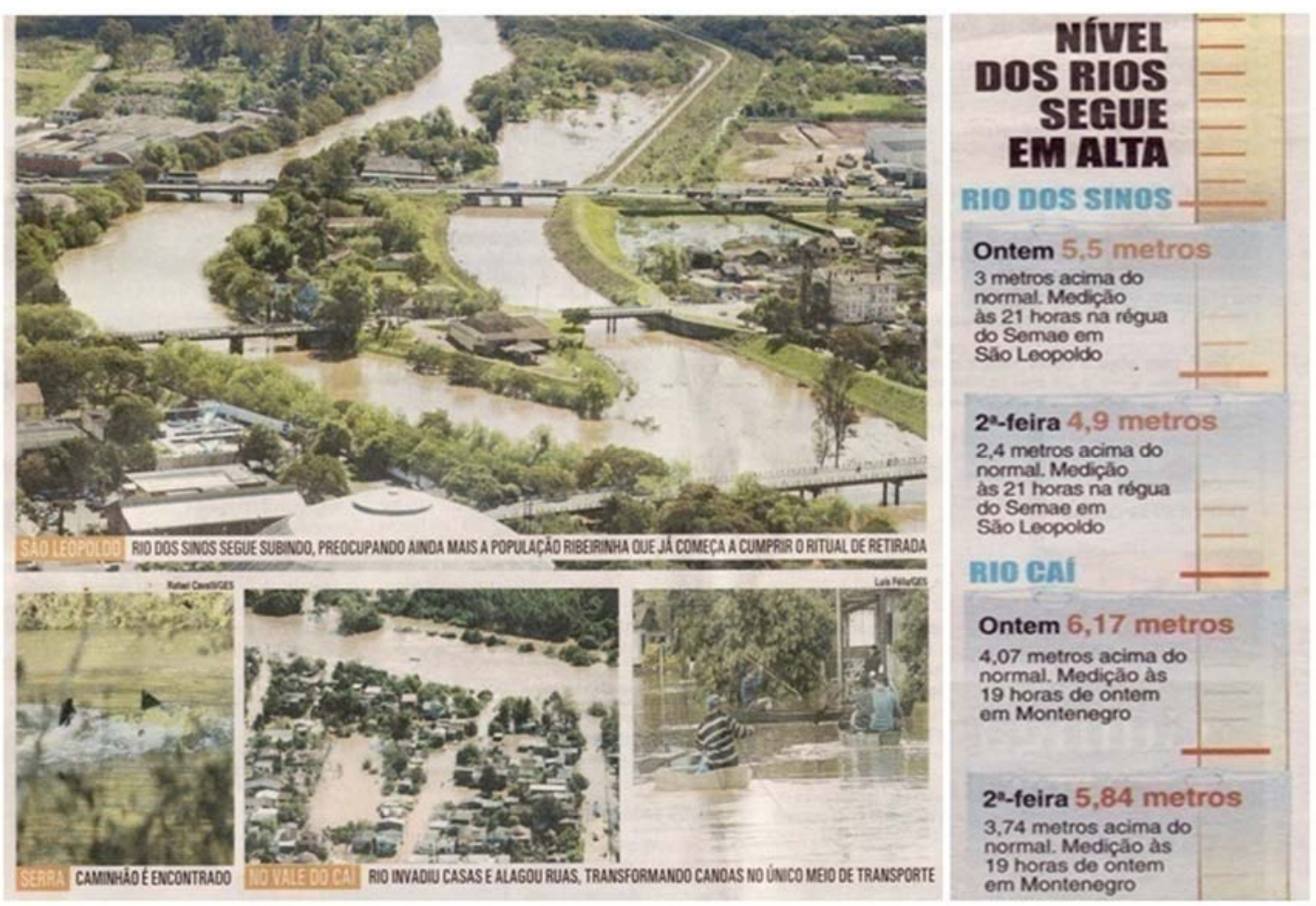

Fonte: .Jornal VS, 30/09/2009.

\section{Defesa Civil faz vistoria em diques do Rio dos Sinos}

Estrułuras são consideradas seguras, mas já sofrem com a urbanização irregular

\section{0}

AUNE ADOLPHS

coordenador da Defesa Civil de São Leopoldo, Siloma Gomes, percorreu o Rio dos Sinos ontem à tarde para observar a situação dos diques. O sistema de proteção é o que impede o rio de invadir a cidade, principalmente em momentos de cheia como a dos últimos dias. A estrutura de argila e areia, porém, sofreu alteraçães em vários pontos $\mathrm{e}$ já causa preocupação, tanto que a Prefeitura vai utilizar cerca de RS 55 milhões na sua recuperação.

"A guarda municipal faz patrulhamentos para inibir a depredação e a Defesa Civil também nos informa dos casos mais graves. Mas a estrutura não está ameaça-
da, é segura", afirma o secretário de Comunicação da Prefeitura de São Leopoldo, Ibanês Mariano.

Segundo Ibanês, a administracão municipal está trabalhando para acelerar o início da manutenção dos diques, que contara com verba do Programa de Aceleração do Crescimen- to (PAC). Os trabalhos devem iniciar ainda este ano, segundo Mariano.

A reportagem do Jomal VS acompanhou a navegação e verificou os pontos preocupantes dos diques. Em toda a extensão urbanizada na margem do rio fissuras provocadas pela populaçáo e pelos meios de transporte na terra, prejudicam a estrutura dos diques. "O trânsito de veiculos em cima do dique é prejudicial, pois acaba desconstituindo seu maciço de terra", destaca Gomes.

A erosão também causa preocupação. "Os cavalos pisoteiam a terra e a afofam Quando chove, essa terra é lavada Em cinco anos, is so terá acabado com o dique. A população não tem consciéncia da sua impor tância. As pessoas constroem na beira do rio e usam a terra do dique."

Já o nivel do rio, que estava em 6 metros na régue da base de captação do Semae, às 15 horas de onten - 30 centímetros a menos que seu pico, na terça-feira -, havia baixado, às 17 horas para 5,90 .

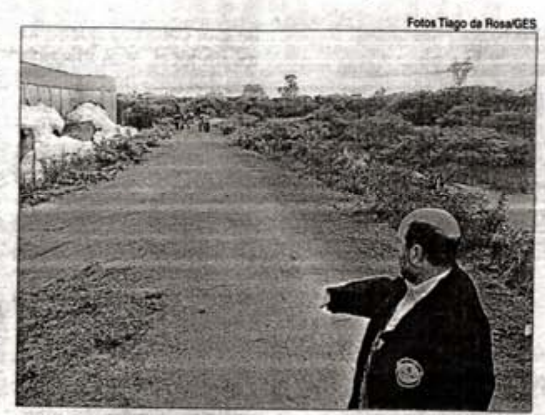

GOMES: Defesa Civil avaliou ontem a situação dos diques

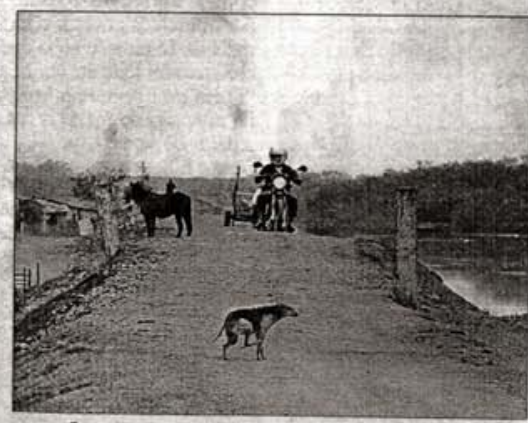

EROSĀO: trânsito sobre o dique e moradias preocupam
Estrutura do trem no Sinos Próximo às obras das sagem das máquinas. O enpontes do metrô, uma cur- genheiro da Trensurb Lino va do no causa a retenção Fantuzzi, que responde pela pelo pelomenos tres vazamentos nhos são provisónios e que no dique que levam a água ficarão abertos somente até para as ruas do bairro Rio a finalização dos pilares que dos Sinos, de acordo com sustentam as pontes. "Posinformações da Defesa Ci- so tranquilizar a população vil. Segundo Gomes, não há de que nada está sendo feirisco de alagamento, pois os to em desacordo com as vazamentos são pequenos. questões ambientais aponO consórcio Nova Via me- tadas pela Fepam e pela reu na estrutura dos diques, abrindo estradas para a pas- cretaria do Meio Ambiente

\section{Poluição na casa de bombas}

Para impedir o trânsito dique. Mesmo assim, os vepróximo da casa de bom- ículos continuam passando bas na divisa entre São Le- No local, há pontos de eroopoldo e Novo Hamburgo, são e caminhos abertos peonde está localizada a Vila la população. Sem contar a Brás, foram colocadas esta- poluição que pode ser vista cas de concreto em cima do em forma de espuma.

\section{Vicentina tem ponto crítico}

O final da Avenida João sas construidas nas derCorrêa, no bairro Vicenti- mas, recuos de terra que na, é um dos pontos mais ficam entre orio eo dique, críticos da estrutura de ar- prejudicam ainda mais a gila e areia. No local, alem estrutura As dermas dede buracos, machaduras e veriam proteger o dede buracos, rachaduras e veriam proteger o rio d pontos de erosão, as ca- urbanização e do lixo.

\section{Casal teve que deixar a casa}

João Batista Vargas da cupados com a contamiSilva, 53 anos e a esposa nacão das galinhas e dos dele, Georgina Assunção, porcos que deixaram no 60 , vivem nas dermas, no local, eles levam comida Vicentin vicentina. Com a cheia do todos os dias para os anirio, o local foi tomado pe- mais em uma carroça, que la água e pelo lixo. Preo- se desloca pelo dique. 
Fonte: Jornal VS, 2007. 